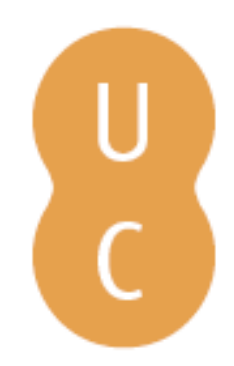

\title{
nombalina
}

\section{Saberes e poderes no mundo antigo: estudos ibero-latino-americanos. volume II - dos poderes}

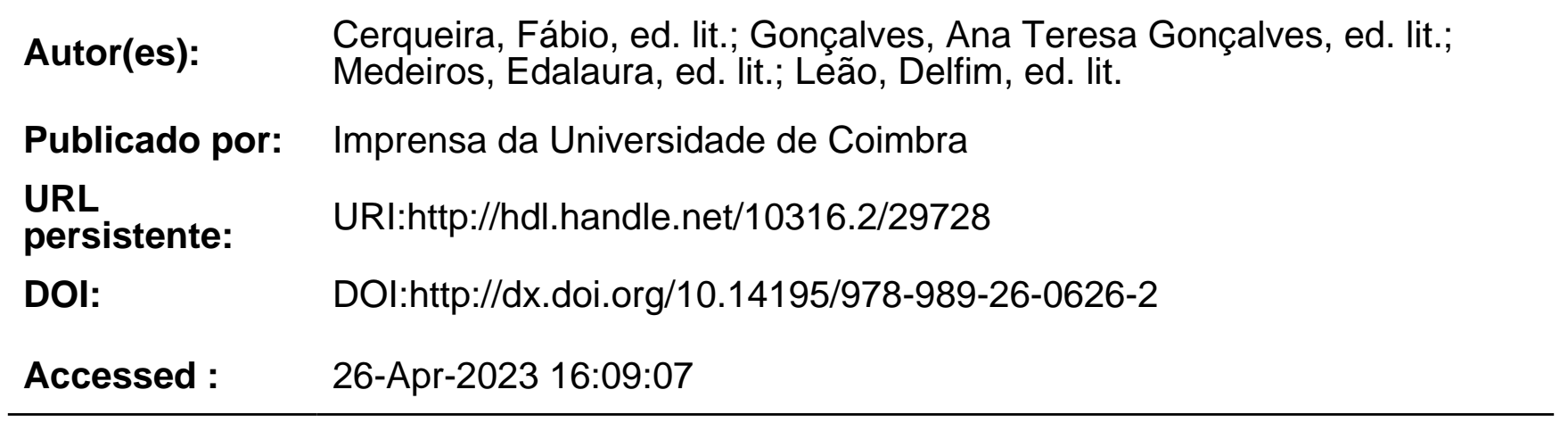

A navegação consulta e descarregamento dos títulos inseridos nas Bibliotecas Digitais UC Digitalis, UC Pombalina e UC Impactum, pressupõem a aceitação plena e sem reservas dos Termos e Condições de Uso destas Bibliotecas Digitais, disponíveis em https://digitalis.uc.pt/pt-pt/termos.

Conforme exposto nos referidos Termos e Condições de Uso, o descarregamento de títulos de acesso restrito requer uma licença válida de autorização devendo o utilizador aceder ao(s) documento(s) a partir de um endereço de IP da instituição detentora da supramencionada licença.

Ao utilizador é apenas permitido o descarregamento para uso pessoal, pelo que o emprego do(s) título(s) descarregado(s) para outro fim, designadamente comercial, carece de autorização do respetivo autor ou editor da obra.

Na medida em que todas as obras da UC Digitalis se encontram protegidas pelo Código do Direito de Autor e Direitos Conexos e demais legislação aplicável, toda a cópia, parcial ou total, deste documento, nos casos em que é legalmente admitida, deverá conter ou fazer-se acompanhar por este aviso.

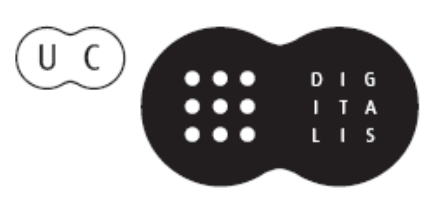




\title{
Saberes e poderes no Mundo Antigo
}

Estudos ibero-latino-americanos

\author{
Volume II - Dos poderes
}

Fábio Cerqueira, Ana Teresa Gonçalves, Edalaura Medeiros \& Delfim Leão (Orgs.)

IMPRENSA DA UNIVERSIDADE DE COIMBRA

UNIVERSIDADE FEDERAL DE PELOTAS

UNIVERSIDADE FEDERAL DE GOIÃS 



\title{
Saberes e poderes no Mundo Antigo
}

Estudos ibero-latino-americanos

\author{
Volume II - Dos poderes
}





\title{
Saberes e poderes no Mundo Antigo
}

\section{Estudos ibero-latino-americanos}

\author{
Volume II - Dos poderes
}

Fábio Cerqueira, Ana Teresa Gonçalves, Edalaura Medeiros \& Delfim Leão (Orgs.)

IMPRENSA DA UNIVERSIDADE DE COIMBRA

COIMBRA UNIVERSITY PRESS

UNIVERSIDADE FEDERAL DE PELOTAS

FEDERAL UNIVERSITY OF PELOTAS

UNIVERSIDADE FEDERAL DE GOIÃS

FEDERAL UNIVERSITY OF GOIÄS 
Todos os VOlumes desta SÉRIE SÃo SUJEITOS A ARBITRAGEM CIENTÍfICA INDEPENDENTE.

Título • Saberes e poderes no Mundo Antigo.

Estudos ibero-latino-americanos. Volume II - Dos poderes.

Organizadores - Fábio Vergara Cerqueira, Ana Teresa Marques Gonçalves, Edalaura Berny

Medeiros \& Delfim F. Leâo

\section{Série Hvmanitas Svpplementvm}

Coordenador Científico do plano de edição: Maria do Céu Fialho

\section{Conselho Editorial}

José Ribeiro Ferreira

Francisco de Oliveira

Maria de Fátima Silva

Nair Castro Soares

Director Técnico: Delfim Leão

\section{OBRa REALIZADa No ÂMBito DAS ACTIVIDADES DA UI\&D Centro de Estudos Clássicos e Humanísticos}

\section{Ediçấo}

Imprensa da Universidade de Coimbra

URL: http://www.uc.pt/imprensa_uc

E-mail: imprensauc@ci.uc.pt

Vendas online:

http://livrariadaimprensa.uc.pt

\section{CoORdENAÇÃo EDITORIAL}

Imprensa da Universidade de Coimbra

Concepção gráfica \& Paginação

Rodolfo Lopes \& Edalaura Medeiros

Pré-IMPRESSÃo

Imprensa da Universidade de Coimbra

1 a EdiçẮ: IUC・ 2013

\section{Impressão e ACABamento}

Simốes \& Linhares

ISBN

978-989-26-0625-5

\section{ISBN DigitAL}

978-989-26-0626-2

\section{DOI}

http://dx.doi.org/10.14195/978-989-26-0626-2

\section{Depósito Legal}

$361439 / 13$

(C) JUNHO 2013.

IMPRENSA dA UNIVERSIDADE DE CoImbra

Classica Digitalia Vniversitatis Conimbrigensis (http://classicadigitalia.uc.pt)

Centro de Estudos Clássicos e Humanísticos da Universidade de Coimbra

Reservados todos os direitos. Nos termos legais fica expressamente proibida a reproduçāo total ou parcial por qualquer meio, em papel ou em edição electrónica, sem autorizaçáo expressa dos titulares dos direitos. É desde já excepcionada a utilizaçáo em circuitos académicos fechados para apoio a leccionaçăo ou extensão cultural por via de e-learning. 


\section{ÍNDICE}

\section{SEÇÃO I}

\section{REPRESENTAÇÕES E IMAGENS DO PODER}

Construcción, representación y legitimación del poder: el paradigma de Julio César

Cecilia Ames e Álvaro Moreno Leoni

Poder, sabedoria e finitude no Satyricon de Petrónio

Delfim F. Leão

Cayo Calígula: del 'civilis princeps' al 'superbus' autócrata

Juan Pablo Alfaro

O processo de construção da imagem do tirano nas Vidas dos Césares de Suetónio

José Luís Lopes Brandão

\section{SEÇÃO II}

\section{SABERES E PODERES JURÍDICOS}

Poderes domésticos en la Roma antigua

Martha Patricia Irigoyen Troconis

Principios de derechos humanos en las Instituiciones de Justiniano

Aurelia Vargas Valencia

\section{SEÇÃO III}

\section{QUESTÃO BÉLICA E POLÍTICA IMPERIALISTA}

Escipion el Africano: un político moderno

Raúl Buono-Core V.

Voces críticas sobre la política imperialista romana: el caso de Cayo Salustio Crispo

Marta Sagristani

Flávio Josefo e o cerco romano a Jotapata (67 d.C.) 


\section{SEÇÃO IV \\ PODER E RELIGIÃO NO IMPÉRIO}

Poder e religião na Ásia Menor: o culto imperial

José Geraldo Costa Grillo e Pedro Paulo Abreu Funari

Controvérsias na identidade cristã segundo Eusébio de Cesareia, em História

Eclesiástica

Edalaura Berny Medeiros e Fábio Vergara Cerqueira

O significado do Contra nos discursos político-religiosos da Antiguidade Tardia: o

Contra os Galileus do imperador Juliano - 361-363 d.C.

Margarida Maria de Carvalho e Daniel de Figueiredo

\section{SEÇÃO V}

\section{MUNDO PROVINCIAL E GRUPOS ÉTNICOS}

Representación de la etnia véneta en Ab Urbe Condita de Tito Livio

Agustín Moreno

O risível, o lastimoso e o ridente em Metamorfoses de Apuleio: a dinâmica das relações sociais na Roma provincial

Luciane Munhoz de Omena

Poder e Território: o Alto Alentejo entre o Império e a Antiguidade Tardia

261

André Carneiro

O poder durante a Antiguidade Tardia no Império romano ocidental e na Lusitania

em particular

283

Mélanie Wolfram

La transición entre la antigüedad y el feudalismo: los vándalos

295

Carlos García Mac Gaw 
Seção I

REPRESENTAÇÕES E IMAGENS DO PODER 



\title{
CONSTRUCCIÓN, REPRESENTACIÓN Y LEGITIMACIÓN DEL PODER: EL PARADIGMA DE JULIO CÉSAR
}

\author{
Cecilia Ames* \\ Álvaro Moreno Leoni** \\ Universidad Nacional de Córdoba - Argentina
}

\section{Introducción}

La fascinación que produce la figura de Julio César no sólo se ha mantenido a lo largo de dos milenios sino que no ha perdido actualidad, de modo que está siempre presente y no dejan de aparecer año tras año publicaciones sobre temas vinculados a su acción política, a sus escritos y a su recepción (MEIER, 1986, p.26-39. RÜPKE, 2008, p.4-6). Nuevas investigaciones, planteos y revisiones contribuyen a engrosar de un modo ilimitado un repertorio bibliográfico que ya resulta inabordable en su totalidad. ${ }^{1}$ Esto no impide, sin embargo, que otras miradas y relecturas intenten construir síntesis diferentes, que enriquecen la reflexión con enfoques innovadores que actualizan la vigencia de temas y figuras paradigmáticas de la Antigüedad romana haciéndolo significativo para nuestros días, para la reflexión política y la educación de nuestros ciudadanos (AMES, 2004, p.95-102). En esta línea de trabajo y desde un humanismo crítico (CANCIK, 1998, p.VII-XI) nos proponemos abordar los diferentes niveles del discurso político de Julio César, entendiendo éste en un sentido amplio, que no se limita al mensaje verbal sino que incorpora el lenguaje icónico y la obra pública con su correspondiente mensaje simbólico (ZANKER, 2007, p.5-9). En este contexto se analizará su obra escrita, los comentarii sobre la guerra de las Galias y sobre la guerra civil, como un todo, tratando de dilucidar la función del de bello gallico para la acción política posterior, esto es, como prolegómeno al bellum civile, las acuñaciones de moneda como un nuevo lenguaje simbólico y la inserción de la obra pública en el programa político. La vinculación entre discurso político, acuñación de moneda y obra pública es importante a la hora de pensar en la

\footnotetext{
* Cecilia Ames es Profesora de Historia Antigua en la Universidad Nacional de Córdoba, Argentina e Investigadora del Consejo Nacional de Investigaciones Científicas y Técnicas (CONICET). Correo postal: Centro de Estudios Avanzados, U.N.C. Av. General Paz 154, Piso 2. 5000 Córdoba, Argentina. Correo electrónico: cecilia.ames@gmail.com

** Álvaro Moreno Leoni es Prof. Asistente de Historia Antigua en la Universidad Nacional de Córdoba y becario doctoral del Consejo Nacional de Investigaciones Científicas y Técnicas (CONICET), Centro de Estudios Avanzados, Universidad Nacional de Córdoba. Correo electrónico: almoreno1983@hotmail.com
} 


\section{Construcción, representación y legitimación del poder}

recepción, pues de este modo se cubre el amplio espectro de la población iletrada que accede a un campo de representaciones diferente al de la escritura, pero no menos expresivo y persuasivo.

La crisis de las instituciones de la república romana que dominó todo el siglo I a.C. y desembocó en la guerra civil, la dictadura de Julio César y el consiguiente cambio institucional que marcó el inicio del Principado de Augusto, ha preocupado desde siempre a historiadores y teóricos de la política. Mientras se transforma la ciudad de Roma, que de ser el centro de un paisaje pequeño se convierte en la ciudad principal de la península itálica y progresivamente en la capital gobernante de un imperio mundial, se transforma también la estructura política interna de la misma ciudad, una Roma republicana que tiene que responder a las desafiantes alteraciones que ha provocado la expansión y la conquista. El sistema republicano tradicional, era un sistema de dominación y gobierno que originalmente había sido concebido para una ciudad-estado. Este sistema, por lo tanto, se volvió totalmente anacrónico en la época de expansión, lo que se hizo evidente de un modo radical en el siglo II a.C. En esta época, sobre todo a partir de la segunda guerra púnica, se agudizan las contradicciones de la estructura social romana y, además, las cada día más evidentes debilidades del sistema de dominio republicano preparan el escenario de conflictos y luchas políticas que dominarán el siglo siguiente y terminarán con la "muerte de la república", la que, si bien es una consecuencia de la paradoja histórica que fue Roma como "república conquistadora", ha quedado paradigmáticamente asociada a la figura de Julio César, que vence a Pompeyo en la guerra civil y se erige en dictator de Roma (CHRIST, 1994). Pero esta lucha, que se acelera en la década de los 50, excede el ámbito del enfrentamiento armado entre optimates y populares, y nos enfrenta al tema del discurso político, ${ }^{2}$ pues los diferentes testimonios que nos han llegado nos abren la mirada a un espacio de la lucha por el poder que no acontece en el campo de batalla. Dicho con palabras de Bourdieu (1988, p.138), la lucha política es también una lucha por la nominación legítima, donde diferentes trabajos de representación pugnan por imponer sentidos.

Desde esta perspectiva vamos a abordar el discurso político, es decir, los diferentes lenguajes de la práctica política de Julio César, quien no sólo vence a Pompeyo en el campo de batalla, sino que lo vence en la lucha simbólica, mediante la construcción de simulacros y diferentes trabajos de representación que dan sentido y legitiman su acción política (ZANKER, 2007, p.15). Sin intentar hacer una comparación anacrónica, hay elementos en el análisis del discurso cesariano que pueden capitalizarse para la reflexión actual, pues, a la hora de analizar las ideologías legitimadoras del acceso al poder por las armas, los consiguientes cambios institucionales y la legitimación de las guerras, es imprescindible rescatar el peso de la cultura romana sobre el pensamiento de occidente. Es aquí donde para nosotros cobra un significado especial la Historia 
Antigua, especialmente la Historia de Roma y sus "discursos", pues en ella se hallan las raíces de estas estrategias que serán la médula del discurso y la práctica política occidental.

Los siguientes cuestionamientos guiarán nuestro trabajo: ¿Cómo se prepara una toma del poder y un cambio institucional desde las mismas instituciones? ¿Cómo se construye una realidad que pueda constituirse en el escenario propicio para este cambio? ¿Qué rol juega el discurso político y las consecuentes redefiniciones, el lenguaje iconográfico y la obra pública con su mensaje simbólico? ¿Por medio de qué mecanismos se legitima el actuar político y el uso de la fuerza? En este contexto se analizará la función del de bello gallico para la acción política posterior, esto es, como prolegómeno al bellum civile, las acuñaciones de moneda como un nuevo lenguaje simbólico y la inserción de la obra pública en el programa político. La vinculación entre palabra e imagen es muy importante a la hora de pensar en la recepción, pues, de este modo, el mensaje alcanza a llegar al amplio espectro de la población iletrada, el público romano contemporáneo que queda excluido de la lectura de las obras.

\section{La obra escrita de Julio César}

Lamentablemente se ha conservado poco de los numerosos escritos que la tradición ha atribuido a Julio César. Se han perdido poemas, discursos, cartas, una polémica contra Catón y un escrito gramatical sobre la analogía y sólo se han conservado siete libros sobre sus campañas en la Galia (59-52 a.C.) y tres libros sobre la guerra civil, que relatan los enfrentamientos con Pompeyo (49-48 a.C.). Al poco tiempo del asesinato de César apareció una especie de "edición completa" redactada con materiales de César y de sus colaboradores. Esta edición contenía los ya mencionados comentarios y la continuación, escritos por diferentes autores (commentarii de bello alexandrino, africo, hispaniensi). Hirtius escribió el libro octavo del de bello gallico, que narra los acontecimientos en la Galia en el 52-51 a.C. y, a su vez, sirve de eslabón entre esta obra y el de bello civile. Pero lo primero que se comprueba al enfrentarse a la figura de Julio César es que su significado no se inscribe en el ámbito de las letras ni en el de la historiografía. Cuando en el año 58 a.C. se dirige a la Galia, ya era desde el 63 a.C. pontifex maximus, había sido cónsul, gobernador de dos provincias y tenía un pequeño ejército bajo su mando, con el que parte a la Galia (MEIER, 1986, p.131-277) Todos los datos que tenemos sobre sus actividades y trayectoria nos llevan a la conclusión de que el objetivo que perseguía no era hacer literatura ni escribir historia, sino hacer política de modo que la escritura de sus res gestae constituyen un momento más de una praxis político-militar que tiene por objetivo la modificación activa de la constelación política de su tiempo. ${ }^{3}$ En efecto, durante la profunda crisis de las instituciones de la república romana se reelaboran modelos que, por un lado, pretenden mostrarse como salvaguardas de las tradiciones que 


\section{Construcción, representación y legitimación del poder}

hicieron grande a la república romana y, por otro, más que un simple reflejo de lo ya existente, constituyen proyectos que tienden a instalar un nuevo paradigma, a imponer significados y modelos como principio de unidad y conducción necesarios para un Estado romano que debe responder a las nuevas dificultades políticas y administrativas que había traído aparejadas la expansión. En este momento tiene lugar la publicación de los "comentarios" de Julio César (WELCH y POWELL, 1998). Su versión de los hechos, el modo de relatar su propio pasado y el del sector del pueblo romano que toma parte en él, se inscribe dentro de un género historiográfico que ha generado y sigue generando una gran polémica: los commentarii sobre la Guerra de las Galias y sobre la Guerra Civil (RICHTER, 1977, p.39-48). A pesar de que su obra escrita se limita a esta dos obras inconclusas, "Julio César como hombre de letras" resultó mucho más que el título de un libro famoso, ya convertido en clásico para los especialistas en la antigüedad romana (ADCOCK, 1958), pues el resultado de la práctica de escritura de este político y militar romano, los commentarii, ha movilizado a una legión de historiadores y filólogos que conquistaron importantes lugares en las universidades y bibliotecas de todo el mundo. No deja de resultar llamativo que aquel general acostumbrado a movilizar legiones desde su posición militar, siga movilizando legiones desde su posición de escritor. El general manda, moviliza y conquista, también con sus escritos. ¿No es esto ya indicativo del contexto en el que se enmarca su práctica de escritura? Esta perspectiva de interpretación de los comentarios como acción política es lo que lleva a Riggsby (2006, p.11), frente a la difícil cuestión de la datación y modalidad de la publicación de la obra, a pronunciarse a favor de una publicación seriada, cada dos años de guerra, y en contra de una publicación de conjunto al final de la campaña, dado el significado que tenía el informar para la propaganda y la legitimación. ${ }^{4}$ Sin embargo, más allá de esta cuestión tan controvertida, podemos conjeturar que la escritura de sus res gestae en la Galia es sólo el prolegómeno a sus res gestae en Roma, que preparan y legitiman la toma del poder que significó el final de la república. Esta conjetura marca el contexto en el que debemos leer y decodificar el de bello gallico. Más allá del afán por aprehender lo real, lo histórico, lo que realmente sucedió, cuando leemos los escritos de César no debemos olvidar que no estamos frente a la guerra de las Galias sino frente a su discurso, pues la Galia, la guerra, el general y sus enemigos son una construcción textual. ${ }^{5} \mathrm{El}$ hecho de que no tengamos a disposición otras fuentes que nos informen sobre la conquista de la Galia le dio al texto de César un lugar privilegiado. ${ }^{6}$ Los comentarios de las guerra de las Galias se encuentran aquí solos, no hay ninguna posibilidad real de controlar la tradición con información proveniente de otras fuentes, de modo que lo único que queda son los argumentos internos, resultado de un exhaustivo trabajo con y en el texto. Los diferentes estudios emprendidos tenían por finalidad determinar el valor del bellum gallicum como fuente histórica, pero esto también dio como resultado, 
frente al instalado concepto de deformación histórica (RAMBAUD, 1966), una valoración de los comentarios para el estudio de la demografía y la organización militar de la Galia, así como para investigar aspectos geográficos y etnológicos (RICHTER, 1977, p.79-95). De ese modo, mientras se les restaba valor histórico por un lado, se le sumaba por otro. La cuestión de la falsedad histórica intencional de los escritos de Julio César llevó a la investigaciones a indagar en otras temáticas, sacándolas del ámbito estricto y reducido del discurso histórico tradicional o de los materiales para la historia (MENSCHING, 1988, p.9-20 y RICHTER 1977, p.39-49) para insertarlas en el ámbito mayor del discurso político.

Nuestro punto de partida es que los comentarios son al mismo tiempo producción textual y acción política. Su lectura es fácil y ágil, sin embargo, debajo de las transparentes formas de expresión, claras en su forma sintáctica, con una disposición ordenada de un vocabulario diáfano, se esconde una cuidadosa reflexión del autor sobre cuánto quiere decir, cuánto no, cómo da forma y ordena sus noticias, cuándo el reproduce o construye los contextos y cuándo los evita o tapa. Pero el autor no expresa jamás estas reflexiones, ni nos da una pista para ello. Su oferta de información es tan soberanamente autocrática como su acción política, o mejor dicho, como la imagen que él mismo construye de su acción. En este contexto resulta operativo el concepto estrategias narrativas (LATACZ, 1978, p.70-73). ${ }^{7}$ Este concepto, que ocupa hoy un lugar importante no sólo en las teorías narrativas sino también en la semiótica y en la sociología, resulta, sin embargo, de la interpretación general de la obra escrita de César (GÖRLER, 1976 y MONTGOMERY, 1973). ${ }^{8}$ La elección del género "comentario", que implica elección de un público y determinación del horizonte de expectativas de los lectores, constituye el primer acto de estrategia.

Sin lugar a dudas, al elegir el género del comentario (RÜPKE, 1992, p.201226), César elige un modo de hacer historia que, desde el punto de vista de la enunciación, no se organiza, como la historiografía clásica tradicional, en torno a un "he visto", que acredita un "digo" en la medida en que digo lo que he visto, sino en un tipo de historia en la que, a través del uso de la tercera persona, borra las marcas de la enunciación y prioriza ciertos criterios de verificabilidad y estrategias narrativas que funcionan como operadores de credibilidad. En el estilo propio del informe protocolar da cuenta a sus pares del Senado romano, ${ }^{9}$ en forma minuciosa, de los acontecimientos que se desatan a su llegada a la provincia asignada por el Senado; el detallado relato no se detiene en explicaciones ni discusiones sobre la constitucionalidad de su acción, ni hace mención alguna a las objeciones que su accionar había provocado en el seno de la política romana. Además, las referencias a acontecimientos políticos de Roma están absolutamente ausentes, tapadas por el manto de la objetiva narración de los hechos en tercera persona. 
Pero ¿qué encontramos cuando nos enfrentamos al de bello gallico y tratamos de decodificarlo? ¿qué realidad se construye en el texto? Los comentarios de César sobre la Guerra de las Galias no narran grandes aventuras ni constituyen novelas de héroes o matanzas sangrientas; en esta obra la guerra es presentada como un trabajo racional, ciencia, cálculo (scientia bellandi, ratio belli). Él comenta de un modo sencillo, claro y tendencioso un proceso políticomilitar: la romanización de toda la Galia; sus planes, medidas, acciones y sus "comentarios" sobre ellos están impregnados de racionalidad y disciplina militar y lingüística. "Toda la Galia", términos con los que comienza la obra, es enseguida dividida en tres partes habitadas por diferentes pueblos. La política romana sabrá jugar con estas diferencias: divide et impera. La relación de César con el lugar donde él ha pasado ocho años de su vida aparece en la primera frase como la del hacedor con su objeto, la Galia es el objeto analítico, racional, militar, su presentación resume una expresión geográfica y un programa político que articula propaganda y geografía (RIGGSBY, 2006, p.45). Desde la primera frase estamos frente a los hechos desnudos y nos sumergimos en el dinamismo del general y sus legiones (CANCIK, 1986, p.7-29). Tratando de poner en orden las provincias romanas y por el honor del pueblo romano comienza el conflicto con los helvecios -una guerra que hay que legitimar-; a este conflicto fronterizo del sur de la Galia se le suman otro y otro más, formando una cadena ininterrumpida de guerras y acciones diplomáticas que terminan con la "pacificación" de toda la Galia. La lectura internaliza en el lector la máxima romana: si vis pacem, para bellum.

Cuando César describe las batallas, no se detiene en el comportamiento heroico y la valentía de sus soldados, sino en la preparación y el cálculo, en esto radica la superioridad romana. El libro II nos brinda un claro ejemplo: el ejército de Cesar opera en el año 57 a.C. en Bélgica y de repente son atacados por los Nervios, que con increíble rapidez llegaron y se los veía aparecer por todos los costados. César tenía que hacer todo a la vez (Caes. Gal. 2.20): enarbolar el estandarte, dar la señal de ataque, retirar a los soldados del trabajo, llamar a los que se habían alejado, formar el ejército, arengar a los soldados, dar la contraseña, mientras el tiempo para ello era escaso y el enemigo amenazaba continuamente. Pero ante esto dos cosas le ayudaban (Caes. Gal. 2.20.3-4) ${ }^{10}$ : la ciencia y práctica de sus soldados (scientia et usus) que los hacía tan capaces de dirigirse por las órdenes de otro como por su propia iniciativa, pues habían internalizado táctica, orden y cooperación. Además de fortaleza (virtus), los romanos disponían de conocimiento (scientia) y de dominio de sí mismo, esto es, de disciplina. César no escatima los elogios que le merecen los bárbaros, sean galos o germanos, ellos son valientes y aman la libertad, sus acciones heroicas son reflejo de virtud, están acostumbrados a guerrear y aman las batallas y la fama. Los germanos, por el tipo de alimentación y las costumbres, son fuertes, de gran 
tamaño y se conducen con libertad, porque ellos desde la niñez no están acostumbrados al deber y a la disciplina y no hacen nada en contra de su voluntad (Caes. Gal. 4.1). ${ }^{11}$ El campo de batalla es el escenario donde vemos a romanos y a bárbaros y el comportamiento de uno y otro marca las diferencias y define las identidades. César se enrola claramente en la tradición de la cultura militar helenística ${ }^{12}$ y nos muestra cómo los soldados romanos han internalizado táctica, orden y cooperación, y, además de fortaleza (virtus), disponen de disciplina y constantia (Caes. Gal. 1.40.6). ${ }^{13}$ Por el contrario, los bárbaros desconocen el orden y la conducción, son tan ruidosos y anárquicos que su marcha parece una huida (Caes. Gal. 2.11.1). ${ }^{14}$ Cuando los bárbaros se conducen disciplinadamente, es porque han aprendido de los romanos, por eso Julio César recuerda a sus soldados que los esclavos liderados por Espartaco (73-71 a.C.) pudieron resistir tanto tiempo en su levantamiento porque tenían a su favor la pericia y disciplina que habían aprendido de los romanos (Caes. Gal. 1.40.5-6) ${ }^{15}$ y destaca, además, la capacidad de los bárbaros para imitar y practicar las invenciones de otros (Caes. Gal. 7.22). ${ }^{16}$

Julio César, además, se construye a sí mismo como paradigma de inteligencia y disciplina militar que encarna los valores tradicionales que hicieron grande a la república, es decir, se construye a sí mismo como un modelo que ha de ser reproducido. Pero también construye al ejército romano como "su" ejército y en este marco define al legionario. Los diferentes simulacros en los que se destaca el paradigma del general apuntan a una redefinición de la figura heroica, este general es y debe ser el verdadero héroe romano. ${ }^{17}$ En esto se fundamenta su posterior toma del poder: un general de tal magnitud debe defender su dignidad y el ejército y el pueblo romano deben luchar por ella (RIGGSBY, 2006, p.82-83). ${ }^{18}$ A este fin le son funcionales los diferentes simulacros textuales que tienden a la construcción de la conquista de la Galia como una empresa concluida, la legitimación de la guerra y la definición de la romanidad y la barbarie, para lo cual también se vale de los excursos de carácter geográfico y etnográfico de los libros V y VI, los cuales, como ya hemos mostrado en otro trabajo (AMES, 2003, p.71-75), no son ni digresiones casuales ni interpolaciones de noticias extrañas al género. Su presencia en la segunda parte del de bello gallico resulta clave para la representación de los pueblos bárbaros y para la determinación del canal de la Mancha y del Rin como frontera entre ellos y como frontera del imperio. El excurso del libro $V$ sobre los británicos deja en claro que al otro lado del canal viven pueblos salvajes y peligrosos, enemigos del pueblo romano. La naturaleza de este pueblo tan salvaje impide su romanización y lo deja fuera del dominio romano. César incursiona en la isla británica pero no la conquista ni la "pacifica". El famoso excurso del libro VI se inserta en el comentario ante el segundo paso del Rin, caracteriza a los germanos y, además, a los galos, marcando las diferencias entre ambos. En contraposición a los germanos, los galos, aunque son 


\section{Construcción, representación y legitimación del poder}

desleales e inconstantes, pueden aprender de los romanos e integrarse a su dominio, son claramente romanizables; los germanos, por el contrario, al ser mucho más salvajes, deben permanecer fuera de este proceso. Para que su empresa sea la "pacificación de toda la Galia" primero hay que construir esa Galia como un todo, demarcarla, construir su frontera "natural". Esta demarcación geográfica está unida a las diferencias culturales de los habitantes: los galos que viven a un lado del Rin son completamente diferentes de los germanos que viven al otro lado. Así, bajo la apariencia de la introducción de noticias de carácter geográfico y etnográfico, César "construye" una división entre una Germania a la derecha del Rin y una Galia a su izquierda. Sin duda, César necesitaba la frontera del Rin no sólo como demarcación sino como división étnica para poder presentar su conquista de la Galia hasta el Rin como una empresa cerrada y concluida (RIGGSBY, 2006, p.69-70). El largo excurso etnográfico también consolida la posición de César no sólo como representante de las aspiraciones romanas sino como el garante de la existencia de la Galia, a la que libera del amenazador peligro germano.

Resulta interesante observar, frente a los numerosos trabajos de crítica histórica y filológica, que la coherencia textual de los comentarios de César e incluso entre los dos comentarios, a pesar de las diferencias entre ambos, no se encuentra en el relato de las guerras o campañas militares sino en la representación del otro, es más, las guerras tienen importancia en función de esta representación, que puede tomarse como un hilo conductor para la lectura comprensiva. Pero esta representación del otro tiene por finalidad hablar de la identidad romana, encarnada en César y sus legionarios. La representación imaginaria del bárbaro se hace a partir de lo que no son los romanos, la representación del enemigo en la guerra civil se hace a partir de lo que no es César y sus seguidores. Así, la guerra de las Galias puede leerse como un escrito de definición de identidad romana, donde disciplina y racionalidad militar resultan claves, pues constituyen la base para la legitimación de un acceso al poder inconstitucional, una legitmación moral de la victoria (RIGGSBY, 2006, p.73). De este modo, en el período de crisis republicana donde asistimos a una pugna por el poder, observable en los diferentes trabajos de representación, César reelabora un modelo de ser que, por un lado, rescata lo más caro a un romano tradicional y, frente a sus adversarios republicanos, se presenta como conservador de los verdaderos valores romanos que hicieron grande a la república. Por otro lado, ante las circunstancias, tiende a imponer significados que lo presentan como principio de unidad y conducción necesario para el estado. En el marco de la política romana y del lugar de César en esta lucha por el poder, es comprensible la escritura y publicación de esta obra.

Es así como podemos comprender el de bello gallico como un discurso político en un momento de crisis institucional, un discurso que prepara y legitima 
su retorno a Roma, accediendo al poder por las armas. Pero César no sólo escribe sobre las guerras en la Galia, del mismo modo informa él sobre su próxima guerra, la guerra civil, emprendiendo en esta obra directa e indirectamente una legitimación de su toma del poder por las armas. Sin ningún tipo de exordio, el comienzo abrupto del relato en el de bello civile plantea su lectura en inmediata articulación con el último libro del de bello gallico, el octavo, atribuido a Hirtius, quien hubo de instrumentar a posteriori el recurso de encabalgar semántica y sintácticamente ambos comentarios haciendo de la conclusión del de bello gallico los prolegomena del de bello civile. En esta obra se da cuenta a los ciudadanos y a la posteridad de las circunstancias que motivaron el drástico recurso a las armas en una guerra civil y el no menos drástico ejercicio del poder fundado en la victoria militar. Como en la guerra de la Galia, presenta como legítima la noción de bellum iustum y la consecuente adquisición del ius belli, no ya en relación con los pueblos vecinos y bárbaros, sino precisamente en el seno de la vida institucional romana, en relación con sus conciudadanos romanos. Nuevamente en este escrito la representación del otro se presenta como hilo conductor; con prolijidad destaca que las instituciones ya habían sido quebrantadas por sus enemigos $y$, en tal circunstancia, acude al "pueblo romano", entendiendo por pueblo al ejército, para quejarse. En diferentes instancias argumentativas revierte la prueba, imputando al propio Senado el abuso de las armas contra las instituciones. Convoca a los soldados, se queja de la conducta de Pompeyo (Caes. Gal. 1.1-8) y los exhorta a que defiendan contra sus enemigos el prestigio y la dignidad del general, aquel general bajo cuyo mando habían servido felizmente a la república durante nueve años, habían librado muchos combates victoriosos y pacificado toda la Galia. Sin duda, el de bello gallico es un capítulo preparatorio a la transformación de la república que César de ninguna manera reconoce tener en mente. Como en la guerra de la Galia, expone en la guerra civil las acciones objetables, como el paso del Rubicón, enmascaradas dentro de una conducta de reacción, fundándose en la pretendida sana tradición jurídica romana. Y continuando su tarea de construcción de sí mismo y del otro, el relato deriva en un profuso cuadro de conductas paradigmáticas. Sin odios ni deseos de venganza, presenta un enemigo débil, inseguro e inoperante frente a un general de conducta magnánime, con capacidad de conducción y, fundamentalmente, merecedor de la adhesión de los soldados, basada en la historia generosa de sus hazañas en la Galia. Todo esto lo configura como paradigma de romanidad, pero más allá de la romanidad tradicional, pues los escritos de César definen la identidad de una nueva romanidad, apareciendo por primera vez con pretensión de validez jurídica el recurso al ejército entendido como pueblo como fuente de legitimación de la autoridad y del orden republicano y, con esto, algo cambia definitivamente. 
En efecto, la guerra de las Galias, en su acción y en su texto, son un prolegómeno a la guerra civil y a la toma del poder. Mediante las construcciones textuales paradigmáticas, juega con los conceptos de bellum iustum y ius belli de modo tal que termina mereciendo y poseyendo este ius belli, pudiendo tomar el poder en Roma y erigirse dictador. En la Galia César siempre reacciona, él fundamenta sus ataques a los galos y germanos diciendo que él fue atacado primero, que acude al pedido de ayuda de los aliados y amigos de Roma, que tiene que adelantarse a los germanos, que quieren cruzar el Rin y conquistar toda la Galia; él responde a las supuestas "injurias" que los bárbaros cometen contra el pueblo romano y defiende su "dignidad". Hace todo esto de modo tan paradigmático que legitima su posterior respuesta a las supuestas "injurias" del Senado romano. De la Galia a Roma, de las injurias contra el pueblo romano a la injurias contra él mismo, de la defensa de la dignitas de la república a la defensa de la propia dignitas, de general a dictador, el continuum bellum gallicum-bellum civile resulta evidente $y$, en este contexto, cobran sentido los modelos contruidos en el de bello gallico: El general como paradigma de las virtudes tradicionales y, a su vez, de una nueva romanidad, constituyendo las disciplinadas legiones la base de este proceso, en el que el soldado de la república se convierte en el soldado de César.

\section{Acuñaciones de César}

Las monedas constituyen el grupo de testimonios más rico y completo que se ha conservado de la Antigüedad. Ellas acompañan los hechos y los acontecimientos siempre como contemporáneos, inspiradas por la perspectiva oficial y constituyen el soporte de la publicación corriente de palabra e imagen en un extendido público durante largo tiempo. ${ }^{19}$ En este sentido, Strack considera a las monedas como "permanente órgano de publicación del gobierno", comparable a las acta publica, acta urbis y acta diurna (STRACK, 1933. CHRIST, 1967, p.59). Sin embargo, muchos estudios actualizados e individualizados muestran que las monedas romanas no son los periódicos de los ciudadanos ni el diario del gobernante, ni siquiera la frecuente caracterización como panfleto de propaganda política acierta del todo, pues ellas remiten a un más allá de sí mismas y de un esto aquí y ahora, y obedecen a sus propias leyes y tradiciones. En primer lugar, son el medio de pago oficial de Roma para el mundo, esto es, sus imágenes y leyendas constituyen un documento para la autorepresentación y reconocimiento político y la autolegitimación del estado romano. Esto resulta clave en su medio helenístico, para mantener su dominio, sobre todo a partir del siglo II a.C. y en este contexto debe comprenderse su apropiación y resignificación de modelos griegos. ${ }^{20}$ Pero más allá de esto, las características de las monedas y, sobre todo, la valoración de la imagen entendida como lenguaje icónico significativo, han convertido a la numismática en una fuente invalorable para la historia política, 
económica, del arte y de la religión y como puerta de entrada al mundo de las representaciones de los hombres de la Antigüedad, ocupando un lugar privilegiado para observar la construcción de la identidad.

Durante el período que nos ocupa, asistimos a una transformación de las representaciones iconográficas en las cecas. Las monedas de la república tardía presentan casi como un libro abierto aquel escenario de lucha por el poder en el seno de la oligarquía romana. En efecto, las acuñaciones de la república romana clásica en un principio se orientan a los modelos griegos y así observamos que la moneda, aún en Roma, está dominada por la imagen de las representaciones de divinidades y personajes del ámbito del mito de la ciudad, la res publica en conjunto aparece en cierto modo destacada en bloque. Recién hacia la época de la república tardía, desde el final del siglo II a.C., se modificaron estos principios y se comienza a observar que los maestros monetales y magistrados responsables de la acuñación comienzan a usar las monedas como un instrumento para evocar $y$, de este modo, mantener en la memoria las hazañas de sus antepasados con lo que, a su vez, salvaguardaban su propio prestigio. Los éxitos políticos y militares y las construcciones de los antepasados e, incluso, en algunos casos, sus propias imágenes fueron actualizadas de tal modo que las expresiones de las imágenes y leyendas monetales se volvían finalmente cada vez más actuales. Especialmente en la época de Sila es imposible dejar de reconocer en las imágenes y leyendas acuñadas las referencias a las circunstancias políticas presentes. ${ }^{21}$ Siguiendo esta tradición ya instaurada en la república tardía, Julio César, como otros generales antes de él, procedió desde el 49 a.C. a organizar una acuñación militar propia con grandes emisiones, posteriormente diferentes maestros monetales, en su nombre, lo hicieron bajo sus órdenes. Las imágenes y leyendas de estas primeras series de oro y plata se alejan muy poco de las normas tradicionales. Muy frecuentemente se encuentra de un lado la cabeza ricamente adornada de Venus, la divinidad de la familia Julia y a veces la imagen de Pietas. Al mismo ámbito de la acentuación de la relación especial con una divinidad, que después es precisada con la representación de Venus Victrix, combinada con la tradicional pietas, pertenece también aquel reverso en el que vemos al Eneas llevando sobre uno de sus hombros a su padre Anquises y sosteniendo en su mano derecha el palladium, la prenda clásica de dominio romano (47 a.C.). Esta acuñación es de lo más significativa, pues es la primera vez que aparece en la moneda romana este héroe, que después será el héroe central de la epopeya romana (FUCHS, 1973, p.615-632). ${ }^{22}$ El piadoso Eneas que cantará Virgilio tiene aquí su antecedente, la pietas de Eneas, símbolo de la pietas romana, evoca la pietas Caesaris. De un modo llamativo aparecen frecuentemente en los reversos los atributos sacerdotales, que hacen referencia a César como pontifex maximus.

Un segundo conjunto de imágenes monetales de César recuerda sus éxitos militares en la Galia. En ellas encontramos la cabeza de un barbado galo, en el que 


\section{Construcción, representación y legitimación del poder}

se ha querido ver a Vercingetorix, una personificación femenina de la Galia, signos de victoria de armas típicas celtas, un elefante con la trompa en alto que pisotea un carnyx, la llamativa e inconfundible trompeta de guerra celta (49 a.C.). Aquí César se enrola en la tradición helenística, para la cual la representación de la victoria sobre el celta es un tema paradigmático para la construcción y legitimación del poder (CHANIOTIS, 2005, p.191-204. MITCHELL, 2005, p.281-284). Este recurso fue utilizado ampliamente por los etolios que, tras su victoria sobre los celtas en Delfos (278 a.C.), comenzaron a acuñar una serie de monedas de oro y plata con la imagen de Etolia sentada sobre una pila de escudos celtas (thyreos) (SCHOLTEN, 2000, p.40-41, 102). ${ }^{23}$ Particularmente gráfica resulta la producción en serie de figuras realizadas por los talleres de terracotta de Myrina cerca de Pérgamo, en los cuales un elefante aplastaba un thyreos celta para conmemorar la victoria de Antíoco I sobre los celtas en la llamada batalla de los elefantes (268 a.C.) (MITCHELL, 2005, p.283). La personificación femenina de la Galia es más que elocuente en la acuñación cesariana, con los cabellos sueltos e indómitos, refleja la imagen de la barbarie, que César se ocupará de pacificar y romanizar, siguiendo la tradición helenística que nos recuerda la asociación del combate entre gigantes y dioses olímpicos, atenienses y persas con griegos y celtas del altar de Zeus en Pérgamo (CHANIOTIS 2005, p.191).

La utilización de una gran divinidad, Venus, unida con la demostración de la pietas, reforzada por la elocuente apropiación del héroe troyano Eneas y los atributos sacerdotales por un lado y, por otro, el enfático recuerdo de las victorias en la Galia, constituyen los elementos principales de sus acuñaciones. Si bien otras emisiones muestran imágenes diferentes, divinidades, manos cruzadas como expresión de concordia o alusiones a la libertas, no se puede reconocer un programa específico. Con respecto a las leyendas no se observa ninguna variación y se enrolan en la tradición iniciada en la época de Sila.

Lo llamativo es que las monedas específicamente cesarianas ilustran el discurso de los comentarios, la Galia bárbara dominada y pacificada por aquel general romano victorioso pero piadoso, que respeta lo más caro a la tradición romana, sus antepasados. Esto es lo que nos dice la imagen de Eneas, y la forma de representar a Anquises, sobre los hombros de Eneas pero erguido. Esta es la primera representación de una larga serie que no responde al modelo griego ni helenístico y que implica toda una representación respetuosa de los antepasados, pues la pietas hacia los padres es el prolegómeno de la pietas hacia la patria. En este sentido, si tenemos en cuenta que los comentarios se publicaron en el 51 a.C. y las acuñaciones de moneda comienzan en el 49 a.C. podemos ver en estas acuñaciones la confirmación de los elementos más significativos del discurso del de bello gallico. Su perfecta inserción en el continuum que, desde la guerra de las Galias y pasando por la guerra civil lleva a la instauración y legitimación del poder, un poder basado en las armas y en la pietas de aquel general romano que 
también en su dicurso icónico se presenta como su baluarte. Además, tanto en el de bello gallico como en las acuñaciones de moneda se observan los antecedentes de aquella típica mentalidad imperialista romana que Momigliano analiza teniendo en cuenta la Eneida de Virgilio y analizando las etapas de formación de aquel mito de Eneas que será central en la ideología romana, pues la historia de Eneas es una historia de la autodefinición (MOMIGLIANO, 1992, p.426-465). En la segunda etapa de formación del mito de Eneas, durante los últimos siglos de la república, ayudó a las ambiciones imperialistas de los romanos, de allí que resulte más que significativo el hecho de que César la tome como imagen, siendo que no son muchas las imágenes que aparecen en el repertorio cesariano.

\section{La obra pública de Julio César}

El general y sus legiones, en los comentarios y en sus monedas, definen la identidad romana e ilustran el funcionamiento de esta mentalidad imperialista que también podemos decodificar en el lenguaje de la obra pública. César no escribe un tratado jurídico ni político sobre las posibilidades y derechos de expansión romana ni sobre la forma de gobierno de la república en crisis, César hace, comunica, simboliza, toma el poder y, de vuelta en Roma, sigue encarnando esta mentalidad palpable en sus esfuerzos de representación de sí mismo. El activo general de la Galia continúa igualmente activo en Roma como dictador, él agranda el reino y el imperio.

Efectivamente, así como César logró aumentar (augere) el dominio romano en la Galia, continúa en Roma, en la consolidación de su poder, con esta tarea de "aumentar". En el año 45 a.C., según Dión Casio, gestiona una lex de urbe augenda, una ley para agrandar la ciudad (Dio Cass 43.50.1). El planeaba desviar el Tíber cerca del puente Mulvio y conducirlo al pie del monte Mario y ganar terreno en pendiente o declive, de ese modo podría proteger el campo de Marte de las inundaciones y, a su vez, ese terreno podría ser aterrazado y aprovechado para el cultivo. ${ }^{24}$ El campus Vaticanus se convierte en un nuevo campo de ejercicios. Cicerón se indigna y le escribe a Atico: "aumenta la ciudad (urbem auget), él la ha visto por primera vez en los últimos dos años" (Cic. Att. 13.35-36). ${ }^{25}$ Los dioses están tan ausentes en su actividad urbanística como en sus guerras, los escrúpulos religiosos no constituyen un obstáculo para César: hace demoler el templo de la Pietas y allí ordena construir un teatro (Suet. Jul. 59. CANCIK, 1986, p.18). ${ }^{26}$ Para construir su Foro tuvo que introducir modificaciones esenciales en el Foro romano tradicional: hizo demoler la antigua rostra, podio público de los oradores, y la antigua curia, la casa del Senado (Dio Cass 43.49.3. Plin. NH 7.121). Convirtió en una obra en construcción a los alrededores del comitium, el lugar de las asambleas populares; quería construir un gran templo a Marte, además proyectaba llenar un lago artificial para luchas de barcos (Suet. Jul. 44. Dio Cass 43.23. App. BC 2.102). El gran destructor se presenta como el gran constructor, la 
contrapartida de aquel si vis pacem para bellum del pacificador de la Galia. Al lado de nuevas campañas militares proyectaba nuevas campañas civiles (Suet. Jul. $44.1)^{27}$ así ampliaba el imperio, de la periferia al centro. Sus planes urbanísticos muestran también al estratega.

Sin duda esta actividad constructora de la ciudad también se ubica en el contexto de la república tardía y junto con las acuñaciones de moneda constituye uno de los trabajos de representación en la lucha política que tiene lugar en aquella época. Así como en las monedas se reconocen los síntomas de esta situación en el cambio de tipos que se acuñan, del mismo modo la actividad urbanística toma otros cauces y asistimos a una verdadera transformación de la política constructora que se asocia y responde a las necesidades de representación de los grandes hombres que en este vacío de poder republicano pugnan por imponerse. La actividad urbanística de Roma constituye así un capítulo instructivo en el que puede leerse la historia de este período. El título de un capítulo de la obra de Kolb: "imperialismo romano, grandes personalidades y la imagen de la ciudad en la república tardía" (KOLB, 1995, p.250-271) pone ya de manifiesto esta asociación y marca el contexto en el que deben ser leídas las informaciones de los historiadores y los resultados de la arqueología. Como en el caso de las monedas, nuevamente Sila constituye un hito en esta nueva etapa de la construcción romana (MC. KENDRICK, 1960, p.241-256). Muchas son las obras de construcción y restauración que emprendió, pero lo más representativo y elocuente es, sin duda, entre el 82 y el 78 a.C., su ampliación del pomerium, el límite sagrado de la ciudad, lo que expresa claramente que él, restaurador del poder de la oligarquía senatorial en la república, se consideraba como el nuevo fundador de Roma y, como tal, traza los nuevos límites sagrados la ciudad. La ampliación del dominio romano a Italia, que hizo que el territorio de los ciudadanos abarcara ahora casi toda Italia al sur de los Alpes, ofrecía la legitimación ideológica para aquel acto sacro del trazado de los nuevos límites. Esta nueva frontera es la expresión simbólica del crecimiento del dominio romano y de la ciudad y tiene un significado topográfico y político, pues parece que nunca delimitó el área real de asentamientos (KOLB, 1995, p.693) ${ }^{28}$. En esta línea se enrola la actividad urbanística de César que, en comparación con la de Sila o la de Pompeyo, se puede decir que es pobre, ya que la mayoría de sus planes no se llegaron a realizar. Por falta de tiempo, su obra quedó lejos de la magnificencia de representación que observamos en sus predecesores, pero es absolutamente simbólica de la nueva situación: el cambio de lugar de la rostra significaba en la práctica la desaparición del antiguo comitium, el lugar tradicional de la asamblea popular, e implicaba una fuerte acentuación de las asambleas informales (contiones), que ofrecen un terreno propicio a la demagogia. La destrucción de un espacio público clave para las prácticas políticas tradicionales implica no sólo un cambio en los hábitos de los ciudadanos, sino también un debilitamiento de las 
instituciones, a las que se les priva del lugar físico de funcionamiento. Con esta modificación está operando modificaciones sobre el código de conductas y convenciones expresas o consuetudinarias, se prepara el terreno, el lugar concreto, para este recurso al ejército entendido como pueblo como fuente de legitimación de la autoridad y del orden republicano. De este modo, la modificación de la rostra es la contrapartida de las instancias argumentativas del bellum civile. Sin duda, la obra pública de Julio César se inserta en un discurso de representación unitario, que encuentra su par en las monedas, y ofrece códigos cuya lectura nos coloca frente a topos significativos expresados en el discurso iconográfico y, sobre todo, en el de bello gallico. El desvío del Tíber, aunque no se haya realizado, resulta significativo después que hemos visto cómo en la Galia César puede transformar la naturaleza por medio de la técnica, así también puede hacerlo en Roma. La máquina de guerra romana, que los Atuatucos consideraban una fuerza divina, guarda una relación coherente con los planes colosales de César para modernizar la ciudad. El dictador continúa la tarea del general, el ciudadano continúa la tarea del legionario. La obra pública de César constituye, sin duda, un trabajo de representación que legitima su acción política, su obra pública y sus planes urbanísticos son una continuación de sus guerras y sus discursos.

\section{Conclusión}

De este modo podemos comprender que los escritos, las acuñaciones de moneda y la obra pública pueden leerse como un discurso unitario que ilustra de modo expreso o simbólico con diferentes lenguajes una practica política, militar e institucional. Es un discurso político de la legitimación de la toma del poder por la fuerza de las armas, en un marco de crisis institucional construido como una realidad que desde sí misma exige y está pidiendo su intervención. Los comentarios de Julio César no son ni deformación histórica ni propaganda política, sino discurso político, en el que asistimos a una construcción simbólica y paradigmática de la realidad. Ellos se orientan a la manipulación de la opinión pública con vistas no sólo a la legitimación del recurso a la fuerza sino también y, sobre todo, a la creación del consenso necesario para mantenerse en el poder. La práctica discursiva es una instancia de imposición de sentidos y legitimación; en esta categoría se inscriben los comentarii y la elección de los motivos y leyendas para las emisiones monetales y la obra pública. El discurso político y el lenguaje iconográfico configuran los símbolos y estereotipos configurados como el "deber ser", además es posible reconocer estrategias descriptivas y manipulación del lenguaje icónico orientadas a favorecer y legitimar cambios institucionales y jurídicos. El corpus cesariano, especialmente el de bello gallico, construye la figura ejemplar del general y los soldados que llevan adelante el agrandamiento del imperio romano; además, es generador de otros discursos que aseguran la 
transmisión y reproducción de los modelos y está relacionado con la reproducción o modificación de las condiciones objetivas existentes. De este modo, la obra de César ocupa un lugar importante en la producción de sentidos y representaciones que serán receptadas por agentes sociales que interpretan desde sus propias condiciones objetivas en el marco de la lucha por la obtención de la nominación legítima, este es el lugar de las redefiniciones en la construcción del modelo heroico romano. Visto de esta manera, la lectura del de bello gallico resulta un capítulo instructivo para la comprensión del fenómeno histórico-políticoinstitucional llamado "cesarismo", y, como fundador de una tradición que tendrá un gran futuro en la historia de occidente, se propone como una vía de comprensión para el estudio de este fenómeno en otros momentos históricos, signados por la característica del gobierno militar.

La cultura romana, transmitiendo su militarismo y su racionalidad jurídica al derecho canónico y civil de occidente, ha acuñado nuestra manera de pensar y de hablar. Ella, además, nos ha transmitido los términos racionalidad, militarismo, disciplina, dictadura, ejercicio, deserción, capitulación, y ha enriquecido nuestro vocabulario con sentencias: "divide y reinarás"; "si quieres la paz, prepara la guerra"; "Ilegué, vi y vencí". Historiadores y escritores, no sólo europeos sino también latinoamericanos, nos han transmitido el modelo del legionario valiente y disciplinado y del cauteloso, sensato y exitoso general que supera la barbarie indisciplinada y finalmente, accediendo al poder por las armas, pone orden en la república. Los escritos y la obra de César ocupan en esto un lugar preferencial, su desarrollada inteligencia militar y legitimación del uso de la fuerza la hizo útil a la burguesía y al absolutismo del Renacimiento y de la Edad Moderna; el texto ofreció otros aspectos caros al mundo moderno: legitimación del uso de la fuerza, colonización, imperialismo, y su historia, sus textos y sus obras se instalan en una tradición educativa que no será cuestionada hasta bien entrado el siglo XX. Las escuelas han divertido a los niños con esas hazañas, $y$, de ese modo, ellos recibían inconscientemente su racionalismo militar y su disciplina a través de la clase de historia y del estudio y ejercicio de la sintaxis oracional en la clase de latín. Ahora nos resulta clara la observación de Foucault: Roma ha transportado a la modernidad no sólo el ideal jurídico de la ciudadanía, sino también la técnica de los procedimientos disciplinarios, cuyo modelo fue la legión romana, pues Roma, bajo su faz militar, era el esquema ideal de la disciplina. $Y$ con legiones disciplinadas no sólo se lucha, también se gobierna, pues ellas legitiman la autoridad del dictador que, para dirigirse a ellas, ha modificado el Foro y ha construido una nueva tribuna en el centro de Roma. 


\section{Bibliografía}

ADCOCK, F. Caesar als Schriftsteller. Göttingen: Vandenhoeck \& Ruprecht, 1958 .

AMES, C. Estudios Romanos y Modernidad: un espacio de reflexión a partir de la recepción del discurso cesariano. Semanas de Estudios Romanos, Vol. XII, p.95-103, 2004.

AMES, C. Los comentarios del Señor Julio César. La escritura de la historia como práctica política. Ordia Prima, Vol. 2. p.55-78. 2003.

BOURDIEU, P. La distinción. Criterios y bases sociales del gusto, Madrid: Taurus. 1988.

CANCIK, H., Rationalität und Militär - Caesars Kriege gegen Mensch und Natur. In: Lateinische Literatur, heute wirkend II, Göttingen. 1986.

CANCIK, H. Antik-Modern. Beiträge zur römischen und deutschen Kulturgeschichte, Stuttgart, Weimar: Metzler. 1998.

COLLINS J.H. Caesar as Political Propagandist. ANRW, I 1, Berlin-New York. p.922-966. 1972.

COSTA, R. L. y MOZEJKO, D.T. Los Güemes en la Historia o modos de hacer historia. Escribas, $\mathrm{N}^{\circ}$ Presentación, p.107-136. 2000.

CANFORA, L. Julio César un dictador democrático. Barcelona: Ariel. 2000.

CHANIOTIS, A. War in the Hellenistic World. A Social and Cultural History. Oxford: Blackwell Publishing, 2005.

CHRIST, K. Caesar. Annährungen an einem Diktator. München: Beck. 1994.

CHRIST, K. Römische Geschichte. Einführung-Quellenkunde-Bibliographie. Darmsadt: Wissenschftliche Buchgesselschaft, 1994.

CHRIST, K. Antike Numismatik. Einführung und Bibliographie. Darmstadt: Wissenschftliche Buchgesselschaft, 1967.

FUCHS, W., Die Bildgeschichte der Flucht des Aeneas. ANRW I 4, Berlin-Neu York, p.615632. 1973.

GLÜCKLICH, H. J. Soldaten für Caesar. Vier Szenen aus den "Commentarii", AU 33,5. p.7481, 1990.

GÖRLER, W. Caesar als Erzähler (am Beispiel von BG II 15-17), AU 23,3. p.18-31. 1980.

GÖRLER, W. Die Veränderung des Erzelersstandpunktes in Caesars Bellum Gallicum. Poetica 8. p.70-87, 1976.

GRIFFIN, M. A Companion to Julius Cesar. Oxford: Blackwell, 2009.

HARMAND, J. "Une composante scientifique du Corpus Caesarianum: le potrait de la Gaule dans le "de bello gallico" I-VII" . ANRW I 3, Berlin-New York. p.523-595, 1973.

KOLB, F. Rom. Die Geschichte der Stadt in der Antike. München: Beck, 1995.

KROIMANN, J. Cesar und das Corpus Caesarianum in der neuren Forschung. ANRW I, 3, Berlin-New York. p.457-482, 1973.

LATACZ, J. Zu Cäsars Erzählstrategie (BG I 1-29. Der Helvetierfeldzug), AU 21,3. p.70-87, 1978.

LOHMAN, D. Leserlenkung im Bellum Helveticum. AU 33,5. p.56-73, 1990.

MC. KENDRICK, P. Nabobs as Builders: Sulla, Pompey, Caesar. The Classical Journal 55. p.241-256, 1960.

MANNSPERGER, D. ROM. ET AUG. Die Selbstdarstellung des Kaisertums in der römischen Reichsprägung. ANRW II 1, Berlin-Neu York, p.919-996, 1974

MEIER, Chr. Caesar, München: Deutscher Taschenbuch Verlag. 1986.

MENSCHING, E. Caesars bellum Gallicum. Eine Einführung. Frankfurt am Main: Diesterweg. 1988. 


\section{Construcción, representación y legitimación del poder}

MITCHELL, S., The Galatians: Representation and Reality. In: ERSKIN, A. (Ed.). A Companion to the Hellenistic World. Oxford: Blackwell, 2005, p. 280-293.

MOMIGLIANO, A. Cómo reconciliar griegos y troyanos. In: De paganos, judíos y cristianos. México, p.426-465, 1992.

MONTGOMERY, H., Caesar und die Grenzen. Information und Propaganda in den Commentarii de bello Gallico. Symbolae Osloenses, Vol. 49.1, p.57-92. 1973.

MOZEJKO, D.T. La práctica de la investigación sobre el discurso como práctica. In: Lengua y Literatura, Temas de Enseñanza e Investigación. Córdoba: U.N.C., p.53- 59, 2000.

PASCUCCI, G. Interpretazione linguistica e stilistica del Cesare autentico. ANRW I 3, BerlinNew York, p.488-522, 1973.

RADITSA, L., Julius Caesar and his Writings, ANRW, I 3, Berlin-New York, p.417-456. 1973.

RAMBAUD, M. L'art de la déformation historique dans les Commentaires de César. Thèse Paris 1952, Annales de I'Université de Lyon, Lettres III 23, 1953, 2da. Ed., Paris, 1966.

RICHTER, W. Caesar als Darsteller seine Taten. Heildelberg: Karl Winter Universitätsverlag, 1977.

RIGGSBY, A. Caesar in Gaul and Rome. War in Words. Austin: University of Texas Press, 2006.

ROSENSTEIN, N. Imperatores Victi. Military Defeat and Aristocratic Competition in the Middle and Late Republic. Berkeley: University of Californai Press. 1990.

RÜPKE, J. Wer las Caesars bella als comentarii? Gymnasium 99, p.201-226, 1992.

RÜPKE, J. Domi Militiae. Die Religiöse Konstruktion des Krieges in Rom. Stuttgart: Steiner Verlag. 1990.

RÜPKE, J. Caesar-Gestlat, Gestalter und Gestaltung. AU 51,5, p.4-13, 2008.

RÜPKE, J. Gerechte Kriege - gerächte Kriege. AU 5, p.5-13, 2008.

SCHOLTEN, J. The Politics of Plunder. The Aitolians and their Koinon in the Early Hellenistic Era, 279-217 B.C. Berkeley: University of California Press, 2000.

SIEBENBORN, E. Bellum lustum. AU 33,5, p.39-55, 1990.

STRACK, P.L. Untersuchungen zur römischen Reichsprägung des 2. Jahrhunderts. Stuttgart, 1933.

TIMPE, D. Caesar gallischer Krieg und das Problem des römischen Imperialismus. Historia 14, 1965, p.189-214.

VOGT, J. Caesar und seine soldaten. In: Orbis. Ausgewählte Schriften zur Geschichte des Altertums. Freiburg, p.89-109, 1960.

WELCH, K. y POWELL, A. Julius Caesar Artfull Reporter: The War Commentaries as Political Instruments. London, 1998.

WISEMAN, T. The Publication of De Bello Gallico, en K. Welch y A. Powell (eds.). Julius Cesar as Artful Reporter. London: The Classical Press of Wales, 1998, p.1-9.

ZANKER, P. Augusto e il potere delle immagini. Universale Bollati Boringhieri, 2007.

\footnotetext{
Notas

${ }^{1}$ Bastan dos ejemplos para notar lo evidente en esta afirmación: los artículos recopilados en el Blackwell Companion to Julius Caesar (GRIFFIN, 2009) y el libro de Riggsby (2006).

${ }^{2}$ El término discurso y sus derivados hace referencia al lenguaje verbal, nosotros lo usaremos en un sentido más amplio, incorporando el lenguaje icónico.
} 
${ }^{3}$ Metodológicamente el ineludible punto de partida es preguntarnos por el agente social, por las condiciones objetivas dentro de las que opera, priorizando el lugar desde donde se habla como principio de definición del individuo como agente social y planteando la relación entre el texto y las condiciones de producción en términos de coherencia. Sobre estos presupuestos teóricos cfr. D.T. Mozejko (2000, p.53- 59). Para la aplicación de esta postura teórica a la historiografía argentina cfr. R.L. Costa, D.T. Mozejko (2000, p.107-136).

${ }^{4} \mathrm{El}$ argumento, sin duda, tiene su lógica, pero no alcanza para dilucidar la cuestión: "Nonetheless, I am inclined to accept the theory of serial composition, simply because of the obvious value to Caesar in keeping the public aware of his deeds throughout the war. This historical consideration seems to me to tip the scales where the philological arguments are roughly equal and quite weak on both sides. This weakness is also the subject of one further observation. I argue in Chapter 5 that, for strategic and generic reasons, Caesar wants to give the impression (whether true or not) of writing as he goes, not just year by year, but almost line by line. (More precisely, I will suggest that the choice of genre is in part a way of advancing those strategic aims.) If this is the case, then Caesar may be deliberately writing in a fashion that would (perhaps less deliberately) neutralize internal evidence for a distinction between serial and unitary composition." (RIGGSBY, 2006, p.11).

${ }^{5}$ A pesar de esto, el tratamiento del texto como historia, sea real o deformada, ha dominado la tradición. En efecto, la mayoría de los estudios se han centrado en el cuestionamiento de estos comentarios como discurso histórico desde una perspectiva historiográfica tradicional en la que el historiador, cual detective, trata de sacar a luz la verdad sobre los acontecimientos narrados. Desde la obra de Rambaud sobre el arte de la deformación histórica en los comentarios de César, publicada en 1953, los investigadores no han dejado de discutir en torno al escaso valor de la obra escrita de César como fuente histórica y su carácter propagandístico, a tal punto que la bibliografía al respecto ya casi resulta inabordable.

${ }^{6}$ Aunque no nos detendremos en esto, hay que tener presente la diferencia entre los dos comentarios de César, el de la guerra de las Galias y el de la guerra civil, pues la situación metodológica desde la que podemos abordarlos no es la misma en ambos. Dado que sobre la guerra civil romana hay un mayor número de fuentes a disposición que sobre la guerra de las Galias, se encuentra el bellum civile mucho menos protegido y los historiadores han centrado su tarea en la confrontación de fuentes diversas como fuente de control de la verdad histórica de los acontecimientos narrados en el bellum civile. En efecto, en este caso los comentarios de la guerra civil, como César los narra, pueden ser medidos y comparados con los de Plutarco, Suetonio, Luciano, Dión Casio y Apiano, lamentablemente ya no con Livio, pues los libros correspondientes a este episodio se han perdido. Para la guerra de las Galias la situación es completamente diferente, pues su desarrollo y sus detalles interesaron mucho menos a la historiografía romana al tener poca influencia en el desarrollo romano general.

${ }^{7}$ Además, para la comprensión de la obra de César, este concepto aparece especialmente apropiado, pues el revela desde el comienzo el carácter de comentario como ficción, y no sólo non coloca frente al tema de los elementos ficcionales en narrativas no ficcionales, sino que esta ficción, lograda sobre todo a través de algunas elecciones axiomáticas 
(Grundsatzentscheidungen), como la elección de la forma "comentario", la pseudoobjetividad de la narración en tercera persona y la pseudo-imparcialidad de un aparente estilo riguroso y severo, es ya el primer acto de estrategia narrativa del escritor César.

${ }^{8}$ Görler distingue ente "personale Innensicht" y "auktoriale Perspektive", lo que en la terminología de Montgomery corresponde a la distinción entre "einseitige Erzähltechnik" y "Technik des allgemein orientierenden Epischen". Cfr. H. Montgomery (1973, p.68-80).

${ }^{9}$ En contra de las numerosas investigaciones que sostienen que el destinatario de la obra de César es el círculo senatorial romano, Wiseman (1998) considera que César escribe para sectores más amplios, lo cual genera la atinada crítica de Riggsby (2006, p.12-14).

${ }^{10}$ His difficultatibus duae res erant subsidio: scientia atque usus militum, quod, superioribus proeliis exercitati, quid fieri oporteret non minus commode ipsi sibi praescribere quam ab aliis doceri poterant, et quod ab opere singulisque legionibus singuloslegatos Caesar discedere, nisi munitis castris vetuerat. Hi propter propinquitatem et celeritatem hostium nihil iam Caesaris imperium exspectabant, sed per se quae videbantur administrabant.

${ }^{11}$... a pueris nullo officio aut disciplina adsuefacti nihil omnino contra voluntatem faciunt.

12 Estamos frente a la euexía, eutaxía y philoponía de la cultura militar y gimnástica helenística. Cfr. Chaniotis (2005, p.49-51).

${ }^{13}$ Ex quo iudicari posse quantum haberet in se boni constantia, propteea quod quos aliquamdiu inermes sine causa timuissent, hos postea armatos ac victores superassent. La gran innovación de César, es entender la virtus del soldado como necesaria y responsable pero en tanto dependiente conceptualmente de la del comandante (RIGGSBY, 2006, p.206), lo cual es una fuerte innovación con relación a las concepciones de virtus durante la república media ya que, como sugiere Rosenstein (1990, p.54-91), los soldados no eran responsables directos por los descalabros.

${ }^{14}$ Ea re constituta, secunda vigilia magno cum strepitu ac tumulto castris egressi, nullo certo ordine neque imperio, cum sibi quisque primum itineris locum peteret et domum pervenire properaret, fecerunt ut consimilis fugae profectio videretur.

${ }^{15}$....factum etiam nuper in Italia servili tumultu, quos tamen aliquid usus ac disciplina quam a nobis accepissent sublevarent.

${ }^{16}$ Cfr. También Caes. Gal. 7.30; la gente, que no estaba acostumbrada a esos trabajos (para la fortificación del campamento) quedó tan consternada, que pensaban que debían hacer y soportar todo lo que se les ordenaba.

17 Aquí ya vemos prefigurado al futuro Eneas, que encontrará en la epopeya y en la historiografía romana su formulación definitiva.

${ }^{18}$ Construir a los galos como adversarios crecientemente formidables y como un peligro a ser conjurado contribuye a la propaganda de la dignitas de César.

${ }^{19}$ Sobre características generales de las acuñaciones romanas e indicación de bibliografía especializada Cfr. D. Mannsperger (1974, p.919-996).

${ }^{20}$ Es interesante observar cómo también en las monedas se ponen de manifiesto las "estrategias de apropiación" romanas, ese "ponerse en la esfera de los griegos sin ser griegos", para decirlo con palabras de Momigliano, pues Roma se sirve del mismo lenguaje que los griegos, toma de ellos su modelo, pero comienza a introducir modificaciones que terminarán dándole a las monedas romanas caracteres inconfundibles. 
${ }^{21}$ Zanker (2007, p.15-16) explica que siguiendo la iconografía numismática desde fines del segundo siglo en adelante, es posible ver cómo emergen siempre en primer plano los intereses personales de varios funcionarios de la Ceca. Hasta ese entonces las monedas portaban efigies casi constantes, con las cuales no sólo el Senado sino la ciudadanía entera podía identificarse (por ejemplo Dioniso, los Dioscuros, la dea Roma, Júpiter victorioso, botines de guerra). Ahora en vez de eso, los jóvenes nobles disfrutaban su encargo anual en la Ceca, lo que representaba el inicio de la carrera política, para celebrar la gloria de la familia, o también, más tarde, los propios, frecuentemente insignificantes, méritos personales. Así, por ejemplo, en la época de la dictadura de Sila, un cierto Cayo Manilio Limetano utilizó ambas caras de una moneda para alabar según la moda de la época el origen de su familia, haciéndola descender nada menos que del dios Hermes y de su presunto hijo Odiseo.

${ }^{22}$ Tafel 49-58, esp.53.

${ }^{23}$ Chianotis menciona algunos grupos de testimonios que invitan a la asociación de las victorias de los reyes helenísticos sobre los celtas con las victorias de los griegos sobre los persas. De este modo, así como el persa es el enemigo por excelencia en el mundo griego, el celta es el enemigo por excelencia en el mundo helenístico.

${ }^{24}$ Sin embargo el Tíber no fue desviado, incluso fracasó un intento posterior de regularlo, el Tíber mismo no quería, era un dios y no podía ser obligado, cfr. Tac. Ann. 1.79.

${ }^{25} \mathrm{O}$ rem indignam! gentilis tuus urbem auget quam hoc biennio primum vidit, et ei parum magna visa est quae etiam ipsum capere potuerit. hac de re igitur exspecto tuas litteras. Y Cic. Att. 13.33a: sed casu sermo a Capitone de urbe augenda, a ponte Mulvio Tiberim perduci secundum montis Vaticanos, campum Martium coaedificari, illum autem cam- pum Vaticanum fieri quasi Martium campum. 'quid ais?' inquam; 'at ego ad tabulam ut, si recte possem, Scapulanos hortos'. 'cave facias' inquit; 'nam ista lex perferetur; vult enim Caesar'. ${ }^{26}$...ne religione quidem ulla a quodam incepto absterritus umquam vel retardatus est.

${ }^{27} \mathrm{Nam}$ de ornanda instruendaque urbe, item de tuendo ampliandoque imperio plura ac maiora in dies destinabat: in primis Martis templum, quantum nusquam esset, extruere repleto et conplanato lacu, in quo naumachiae spectaculum ediderat. 



\title{
PODER, SABEDORIA E FINITUDE NO SATYRICON DE PETRÓNIO
}

\author{
Delfim F. Leão* \\ Universidade de Coimbra - Portugal
}

No Satyricon há três personagens que (real ou ficticiamente) detêm um grande poder: Trimalquião, Licas e Eumolpo. ${ }^{* *}$ Do primeiro e do terceiro é legítimo ainda dizer-se, sem risco de exagero, que são possivelmente as criações petronianas mais emblemáticas. Quanto a Licas, não se pode emitir o mesmo juízo, ao menos a avaliar pelo estado actual da obra, pois a sua presença estendese apenas ao longo do episódio que relata a viagem que transporta os scholastici desde a Graeca urbs, onde decorre a parte central da obra, até Crotona, onde se desenvolverão os eventos que conduzirão à cena final, marcada pelos termos burlescos do testamento de Eumolpo. Contudo, há indícios claros de que as duas personagens constantes ao longo da obra - os jovens amantes Encólpio e Gíton terão estado envolvidos em outro tipo de aventuras com Licas e Trifena, na parte perdida do Satyricon, o que deixa prever que Licas poderia ter uma importância maior do que a que possui na parte conservada da obra.

Um segundo traço comum àquelas três personagens é o facto de todas estarem envolvidas com a imagem da morte ou finitude - seja de forma real, anunciada ou simplesmente encenada. Em terceiro lugar, é de assinalar que os três homens estão ligados, de preferência, a determinados espaços urbanos: Licas, embora pereça no mar, provém de anteriores aventuras, que talvez se tenham passado em Marselha ${ }^{1}$; Trimalquião aparece na Graeca urbs e, depois do seu funeral fictício, quase não volta a ser referido; Eumolpo, que conhece Encólpio e Gíton também na Graeca urbs, protagoniza a sua maior aventura conhecida em Crotona, lugar onde, em princípio, acabará por falecer.

Por último, pode-se assinalar também a imagem de sapiens que tanto Trimalquião como Eumolpo procuram cultivar em vários momentos da sua actuação, ainda que com resultados nem sempre bem conseguidos, contribuindo assim para a dimensão paródica e satírica do universo recriado no romance. Licas não exibe, por si próprio, este mesmo brilho (pseudo)intelectual, mas a morte efectiva a que se verá sujeito acabará por inspirar noutros - especialmente em Encólpio - amargas reflexões sobre a existência humana que ajudam a cumprir, à

\footnotetext{
*leo@fl.uc.pt

** Agradeço aos demais organizadores a gentileza de me haver convidado para participar neste volume. Na análise proposta da relação entre poder e morte, foi recuperado o essencial da abordagem feita em LEÃO, 1998a, p.99-117, embora com reformulações e inclusão de novos argumentos.
} 


\section{Poder, Sabedoria e Finitude no Satyricon de Petrónio}

sua maneira, este mesmo perfil de uma sabedoria que ora procura impor-se pelas palavras ora decorre da vivência de situações extremas. A análise proposta ao longo deste estudo assentará, por conseguinte, na abordagem do padrão estabelecido por estas três personagens, tendo por fio condutor a maneira como a imagem do poder se articula com o tema da finitude humana e com o tipo de ensinamentos que podem inspirar em quem vive ou simplesmente testemunha essa tensão dialógica.

\section{Trimalquião}

Um tema tradicional, que encontra um notável tratamento no Satyricon, é o motivo dos 'caçadores de heranças'. O mote dos heredipetae pressupõe três realidades diferentes, mas correlativas: o poder inerente a quem é rico; a hora da morte, mais ou menos veladamente desejada pelas pessoas que gravitam à volta da vítima eleita; a falta de herdeiros legítimos, cuja existência comprometeria a possibilidade de se vir a ser contemplado no testamento. Não surpreende, por isso, que este motivo se encontre presente, no todo ou em parte, nas aventuras que envolvem as três personagens eleitas para análise, embora com especial impacto nos casos de Trimalquião e Eumolpo. A crítica tem estudado, sobretudo, Trimalquião, uma atenção justamente atribuída a esta criação petroniana incontornável, protagonista de um episódio igualmente famoso e único: a Cena Trimalchionis. Será aliás por esta parte central da obra que se vai iniciar a análise. Com efeito, a riqueza do liberto - logo secundada pela sua jactância - é imensa. ${ }^{2}$ Muitos são os pormenores, ao longo do Festim, que salientam essa realidade, mas bastará recordar apenas os que forem mais ilustrativos do problema que se pretende discutir. ${ }^{3}$

Um dos testemunhos mais interessantes é facultado por Hérmeros, um conviva que tinha explicado a Encólpio o jogo de palavras encoberto em carpe e Ihe dera informação sobre a incansável Fortunata, a esposa de Trimalquião. ${ }^{4}$ Hérmeros fala de Trimalquião nestes termos (37.8-38.1):

Ipse Trimalchio fundos habet, qua milui uolant, nummorum nummos. Argentum in ostiarii illius cella plus iacet, quam quisquam in fortunis habet. Familia uero babae babae, non mehercules puto decumam partem esse quae dominum suum nouerit. Ad summam, quemuis ex istis babaecalis in rutae folium coniciet. Nec est quod putes illum quicquam emere. Omnia domi nascuntur: lana, citrea, piper; lacte gallinaceum si quaesieris, inuenies.

Quanto a Trimalquião, tem propriedades que se estendem por onde os milhafres andam a espraiar o voo, rios e rios de dinheiro. Há mais prata pelo chão do quarto do seu porteiro, do que muito boa gente tem no seu património. Quanto à criadagem - ora, ora! Tenho para mim, caramba, que nem a décima parte conhece o patrão. Em suma: é bem capaz de enfiar na ponta dum chinelo qualquer um desses lambe-botas. E não vás pensar 
que ele compra seja o que for. É tudo produção da casa: lã, limões, pimenta; leite de galinha, se o pedires, aí o hás-de encontrar.

É natural que o retrato esteja um pouco magnificado, pela evidente admiração que Hérmeros nutre pelo sucesso conseguido por Trimalquião ${ }^{5}$. No entanto, as afirmações que faz parecem confirmar-se: a referência à abundância de objectos em prata é um eco das primeiras impressões de Encólpio ao entrar na casa do seu anfitrião. ${ }^{6}$ Por outro lado, a ideia de que a criadagem era tão numerosa que a maior parte nem conhecia o senhor também se afigura aceitável: nesse sentido aponta o relatório de contas oportunamente exposto no decurso do Festim (53.1-10), ainda que se desconte uma larga margem para o exagero. Por tudo isto, Hérmeros pode afirmar, com satisfação: quemuis ex istis babaecalis in rutae folium coniciet. ${ }^{7}$

Ainda hoje em dia, em meios rurais, a riqueza de um proprietário pode avaliar-se, muitas vezes, pelo facto de não precisar de comprar os bens de primeira necessidade, ideal de autonomia de que apenas os mais ditosos se podem gloriar. Trimalquião, segundo Hérmeros, gozava dessa felicidade doméstica: omnia domi nascuntur: lana, citrea, piper. Em casa dele se encontraria, inclusive, o que para outros seria difícil ou até impossível de achar (lacte gallinaceum, si quaesieris, inuenies). ${ }^{8}$

O poder do anfitrião está presente no próprio nome que Petrónio the atribuiu, certamente para salientar este aspecto da sua personalidade. Trimalquião significará algo como 'três vezes rei' ou 'três vezes poderoso' (cf. SCHMELING, 1969, p.9) ${ }^{9}$. Por outro lado, a presença do radical tri- remete para o número três, que parece ter alguma importância ao longo da obra e que poderá sugerir alguns indícios, ainda que apenas hipotéticos, sobre a real extensão do Satyricon, pois, como se comentava no início deste estudo, as personagens de Trimalquião, Licas e Eumolpo parecem relacionar-se preferencialmente com três espaços urbanos distintos. $^{10}$

Ainda relativamente ao tema do poder de Trimalquião, há, na Cena, um passo particularmente rico para a história do fundo económico e social deste período da época imperial. Trata-se do momento em que o liberto, zangado com a esposa, Fortunata, começa a ceder às instâncias dos amigos para que esqueça o incidente doméstico. Esporeado por esta escaramuça familiar que Ihe garantira, uma vez mais, a atenção geral, o anfitrião resolve narrar a história da sua vida (75.8-77.6). ${ }^{11}$ Vida que constitui um exemplo de aplicação e de pertinácia - o coricillum ('geniqueta do coração') que pulsa em homens de fibra, algo de que se não podem ufanar os scholastici. Essa capacidade empreendedora está bem patente nas suas palavras (76.8): quicquid tangebam, crescebat tamquam fauus. ${ }^{12}$ Trimalquião tem, de resto, plena consciência da importância que a riqueza acumulada representa para o juízo da sociedade (77.6): 
Credite mihi: assem habeas, assem ualeas; habes, habeberis. Sic amicus uester, qui fuit rana, nunc est rex.

Vão por mim: pataca que tenhas, pataca que vales; na conta do que tiveres, é nessa que serás tido. Assim o vosso amigo, que já foi rã, agora é rei.

Por isso, Trimalquião não tem ilusões. Sabe que a consideração de que desfruta e os sorrisos amáveis que todos lhe dispensam se dirigem, de preferência, ao seu dinheiro. Fora aliás essa realidade algo amarga que ele deixara entrever, pouco antes, ao escudar-se nas palavras do mathematicus ${ }^{13}$ Serapas $(77.1-2)$ :

"Tu dominam tuam de rebus illis fecisti. Tu parum felix in amicos es. Nemo umquam tibi parem gratiam refert. Tu latifundia possides. Tu uiperam sub ala nutricas." Et, quod uobis non dixerim, etiam nunc mi restare uitae annos triginta et menses quattuor et dies duos.

«Tu empalmaste a patroa com os favorzinhos que sabemos. Tu tens pouca sorte com os amigos. Nunca ninguém te agradece à medida do teu favor. Tu és dono de grandes propriedades. Tu alimentas uma víbora no peito.» $E$ acrescentou - coisa que nem lhes devia contar - que agora ainda me restam de vida trinta anos e quatro meses e dois dias.

As revelações acumulam-se, com um nexo de causalidade nem sempre claro, como era próprio da linguagem mediática. A relação, contudo, existe. 0 primeiro dado prende-se com a forma como Trimalquião tinha conseguido entrar nas boas graças da patroa e, de resto, também nas do senhor: a referência maliciosa a de rebus illis abrange as cumplicidades amorosas, mencionadas em 69.3 e 75.11. Depois, sem olhar ao facto de que poderia ofender os convivas, afirma a solidão a que se vê votado e a falta de reconhecimento à altura do seu favor: Tu parum felix in amicos es. Nemo umquam tibi parem gratiam refert. Trimalquião tem a desculpa de estar simplesmente a repetir as palavras do mathematicus, mas, como se verá, no íntimo concordava com elas. Em seguida, é de novo mencionada a riqueza que possui, garantia última da sua importância: $T u$ latifundia possides. Por fim, lança uma frechada a Fortunata, que ainda limpava as lágrimas quentes da discussão: Tu uiperam sub ala nutricas. ${ }^{14}$

A informação que guarda para último lugar, anunciada como novidade e como quem confia um segredo (quod uobis non dixerim), remete para outro traço da personalidade do liberto, patente na preocupação de revelar os anos, meses e dias que ainda terá de vida. Esta obsessão com a morte não se trata propriamente de tanatofilia, como por vezes se afirma, mas antes de tanatofobia. ${ }^{15}$ Nesta linha se integra, também, a superstição, que de forma recorrente o acabrunha. ${ }^{16}$ Trimalquião não fala da morte por esta o atrair, mas simplesmente para sentir a ilusão de que a pode dominar, de que pode prever a sua chegada e as 
consequências que desencadeará. Sobre este aspecto da sua personalidade, embora bastante discutido, convirá relembrar alguns pormenores. ${ }^{17}$

Significativa e reveladora da forma como Petrónio trabalhou esta personagem é a primeira caracterização indirecta feita, na antecâmara do Festim, por unus seruus Agamemnonis, que vem dizer a Encólpio e aos amigos onde irão comer naquela noite (26.9):

"Quid? Vos» - inquit - «nescitis, hodie apud quem fiat? Trimalchio, lautissimus homo ... horologium in triclinio et bucinatorem habet subornatum, ut subinde sciat, quantum de uita perdiderit.»

«Então?» - atalhou ele - "Vocês não sabem em casa de quem se faz hoje a festa? É Trimalquião, um tipo cheio de classe, que tem, na sala de jantar, um relógio e um corneteiro todo aperaltado, para saber, a cada momento, quanto tempo da sua vida se escoou.»

Além da nota passageira, relativa ao presumível refinamento de Trimalquião (lautissimus homo), o traço que o escravo salienta como 'cartão de visita' é o facto de o futuro anfitrião ter sempre à disposição um corneteiro pessoal. $^{18} \mathrm{O}$ servo de Agamémnon menciona este aspecto certamente para salientar a excentricidade do liberto, mas o seu significado tem seguramente implicações mais profundas que se tornam evidentes quando o servo explica a razão de ser da existência deste pormenor: ut subinde sciat, quantum de uita perdiderit. $^{19}$

Este padrão torna-se mais consistente à medida que o banquete vai avançando. Em certa altura, Trimalquião ordena que tragam para a mesa um esqueleto de prata articulado (34.8), que lança sobre a mesa, de maneira a levá-lo a assumir diferentes posições, fazendo em seguida considerações várias sobre a caducidade da vida humana. ${ }^{20}$ Encontra-se a mesma ideia na intervenção dos libertos, quando estes falam mais espontaneamente entre si, no momento em que o anfitrião se ausenta da mesa. ${ }^{21}$ Outro tanto se pode afirmar relativamente às histórias narradas no decurso do Festim: a do vidro inquebrável (51.1-6) e a das feiticeiras (63.1-10), ambas contadas por Trimalquião, e a história do lobisomem (61.5-62.14), da responsabilidade de Níceros. ${ }^{22}$ O tema atinge o desenvolvimento máximo com a leitura do testamento do anfitrião (71.1-4), a descrição do seu mausoléu (71.5-12) e, por último, com a teatralização do seu funeral (77.7-78.8) e consequente intervenção do corpo de uigiles. De momento, não interessam tanto os pormenores de cada um destes passos como certas afirmações que Trimalquião faz e que ajudam a reconstituir os seus sentimentos mais sinceros.

Já se viu como ele está bem consciente da circunstância de que o afecto que lhe dispensam vem mesclado de interesses mesquinhos. De resto, o próprio liberto explora essa realidade, quando refere as cláusulas do testamento (71.3): 
Et haec ideo omnia publico, ut familia mea iam nunc sic me amet tamquam mortuum.

E assim, torno públicas todas estas vontades, para que o pessoal da casa me ame, desde agora, como se eu já estivesse morto!

O choro para o qual, por mero impulso mecânico, logo todos se deixam arrastar (71.4) dá ao senhor da casa a ilusão de ser genuinamente amado. No entanto, pouco antes, isento desta efusão sentimentalista, o novo rico tece um comentário que remete para uma consciência da realidade bem mais amarga. A afirmação é feita quando ele dá a ordem de trazerem para a sala de jantar o seu cão, Cílax, praesidium domus familiaeque. ${ }^{23}$ Assim que fazem sentar o animal diante da mesa, o dono toma a atitude seguinte (64.8):

Tum Trimalchio iactans candidum panem, "Nemo» - inquit - «in domo mea me plus amat.»

Foi então que Trimalquião, atirando <ao animal> um pão branco, comentou: «Cá em casa, ninguém me tem mais afeição do que ele.»

O desabafo parece excessivo ao favorito do anfitrião, Creso, que incitou a sua cadelita a desafiar Cílax para a luta, um combate que depressa mostrou ser desigual. ${ }^{24}$ Poderá argumentar-se que a dedicação dos cães aos seus donos é proverbial, pelo menos desde Homero. ${ }^{25}$ É uma objecção válida, mas talvez Trimalquião sentisse, igualmente, que Cílax era o único que Ihe dedicava uma afeição desinteressada. Junte-se a esta possibilidade a reacção que houve no triclínio, quando um dos equilibristas caiu sobre o anfitrião (54.1):

Conclamauit familia, nec minus conuiuae, non propter hominem tam putidum, cuius etiam ceruices fractas libenter uidissent, sed propter malum exitum cenae, ne necesse haberent alienum mortuum plorare.

Desatou a criadagem aos gritos, no que foi seguida pelos convivas: não por causa de um fedorento daqueles, ${ }^{26}$ a quem, de bom grado, veriam o pescoço partido, mas sim pelo mau desfecho do banquete, caso tivessem de chorar um morto que thes era estranho.

O medo de alienum mortuum plorare é generalizado; o Encólpio-narrador não distingue o sentimento dos scholastici do dos outros convivas. Apenas Fortunata parece mostrar genuína preocupação (54.2). Ou seja, a encenação seria partilhada pelos convivas somente até ao ponto em que todos pudessem retirar algum proveito dela, mas basta indiciar com uma primeira contrariedade para se começarem a revelar os reais sentimentos das pessoas envolvidas na representação da farsa. 
Por último, se Trimalquião estivesse certo de vir a ser recordado com saudade, depois de morto, talvez não visse a necessidade de fazer um mausoléu tão sumptuoso como o que arquitectara (71.6 e 71.11):

[....] ut mihi contingat tuo beneficio post mortem uiuere. [....] Horologium in medio, ut quisquis horas inspiciet, uelit nolit, nomen meum legat.

[....] a fim de que eu consiga, através da tua benevolente aplicação, a graça da vida depois da morte. [....] E um relógio ao centro, para que quem vir as horas, com ou sem vontade, tenha de ler o meu nome.

O objectivo é claro: o novo-rico pretende que o seu túmulo seja um verdadeiro monumentum, isto é, algo que lhe assegure um lugar na memória dos vivos (Cf. SCHLANT, 1991, p.51-53). Poderá dizer-se, com razão, que estas ideias mais não exprimem do que a usual jactância do liberto. Mas verdade é, também, que Trimalquião sentia a mágoa de não ter ninguém que continuasse o seu nome e perpetuasse o império por ele conquistado. Esse pesar é revelado na sequência da zanga com Fortunata (74.15-16):

Et ego, homo dipundiarius, sestertium centies accipere potui. Scis tu me non mentiri. Agatho unguentarius proxime seduxit me et "Suadeo," - inquit "non patiaris genus tuum interire." At ego dum bonatus ago et nolo uideri leuis, ipse mihi asciam in crus impegi.

E eu, simplório de dez-réis, que podia ter arrebanhado uns bons dez milhões de sestércios! Tu bem sabes que não estou a inventar. Ainda no outro dia, Agatão, o perfumista, me chamava à parte e me dizia: «Ouve o meu conselho: não deixes que a tua linhagem se extinga.» Mas eu, que vou dando uma de bonzinho e que não quero parecer um sujeito sem palavra, ando a malhar nas canelas.

Trimalquião acabou por não seguir o conselho de Agatão (non patiaris genus tuum interire), talvez por dívida de gratidão a Fortunata, em reconhecimento dos sacrifícios que esta fizera por alturas do desaire inicial dos seus empreendimentos. ${ }^{27}$ Trata-se de um homem que conseguiu singrar na vida, até atingir um lugar de relevo no seu meio, graças à riqueza e ao poder de que a boa sorte o dotou. Apesar de tudo, é um ser inquieto. Sente que a atenção que Ihe dispensam, salvo raras excepções, é mais interesseira que genuína. A sombra da morte tolda-lhe, cada vez mais, os dias, e o liberto ensaia a ilusão de controlar esse momento final, procurando torná-lo presente e adivinhar os efeitos que irá provocar. Mas pesa-lhe que toda a sua vida caia no olvido, pois não tem descendência que the perpetue o nome. ${ }^{28}$ Por isso, procura conquistar um lugar no coração dos mais directos colaboradores e garantir a perenidade no seu monumentum. Trimalquião é, no fundo, simplesmente um homem só e acaso amargurado. A grande lição de vida deste novo-rico consiste na sua notável 
capacidade empreendedora (o coricillum atrás evocado) que o marca e distingue pela positiva em relação ao grupo dos scholastici que ele convida para abrilhantar o Festim. Mas a consciência da finitude e do isolamento com os quais afinal convive acaba por toldar, mais do que a sua falsa erudição, a luz que ilumina esta notável criação petroniana.

\section{Licas}

Se, para a figura anterior, havia inúmeros estudos relativos ao tema em análise, já no caso de Licas a ausência de análises sistemáticas é bastante mais evidente. No entanto, a questão do poder e da morte está nele gravada com incontestável clareza. Uma vez que Licas e Trifena integraram, forçosamente, aventuras da parte não conservada do Satyricon, a informação disponível sobre estas personagens é menos abundante, mas suficiente para a demonstração pretendida.

Uma vez desfeitos os laços de amizade que os uniam a Ascilto, os dois amantes Encólpio e Gíton resolvem embarcar, juntamente com o poeta Eumolpo e o seu mercenário Córax, num navio que se preparava para zarpar. A bordo, Encólpio tenta acalmar o ciúme que Gíton a cada passo lhe inspirava e procura conciliar o sono. Ainda não adormecera e já o afligia um pesadelo, infelizmente de contornos cada vez mais nítidos. Vozes conhecidas o deixaram em alvoroço, bem como ao companheiro. Urgia perguntar a Eumolpo, com fugidia esperança, o nome do dono do barco onde incautamente se tinham deixado encerrar. $O$ velho poeta levou a mal que o importunassem e foi dizendo, em tom de reprimenda (100.6-7):

Hoc erat - inquit - quod placuerat tibi, ut subter constratum nauis occuparemus secretissimum locum, ne nos patereris requiescere? Quid porro ad rem pertinet, si dixero Licham Tarentinum esse dominum huiusce nauigii, qui Tryphaenam exulem Tarentum ferat?

Ah, então era esta - vociferou ele - a veneta que trazias? Assim que estivéssemos instalados no canto mais retirado, debaixo da coberta do navio, tu não nos deixares pregar olho! Que adianta ao caso, se eu disser que o dono deste barco é Licas de Tarento, que a Tarento leva Trifena, a desterrada?

A revelação atingiu-os como um raio desferido pelo pai dos deuses. Não havia salvação aparente. Sem o saber, Eumolpo tinha atraído os dois jovens ao antro do Ciclope, ao senhorio dos seus piores inimigos: Licas e Trifena. Só lhes restava apelar à piedade do poeta, companheiro de letras (101.2): miserere [....] morientium. $^{29}$ 
Mas Eumolpo resistia à acusação e ao apelo, sem ver justificação para tal dramatismo, e dá mais informações sobre o proprietário da embarcação, para se certificarem de que falavam de pessoas diferentes (101.4-5):

Quae autem hic insidiae sunt - inquit - aut quis nobiscum Hannibal nauigat? Lichas Tarentinus, homo uerecundissimus et non tantum huius nauigii dominus quod regit, sed fundorum etiam aliquot et familiae negotiantis, onus deferendum ad mercatum conducit. Hic est Cyclops ille et archipirata, cui uecturam debemus; et praeter hunc Tryphaena, omnium feminarum formosissima, quae uoluptatis causa huc atque illuc uectatur.

Mas afinal, que justifica agora estas aflições - inquiriu -, ou quem será esse Aníbal que connosco viaja? Licas de Tarento, homem de muito respeito, e que não é só dono deste barco que governa, como também senhor de algumas propriedades e de uma casa de comércio, e que trata o transporte de cargas para o mercado. Aí têm o Ciclope e o chefe de piratas ao qual devemos esta viagem! $E$, além dele, Trifena, a mais bela de todas as mulheres, que passa o tempo a viajar de um lado para o outro, só por diversão.

O passo torna claro o poder de Licas, já indiciado através do medo que infundia em Encólpio e Gíton, embora este receio também pudesse ser explicado pela consciência pesada devido a alguma afronta que os dois jovens contra ele tivessem cometido e pela possível crueldade do capitão. ${ }^{30}$ Ainda assim o poder de Licas parece constituir um traço seguro, como se depreende do facto de Eumolpo referir a consideração social de que o capitão gozava e os bens que possuía, derivados por certo da actividade a que se dedicava.

Logo a seguir a esta revelação, Gíton esclarece a Eumolpo o motivo por detrás do temor que os invadia (101.6): hi sunt [....] quos fugimus. ${ }^{31}$ Por conseguinte, a medida que urgia agora empreender era encontrar uma forma de escapar à vista destes inimigos. Vários planos são propostos e rejeitados; por fim, escolhem exactamente a solução que viria a expor o seu disfarce. Decidem vestir a pele de escravos fugitivos, e têm, para isso, de se despojar das suas cabeleiras. É neste acto - voto supremo dos náufragos e, por tal motivo, um sinal de mau agoiro $^{32}$ - que são surpreendidos por um passageiro enjoado (103.5-6), o qual, de manhã, os denuncia ao capitão (104.5). Licas decide castigar os faltosos com boa dose de vergastadas e é nesse momento que se descobre a verdadeira identidade de Encólpio e de Gíton (105.5-11). Os ânimos exaltam-se e os passageiros dividem-se em duas facções: uns apoiam, outros atacam os impostores. As feridas - ligeiras - começam a aparecer, até que a intervenção radical de Gíton, seguido de Trifena e do piloto do barco (108.9-14), põe fim à peleja: o dux Eumolpos (109.1) aproveita a ocasião para firmar um tratado de paz.

Os ânimos arrefecem e a calmaria do mar convida, igualmente, à confraternização. Come-se, bebe-se e não faltam, sequer, as histórias picantes 
que despertam os apetites e as risadas sonoras. Mas, entretanto, não se toldara apenas o coração de Encólpio. O céu carregou o semblante e o mar respondeu com agitação crescente ao desafio das nuvens e dos ventos. Vão seria o esforço dos homens: o barco baloiçava, como frágil folha, segundo o capricho das ondas. O naufrágio era inevitável. Licas, o capitão, não foi o último a abandonar o barco como ditava o regulamento -, mas antes o primeiro. O vento arrojou-o ao mar e logo uma onda lhe deu o abraço letal (114.6). Navio, equipagem e passageiros, todos se tornaram presa das águas. ${ }^{33}$

Se o destino dos outros não se vislumbra com clareza (o texto apresenta várias lacunas), certo é que Encólpio, Gíton, Eumolpo e Córax conseguem atingir a costa, ainda que desfalecidos por experiência tão traumatizante. Pela manhã, as ondas devolvem à terra o corpo de alguém que não tivera a mesma sorte (115.911):

Hunc forsitan - proclamo - in aliqua parte terrarum secura expectat uxor, forsitan ignarus tempestatis filius aut pater; utique reliquit aliquem, cui proficiscens osculum dedit. Haec sunt consilia mortalium, haec uota magnarum cogitationum. En homo quemadmodum natat!

Adhuc tamquam ignotum deflebam, cum inuiolatum os fluctus conuertit in terram, agnouique terribilem paulo ante et implacabilem Licham pedibus meis paene subiectum.

A este, quem sabe, - exclamo em alta voz - nalgum lugar da terra, o está aguardando a mulher, posta em sossego, quem sabe se um filho, desconhecedor da tempestade, ou então um pai; em todo o caso, alguma pessoa deixou, a quem, ao partir, deu um beijo. São estes os desígnios dos mortais, estes os seus votos de grandeza! É ver em que mar de incertezas o homem flutua!

Continuava a lamentá-lo como a um desconhecido, quando a rebentação das ondas virou para terra o rosto dele, ainda não desfigurado: foi então que reconheci Licas - pouco antes, terrível e implacável -, prostrado, quase, a meus pés.

Encólpio começa por não reconhecer a identidade do cadáver que vê a boiar na água, mas deixa-se inundar, ainda assim, por um sentimento de compaixão, de solidariedade para com aquela pessoa, falecida longe da família, que por conseguinte ignorava a notícia do infortúnio. ${ }^{34}$ Mas, por outro lado, esta evocação dos familiares ilustra também o privilégio que é poder contar com alguém que, mais tarde ou mais cedo, chore a dor da ausência de algum ente querido. Decorrentes destas considerações, seguem-se, naturalmente, reflexões sobre a precariedade dos desígnios humanos: haec sunt consilia mortalium, haec uota magnarum cogitationum. Este pessimismo não é introduzido de forma artificial: está em consonância com a gravidade do momento. O desabafo final (En homo quemadmodum natat!), se bem que sugerido pela visão daquele corpo 
arrastado ao sabor das ondas, é um comentário genérico sobre as incertezas da existência humana. No mar da vida, frequentes são os escolhos e as tempestades que assaltam de improviso o homuncio e o fazem compreender que não é, afinal, timoneiro seguro da sua navegação. Há, quantas vezes, forças superiores que funcionam como correntes contrárias que se não detêm perante a resistência que Ihes seja oferecida.

Mas a surpresa maior ainda estava para vir. Revela-se quando a ondulação faz virar o rosto do náufrago e Encólpio reconhece o implacável Licas. O poder e a arrogância, que, pouco antes, tornavam Licas num homem temido e num perigoso inimigo, depressa se viram transfigurados pela existência mais humilde de todas, a inerte sujeição ao inimigo: pedibus meis paene subiectum.

Esta situação de abandono poderá talvez ser agravada devido ao isolamento de Licas. Na parte conservada do romance, não se lhe refere outro familiar que não seja Hédile, ${ }^{35}$ a qual, possivelmente em consequência de uma anterior ligação com Encólpio, não mais o acompanha. A aceitar-se esta hipótese, Licas não tinha, à semelhança de Trimalquião, quem lhe perpetuasse o nome e a linhagem. O liberto procurara, ao menos, assegurar um funeral condigno. O capitão do navio naufragado nem isso conseguira predispor (115.20):

Et Licham quidem rogus inimicis collatus manibus adolebat. Eumolpus autem dum epigramma mortuo facit, oculos ad arcessendos sensus longius mittit.

Quanto a Licas, a esse o consumia uma pira, erguida pela mão dos seus inimigos. Eumolpo, contudo, enquanto compõe um epicédio para o morto, alonga a vista pela distância do horizonte, em busca de inspiração.

São os inimigos confessos de Licas, amolecidos por sentimentos humanitários inspirados por aquela situação extrema, que lhe garantem as honras derradeiras. Tal como acontecera com Trimalquião, a arrogância do poder convive de perto com a imagem da morte - ainda que neste caso seja cruel e bem real, e não uma miragem que em vão procura ser controlada pela teatralização. À sua maneira, Trimalquião procurara sintetizar várias lições de vida, que dispensava aos convivas que atraíra ao labirinto da sua casa. Licas não parece cultivar de forma deliberada arroubos de sapiente, mas a sua morte acaba por inspirar aos antigos inimigos idêntico tipo de reflexões amargas sobre a humana finitude.

\section{Eumolpo}

No texto evocado no final da secção anterior, Eumolpo tentava compor um epitáfio em homenagem a Licas e, para isso, ia espraiando a vista pelo horizonte, provavelmente em busca de inspiração. Esta atitude é normal num poeta e, por conseguinte, o seu entendimento pode esgotar-se nessa interpretação mais imediata. Mas talvez, no seu íntimo, o Bom Cantor se preparasse para a 


\section{Poder, Sabedoria e Finitude no Satyricon de Petrónio}

eventualidade de vir, também ele, a protagonizar um fecho semelhante, como viria de facto a acontecer algum tempo depois. Na realidade, uma vez refeitos do susto do naufrágio, os sobreviventes metem-se ao caminho e, horas depois, avistam uma cidade, cuja identidade Ihes é desconhecida. Obtêm então de certo uilicus a explicação de que se trata de Crotona, centro urbano outrora florescente, mas agora infestado de heredipetae (116.1-9). Eumolpo vê nesta praga dos 'caçadores de heranças' a oportunidade ideal para inverter a lógica desta forma de exploração social instituída e transformar os captatores em captati. A fim de pôr o plano em acção, necessita da conivência dos companheiros (Córax, Encólpio e Gíton), que prontamente aceitam fazer o papel de escravos de Eumolpo e, assim, contribuir para a ficção engendrada. ${ }^{36} \mathrm{Na}$ montagem da comédia, nenhum pormenor é descurado (117.6-8):

Post peractum sacramentum seruiliter ficti dominum consalutamus,
elatumque ab Eumolpo filium pariter condiscimus, iuuenem ingentis
eloquentiae et spei, ideoque de ciuitate sua miserrimum senem exisse, ne
aut clientes sodalesque filii sui aut sepulcrum quotidie causam lacrimarum
cerneret. Accessisse huic tristitiae proximum naufragium, quo amplius uicies
sestertium amiserit; nec illum iactura moueri, sed destitutum ministerio non
agnoscere dignitatem suam. Praeterea habere in Africa trecenties
sestertium fundis nominibusque depositum; nam familiam quidem tam
magnam per agros Numidiae esse sparsam, ut possit uel Carthaginem
capere.

Depois de prestarmos juramento e de nos disfarçarmos de escravos, saudámos em coro o nosso amo e aprendemos todos a mesma lição: Eumolpo acabara de perder um filho, jovem de grande eloquência e muito promissor. Por isso, o pobre do velho decidira abandonar a cidade onde habitava, para que nem os amigos e companheiros do filho, nem a visão do seu túmulo fossem, dia após dia, causa de lágrimas. Acrescia a esta desgraça o naufrágio recente, onde perdera mais de dois milhões de sestércios; não o perturbava tanto o prejuízo como a incapacidade para tornar reconhecida a sua posição, agora que estava sem servidores. Possuía, ainda, em África, trinta milhões de sestércios em propriedades e em títulos de crédito. E quanto à criadagem, era tanta a que tinha espalhada pelas suas terras da Numídia, que até poderia tomar Cartago de assalto.

O plano tinha sido cuidadosamente pensado para ir ao encontro das expectativas que, segundo informação do uilicus, os heredipetae partilhavam. ${ }^{37}$ Primeiro, a perda recente do filho, desgosto ainda mais pungente, porquanto havia que tomar em conta as promissoras qualidades do falecido. A mágoa inconsolável levara o pai a evitar tudo o que pudesse avivar a recordação da tragédia; para espairecer, decidira viajar, mas a sorte, uma vez mais, Ihe fora desfavorável, acrescentando às suas desgraças o agravo de um naufrágio recente. 
Até aqui, a invenção procurava tornar o episódio verosímil e espevitar o interesse dos heredipetae, na ânsia, certamente, de que estes começos auspiciosos se vissem confirmados pelo factor mais importante: a desejada riqueza que pudesse servir de saque. E ela aí estava, nédia e luzidia; já podiam esfregar as mãos de contentamento. Apesar das avultadas perdas no naufrágio, os bens do velho atingiam ainda proporções quase lendárias.

O cozinhado tinha todos os ingredientes para agradar aos captatores. E assim aconteceu (124.2-4). Ao poeta-contista-burlador-pai extremoso uma coisa pesava mais do que a perda dos haveres no naufrágio: a incapacidade de conseguir o reconhecimento público da sua dignidade, agora que se encontrava sem servidores que pudessem fazer prova solene da sua importância. E é neste momento que os caçadores de heranças passam de predadores a presas, pois logo se disponibilizaram para conceder ao velho todas as necessárias prodigalidades, enquanto Ihe não chegassem reforços de casa.

O tema dos captatores captati é um dos mais tratados na tradição satírica $^{38}$ e Petrónio decerto o teve presente na construção das aventuras em Crotona. Contudo, também no caso de Eumolpo se detecta, de forma clara, a exploração do motivo que tem vindo a ser analisado. Embora a sua fortuna e poder comecem por ser fictícios, a verdade é que, pouco tempo decorrido, se tornam reais, em consequência das liberalidades dos caçadores de heranças. $O$ próprio Encólpio, mais alegre e viçoso com a vida fácil que agora levava, o reconhece claramente (125.1): ${ }^{39}$

Eumolpus felicitate plenus prioris fortunae esset oblitus adeo ut tsuist iactaret neminem gratiae suae ibi posse resistere impuneque suos, si quid deliquissent, beneficio amicorum laturos.

Eumolpo, inchado com a presente abundância, tinha-se esquecido das misérias passadas, a ponto de se vangloriar aos da casa de que ninguém ali poderia escapar à sua influência e de que, se eles cometessem algum delito, ficariam impunes, graças à intervenção dos seus amigos.

O mesmo Encólpio, porém, logo depois de fazer estas reflexões, dá voz ao receio de que a sorte deixasse talvez de lhes ser favorável e o engano se tornasse conhecido (125.3-4). ${ }^{40}$ Efectivamente, a situação ameaçava alterar-se, porque Eumolpo não retribuía a generosidade dos heredipetae e estes começavam a refrear as larguezas (141.1), ou até porque o estado de saúde do velho parecia terse mesmo degradado, aproximando-se o dia da sua morte. Inicialmente, a doença fazia parte da ficção criada. ${ }^{41}$ Podia, assim, acontecer que o velho estivesse apenas a tentar ganhar tempo até encontrar a melhor oportunidade para se pôr em fuga, juntamente com os mais directos colaboradores. Mas a hipótese de que, desta vez, a debilidade física fosse real está mais de acordo com o modelo analisado para Trimalquião e Licas, pois estabelece um paralelo com o 
encerramento das aventuras vividas na Graeca urbs e no mar, ao fazer uma conexão entre poder e finitude. A verificar-se esta hipótese, o testamento de Eumolpo constituiria a sua derradeira e maior falácia. Vale a pena recordar os termos em que está elaborado (141.2-4):

Omnes qui in testamento meo legata habent, praeter libertos meos, hac condicione percipient quae dedi, si corpus meum in partes conciderint et, astante populo, comederint... Apud quasdam gentes scimus adhuc legem seruari, ut a propinquis suis consumantur defuncti, adeo quidem ut obiurgentur aegri frequenter, quod carnem suam faciant peiorem. his admoneo amicos meos ne recusent quae iubeo, sed quibus animis deuouerint spiritum meum, eisdem etiam corpus consumant...

Todos os que são contemplados no meu testamento, à excepção dos meus libertos, só entrarão na posse dos bens que Ihes leguei com esta condição: cortarem em pedaços o meu corpo e, na presença do povo, o devorarem... Sabemos que, entre certos povos, ainda agora se observa o costume de que os defuntos sejam comidos pelos familiares, a ponto de, frequentemente, os enfermos serem repreendidos por estragarem a qualidade das próprias carnes. Com isto aconselho os meus amigos a não recusarem fazer o que Ihes proponho. Pelo contrário, com o mesmo ânimo com que desejaram o meu último suspiro, dêem agora conta do meu corpo...

Aos que se afadigavam à sua volta, na ânsia de conseguirem presa de vulto, mais não será deixado que um corpo velho, curtido pelos anos, e a consciência de haverem sido enganados por quem projectavam burlar. Com efeito, os heredipetae estavam cegos pela fama da riqueza de Eumolpo, pelo que bem depressa houve quem estivesse disposto a seguir a cláusula do testamento ${ }^{42}$. A situação é tanto mais significativa se se tiver em consideração que este último episódio acontece em Crotona, antigo bastião do pitagorismo. Segundo as palavras do uilicus (116.9), a cidade, infestada pela praga dos caçadores de heranças, assemelha-se a um campo semeado de morte. Recorde-se que a questão da morte levantava algumas reservas aos pitagóricos. ${ }^{43}$ Por outro lado, esta corrente filosófica era partidária do vegetarianismo. ${ }^{44}$ No entanto, ao arrepio dessa antiga tradição, os Crotoniatas não só se alimentam de carne $(136.1 ; 137.12)$ como vão ainda mais longe: levam a avidez pelo dinheiro ao ponto de não recuarem perante uma condição que pressupõe, para ser satisfeita, a antropofagia. Mesmo admitindo que Petrónio esteja a parodiar um topos da retórica, torna-se difícil não considerar profundamente trágica e pessimista a cena final do Satyricon.

Esta interpretação ganha a devida consistência quando aliada aos exemplos de Trimalquião e de Licas. Estes dois e Eumolpo são as personagens de quem se diz mais claramente que detêm grande poder. Curiosamente, nenhum deles o exerce ao mesmo tempo que outro. A cada um corresponde determinado 
espaço geográfico onde se faz sentir a sua influência: a escuridão da Graeca urbs, o barco no mar imenso, a claridade impudica de Crotona. E apenas quando termina a força de um se começa a sentir a do seguinte. De forma obstinada, também, convivem com a imagem da solidão ${ }^{45}$ e da finitude humana.

Trimalquião procura controlar esse momento derradeiro através de previsões e ensaios cénicos de quando e como será a sua partida para o mundo do Além. E o lugar que não terá no coração dos homens procura garanti-lo na grandeza do seu monumentum fúnebre.

Licas tenta fugir a um destino marcado, observando, com fervor religioso, presságios e admonições divinas. No entanto, o mesmo vento que impelia as velas das suas embarcações o empurra para o abraço mortal das vagas enfurecidas. Não tem pai, mulher, filho que o chorem no momento da despedida, e serão mãos inimigas que se encarregarão de erguer a pira, que lhe resgate a passagem para outra dimensão.

Eumolpo toda a vida foi um aventureiro. A única riqueza com que acenava era o brilho do intelecto, que amargos dissabores lhe causou e também algumas alegrias. Em Crotona, vai passar os últimos dias da vida como o rei que os heredipetae julgavam que ele era. E será, certamente, recordado. Pelos companheiros de aventura, que simbolicamente liberta, à hora da morte (talvez para uma existência menos atribulada); pelos captatores, que nunca hão-de ser capazes de digerir o ludíbrio, maior ainda que a pretensa riqueza do velho. $A$ ironia suprema do testamento de Eumolpo mostra ainda que ele foi capaz de ser bem sucedido num campo onde outros scholastici haviam falhado: por ter a capacidade para se adaptar a circunstâncias desfavoráveis e delas retirar proveito próprio. Essa aptidão fica a dever-se, antes de mais, à própria experiência decorrente da idade, mas também a um tipo de habilidade que levou a que ele fosse várias vezes visto (de forma paródica ou não) como um sábio, émulo de Sólon ou de Sócrates, capaz de exercer uma influência positiva sobre quem com ele convivia. ${ }^{46}$ Por conseguinte, em Eumolpo identifica-se também este aspecto analisado já para Trimalquião e Licas: o de incarnar ou estimular determinado tipo de reflexão sapiencial. De resto, a consciência cristalizada do jogo que alimenta os interesses mundanos aproxima em particular o liberto e o velho poeta, embora por vias bastante distintas. Trimalquião, herdeiro de um carácter eminentemente prático e sem grandes capacidades eruditas, é um exemplo vivo de realização a nível económico, que se reflecte na projecção social e mesmo política. Eumolpo situa-se no extremo oposto; deve identificar-se com o grupo dos intelectuais, partilhando com estes a vagabundagem e o parasitismo existencial, embora não se lhe possa apontar a ingenuidade dos jovens scholastici (sobretudo de Encólpio), sendo também ele representante de um tipo de sabedoria ambivalente e até certo ponto bem sucedida. 
Através destas três notáveis criações literárias, Petrónio dá um elucidativo exemplo da forma como o poder (real ou teatralizado) convive com a imagem da efemeridade das coisas humanas, e do tipo de moralidade mundana que resulta da actuação dessas personagens, facultando também um desenho muito expressivo da sociedade romana no primeiro século da era cristã.

\section{Bibliografia citada}

ANDERSON, G. Trimalchio at Sousa-on-sea. AJPh 102, p.50-53, 1981.

ARROWSMITH, W. Luxury and death in the Satyricon. Arion 5, p.304-331, 1966.

BAJONI, M.G. La scena comica dell' irrazionale (Petr., 61-63 e Apul., Met., 1.6-19 e 2.21-30). Latomus 49, p.148-153, 1990.

BALDWIN, B. Trimalchio's domestic staff. Acta Classica 21, p.87-97, 1978.

BARCHIESI, A. II nome di Lica e la poetica dei nomi in Petronio. MD 12, p.169-175, 1984.

BARCHIESI, M. L'orologio di Trimalcione (struttura e tempo narrativo in Petronio). In: I moderni alla ricerca di Enea. Roma: Bulzoni, 1981, p.109-146.

BORGHINI, A. Lupo mannaro: il tempo della metamorfosi (Petr. Satyr. 62.3). Aufidus 14, p.29-32, 1991.

BRAVO GARCÍA, A. El Satiricón como reflejo de la esclavitud de su tiempo. CFC 6, p.195208, 1974.

CAMERON, A.M. Myth and meaning in Petronius: some modern comparisons. Latomus 29, p.397-425, 1970.

CAMERON, H. D. The Sibyl in the Satyricon. CJ 65, p.337-339, 1970.

CASTORINA, E. La lingua di Petronio e la figura di Trimalchione. SicGymn 26, p.18-40, 1973.

CONTE, G.B. Petronio, Sat. 141: una congettura e un'interpretazione. RFIC 120, p.300-312, 1992.

DUMONT, J.Ch. Le décor de Trimalcion. MEFRA 102, p.959-981, 1990.

FEDELI, P. Petronio: Crotone o il mondo alla rovescia. Aufidus 1, p.3-34, 1987.

FEDELI, P. e DIMUNDO, R. I racconti del Satyricon. Roma: Salerno, 1988.

GAGLIARDI, D. Il corteo di Trimalchione. Nota a Petron. 28.4-5. RFIC 112, p.285-287, 1984.

GAGLIARDI, D. Il tema della morte nella Cena petroniana. Orpheus 10, p.13-25, 1989.

GAGLIARDI, D. L'umanità di Trimalchione (Satyricon 76-77). Orpheus 15, p.13-20, 1994.

HORSFALL, N. 'The uses of literacy' and the Cena Trimalchionis. G\&R 36, p.74-89, 1989.

KNOCHE, U. Die römische Satire. Trad. ital. La satira romana. Brescia: Paideia, 1969.

LABATE, M. Di nuovo sulla poetica dei nomi in Petronio: Corax 'il delatore'?. MD 16, p.135146, 1986.

LEÃO, D.F. Uma história de feiticeiras. Boletim de Estudos Clássicos 24, p.49-54, 1995.

LEÃO, D.F. Trimalquião: a humanitas de um novo-rico. Humanitas 48, p.161-182, 1996a.

LEÃO, D.F. Petrónio e Süskind: o desfecho canibalesco. Boletim de Estudos Clássicos 26, p.102-121, 1996b.

LEÃO, D.F. Satyricon (117): encenação de uma comédia. Boletim de Estudos Clássicos 27, p.38-44, 1997.

LEÃO, D.F. As ironias da Fortuna. Sátira e moralidade no 'Satyricon' de Petrónio. Lisboa: Edições Cilibri, 1998a.

LEÃO, D.F. Sólon e Eumolpo: a degradação do modelo. Humanitas 50, p.127-149, 1998b. 
LEÃO, D.F. Petrónio. Satyricon. Tradução do latim e introdução. 2a ed., Lisboa: Cotovia, 2006a.

LEÃO, D.F. Petrónio e a inconstância dos pueri delicati. Humanitas 58, p.119-131, 2006b.

LEEMAN, A.D. Morte e scambio nel romanzo picaresco di Petronio. GIF 20, p.147-157, 1967.

MARTIN, R. La Cena Trimalchionis: les trois niveaux d'un festin. BAGB, p.232-247, 1988.

MARTINI, R. Corax mercennarius Eumolpi. Labeo 7, p.341-348, 1961.

MARZULLO, A. Elementi satirici e popolareschi nella Cena Trimalchionis. Atti e Mem. Accad. di Scienze. Lett. ed Arti di Modena 1, p.175-227, 1959.

MÜLLER, K. e EHLERS, W. Petronius, Satyrica. 4a ed.Munique: Artemis \& Winkler, 1995.

NARDOMARINO, F. Petronio, Satyricon 141: il testamento e la scelta necrofagica. Aufidus 11-12, p.25-59, 1990.

PERROCHAT, P. Mentalité et expression populaires dans la Cena Trimalchionis. IL 13, p.6269, 1961.

RANKIN, H.D. Petronius the artist. Essays on the Satyricon and its author. The Hague: Martinus Nijhoff, 1971.

SCAROLA, M. Un naufragio da capelli (Petronio, Sat. 101-115). AFLB 29, p.39-56, 1986.

SCHLANT, E. Petronius: our contemporary. Helios 18, p.49-71, 1991.

SCHMELING, G. The literary use of names in Petronius' Satyricon. RSC 17, p.5-10, 1969.

SEGURA RAMOS, B. El 'tempo' narrativo de la Cena Trimalchionis. Emerita 44, p.143-155, 1976.

SHEY, H.J. Petronius and Plato's Gorgias. CB 47, p.81-84, 1971.

SULLIVAN, J.P. The Satyricon of Petronius. A literary study. Trad. ital. II Satyricon di Petronio. Uno studio letterario. Firenze: La Nuova Italia, 1977.

TRACY, V.A. Aut captantur aut captant. Latomus 39, p.399-402, 1980.

VEYNE, P. La Vénus de Trimalcion. Latomus 23, p.802-806, 1964.

VEYNE, P. La société romaine. Paris: Seuil, 1990.

WALSH, P.G. The Roman novel. The Satyricon of Petronius and the Metamorphoses of Apuleius. Cambridge: Cambridge University Press, 1970.

\footnotetext{
Notas

${ }^{1}$ É uma hipótese antiga e largamente difundida. É certo que o encontro de Encólpio com Licas também pode ter-se verificado na Campânia ou de qualquer modo, como a profissão de armador requer, em uma cidade portuária. Sobre esta discussão, vide KNOCHE, 1969, p.135-137; SULLIVAN, 1977, p.30-32.

2 Não são convincentes tentativas, como a de BALDWIN, 1978, para diminuírem drasticamente essa realidade.

${ }^{3}$ Para outros exemplos, vide e.g. 28.7-8; 29.3-8; 30.2-3; 32.4; 33.2; 34.2-3; 47.11-13; 52.1. Algumas das referências são, certamente, hiperbólicas, servindo por conseguinte para caracterizar a megalomania do liberto: 48.1-3; 53.1-10; 67.7-8.

${ }^{4} 36.5-8$ e $37.1-8$, respectivamente. Do senhor da casa, já tinha dito (37.6): ipse nescit quid habeat, adeo saplutus est ('ele nem sabe o que possui, podre de rico como é'). Para as citações, adopta-se MÜLLER e EHLERS, 1995; para a tradução, LEÃO, $2006 a$.
} 
${ }^{5}$ Notar que é o mesmo Hérmeros quem, mais adiante (57.1-58.14), fica encolerizado perante a falta de decoro que Ascilto e Gíton mostram ter à mesa, certamente toldados pela bebida. Contudo, esta reacção do liberto também pode constituir apenas um sentimento de solidariedade por alguém que é da mesma classe, contra outras pessoas que o não são.

${ }^{6}$ Cf. 28.8: In aditu autem ipso stabat ostiarius prasinatus, cerasino succinctus cingulo, atque in lance argentea pisum purgabat. 'Precisamente à entrada, encontrava-se especado o porteiro, de farda verde, apertado num cinto cor de cereja, a descascar ervilhas para uma travessa de prata.'

${ }^{7}$ Será curioso recordar que é contra um desses possíveis 'parasitas' ou 'aduladores' - de que fazem parte os scholastici - que Hérmeros se indigna. A argumentação com que atacará Ascilto não se desvia muito desta consciência da superioridade patrimonial.

${ }^{8}$ A frase alude, obviamente, a uma impossibilidade proverbial.

9 A preocupação do liberto em se rodear de nomes propiciatórios (como a esposa Fortunata ou o puer delicatus Creso) remete, em última análise, para a sua superstição, um traço que partilha aliás com os demais ex-escravos. Sobre o nome de Trimalquião, vide ainda WALSH, 1970, p.114; ANDERSON, 1981, p.50. Interpretação depreciativa do nome em CASTORINA, 1973, p.22-23 e n.16.

${ }^{10}$ Se o enredo do Satyricon estivesse ligado a estes três espaços geográficos, a parte perdida seria, essencialmente, a primeira, já que, morto Eumolpo, o final do romance estaria próximo. Sobre a possível simbologia do número três e do esquema da triplicação aplicado a vários dos episódios da obra, vide LEÃO, 1998a, p.57-58. Relativamente aos três níveis de leitura que permite o banquete do liberto, vide MARTIN, 1988, p.242-244.

${ }^{11}$ Sobre o universo de interesses do Festim e sobre a questão do poder de Trimalquião, vide MARZULLO, 1959; PERROCHAT, 1961, p.62-69; VEYNE, 1964; 1990; BRAVO GARCÍA, 1974; SEGURA RAMOS, 1976; HORSFALL, 1989; DUMONT, 1990.

12 'Tudo o que eu tocava, crescia que nem favo de mel.'

${ }^{13}$ Costuma traduzir-se o termo por 'astrólogo', 'adivinho'; e essa é, provavelmente, a acepção que assume neste contexto. Mas não deixa de ser significativo salientar que havia duas categorias de pitagóricos: os acusmatici e os mathematici, de alguma forma ligados à cidade de Crotona. Embora a conexão estabelecida por Serapas seja ténue, é possível que este seja mais um pormenor a aproximar Trimalquião das aventuras passadas em Crotona.

${ }^{14}$ Cf. 75.9 e 77.4: uiperae huius sessorium ('a sala de estar desta víbora').

${ }^{15}$ Convém reconhecer, apesar de tudo, que, à força de procurar tornar conhecida uma realidade futura, se vai entrando na sua intimidade e ganhando por ela uma espécie de simpatia (que não é, forçosamente, atracção).

${ }^{16}$ E.g. 30.4-6; 32.3; 39.8; 64.1; 74.1-5. Vide observações em CASTORINA, 1973, p.36-38.

${ }^{17}$ Entre os numerosos estudos consagrados a esta debatida questão, vide ARROWSMITH, 1966; LEEMAN, 1967; A. M. CAMERON, 1970; H. D. CAMERON, 1970; GAGLIARDI, 1989; SCHLANT, 1991. GAGLIARDI, 1984, sugere que a comitiva que acompanha o liberto desde as termas públicas até sua casa, no início do Festim, possui (286) «la facies d'un piccolo corteo funebre, nel quale Trimalchione sembra aver l'aria del defunto accompagnato all'estrema dimora». É uma hipótese curiosa, que se integra na economia do episódio, mas não absolutamente necessária. 
${ }^{18}$ Sobre a discutível 'elegância' e 'erudição' de Trimalquião, vide LEÃO, $1996 a$.

${ }^{19}$ Quando o leitor toma conhecimento da previsão de Serapas, não pode deixar de pensar que Trimalquião está a fazer a contagem decrescente do tempo que lhe resta de vida. Sobre a importância simbólica do relógio, vide BARCHIESI, 1981, p.109-146.

${ }^{20}$ Vários outros passos reflectem perspectiva semelhante. E.g. 34.6-7; 39.13; 48.8; 55.1-3; $65.5 ; 65.10-11$.

${ }^{21}$ Cf. $41.10-12 ; 42.1-7 ; 43.6-8 ; 44.1$ sqq.; 45.1 sqq.

22 Sobre esta temática, vide FEDELI E DIMUNDO, 1988, passim; BAJONI, 1990; BORGHINI, 1991; LEÃO, 1995.

${ }^{23}$ 64.7: 'guardião da casa e dos seus habitantes'.

${ }^{24}$ Para uma análise deste e de outros episódios à luz da temática da inconstância dos pueri delicati, vide LEÃO, $2006 b$.

${ }^{25}$ Não tanto na llíada, onde os cães se comportam como animais selvagens que devoram o corpo dos heróis caídos, como na Odisseia, onde se encontra o episódio inesquecível de Argos, cão de Ulisses, o único a reconhecer o dono, que saúda com um aceno de cauda, para logo mergulhar nas sombras da morte (Od. 17.290-327).

${ }^{26}$ Este comentário depreciativo refere-se ao equilibrista e não a Trimalquião.

${ }^{27}$ Cf. 76.7. Sugestão de GAGLIARDI, 1994, p.16 e n.15. Embora o estudioso não trate deste aspecto, a verdade é que, por vezes, Trimalquião parece dar mostras de alguma real filantropia e compreensão: 59.1-2; 64.13; 70.10-71.1; 73.6; 74.6. Outras vezes, contudo, a humanidade aparente destina-se apenas a torná-lo o centro das atenções: 49.3-10; 52.4-6; 54.5. Neste último sentido, o dispensator é um reflexo descolorido do patrão: cf. 30.7-11. Sobre as vertentes da humanitas de Trimalquião, vide LEÃO, $1996 a$.

${ }^{28}$ ARROWSMITH, 1966, p.321-322, salienta que "childlessness is, among the Roman moralists, the typical trait of an unnatural society organized on the principle of luxuria. It is also an overt theme in the Satyricon, culminating in the cannibalism at Croton.»

29 'Tem piedade [....] destes moribundos.'

${ }^{30}$ Uma das interpretações para o nome de Licas é a de 'cruel'. Ele, contudo, afirma não ter esse defeito (106.3). Cf. WALSH, 1970, p.99; para outros significados, vide BARCHIESI, 1984, p.169.

31 'É deles, precisamente, [....] que andamos a fugir.'

32 Já antes tinha havido uma referência à possibilidade do naufrágio (101.7). Curiosamente será esse desastre a pôr fim à aventura com Licas e Trifena, ao menos por aquilo que conhecemos do Satyricon. A ocorrência de um naufrágio estava dentro da tradição do romance grego, que esta obra parcialmente parodia. Por outro lado, BARCHIESI, 1984, p.173-175, retomando uma tese antiga de HEINZE, sugere que Licas está destinado, pelo nome, a morrer no mar, como o Licas do mito de Hércules. O dono do barco parece estar consciente de que o seu nome não é de bom auspício, pois tem o cuidado de atender a todos os possíveis avisos divinos: considera admonitório o sonho de Priapo (104.1-4); manda chicotear, em desagravo à Tutela do navio, os passageiros que cortaram o cabelo (105.4); e à beira do fim, ainda roga a Encólpio que restitua ao barco a veste sacra e o sistro de Ísis (114.5) Mas nem assim consegue escapar às garras do destino. Vide ainda SCAROLA, 1986; LEÃO, $1996 b$. 
${ }^{33}$ Licas é o único de quem se narra expressamente a morte. Trifena é recolhida num bote salva-vidas pelos escravos (114.7) e outros passageiros conseguem auxílio de uns pescadores (114.14). Este tratamento diferente dado a Licas não deve ser gratuito, como adiante se verá.

${ }^{34}$ SULLIVAN, 1977, p.192 sqq., é de opinião que estas considerações de Encólpio mais não constituem do que paródia ao estilo apaixonado de muita da prosa de Séneca, sobretudo das cartas, indicando, para isso, certos paralelos. É uma sugestão pertinente, mas importa reconhecer, da mesma forma, que as ideias expostas neste passo, sobre a instabilidade da vida humana, encontram eco em muitos outros pontos da obra. É essa realidade que permite estabelecer um padrão de pensamento mais sério que o simples nível da paródia.

${ }^{35}$ Será uma dedução defensável de passos como 106.2 e 113.3: Non dubie redierat in animum Hedyle expilatumque libidinosa migratione nauigium. 'Certamente, tinham-lhe vindo à memória a traição de Hédile e a pilhagem do seu navio por aquela súcia de depravados.' Por outro lado, a referência a expilatum nauigium sugere que o episódio ocorreu não em Tarento, de onde Licas é natural, mas em outra cidade portuária onde o navio estava fundeado (Marselha? um porto da Campânia?) e onde teria talvez conhecido Encólpio, Gíton e (porventura antes) Trifena, que levava agora para Tarento.

${ }^{36}$ Para a leitura deste episódio à luz da estratégia de encenação de uma comédia, vide LEÃO, 1997.

${ }^{37}$ Cf. 116.7-8. Resumidamente, só obtinha consideração social quem fosse rico e não tivesse parentes/herdeiros próximos. Melhor ainda: se fosse velho, doente e estivesse à beira da morte, pois nesse caso as expectativas de lucro próximo tornavam-se muito mais sorridentes.

${ }^{38}$ Para outros paralelos, vide WALSH, 1970, p.103-104.

39 Acrescente-se aos pormenores deste passo a informação de que, entretanto, novos escravos tinham sido adquiridos, num indício claro de prosperidade (139.5).

40 Um dos receios era que o criado a soldo, Córax, os viesse a denunciar. Sobre esta hipótese, vide observações de MARTINI, 1961; LABATE, 1986.

${ }^{41}$ Cf. 117.9 e $140.6-9$.

${ }^{42}$ Trata-se de Górgias (141.5), a quem pertence, possivelmente, a argumentação com que termina a parte conservada do Satyricon (141.6-11). Sobre as relações entre o romance e o Górgias platónico, vide SHEY, 1971, p.81-84; CONTE, 1992. Visão da antropofagia como motivo literário em RANKIN, 1971, p.100-105; LEÃO, 1996b. Sobre a questão dos captatores captati, vide TRACY, 1980; NARDOMARINO, 1990.

${ }^{43}$ Conforme assinala NARDOMARINO, 1990, p.57: "L'idea della morte, tanto distante dall'ambiente pitagorico (si ricordi che agli iniziati non era consentito prendere parte ai funerali), diviene onnipresente nella Crotone di Petronio».

${ }^{44}$ Sobre este tema e a forma como contribui para caracterizar Crotona como um 'mondo alla rovescia', vide FEDELI, 1987, esp. p.20-21.

45 No caso de Eumolpo, a solidão é mais virtual que real, pois o velho mostra-se francamente extrovertido e convivente, embora a sua veia poética nem sempre seja bem acolhida.

${ }^{46}$ Para a análise de Eumolpo enquanto incarnação paródica do sapiens, vide LEÃO, $1998 b$. 


\title{
CAYO CALÍGULA: DEL 'CIVILIS PRINCEPS' AL 'SUPERBUS' AUTÓCRATA*
}

\author{
Juan Pablo Alfaro \\ Pontificia Universidad Católica Argentina
}

\section{Introducción}

En marzo del año 37 d.C., tras la muerte del caesar Tiberio Claudio Nerón, los senadores romanos confirieron a su sobrino nieto e hijo adoptivo, Cayo Julio César Germánico, más conocido por su agnomen "Calígula", los poderes públicos más importantes que gozaba su tío abuelo. De esta manera, con tan sólo veinticuatro años de edad, Calígula se constituyó en el princeps civitatis, "primer ciudadano", de Roma y su imperio. En dicho momento, el estado romano estaba organizado políticamente bajo el régimen denominado Principado ${ }^{1}$, en alusión a la posición preeminente que ostentaba el princeps. Esta particular forma de gobierno unipersonal, construida progresivamente por Octaviano el Augusto (63 a.C. - 14 d.C.), fue la consecuencia fundamental del agónico proceso de guerras civiles que puso en jaque a la res publica ${ }^{2}$ romana en el siglo I a.C. El nuevo régimen dio término a estos conflictos que no pudieron ser resueltos en el marco de las instituciones tradicionales. Pero el costo de la nueva pax, fue delegar prácticamente la totalidad del poder en una sola persona: el princeps.

Sin embargo, debido a la oscuridad, parcialidad y contradicciones de las fuentes primarias, una definición precisa y concreta de la naturaleza del poder de Augusto y sus sucesores es difícil de consignar. Los problemas jurídicos que ya en la antigüedad provocó la posición del emperador ${ }^{3}$ y el carácter extraordinario de su poder (PETIT, 1969, p.112 y ss), sugieren que busquemos sus bases, también, en ámbitos ajenos al derecho público. Al respecto, el problema principal lo suscita el hecho que, pese a la instauración del nuevo sistema político, tanto el Senado como las magistraturas, instituciones rectoras del régimen anterior, continuaron formando parte integral de la res publica. El objetivo de esta permanencia ha sido visto por gran parte de la historiografía como una suerte de "fachada republicana" bajo la cual deliberadamente se pretendía ocultar el verdadero carácter autocrático del poder imperial (HOMO, 1928, p.261-263; JONES, 1974, p.103104; GRIMAL, 2000, p.79-80). Pero "fachada" o no, la permanencia de dichas

\footnotetext{
* Ponencia presentada en el $V$ Simposio ADEISE (Asociación de Estudios Interdisciplinarios Sobre Europa): "Patria, Nación, Estado en Europa: Teorías y Realidades", Facultad de Filosofía y Letras, Universidad Nacional de Cuyo, Mendoza, 21-23 Abril, 2010.
} 
Cayo Calígula: del 'civilis princeps' al 'superbus' autócrata

instituciones era un hecho, y como tal, no podía dejar de tener sus consecuencias en la realidad.

En un artículo revelador, Andrew Wallace-Hadrill conceptualizaba esta realidad del poder imperial como "ambivalente". Y afirmaba que dicha "ambivalencia" era un elemento esencial de esta particular forma de monarquía. Tanto la indiscutible autocracia que le otorgaba la amplitud de sus facultades, como el sostenimiento de dicha "fachada" republicana, eran elementos inseparables del rol del emperador. De esta forma, ante los ojos romanos, el princeps aparecía en una posición intermedia entre un ciudadano y un rey ("Between citizen and king"). De acuerdo con este autor, por diferentes medios, varios de los emperadores del Alto Imperio buscaron sostener e incluso promover dicha "ambivalencia". Este comportamiento se debe principalmente a que la instauración del nuevo orden político mantuvo intacto el jerárquico orden social tradicional ${ }^{4}$.

Según Wallace-Hadrill, el ideal que motivó a Augusto, su sucesor Tiberio y otros príncipes del siglo I y II a actuar de esta manera, se puede definir según el término latino civilitas; esto es, una pauta de comportamiento que se materializaba en determinadas conductas "virtuosas" del emperador. En primer lugar, ésta se manifestaba por un ejercicio moderado del poder ilimitado que poseían (moderatio). En segundo lugar, se expresaba por la condescendencia (comitas) para con el resto de los ciudadanos y, fundamentalmente, para con sus pares estamentales. Gracias a ello, los emperadores lograban la lealtad de la aristocracia imperial, grupo social preeminente de cuyas filas salían los hombres que ocupaban los principales cargos civiles y militares del imperio. Por otro lado, de esta manera el princeps aparecía como el garante de su prestigio social y privilegio estamental (WALLACE-HADRILL, 1982, p.32-48). Con esta conducta, Augusto y sus sucesores buscaron conciliar el nuevo orden político con el orden social tradicional, y así, dar estabilidad y legitimidad a su extraordinaria posición dentro del estado 5 .

Una primera lectura de las fuentes literarias que se refieren al principado de Calígula, permitiría rápidamente comprobar que, a partir de un determinado momento, el nuevo princeps llevó a cabo un cambio radical de la política imperial. Este cambio se manifestó principalmente en una modificación sustancial de la relación entre el emperador y la aristocracia romana, representada políticamente por las instituciones tradicionales, y amparada socialmente por el derecho preexistente. Progresivamente, el joven Cayo abandonó el comportamiento y las formas de trato con dicho grupo que caracterizaron el proceder político de sus antecesores (la civilitas). En la medida de sus posibilidades, procuró marginarlo de la dirección del estado e incluso, según se puede apreciar en las fuentes, lo sometió a la humillación social y a la persecución física cuando lo creyó necesario. 
De esta manera, Calígula parecía desligar al poder imperial de su "fachada" republicana y ostentar su verdadero carácter autocrático.

Pese a las grandes divergencias que ha generado su figura entre los académicos, este estilo autocrático de ejercer el poder, ha sido una característica esencial de Calígula que, condenada por unos o justificada por otros, nadie se ha atrevido contradecir. La discusión sale a la luz cuando se intentan determinar las posibles razones que motivaron su autoritaria manera de gobernar. Evidentemente, múltiples han sido las causas que han de responder esta cuestión y sería imposible abordar aquí todas ellas. En esta breve exposición, simplemente pretendemos explorar algunos elementos del carácter autocrático de Calígula desde el punto de vista ideológico ${ }^{6}$. Para ello, se buscará y analizará en los testimonios de las fuentes grecolatinas ciertos gestos que denoten, no simplemente su estilo autoritario de ejercer el poder, sino también su convicción ideológica de que dicha modalidad es la que mejor convenía para dirigir la res publica, lo cual a su vez nos ofrecería algunas pistas claves para comprender la concepción que él tenía de este "ambivalente" poder imperial.

\section{La centralización del poder}

En orden a mostrar el semblante de cada uno de los césares, la tradición literaria alto-imperial, profundamente comprometida con los círculos senatoriales, ha dedicado numerosos párrafos a las relaciones de cada uno de ellos con el Senado y sus miembros. Con respecto a Calígula, la historiografía moderna ha postulado su carácter autocrático fundándose principalmente en estos testimonios. En primer lugar, se podría afirmar que la acción de Cayo para con esta alta asamblea, reservorio político de la elite, se caracterizó por la ignorancia institucional. Afirma Dion Casio que cuando Calígula decidió ejecutar a su primo y candidato a la sucesión, Tiberio Gemelo ${ }^{7}$ (19-37/38), lo hizo "sin enviar comunicación alguna al Senado", y que, posteriormente, "hizo lo mismo en muchos otros casos" (Dio Cass 59.8.2). Evidentemente, ya en la primera parte de su principado, Calígula daba indicios de ignorar en un asunto de la más alta importancia política ${ }^{8}$, la posible acción e incluso opinión de los senadores. En su concepción del estado, el Senado ya aparecía como una institución prescindible que nada tenía que hacer u opinar en un menester de tal importancia.

Tras la serie de conspiraciones que atentaron contra su vida en el año $39^{9}$, este razonamiento de Cayo comenzó a manifestarse con mayor fuerza. De campaña en las Galias, tras reprimir allí un poderoso complot que involucró a gran cantidad de romanos de primer rango e incluso del círculo íntimo del emperador ${ }^{10}$, recibió una embajada senatorial. Según Suetonio:

Cuando los emisarios del Senado fueron a suplicarle que apresurara su regreso, exclamó: Iré, sí, iré, y ésta conmigo, golpeando la empuñadura de 
Cayo Calígula: del 'civilis princeps' al 'superbus' autócrata

la espada que llevaba ceñida. Añadió que sólo volvía para los que lo deseaban, para los caballeros y para el pueblo, pero que los senadores no encontrarían en él ni ciudadano ni príncipe (Suet. Cal. 49.1).

Mediante esta amenaza, Suetonio enfatizaba la profunda hostilidad que Calígula adoptó, a partir de un determinado momento, contra los senadores ${ }^{11}$. Por otro parte, la ignorancia política de Calígula hacia ellos se manifiesta allí ingeniosa y explícitamente al anunciarles que ya no tendrían relación alguna con quien poseía el poder real del estado (el príncipe) y era, en última instancia, el garante de su prestigio y privilegio social. Dicho comportamiento del emperador no podía tener otra consecuencia en el plano político que una mayor centralización en la toma de decisiones en su persona y la consecuente marginación del aristocracia senatorial al respecto. Por ello, Dion Casio afirma que,

...dado que nunca deseaba que asunto alguno fuera discutido, comunicaba tan solo una pequeña parte del mismo en un escrito a todos los senadores, pero la mayoría de estos los comunicaba a los cónsules (a quienes utilizaba como brazos ejecutores de sus decisiones), y luego a veces, ordenaba que se leyeran en el Senado" (Dio Cass 59.24.8).

El descubrimiento de procesos conspirativos en el año 39 fue el disparador del segundo aspecto que caracterizó la relación de Calígula con los senadores: la pretensión de someterlos políticamente a su voluntad y neutralizar, así, a los elementos hostiles. Para ello, el joven Cayo procedió, en primer lugar, a la humillación social. Al respecto, el historiador alemán Aloys Winterling realizó recientemente un perspicaz análisis de las formas de comunicación entre este princeps y la aristocracia romana. Según el autor, tras la llamada "conspiración de los consulares" (enero del 39), Calígula "no hizo rodar cabezas arbitrariamente (como las fuentes parecen proferir), sino que, más bien, se ocupó del puesto de la aristocracia en el Senado, en sus relaciones de patronazgo y en su jerarquización, confrontándola con la verdad, desagradable, de la existencia de un Principado y la ambigüedad esencial de su propio comportamiento en las nuevas relaciones de poder. Obligó a la aristocracia a humillarse. La deshonró a fuerza de cinismo y de una serie de actos simbólicos. La sumió en la impotencia y la expuso al ridículo" (WINTERLING, 2006, p.100).

Según Winterling (2006, p.132), “la degradación más dolorosa de la aristocracia tuvo lugar, sin duda en el contacto personal del emperador". Al respecto, el escritor romano que nos ha dejado mayores testimonios fue Cayo Suetonio Tranquilo (70-130 aprox.), un caballero romano intelectualmente comprometido con la "monarquía moderada" de los primeros Antoninos ${ }^{12}$. Desde una finalidad pedagógica (y profundos intereses ideológicos), en su De Vita Caesarum Suetonio construye "buenos" o "malos" emperadores a partir de la 
relación que éstos tenían con el orden moral, social y jurídico tradicional (SHARROCK, 2002, p.369) $^{13}$. En su biografía de Calígula, el equite enumera diferentes aspectos de la vida de este emperador en orden a construir el arquetipo del "mal gobernante". Por ejemplo, y en relación al tema que nos compete, afirmaba que...

tampoco con los miembros del Senado mostró respeto ni indulgencia. Consintió que muchos de ellos, honrados con las primeras dignidades, corriesen a pie y con la toga junto a su carro por espacio de muchas millas, y que durante sus comidas permaneciesen de pie detrás de su lecho o a sus pies con una servilleta debajo del brazo (Suet. Cal. 26.2).

En el mismo recinto del Senado, tras la mencionada conspiración, Calígula injurió y echó en cara a los senadores los pecados que muchos de ellos habían cometido en tiempos de Tiberio, haciéndolos quedar públicamente como cómplices y verdugos de la crueldad de este emperador:

injurió con frecuencia a todos los senadores a la vez, llamándoles o bien clientes de Sejano, o bien delatores de su madre y de sus hermanos, y mostrando los documentos que había fingido arrojar al fuego, justificaba la crueldad de Tiberio, porque aquellas acusaciones decía, la hicieron necesaria (Suet. Cal. 30.2).

Con estas exhortaciones, cuyo discurso Dion cita en forma casi completa (Dio Cass 59.16.2-4), Calígula enrostró a los senadores el hecho de haber, en un primer momento, colmado servilmente de honores a Tiberio y Sejano ${ }^{14}$, para luego comportarse contradictoriamente después de la muerte de ambos (condenando la memoria del primero y ratificando la ejecución del segundo). Winterling concluye que de esta manera, el joven Cayo dejaba al descubierto, la verdadera relación existente entre la aristocracia y el emperador: no más que adulación e hipocresía. Y de esta manera quebró las tradicionales formas de trato y comunicación entre la aristocracia romana y el princeps (WINTERLING, 2006, p.94 y ss). Calígula abandonó la comitas, elemento sustancial del civilis princeps como pauta de comportamiento, y dejaba en claro la forma en que, de aquí en más consideraría y trataría a sus pares estamentales:

A continuación (decía Cayo en el Senado citando consejos de Tiberio) no demuestres afecto alguno ni cuidado por ninguno de ellos (los senadores). Dado que todos ellos te odian y rezan por tu muerte; y te asesinarán si pueden. No te detengas en considerar, por lo tanto, que actos tuyos los complacerán, ni te importe lo que digan, solamente busca tu propio placer y seguridad; también serás honrado por ellos, tanto si lo desean o no (Dio Cass 59.16.5-6).

Y no solamente en el Senado, donde sólo los senadores podían ser testigo de sus injurias, sino también frente a los ojos de toda la sociedad, Calígula 
Cayo Calígula: del 'civilis princeps' al 'superbus' autócrata

procedió a dicha humillación social. Para ello recurrió a ciertos actos con un fuerte contenido simbólico cuyo objeto también era rebajar explícita y públicamente la posición social de los nobilis romanos. Flavio Josefo (37-101 aprox.), intelectual judío profundamente compenetrado con las costumbres romanas de su época ${ }^{15}$, comentaba que hacia finales del principado de Cayo en los espectáculos teatrales...

no había sitios especiales señalados para los senadores o los caballeros, todos se sentaban mezclados, los hombres con las mujeres, los esclavos con los hombres libres (J. AJ 19.1.13).

Este hecho, que Suetonio confirma y de cuyas consecuencias (apretujones, disturbios, etc.) sostiene que Cayo "se complacía" (Suet. Cal. 26.4), demuestra cómo el princeps apuntó, desde una finalidad política, contra privilegios estamentales profundamente arraigados en la costumbre y tradición de la nobilitas $^{16}$. De esta manera sometió públicamente a muchos ilustres individuos a una vejación insultante para un ciudadano perteneciente a los primeros órdenes de la sociedad. Con este mismo criterio, a través de una disposición desconcertante incluso para un caballero como Suetonio, Calígula...

Prohibió a los romanos más nobles las antiguas distinciones de sus familias: a Torcuato, el collar; a Cincinato, el pelo rizado; a Cn. Pompeyo, que pertenecía a esta antigua familia, el nombre de Magnus (Suet. Cal. 35.1).

En varios casos, las conspiraciones provocaron, sin dudas, una serie de persecuciones y ejecuciones dirigidas por Cayo que consagraron su pretensión de someter a la elite. Aunque definitivamente no es posible comprobar un proceso de ejecuciones a gran escala según sugieren los autores antiguos (BARRETT, 2000, p.235; WINTERLING, 2006, p.127), evidentemente, la persecución política de muchos protoí, fue para Calígula una efectiva herramienta para neutralizar a aquellos que consideraba potenciales opositores y conspiradores. De acuerdo con Dion Casio,

"en aquellos días y en los siguientes muchos de los hombres de primer rango encontraban la muerte por una condena judicial, y otros muchos corrieron la misma suerte acabando como gladiadores. No había, de hecho, otra cosa que asesinatos" (Dio Cass 59.13.3).

Desde el otro lado del Mediterráneo, refiriéndose a estos acontecimientos, Filón de Alejandría decía:

"La cosa (es decir, la supuesta crueldad de Calígula) adquirió ya particular notoriedad en razón de los sucesivos asesinatos de los hombres de mayor jerarquía, al punto de que nadie dejaba de comentar estos impíos crímenes, si bien no abiertamente debido al temor, sino en cautelosos corrillos" (Philo Leg. 10.66). 


\section{Optimus Maximus Caesar}

Ahora bien, ¿por qué a partir de un determinado momento, Calígula procedió progresivamente a ignorar y marginar políticamente a las instituciones tradicionales, e incluso a deshonrar y perseguir a varios de aquellos que las integraban? Evidentemente, y en esto coincide gran parte de la historiografía de los últimos años, las conspiraciones han sido decisivas en dicho cambio. Pero ello no lo explicaría todo. Augusto y Tiberio también fueron víctimas de procesos conspirativos (Suet. Aug. 19; Tib. 25 y 65). Pero se han cuidado de dirigir sus reacciones, en ocasiones más sangrientas, a individuos precisos. En ningún momento, golpearon la jerarquía social preexistente ni pretendieron diluir la mencionada "ambivalencia" esencial de la monarquía imperial. Probablemente, a sabiendas de que ello provocaría más conspiraciones y oposición aristocrática. De hecho, cuando la circunstancia lo permitió, Augusto perdonó a sus conspiradores para valerse del prestigio que otorgaba, a los ojos de la sociedad romana, la clementia, y fortalecer aún más su posición ${ }^{17}$. Por estas razones consideramos necesario, para comprender más cabalmente las razones del comportamiento autocrático de Calígula, poner especial atención en la forma que éste concebía el poder excepcional que el Senado y el pueblo romano le habían otorgado en la primavera del 37. Para ello, las fuentes nos ofrecen algunas expresiones y gestos suyos que ayudan a develar en parte esta cuestión

En primer lugar, esta concepción autocrática se entiende mejor si la analizamos a la luz de la relación que tenía Calígula, en cuanto princeps, con la legislación romana preexistente. Al respecto, el filósofo judío Filón de Alejandría (20 a.C.- 50 d.C. aprox.), al relatar la circunstancia en la cual Cayo ejecutó a su primo Gemelo, buscaba dejar en claro cómo Cayo consideraba las leyes:

Se cuenta que el joven (Gemelo) recibió la orden de darse muerte con sus propias manos, bajo la vigilancia de un centurión y un capitán, a quienes Cayo había ordenado no tomar parte en el sacrilegio, con el pretexto de que no es lícito que los descendientes de los emperadores sean muertos por otros. Es que en medio de sus ilegalidades se acordaba de las leyes, y de la santidad en medio de sus actos impíos, aunque la verdadera naturaleza de unas y otras eran para él objeto de irrisión (Philo Leg. 5.30).

En este testimonio ${ }^{18}$, el exégeta judío acusa a Calígula de manipular la ley y al mismo tiempo, confirmando ideológicamente esta acción, pone el acento en la manera despectiva que Cayo consideraba cualquier disposición normativa precedente, tanto civil como religiosa.

Por su parte, con ánimo de escandalizar a su auditorio, Suetonio atestigua que en ocasión de un espectáculo en el cual Calígula había repartido comida y presentes, al ver a un senador que disfrutaba animosamente su banquete, lo nombró "pretor extraordinario" (Suet. Cal. 18.2.) ${ }^{19}$. Sin duda, éste cargo era más 
Cayo Calígula: del 'civilis princeps' al 'superbus' autócrata

bien honorífico que ejecutivo. Pero su otorgamiento manifiesta la falta de respeto o desidia que sentía el joven Cayo por la carrera de méritos, los procedimientos legales formales e incluso por el valor institucional de las magistraturas. Por otra parte, el mismo autor asegura que, con objeto de percibir más impuestos, consideró que muchos habitantes del imperio disfrutaban la ciudadanía ilegalmente, y "cuando le presentaban diplomas firmados por Julio César o Augusto, los anulaba como títulos viejos y sin valor" (Suet. Cal. 38.1). Al igual que Filón de Alejandría, Suetonio intenta destacar aquí la manipulación y degradación que padeció la ley en tiempos de Cayo. Hecho éste que se manifiesta con mayor fuerza en otros aspectos del desarrollo institucional del estado durante su gobierno.

Que Calígula desestimara o manipulara las distintas leyes según sus necesidades y/o deseos coyunturales, implicaba necesariamente, que no se considerara sometido a ellas ni mucho menos, a aquellos magistrados que, en menor medida, también las administraban. Con el mismo criterio de Suetonio, el primero de una extensa lista de actos de Calígula que el senador Casio Dion Cocceiano (160-230 aprox.) cataloga como "censurados por todos", fue el hecho de haber solicitado permiso al Senado para obligar a muchos ciudadanos a que peleen como gladiadores en la arena. En virtud de ello el historiador de Bitinia concluía "que le estaba permitido hacer cualquier cosa que desease, incluso aquello prohibido por la ley" (Dio Cass 59.10.1-2). Con este testimonio, Dion pone en evidencia la pretensión de Calígula de no estar sometido a las restricciones legales. Por su parte, Suetonio es bien claro al referir la concepción autocrática que Calígula tenía de su poder cuando informa que en cierta ocasión, el joven Cayo,

reconvenido por su abuela Antonia (la matrona de la casa imperial más prestigiosa y honrada en esos tiempos), no solo no se limitó a atenderla, sino que le dijo: recuerda que todo me está permitido, y sobre todos (Suet. Cal. 29.1).

Por otra parte, luego de ejecutar a su primo Tiberio Gemelo, tras acusarlo de usar antídotos durante las cenas, exclamó sarcásticamente: “¿un antídoto contra César?” (Suet. Cal. 29.1). De esta forma, Calígula ponía de manifiesto la concepción que tenía de su imperium: un poder sin límites, incontenible por persona o institución alguna. Si bien es difícil comprobar que Calígula haya referido literalmente dichos comentarios, Suetonio parece ser bien claro en lo que con ellos quiere representar: en virtud de la forma que concebía su propio poder como César, Cayo entendía que de su voluntad dependía la totalidad de las cosas, e incluso la vida de aquellos que lo rodeaban. Probablemente hayan sido estas ideas lo que le motivó a exigir, a partir de un determinado momento y según confirma Suetonio, el título de Optimus Maximus Caesar, el más grade y mejor de 
los césares, tergiversando la fórmula religiosa Júpiter Óptimo y Máximo (Suet. Cal. 22.1).

Siguiendo esta idea, el mismo Suetonio afirma que durante un festín, Calígula comenzó a reír sarcásticamente, y contestando a los dos cónsules que estaban sentados junto a él preguntando de qué reía, dijo:

es que pienso que puedo con una señal, haceros estrangular a los dos (Suet. Cal. 32.3).

Esta broma de mal gusto, propia de su oscuro sentido del humor y de lo

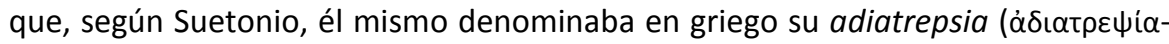
inverecundia-desvergüenza) (Suet. Cal. 29.1), permite reconocer dos aspectos importantes de su concepción del poder. En primer lugar, una manifiesta irrespetuosidad hacia éstos magistrados, cuya investidura podía significar, en teoría, una limitación a su poder. En segundo lugar, el carácter ilimitado del mismo, pues podía, sin mayor justificación que su propio deseo, hacer ejecutar a cualquiera, incluso, a altos funcionarios del estado y de raigambre aristocrática. Como dijimos anteriormente, esta forma de comprender su propio poder, llevó a Cayo a no considerarse a sí mismo como un ciudadano sujeto a la ley como el resto de los romanos. Su posición de princeps, lo dispensaba de dicha sujeción. Según Suetonio,

más de una vez vanaglorióse de convertir muy pronto en inútil y despreciable toda la ciencia de los jurisconsultos, constituyéndose él en único árbitro y juez (Suet. Cal. 34.2).

Sin lugar a dudas, como bien afirma Wallace-Hadrill, era una verdad que el poder del emperador lo situaba por encima de la ley: ¿pues quién se atrevería a acusar a él o a alguien de su familia por delito alguno? Pero abusar de dicha posición, aclara el autor, podía ser considerado como signo de tiranía. No obstante ésta posición extraordinaria "podía ser ritualizada si el emperador pretendía actuar ad privati hominis modum (al modo de un hombre privado)" (WALLACE-HADRILL, 1982, p.39). Por el contrario, Calígula abandonó esta moderatio, y pretendió imponer su palabra y su voluntad por encima de toda ley o institución. Desde el punto de vista jurídico, este avasallamiento del imperium, cualquiera fuere su naturaleza, sobre la ley, apuntaba directamente contra la libertas del ciudadano convirtiéndolo de hecho en un súbdito ${ }^{20}$.

Esta idea de supremacía desarrollada en el plano político y jurídico, se complementaba en el plano social con la idea de una superioridad de la naturaleza de su persona respecto del resto de los ciudadanos. Idea ésta que especialmente buscó difundir e imponer entre aquellos que, por razones ideológicas, más se resistirían a ello: los senatoriales. Por esta razón, Calígula 
Cayo Calígula: del 'civilis princeps' al 'superbus' autócrata

consideraba insignificantes todos los honores que le eran conferidos (por el Senado) (...) Ya que, en un momento determinado, no quería que pareciera que honor alguno otorgado a él, estuviera en poder de los senadores, ya que esto implicaría que ellos eran sus superiores y podían dispensarle honores como si él fuera inferior a ellos (Dio Cass 59.23.3).

En concordancia con ello, hemos visto anteriormente que Calígula prohibió a varias familias de la más rancia aristocracia romana hacer uso de sus antiguas distinciones nobiliarias (Suet. Cal. 35.1). Atestigua Dion Casio que a Gn. Pompeyo, su juventud lo salvó de la ejecución por portar el título de Magno que su insigne antepasado obtuvo para su familia por sus servicios a la república (Dio Cass 60.5.78). Por otro lado, Suetonio afirma que Cayo "prohibió que en adelante se pudiese labrar, sin orden o autorización suya, la estatua de ningún hombre vivo" (Suet. Cal. 34.2). Evidentemente, Calígula sólo admitía honores y distinciones dirigidos a él o a aquellos beneficiados por el don de su gracia. Esta actitud, que buscaba elevar a su persona por sobre el resto de los aristócratas, tenía como efecto colateral inmediato una tendencia a la igualación de dicho grupo con el resto de la población del imperio y el socavamiento de su prestigio y privilegios tradicionales.

Dion da pruebas de ambos objetivos de Calígula al atestiguar que "solía besar muy poco; de hecho, a la mayoría de los senadores meramente les extendía su mano o su pie en busca de homenaje". En contrapartida, a continuación el autor destaca que, a pesar de ello y bajo la mirada de todos, "besaba actores todos los días" (Dio Cass 59.27.1). El mismo Suetonio confirma que besaba al pantomimo Mnester "en pleno teatro" (Suet. Cal. 55.1). Denegando el don de su ósculo a los hombres de primer rango, sometiéndolos incluso a una actitud simbólicamente servil, y otorgándolo generosamente a individuos de baja estofa, Calígula minaba la jerarquía social (WINTERLING, 2006, p.138), cuyo aseguro era, en tiempos augustales, la concesión fundamental que el princeps había ofrecido a la nobilitas y, por ende, una de sus fuentes de legitimidad. Flavio Josefo, siendo más categórico respecto de las políticas sociales de Cayo, argüía que:

También autorizó a los esclavos a acusar a sus amos, atribuyéndoles cualquier delito. Para agradarle y por sugestión suya interpretaban muchos hechos como crímenes (J. AJ 10.1.2).

De esta forma, Calígula pretendía mostrar a sus pares estamentales, los nobilis, y al resto del mundo que él no era su igual, un ciudadano primus inter pares, sino un hombre de naturaleza diferente; obviamente, superior. Pero, al mismo tiempo, con esta conducta pretendía rebajar a aquellos que, por su posición, los nobilis, no iban a aceptar esta nueva realidad. Por su parte, a éstos debería parecerles bastante anormal la carencia real de Cayo de la fuente principal de legitimidad que tanto a Augusto, como a Tiberio, le otorgó "la dirección del estado por consentimiento universal" (Aug. RG 6.15), esto es, la 
auctoritas. Desde el punto de vista aristocrático, la auctoritas, debía ser un elemento constitutivo del princeps civitatis a la hora de aceptar la superioridad de su posición política por sobre el resto de los nobles.

Retomando la definición del maestro Theodor Mommsen, la auctoritas "era más que una opinión y menos que una orden. Es una opinión que no conviene no tomar en cuenta". Esta era, evidentemente, la lógica mediante la cual, la aristocracia romana justificaba su obediencia al princeps. En la medida, claro está, que éste garantizara sus aspiraciones sociales, económicas e incluso, políticas. Al respecto, compartimos con Petit la tesis de que en los primeros tiempos del Principado, la auctoritas seguía siendo una noción moral, no jurídica, que, aparte del título de Augustus, estaba indefectiblemente unida al ejercicio de las magistraturas y a los grandes servicios ofrecidos por un ciudadano al estado (Petit, 1969, p.118). Sin dudas, desde Augusto en adelante, la auctoritas quedó reservada al emperador. Pero las extraordinarias circunstancias de acceso al poder de Calígula dejaban grandes dudas sobre su real posesión. Al respecto, Nony afirma que "Calígula no tomó, hablando con propiedad, el poder, sino que el Senado y el pueblo romano se lo entregaron entusiasmados a él, que no estaba, como Augusto en el año 27 a.C. o como Tiberio en el 14 d.C., en posesión de la menor autoridad, la menor magistratura" (Nony, 1989, p.19). ${ }^{21}$.

Por su inexperiencia en los servicios públicos, Calígula no podía, ni sabía, encontrar en el carisma que brindaba la auctoritas, un fundamento sustentable para justificar su superioridad política. Por esta razón, lo más probable es que, con objeto de consolidar su posición, el joven Cayo haya buscado en otro lugar la justificación ideológica del poder que ejercía y, sobre todo, de la forma en que lo hacía. Tal vez encontremos aquí una de las claves para comprender aquello que los autores romanos han postulado como el síntoma principal de su afamada demencia: reclamar para sí la naturaleza divina. Acerca de este fenómeno, la historiografía moderna nos ha alertado sobre la forma en que las fuentes han manipulado la información al respecto (NONY, 1989, p.241-247; BARRETT, 2000, p.140-153; WINTERLING, 2006, p.139-152). No obstante, esta investigación considera que dos elementos se perciben como incuestionables. En primer lugar, el hecho de que, a partir de un determinado momento, Calígula comenzó a exigir honores divinos para su persona en determinadas regiones del imperio ${ }^{22}$.

Si bien, nada confirma que haya hecho lo mismo dentro del pomerium, se puede constatar que allí dio vía libre a las manifestaciones individuales de adoración que implicó la odiosa pero incontenible espiral adulatoria en que estaba sumergida la nobleza romana ${ }^{23}$. En este punto, el joven Cayo hizo a un lado la práctica ritualizada de rechazar honores desmesurados, recusatio, la cual era un comportamiento constitutivo de la civilitas del príncipe ${ }^{24}$. Un segundo elemento patente del proceso de auto-deificación de Calígula era que, a pesar de las 
Cayo Calígula: del 'civilis princeps' al 'superbus' autócrata

conclusiones de los escritores grecolatinos, dicha fenómeno no puede atribuirse absolutamente a la locura o delirio místico del joven emperador, sino a una deliberada política de estado. Política ésta, cuyo origen ideológico difícilmente podamos encontrarlo en la cultura política tradicional de los romanos. Tal vez, hallemos la clave de esta concepción en la fuente de ideas que provenían del Oriente Helenístico y, cuya construcción política, desde la instauración del Principado tenía más actualidad que nunca: la monarquía absoluta de derecho divino.

\section{Conclusión}

A lo largo de la exposición, hemos podido apreciar que, partir de un determinado momento y de manera progresiva, Calígula puso en marcha los elementos que compusieron su autocrática forma de ejercer el poder imperial. En primer lugar, comenzó a ignorar políticamente la acción u opinión de los senadores y magistrados y, por ende, a marginarlos paulatinamente de la toma de decisiones. Si bien el ascenso del Principado había puesto el poder del Senado y las magistraturas en términos relativos, estas instituciones permanecieron con una función capital para la elite. El acceso a éstas otorgaba un prestigio estamental cuyo menosprecio desde el poder imperial parecía socavar. En sintonía con esta conducta, Calígula manifestó explícitamente su pretensión de no restringir su voluntad a institución o ley alguna preexistente. De este modo, a los ojos de los aristócratas el joven Cayo ponía fin a una característica consubstancial al rol del princeps modelado por Augusto: la moderatio.

En segundo lugar, desde el proceso conspirativo del año 39, Calígula procedió a neutralizar a la aristocracia romana, sometiéndola a su arbitrio por medio de la humillación y, cuando la circunstancia lo requirió, la persecución física. En el presente trabajo hemos visto que el joven emperador golpeó la piedra angular del fundamento de toda aristocracia: su honor. De esta manera, Cayo buscaba rebajarla socialmente al tiempo que proclamaba la superioridad de su persona por sobre el resto de los ciudadanos y en particular de sus pares estamentales. Así vemos como, Calígula combinaba el abandono de la moderatio y la comitas, desechando la ideología que, según expone Wallace-Hadrill, subyacía detrás de dichos comportamientos: la civilitas. Al mismo tiempo, ponía en práctica nuevas conductas "viciosas" que los escritores romanos denominaban arrogantia o superbia ${ }^{25}$. Este cambio de actitud, tan perjudicial para los sectores aristocráticos, podría explicar, por un lado, que se formasen nuevos complots contra su gobierno y, consecuentemente, que se incrementase su superbia. Por otro lado, ello explicaría que tras la conjura que acabó con su vida ( 24 de enero del 41), la reacción nobiliaria se tradujera en los virulentos retratos que, sobre él, 
labraron autores como Suetonio o Dion Casio, estrechamente vinculados a la elite.

Pero más allá de las circunstancias políticas de su gobierno, la pretensión de Calígula de poseer una naturaleza superior, se puede entender mejor si tenemos en cuenta la posibilidad de la influencia de alguna novedosa concepción política que mediara entre él y dicha ambición. Por ello consideramos legítimo preguntarnos, ¿qué filosofías, ideas o pensamientos políticos pudieron haber influido en un cambio tan radical del rol del emperador? Si tenemos en cuenta la manera en que progresivamente Calígula buscó concentrar el poder y, haciendo uso de su imperium, avasalló a las instituciones y leyes romanas garantes del orden social y la libertas de los ciudadanos. Y si consideramos también la forma en que consecuentemente procedió a exigir o promover un culto dirigido a su persona en vida. Sería factible inferir que la ideología subyacente en aquello que los antiguos llamaban superbia o arrogantia, estuviera influenciada por ideas tomadas de una concepción política que, aunque también mediterránea y todavía contemporánea, contrastaba con la tradición y cultura política romana: la monarquía absoluta de derecho divino procedente del Oriente Helenístico.

\section{Bibliografía}

ADORNO, T.W. y Horkheimer, Max. La sociedad. Lecciones de Sociología. Buenos Aires: Proteo, 1969.

ALFÖLDY, G. Historia social de Roma. Madrid: Alianza, 1996.

BARRETT, A. Calígula: The corruption of power. London: Routledge, 2000.

BELL, H.I. Anti-semitism in Alexandria. The Journal of Roman Studies, Vol. 31. p.1-18, 1941.

GUNDERSON, E. The ideology of the Arena. Classical Antiquity, 15, 1996.

GRIMAL, P. El imperio romano. Barcelona: Crítica, 2000.

HOMO, L. Instituciones políticas romanas. De la ciudad al estado. Barcelona: Cervantes, 1928.

FINLEY, M. El nacimiento de la política. Barcelona: Crítica, 1986.

JONES, A.H.M. Augusto. Buenos Aires: Eudeba, 1974.

KYLE, D.G. Spectacles of death in ancient Rome. London, Routledge, 1998.

MEIJER, F. Emperors don't die in bed. New York: Routledge, 2004.

MELLOR, R. The roman historians. London: Routledge, 1999.

MILANOVIC, B., LINDERT, P.H. \& WILLIAMSON, J.G. Measuring Ancient Inequality. NBER, Working Paper 13550 (October 2007), disponible en http://www.nber.org.

NONY, D. Calígula. Madrid: Edaf, 1989 (1ra ed. en francés, 1986).

ORAÁ, E.T. La carrera política de los miembros de la domus augusta en el periodo julioclaudio. En: del Real, A. y otros; Urbs Aeterna. Actas y colaboraciones del Coloquio Internacional: Roma entre la literatura y la historia. Pamplona: Eunsa, 2003.

PETIT, P. La paz romana. Barcelona: Labor, 1969.

SCHWARTZ, MATTHEW B. Greek and Jew: Philo and the alexandrian riots of 38-41 CE. Judaism, 49, no 2, p.206 ss, 2000 (Spring).

SHARROCK, A. \& ASH, R. Fifty key classical authors. London: Routledge, 2002.

SYME, R. The roman revolution. Oxford: Clarendon Press, 1939. 
Cayo Calígula: del 'civilis princeps' al 'superbus' autócrata

WALLACE-HADRILL, A. Civilis princeps: between citizen and king. Journal of Roman Studies, 72, p.32-48, 1982.

WINTERLING, A. Calígula. Barcelona: Herder, 2006 (1ra ed. en alemán, 2003).

\begin{abstract}
${ }^{1}$ Algunos testimonios latinos que se refieren al Principado como forma de gobierno se pueden ver en Suetonio: Tib. 7.1 (principatus initia), 25.3 (societatem principatus), 68.4; Cal. 22.1 (speciemque principatus in regni formam converteret), 31 (Augusti principatum), 38.2 (Tiberi principatus); Cl. 11.3 (exordium principatus); Gal. 8.1 (neronis principatum); Ves.12 (ab initio principatus); Tit. 9.1 (docens principatum fato dari); Dom. 3.1 (inter initia principatus).

${ }^{2}$ El término res publica es entendido aquí de acuerdo a su significado etimológico original, es decir, tal y cómo los romanos lo entendían: "cuestión común" o "cosa de todos", que mal podríamos traducir con la palabra "Estado" en su acepción moderna, pues implica algo más amplio, y mucho menos entenderlo como un sistema político determinado, significado moderno del término "república". Tal vez podría definirse aquí como conjunto de instituciones que regían el orden jurídico, político, social y religioso en el cuál se desenvolvía el hombre romano en tanto ciudadano.

${ }^{3}$ Nombre que los romanos y la historiografía posterior dieron al princeps en virtud de su imperium.
\end{abstract}

4 El predominio social de una elite aristocrática conformada por aquellos individuos que formaban parte del orden senatorial y el primer segmento del orden ecuestre se consagró políticamente durante el Principado por el fin del funcionamiento de los concilios populares. Según la estimación de Branko Milanovic, hacia el final del principado de Augusto, en sentido amplio, este sector no representaba más del $0,3 \%$ de la población del imperio. (MILANOVIC, LINDERT, WILLIAMSON, 2007)

${ }^{5}$ En tiempos del Principado, "el talante senatorial se expresaba orgullosamente en la conciencia de pertenecer al orden más ilustre (amplissimus ordo) y paralelamente también en la convicción de que cualquier senador que reuniese plenamente las condiciones para ser miembro de su estamento, podía tenerse por no inferior a ninguna otra persona". (ALFÖLDY, 1996, p.161). De hecho, el ingreso a dicho estamento de homines novi que promovió el Principado fortaleció la conciencia de pertenencia estamental pues estos "mejor que nadie asumían y exponían el ideario de su nuevo círculo social, con el que ellos se identificaban plenamente; Tácito o Plinio constituyen los mejores ejemplos de ello". Idem, p. 163.

${ }^{6}$ Retomamos aquí el concepto esbozado por Moses Finley en su trabajo Politics in the ancient World (El nacimiento de la política) publicado en 1983, según el cual se podría definir ideología como el "complejo entero de creencias y actitudes", que referido a la política, determinaría una conducta política determinada. (FINLEY, 1986, p.171 y ss). Esta definición se podría complementar con la idea desarrollada en los años '60 por T.W. Adorno y Max Horkheimer (1969, p.191), según la cual la ideología es "justificación" de una realidad o situación determinada, en este caso política.

${ }^{7}$ Apenas asumió, Calígula le había concedido el título de princeps iuventutis reservado a los príncipes de la casa imperial y candidatos naturales a la sucesión.

${ }^{8}$ La grave enfermedad que padeció Calígula a los 8 meses de su principado, probablemente motivó a los hombres en cuyas manos estaba la dirección de los asuntos del estado, como 
Nevio Sutorio Macro, prefecto de la guardia pretoriana, o Marco Junio Silano, hombre preeminente en el Senado y suegro de Calígula, a preparar la sucesión de Tiberio Gemelo. Repuesto de su enfermedad, es probable que Calígula haya reaccionado violentamente contra este entramado político lo cual explicaría la caída sistemáticamente de éstos tres hombres. Cfr. NONY, 1989, p.197-198. Si bien, teniendo en cuenta que Gemelo era hijo adoptivo de Cayo, legalmente éste no estaba a dar explicaciones ante nadie para ejecutarlo, el hecho parece ser tomado por Dion para demostrar la tendencia política referida.

${ }^{9}$ Las recurrentes conspiraciones de la aristocracia contra los emperadores era un problema estructural del Principado producto de las tensiones que provocó la introducción del nuevo régimen político con el orden social preexistente. "Nada tenía de extraño para los senadores hacer entender al emperador que su autoridad, aunque enorme, no era ilimitada y que sus poderes formales no estaban establecidos en lugar alguno. Los emperadores que iban muy lejos a los ojos de los aristócratas eran criticados. Mayormente dicha crítica moría luego de un tiempo, pero ocasionalmente el emperador entendía el mensaje de que mejor cuidara sus pasos" (MEIJER, 2004, p.3).

${ }^{10}$ Sobre la conspiración que se tramó contra Calígula en el verano del año 39 ver: WINTERLING, 2006, p. 102-114.

11 Esta conspiración, como otras descifradas por la historiografía moderna, fue deliberadamente silenciada por Suetonio y desestimada Dion Casio (Dio Cass 59.22.5-23.2). De hecho, extraña que Suetonio la mencione "al pasar" en su Vida de Claudio (Suet. Cl. 9.1) y no se refiera para nada a ella en su Vida de Calígula.

12 Por influencia de su amigo Plinio el Joven, Suetonio alcanzó el cargo de studiis (investigador) y de bibliotheca (bibliotecario imperial) bajo el principado de Trajano. Luego, con Adriano, fue secretario privado del emperador como ab epistulis, donde trabó amistad con el Prefecto del Pretorio Septicio Claro. (MELLOR, 1999, p.147) Ver también: Suet. Dom. 23.2.

${ }^{13}$ Según Wallace-Hadrill (1982, p.43), en su narración, Suetonio busca "categorizar el comportamiento imperial bajo sus aspectos separados, encontramos por primera vez un intento de describir el patrón de comportamiento de cada César en dicha área. Civilitas describe el patrón del buen emperador, superbia el del malo".

${ }^{14}$ Prefecto de la guardia pretoriana durante gran parte del principado de Tiberio (14-31).

${ }^{15}$ Según lo atestigua en su Autobiografía (J. Vit. 76.422-429), Josefo vivió gran tiempo en Roma en compañía de los emperadores Flavios, siendo tenido en gran estima por estos tres príncipes. Tras la guerra de Roma con los judíos en el año 68-69, Vespasiano lo tuvo a su lado y le concedió la ciudadanía romana.

${ }^{16}$ La ocupación de asientos en los espectáculos, con escalonados niveles de espectadores, desde los senadores hasta las mujeres y los esclavos, "ha sido muchas veces utilizado como una metáfora de la ordenación jerárquica de la sociedad romana" (KYLE, 1998, p.3). Según Erik Gunderson (1996, p. 125), los asientos en los espectáculos eran "un mapa ideológico de la estructura social del estado romano".

17 "La clementia (de Augusto) se transformó en una de sus virtudes cardinales; y el historiador Veleyo Patérculo exaltó fervientemente la clemencia del líder de Italia después de Actium" (Vell. 2.86.2. SYME, 1939, p.299). Por otra parte, Suetonio pone en evidencia el 
contraste entre el comportamiento de Calígula y Tiberio cuando, luego de narrar las conspiraciones y sediciones de que fue víctima el sucesor de Augusto al asumir el principado, el equite afirmaba que "libre ya de recelos, se condujo al principio con gran moderación, y vivió con tanta sencillez como un particular" (Suet. Tib. 26.1).

18 Evidentemente, debemos entender esta animosidad de Filón en un contexto de hostilidad entre uno de los líderes intelectuales judíos del siglo I y un emperador que perjudicó a dicho pueblo en delicados asuntos de carácter político y religioso. Entre los años 38 y 40 una serie de disturbios enfrentaron a judíos y griegos en Alejandría como consecuencia de la introducción e imposición del culto al nuevo emperador en dicha ciudad. Ambos grupos enviaron legados a Calígula para dirimir la cuestión quien, no sólo favoreció la posición griega sino también decidió establecer una estatua suya en el Templo de Jerusalén suscitando la reacción de todo el judaísmo. Sobre el conflicto entre judíos y alejandrinos ver: BELL, 1941, p.1-18; SCHWARTZ, MATTHEW, 2000, p.206 ss.

${ }^{19}$ En el siglo I a.C., Catón el Menor también había recibido esta distinción departe del Senado en sesión especial por haber salvaguardado un tesoro (Plut. Cat.Mi. 39.3).

${ }^{20}$ Según Pierre Grimal (2000, p.9) “la distinción, muy estricta, y obstinadamente mantenida entre lo que depende del imperium y lo que depende de las leyes, era el fundamento de la libertas, el estatuto jurídico que distinguía al hombre libre del esclavo".

${ }^{21}$ Esta anomalía se debía, sin dudas, a que, "tras la muerte de su hijo, Tiberio abandonó la práctica augustea de asociar al trono a los posibles herederos, a la que había sido fiel en la primera mitad de su reinado (...). En gran medida, como consecuencia del cambio de política llevado a cabo por Tiberio, ninguno de sus sucesores tenía la menor experiencia en la administración provincial, en la diplomacia internacional o en el gobierno de las legiones en el momento de su acceso al trono (...). La desconfianza y la inseguridad aparecen entonces como condicionantes determinantes en la formación de los príncipes de la Domus Augusta. Con ello, sin embargo, se descuidaba inevitablemente uno de los pilares del régimen, la fidelidad de las legiones a la familia imperial”. (ORAÁ, 2003, p.757-758).

22 La pretensión de Calígula de establecer una estatua suya en el Templo de Jerusalén (Philo Leg. 30.198; J. AJ 18.8.2) debe ser comprendida dentro de este contexto. Especialmente, teniendo en cuenta que, según Filón, Calígula estaba "al tanto de que se trata del más hermoso de los templos de todas las regiones, embellecido incesantemente desde tiempos inmemoriales con ininterrumpidos pródigos y donativos". Rápidamente, ello provocó la reacción inmediata de dicho pueblo y las acusaciones de demencia que arguyen las fuentes judías de la época (Josefo y Filón). Dion Casio pone en evidencia esta misma política al afirmar que Cayo había ordenado que un recinto sagrado debía ser establecido para su adoración en Mileto. Según Dion, "deseaba apropiarse para su propio culto el gran y sumamente hermoso templo que los milesios estaban construyendo para Apolo" (Dio Cass 59.28.1).

${ }^{23}$ El caso paradigmático es el de Lucio Vitelio, un noble que acopiaba altísimo honores, que se prosternó ante el emperador llamándolo "dios". (Suet. Vit. 2.5. Dio Cass 59.27.2-6).

${ }^{24}$ La recusatio "fue ritualmente llevada a cabo a través del principado de cada emperador, en una asombrosa variedad de contextos". (WALLACE-HADRILL, 1982, p.37).

${ }^{25}$ Suetonio se refiere explícitamente a la superbia de Calígula en dos ocasiones. Primero al referir que "trató a los restantes órdenes (ecuestre y muchedumbre) con la misma 
superbia (soberbia-insolencia) y crueldad" (Suet. Cal. 26.4). Luego al afirma que "no trató a la humanidad de otra época con menos malicia que superbia y crueldad". (Suet. Cal. 34.1). 



\title{
O PROCESSO DE CONSTRUÇÃO DA IMAGEM DO TIRANO NAS VIDAS DOS CÉSARES DE SUETÓNIO
}

\author{
José Luís Lopes Brandão \\ Universidade de Coimbra - Portugal
}

As Vidas dos Césares de Suetónio não se apresentam maioritariamente como uma narrativa cronológica: esta tende a restringir-se aos factos relativos à ascensão dos imperadores e à sua morte. Pelo meio, distribuem-se as diversas species (rubricas) relativas aos aspectos que devem ser tratados numa Vida. As rubricas não estão, por seu turno, organizadas por simples acumulação de materiais exemplificativos, como poderia parecer à primeira vista, mas segundo uma certa progressão e em conexão com o todo de cada biografia. Nas secções relativas ao governo dos imperadores, a parte que trataremos neste estudo, vamos encontrar características que já se apresentavam em gérmen no relato das actividades que antecederam a chegada ao poder e que serão completadas (confirmadas ou postas em causa) na narrativa da morte. E estes traços já estão muitas vezes presentes nos antepassados, rubrica com que geralmente se iniciam as Vidas. $^{1}$

Para a descrição dos feitos do governante Suetónio vai colocar os critérios éticos à frente dos cronológicos. E o carácter dos imperadores é avaliado quer pela sua actividade governativa, quer pela vida privada. Uma vez que se trata de ilustração de vícios e virtudes, a progressão procurada tem a ver com a intensidade de determinado traço moral. O biógrafo manifesta claramente 0 intuito de criar uma imagem que se apresenta completa no final. No caso dos maus imperadores, observa-se uma progressão para o vício, e em último lugar tendem a aparecer os comportamentos mais horrendos. Mas temos de ter em conta que superbia, crudelitas, auaritia, libido eram, na altura, elementos convencionais da descrição do tirano. ${ }^{2}$

\section{Vida de Tibério}

No caso de Tibério, a progressão para a tirania é inequívoca. As gradações presentes nesta Vida sugerem que houve criação da imagem do tirano detestado e temido, cruel e sempre temeroso de revoltas. Depois do relato do começo feliz do principado, em que Tibério vive quase como cidadão privado (Tib. 26.1) e conserva uma aparência de liberdade ${ }^{3}$, o biógrafo introduz uma mudança, assinalada por paulatim, no comportamento do imperador (Tib. 33). Começa a manifestar-se o princeps (termo aqui entendido no sentido de tendência para a tirania), embora de modo variado e ainda inclinado sobretudo para o bem público; e nota-se já o 
O processo de construção do imagem do tirano ...

aumento de rigor na aplicação da lei. O déspota começa a crescer ${ }^{4}$, passando a governar com maior firmeza e determinação, como revelam as medidas de contenção de despesas (Tib. 34). A repressão mostra já plena força com a proibição dos ritos egípcios e judaicos e com a expulsão dos astrólogos (Tib. 36). Atinge-se o auge desta fase com as medidas para a restauração da ordem, ilustrada com vários acontecimentos. $^{5}$

Entramos numa fase de visível transição (Tib. 38-40). Suetónio, acaso para acentuar as contradições do príncipe, lembra que ele, durante dois anos, não se ausentou de Roma, embora anunciasse e preparasse contínuas viagens (Tib. 38). Ao narrar a partida de Tibério para a Campânia (Tib. 39), na sequência da morte de Germânico e do filho Druso, Suetónio centra-se na forma milagrosa como o imperador escapou ileso de uma derrocada na gruta de Spelunca, sem retirar as ilações políticas de tal evento. ${ }^{6}$

Consagrar um templo a Júpiter Capitolino em Cápua e outro a Augusto em Nola ${ }^{7}$, era apenas o pretexto oficial da viagem, pois Tibério rumou a Cápreas. 0 motivo que o biógrafo apresenta para a predilecção do imperador por esta ilha está ligado ao carácter do próprio: não se tratava da inegável beleza do lugar, mas da sua inacessibilidade. ${ }^{8}$ O biógrafo procura, assim, acentuar a crescente misantropia do imperador. ${ }^{9} \mathrm{~A}$ instalação definitiva na ilha é o ponto de charneira na evolução do principado de Tibério. Se já atrás (Tib. 33) houve sinais de afirmação do déspota, agora a viragem é completa: entramos na fase negativa do governo. A negligência ou demissão de Tibério em relação às questões políticas é tratada, como faz habitualmente Suetónio nestes assuntos, num breve resumo cheio de generalizações ${ }^{10}$; a narrativa centra-se no estudo do carácter e degradação dos comportamentos:

Ceterum secreti licentiam nanctus et quasi ciuitatis oculis remotis, cuncta simul uitia male diu dissimulata tandem profudit: de quibus singillatim ab exordio referam.

Mas, dado que encontrara a conivência do retiro, e os olhares da cidade, estavam, por assim dizer, afastados, deu largas, de uma assentada, a todos os vícios há longo tempo mal dissimulados. Desses vícios vou eu agora tratar, um por um, desde o início. ${ }^{11}$

Com a afirmação de uitia male diu dissimulata, o biógrafo sugere que toda a vida anterior tem de ser vista a uma nova luz: os vícios já existiam, mas eram dissimulados pela suposta hipocrisia de Tibério. O tratamento per species impõe uma analepse (ou uma série de analepses, para os vários vícios), introduzida pela expressão $a b$ exordium referam. ${ }^{12}$ Começa pela avidez de vinho, que se manifestava já no início da carreira militar. Com um postea, introduz-nos bruscamente no período do principado (Tib. 42.1), e transita da ebriedade para a luxúria (Tib. 42.2). 
O biógrafo, como é seu hábito, usa rumores com valor de prova das depravações ocorridas no secretismo da ilha (Tib. 43). O exílio de Cápreas favorece a criação de mitos em torno da sexualidade do imperador. ${ }^{13}$ Tibério cria à sua volta um teatro pornográfico e mitológico, consonante com o gosto da época encenações que, para o biógrafo, são apenas motivadas pelo voyeurismo do velho depravado: uma clara cedência às versões mais romanescas resultantes da calúnia. Perante a monstruosidade dos factos, o biógrafo parece manifestar alguma incredulidade ${ }^{14}$, mas, apresentados em gradação, surgem os actos de pedofilia a que se entregava pela natura e pela idade; o escandaloso quadro de Parrásio, colocado no quarto de dormir ${ }^{15}$; a violação de um minister de um sacrifício no final da cerimónia; o abuso de matronas, de que é exemplo paradigmático o caso de Malónia, que, como Lucrécia, prefere o suicídio (Tib. 45).

O vício da avareza (pecuniae parcus ac tenax) (Tib. 46) exige nova analepse (Tib. 47), uma vez que o autor prometera tratar os traços ab exordio (Tib. 42). A centralização da análise em tal vício manifesta-se também na forma como Suetónio desvaloriza actos de liberalidade, ao atribuir carácter de excepção (bis omnino) à ajuda que Tibério dá ao povo, através de um crédito e do reembolso de proprietários de insulae destruídas pelo fogo (Tib. 48.1), e às cidades da Ásia destruídas por um terramoto. ${ }^{16} \mathrm{E}$ a gradação continua: procedente mox in tempore etiam ad rapinas conuertit animum (Tib. 49.1) ("com o decorrer do tempo, voltou também o seu espírito para a rapina"). Nesta perspectiva se aduz uma série de exemplos, apresentados não em sucessão cronológica, mas segundo uma ordem de intensidade: forçou ao suicídio o abastado Gneu Lêntulo ${ }^{17}$; fez condenar Lépida para agradar a Quirínio, homem rico e sem herdeiros ${ }^{18}$; explorou particulares e cidades nas províncias; e, a culminar, espoliou e matou Vonones, rei dos Partos, refugiado com grandes riquezas em Antioquia. Se este facto é anterior aos outros, é colocado no cúmulo da gradação, devido ao agravo: um rei estrangeiro buscava protecção e foi atraiçoado. ${ }^{19}$ Suetónio força a ordem dos factos de modo a sugerir a ligação entre a gradação do ponto de vista moral e cronológico.

A seguir, introduz outra rubrica, na qual trata diacronicamente o odium contra os familiares (Tib. 50.1), para se centrar no relacionamento com a mãe, através de uma longa lista de focos de conflito que culmina na total falta de pietas, manifesta na ausência das exéquias e negação de honras divinas. ${ }^{20}$ Suetónio tenta depois provar que Tibério não tem patria caritas (Tib. 52.1), nem para com o filho biológico, Druso, nem com o adoptivo, Germânico. Fica arredada a hipótese de estas mortes serem a causa do afastamento para Cápreas. ${ }^{21}$ Vão sendo sistematicamente eliminados aos olhos do leitor os melhores traços do retrato de Tibério. Acresce a perseguição até à morte da viúva de Germânico, Agripina (Tib. 53), e dos filhos, Nero e Druso (Tib. 54). Por fim, o âmbito alarga-se: o 
O processo de construção do imagem do tirano ...

ódio contra os antigos amigos e íntimos, conselheiros (Tib. 55) e convidados gregos (Tib. 56).

Neste momento, Suetónio, com uma nova rubrica, introduz mais uma análise retrospectiva para tentar explicar a origem e a evolução da saeua ac lenta natura, que, já na infância, o preceptor de retórica, reconhecia em Tibério e, por isso, Ihe chamava "barro amassado em sangue". Suetónio, como era norma no seu tempo, concebe o carácter como algo inato, embora os vícios se acentuem com a idade. A gradação corresponde ao progressivo abandono da dissimulação:

Sed aliquanto magis in principe eluxit, etiam inter initia cum adhuc fauorem hominum moderationis simulatione captaret.

Mas, uma vez príncipe, manifestou-se muito mais o seu carácter, e mesmo nos começos, quando ainda granjeava o favor das pessoas simulando moderação. (Tib. 57.1)

A seguir introduz-se a aplicação da lex maiestatis, levada até ao ridículo. ${ }^{22}$ A apregoada tolerância de Tibério em relação aos versos satíricos (Tib. 28) parece ser agora posta em causa. ${ }^{23}$ Diz o biógrafo que Tibério, numa primeira fase, os atribuía aos descontentes e repetia: 'Oderint, dum probent!' ("Odeiem-me, desde que me aprovem!"). Mas depois acrescenta: dein uera plane certaque esse ipse fecit fidem ("depois ele próprio tratou de garantir que eram verdadeiros e completamente acertados"). Os versos são, pois, transcritos com intenção caracterológica.

Os versos são, pois, transcritos com intenção caracterológica. Mas o contexto em que surgem é o da crueldade e não da falta de libertas, como se vê pelos capítulos anteriores e seguintes. Com efeito, Suetónio não dá, neste contexto, exemplos de repressão sobre poetas, mas transita para a história do pescador que subira a escarpas para oferecer ao imperador melhor peixe que pescara (Tib. 60). Sem o imaginar, o pescador tinha posto em causa a razão pela qual o imperador apreciava esta ilha: a segurança. A razão do suplício foi o choque sofrido: territus quo is a tergo insulae per aspera et deuia erepsisset ad se ("aterrorizado porque ele escalara, desde a parte de trás da ilha, por escarpas inacessíveis, até junto dele"). ${ }^{24} \mathrm{E}$ a reacção do imperador é desproporcionada.

Chegámos à parte mais cruenta da Vida ${ }^{25}:$ mox in omne genus crudelitatis erupit ("em breve irrompeu em todo o género de crueldades"). Contra a tese da funesta influência de Sejano, Suetónio quer provar que a responsabilidade dos crimes contra os filhos de Germânico recai sobre Tibério, uma vez que ele próprio mandara matar um, quando Sejano já era suspeito, outro, somente depois do temível prefeito ter sido executado. ${ }^{26}$

Entre as características dos tiranos destaca-se, pois, a crudelitas ou saeuitia $^{27}$. O biógrafo, preocupado com a extensão do relato, propõe-se fazer um 
sumário: Singillatim crudeliter facta eius exequi longum est; genera uelut, exemplaria saeuitiae, enumerare sat erit (Tib. 61.2.) ("seguir uma a uma as acções cruéis tornar-se-ia longo; basta enumerar, a título de exemplo, os tipos de crueldades"). A partir daqui, Suetónio, generalizando, transforma casos particulares em procedimentos habituais, como a violação de virgens antes de as estrangular, porque a lei proibia aplicar este castigo a donzelas (Tib. 61.5), situação de que só se conhece o caso da filha de Sejano. ${ }^{28} \mathrm{O}$ clima de terror é acentuado pelas frases, naturalmente exageradas: nemini delatorum fides abrogata. Omne crimen pro capitali receptum (Tib. 61.3) ("não se pôs em dúvida a palavra de nenhum delator. Toda a acusação era considerada capital"). E a gradação continua: Auxit intenditque saeuitiam exacerbatus indicio de morti filii Drusi (Tib. 62.1) ("aumentou e estendeu a sua crueldade, exasperado pela denúncia sobre a morte do seu filho Druso").

A imagem do tirano cruel e misantropo evolui para a condição de odiado e aterrorizado $^{29}$, que o leva a exageradas precauções com os oráculos e com os homens (Tib. 63.2-64). E até a narrativa da desgraça de Sejano é subordinada ao tema do medo de Tibério. O prefeito aparece mais como uma vítima do dolo do imperador (Tib. 65) do que como um conspirador. Tibério envia uma pudenda miserandaque oratio ao senado e, receando um tumulto, prepara navios para o caso de ser necessário fugir. Nem depois de sufocada a conjura se sente mais seguro: não sai da Villa louis durante nove meses. Suetónio apresenta-nos agora uma alma atormentada (anxia mens), fustigada por toda a espécie de injúrias, expressas em libelli e numa carta do rei dos Partos, Artábano (Tib. 66). E, no clímax dos clímaces (indicado por postremo) aparece um Tibério desgostoso consigo próprio (Tib. 67).

Atingido o momento culminante da $V i d a^{30}$, Suetónio faz a descrição geral do biografado. Mas os traços principais continuam presentes nas rubricas do retrato físico, religião e estudos literários. No que respeita à descrição física (Tib. 68.1.2), Suetónio atribui a Tibério os traços dos Cláudios, apresentados no início da Vida. A transição para a descrição psicológica é feita através da rigidez do caminhar, o porte arrogante, o ar sombrio, o jeito taciturno (Tib. 68.1.3). A avisada opinião de Augusto confirma o determinismo biológico: os vícios de Tibério provêm da natureza. ${ }^{31}$ Este determinismo é, de certo modo, agravado pela conviç̧ão de Tibério, derivada do cultivo da astrologia, de que tudo é governado pelo fatum, e, por outro lado, pela negligência em relação aos deuses e práticas religiosas (Tib. 69), a exemplo dos piores tiranos. Mesmo no cultivo das artes liberais, em si um dado positivo, se manifesta o ethos, pela a constatação de que ... adfectatione et morositate nimia obscurabat stilum (Tib. 70.1) ("obscurecia o estilo pela afectação e excessivo rigor"). 
O processo de construção do imagem do tirano ...

\section{Vida de Calígula}

O relato da governação de Calígula começa com factos muito positivos que, ainda que de forma aparatosa, revelam um governante justo. A preocupação do biógrafo, nesta fase, é assinalar uma imagem favorável do filho de Germânico. Mais ainda, o biógrafo parece empreender mesmo uma desculpabilização de certos actos que possam parecer desonrosos. ${ }^{32}$ Mas a violência contra os derrotados do concurso de Lugduno (Cal. 20) prenuncia uma deterioração no comportamento do príncipe.

Se, na narrativa destas acções, o biógrafo diz que tratou quasi de principe, $^{33}$ propõe-se, de seguida, tratar de monstro ${ }^{34}$, de modo a sugerir uma transformação radical no comportamento do imperador, mesmo que para isso seja preciso forçar os dados históricos. ${ }^{35}$ Tudo o que para trás se disse de bom se transforma agora num prelúdio ilusório, fruto da dissimulatio, arte que Gaio dominava (Cal. 10.2). Suetónio começa esta parte com as aspirações à usurpação de prerrogativas monárquicas e divinas, sinais de inciuilitas (Cal. 22). Segue-se a impietas para com os antepassados e para com os familiares, a culminar no incesto com Drusila e prostituição das irmãs (Cal. 24). Na mira de obter o efeito desejado - acumular actos do Calígula monstro -, o biógrafo não só desloca a morte da avó Antónia (ocorrida a 1 de Maio 37 d.C.) para a fase negativa do principado (Cal. 23.2), mas entra mesmo em contradição com o que dissera sobre as honras a ela concedidas. ${ }^{36}$

O carácter de Calígula manifesta-se também na forma torpe como faz e desfaz os seus casamentos: o espírito tirânico está patente no arrebatamento das esposas aos maridos (Cal. 25.1). Como no caso de Tibério, a ferocidade manifestase na sua leviandade e frieza em relação a próximos e amigos (Cal. 26), como o seu parente Ptolemeu, neto de Marco António, Mácron e a esposa. Segue-se o desrespeito para com os senadores e os cônsules, e a superbia uiolentiaque com que trata as restantes ordens.

Chegado a este ponto, provada que foi toda a ausência de escrúpulos, o biógrafo trata as demonstrações da saeuitia ingenii no seu mais elevado grau. ${ }^{37}$ Uns capítulos atrás, Suetónio dissera que muitos fizeram votos de combater na arena e de oferecer a própria vida pela saúde do imperador; agora informa que Calígula exige o cumprimento dos votos. O retardamento desta informação é uma consequência da divisão por species, mas também é verdade que a anterior omissão permite aumentar agora o efeito. Sem evitar os pormenores mais cruéis, Suetónio continua a gradatio ${ }^{38}$ e passa a referir os actos acompanhados de palavras (Cal. 29-31). Como Tibério, Calígula parece manifestar consciência da sua psicologia, mas, longe de sentir pesar, mostra-se orgulhoso dos seus defeitos. A sua desfaçatez é expressa em frases onde impera a crueldade e o humor negro, 
características que já vinham associadas no antecessor. Se Calígula dissera que tinha queimado os processos relativos à mãe e aos irmãos, com a garantia de que não os tinha lido, vem agora exibir os documentos de forma ameaçadora. Aparece como um ímpio perjuro, pois jurara pelos deuses que não os lera nem lhes tocara. $^{39}$ Sucedem-se ditos, célebres pela crueldade e pelo humor negro, que culminam no lamento de que nenhuma catástrofe acontecia no seu principado (Cal. 31). Suetónio acrescenta ainda uma rubrica sobre a saeuitia de acções e palavras especificamente em momentos de lazer (Cal. 32-33), ilustrada com outros exemplos terríveis. A gradação continua e os alvos são agora homens de todos os tempos (Cal. 34-35). Além disso, faz-se a transição da superbia e saeuitia para o liuor ac malignitas.

Outra característica usual do tirano é a impudicitia e abuso de matronas e de homens livres. Além do comércio carnal com o pantomimo Mnester e com homens nobres, do incesto com as irmãs e do amor pela cortesã Pirális, diz-se que Calígula não respeitou, à semelhança de Tibério (Tib. 45), nenhuma mulher, por mais ilustre que fosse (Cal. 36.1). Soa a generalização o envio de ordens de divórcio a algumas mulheres em nome dos maridos ausentes de Roma. ${ }^{40} \mathrm{~A}$ dissipação com sumptuosidades (Cal. 37) é outro traço habitual no tirano e tem como consequência a rapina, mascarada sob as mais diversas formas, para fazer face aos gastos (Cal. 38-42): calúnias, leilões, impostos inauditos, exploração, contribuições para o imperador.

A seguir o biógrafo entra na descrição das desconcertantes actividades militares de Calígula (Cal. 43ss), para, no final, retomar o topos da crueldade gratuita - a nefanda atrocitas que o leva a planear dizimar as legiões que se tinham rebelado contra Germânico depois da morte de Augusto. ${ }^{41}$ Uma consequência da tirania em contexto romano é o desrespeito pelo senado. De regresso a Roma, manifesta a hostilidade à altiva ordem (Cal. 49.1). As ofensas ao senado pagam-se caras. O biógrafo diz que Calígula pereceu quatro meses mais tarde, quando projectava crimes ainda maiores, como mudar a corte para Âncio e depois para Alexandria e eliminar os membros mais ilustres da ordem senatorial e dos cavaleiros. ${ }^{42}$ Como evidência destes crimes, Suetónio regista a descoberta de duas listas negras com nomes sugestivos, "o gládio" e o "punhal", e um cofre de venenos (Cal. 49.3).

Mas antes de encetar a narrativa da morte, o biógrafo introduz, como se fez para Júlio César e Tibério, as habituais rubricas sobre o aspecto, o carácter e os interesses de Calígula. Nota-se uma intenção caricatural. ${ }^{43} \mathrm{~A}$ desproporcionalidade e o excesso são comuns ao carácter e ao aspecto físico que o tornam num monstrum. Do retrato físico, Suetónio rapidamente transita para o psicológico, de que o primeiro é um reflexo: Valitudo ei neque corporis neque animi constitit ("nem tinha firme a saúde do corpo nem a da alma"). E a situação 
O processo de construção do imagem do tirano ...

torna-se mais dramática quando o biógrafo faz saber que Calígula tinha consciência do seu estado mental e parecia sofrer com isso: por várias vezes pensou retirar-se para purgar o cérebro. E para tal loucura procuram-se explicações. Corre o boato de que Cesónia Ihe dera um filtro de amor. ${ }^{44}$ Numa tentativa de interpretação das contradições de Calígula, Suetónio atribui a causa do distúrbio mental à conjugação de um atrevimento extremo com um medo exagerado. ${ }^{45} \mathrm{~A}$ rubrica da religio é introduzida no contexto das incoerências do imperador, que, por um lado, despreza os deuses e, por outro, tem horror a trovões. O biógrafo alonga-se a relatar vários exemplos do extremo medo, quer dos fenómenos naturais quer de possíveis ataques de inimigos (Cal. 51.2). A perturbação mental manifesta-se também na indumentária e no calçado. Note-se a construção em clímax, do mais digno para o mais escandaloso:

Vestitu calciatuque et cetero habitu neque patrio neque ciuili, ac ne uirili quidem ac denique humano semper usus est.

Nas roupas e no calçado e no restante trajar não usou o tradicional do seu país, nem o habitual dos cidadãos, nem sequer masculino - e, em suma, nem humano. (Cal. 52)

A indumentária, consonante com a descrição do monstrum, revela o carácter imoral e inumano do imperador, sugere as suas tendências histriónicas e, juntamente com o semblante, representa outro aspecto da quebra das convenções própria do tirano. ${ }^{46}$

Suetónio mostra claramente para onde tendem os interesses de Calígula: desprezo pelas disciplinas tradicionais, dedicação à eloquência e, sobretudo, a outras artes ${ }^{47}$. A progressão do gosto de Calígula pelas artes cénicas e circenses culmina com o favorecimento ad insaniam (Cal. 55.1) do pantomimo Mnéster, dos gladiadores trácios, dos aurigas da equipa dos verdes e sobretudo do seu cavalo, que, segundo o rumor, pretendia elevar à categoria de cônsul (Cal. 55.3). A partir daqui entramos na narrativa da morte. Assim se estabele a relação de causaefeito entre os comportamentos anteriores e o assassínio de que Calígula foi vítima (Cal. $56 \mathrm{ss}$ ): Ita bacchantem atque grassantem non defuit plerisque animus adoriri ("perante tal delírio báquico e tal devastação não faltou a muitos a coragem de o atacar").

\section{Vida de Nero}

Nero retoma e amplia os vícios de Calígula. O biógrafo começa por descrever a parte boa da governação: o tom não é de censura, mas também não é totalmente elogioso, devido à cambiante que denuncia o carácter teatral de ostentação de virtudes: pietas (Nero 9), liberalitas, clementia, comitas (Nero 10.1). Depois da rubrica relativa aos jogos (Nero 11-13), cuja extensão e género de 
espectáculos descritos são reveladores das tendências deste imperador, o biógrafo insere a enumeração dos consulados (Nero 14) e uma espécie de catálogo de medidas justas que contribuem para uma imagem positiva: exercício da justiça (Nero 15); decisões políticas e administrativas (Nero 16-17); regulamentação dos gastos sumptuários - medidas que contradizem o veredicto posterior. ${ }^{48}$ Inclusivamente, Nero é louvado, por um lado, por não desejar expandir o Império, e, por outro, por não retirar da Britânia, demonstrando pietas para com Cláudio (Nero 18).

Subitamente, Suetónio introduz na biografia uma divisão semelhante à que estabelecera na Vida de Calígula. Aos factos que acabara de apresentar, "em parte, não merecedores de repreensão e, em parte, merecedores de um louvor não regateado", opõem-se infâmias e crimes (probra ac scelera) ${ }^{49}$, relatados a seguir. Às desonrosas actividades histriónicas, longamente descritas (Nero 20-25), Suetónio acrescenta uma série de características enunciadas em epígrafe, petulantia, libido, luxuria, auaritia, crudelitas, considerados naturae uitia e não próprios da idade. A progressão é acentuada com a informação de que tais vícios eram exercidos, a princípio, de modo discreto. ${ }^{50}$ Assim se verifica com as saídas nocturnas, à semelhança do que fizera Calígula, e na forma como, durante o dia, se fazia transportar secretamente ao teatro (Nero 26.2). A gradatio na descrição dos vícios implica o retirar da máscara:

Paulatim uero inualescentibus uitiis iocularia et latebras omisit nullaque dissimulandi cura ad maiora palam erupit.

Mas, gradualmente, com o recrudescimento dos vícios, deixou-se de brincadeiras e de mistérios e, sem nenhuma preocupação de dissimular, irrompeu às claras nos maiores excessos. (Nero 27.1)

Entre estes abusos, figuram banquetes fora de horas e orgias (Nero 27.2-3).

Suetónio transita assim para a exploração da libido. 0 desafio às regras e a propensão de Nero para quebrar limites proibidos revela o comportamento tirânico: tem comércio carnal com rapazes de nascimento livre (ingenuorum paedagogia); tem como concubinas mulheres casadas (nuptarum concubinatus); viola a vestal Rúbria (Vestali uirgini Rubriae uim intulit) ${ }^{51}$; pensa em casar com a liberta Acte e trata de arranjar quem declare que é de linhagem real; castra Esporo para o transformar em mulher; deseja o incesto com Agripina (Nero 28.2). A gradação no tratamento da libido atinge o máximo com a prostituição da pudicitia, através de um jogo, em que o imperador se entrega sexualmente a um liberto (Nero 29). Por preferir o que Gascou chama a ordem "intensiva" à ordem cronológica $^{52}$, Suetónio coloca, no cúmulo da gradação, a prostituição da pudicitia. $^{53}$ A homossexualidade passiva, agravada por se tratar, neste caso, de 
O processo de construção do imagem do tirano ...

submissão sexual a uma pessoa de estatuto social inferior, implicava, como é sabido, maior degradação.

A seguir Suetónio entra na descrição da luxuria. No esbanjamento, Nero aproxima-se de Calígula, por quem nutre admiração. ${ }^{54}$ Tal como ele, Nero promove favorecimentos indevidos: ao citaredo Menécrates e ao gladiador Espículo (Nero 30.2). A comitiva das suas deslocações é aparatosa (Nero 30.3). Mas - cúmulo da luxuria e extravagância é a construção da Domus Áurea, ${ }^{55}$ cuja descrição parece assentar nos tópicos da diatribe contra a sumptuosidade. ${ }^{56}$ Tal como Calígula, depois de arruinado, Nero volta-se para a calúnia e para a rapina. ${ }^{57}$ E à semelhança de César, despoja os templos (Nero 32.4. Cf. Jul. 54.3), outro crime típico do tirano retórico. ${ }^{58}$

Os parricidia et caedes de Nero começam com o pater adoptivo (Nero 33.1) e terminam na patria (Nero 38 ). ${ }^{59}$ Primeiro os familiares mais próximos: Cláudio (Nero 33.1), Britânico (Nero 33.2-3), a mãe (Nero 34.1-4), a tia (Nero 34.5), as esposas (Nero 35.1-3). A crueldade levada até ao parricídio, quando está em jogo a conquista do poder, já era tratada nas declamações das escolas de retórica latinas $^{60}$. Suetónio procura tornar Nero cúmplice na morte de Cláudio ${ }^{61}$, ao passo que, no relato da morte deste imperador (Cl. 44), não fora insinuada a cumplicidade do sucessor, mas tão-somente a acção de Agripina. A ideia de que o tirano é, por natureza, parricida tem um modelo trágico em Édipo, um dos papéis que Nero representava. ${ }^{62}$ R. Mayer encontra na narrativa do assassínio de Popeia, com um pontapé, quando ela se encontrava grávida (Nero 35.3), uma tentativa de assimilar Nero a um tirano, Periandro, que, entre outras semelhanças com aquele imperador (como o incesto e o projecto de abertura de um canal no Istmo de Corinto), terá matado, segundo Diógenes Laércio, a esposa grávida, num momento de cólera, com um pontapé (D.L. 1.94). ${ }^{63}$

O círculo alarga-se para a morte de outros familiares ${ }^{64}$ e pessoas ligadas por algum laço de proximidade. ${ }^{65}$ Entre estas mortes são colocadas a do seu expreceptor, Séneca, e a do prefeito do pretório, Burro, seus conselheiros. ${ }^{66}$ Neste processo gradativo passa-se aos crimes contra pessoas de fora da casa imperial e estrangeiros, ${ }^{67} \mathrm{em}$ que se incluem os conspiradores. E a progressão continua ainda com o alargamento do leque das vítimas e das causas do castigo: quem lhe apetecesse e a qualquer pretexto. ${ }^{68}$ Mas as pessoas apresentadas - Suetónio escusa-se de referir os restantes - são figuras gradas, acusadas por motivos políticos: Salvidieno Órfito; Cássio Longino; Trásea Peto. ${ }^{69}$ A culminar, surge o rumor de que dava a comer homens vivos a um polyphagus egípcio (Nero 37.2). Seguem-se exclamações em que Nero, como já antes Calígula, se mostra ébrio do poder ilimitado que possui. ${ }^{70}$

No cúmulo da gradação da crudelitas, figura o atentado contra o povo e contra os muros da patria. ${ }^{71} \mathrm{~A}$ narração, voluntariamente tendenciosa, não só 
apresenta como inquestionável a culpabilidade do imperador no incêndio de 64, suspeita que Tácito põe em dúvida (Tac. Ann. 15.38.1), como procura ainda acentuar o horror com o histrionismo de Nero (Nero 38.2) e rumores infundados de pilhagem. ${ }^{72}$

Porém, Suetónio salienta a notável tolerância de Nero em relação aos ditos e poemas difamatórios (Nero 39.1). Mas nos versos é visível a perda do apoio popular. Sugere-se que, a partir do incêndio, o principado se desagrega: passa-se a narrar o castigo do tirano (Nero 40ss), apesar de, historicamente, Nero ainda governar vários anos: talem principem paulo minus quattuordecim annos perpessus terrarum orbis tandem destituit" ("após ter suportado tal príncipe pouco menos que catorze anos, o orbe da terra destituiu-o finalmente").

\section{Vida de Domiciano}

Quanto a Domiciano, cria-se progressivamente a imagem de um tirano misantropo e cruel: sublinha-se a continuidade entre a natureza, as vicissitudes da vida e a evolução negativa na condução do Império: Circa administrationem autem imperii aliquamdiu se uarium praestitit, mixtura quoque aequabili uitiorum atque uirtutum, donec uirtutes quoque in uitia deflexit: quantum coniectare licet, super ingenii naturam inopia, rapax, metu saeuus (Dom. 3.2). («No que respeita à administração do Império, mostrou-se longo tempo variável, com uma mistura igualmente equilibrada de vícios e virtudes, até que fez mesmo descambar as virtudes em vícios: quanto se pode conjecturar, na sequência das suas inclinações naturais, a carência tornou-o rapace, e o medo tornou-o cruel»). Fica assim sugerida a ideia da correspondência entre uma evolução cronológica e uma evolução psicológica e moral, em que os vícios naturais do imperador se manifestam gradualmente, impulsionados por uma característica psicológica (o medo) e por força das circunstâncias (carência). ${ }^{74}$

Entre os aspectos positivos do principado de Domiciano figura o evergetismo: jogos, distribuições ao povo, banquetes públicos (Dom. 4), política de grandes construções (Dom. 5). Igualmente positivas se consideram as expedições militares contra os Catos, contra os Sármatas e contra os Dacos, relatadas em síntese, como é hábito do biógrafo, ${ }^{75}$ bem como as as medidas administrativas (Dom. 7-9). Ao acentuar uma evolução cronológica de bom para mau, o biógrafo leva o leitor a pensar que todas as medidas positivas acontecem na primeira fase do governo, o que não corresponde à verdade histórica. ${ }^{76}$

Suetónio é impreciso sobre a duração desta fase positiva. ${ }^{77}$ Mas o facto de repetir que este estado de graça acontecia inter initia («nos começos») e aliquamdiu («por algum tempo») (Dom. 9.1), prepara, desde logo, o leitor para uma mudança inevitável. Com efeito, logo a seguir (Dom. 10), o biógrafo pode constatar: Sed neque in clementiae neque in abstinentiae tenore permansit, et 
O processo de construção do imagem do tirano ...

tamen aliquanto celerius ad saeuitiam desciuit quam ad cupiditatem («mas não perseverou nem na clemência nem no respeito pelo alheio, e, no entanto, degenerou muito mais rapidamente para a crueldade que para a cobiça») acentuando a progressão cronológica. ${ }^{78}$ Os casos apresentados falam por si: fez executar um discípulo do pantomimo Páris, pelo simples facto de se assemelhar ao mestre na arte e na beleza; ${ }^{79}$ Hermógenes de Tarso, devido a umas alusões (figurae) na sua história; um pater familias por ter apoiado os gladiadores trácios. ${ }^{80}$ Segue-se uma lista de execuções de senadores e mesmo antigos cônsules em que, para provar que Domiciano é um tirano cruel, se acentua expressamente a futilidade dos pretextos ${ }^{81} \mathrm{e}$ a forma excessiva como reage com base em simples desconfiança. ${ }^{82}$ É a suspeita de conjura que motiva a execução de Cívica Cereal, então procônsul da Síria, ${ }^{83}$ de Salvidieno Órfito ${ }^{84}$ e de Acílio Glabrião, ${ }^{85}$ que estavam no exílio, e de Élio Lâmia. ${ }^{86}$

A técnica adoptada é acentuar a culpa de Domiciano, considerando leves, menores ou até fúteis os crimes dos condenados. Mas as culpas não seriam tão veniais como Suetónio quer fazer crer: a morte de Sálvio Otão Coceiano não se ficaria a dever à celebração pura e simples do aniversário do falecido imperador Otão; ${ }^{87}$ Salústio Luculo não seria certamente morto só por permitir que chamassem "luculiano" a certo tipo de lança; ${ }^{88}$ Flávio Sabino dificilmente terá sido executado apenas pelo erro do arauto que o proclamou imperator, em vez de consul..$^{89}$ Além do mais, existe, em uma das anedotas, amálgama de informação e omissão de um nome: diz-se que Júnio Rústico foi morto por ter escrito as laudes de Trásea Peto e de Helvídio Prisco e os ter apelidado sanctissimi uiri. Ora não consta que Júnio Rústico, autor da laus de Trásea, tenha escrito também uma laus de Prisco - esta seria da autoria de Herénio Senecião, omisso em Suetónio. ${ }^{90}$ Entre as vítimas aparece uma figura que Vespasiano poupara: Métio Pompusiano, a quem um horóscopo anunciava o império. A morte desta personagem acentua $o$ contraste entre a clementia de Vespasiano e a saeuitia de Domiciano. ${ }^{91} \mathrm{E}$ o confronto entre o tratamento benevolente da morte de Helvídio Prisco, no principado de Vespasiano, e a condenação da morte de Helvídio filho, no de Domiciano, lança sobre o biógrafo a suspeita de parcialidade. ${ }^{92}$ Além disso, as mortes apresentadas não pertencerão todas a uma fase adiantada do governo, como o biógrafo pretende fazer crer, ao propor uma evolução cronológica na crueldade do príncipe. ${ }^{93}$

A gradação na saeuitia é datada por referência à guerra civil movida por Lúcio António: Verum aliquanto post ciuilis belli uictoriam saeuior ${ }^{94}$ («Mas tornou-se muito mais cruel depois de sair vitorioso da guerra civil»). A verdade é que, para conseguir a impressão desejada, Suetónio sugere, mais uma vez, uma falsa cronologia: a maioria das mortes anteriormente referidas são certamente posteriores a este marco. ${ }^{95} \mathrm{O}$ biógrafo refere ainda atrocidades, como a invenção 
José Luís Lopes Brandão

de um novos tipos de tortura. ${ }^{96} \mathrm{O}$ grau seguinte nesta progressão é o cinismo com que aplicava as penas: Erat autem non solum magnae, sed etiam callidae inopinataeque saeuitia (Dom. 11.1) («Era pois de uma crueldade, não só brutal, mas também astuta e imprevisível»). Já vimos que o humor negro é apanágio dos grandes tiranos. $^{97}$

O biógrafo passa ao tema da rapina, já anunciado atrás. A causa é, como em Calígula e em Nero, a carência das finanças, devido aos gastos com construções, espectáculos e aumento do soldo: ${ }^{98}$ é o reverso da medalha do evergetismo imperial. ${ }^{99}$ A anterior abstinentia (Dom. 9.1), a recusa das heranças da parte de quem tinha filhos vivos (Dom. 9.2), a repressão das fiscales calumniae e o castigo dos delatores, pomposamente ostentado (Dom. 9.3), são anulados agora pela constatação de que bona uiuorum ac mortuorum usquequaque quolibet et accusatore et crimine corripiebantur ${ }^{100}$ ("confiscavam-se os bens dos vivos e dos mortos onde quer que fosse, qualquer que fosse o acusador ou 0 crime»). O facto de se não apresentarem exemplos concretos faz pensar na habitual generalização por parte do biógrafo. Como ponto culminante desta prática de extorsão, Suetónio refere o excesso de rigor posto na colecta do ludaicus fiscus aos judeus (e prosélitos não declarados) que disfarçavam a origem para fugirem ao imposto. O biógrafo atesta a veracidade do facto com o testemunho pessoal (interfuisse me adulescentulum memini): a impressão que lhe causara a inspecção de um nonagenário, na presença de largo conselho, para averiguar se era circunciso. ${ }^{101}$

A seguir, faz-se a apresentação diacrónica da inciuilitas de Domiciano, que, desde a juventude, se mostra arrogante e sem moderação nas palavras e nos actos, ${ }^{102}$ a começar pela desconsideração para com Cénis, concubina de Vespasiano. Os exemplos seguintes lembram de perto os descritos ao longo do capítulo 76 da Vida de Júlio César: facta e dicta que, agravados pela falta de comedimento na aceitação de honras, tornaram justificada a morte do ditador. (Jul. 76.1). Assim se constrói a gradação na actividade de Domiciano como imperador ${ }^{103}$, até se tornar no tirano odiado de todos (Dom. 14.1), altura em que se inicia o relato da morte. $^{104}$

Só depois da narrativa da morte e do funeral aparecem as rubricas descritivas: o retrato físico (Dom. 18), os gostos desportivos (Dom. 19), os estudos liberais (Dom. 20), os hábitos (Dom. 21) e a libido (Dom. 22), com nítido paralelismo estrutural com Nero (Nero 51ss.). Com o físico amolecido, Domiciano é apresentado como um decadente e preguiçoso, incapaz de fazer qualquer tipo de esforço. ${ }^{105}$ Censura-se a negligência revelada nos liberalia studia e afirma-se que só lê os commentarii de Tibério. ${ }^{106} \mathrm{E}$ como é habitual nos tiranos, tem um apetite sexual desmedido. 
O processo de construção do imagem do tirano ...

\section{Vida de Galba}

No que diz respeito aos efémeros imperadores de 68-69 d.C., como o período de governação é muito curto, a gradação não tem a mesma amplitude. Mas, nos casos de Galba e Vitélio, é visível a progressão até um estádio de degradação moral que terá como consequência a morte. A imagem positiva de general austero de que Galba gozava antes da chegada ao poder supremo, e que Ihe garantira a posse do império, esfuma-se. A explicação deste insucesso encontra-a Suetónio no carácter de Galba. Dois vícios se salientam e que, afinal, já eram conhecidos: Praecesserat de eo fama saeuitiae simul atque auaritiae ("Tinham-no precedido a fama, que sobre ele corria, ao mesmo tempo de crueldade e avareza"). ${ }^{107}$ Como habitualmente, os traços negativos do carácter tendem a agravar-se com a ascensão ao poder; e o que era fama torna-se triste realidade: Ea fama et confirmata et aucta est, ut primum urbem introiit (Gal. 12.2) ("Essa fama foi confirmada e agravada, mal entrou na Urbe"). Seguem-se exemplos dos excessos de zelo: despromoveu e dizimou os classiarii, que Nero elevara de remadores a soldados de pleno direito; desmobilizou a coorte da guarda germânica e enviou-a sem recompensa para a sua pátria. Ao encetar a descrição do governo propriamente dito (Gal. 14-16), o balanço pende claramente para o lado negativo:

Maiore adeo fauore et auctoritate adeptus est quam gessit imperium, quanquam multa documenta egregii principis daret; sed nequaquam tam grata erant, quam inuisa quae secus fierent.

Gozou de maior apoio e prestígio ao assumir o império do que ao governálo. Embora desse muitas provas dignas de um príncipe distinto, todavia de modo algum tão gratas como odiosas se tornaram as más acções. ${ }^{108}$

Ora Suetónio não apresenta nenhuma boa acção. ${ }^{109} \mathrm{Em}$ contrapartida, acentua a submissão do imperador a três homens (Tito Vínio, Cornélio Lacão e o liberto Ícelo), já apelidados de "pedagogos" pelo vulgo, e as incoerências daí resultantes: modo acerbior parciorque, modo remissior ac neglegentior quam conueniret principi electo atque illud aetatis ${ }^{110}$ ("ora mais rígido e poupado, ora mais brando e perdulário do que era conveniente para um príncipe eleito e para a sua idade"). As condenações aparecem em catadupa: quosdam claros ex utroque ordine uiros suspicione minima inauditos condemnauit ("condenou alguns ilustres varões de uma e outra ordem, à mínima suspeita, sem os ouvir"). ${ }^{111}$

Galba segue uma política de exagerada contenção, ${ }^{112}$ na qual se vislumbra um esforço para fazer face à dilapidação dos cofres do Estado operada por Nero, mas o biógrafo retém o aspecto negativo do excesso das medidas e a contradição do governo: favorecimentos, castigo de inocentes, impunidade aos 
José Luís Lopes Brandão

culpados, ao ponto de se poupar a vida, contra o pedido do povo romano, a Haloto e Tigelino, agentes de Nero. ${ }^{113} \mathrm{O}$ abuso de poder gera ódio que leva à revolta: Per haec prope uniuersis ordinibus offensis uel praecipua flagrabat inuidia apud milites ${ }^{114}$ ("Com estas acções provocou a hostilidade de quase todas as ordens, mas o rancor ardia principalmente entre os soldados").

\section{Vida de Vitélio}

A actuação de Vitélio como imperador é iniciada com duas medidas consideradas louváveis, que levam o biógrafo a comentar:

egregie prorsus atque magnifice et ut summi principis spem ostenderet, nisi cetera magis ex natura et priore uita sua quam ex imperii maiestate gessisset.

procedia com nobreza, no fim de contas, e com grandeza, ao ponto de criar até a esperança num eminente príncipe, se, quanto ao resto, não agisse mais segundo a natureza e a vida anterior que segundo a majestade do império. (Vit. 10.1)

Logo no campo de batalha de Betríaco, contra as tropas de Otão, tem reacções que o biógrafo qualifica de uanitas e insolentia perante os cadáveres de concidadãos (Vit. 10.3). A semelhança com Nero, cujo modelo Vitélio pretenderia seguir (Vit. 11.2), diz respeito ao que aquele tinha de mais negativo e processa-se não só no plano da actuação política, mas também no moral. Para mais, Vitélio tinha encorajado as ambições artísticas do último dos Júlio-Cláudios (Vit. 4). Como vícios principais, a luxuria e a saeuitia (Vit. 13.1) fazem de Vitélio uma caricatura de Nero. A luxúria concretiza-se na gula, vício no qual ele manifesta a sua desmesura e que também era superlativado por Cláudio ( $C l$. 33.1). O cúmulo deste vício é expresso por homo non profundae modo, sed intempestiuae quoque ac sordidae gulae (Vit. 13.3) («homem não só de uma gula sem fundo, mas também despropositada e abjecta»).

A saeuitia é tal que, pelas semelhanças verbais, corresponde ao grau mais elevado da crueldade de Nero: é exercida contra quem quer que seja e a qualquer pretexto. ${ }^{115}$ Suetónio parece desdobrar informações retiradas de uma mesma história, distribuídas em gradação ao longo da rubrica, com se se tratasse de pessoas diferentes. Conta que, a um doente que, durante um acesso de febre, lhe pedia água, o próprio Vitélio Ihe deu veneno num copo de água fria (Vit. 14.1); a outra vítima, depois de a condenar, mandou reconduzi-la de novo à sua presença e, quando todos celebravam já a sua clemência, ordenou que a matassem à sua frente (Vit. 14.2). Ora a comparação com Tácito parece indicar a utilização de elementos da narrativa da morte de Júnio Bleso. ${ }^{116}$ A tirania manifesta-se também nos jogos, à maneira de Calígula, com quem Vitélio partilhava o gosto pelas 
O processo de construção do imagem do tirano ...

corridas: manda executar uns homens da plebe por terem caluniado a facção azul. ${ }^{117}$ Mas o seu maior ódio era aos bufões e astrólogos. ${ }^{118}$

A semelhança com Nero vai até à acusação de matricídio. Cai sobre Vitélio a suspeição de responsabilidade na morte da mãe, a quem teria negado alimento durante uma enfermidade, movido por um oráculo que lhe prognosticava um longo reinado, se sobrevivesse aos pais. Outros dizem que a mãe, desgostosa da situação do momento e temerosa do que se seguiria, pediu veneno ao filho e que este Iho deu sem se fazer rogado. Este crime marca o auge da sua saeuitia. ${ }^{119}$

\section{Vida de Júlio César}

Um tratamento à parte entre os imperadores tirânicos merece Júlio César. Assegurado o poder de César, sem rivais, Suetónio passa a descrever a tarefa administrativa (Jul. 40-44). ${ }^{120}$ Entre a magnitude dos projectos (que incluem a abertura do istmo de Corinto e a guerra aos partos), surge a primeira referência à morte, como desaire que vem cercear tais planos. ${ }^{121}$ Mas, cumprido o curso da vida, muito há ainda para dizer. Entramos na parte organizada por rubricas: ${ }^{122}$ descrição física e cuidados corporais (Jul. 45.1-2), vestuário (Jul. 45.3), tendência para o fausto e desbaratamento (Jul. 46-47), disciplina doméstica (Jul. 48), impudicitia (Jul. 49), adultérios (Jul. 50-52), moderação no vinho e na comida (Jul. 53), falta de abstinentia nos cargos civis e militares (Jul. 54), eloquentia militarisque res (respectivamente, Jul. 55-56 e 57-70), studium et fides para com os clientes (Jul. 71), facilitas para com os amigos (Jul. 72), prontidão a perdoar as ofensas (Jul. 73), lenitas na vingança (Jul. 74), moderatio e clementia (Jul. 75). Nesta imagem de cambiantes há aspectos bastante positivos que distinguem nitidamente César dos outros tiranos: as qualidades da fides, da facilitas, do perdão e, no clímax, uma extraordinária clemência ${ }^{123}$, comprovada com vários exemplos.

No que respeita à descrição física e aos cuidados com o corpo e com o vestuário, destaca-se o carácter efeminado, consonante com a já analisada narrativa da ligação com Nicomedes (Jul. 49). $O$ abuso das matronas, característico dos tiranos, inicia a descrição dos adultérios ${ }^{124}$, aos quais se associa a sumptuosidade, pelos donativos à amante Servília (Jul. 50.2), pelos gastos com as mulheres das províncias, como entoam os soldados no triunfo ${ }^{125}$, pelos donativos à rainha Êunoe e pela vida faustosa em companhia de Cleópatra (Jul. 52.1). A consequência normal do fausto é a falta de abstinentia (Jul. 54.1), que culmina em rapina e sacrilégio (Jul. 54.2). Nestes aspectos não se diferencia muito de outros tiranos.

Mas César é apresentado acima de tudo como um homem de acção. (Jul. 57 ss). Apesar de se tratar de rubricas, os exemplos apresentados transformam a descrição em narrativa dinâmica que sugere o carácter de excepção da personalidade de César. Suetónio procura mostrar que César é um bom general 
que mantém a disciplina (Jul. 65), que é tolerante nas faltas e rigoroso com desertores e revoltosos (Jul. 67.1), pelo que gera soldados devotados e fortíssimos (Jul. 68). Intercalada, surge a descrição do cavalo (Jul. 61): um animal de pés quase humanos, que não tolera outro cavaleiro, complementa a imagem de um general. Mas o facto de César o criar com cuidado, porque os harúspices tinham prognosticado para o seu dono o imperium orbis terrae, atesta o seu carácter ambicioso. Parece haver aqui uma imitação de Alexandre, que César admirava. Há uma reminiscênica do famoso cavalo do macedónio: Bucéfalo. ${ }^{126}$

A ausência de temor religioso, ao ponto de subordinar a religião aos seus objectivos (Jul. 59), sugere insolência. Mas a alternância de traços de carácter muito negativos com outros muito positivos fazem de César, em parte um tirano, em parte um bom governante. Em suma, se partilha com os tiranos a inciuilitas, uma arrogância perigosa para a República e que o conduzirá aos Idos de Março honras desmedidas, que superam os limites humanos (Jul. 76.1) - a sumptuosidade, a irreligiosidade, a homossexualidade e o abuso de matronas, distingue-se, além da clementia, pela moderação na comida e na bebida - traço que o afasta da moleza decadente dos tiranos nédios e é consonante com a austeridade do general.

\section{Considerações finais}

A construção da imagem destes imperadores segue as linhas gerais do discurso sobre a tirania. O biógrafo procura ilustrar a progressiva manifestação das qualidades próprias dos tiranos e o grau da sua ocorrência. Seria errado acreditar em tudo o que se diz, mas também não seria correcto rejeitá-lo sem mais. As características apontadas correspondem a uma descrição verosímil para os contemporâneos do biógrafo. ${ }^{127}$ Do ponto de vista doutrinal, tomando como exemplo os monarcas helenísticos, todo o tirano evidenciaria à partida inciuilitas, saeuitia ou crudelitas, luxuria, rapacitas, libido exagerada (que inclui abuso de matronas e homens livres, impudicitia e incesto) e impietas contra os deuses, contra a pátria e contra a família (parricídios, matricídios, morte de familiares). E, se não apresentava estas características, conclui-se que as dissimulava: é uma forma cómoda de explicar, sem entrar em contradição, o tradicional período bom de príncipes como Calígula ou Nero. Ora Suetónio, ao escolher das fontes as versões mais romanescas, apresenta narrativas, baseadas muitas vezes em rumores, que correspondem precisamente ao desenvolvimento daquelas características. Combinando estas versões com as técnicas da gradação e da generalização, o biógrafo acentua aqueles traços.

Pelo contrário, a construção progressiva da imagem de um bom imperador assenta na conexão com as virtudes opostas às características dos tiranos: a tónica é colocada nas boas acções, de modo a que os piores comportamentos 
O processo de construção do imagem do tirano ...

sejam relegados para uma fase inicial ou para um plano secundário. A transformação do jovem Octávio, cruel, no magnânimo Augusto tem, pelo contraste, um efeito positivo no leitor. No caso de Vespasiano, além da desculpabilização do vício de avareza, o humor, associado ao carácter afável, contribui para favorecer a imagem do imperador. Os vícios de Tito ficam reduzidos a pecadilhos da juventude, perante uma transformação que se opera quando se torna imperador. Otão transforma-se num bom imperador no derradeiro momento - pela morte corajosa. A biografia de Cláudio distingue-se das restantes, pelos contrastes que ocorrem a cada passo entre aspectos positivos e negativos: o biógrafo procura apresentar (embora injustamente) um imperador incoerente, submetido a mulheres e libertos.

A estrutura das Vidas, organizada em função do carácter, sugere uma progressão que se efectiva na criação gradual de uma impressão na mente do leitor, tendo em vista um final catártico alcançado pela narrativa da morte. Tratase de um tratamento ficcional de factos históricos cujo resultado é naturalmente moralizante. Este efeito é mais forte nas Vidas dos piores dos imperadores, onde a progressão para o vício ultrapassa os limites do suportável. Mas também nos bons governantes há um crescendo na revelação do carácter, organizada, neste caso, de modo a deixar no final uma imagem tanto quanto possível impoluta.

\section{Bibliografia citada}

ALFÖLDY, G. La politique provinciale de Tibère. Latomus, 24, p.824-844, 1965.

BALDWIN, B. Executions, trials, and punishment in the reign of Nero. PP, 22, p.425-439, 1967.

BALDWIN, B. Suetonius. Amsterdam: Hakkert, 1983.

BARRETT, A. A. Caligula. The corruption of power. London / New York: Routledge, 1989 (2000).

BENEDIKTSON, D. Th. Caligula's madness. Madness or interictal temporal lobe epilepsy? CW, 82, p.370-375, 1988.

BLAISON, M. Suétone et l’ ekphrasis de la Domus Aurea. Latomus, 57, p.617-624, 1988.

BRADLEY, K. R. Suetonius' Life of Nero. An historical commentary. Bruxelles: Latomus, 1978.

BRANDÃO, J. L. Tirano ao tibre! Estereótipos de tirania nas Vidas dos Césares de Suetónio". Humanitas, 60, p.115-137, 2008.

BRANDÃO, J.L. Máscaras dos Césares. Teatro e moralidade nas Vidas suetonianas. Coimbra, CECH-Classica Digitalia, 2009.

CIZEK, E. Structure et idéologie dans les Vies des douze Césars de Suétone. Paris: Les Belles Lettres, 1977.

COLEMAN, K. M. The emperor Domitian and literature. ANRW, II. 32.5, p.3087-3115, 1986.

COUISSIN, J. Suétone physiognomoniste dans les Vies des XII Césars. REL, 31, p.234-256, 1953.

CROISILLE, J. M. L'art de la composition chez Suétone d'après les Vies de Claude et de Néron. AlIS, 2, p.73-87, 1970.

DELLA CORTE, F. Svetonio eques Romanus. Firenze: La Nuova Italia, 1967. 
José Luís Lopes Brandão

DUNKLE, J. R. The Greek tyrant and Roman political invective of the late Republic. TAPhA, 96, p.151-171, 1967.

DUNKLE, J. R. The rethorical tyrant in Roman Historiography: Sallust, Livy and Tacitus. CW, 65, p.12-20, 1971.

DUPONT, F. ET ÉLOI, T. L'érotisme masculin dans la Rome antique. Paris: Belin, 2001.

EVANS, E. C. Physiognomics in the Roman empire. CJ, 45, p.277-282, 1950.

GALLI, F. Svetonio, Vita di Domiziano. Intr., trad. e comm. Roma: Ateneo, 1991.

GASCOU, J. Suétone historien. Paris: de Boccard, 1984.

GIUA, M. A. Tiberio simulatore nella tradizione storica pretacitiana. Athenaeum, 53, p.352363, 1975.

GIUA, M. A. Sulla biografia suetoniana di Tiberio. Tradizione e struttura. Athenaeum, 56, p.329-345, 1978.

GIUA, M. A. Una lettura della biografia svetoniana di Tiberio. ANRW, II. 33, 5, p. 3733-3747, 1991.

GRELLE, F. La correctio morum nella legislazione flavia. ANRW, II. 13, p.340-365, 1980.

GUASTELLA, G. Gaio Svetonio Tranquillo, La vita di Caligola. Testo, trad. e comm. Roma: La Nuova Italia Scientifica, 1992.

HALLET, J. P. Morigerari. Suetonius, Tiberius, 44. AC, 47, p.196-200, 1978.

HURLEY, D. W. An historical and historiographical commentary on Suetonius'Life of $C$. Caligula. Atlanta: Scholars Pr., 1993

JONES, B. \& MILNS, R. Suetonius: the Flavian emperors. A historical commentary. London: Bristol Classical Press, 2002.

JONES, B. W. Suetonius. Domitian. Ed. with intr., com. and bibl. London: Bristol Classical Press, 1996.

KATZ, R. S. The illness of Caligula. CW, 65, p.223-225, 1972.

KERESZTES, P. The Jews, the Christians and the emperor Domitian. VChr, 27, p.1-28, 1973.

LE ROUX, P. Galba et Tarraco. À propos de Suétone, Galba XII, 1. Pallas, 31, p.113-124 et 192, 1984.

LEVICK, B. Tiberius the Politician. London / New York: Routledge (rev. ed.), 1999.

LINDSAY, H. Suetonius, Tiberius. Edited with intr., com. and Bibliography. London: Bristol Classical Press, 1995.

LOUNSBURY, R. C. Inter quos et Sporus erat: The making of Suetonius' Nero. ANRW, II, 33, 5, p.3748-3779, 1991.

LUCAS, J. Un empereur psychopathe. Contribution à la psychologie du Caligula de Suétone. AC, 36, p.159-189, 1967.

MARTIN, R. Les douze Césars: du mythe à la réalité. Paris: Les Belles Lettres, 1991.

MASSARO, V. \& MONTGOMERY, I. Gaius - Mad, Bad, III, or all Three?. Latomus, 37, p.894909, 1978.

MASSARO, V. \& MONTGOMERY, I. Gaius (Caligula) doth murder sleep. Latomus, 38, p. 699700, 1979.

MAYER, R. What caused Poppaea's death ? Historia, 31, p. 248-249, 1982.

MORFORD, M. P. The distortion of the Domus Aurea tradition. Eranos, 66, p.158-179, 1968.

MORGAN, L. Leui quidem de re... Julius Caesar as tyrant and pedant. JRS, 87, p.23-40, 1997.

MURISON, Ch. L. Suetonius Galba, Otho, Vitellius. Ed. with intr. and notes. London: Bristol Classical Press, 1992. 


\section{O processo de construção do imagem do tirano ...}

OLIVEIRA, F. Biografia dos imperadores em Plínio o Antigo. Biblos, 71, p. 67-84, 1995.

OLIVEIRA, F. La imagen del gobernante ideal en Plinio el Viejo. In: J. A. Sánchez Marín, J. Lens Tuero, C. López Rodríguez (eds.). Historiografía y biografía. Madrid, 1997, p.119138.

SARTORI, A. L'evergetismo dei militari graduati in congedo: in margine a Svet. Tib. 37. MEFRA, 102, p.687-697, 1990.

SEAGER, R. Tiberius. London: Eyre Methuen, 1972.

SOUTHERN, P. Domitian tragic tyrant. London / New York: Routledge, 1997.

STEWART, A. F. To entertain an emperor. Sperlonga, Laokoon, and Tiberius at the dinner table. JRS, 67, p.76-90, 1977.

STOK, F. Ritratti fisiognomici in Svetonio. In: Biografia e autobiografia degli antichi e dei moderni, a cura di Italo Gallo e Luciano Nicastri. Napoli: Ed. Scientifiche Italiane, 1995, p.109-135.

TABACCO, R. Il tiranno nelle declamazioni di scuola in lingua latina. Memorie della Accademia delle Scienze Morali, Storiche e Filologiche di Torino II. Classe di Scienze Morali, Storiche e Filologiche, serie V, vol.9. Torino, p.1-141, 1985.

TOWNEND, G. B. The trial of Aemilia Lepida in A. D. 20. Latomus, 21, p.484-493.

VERDIERE, R. À verser au dossier sexuel de Néron. PP, 30, p.5-22, 1975.

WARDLE, D. Suetonius' Life of Caligula. A commentary. Bruxelles: Latomus, 1994.

WARMINGTON, B. H. Suetonius Nero. Text, with intr. \& notes. Bristol Class. Pr. (2a ed.), 1999.

\footnotetext{
Notas

${ }^{1}$ Na elaboração deste trabalho foi usado diverso material de Brandão (2008, p.115-137; 2009, p.199-252).

${ }^{2}$ Crueldade, avidez e violência sexual são elencados, como traços típicos do tirano, em Quintiliano (Quint. Decl. 329). Vide Tabacco (1985, p.87 e 131). São traços do género dos usados, por exemplo, por Tito Lívio na descrição do famoso Tarquínio-o-Soberbo (Liv. 1.49 ss), por demais arrogante e cruel, ou de Jerónimo, tirano de Siracusa (Liv. 24.5.3-6), de quem se refere, além de arrogância e crueldade, outros elementos significativos, como o uso de trajes sumptuosos, a ostentação de um corpo de guarda-costas e a propensão para uma libido sem precedentes. Vide Dunkle (1971, p.16-17). São termos igualmente usados por Cícero, para classificar as actividades de Verres, Clódio, Pisão, Gabínio ou António, como demonstra Dunkle (1967, p.151-171) e também por uma das fontes de Suetónio, o naturalista Plínio, nos elementos biográficos que sobre os imperadores transmite, como demonstra Oliveira (1995, p.67-84). Vide também Oliveira (1997, p.119-138).

${ }^{3}$ Tib. 30. Cf. Tac. Ann. 1.77.3; 4.6.2.

${ }^{4}$ Vide Giua (1978, p.331; 1991, p.3736).

${ }^{5}$ Exemplar é a repressão da exploração, por parte da plebe de Polência, do evergetismo dos herdeiros de um primipilo, mediante a retenção do seu funeral no foro (Tib. 37.3). Suetónio, ao querer mostrar a desproporção do uso da força (duas coortes entram na cidade de espada em riste e ao som de clarins), parece exagerar, quando diz que Tibério "lançou na prisão, para o resto da vida, a maior parte da plebe e dos decuriões". Vide Sartori (1990, p.687-697).
} 
${ }^{6}$ Suetónio denota gosto por estes acasos que poderiam alterar a história. Para Tac. Ann. 4.59, o acidente não têm importância em si, mas pelas suas consequências políticas: Tibério foi salvo por Sejano, que se torna assim digno de total confiança e todo poderoso, com consequências nefastas na evolução deste principado; vide Gascou (1984, p.419-420).

${ }^{7}$ Tib. 40. Cf. Tac. Ann. 4.57.1; 4.67.1.

${ }^{8}$ Ao passo que Tácito, junta à inacessibilidade o clima temperado e a beleza do lugar (Tac. Ann. 4.67.2).

${ }^{9} \mathrm{O}$ facto de ele se deslocar ao continente (na sequência da derrocada de um anfiteatro que custou a morte de vinte mil pessoas - contra as 50000 referidas por Tácito, Ann. 4.63) e de permitir a aproximação de todos é apresentado como uma grande concessão: Tanto magis, quod urbe egrediens ne quis se interpellaret edixerat ac toto itinere adeuntis submouerat ("Tanto mais que, ao sair da Urbe, publicara um edicto para que ninguém o importunasse, e, em todo o trajecto, mandara afastar os que se aproximavam."). Ao acentuar-se o carácter de excepção de tal facto, o biógrafo cria a imagem de um imperador desconfiado e misantropo. Como outrora em Rodes (Tib. 11), Tibério impõe de novo um exílio a si próprio.

${ }^{10}$ Tib. 41. Vide Levick (1999, p.127-128).

${ }^{11}$ Tib. 42.1. A ideia da mudança na conduta é como que um cliché na tradição sobre os imperadores da dinastia júlio-cláudia. Vide Giua (1975, p.353ss).

${ }^{12}$ Vide Giua (1978, p.331). Sobre o topos da hipocrisia em Suetónio e Tácito, vide Lindsay (1995, p.14) e Giua, 1975, p.352-363).

${ }^{13}$ Como sugerem Dupont e Éloi (2001, p.295). A referência a jovens vestidos de Pãs e ninfas bem como à alcunha de capríneo que o vulgo dá ao imperador (Tib. 43.2) sugere uma sexualidade inspirada na dos sátiros. Tácito (Ann. 6.1) lembra que se trata de crimes tirânicos (more regio) sobre a juventude de nascimento livre.

${ }^{14}$ Tib. 44.1: Maiore adhuc ac turpiore infamia flagrauit, uix ut referri audiriue, nedum credi fas sit.

${ }^{15}$ Tib. 44.2: in qua Meleagro Atalanta ore morigeratur - "no qual Meleagro e Atlante se satisfaziam sexualmente com a boca um ao outro", se aceitarmos a tradução de morigerari no seu sentido médio-passivo de 'estimulação mútua', como propõe Hallet (1978, p.196200). O interesse de Tibério por arte erótica, aliado à especulação sobre as suas actividades em Cápreas, poderá estar na origem da tradição hostil que o representa como um pervertido sexual; assim o afirma Lindsay (1995, p.14 e 142).

${ }^{16}$ Tib. 48.2. Vide Giua (1978, p.341), Alföldy (1965, p.830-831).

${ }^{17}$ Morto em 25 d.C.; cf. Tac. Ann. 4.44.1.

${ }^{18}$ Condenada em 20 d. C. (cf. Tac. Ann. 3.23.1). É um processo complexo; vide Townend (1962, p.484-493).

${ }^{19}$ Tib. 49.2. Segundo Tácito (Ann. 2.68), ele foi assassinado em 19 d. C., na fuga para a Arménia, por um praefectus equitum, sem responsabilização de Tibério. Vide demonstração em Gascou (1984, p.408-410).

${ }^{20}$ Tib. 50.2-51.2. A recusa de honras atribuídas à mãe, interpretada pela tradição hostil como desentendimento, seria uma política oficial de moderação que Tibério também aplicava à sua pessoa. Vide Lindsay (1995, p.151).

${ }^{21}$ Causa apresentada em Tib. 39. Vide Gascou (1984, p.363). 
22 Tib. 58. Tácito (Ann. 1.72.3), remete a orientação de Tibério para a aplicação da lex maiestatis ao ano 15. Vide Giua (1978, p.332; 1991, p.3737).

${ }^{23}$ Tib. 59.2. Giua (1978, p.342-344), aponta várias contradições que ocorrem em Tácito e Suetónio, mas são mais visíveis no segundo, devido à estrutura da biografia: pertenceriam a uma tradição anterior.

${ }^{24}$ Como já vimos, a razão para a escolha da ilha por parte de Tibério é, para Suetónio, a inacessibilidade do lugar: Tib. 40. Cf. Tac. Ann. 4.67.2.

${ }^{25}$ Segundo Giua (1991, p. 3737), só no capítulo 60 se chega verdadeiramente ao período de vícios que fora anunciado no cap. 42, contraposto a toda uma fase precedente de moderação, e se entra na descrição da louca desumanidade de Tibério, desencadeada sem freios no isolamento de Cápreas.

${ }^{26}$ Tib. 61.1. A acção de Sejano provocou actos e palavras de hostilidade por parte das vítimas que não foram obliterados depois da morte, como afirma Levick (1999, p.173). Vide Seager (1972, p.214-215).

${ }^{27}$ Dunkle (1971, p.14-15) nota que, a partir dos últimos anos de Cícero, o termo crudelitas começa a ser substituído por saeuitia na descrição popular do tirano. Acrescenta que o último implica conotações de histerismo e sadismo maníaco, uma vez que primariamente se refere à ferocidade dos animais selvagens. Em Suetónio, prevalece saeuitia. Vide Tabacco (1985, p.89-116).

${ }^{28}$ Cf. Tac. Ann. 5.9.2; Dio Cass 58.11.5. Vide, para este e outros casos de generalização, Gascou (1984, p.452-456).

${ }^{29}$ Tib. 63.1: de inuisus ac detestabilis; praetrepidus; contumeliis obnoxius.

${ }^{30}$ Para a progressão gradativa até ao clímax, vide Cizek (1977, p.124-125). Segundo este autor, tal climax aproxima Tibério, sem o colocar ao mesmo nível, de Calígula e de Nero.

${ }^{31}$ Tib. 68.3: naturae uitia esse, non animi. Vide Martin (1991, p.59-64).

${ }^{32}$ Como o facto de assumir sozinho o terceiro consulado em Lugduno. 0 facto é que o afastamento de Roma o impedira de saber que o colega tinha falecido pouco antes do início do novo ano (Cal.17.1). Semelhante julgamento aparece em Díon Cássio (Dio Cass 59.24.2).

${ }^{33}$ E este quasi (Cal. 22.1), muitas vezes ignorado por tradutores e comentadores, parece sugerir que Suetónio questiona a sinceridade e o mérito das acções de Calígula, como nota Wardle (1994, p.92).

${ }^{34} \mathrm{O}$ termo monstrum sugere uma extraordinária enormidade, estranha às normas naturais, que provoca maravilha ou horror e que pode conter em si o sentido religioso de um presságio. Como acontece em Gal. 18.1: magna et assidua monstra iam inde a principio exitum ei, qualis euenit, portenderant. Monstrum associa-se etimologicamente a moneo. Vide Guastella (1992, p.157).

35 Esta divisão da narrativa em princeps e monstrum é mais o resultado da técnica biográfica de Suetónio (repetida na biografia de Nero, 19.3), do que um dado histórico, uma evolução cronológica. Na primeira fase da biografia, narram-se também acontecimentos que pertencem já a uma fase avançada do governo, como a ponte de Baias (Cal. 19) ou o concurso de Lugduno (Cal. 20). Vide Guastella (1992, p.18-19, e 156-157), Wardle (1994, p.202). Em todo o caso, geralmente aceita-se que houve uma mudança: a um período inicial bom, segue-se depois um mau. Fílon faz coincidir a mudança com a 
doença de 37 (Philo Leg 13); Díon Cássio diz que a mudança ocorre em 38 (Dio Cass 59.2.63.1); Josefo sustém que a mudança ocorre depois de dois anos de bom governo (J. AJ 18.256). Vide Hurley (1993, p.83 e n.41).

${ }^{36}$ É que antes tratava de pietas, mas agora é de impietas. Cf. Cal. 15.2: Post haec Antoniae auiae, quidquid umquam Liuia Augusta honorum cepisset, uno senatus consulto congessit. Vide Gascou (1984, p.365). Só Suetónio fala no boato de envenenamento de Antónia.

37 Cal. 27.1: Saeuitiam ingenii per haec maxime ostendit. Em Cal. 11, fala-se de natura saeua atque probrosa. Cf. Tib. 57.1: saeua ac lenta natura.

${ }^{38}$ Cal. 29.1: immanissima facta augebat atrocitate uerborum.

${ }^{39}$ Cal. 30.2; cf. 15.4. Não é de crer que Suetónio, que tanto cuidado coloca na recolha e análise, se mostre descuidado ou esquecido do que atrás dissera sobre a queima dos processos, como sublinha Wardle (1994, p.86). Suetónio parece querer colocar diante do leitor a progressiva revelação do carácter de Calígula.

${ }^{40}$ Cal. 36.2. Deve tratar-se do caso de Lólia Paulina, esposa de Mémio; cf. Dio Cass 59.12.1. Vide Gascou (1984, p.488, n.145). A abordagem de erotica tem em Suetónio uma função crucial: demonstrar que Calígula viola todas as normas sexuais através da homossexualidade, incesto, adultérios e travestismo. O seu relacionamento sexual prova a sua monstrositas; vide Wardle (1994, p.275), Martin (1991, p.157-158).

${ }^{41}$ Cal. 48.1. A história soa a exagero de Suetónio: poucos ou nenhuns dos soldados envolvidos no motim de 14 estariam ainda ao serviço em 40 . O facto de se dizer que era um projecto levanta a suspeita de que se trataria de um rumor hostil.

${ }^{42}$ Cal. 49.2. A referência antecipada à morte, oito capítulos antes da narração, faz lembrar Jul. 44.4. Também o projecto da mudança da capital para Alexandria, referido no contexto da narrativa da morte, cria um paralelo com Júlio César (Jul. 79.3) e com Nero (Nero 47.2).

${ }^{43}$ Cal. 50.1. Vide Guastella (1992, p.263-264), Gascou (1984, p.607-610). Há quem proponha a influência da tradição fisiognomónica (que Suetónio conheceria) na descrição de Calígula, como pretendem Evans (1950, p.277-282), Coussin (1953, p.234-256), Stok (1995, p.109-135). Colocam sérias reservas à aplicação dos princípios destas teorias às Vidas dos Césares Baldwin (1983, p.500) e Gascou (1984, p.592-598). Vide Wardle (1994, p.323-327). De qualquer modo, é obvio que Suetónio concebia a fealdade física de Calígula como reflexo da desordem psíquica; vide Martin (1991, p.67-70).

${ }^{44}$ Cal. 50.2. Várias são as hipóteses modernas que apontam para uma doença do foro psíquico ou neurológico: vide Lucas (1967, p.159-189), Katz (1972, p.223-225), Massaro e Montgomery (1978, p.894-909; 1979, p. 699-700); contra, vide Morgan (1973, p.327-329). Nem Suetónio nem Dion (Dio Cass 59.8.1-3), consideram a doença significativa para o comportamento do imperador. De resto, Fílon afirma sem hesitar que a doença era estritamente física e que o imperador recuperou completamente (Philo Leg. 16 e 19). Benediktson (1988, p.370-375) defende que Calígula sabia que tinha problemas e que o boato do filtro de Cesónia poderia ter provindo da boca dele próprio. Quando dizia que recorreria à tortura para saber por que razão a amava tanto (Cal. 33), Calígula queria dizer que pensara recorrer à tortura (de escravos, certamente) para apurar se ela lhe tinha dado de facto qualquer afrodisíaco. Vide também Barrett (1989 [2000], p.73).

${ }^{45}$ Cal. 51.1. Vide Baldwin (1983, p.516).

${ }^{46}$ Vide Dunkle (1967, p.170; 1971, p.18-19). 
${ }^{47}$ Ex disciplinis liberalibus minimum eruditioni, eloquentiae plurimum attendit... (Cal. 53.1); sed et aliorum generum artes studiosissime (Cal. 54.1). Trata-se de estabelecer a conexão entre educação e carácter: julgava-se que as disciplinae liberales formavam um carácter virtuoso.

${ }^{48}$ Nero 16.2. A perseguição aos cristãos é colocada aqui entre as medidas boas de Nero e sem qualquer conexão com o incêndio de 64, cuja responsabilidade será mais à frente totalmente imputada ao imperador.

${ }^{49}$ Nero 19.3. Uma fractura na Vida que traz consigo a repartição de alguns episódios entre aspectos positivos e negativos; vide Gascou (1984, p.369-373).

${ }^{50}$ Sensim... et occulte (Nero 26.1). Vide Lounsbury (1991, p.3752).

${ }^{51}$ Nero 28.1. O episódio é duvidoso: vide Verdière (1975, p.7). Vide Martin (1991, p.144) e Warmington (1999, p.54).

${ }^{52}$ Vide Gascou (1984, p.414).

53 Quando, segundo Verdière (1975, p.17-19), o suposto casamento com Doríforo / Pitágoras, em que Nero faz de mulher, teria ocorrido em 64, na altura em que Popeia dá uma filha a Nero, e o casamento com Esporo, em que este coloca o véu, aconteceria entre a morte de Popeia e a viagem de Nero à Grécia (65-66).

${ }^{54}$ Nero 30.1, cf. Cal. 37. Vide Lousbury (1991, p.3755), Gascou (1984, p.370-371).

${ }^{55}$ Nero 31.1: Non in alia re tamen damnosior quam in aedificando domum...

${ }^{56}$ Nero 31.2. Cf. Tac. Ann. 15.42-43. Morford (1968, p.158-179), vê nas descrições da Domus Aurea, em Suetónio e Tácito (Ann. 15.42-43), distorções resultantes da linguagem retórica das declamationes - a diatribe contra a luxuria. Blaison (1998, p.617-624) mostra que a descrição de Suetónio não corresponde à realidade, mas é uma ekphrasis de uma morada sumptuosa, de acordo com uma tradição fixada desde os poemas homéricos.

${ }^{57}$ Nero 32.1: ... calumniis rapinisque intendit animum. Cf. Cal. 38.1; Dom. 12. Esta é uma característica dos tiranos, já manifesta em Júlio César: Jul. 54.3.

${ }^{58}$ Cf. Quint. Decl. 329; Sen. Con. 5.8; 9.4; Quint. Inst. 3.6.78. A descrição retórica do tipo tirânico que delapida o património para satisfazer os seus apetites desmedidos e depois progride para a espoliação dos cidadãos e dos templos encontra fundamento em Platão (Plat. Rep. 9.573 d-575; cf. Arist. Pol. 1305 b 39 ss). Vide Tabacco (1985, p.28-29, 118, n.327).

${ }^{59}$ Vide Lounsbury (1991, p.3753).

${ }^{60}$ Cf. Quint. Decl. 322. Vide Tabacco (1985, p.111).

${ }^{61}$ Cuius necis non auctor, at conscius fuit (Nero 33.1).

${ }^{62}$ A substância doutrinal sobre o tirano à moda grega poderá ter sido introduzida na sociedade romana através da tragédia. Vide Dunkle (1967, p.153-154; 1971, p.12-13). De resto, outras conexões míticas e trágicas são evocadas pelo biógrafo para caracterizar o comportamento de Nero a propósito do matricídio. Divulgam-se escritos que o associam a Orestes e Alcméon (Nero 39.2), e ele próprio se diz perseguido pelas Fúrias (Nero 34.4).

63 Mayer (1982, p.248-249). A comparação do passo com a versão de Tácito e de Díon Cássio indicia um acidente e não uma intenção deliberada de Nero (Tac. Ann. 16.6; Dio Cass 62.27).

${ }^{64}$ Nero 35.4: Nullum adeo necessitudinis genus est, quod non scelere perculerit. 
${ }^{65}$ Nero 35.4: (...) similiter [inter] ceteros aut affinitate aliqua aut propinquitate coniunctos; in quibus Aulum Plautium iuuenem, quem cum ante mortem per uim conspurcasset.

${ }^{66}$ Nero 35.5. O assassínio de Burro é confirmado por Díon, enquanto Tácito hesita entre doença e envenenamento (Dio Cass 62.13.3; Tac. Ann. 14.51.1). Provavelmente nunca se saberá se esta morte teve causas naturais ou se a doença forneceu uma conveniente camuflagem para o assassínio: vide Bradley (1978, p.218).

${ }^{67}$ Nero 36.1: Nec minore saeuitia foris et in exteros grassatus est.

${ }^{68}$ Nero 37.1: Nullus posthac adhibitus dilectus aut modus interimendi quoscumque libuisset quacumque de causa. Segundo Baldwin (1967, p.425-439), não há razão para crer que tenha havido um período de terror no principado de Nero.

${ }^{69}$ Suetónio transforma a morte de Trásea num simples exemplum da crueldade de Nero, deixando de lado toda a perspectiva histórico-política, sublinhada longamente por Tácito (Ann. 16.21-22); vide Gascou (1984, p.436).

${ }^{70}$ Nero 37.3: negauit quemquam principum scisse quid sibi liceret. Cf. Cal. 29.1: 'memento' ait 'omnia mihi et <in> omnis licere.'

${ }^{71}$ Nero 38.1: Sed nec populo aut moenibus patriae pepercit. É interessante o uso do termo patria (raro em Suetónio) que enfatiza a solenidade do momento; a abordagem subjectiva remete para a noção de parricida; vide Bradley (1978, p.227-228), Warmington (1999, p.72).

${ }^{72}$ Nero 38.3: Ac ne non hinc quoque quantum posset praedae et manubiarum inuaderet, pollicitus cadauerum et ruderum gratuitam egestionem nemini ad reliquias rerum suarum adire permisit. Tácito (Ann. 15.43.2) coloca a promessa de remover escombros e cadáveres entre as medidas louváveis de Nero, o que sugere que tanto Tácito como Suetónio usaram a mesma fonte, que era favorável, mas que Suetónio terá manipulado. A proibição de as pessoas se aproximarem dos escombros é uma medida compreensível, dado o perigo de derrocadas. Vide Bradley (1978, p.235) e Warmington (1999, p.73).

${ }^{73}$ Nero 40.1. Cf Cal. 56: Ita bacchantem atque grassantem non defuit plerisque animus adoriri.

${ }^{74}$ Vide Gascou (1984, p.398; 431 e 684), Badlwin (1983, p.298).

75 Dom. 6.1. Uma lista muito incompleta: vide Jones (1996, p.53), Jones e Milns (2002, p.134-135).

${ }^{76}$ Por exemplo, Suetónio sugere indevidamente que a punição da vestal Cornélia e seus cúmplices se situa na fase inicial (Dom. 8.4). Segundo Galli (1991, p.78), o suplício de Cornélia teria acontecido em 89, ou, segundo Grelle (1980, p.347), em fins de 90 ou decurso de 91 . Gascou (1984, p.400), acentua que aconteceu na parte final do principado de Domiciano. Além disso, Suetónio não liga o incestum de Cornélia ao de Domiciano com a sobrinha Júlia, como faz Plínio (Plin. Ep. 4.11). Vide Jones (1996, p.78), Jones e Milns (2002, p.142-143).

77 Vide Baldwin (1983, p.298).

78 Dom. 10.1. Vide Gascou (1984, p.696). Segundo Baldwin (1983, p.487), com esta transição pretende-se salientar a imagem de Domiciano como um segundo Tibério (cf. Tib. 42.1). 
${ }^{79}$ Se o discípulo foi morto, tem de se pressupor - Suetónio não o diz - que Páris, por quem a esposa imperial se apaixonara, foi suprimido por ter sido alvo deste amor. Segundo Díon Cássio, foi morto no meio da rua (Dio Cass 67.3.1).

${ }^{80}$ Dom. 10.1. Domiciano apoiava os mirmilões. Iguais manifestações de partidarismo tirânico em Cal. 32.2 e Vit. 14.3.

${ }^{81}$ leuissima quemque de causa... uerum et ueteres et innoxios iocos (Dom. 10.2). O uso de quod com imperfeito do conjuntivo desvaloriza as razões do imperador: quod ... circumferret quodque indidisset; quod... passus esset; quod... edidisset appellassetque (Dom. 10.3); quod... pronuntiasset (Dom. 10.4).

${ }^{82}$ Como sugerem as expressões: quasi molitores rerum nouarum (Dom. 10.2); quasi... diuortium suum cum uxore taxasset (Dom. 10.4).

${ }^{83}$ C. Vetuleno Cívica Cereal pode ter estado associado ao levantamento do falso Nero no Oriente em 88-89; ou pelo menos Domiciano não acreditou que ele não estivesse: vide Southern (1997, p.104 e 112).

${ }^{84}$ Este foi desterrado em consequência de um processo que envolvia Nerva e Apolónio de Tíanos, como nota Filóstrato (Philostr. VA 7.8; 7.33; 8.7.10). Foi executado mais tarde, talvez por envolvimento em algum tipo de conjura. $O$ facto de o pai dele ter sido executado por Nero, deixaria ressentimento suficiente na família para encorajar uma vingança na pessoa do imperador reinante: vide Southern (1997, p.116).

${ }^{85}$ Segundo Díon Cássio, Acílio Glabrião foi morto, acusado de ateísmo e muitos outros crimes, entre os quais, de combater, como gladiador, com bestas ferozes (Dio Cass 67.14). Os feitos na arena provocaram a inveja do imperador. Há quem tente provar que ele era cristão: vide Southern (1997, p.15).

${ }^{86}$ Dom. 10.2. Domiciano arrebatara-lhe a esposa. É morto por uns ditos de espírito sobre o caso. O ressentimento deve tê-lo atirado para a oposição, e Domiciano, desconfiado, devia temer uma reacção violenta e procurou suprimi-lo: vide Southern (1997, p.116).

${ }^{87}$ Dom. 10.3. Tratava-se da subversiva veneração da memória de um homem que fora imperador: assim se lembraria que o familiar vivo podia aspirar ao principado; vide Galli (1991, p.81-82), Southern (1997, p.116).

${ }^{88}$ Dom. 10.3. Provavelmente teria aderido à revolta de Lúcio António Saturnino em 89, ou poderia ter caído em desgraça pela sua oposição à política não expansionista de Domiciano na Britânia, o que o tornava um potencial traidor aos olhos do imperador, que se mostrava mais consciente dos perigos depois da revolta de Saturnino: vide Jones (1983, p.629-633), Galli (1991, p.82), Jones (1996, p.91), Jones e Milns (2002, p.147).

${ }^{89}$ Dom. 10.4. É suspeita a ligação da morte ao equívoco do praeco, uma vez que T. Flávio Sabino foi designado como colega de consulado de Domiciano para o ano de 82 e viveu o suficiente para ocupar o cargo. Existiria certamente a suspeita de adesão a uma conjura: vide Gali (1991, p.84), Southern (1997, p.43).

${ }^{90}$ Dom. 10.3. Cf. Dio Cass 67.13.2; Tac. Ag. 2; Plin. Ep. 1.5. Segundo Díon, o apelido de santo é apenas atribuído a Trásea (por Aruleno Rústico). Vide Della Corte (1967, p.96-98).

${ }^{91}$ Dom. 10.3. Cf. Ves. 14; Dio Cass 67.12.3. Vide análise das divergências dos relatos em Gascou (1984, p.326-328). Tal como a apresenta Díon Cássio, esta informação devia circular conjuntamente em fontes posteriores à morte de Domiciano (Dio Cass 67.12.2-4). 
92 Helvídio pertence a um grupo, unido por laços familiares e de amizade com um longo historial de oposição estóica: Cecina Peto, Trásea Peto, Helvídio Prisco, Aruleno Rústico, Herénio Senecião, os dois últimos executados por Domiciano e talvez em conjunto com Helvídio filho. No grupo se incluem mulheres como Árria, a heróica esposa de Cecina Peto, e Fânia, filha de Trásea Peto e esposa de Helvídio Prisco filho. Vide Southern (1997, p.113114).

${ }^{93}$ A morte de Flávio Sabino (Dom. 10.4), primo de Domiciano, poderá ser anterior, mas é tomada como a acme do furor assassino de Domiciano, dado o parentesco e o absurdo da causa. Terá sido executado entre 82 e 89 , uma vez que a mulher, a filha de Tito, Ihe sobreviveu (Dom. 22) e morreu, o mais tardar, em 89: vide Galli (1991, p.84), Gascou (1984, p.412-413). Mais provavelmente a execução terá ocorrido, juntamente com a de outros senadores, entre Outubro de 82 e Setembro de 83. Vide Southern (1997, p.43).

${ }^{94}$ Dom. 10.5. A guerra civil aconteceu em Janeiro de 89.

${ }^{95}$ Se tomarmos como referência as datas adoptadas por Gascou (1984, p.411-413, e 691), Cívica Cerial morre por volta de 89; Salvidieno Órfito, por volta de 93; Acílio Glabrião, cônsul com Trajano em 91 (cf. Dio Cass 67.14.3), foi morto em 95; Élio Lâmia em 93 (ou em 85, segundo Galli, 1991, p.59); Métio Pompusiano, talvez em 91; a desgraça de Salústio Luculo é colocada entre 86 e 96 (ou entre 89 e 90, segundo Galli); Júnio Rústico em 93; a expulsão dos filósofos de Itália poderá ter acontecido em 93 (vide Galli, 1991, p.82).

${ }^{96} \mathrm{O}$ facto de o biógrafo não mencionar os nomes destas vítimas pode explicar-se com uma providência de Domiciano que, para abafar o escândalo, proibiu a menção dos nomes nos registos: cf. Dio Cass 67.11.3.

${ }^{97}$ Cf. Cal. 29.1: Immanissima facta augebat atrocitate uerborum.

${ }^{98}$ Dom. 12.1: Exhaustus operum ac munerum inpensis stipendioque, quod adiecerat. Cf. Cal. 38.1; Nero 32.1. Vide Gascou (1984, p.749, n.261). Exhaustus é exagero do biógrafo, como notam Jones e Milns (2002, p.150-151): Domiciano teria recursos suficientes, mas quereria mais (cf. Plin. Pan. 50.5) para o seu programa de construções monumentais.

${ }^{99}$ Ficam assim ensombradas pelo exagero nos gastos medidas anteriormente apresentadas como positivas (Dom. 4-5). Então sublinhou apenas a generosidade do imperador: só agora aborda as consequências nefastas; vide Gascou (1984, p.372).

${ }^{100}$ Dom. 12.1. Esta atitude contrasta com a de Tito, que desencoraja e castiga os delatores (Tit. 8.5), e faz lembrar a de Nero, pela repressão indiscriminada: Nullus posthac adhibitus dilectus aut modus interimendi quoscumque libuisset quacumque de causa (Nero 37.1).

${ }^{101}$ Dom. 12.2. Suetónio faz referência à taxa da didracma, que os Judeus já pagavam para o templo de Jerusalém e, que, depois da destruição deste, no ano 70, passaram a pagar para o templo de Júpiter Capitolino, o que Ihes dava o direito de praticarem livremente a sua religião: cf. J. BJ 7.6.6; Dio Cass 66.7.2. Vide Keresztes (1973, p.1-7), Galli (1991, p.86-88).

102 Dom. 12.3: Ab iuuenta minime ciuilis animi confidens etiam et cum uerbis tum rebus immodicus. Vide Martin (1991, p.312-313).

${ }^{103}$ Cizek (1977, p.120), não concorda que haja gradações na Vida de Domiciano. Segundo este autor, o biógrafo prefere apresentar uma imagem de matizes.

${ }^{104}$ Per haec terribilis cunctis et inuisus, tandem oppressus est $<\ldots . .>$ amicorum libertorumque intimorum simul et uxoris (Dom. 14.1). É notável o paralelismo com as Vidas de Calígula e de Nero: Cal. 56.1; Nero 40.1. Vide Croisille (1970, p.78, n.5), Gascou (1984, p.790). 
${ }^{105}$ Dom. 19. A mesma ideia em Tac. Ag. 40; Plin. Pan. 14; Dio Cass 67.6.3.

106 Dom. 20. As críticas de Suetónio parecem injustas. Coleman (1986, p.3087-3095), sustenta que Domiciano teria talento literário, mas, ao chegar ao poder, terá revelado uma conscienciosa preocupação com o governo e legislação, facto que o levou a abandonar a actividade literária.

107 Gal. 12.1. Para Le Roux (1984, p.113-124), Suetónio mostra-se dividido entre a aprovação da revolta de Galba contra Nero e a condenação dos excessos que provocou por culpa do carácter do imperador e do contexto de guerra civil.

$108 \mathrm{Gal}$. 14.1. Cf. Tac. Hist. 1.7.2. A ideia de que era um bom cidadão privado e um mau imperador também vem expressa em Tácito: et omnium consensu capax imperii, nisi imperasset (Tac. Hist. 1.49.4).

${ }^{109}$ Tácito e Díon Cássio expõem as boas acções (Tac. Hist. 1.49. Dio Cass 64.2.1-3.4).

${ }^{110}$ Gal. 14.2. Cf. Tac. Hist. 1.13.1. Vide Martin (1991, p.286-287).

${ }^{111} \mathrm{Gal}$. 14.3. Cinco expressões (quosdam - claros - ex utroque ordine - suspicione minima inauditos) apresentadas em gradação emotiva, que sugerem a imagem de um tirano sedento de sangue Como salienta Murison (1992, p.68), o propósito desta enumeração não é restringir a referência através de uma definição cuidadosa, mas criar a impressão de tirania crescente e sangrenta.

${ }^{112}$ Gal. 15.1. Cf. Plutarco. Gal. 16. 3-4; Tac. Hist. 1.20.

${ }^{113} \mathrm{Gal}$. 15.2. Mas Suetónio silencia a eliminação, com o aplauso do povo, de vários agentes de Nero, como se vê pelo confronto com Plutarco, Gal. 17.2-3, e Dio Cass 63.3.4.

${ }^{114} \mathrm{Gal}$. 16.1. Esta afirmação sugere que a queda de Galba é uma consequência directa da conduta anterior. Suetónio costuma colocar a supressão dos imperadores em explícita relação com a conduta precedente: cf. Jul. 76.1; Cal. 56.1; Nero 40.1; Dom. 14.1. Vide Cizek (1977, p.129-130).

${ }^{115}$ Vit. 14.1: Pronus uero ad cuiuscumque et quacumque de causa necem atque supplicium; cf. Nero 37.1: Nullus posthac adhibitus dilectus aut modus interimendi quoscumque libuisset quacumque de causa. Contrasta com esta afirmação de Suetónio a notícia, dada por Díon Cássio, de que suprimiu reduzido número de otonianos (Dio Cass 66.6.2).

${ }^{116}$ Tac. Hist. 3.39.1. Vide Murison (1992, p.162-163).

117 Vit. 14.3. Também Calígula se ofende por a plebe apoiar outra equipa: Cal. 30.2. Domiciano condena um indivíduo que apoia os gladiadores Trácios (Dom. 10.1).

118 Vit. 14.4: Nullis tamen infensior quam uernaculis et mathematicis.

119 Vit. 14.5. Tácito dá notícia de uma opportuna mors, ocorrida poucos dias antes da de Vitélio (Tac. Hist. 3.67.2). Sobre a organização em clímax (Vit. 12-14), vide Cizek (1977, p.132-133).

${ }_{120}$ Jul. 40.1: Conuersus hinc ad ordinandum reipublicae statum...

$121 \mathrm{Jul}$. 44.4: Talia agentem atque meditantem mors praeuenit.

$122 \mathrm{Jul}$. 44.4: De qua prius quam dicam, ea quae ad formam et habitum et cultum et mores, nec minus quae ad ciuilia et bellica eius studia pertineant, non alienum erit summatim exponere.

$123 \mathrm{Jul}$. 75.1: Moderationem uero clementiamque cum in administratione tum in uictoria belli ciuilis admirabilem exhibuit. 
José Luís Lopes Brandão

124 Jul. 50.1: Pronum et sumptuosum in libidines constans opinio est, plurimasque et illustres feminas corrupisse.

125 Jul. 51: Aurum in Gallia effutuisti, hic sumpsisti mutuum.

${ }^{126}$ Cf. Plut. Alex. 61.

${ }^{127}$ Vide Dupont e Éloi (2001, p.263-323). 

Seção II

SABERES E PODERES JURÍDICOS 



\title{
PODERES DOMÉSTICOS EN LA ROMA ANTIGUA
}

\author{
Martha Patricia Irigoyen Troconis ${ }^{*}$ \\ Universidad Nacional Autónoma de México
}

\section{Introducción}

En la antigua Roma, la situación general de un romano estaba determinada por su pertenencia a una gens o a una familia específica, por su calidad de hombre libre o de esclavo, por su riqueza, edad, género, pero también por sus costumbres y tradiciones familiares. De acuerdo con la época, en Roma existieron algunas diferencias notables como, por ejemplo, entre lo que llamamos "clases sociales": los patricios y los plebeyos, "clases políticas": los ciudadanos comunes y los magistrados -entre quienes también había rangos distintos- y "clases de ciudadanos" entre quienes tenían la ciudadanía romana y quienes no la tenían.

Si bien es cierto que la familia es considerada como el núcleo constitutivo de cualquier forma de sociedad, también lo es el afirmar que ésta es un reflejo de los principios y valores que la rigen. Como en muchas otras sociedades, la estructura primaria de la familia romana se construyó sobre la unión indispensable de un hombre y una mujer, así como de uno o varios hijos, pero también de una serie de personas y complejos factores que, considerados singularmente y en conjunto, se fueron definiendo y diferenciando entre sí a través de distintos momentos históricos. Según veremos más adelante, la situación de cualquier miembro de una familia dependía del tipo de relación o vínculo que tuviese con el "jefe" de la misma, el paterfamilias, es decir, dependía de que fuese jurídicamente independiente o no ${ }^{1}$.

A lo largo de su historia, el cuadro de la sociedad romana se nos presenta como un enorme mosaico en el que cada tesela representa uno de estos factores, y donde cada una tiene su forma y colorido propios, de modo que, unida a todas las demás, hace posible que se perciba en su conjunto el cuadro completo de la vida familiar y social. A partir de algunas fuentes jurídicas y literarias, en este trabajo nos concentraremos en comentar la autoridad y los poderes que durante el final de la época republicana ejercía el miembro de la familia más poderoso, el paterfamilias. Este trabajo no pretende ser exhaustivo sobre las peculiaridades y precisiones jurídicas correspondientes, puesto que para ello existen manuales y trabajos monográficos especializados. Por ello, esta será, más bien, una exposición de las generalidades sobre el tema. Comencemos por aclarar el

\footnotetext{
* Investigadora Titular del Centro de Estudios Clásicos. Instituto de Investigaciones Filológicas.marpat@unam.mxe mariri@prodigy.net.mx
} 
Poderes domésticos en la Roma antigua

concepto de "familia" en Roma.

\section{Estructura jurídica de la familia Romana}

La palabra latina familia no tiene el mismo rango semántico y significado que nuestra actual palabra "familia". Para nosotros, es evidente que la noción de la familia nuclear se compone de tres elementos, que son un padre, una madre y un número no específico de hijos. A nuestro moderno entender, 'una familia' puede incluso comprender a los parientes paternos, a los maternos, a tíos, tías, sobrinos y sobrinas. Sin embargo, la palabra latina familia tiene varias acepciones $^{2}$. En sentido lato, comprende el conjunto de personas subordinadas a una sola, denominada paterfamilias; ${ }^{3}$ pero también incluye todas las $\operatorname{cosas}^{4}$ que se encuentran dentro del patrimonio de éste.

Pero esta no es la única noción totalmente ajena a la que actualmente tenemos sobre la familia...

Una segunda acepción de familia se refiere al conjunto de esclavos que tiene una pareja, pues legalmente, tanto el marido como la esposa podían tener, cada quien, sus propios esclavos. Este significado es quizá el más usual en latín, pues etimológicamente familia proviene de famulus ${ }^{5}$.

En primer lugar, utilizado el término familia para designar a personas libres, se refiere a aquellos que se encuentran sujetos de manera natural o legal al poder del paterfamilias, el patriarca o cabeza de la misma, incluida la esposa, los hijos y los nietos. También podía comprender a un círculo más amplio de 'agnados', esto es, los familiares por parentesco sanguíneo por vía masculina hasta el sexto grado. Esto significa que los hijos e hijas de un hombre se encontraban en la misma familia al igual que sus hermanos, los hijos de sus hermanos, y sus hermanas. Sin embargo, los hijos de las hermanas casadas y los hijos de sus esposas no formaban parte de su familia, sino que eran miembros de las familiae de sus maridos o de las familiae de sus padres, respectivamente.

Este principio agnaticio también implica un tercer significado de familia: según Ulpiano, dicho concepto también se puede aplicar a todas las personas que descienden de un mismo progenitor: "Item appellatur familia plurium personarum, quae ab eiusdem ultimi genitoris sanguine proficiscuntur (sicuti

dicimus familiam Iuliam, quasi a fonte quodam memoriae ${ }^{6}$. En este pasaje -así como en muchos otros textos jurídicos y literarios- el concepto de familia está utilizado de una manera más bien vaga, pues bajo esta categoría podían entrar todos aquellos miembros que, de acuerdo con la terminología estrictamente tradicional de la época republicana, constituirían una gens ${ }^{7}$, la cual comprendía no sólo a los agnados y a los parientes más distantes, sino a todos los descendientes nacidos libres de un mismo antepasado (como la gens lulia siempre sostuvo que sus miembros descendían de Eneas, por ejemplo). De algunas gentes patricias, 
tales como la Fabia y la Cornelia, se sabe que tenían cultos, rituales y sepulcros comunes, así como costumbres distintivas. Sin embargo, al parecer, estas características no debieron ser universales y no existe evidencia de que, a mediados o fines de la República, los linajes aristocráticos hayan mantenido un fuerte sentido de cohesión social o política.

Lo que sí tenían en común los miembros de cada gens era el nombre (nomen), pues el sistema republicano de los tres nombres (tria nomina) para los varones se fabricó a partir del nombre gentilicio (nomen gentile). El primer nombre (praenomen), como Caius, Gaius, Marcus, etc., no era distintivo. Además de algunos pocos praenomina que algunas familias usaron de modo exclusivo (como Appius en la gens Claudia), hubo sólo unos diecisiete nombres prenominales disponibles para todos los varones romanos, mientras que las mujeres ni siquiera los tenían. Lo que constituía la identidad real de un romano era su nombre "medio", es decir, el nombre de la gens. Por ejemplo, lulius, Claudius y Cornelius eran los nombres de todos los descendientes de las gentes patricias, mientras que Caecilius, Sempronius y Tullius, junto con muchos otros más, pertenecían a los plebeyos. A mediados de la época republicana, comenzó a utilizarse un tercer nombre: el cognomen o apodo. Algunos de éstos respondían a cualidades, defectos o características personales, como por ejemplo, el de Marco Tulio Cicerón (Cicero='garbanzo'), famoso orador y cónsul en el 63 a.C., y el del censor del siglo IV, que llegó a ser conocido como Apio Claudio 'el Ciego' (Caecus $=$ 'ciego').

Otro término estrechamente relacionado con los de familia y gens, que ya hemos explicado aquí, es el de domus, cuyo rango semántico se traslapa con las connotaciones de aquéllos y, por tanto, conviene aclarar. La palabra se usaba regularmente para denotar no sólo el espacio físico, la casa, sino también a todas las personas que habitaban y convivían en ella, es decir, a la esposa, los hijos, los esclavos, los libertos y, ocasionalmente, a los clientes. En este sentido, se diferencia de la acepción jurídica de familia que arriba mencionamos ${ }^{8}$. Fue sólo hasta el final de la época republicana y comienzos del imperio, que las palabras familia y domus comenzaron a tomar otro sentido y se aplicaron a un grupo de personas cada vez mayor: un grupo que incluía no sólo a los parientes 'agnados' (antepasados y descendientes por vía masculina), sino también a los parientes 'cognados's.

En segundo lugar, utilizado el término familia para designar a personas libres, se refiere a los esclavos manumitidos, los libertos (liberti) ${ }^{10}$, que conservaban el nombre del dueño anterior y hacia el cual debían tener ciertas consideraciones de por vida, tales como prestar su fides, obsequium, reverentia, honor y alimenta ${ }^{11}$. Sin embargo, esta no era la única formalidad legal: existen inscripciones sepulcrales que indican que algunos esclavos y libertos tendían a 


\section{Poderes domésticos en la Roma antigua}

contraer matrimonio -o a tener relaciones de facto- dentro de la familia y más aún, a unirse con parientes para fines funerarios, por ejemplo. Asimismo, las obligaciones recíprocas entre los esclavos y los dueños podían perdurar hasta por varias generaciones e, incluso, crear vínculos afectivos más allá de los límites que pudiese marcar su estatus. $^{12}$

\section{Los poderes del paterfamilias}

Quizá el rasgo más importante que hay que destacar sobre la familia romana, sea el hecho de que se trataba de un conjunto de personas que, como ya señalamos, vivían bajo un mismo techo, en una sola casa (domus) y que estaban estrictamente sometidas a la autoridad y a las órdenes del patriarca o varón de mayor edad (paterfamilias), independientemente de que éste fuese célibe o impúber ${ }^{13}$. Como mencionamos antes, dicho conjunto de personas comprendía no sólo a la esposa y a los hijos solteros, sino también, a los hijos casados, las nueras, los nietos, nietas, bisnietos y bisnietas, esclavos y clientes. En realidad, el paterfamilias ejercía no un solo poder sobre todas esas personas, sino la combinación de varios poderes, dependiendo del tipo de vínculo o relación que tuviera con cada una de ellas, según veremos a continuación.

\section{1) Manus}

En primer lugar, sobre la esposa, la materfamilias, el paterfamilias ejercía el poder denominado manus ${ }^{14}$, siempre y cuando ella hubiese aceptado quedar bajo el control de su esposo, junto con todos sus bienes, mediante la celebración de un matrimonio cum manu. ${ }^{15}$ La mujer casada in manu quedaba en calidad de hija de su marido (loco filiae) y hermana agnada de sus hijos. Si el marido era alieni iuris, es decir, si dependía jurídicamente de su propio pater, ella quedaba bajo la potestad de su suegro, como nieta (neptis loco), o como bisnieta cuando la manus era del nieto de aquel paterfamilias. En ambos casos, la manus, que siempre pertenecía al marido, quedaba como "absorbida" en la patria potestad bajo la que el marido se hallaba.

Cuando la mujer era alieni iuris, la entrada bajo la potestad marital (conventio in manum) producía efectos análogos a los de la adopción; si la mujer era sui iuris, los efectos eran análogos a la arrogación (adrogatio): aunque la mujer no pudiese atraer personas sometidas a la patria potestad, su patrimonio sí pasaba al esposo, que adquiría la manus sobre ella. Es decir, mediante la conventio in manum, el esposo se convertía automáticamente en dueño y administrador de los bienes de la esposa.

La conventio in manum podía tener lugar de tres diferentes modos: coemptione, farreo y usu ${ }^{16}$.

La coemptio ${ }^{17}$ consistía en la mancipación de la mujer, es decir, una 'venta 
ficticia' de ésta, que el padre celebraba con el futuro esposo. En el siglo I a.C. tenía escaso empleo y, al parecer, casi sólo se usaba para que la mujer se liberara de la grave tutela agnaticia (tutelae evitandae causa) y para que pudiera hacer testamento (testamenti faciendi causa), es decir, con fines distintos del único que había tenido en su origen.

La confarreatio ${ }^{18}$ era una ceremonia religiosa, celebrada ante diez testigos y un sacerdote de Júpiter (flamen dialis) o el Pontífice Máximo, en la que debían pronunciarse palabras solemnes (solemnia verba). Dicha ceremonia se llamaba así debido a que los esposos ofrecían y compartían un pan hecho de espelta (panis farreus). En época de Cicerón la confarreatio se empleaba ya muy poco y en tiempos de Tiberio era más raro que se celebrase, pues este mismo emperador abolió sus efectos civiles.

El varón también podía adquirir la manus mediante una especie de usucapión (usus) ${ }^{19}$, que consistía en la convivencia matrimonial durante un año ininterrumpido. Si al término de éste, la mujer deseaba interrumpir dicho usus $-\mathrm{y}$, por tanto, dar por extinguida la manus- debía ausentarse tres noches consecutivas del domicilio conyugal (trinoctium) ${ }^{20}$ y pasarlas con su familia de origen.

La manus se podía extinguir por la muerte o la capitis deminutio de uno de los cónyuges, por la venta fingida de la mujer a un tercero -o a la persona bajo cuya potestad se encontraba con anterioridad al matrimonio, y que luego la manumite (remancipatio o dimissio ex manu) ${ }^{21}$, o mediante la diffarreatio ${ }^{22}$, que consistía en una ceremonia religiosa igual a la confarreatio, pero de efecto contrario.

A fines de la República, debido al fenómeno que algunos estudiosos (Cfr. DEL CASTILLO, 1976. FAU, 1978.) han caracterizado como "la emancipación de la mujer romana", el matrimonio cum manu se va haciendo menos frecuente, y tanto el usus como la confarreatio caen en desuso casi totalmente. En época imperial, la modalidad de matrimonio más frecuente es sine manu, en el que la mujer sigue bajo la potestad de su padre o bien queda como sui iuris, y la confarreatio se practica de manera excepcional en el Principado.

\section{2) Patria potestas}

El segundo tipo de poder que tenía el paterfamilias era la llamada patria potestas $^{23}$, que ejercía sobre los descendientes legítimos (liberi), incluidos los de ulterior grado por línea masculina. La raíz pot- (la misma de possessio) alude al poder sobre otras personas, así como la capacidad para ejercitarlo; no la tienen los sometidos a un paterfamilias que son alieni iuris, ni de manera plena, las mujeres; tampoco los impúberes y los locos, quienes carecen de juicio suficiente para administrar su patrimonio. 


\section{Poderes domésticos en la Roma antigua}

En primer lugar, se basaba en el principio de que no existía ningún límite de edad ${ }^{24}$ para ninguna de las partes involucradas, es decir, el paterfamilias y el descendiente, mientras ambas estuviesen vivas: sólo a la muerte del pater era posible que los miembros varones de su familia se convirtiesen a su vez en patresfamilias y en sui iuris, es decir, en personas jurídicamente independientes. Por ello, este mismo principio implicaba que cualquier romano carente de un ascendiente masculino vivo, aunque él mismo fuese soltero o aún un jovencito (pupillus), fuese necesaria, automática y técnicamente un paterfamilias.

Los romanos tuvieron conciencia de que la patria potestad era una institución única y específicamente romana, como bien observó Gayo ${ }^{25}$ y, aunque moderada en su ejercicio por los mores maiorum ${ }^{26}$, constituía un poder absolutamente sin restricciones, es decir, un poder "totalitario" (Cfr. KASER, 1938. WATSON, 1967).

Los derechos y poderes concretos del paterfamilias suman una lista impresionante. Por principio de cuentas, su autoridad legal se establecía en el momento del nacimiento: un hijo nacido de un matrimonio legítimo (iustum matrimonium) inmediatamente quedaba bajo la potestas del paterfamilias. Sólo el padre tenía el derecho de reconocer al recién nacido como legítimo y, como así hiciera, de asentir a su crianza. Dicho reconocimiento consistía en levantar al bebé del suelo, donde debía ser depositado al momento de nacer; enseguida, si decidía aceptarlo como un nuevo miembro de su familia, debía cargarlo (filium tollere). En caso de que se rehusara a cargarlo, el bebé debía ser expuesto y abandonado a su suerte: a morir o a ser hecho esclavo por quien se compadeciese de él.

Esta segunda opción era considerada como parte del indiscutible e ilimitado poder del paterfamilias para ordenar la muerte de sus hijos, no sólo los recién nacidos, sino también los adultos, hombres y mujeres, sin que hubiese impunidad alguna de por medio. A dicho poder se le denominó ius vitae necisque, es decir, el derecho sobre la vida y la muerte de los miembros de la familia. Este fue, y es aún considerado por los estudiosos, como el elemento más notorio e importante de la patria potestas ${ }^{27}$. El padre podía infligir castigo sobre cualquiera y sobre todos los miembros de su familia, incluyendo a la esposa (si se encontraba in manu), en caso de que alguno de ellos hubiese incurrido en algún comportamiento ofensivo para la reputación de su familia. Este tipo de jurisdicción era tan amplio, que incluía el derecho de mandarlos matar por delitos serios sin necesidad de hacer una demanda judicial, sin aprobación de magistrados o jueces, sino únicamente después de haber convocado a un consejo familiar. Más aun, el padre tenía el derecho de vender a sus hijos como esclavos o entregarlos en garantía (nexum) ${ }^{28}$ a algún acreedor.

Otros poderes de considerable importancia -quizá menos terribles que los anteriores- que tenía el paterfamilias sobre los hijos, eran los siguientes:

Un pater tenía el control absoluto sobre el matrimonio de sus hijos: no sólo 108 
tenía el poder decisivo en el momento de arreglar las nupcias, sino también se requería el consentimiento de los patresfamilias de los prometidos (en el caso de que ambos aún estuvieran in potestate) para que el matrimonio fuese considerado legítimo, y cualquier pater podía, incluso, promover el divorcio.

El paterfamilias, y sólo él, podía promover un juicio o cualquier acción legal; sólo él tenía la propiedad absoluta de todo lo que cualquier miembro de su familia pudiese poseer o adquirir en propiedad. Aquí vemos, una vez más, que aún su esposa e hijos adultos (que, obviamente, eran alieni iuris) no podían tener ninguna propiedad ni capacidad legal alguna. Por lo tanto, su patria potestas incluía no sólo el poder total de vender sus propiedades, por ejemplo, sino también el de disponer de los bienes raíces a su entero antojo en cualquier momento. Sólo el paterfamilias tenía el derecho de hacer un testamento legalmente válido y sólo él tenía la libertad de eliminar a una parte o a la totalidad de los integrantes de su familia por medio de la desheredación: bastaba con que desconociese a sus propios descendientes para establecer nuevos herederos con quienes, incluso, no tuviese vínculos sanguíneos. ${ }^{29}$

La intensidad y dimensión de la patria potestas fueron aminoradas con el transcurso de los años, sobre todo por influencia y efecto del Cristianismo, de suerte que los países europeos y latinoamericanos que fueron receptores de la tradición jurídica romana, sólo recogieron una parte residual de la antigua patria potestad romana, haciéndola equiparable a lo que modernamente conocemos como la tutela sobre los menores de edad.

\section{3) Dominica potestas}

Como mencionamos antes, así como dentro de la familia se contaban los libres (liberi), así también se contaban los esclavos (servi), quienes estaban permanentemente sometidos a la potestad de su dueño (dominica ${ }^{30}$ potestas), al grado de contarse como parte de las res mancipi ${ }^{31}$ de su dueño (dominus).

Entre las causas de la esclavitud se contaban: a) el haber nacido de madre esclava; b) el haber sido capturado por los enemigos durante la guerra, y c) haber incurrido en deudas que mereciesen la esclavitud como castigo o pena legal.

Los esclavos también eran considerados como cosas en propiedad y, por tanto, no eran sujetos de derecho; sus dueños tenían el poder absoluto para disponer de ellos en todo momento $y$, por lo general, recibían un trato desfavorable. Desde época arcaica hasta todavía tiempos de Claudio y Adriano, por haber cometido algún delito, podían sufrir penas más severas y deshonrosas que los hombres libres: podían ser arrojados a las fieras (ad bestias) en el Circo, condenados a hacer trabajos forzados en las minas (ad metalla) o incluso, podían ser castrados.

A la luz de la celebración de ciertas fiestas religiosas como, por ejemplo, los 
Compitalia y los Saturnalia, a las que tenían acceso los esclavos, así como la celebración de ciertos actos jurídicos, como el prestar juramento solemne (iusiurandum) y el tener la capacidad para intervenir en servicios públicos, ya fuese como "esclavos del pueblo romano" (servi publici), ya como representantes de dueños particulares, es que el estudio sobre la condición de los esclavos se vuelve interesante, pues este tipo de actos son, justamente, los que les dotan de una cierta "calidad humana", es decir, no pueden ser considerados totalmente como cosas u objetos.

Para los romanos, hubo otro tipo de personas que podían encontrarse en una situación similar a la esclavitud. Éstas eran: a) los niños abandonados y recogidos (alumni), a quienes el amo (nutritor) solía manumitir al llegar a la pubertad; b) los hombres libres que se alquilaban como gladiadores (auctorati); c) quienes tenían una pena pecuniaria que solventar (addicti), y d) los hijos que habían sido vendidos dentro de Roma y que debían ser manumitidos para recuperar la libertad. Para todos ellos, la forma de alcanzar la libertad debía ser mediante la manumisión (manumissio), un acto de disposición voluntaria por parte del dominus, en el que el propio esclavo "compraba" su libertad. Mediante la proclamación oficial de la manumisión, cualquier esclavo se hacía libre, sino que también se convertía en ciudadano.

\section{Patronatus}

Otras personas que también formaban parte de una familia romana eran los libertos y los clientes. Ambos coincidían en estar subordinados voluntariamente a un paterfamilias, quien en algún momento anterior había sido, respectiva e igualmente, su patrono (patronus). La diferencia entre un liberto (libertus) y un cliente (cliens) radicaba en que el primero había sido esclavo y luego había sido manumitido por su exdueño, y el segundo, siempre había sido un hombre libre.

Los esclavos, una vez manumitidos, se convertían en libertos y así, constituían la clase social de los libertini, en oposición a los ingenui, que habían nacido libres.

El poder del patronatus ${ }^{32}$ consistía en un deber moral, por parte de los libertos, de conducirse con respeto y reverencia (obsequium) hacia el patrono, así como el deber de cuidar al mismo, sobre todo, al momento de llegar a la vejez, de modo que no le faltase el sustento (alimenta). Por su parte, el patrono queda obligado, también moralmente, a prestar su fides a los libertos, también se obliga a dar los alimenta y, eventualmente, a falta de descendencia legítima, el patrono podía nombrar herederos de su patrimonio a sus libertos. Desde el s. II d.C. se hizo frecuente que los patronos encomendaran a sus libertos el cuidado de sus sepulturas al momento de morir, con la promesa y garantía de que ellos mismos 
podrían ser acogidos allí al momento de su muerte.

Para garantizar el deber del liberto, antes de que éste fuese manumitido, debía prestar un juramento solemne (iusiurandum) de que prestaría determinados servicios (operae) al patrono. En caso de incumplimiento, el patrono podía pedir que el liberto fuese retenido por otra persona, volviendo así a la condición de esclavo.

A diferencia de la patria potestas del paterfamilias, que se extendía a todos sus descendientes, este derecho de patronato no se podía extender sobre los descendientes del liberto, pero sí se transmitía a la familia del patrono. Es decir, era un poder que se extendía más allá de la muerte.

\section{Clientela}

El último grupo de personas pertenecientes a la familia romana era el de los clientes (clientes) quienes, como mencionamos arriba, se diferenciaban de los libertos en que nunca habían sido esclavos. Al poder que el paterfamilias ejercía sobre ellos, recibía el nombre de clientela ${ }^{33}$.

Según el estudioso Franciosi (1988, p.150 ss; 1995, p.109 ss.), es probable que el origen de la clientela se encuentre en el hecho de que muchas familias patricias empobrecidas se hubiesen visto en la necesidad de subordinarse a otras enriquecidas de la misma gens. Para una buena comprensión de muchas instituciones del derecho privado romano se debe tener presente la presencia de las clientelas, siempre subordinadas a los patronos, sobre todo, en razón de que los clientes tenían el deber de ayudar a sus patronos como fieles partidarios en sus campañas políticas y en otros servicios; los patronos, a su vez, tenían la obligación de corresponderles en caso de pleitos legales, en donde los patronos intervenían como abogados o fiadores.

El deber por parte del patronus de proteger a sus clientes tenía un carácter no sólo moral, sino también sagrado y su incumplimiento daba lugar a la llamada execración (execratio), que exponía a quien lo cometía, a la venganza divina y, por tanto, era legalmente declarado detestable mediante la sentencia "sacer esto", utilizada desde el siglo $\mathrm{V}$ a.C. ${ }^{34}$

\section{Conclusión}

Como hemos visto, eran múltiples los poderes que el paterfamilias desplegaba entre los miembros de su domus. Ninguno de éstos escapaba de su vista ni de su poder. Cicerón cuenta ${ }^{35}$ que, de acuerdo con la disciplina y costumbres de los antepasados (mores maiorum), el famoso censor Apio Claudio "el Ciego", a pesar de su avanzada edad y ceguera, llegó a ser el paterfamilias de una gran domus, que incluía a cuatro fornidos hijos -varios de los cuales llegaron a ser cónsules- a cinco hijas y a muchos clientes. 


\section{Poderes domésticos en la Roma antigua}

Dada la importancia de las relaciones de poder y de la transmisión de la propiedad entre las familias romanas, puede comprenderse dicha concentración; sin embargo, es necesario que echemos un vistazo más allá de lo que dictaban las leyes para descubrir no sólo la práctica, sino las normas que la misma sociedad establecía para regular el comportamiento entre los miembros de la familia.

El estereotipo de la familia patriarcal de "los viejos tiempos" fue, sin duda, una elaboración cultural que en tiempos de la República sirvió a fines ideológicos y propagandísticos, pues nos da indicios sobre los valores morales, las actitudes y ambiciones $-\mathrm{y}$ tal vez sobre los temores colectivos y deseos nostálgicos- de los varones de edad media que pertenecían a la 'élite' urbana durante los siglos II y I a.C., como lo eran entonces Catón el Viejo y el mismo Cicerón.

\section{Bibliografía}

BERGER, A. Encyclopedic Dictionary of Roman Law. Transactions and Proceedings of the American Philological Association, n.s.43, Philadelphia: American Philosophical Society, 1953.

BUCKLAND, W.W. The Roman Law of Slavery. Cambridge: University Press, 1908.

D’ORS, A. Derecho Privado Romano. Pamplona: Ediciones Universidad de Navarra, S.A., 9a . ed., 1997.

DEL CASTILLO, A. La emancipación de la mujer romana en el siglo l d.C. Granada: Universidad de Granada, 1976.

DICCIONARIO DE LA LENGUA ESPAÑOLA, 22a. Ed, Madrid: Real Academia Española, 2001.

FAU, G. L'emancipation fémenine dans la Rome anticue. París, 1978.

FRANCIOSI, G. Ricerche sulla organizzazione gentilizia romana III, Napoles: Jovene, 1995.

FRANCIOSI, G. Ricerche sulla organizzazione gentilizia romana II, Napoles: Jovene, 1988.

HARRIS, W.V. The Roman father's power of life and death. In: BAGNALL, R. S. y HARRIS, W.V. (eds.). Studies in Roman law in memory of A. Arthur Schiller. Leiden: Brill Academic Publishers, 1986, p.81-95.

KASER M. Der Inhalt der patria potestas. ZSS, 58, p.62-87, 1938.

LEWIS, Ch., A Latin Dictionary. Oxford: Clarendon Press, 1984.

SALLER, R.P. Patriarchy, property and death in the Roman family. Cambridge: University Press, 1994.

SEGURA MUNGUÍA, S. Diccionario por Raíces del Latín y de las voces derivadas. Bilbao: Universidad de Deusto, 2006.

SOBRE EL SIGNIFICADO DE LAS PALABRAS (Digesto, 50.16.195, pr.-5). Estudio introductorio, traducción, anotación e índices de Martha Patricia Irigoyen Troconis, Instituto de Investigaciones Filológicas-Instituto de Investigaciones Jurídicas, México: Universidad Nacional Autónoma de México, 2a. ed., 2005.

THOMAS. Vitae necisque potestas: Le père, la cité, la mort. In: Du châtiment dans la cité: Supplices corporels et peine de mort dans le monde antique. Rome, 1984, p.499-548.

TREGGIARI, S. Roman Freedmen during the Late Republic. Oxford: Oxford Clarendon Press, 1969, p.11-20.

VOGT, J. Ancient Slavery and the Ideal of Man. Oxford: Blackwell, 1974, p.104-114. 
Martha Patricia Irigoyen Troconis

WATSON, A. Rome of the XII Tables: Persons and property. Princeton: University Press, 1975.

WATSON, A. The law of persons in the later Roman Republic. Oxford: Clarendon Press, 1967.

\begin{abstract}
Notas
${ }^{1}$ Los términos "jurídicamente independiente" y "jurídicamente dependiente" corresponden a los términos técnicos latinos sui iuris y alieni iuris, que más abajo se explicarán.

${ }^{2}$ El jurista Ulpiano, que floreció en el s. III d.C., dedica parte de su libro cuadragésimo sexto al Edicto a los diversos significados legales de la palabra. Vid. Sobre el Significado de las Palabras (Dig. 50.16) fr.195, pr.-5.

${ }^{3}$ Puesto que -familias es un genitivo arcaico, el término puede traducirse, de manera equívoca, como "padre de familia". Sin embargo, jurídicamente hablando, la palabra pater no se debe traducir como "padre", sino como "jefe, cabeza" (de familia). Vid. infra n. 10.

4 "El derecho romano antiguo y clásico distinguió las cosas más permanentes (desde el punto de vista de la antigua economía agraria) de las destinadas al cambio, es decir, las res mancipi de las res nec mancipi. Son del mancipium los terrenos en el suelo de Italia (fundi Italici), con sus servidumbres rústicas, los esclavos y los animales que sirven para ser montados o tirar de un carro o de un arado". Vid. D'ORS, 1997, §133.
\end{abstract}

${ }^{5}$ Del osco famel = lat. servus. Vid. SEGURA MUNGUÍA, 2006, 1.124.

${ }^{6}$ Dig. 50.16.195.4: “Asimismo se llama 'familia' a la de varias personas que proceden de la sangre de un mismo progenitor, el más lejano (como cuado decimos la 'familia Julia'), como memorias que provienen de una misma fuente". La traducción es mía. Vid. n.2.

${ }^{7}$ En este sentido, considero que la mejor traducción de gens es el término antropológico "linaje", y no el acostumbrado término "clan", pues la gens era una comunidad mucho más amplia que la familia.

${ }^{8}$ Vid. supra n.4.

${ }^{9}$ Para efectos sucesorios, principalmente, el derecho romano llegó a distinguir dos tipos de parentesco: el agnaticio, que está fundado sobre la potestad del paterfamilias, y que se asimila a nuestra "familia civil". Aunque entre ascendientes y descendientes exista un vínculo de agnación (adgnatio/agnatio), los hijos suceden a sus padres como herederos legítimos (heredes sui) y no como agnados, y los padres nunca suceden a sus hijos. Para efectos sucesorios, los adgnati son todas aquellas personas, empezando por los hermanos, que estarían bajo una misma patria potestad de no haber muerto el antecesor común. El parentesco cognaticio o "natural", a diferencia del agnaticio, se basa en los vínculos de sangre y no en la patria potestad. Dicho parentesco de sangre es el único que puede establecerse a través de las mujeres, ya que éstas, al no tener patria potestas, no pueden atraer a sus descendientes a la potestad de sus propios padres. Vid. D'ORS, 1997, §205 y ss.

10 “... Ad personas autem refertur familiae significatio ita, cum de patrono et liberto loquitur lex..." (Dig. 50.16.195.1).

${ }^{11}$ De éstos trataremos más adelante, bajo el subtítulo 4.

${ }^{12}$ En este sentido, la manumisión puede considerarse como un acto afectivo: el dueño o la dueña decide otorgar la libertad al esclavo o esclava que le ha sido fiel, al que fue su pedagogo o nana, o al que fue su peluquero o secretario. Cfr. TREGGIARI, 1969, p.11-20. VOGT, 1974, p.104-114. 
${ }^{13}$ La palabra pater se refiere, más bien, al poder que tiene un varón y no tanto al hecho biológico de engendrar, de ahí que un niño huérfano también sea paterfamilias, pues no tiene hijos ni tampoco un padre a quien esté sometido. Por ello, el término latino paterfamilias se traduce al español no como "padre de familia", sino como "cabeza o jefe de familia".

${ }^{14}$ Literalmente, "mano"; como término técnico jurídico, se entiende como "poder marital". Cfr. BERGER, 1953, s.v. manus.

${ }^{15}$ Cuando la mujer aceptaba quedar bajo la manus de su futuro marido, no sólo tenía que renunciar a su estatus previo de hija (filiafamilias) bajo la potestad de su padre, sino también tenía que dejar a su familia agnaticia para entrar a formar parte de la familia del marido -o de la del padre de éste.

${ }^{16}$ Gaius Inst. 1.110 ss.: "Olim itaque tribus modis in manum conveniebant: usu, farreo, coemptione".

${ }^{17}$ Gaius Inst. 1.113: "Coemptione vero in manum conveniunt per mancipationem, id est per quandam imaginariam venditionem; nam adhibitis non minus quam $V$ testibus civibus Romanis puberibus, item libripende, emit vir mulierem, cuius in manum convenit".

${ }^{18}$ Ulp. Reg. 9: "Farreo convenitur in manum certis verbis et testibus $X$ praesentibus et sollemni sacrificio facto, in quo panis quoque farreus adhibetur"; Gaius Inst. 1.112: "Farreo in manum conveniunt per quoddam genus sacrificii, quod lovi Farreo fit; in quo farreus panis adhibetur, unde etiam confarreatio dicitur; complura praeterea huius iuris ordinandi gratia cum certis et sollemnibus verbis praesentibus decem testibus aguntur et fiunt. Quod ius etiam nostris temposibus in usu est: nam flamines maiores, id est Diales, Martiales, Quirinales, item reges sacrorum, nisi ex farreatis nati non leguntur: ac ne ipsi quidem sine confarreatione sacerdotium habere possunt".

${ }^{19}$ Gaius Inst. 1.111: "Usu in manum conveniebat, quae anno continuo nupta perseverabat; quia enim velut annua possessione usu capiebatur, in familiam viri transibat filiaeque locum optinebat".

${ }^{20}$ Idem: "Itaque lege duodecim tabularum cautum est, ut si qua nollet eo modo in manum mariti convenire, ea quotannis trinoctio abesset atque eo modo uiusque anni usum interrumperet".

21 "La remancipatio podía hacerse a favor del padre de la mujer o a favor de un fiduciario que luego la manumitía para dejarla sui iuris". D’ORS, 1997, § 222, n.1.

${ }^{22}$ Fest., s.v. diffarreatio: "Genus erat sacrificii, quo inter virum et mulierem fiebat dissolutio. Dicta diffarreatio, quia fiebat farreo libo adhibito".

${ }^{23}$ Nótese que el adjetivo patrius-a-um = del padre, paterno(a), como derivado del sustantivo pater, denota una cualidad del mismo. Cfr. SEGURA MUNGUÍA, 2006, 2.351. En este sentido, el lenguaje expresa congruentemente el poder jurídico que se le confiere al pater. En español, el adjetivo "patrio(a)" significa, en su primera acepción: "Perteneciente o relativo a la patria" y, en la segunda: "Perteneciente al padre o que proviene de él" (como se ha conservado sólo en el caso en que se refiere a la potestad). Cfr. DICCIONARIO DE LA LENGUA ESPAÑOLA, 2001.

${ }_{24}$ De hecho, para los romanos nunca existió algo así como una edad específica para la "mayoría de edad". 
${ }^{25}$ Gaius Inst. 1.55: "Item in potestate nostra sunt liberi nostri, quos iustis nuptiis procreavimus. Quod ius proprium civium Romanorum est (fere enim nulli alii sunt homines, qui talem in filios suos habent potestatem, qualem nos habemus) idque divi Hadriani edicto, quod proposuit de his, qui sibi liberisque suis ab eo civitatem Romanam petebant, significatur".

${ }^{26}$ Los mores maiorum, las tradiciones prácticas de los antepasados o la antigua (buena) moralidad, constituyeron la primera manifestación del derecho romano arcaico.

${ }^{27}$ Para mayores detalles, vid. THOMAS, 1984. HARRIS, 1986. SALLER, 1994.

${ }^{28}$ Vid. D'ORS, 1987, § 348, n.2: "Se dice que el nexum fue un negocio libral similar a la mancipatio, por el que una persona sometía su propio cuerpo como garantía de una deuda contraída a modo de préstamo". La ley de las XII Tablas se refería al nexum juntamente con la mancipatio para dar fuerza jurídica (ita ius esto) a la nuncupatio, la declaración solemne mediante se determinaba algo sobre la cosa vendida (Lex XII Tab. 6.1). Véase también, WATSON, 1975.

${ }^{29}$ Para más detalles, véase Ibid, p.52-70.

${ }^{30} \mathrm{El}$ adjetivo dominicus- $a-u m$ = del dueño, deriva del sustantivo dominus, puesto que éste era el nombre que recibía el paterfamilias en relación con sus esclavos. Cfr. Ibid, p.954.

${ }^{31} \mathrm{Cfr}$. supra n. 4. Para mayor información sobre el tema de la esclavitud es fundamental la consulta de BUCKLAND, 1908.

${ }^{32}$ El sustantivo patronatus-us es la condición del patrono: "the character and condition of a patron, patronship, patronage". Vid. LEWIS, 1984, s.v. patronatus. Éste proviene del sustantivo patronus = patrono, que deriva, a su vez, de pater. Cfr. SEGURA MUNGUÍA, 2006, 2.351. Pienso que este término quizá haya surgido por la relación afectiva y la fides que debían guardarse recíprocamente tanto el exdueño como el esclavo ya manumitido. Vid. supra, p. 3.

${ }^{33}$ El sustantivo clientela-ae deriva de cliens-ntis = cliente, el que está bajo la protección de un patronus. Cfr. SEGURA MUNGUÍA, 2006, p.696.

${ }^{34}$ Vid. Lex XII Tab. 8.21.

${ }^{35}$ Cfr. Cic. Sen. 37; Cic. Pro Cael. 33-4. 



\title{
PRINCIPIOS DE DERECHOS HUMANOS EN LAS INSTITUCIONES DE JUSTINIANO
}

\author{
Aurelia Vargas Valencia* \\ Universidad Nacional Autónoma de México
}

El propósito del presente trabajo es evidenciar las medidas humanitarias que, en el curso de la primera mitad del siglo VI d.C., fueron emitidas por el emperador Justiniano en el Imperio Romano de Oriente, en su obra legislativa que lleva por título Corpus luris Civilis, y más específicamente en la parte introductoria de dicha obra: las Instituciones.

Los textos de las Instituciones de Justiniano en los que se pueden apreciar medidas que hoy podríamos catalogar como principios de derechos humanos como la libertad, la tolerancia y la igualdad, entre otros, tuvieron su repercusión en los pensadores novohispanos del siglo XVI, hecho que explica, en buena medida, la permanencia en México de una tradición en este rubro. No en vano, a propósito de la "conquista" española, hubo autores novohispanos que debatieron sobre la dignidad de los indígenas $y$, apoyados con frecuencia en los textos del Corpus luris, defendieron a los naturales de América. De este modo, el pensamiento de aquellos hombres es determinante en la conformación de la cultura jurídica que llega hasta nuestros días.

\section{Las Instituciones y su trascendencia}

En las fuentes del pensamiento jurídico novohispano, cuya influencia pervive hoy, existe una parte importante de textos escritos en lengua latina que representa una honda y secular tradición proveniente de la época clásica de la jurisprudencia romana, y aún anterior. Pero en la actualidad, aunque se suele tener la idea general de que nuestro sistema jurídico es heredero del Derecho romano, sin embargo al parecer se ha olvidado por qué, y se ha olvidado también el contenido in extenso de muchos de sus textos.

En México son pocos los estudios que dan cuenta de la tradición europea de los textos jurídicos latinos, y muy escasas son las obras que explican cómo se trasladan al Nuevo Mundo las instituciones jurídicas que, en calidad de lus Commune, están presentes en Europa desde su conformación como entidad cultural.

Las Instituciones son una obra jurídica que es parte del Corpus luris. Fueron promulgadas el año 533 d.C., en Constantinopla -actual Estambul- por orden del

\footnotetext{
* Investigadora. Centro de Estudios Clásicos - Instituto de Investigaciones Filológicas
} 
Principios de derechos humanos en las Instituciones de Justiniano

emperador Justiniano. Son una compilación hecha a partir de fuentes que provenían de épocas precedentes tanto de la jurisprudencia romana como de la legislación imperial, mismas que habían sido aprovechadas para la composición de otras dos partes del Corpus: el Código-cuya primera versión se había promulgado en 528 d.C.-, y el Digesto, cuyos trabajos estaban por concluirse.

Por mandato del emperador, la composición de las Instituciones fue encomendada a una comisión de juristas formada por Teófilo, Doroteo y Triboniano. Éste presidió y supervisó el trabajo que seguía una tradición en la elaboración de instituciones, la cual, según Ortolán (1976: 18), inició con las Instituciones de Gayo y concluyó precisamente con las de Justiniano, aseveración que, a mi juicio, habría que contrastar con una tradición más antigua que nos remite a obras de esta índole en otras áreas del conocimiento, como, por ejemplo, las Instituciones oratorias de Marco Fabio Quintiliano.

Además de Justiniano y Gayo, autores de Institutiones fueron también Marciano, Florentino, Paulo, Ulpiano y Calístrato. Las obras de todos ellos, pero en especial la de Gayo, junto con sus Res cottidianae, sirvieron de base para la redacción de las de Justiniano, además de varias constituciones imperiales, como él mismo lo refiere en la constitución "Imperatoriam":

Quas ex omnibus antiquorum institutionibus et praecipue ex commentariis Gaii nostri tam institutionum quam rerum cottidianarum aliisque multis commentariis compositas ..." (Const.Imp. § 6)

Las cuales, compuestas a partir de todas las instituciones antiguas, pero sobre todo de los comentarios de nuestro Gayo, tanto de sus Instituciones como de sus Res cottidianae y de los comentarios de muchos otros...

La realidad es que, de todos estos textos de Institutiones, fueron las de Justiniano las que tuvieron una gran influencia en los siglos posteriores a su composición, tanto en la enseñanza del Derecho en las universidades europeas y del Nuevo Mundo, como en su utilización como fuente de ley en Oriente.

En cuanto a esta cualidad, es importante señalar que, desde su elaboración, las Instituciones de Justiniano fueron concebidas no sólo como un texto para la enseñanza del Derecho en el primer año de Universidad, sino también como un texto con carácter de ley vigente. El emperador lo manifiesta en el mismo parágrafo de la constitución "Imperatoriam", con las siguientes palabras:

Quas ... et legimus et cognovimus et plenissimum nostrarum constitutionum robur eis accommodavimus (Const.Imp. § 6)

las ... hemos leído y entendido, y les hemos aplicado el plenísimo vigor de nuestras constituciones 
Aurelia Vargas Valencia

En el cuerpo del texto, Justiniano deja ver en distintos pasajes, el interés que tenía por publicar esta obra; pero sobre todo enfatiza (§ 2), la ardua labor que implicó llevarla a cabo y cómo se hizo:

Et cum sacratissimas constitutiones antea confusas in luculentam creximus consonantiam, tunc nostram extendimus curam et ad immensa prudentiae veteris volumina, et opus desperatum quasi per medium profundum euntes caelesti favore iam adimplevimus. (Const.Imp. § 2)

Después que redujimos a una consonancia las sacratísimas constituciones antes confusas, hemos dirigido nuestro cuidado a los inmensos volúmenes de la jurisprudencia, y caminando como sumergidos en un abismo de dificultades, concluimos, con el favor del cielo, tan arduo trabajo.

Fue, en efecto, un trabajo que él leyó y revisó antes de autorizar su publicación, y es un dato de no poca importancia, si se considera que esto representa la utilidad práctica que tuvo para su momento histórico, es decir, la recepción del derecho romano en la nueva capital del imperio, en la nueva Roma, como fue llamada aquella ciudad situada a orillas del Bósforo. Así desde la Urbs presidida por Justiniano, el derecho romano volvió a extenderse, adecuándose a las nuevas circunstancias, a todos los pueblos que conformaban el nuevo imperio que, bajo Justiniano, alcanzó una expansión similar a la que había tenido anteriormente el imperio romano. Él mismo lo manifiesta en el título que trata sobre las fianzas (Just. Inst. 4.11.7), pero que bien puede aplicarse a todos los temas incluidos en su legislación, con las siguientes palabras: "Decretamos que estas reglas se apliquen, no sólo en nuestra regia ciudad, sino también en todas las provincias", voluntad que expresó también en su proemio "por las leyes que hemos promulgado o compilado se rigen todos los pueblos" (Const.Imp. §1)

El Corpus luris no sólo tiene importancia en sí mismo. Es en realidad punto de referencia y clave esencial para comprender un fenómeno histórico de enorme duración y de gran trascendencia, que si bien comienza en el siglo VI en Constantinopla, sin embargo los contenidos de la magna obra jurídica se remontan a la época de la jurisprudencia clásica romana, con ilustres jurisconsultos como Ulpiano, Paulo, Sabino, Juliano y Papiniano, entre otros, así como a legislaciones de emperadores que precedieron a Justiniano; pero al mismo tiempo, es una obra que se proyecta hacia el futuro, a etapas posteriores de su composición, caracterizadas por el trabajo de filólogos y juristas de la escuela medieval de Bolonia, a partir del siglo XI d.C., con autores como Irnerio en primer lugar, pero también con Acursio, Bártolo de Sassoferrato, Baldo de Ubaldis y Cuyacio, hombres que contribuyeron a configurar el saber jurídico de Europa y de los países europeizados, a partir del estudio del Corpus luris Civilis. 
Principios de derechos humanos en las Instituciones de Justiniano

Según Álvaro d'Ors, para la historia cultural del Occidente, la compilación de Justiniano constituye uno de sus tres grandes fundamentos, junto con los filósofos griegos y con la Biblia (1991: 41).

Amén de su obra a favor de la religión cristiana, de su fama como constructor de grandes edificios siguiendo el ejemplo de los emperadores romanos del pasado, y el ideal clasicista de recuperar la unidad perdida del imperio romano, lo cual logró en buena medida durante los años de su reinado, que sumaron más de treinta (527 a 565 d. C.), Justiniano se distingue, sobre todo, por su obra legislativa. Tuvo como directrices lograr una sola Iglesia, un solo Estado y un solo Derecho. El ideal de Justiniano era, pues, crear una legislación común, y el Corpus luris cumplía ampliamente esa expectativa. Antonio Guarino opina que Justiniano actuó en esto, más que como un soñador romántico, prendido de exaltaciones utópicas, como un personaje coligado orgánicamente a los siglos que le precedieron, consciente de estar recuperando el riquísimo patrimonio antiguo para la administración de la justicia. En el Corpus luris fueron compiladas, si bien de manera selectiva por las necesidades de su momento histórico, la ciencia jurídica romana y la legislación imperial anteriores a su época.

\section{Principios de derechos humanos en las Instituciones de Justiniano}

Entre los diversos contenidos de los temas que abarcan las Instituciones, a saber "personas", "cosas" y "acciones" (términos técnicos), encontramos principios humanitarios que son precisamente parte de las innovaciones introducidas por la legislación justinianea. Sobre los temas que tratan las Instituciones, los compiladores de su texto remiten con frecuencia a sus antecedentes en la antigüedad clásica, a veces incluso a las Doce Tablas. La remisión suele comenzar por hacer un breve recuento histórico de la institución jurídica o del término en cuestión, explicando cómo era en Roma, para luego generalmente concluir con su propuesta, en la que suele indicar cómo y por qué se hace la adecuación. Muchas de las resoluciones justinianeas significaron una política de equidad que tendieron a suprimir desigualdades sociales, e incluyeron medidas más humanitarias y justas para los hijos, las mujeres, los libertos y los esclavos.

Es necesario considerar la estructura social en cuyo marco se había generado y desarrollado el Derecho de la antigua Roma recibido en la legislación justinianea, para comprender en qué sentido y en qué medida se dan las innovaciones. Los cambios introducidos por Justiniano tienden a la simplificación legislativa, destacan entre ellas, algunas medidas que benefician a las mujeres en su calidad de madres, esposas o hijas. ¿Sería acaso por influencia de su mujer Teodora? Lo cierto es que las fuentes dejan ver cómo, mientras en la sociedad republicana de la antigua Roma, las instituciones jurídicas habían sido más 
Aurelia Vargas Valencia

rigurosas, Justiniano genera medidas más naturales y más acordes con las reglas de la equidad. Así por ejemplo, modificó algo nuclear en la estructura del derecho clásico como la composición civil de la familia y los derechos derivados de esa composición; defendió el parentesco natural y los vínculos de sangre ante el parentesco agnaticio o civil que caracterizaba el derecho clásico (siglo I a.C. a II d.C.).

Un hecho que no parece irrelevante y que probablemente influyó para que el emperador tuviera esa sensibilidad para lograr una mayor igualdad entre los ciudadanos, es el antecedente de que su tío Justino -a quien el mismo Justiniano había sucedido en el imperio-, había abolido las antiguas leyes que prohibían las nupcias entre personas de clase senatorial con las que no lo eran, precisamente para permitir que Justiniano se casara con Teodora, una comediante que llegó a tener -según d'Ors (1991: 14) una influencia poderosa en las decisiones de su consorte, al grado que se dijera que ella mandaba no menos que su marido.

\section{Los testimonios de las fuentes}

Si vamos a las fuentes, veremos, por principio, que Justiniano basa su pensamiento en medidas que aluden a los principios del ius naturale, del modo siguiente:

Justo en el comienzo de las Instituciones, bajo el título "De iustitia et iure" (Just. Inst. 1.4), tras iniciar con la definición de "Justicia" (iustitia est constans et perpetua voluntas ius suum cuique tribuens), Justiniano recoge en su obra la clasificación del derecho dividida en derecho natural, de gentes (o ius gentium) y el civil, así como la división de este último en público y privado. Asimismo menciona el propio Justiniano-, el derecho civil es tripartito, pues fue recogido tanto de preceptos del derecho natural, como del de gentes y del civil.

La preocupación del emperador por incluir en su legislación el concepto del derecho natural, proveniente de una tradición anterior, es un hecho muy significativo porque con ello asegura la recepción de un importantísimo concepto que influyó en el pensamiento jurídico de Occidente, sobre todo si tomamos en cuenta que las Instituciones de Justiniano, a diferencia de las de Gayo, tuvieron carácter de ley y, por tanto, aplicación en la práctica legal.

El pasaje de la fuente dice así:

lus naturale est, quod omnia natura animalia docuit, nam ius istud non humani generis proprium est, sed omnium animalium, quae in caelo, quae in terra, quae in mari nascuntur. (Just. Inst. 1.2)

Derecho natural es el que la naturaleza ha enseñado a todos los animales, pues este derecho no es propio sólo del género humano, sino de todos los animales que nacen en el cielo, en la tierra y en el mar. 
Principios de derechos humanos en las Instituciones de Justiniano

De las otras divisiones, es decir, del ius gentium y el ius civile, Justiniano menciona lo siguiente :

Ahora bien, el derecho se divide así: en civil o de gentes. Todos los pueblos que se rigen por leyes y costumbres hacen uso, en parte de su propio derecho, en parte de un derecho común a todos los hombres, pues lo que un pueblo establece para sí como derecho, es característico de esa ciudad y es llamado derecho civil, como derecho propio de la misma ciudad. Pero el derecho que .... <se > constituye entre todos los hombres, ése es observado por igual en todos los pueblos y es llamado derecho de gentes, como derecho del que todos los pueblos hacen uso. Y así, el pueblo romano hace uso, en parte de su propio derecho, y en parte del derecho común a todos los hombres. (Just. Inst. 1. 2.1)

De este modo, Justiniano deja claro que, el derecho civil y el ius gentium están vinculados en tanto que uno atañe internamente a una nación, y el otro es compartido entre las naciones.

Con estas definiciones Justiniano deslinda claramente los conceptos de "derecho natural", "derecho de gentes" (o ius gentium) y "derecho civil". Es importante no confundir el derecho natural con el ius gentium, porque es precisamente la diferencia que Justiniano señala para deslindar la institución "esclavitud" del derecho natural, pues la ubica como una práctica derivada de la convención entre los hombres, que sin embargo va contra la naturaleza. Justiniano, en Inst. 1.2.2, lo expresa así:

iure enim naturali ab initio omnes homines liberi nascebantur. (Just. Inst. 1.2.2)

según el derecho natural, de inicio, todos los hombres nacían libres.

Y más adelante, en el capítulo "De iure personarum" donde ofrece la clasificación de las "personas" que recoge de Gayo, define la esclavitud de esta manera:

Servitus autem est constitutio iuris gentium, qua quis dominio alieno contra naturam subicitur. (Just. Inst. 1.3.2)

La esclavitud, en efecto, es una institución del derecho de gentes, por la que alguno, contra la naturaleza, es sometido a un dominio ajeno.

Lo cual se refuerza en lo dicho previamente:

bella etenim orta sunt et captivitates secutae et servitutes, quae sunt, iuri naturali contrariae. iure enim naturali ab initio omnes homines liberi nascebantur. (Just. Inst. 1.2.2) 
Aurelia Vargas Valencia

En efecto, surgieron las guerras y se siguieron los cautiverios y las servidumbres, los cuales son contrarios al derecho natural: pues según el derecho natural, de inicio, todos los hombres nacían libres.

Como puede apreciarse, Justiniano defiende, al menos por la selección de este tipo de textos para incluir en su compilación, el principio de la libertad como algo inherente a la dignidad humana; y extiende ese principio de libertad a los demás seres vivos, según la definición que hemos visto sobre el derecho natural.

Asimismo, a partir de esta concepción, podemos entender que se desprenden también las medidas que defienden a los esclavos contra la crueldad de sus dueños. Por ejemplo, podemos ver que en Inst. 1.8.2 dispone que el dominus que maltrata a un esclavo cruelmente "con más dureza que la equidad permite" o haciéndolo pasar hambre, por lo que éste ha ido a refugiarse a un edificio sagrado, quede obligado a no tenerlo más como su esclavo; y si desobedeciera, sepa que serán utilizadas medidas más severas contra él.

Igualmente en el caso de los "libertini", es decir, los que después de haber nacido esclavos, obtuvieron la libertad. De éstos había varias clases cuyas diferencias Justiniano suprime argumentando: "por consejo del ilustre Triboniano, hemos incluido una constitución que suprime a los dediticios... (y) a los latinos junianos, y hemos hecho ciudadanos romanos a todos los libertos sin establecer, como en otro tiempo, ni diferencias de edad, ni de especie de propiedad del que manumitía, ni forma de manumisión, añadiendo muchos medios por los cuales puede darse libertad a los esclavos..." (Just. Inst. 1.5.3).

Tomando estos pasajes como ejemplos de medidas que asume Justiniano para moderar la rigidez de los usos y clasificaciones que le precedieron, podemos decir que, si bien en su época no había sido superada aquella "Divisio personarum", según la cual "Omnes homines aut liberi sunt aut servi" ("Todos los hombres son libres o esclavos") (Just. Inst.1.3 pr.), sin embargo dictó medidas que tendían a favorecer la libertad en las que, de acuerdo con el contexto histórico que rodeó a Justiniano, no deja de advertirse la influencia del pensamiento cristiano, que había llegado a consolidarse en esos tiempos que constituían ya los comienzos de la Edad Media.

Otro ejemplo de medidas en que se protege la libertad de un esclavo en caso de duda, podemos verlo en el caso de un esclavo que es instituido heredero por su dueño sin mencionar expresamente que le da la libertad. Justiniano dice: "hemos establecido que (...) por el solo hecho de ser nombrado heredero, quede libre, pues no es creíble que el señor, eligiendo a un esclavo como heredero, haya querido dejarlo en esclavitud. (Just. Inst. 1.6.2)

Estas medidas se relacionan, como vemos, directa o indirectamente, con la defensa del principio de libertad. Son medidas que implican una tendencia a la simplificación, y en ocasiones también a la generalización -aunque no deja de 
Principios de derechos humanos en las Instituciones de Justiniano

haber ejemplos que muestran la especialización de ciertos conceptos e instituciones jurídicas-, pero sobre todo son medidas que reflejan la búsqueda, por parte de los compiladores justinianeos, de una equidad incluyente y humanista.

En el caso de las mujeres, quizás el beneficio más importante sea el que se relaciona con la equiparación de éstas y los varones en el tema de las sucesiones. Entre los pasajes de las Instituciones encontramos el dictado justinianeo de que la calidad de descendiente para efectos de herencia, sea conferido por igual a mujeres y a varones, atribuyéndoles equiparación en el mismo grado y orden de sucesión, aunque acepte que la porción a las mujeres se disminuya en un tercio "con el propósito de respetar a los antiguos que defendían más el derecho por vía de varón y agnaticio". (Just. Inst. 3.1.15)

Como éste, existen en las Instituciones ejemplos de otros casos de equiparaciones: véase por ejemplo los casos que se ubican en Inst. 2.19.6 y en 2.20.3.

Sirva esto de muestra sobre el tipo de medidas que Justiniano emite a través de su compilación, con el propósito de procurar un equilibrio y una moderación respecto de las relaciones humanas que operaban en la sociedad de su tiempo, medidas que podemos encontrar tanto en las Instituciones como en el resto del Corpus luris. Un capítulo aparte merecería, por ejemplo, el tratamiento de las fuentes a partir de las cuales puede evidenciarse que la legislación y la jurisprudencia romanas protegieron el pluralismo cultural, lo cual puede verse de manera muy clara en la consideración de las categorías del lus civile en relación con el lus gentium, tomándolo como punto de partida para procurar la pluralidad cultural. En un estudio de esta índole, no pueden dejar de considerarse sus probables orígenes en el derecho generado por los romanos para atender a los Peregrini o extranjeros, ni tampoco las prácticas que en la antigua Roma solían llevar a cabo los feciales, quienes celebraban ya tratados internacionales, y generaban un sistema que iría más allá de su propia Urbs, es decir, a un contexto entre las naciones.

\section{Conclusión}

Las Instituciones de Justiniano constituyen una obra de significativa importancia para la historia jurídica de Occidente. Sus contenidos fueron recibidos y estudiados por autores del medioevo europeo y de épocas subsecuentes, de forma incluso más persistente que cualquiera de las demás partes del Corpus iuris civilis; constituyeron la base de la formación de los juristas en las universidades europeas desde la Edad Media, así como de las universidades fundadas en América en distintos territorios ocupados por los españoles, entre las cuales se encuentra la Real Universidad de México. Asimismo, sus enseñanzas 
Aurelia Vargas Valencia

tuvieron vigencia hasta muy entrado el siglo XIX, el siglo en que fue elaborada la mayor parte de los códigos civiles americanos y europeos que están vigentes en nuestro mundo moderno. Entre los textos que transmiten las Instituciones, cuyo contenido abarca un saber no sólo de su época -primer tercio del siglo VI d.C. sino desde etapas de la jurisprudencia romana arcaica y clásica, existen varios conceptos que dan cuenta de una legislación más humanitaria en comparación con los tiempos que le precedieron, motivo que inspiró el presente trabajo, en el pretendo ofrecer una breve muestra sustentada de manera directa en textos de las Instituciones con traducciones originales de quien esto escribe.

Existe una constante en el discurso de Justiniano: acostumbra plantear un principio o una institución jurídica comenzando por exponer cómo era en el derecho antiguo con la intención de indicar que conoce los antecedentes de la institución en cuestión, para luego justificar las adaptaciones o las reformas que introduce, reuniéndolas muchas veces en una solución general. Este hecho ha provocado que, por la recopilación de las fuentes antiguas, unos lo consideren "clasicista"; pero por los cambios que introduce, otros lo consideren "vulgarizador". Vulgarizador o no, lo cierto es que mediante su compilación brindó respuesta a los retos que su momento histórico le exigía, y en ese ejercicio permitió a la posteridad el conocimiento de la riqueza jurisprudencial y legislativa romanas como parte de una rica herencia cultural que hoy comparten varias naciones europeas y latinoamericanas. De este modo, estudiar la trayectoria del Corpus luris en general, y de las Instituciones en particular, a lo largo de sus distintas etapas, nos permite tomar conciencia del movimiento secular de un fenómeno histórico de larga duración, así como de su enorme actualidad.

\section{Bibliografía}

BERGER, A. Encyclopedic Dictionay of Roman Law. Philadelphia: The American Philosophical Society, 1968.

BRAUDEL, F. La historia y las ciencias sociales. Madrid, Alianza, 1986.

D'ORS, A. Derecho Privado Romano. Pamplona: EUNSA, 1991.

KRUEGER, P. et MOMMSEN, T. Corpus luris Civilis. Berlín: apud Weidmannos, 1973.

ORTOLÁN, M. Instituciones de Justiniano, Trad. del francés al español de Fco. Pérez de Anaya y M. Pérez Rivas. Buenos Aires: Heliasta, 1976.

VARGAS VALENCIA, A. Las Instituciones de Justiniano en Nueva España, 2ª. ed., México: UNAM, 2011.

WIEACKER, F. Historia del derecho privado de la Edad Moderna. Madrid: Aguilar, 1957. 

Seção III

QUESTÃO BÉLICA E POLÍTICA IMPERIALISTA 



\title{
ESCIPION EL AFRICANO: UN POLÍTICO MODERNO
}

\author{
Raúl Buono-Core V. \\ Pontificia Universidad Católica de Valparaíso \\ Universidad de Chile
}

Publio Cornelio Escipión comanda un ejército en España a los 24 años. En efecto, el año 210 a.C. Escipión recibe el imperium por unanimidad de los comicios, con el fin de sustituir en España a su padre y a su tío. La sanción popular del comando de Escipión aparece como una manifestación de consenso hacia una familia o sector político, que combatiendo en un difícil escenario, se había conquistado la confianza de los soldados, principalmente, por tener en cuenta sus sentimientos y los de la opinión pública. Estos hechos marcan el inicio de un proceso progresivo de militarización de las magistraturas políticas en Roma, que hará, que la dimensión militar comience progresivamente a subordinar a las otras dimensiones de la vida romana, produciéndose un paulatino desequilibrio, que en gran medida desencadenará las grandes crisis de finales de la República. Si se revisan las costumbres y las formas de acción tradicionales en Roma, la designación de Escipión fue un acto inédito. Se abandona la antigua tradición de hacer coincidir la importancia de un cargo con la edad del que lo iba a asumir. El tiempo de personajes como Quinto Fabio Máximo comienza a declinar para dar a paso a figuras jóvenes como la de Escipión, con una nueva concepción de la guerra, con una mentalidad empapada por un estilo helenístico, en la que germinan las primeras ideas imperialistas de las clases dirigentes romanas. Esto lo deja en evidencia Escipión el año 205 a.C., cuando se dirige a Roma para informar personalmente de las campañas realizadas y solicitar para si mismo el consulado. En momentos en que la guerra parece llegar a su fin, una alternativa que al fin y al cabo, alivia a una generación cansada y consumida por muchos años de vida pública, el propone llevar la guerra a África y combatir a Cartago en su territorio. Como sabemos, a pesar de la decidida oposición de Quinto Fabio Máximo y de sus partidarios, el 205 a.C. es designado cónsul con una gran mayoría de votos de los sectores patricios y populares. Entre el 204 a.C. y el 202 a.C., aparece una faceta diferente de Escipión, la del diplomático. En efecto, con Aníbal de regreso en África y capturado Sifax, Escipión pacta una alianza con Massinisa rey de Numidia,

\footnotetext{
* Profesor Titular de Historia Antigua Greco-Romana en la Pontificia Universidad Católica de Valparaíso, y de la Universidad de Chile, Casilla 4059, Valparaíso-Chile, rbuonocu@ucv.cl
} 


\section{Escipion el Africano: un político moderno}

el cual al parecer, estaba decidido a contener el expansionismo cartaginés en África. Este tratado le da algunos dividendos, porque una vez derrotada Cartago, le garantiza a los púnicos una cierta independencia, impidiendo que se produzca un vacío de poder en esa zona de África, que en el futuro le pudiera producir a Roma serios problemas.(PIb. 15.18. Liv. 30-37. App. BP 154).

Cuando Aníbal cruza los Alpes, avanza hacia el Sur a través del Valle del Po, siendo su objetivo encontrarse con los insubrios. Ante esta situación, el Senado romano asigna al sector del Po dos legiones cedidas por el cónsul Escipión al pretor Manlio, con el fin de doblegar la insurrección de primavera, legiones que avanzan para encontrar a Aníbal. Las comanda Publio Cornelio Escipión, elegido cónsul con el fin de combatir a Aníbal, quien se encuentra por primera vez al mando de un ejército. Había navegado y desembarcando en Pisa después de haber dejado gran parte de sus tropas en Marsella. Avanza hacia el Po con órdenes del Senado de retomar el comando de las dos legiones que habían luchado contra los boes al mando del pretor Manlio Atilio. Estas dos legiones que sumaban un poco menos de 20.000 hombres, tenían escasa experiencia militar y su composición era de reclutas de primer servicio o soldados jóvenes con poca experiencia y personalidad. Para obtener alguna superioridad, el cónsul Publio Cornelio Escipión solicita al Senado que le envíen otras dos legiones consulares confiadas al colega Tiberio Sempronio Longo que venía en viaje desde Sicilia. La batalla del Ticino es el primer encuentro entre Aníbal y Roma en suelo itálico después de la célebre travesía de los Alpes, momento en el cual, Escipión con 17 años, acompaña a su padre que comanda las fuerzas romanas. A pesar de que su primera experiencia bélica se cumple con el sello de una derrota (Plb. 10.3), lo hace con dignidad, salvando en un acto heroico a su padre Publio de una muerte segura junto a un grupo de caballeros, hecho por el cual el mismo padre lo reconoce públicamente como su salvador, homenajeándolo con la corona cívica, corona que Escipión rechaza, señalando que la acción que había emprendido se recompensaba por si misma (Plb. 10.3). Estos hechos lo ennoblecen y lo impulsan a arriesgarse con valor cuando los intereses de Roma estén en peligro, pero sin dejar de ser prudente, cuando la ocasión lo requiere (Plb. 10.3).

Hechos como estos le dan fama a Escipión, sobre todo en los sectores populares, permitiéndole iniciar una carrera militar con un buen pronóstico. En efecto, dos años mas tarde, el 216 a.C., T. Livio nos da la noticia que ya en esa fecha se ha convertido en uno de los tribunos militares de los cuales depende el nombramiento de los comandos de las legiones; en otras palabras, ya es un oficial de estado mayor.

En otro momento, el joven Escipión fue testigo como subalterno, de la devastadora derrota de Canas. No sabemos con certeza si participó en la batalla, pero si seguimos el relato de T. Livio, es muy probable que el haya formado parte 
de los 14.000 sobrevivientes que renunciando a rendirse al enemigo, logran encontrar refugio en la localidad de Canosa, después de haber eludido a la caballería cartaginesa que iba en su persecución (Liv. 12.53). Sabemos que solo 4.000 llegan a Canosa, entre ellos cuatro tribunos militares. Por unanimidad y consenso, se nombra al joven Publio Escipión y a Apio Claudio comandantes superiores (Liv. 12.53), permitiéndoles destacarse en un momento en que solo las tinieblas rodean Roma. La corriente de opinión lleva a Roma a negociar o a salvarse de alguna manera. Contra esa corriente Escipión, en una actitud reactiva pero también creativa, propone la salvación de la República con una metodología diferente, lo que se corrobora cuando con un grupo de sus camaradas se dirige donde se encuentra Lucio Cecilio Metelo, quien había mostrado intenciones de huir de Roma, y desenvainando la espada por encima de las cabezas de los asistentes, jura que no abandonará la causa de la República y del pueblo romano, y que no permitirá a ningún ciudadano romano abandonarla, poniendo al juicio de los dioses su familia y sus bienes si esto no se cumple. La consecuencia de este acto esencialmente político, es que todos los seguidores de Metelo se unen a Escipión (Liv. 12.53). Después de estos hechos, Escipión y Claudio, demostrando el respeto a las instituciones y leyes de Roma, se ponen a las órdenes de Varrón, el cónsul sobreviviente de Canas, quien se encuentra en Venosa. Roma tradicionalmente atribuye a la fides como valor moral la fuerza para continuar combatiendo, confiando en que la victoria podría premiar la virtud de todo un pueblo y hacer aparecer la voluntad de resistir. De la fides nace la fuerza, y de ella se alimenta la voluntad romana de victoria. Ahora con Escipión, aparece una nueva mentalidad: la voluntad de conquista.

El hermano mayor de Escipión, Lucio, es candidato a edil, cargo que se constituye en el primer paso del cursus honorum, hasta los mayores como la pretura y el consulado. Las competencias específicas de los cuatro ediles, dos plebeyos y dos curules, es decir, patricios; se encargaban del control y la vigilancia para un normal desarrollo de la vida de la ciudad, sobre todo, en asuntos relacionados con el abastecimiento, los mercados, la construcción y la organización de los espectáculos públicos. No está en los planes de Publio competir con su hermano, pero acercándose el día de la elección, y viendo que difícilmente su hermano será elegido, y considerando además la simpatía que el pueblo le otorga, logra que sean elegidos ambos, una demostración palpable del afecto que sentía por él (Plb. 10.4-5). Hechos como estos son los que comienzan a tejer la leyenda probablemente promovida por la gens Cornelia (GABBA, 1975, p.3, 13$,$) , en la que por ejemplo, sus sueños, inspirados por los dioses y las visiones$ nocturnas, son advertencias y sugerencias divinas como convocadas por un oráculo, fundamentales para obtener sus logros (Liv. 26.29). La imitatio o imagen de Alejandro Magno y la formula se su filiación divina será otro aspecto ensayado 


\section{Escipion el Africano: un político moderno}

por Escipión para su beneficio y el de sus seguidores. En tiempos de confusión como los que se vivían, en el que se espera la aparición de un héroe que se presente como un salvador, premunido en parte de ciertas facultades divinas que le dan un carácter sobrehumano, es una situación que nos recuerda la imagen de los héroes homéricos, imagen que persiste en la memoria histórica de Roma desde su fundación. En momentos tan dramáticos como los que se viven, un pueblo como el romano, al sentirse abandonado por sus dioses, concentra en Escipión una salida a sus ruegos y en cierta manera, a una recuperación de la fe en las divinidades tradicionales. La opinión según la cual, esta pretendida inspiración divina posee una base religiosa y no solamente intelectual, se confirma en parte en la conducta de Escipión durante las guerras sirias del 190 a.C., cuando en calidad de miembro del colegio de sacerdotes de Marte, se retrasa en la retaguardia del ejército, obligando a esperarlo sobre el Helesponto, en cuanto las normas rituales obligaban a los miembros de la orden a permanecer donde se encontraban durante la fiesta hasta el fin del mes. (Recordemos que los sacerdotes consagrados al culto de Marte celebraban periódicamente solemnes ceremonias y gozaban de gran prestigio). Hoy la historiografía moderna, coincide en que esos relatos no son otra cosa que recursos propagandísticos-psicológicos, que tuvieron un gran asidero en la población. Estos recursos aparecen solo ocasionalmente en los discursos de Escipión, pero reflejan, de que manera el Africano, cómo un verdadero actor político, tratará y manipulará la naturaleza humana en los momentos de mayor crisis. Cuando toma la toga viril, preparando los ánimos, no desarrolla jamás un acto público o privado sin ir primero al Capitolio, entrar en el templo, sentarse solo y dejar pasar el tiempo (App. Hisp. 6.23). Esa imagen de hombre providencial es parte indudable de su estrategia política. Se trata de un individuo sin experiencia política y demasiado joven para competir con rivales de la estatura de Quinto Fabio Máximo, su más ácido crítico. Sin embargo puede demostrar sus interesantes éxitos militares, su inteligencia y sobretodo, parentesco con una familia de gran prestigio que abriga sus deseos de conseguir un Imperio para Roma.

En España la guerra no iba bien para la causa romana. Los Escipiones Publio y Cornelio, habían sido sorprendidos en forma separada a la cabeza de sus respectivas legiones, siendo estas destruidas y ambos hermanos muertos en el campo de batalla quedando el ejército de Asdrúbal como dueño del campo. En Roma estos hechos fueron un duro golpe que la caída de Capua solo en parte atenuó. Claudio Nerón fue enviado a España con un cuerpo expedicionario que debería haber obstaculizado los preparativos de Asdrúbal para cruzar los Pirineos y caer sobre Italia. Para comandar los ejércitos de los dos comandantes muertos aparece como el más idóneo el joven Publio Escipión, a esas alturas, convertido en un personaje carismático, amado por su coraje y sagacidad, demostrando en 
todo momento su fe en una salida victoriosa de la guerra. Es demasiado joven para que el Senado le confiriera el cargo de buenas a primeras. Además, aspirantes de otras facciones políticas no faltaban; por esa razón el Senado decide confiar a los comicios la responsabilidad de designar a un nuevo general en España, consiguiendo el acuerdo tácito de que Escipión se presentase como candidato único. De esta manera es elegido pro cónsul por unanimidad. Para armonizar las tendencias y como reconocimiento de la confianza depositada en él, el Senado designa como su colega al pro pretor M. Giunio Silano, con un imperium menor. En este caso, las antiguas tradiciones acerca del valor de la experiencia no se respetan, algo que para personajes como Quinto Fabio Máximo resulta a lo menos inquietante. En el fondo estaban entrando en un proceso de colisión dos visiones muy diferentes de la política en Roma. Cuando Escipión se hace cargo del ejército en España, realiza un rito de purificación y se dirige al ejército con palabras grandilocuentes. El 210 a.C. se hace responsable de las operaciones en Tarragona. El 209 a.C. aparece ante Nueva Cartago, tomando a la ciudad por sorpresa, mientras Asdrúbal lo espera sobre las montañas de Andalucía. Con un ejército de 30.000 hombres y una flota de 36 navíos a las órdenes de Cayo Lelio, toma la ciudad por asalto en una operación fulminante haciéndose de 10.000 prisioneros, un triunfo sobre todo para Escipión. Posteriormente obtiene un éxito más resonante aún, en Becula, centro de una región minera que había dado a Cartago el respiro financiero necesario para enfrentar los gastos de la Primera Guerra Púnica, y luego a Aníbal, los medios para organizar la expedición a Italia. Si se compara el estilo del mando militar de Quinto Fabio Máximo y de su colega Q. Fulvio Flaco, más cautelosos y timoratos, el exitoso estilo de Escipión es totalmente antagónico desde un punto de vista estratégico. Por tal razón se nombra cónsul a C. Nerón, el más querido después de Fabio y Fulvio; continuándose con una política que busca la armonía ante el peligro de la guerra, olvidándose los antiguos antagonismos y nombrándose a M. Livio Salinator. Asdrúbal en España consigue escapar de las legiones de Escipión y se pone en camino a Italia atravesando los Pirineos. En la primavera del 207 a.C., se dirige hacia el Rodano, para llegar en otoño a la llanura paduana. Por otra parte, Escipión en menos de cuatro años se apropia de todas las posesiones cartaginesas en España, lo cual deja a Roma con un territorio que habría soñado tener. La buenas noticias de los éxitos del joven Escipión en España, las toman en Roma como un designio de la providencia, lo que Escipión explota, con el propósito de hacer más sólida su imagen de líder inspirado por los dioses; recordemos que en España fue proclamado rey (Plb.10; 28.3; 40.2-5). El 205 a.C., Escipión se dirige a Roma con el objeto de dar cuenta personal de sus campañas y con el fin de solicitar el consulado. Sin lugar a dudas que en esos momentos es uno de los predilectos de las multitudes, ante las cuales podía mostrar consistentes triunfos 


\section{Escipion el Africano: un político moderno}

y trofeos, por el hecho de ser el único general que propone la derrota de Aníbal como la solución final del conflicto, frente a la alternativa de una paz poco clara, que estaba en los objetivos de la antigua generación que optaba por la seguridad y la tranquilidad, cansada y consumida por largos años de vida pública. Escipión está consciente que la guerra en Italia se ha transformado para los habitantes de la península en una realidad insoportable y dramática. Hay acuerdo en ese punto como también de que enfrentar a Aníbal en la península puede ser peligroso, considerando el estado de fatiga general y los malos resultados conseguidos hasta ese momento. De ahí que Escipión se incline por la vía de continuar la guerra en África, señalando en sus discursos electorales que esto sería como recomenzar la guerra (Liv. 28.40-44). Mirado en un contexto más amplio, significa la manutención o prolongación de una estrategia iniciada cuando Publio y Gneo llevaban a cabo sus campañas en España. Ahora Escipión hijo las mantenía, impidiendo que Fabio y su grupo controlaran la dirección de la estrategia en Italia. Sabemos que la guerra fue financiada en gran parte por contribuciones privadas, de campesinos romanos e itálicos y por los sostenedores de las ideas expansionistas en Roma. Durante la campaña electoral Fabio Máximo y sus partidarios, conservadores y tradicionalistas, se le opusieron tenazmente, sosteniendo que era más importante la paz en Italia que la guerra en África. Es probable que hayan visto en Escipión una similitud con el estilo de Aníbal, lo que los perturbaba, por estimarlo contradictorio e inaceptable. Seguramente en la mente de Escipión, ya se elaboraba la imagen de un Imperio. La postura del Africano es osada, por lo que el Senado prefiere no arriesgarse, siendo designado cónsul con una importante mayoría de votos patricios y populares. En cambio, su colega Publio Licinio Craso, estaba ligado a los sectores oligárquicos. Escipión toma el mando de las fuerzas en Sicilia con la facultad de llevar la guerra al continente africano si lo estimaba indispensable. Su decisión fue motivo de una cerrada discusión en el Senado, en la que se destacó Fabio Máximo, enfrentándolo e increpándolo, sosteniendo que era un joven que irresponsablemente los conduciría a una catástrofe, ataques que a Escipión no lo hicieron ceder, por el gran respaldo que había recibido. Entonces, el poder popular se enfrenta al Senado, convirtiéndose en un precedente político que en el futuro traerá serias consecuencias.

Recordemos que al asentarse el fenómeno del imperialismo la economía tradicionalmente agrícola se va transformando en una economía de carácter mercantil e industrial, sumado al aumento progresivo de la esclavitud. La sociedad romana sufre profundas transformaciones en las que la antigua clase dirigente patricia va a ser reemplazada por una nueva clase dirigente patricio - plebeya, es decir, la nobilitas. A su lado, pero en posturas antagónicas, están los equites, los grandes comerciantes, los industriales, los banqueros, en otras palabras, los hombres de negocios. El resto de la antigua plebe conforma los estratos 
inferiores, que van de medianos a pequeños propietarios, los pequeños comerciantes, los artesanos, todos los trabajadores libres, incluyendo al proletariado urbano, que va aumentando al crecer la ciudad y al expandirse el fenómeno de la esclavitud. Las magistraturas y el Senado, por lo tanto, todo el gobierno del Estado y la administración de la justicia, están en manos de la nobleza patricio - plebeya. Los equites se constituyen en un poderoso grupo de presión que defiende sus propios intereses económicos aliándose con una y otra parte. Los dictámenes del Senado no solo dejan de ser indiscutibles, sino que aparece en escena la fuerza que tiene el pueblo cuando es interpretado por un caudillo del calibre de Escipión. Así entonces, se dedica a la tarea de preparar una flota y sus fuerzas son reforzadas con los veteranos de Canas. El 204 a.C. se desplaza con su ejército hacia las costas de África desembarcando con 25.000 hombres, de los cuales 2.500 formaban su caballería: como lo había anunciado durante su campaña, la guerra comenzaba nuevamente. Mientras tanto, Magón, uno de los hermanos de Aníbal, derrotado por Escipión en España y refugiado en las Baleares, había reagrupado a su ejército y desembarcado en Italia, en las costas de Liguria. Temblorosa Cartago por los acontecimientos, lo había apoyado, enviándole hombres, dinero y elefantes. Con ese dinero Magón recluta hombres en las Baleares y la Liguria, donde es apoyado con una flota. Toma Génova en la que se acuartela para pasar el invierno, desde donde se mantiene en contacto con las tribus galas y con los municipios etruscos. Sin llegar a crear el problema que produjo Asdrúbal, estos acontecimientos inquietan a los romanos a pesar de que Aníbal no tiene posibilidades reales de entrar en contacto con Magón. La inseguridad aumenta el deseo de hacer efectiva la paz, que no pocos sostienen y esperan, pero los hechos continúan resultando favorables para Escipión y su política de expansión y de mantención de las hostilidades. Aníbal entrega la ciudad de Locri a Roma ante la imposibilidad de defenderla por más tiempo. Magón queda bloqueado en la Liguria. Varias tentativas son bloqueadas por las fuerzas romanas a pesar de su voluntad y capacidad estratégica. Esta coyuntura deja a Escipión en una excelente posición para planificar y llevar a cabo el asedio de Utica. No obstante un encuentro naval en aguas de Utica deja a Escipión en una inconfortable situación, de modo que su aventura africana no se inaugura bajo buenos auspicios, debiendo retirarse, fortificándose en la llamada Castra Cornelia, una de las más perfectas ciudadelas militares. Detrás de esos parapetos pasará Escipión el invierno del año 204 a.C., en tanto que Aníbal, encerrado en Crotona, construye navíos. Las fracasadas gestiones de Aníbal para concretar una alianza con Sifax, se harán efectivas luego de que Escipión entra en contacto con Massinisa, rey de Numidia. Sin embargo las propuestas que ulteriormente hará Sifax serán rechazadas por Escipión, lo cual provocará lo inevitable. Un ataque nocturno desencadena el desastre cartaginés. Después, las fuerzas del Africano se 


\section{Escipion el Africano: un político moderno}

dirigirán hacia la ciudad de Cartago, donde Escipión resultará el vencedor en la batalla de los Campos Magnos, a un centenar de kilómetros de Utica. Las consecuencias están en que las fuerzas de Siface se separarán del grueso del contingente cartaginés, debilitándolo. Esta circunstancia y los resultados finales de la batalla, dan la razón a la política sostenida por Escipión en el Senado romano, muy a pesar de los sectores que estaban detrás de Quinto Fabio Máximo.

Todos estos acontecimientos traen por consecuencia el comienzo de un proceso progresivo de militarización de las magistraturas políticas romanas que hará que la dimensión militar de la vida romana comience a subordinar otros proyectos, y, de esa manera, iniciándose un paulatino desequilibrio que desencadenará la crisis del siglo I a.C.

A la luz de la psicología moderna, no se puede dejar de considerar la posibilidad de que los sueños de Escipión hayan sido auténticos y no un invento, porque que es sabido que un deseo fuerte y poderoso es posible hacerlo formar parte del sueño. En todo caso, cualquiera que haya sido el origen y veracidad de sus visiones, no debe haber dudas sobre la habilidad que el tuvo para sacarles provecho y darles una utilidad práctica. En situaciones como esta, destaca su entereza moral, al usar este poder exclusivamente en beneficio de Roma, y nunca, al menos directamente, en su propio bien, aún cuando, por rebalse, terminó también beneficiándose. Cuando tiempo después llegan las acusaciones y las angustias, y una República ingrata se olvida de su salvador, Escipión jamás invoca alguna visión divina como un recurso para su defensa, mostrándose siempre con una gran discreción. La elección de Escipión en el cargo de edil curul, es históricamente importante, no solo porque nos permite ver la primera etapa de su éxito y de su influencia sobre los ciudadanos, sino también, porque entrega las causas que revelarán su posterior declinación política. Esta orgullosa victoria fue un desafío a la tradición y a sus normas, lo que contribuirá a acrecentar el resentimiento y los celos que inevitablemente acompañan el temprano éxito del joven Publio.

El primer movimiento que sus enemigos hacen es acusarlo de apropiación indebida de la indemnización pagada por Antíoco. La indignación del Africano es enorme respondiendo que el tiene las cuentas pero que no se las va a mostrar a un cualquiera. Ante la insistencia le ruega a su hermana que las traiga; recibido el cuaderno, lo muestra y lo destroza a la vista de todos arrojándolo sobre el suelo del Senado. Esta anécdota en general es confusa y tiene una difícil explicación, pero refleja indudablemente una tendencia negativa de ciertos grupos hacia Escipión, tendencia que se manifiesta desde los primeros momentos de su ingreso a la política. El gesto es de una gran dignidad, muy humano pero tal vez demasiado confrontacional para los tiempos que se viven. No olvidemos que 
Escipión, no solo salva a Roma sino que la deja en el camino del dominio del mundo; aún así, sus enemigos lo conminan a rendir cuentas en público por 4 millones de sestercios, cuando gracias a él, las arcas del Estado se habían enriquecido en 200 millones (Plb. 23.14). Debemos recordar también, que Escipión ya era un hombre enfermo, un mal que poco tiempo después le provocará la muerte, enfermedad que posiblemente lo tensiona aún más y lo pone de mal humor. A lo anterior, debemos sumar la seguridad que los años le habían dado, y que lo acerca al perfil de una persona más bien arrogante. Polibio se refiere a que en una ocasión, Escipión replica duramente diciendo "que no es decoroso para el pueblo romano escuchar a quien osa acusar a Publio Cornelio Escipión, por cuya obra los acusadores tienen la libertad de hablar" (Plb. 24.9). Recordemos que había rechazado el poder real cuando se le quiso imponer, contentándose con permanecer como un ciudadano de carácter reservado, gesto que al parecer no se le reconoce.

Este acto de provocación de Escipión, que contiene los gérmenes del cesarismo, da a sus enemigos la oportunidad que probablemente esperaban desde hace bastante tiempo. Dos tribunos, los Petilios, instigados por Catón, inician una causa en su contra bajo la acusación de dejarse sobornar por Antíoco a cambio de las condiciones benignas que se le impusieron. Este peligro es percibido por Marco Porcio Catón, quien permanentemente intenta abatirlo por su carácter de verdadero símbolo viviente. Para Catón, el respeto de la fides y de los deberes que de ella derivan, son la virtud esencial y más auténtica del pueblo romano. A partir de esa noción se profundiza el pensamiento y la conducta política. Roma puede mantener intacto y seguro el predominio que se había merecido gracias al constante respeto del ius gentium. Para Catón, el poder de Roma no es el resultado de la fuerza sino de la fides. Considera que el pueblo romano puede asegurar la defensa de sus territorios con cualquier medio a su alcance, pero debe abstenerse de guerras de conquista al estilo de macedonio, por innecesarias y contrarias al derecho. Por lo mismo, no se debe aceptar que en el Senado existan figuras superiores en dignitas o en auctoritas a sus pares. Resulta evidente que a Catón, Escipión le resultaba incómodo, pero su figura estaba avalada por la oligarquía senatorial o por la mayor parte de sus miembros. A pesar de esto, Catón hará lo imposible por destruirlo, reintentando recuperar los mores maiorum. Se convierte en el líder del grupo que se opone a la difusión de la cultura griega, viéndola como un instrumento de una subversión no solo social sino también política: el caso del famoso senatus consulta de Bachanalibus, es un claro ejemplo. Para ellos Escipión representa lo helenístico, lo antiromano, por eso Catón considera que se ha alejado de la fides romana. Sabemos que en el mundo griego, por motivos propagandísticos, se hacen circular profecías que anuncian la ruina de Roma como inminente e inevitable (MARTELLI, 1978, p.123- 


\section{Escipion el Africano: un político moderno}

131). Hay una psicosis de agresión a Roma, por lo que esta se cierra al exterior, mientras que en el interior se inicia una caza de brujas, reacción natural en un estado que se siente seriamente amenazado, surgiendo una política en que la seguridad en tiempos de paz se garantiza con la presencia de una fuerza militar de tipo disuasivo (PASCHOUD, 1967, p.110 y ss). Estos hechos causarán en Roma una oleada de excitación y de quejas. Los acontecimientos son comentados y enfrentados a partir de las diversas tendencias representadas en el Senado. (Liv. 38.50). Algunos reprochan no solo a los tribunos de la plebe, sino a toda la ciudadanía, la que no está dispuesta a aceptar un error de esa magnitud. El profesor Emilio Gabba, recuerda que en los Escipiones está presente la idea de una posible decadencia de Roma unida a la inestabilidad de la Fortuna. "Las lagrimas de Escipión Emiliano frente a Cartago en llamas el 146 a.C..., y las reflexiones melancólicas y pesimistas sobre la movilidad de la Fortuna que se habría podido manifestar en el futuro dañina para Roma, son sin duda hechos reales sostenidos por Polibio" (GABBA, 1975, p.16; Plb. 38.21.2-3. Diod. 32.34. App. Lib. 628-630=Plb. 38.22). Las más grandes ciudades estados del mundo parece ser que se han puesto de acuerdo casi al mismo tiempo, para demostrar su ingratitud hacia sus ciudadanos más ilustres. Cartago derrotada, había mandado al exilio a un Aníbal derrotado; Roma triunfal, se propone expulsar al vencedor de Cartago, a Escipión el Africano.

Siguiendo la línea de Catón, los acusadores de Escipión argumentan que ningún ciudadano debe considerarse por sobre el resto como para no sentirse en situación de responder por su conducta; por el contrario, todos deben alegrarse de que eso fuera así. Cuando se llega al día de la audiencia, Escipión se hace acompañar por una gran cantidad de ciudadanos de distintas clases, entrando al Foro como acusado (Liv. 38.50). Cuando se inicia el juicio, los tribunos al no tener pruebas sólidas hacen uso de las antiguas acusaciones sobre que en los cuarteles de invierno de Sicilia, donde el lujo imperaba, existían hábitos y costumbres de tipo griego. Las voces eran de los Petilios, pero las palabras eran de Catón, quien había sido discípulo de Fabio y había promovido las acusaciones sobre Sicilia, las que una comisión investigadora consideró sin fundamento. Después, los tribunos lo acusan de apropiación indebida de dinero y destacan que la "devolución sin rescate del hijo prisionero y la generosidad de Antíoco hacia Escipión en todo el resto de los asuntos, daban la impresión de que la paz y la guerra dependieran solo de él (Liv. 38.51). Los tribunos, con sus palabras demuestran a medida que hablan, que la causa es inconsistente, sobre todo, porque el acusado es intocable en su honor. Lo único que pueden hacer es debilitar su popularidad. El debate dura hasta la noche, por lo que se acuerda una nueva sesión al día siguiente. Cuando a la mañana siguiente los tribunos ocupan sus lugares en el aula y el acusado es invitado a responder, la respuesta de Escipión es en el estilo que lo 
caracteriza durante su carrera política. Nadie al parecer está en condiciones de presentar pruebas de ningún tipo; su orgullo no está en esos momentos para enredarse en explicaciones, además de tener claro que habría sido inútil tanto para sus adversarios como para sus amigos. Por lo tanto obtiene un último triunfo en uno de sus últimos contraataques, en el cual su psicología política resulta evidente. Los hechos los relata T. Livio: "En tal día como hoy, tribunos de la plebe, y vosotros Quirites, combatí bien y con éxito en África, en batalla campal contra Aníbal y los cartagineses. Por consiguiente, como lo que corresponde a esta fecha es dejarse de litigios y disputas, yo voy a subir al Capitolio directamente desde aquí para rendir un homenaje a Júpiter Optimo Máximo, a Juno y a Minerva y a los demás dioses protectores del Capitolio y la ciudadela, para agradecerles por haberme dado, en esta jornada y en tantas otras, el ánimo y la posibilidad de servir dignamente a la República. Igualmente, todos aquellos que lo puedan hacer, venid conmigo y juntos rogaremos a los dioses para tener ciudadanos eminentes semejantes a mi, en el supuesto de que desde los 17 años hasta la vejez vosotros siempre os habéis anticipado con vuestros honores a mi edad, y yo he ido con mis actos por delante de vuestros honores" (Liv. 38.51).

Pronunciadas estas palabras, Escipión se dirige al Capitolio, momento en el cual lo sigue toda la asamblea; al final abandonan la sala hasta los escribientes y los alguaciles, quedando solo en una sala desierta los acusadores de Escipión. Probablemente ese día, por decisión del pueblo y por su el testimonio de grandeza, fue más glorioso para él que su ingreso triunfal a Roma después de la derrota de Cartago y la derrota del rey Sifax. Este fue su último día de gloria, después, no viendo en el horizonte mas que odiosidad de los partidos y sus luchas con los tribunos, disponiendo de la posibilidad de postergar para otra fecha la causa, se va a Liternino, una zona en torno a Literno, un antiguo lugar de la región de la Campaña que se ubicaba donde actualmente se encuentra la ciudad de Giugliano, cerca de Nápoles, lugar en el cual Escipión es dueño de una villa. EI exilio final que Escipión se impone a si mismo, con el fin de alejarse de una tierra ingrata, hace que su brillante carrera concluya en las sombras. De esta decisión se puede deducir que Escipión no tuvo ningún interés en volver a presentarse cuando el proceso se reanudara. Su fuerte carácter, su sentido de la dignidad, su imagen de uno amparado por los dioses, no le permiten exponerse a las humillaciones de sus adversarios (Liv. 38.51-52). Por eso, cuando Escipión es citado, Lucio Escipión lo justifica informando que su salud le impide asistir, a pesar de que los tribunos que sostienen la acusación no aceptan la excusa afirmando que todo se debe al habitual desprecio a las leyes que Escipión ha demostrado permanentemente, criticando al pueblo por haberlo acompañado al Capitolio y por su falta de resolución: "Tenéis ahora el pago de su temeridad; os ha abandonado a vosotros a su vez aquel bajo cuya iniciativa e instigación os habéis 


\section{Escipion el Africano: un político moderno}

alejado de nosotros, y de día en día va a menos nuestro coraje de tal forma que, mientras hace 17 años, cuando el tenía un ejército y una flota nos atrevimos a mandar a Sicilia tribunos de la plebe y un edil para que lo arrestaran y lo trajeran de vuelta a Roma, ahora que es un ciudadano privado no nos atrevemos a mandar a alguien que lo saque de su casa de campo para defenderse en juicio" (Liv. 38.52). A pesar de esto, los acusadores no logran su intento. El tribuno Tiberio Graco, disiente de la proposición, declarando que la justificación de la enfermedad argumentada por el hermano Lucio Escipión le parecía suficiente. Queda en evidencia que el no habría permitido que Escipión fuese sometido a proceso antes de viajar a Roma, y si eso hubiese ocurrido, Tiberio habría intervenido en su ayuda a fin de que no fuese obligado a defenderse en juicio.

A partir de su leyenda, Escipión, con el beneplácito de los dioses y de los hombres, había subido a tal altura por las gestas cumplidas y por los honores conferidos por el pueblo romano, que el verlo al pie de los rostra, de acusado, obligado a escuchar las injurias de los jóvenes, era un espectáculo mas indigno y deprimente para el pueblo romano que para el mismo (Liv. 38.52).

Graco pronuncia un discurso vibrante de indignación: “¿Va a estar aquí a vuestros pies, tribunos, el gran Escipión conquistador de África? ¿Para eso derrotó y puso en fuga en Hispania a cuatro valientes generales cartagineses y a sus cuatro ejércitos? ¿Para eso capturó a Sifax, venció a Aníbal, hizo a Cartago tributaria nuestra, obligó a Antíoco a retirarse más allá de la cadena montañosa del Tauro-? ¿Para sucumbir delante de los dos Petilios, para que vosotros buscaseis la palma del triunfo sobre Publio el Africano? ¿Nunca llegarán los varones preclaros, por algún mérito personal o por algún honor conferido por vosotros, a una ciudadela segura y de algún modo sacrosanta sonde su ancianidad descanse sino venerable al menos libre de los ataques?" (Liv. 38.52). Estas palabras producen una impresión tal, que el Senado convoca a una sesión extraordinaria en la cual se le agradece a Tiberio Graco que haya puesto los intereses del estado por encima de las rivalidades personales (Liv. 38.53). Los acusadores se encuentran entonces enfrentados a una hostilidad general por lo que el proceso judicial es anulado.

Después de estos hechos, el silencio cae sobre el Africano, pasando el resto de su vida en Literno. Cuentan que murió en el campo pidiendo que se le diese sepultura ahí mismo, y se levantara en ese lugar su monumento funerario para que no se le rindiesen honras fúnebres en una patria ingrata (Liv. 38.53). Parece como la fecha más probable de su muerte el 183 a.C., poniendo fin a su exilio voluntario, pero el lugar donde se construye su monumento funerario no es claro en las fuentes, las que afirman que hubo uno en Roma y otro en Literno. En el momento de su muerte tiene solo 52 años. Por una inquietante coincidencia, su gran rival, Aníbal, también muere en el mismo período y probablemente en el 
mismo año, a los 64 años de edad. Aníbal, después de Magnesia, había huido a Creta para después buscar refugio en Bitinia. El Senado romano demuestra su buen sentido, al comprender que habría sido un acto indigno desalojar a Aníbal de su último refugio, pero el comandante local, Flaminino, intriga para que lo asesinen, cosa que como se sabe, no ocurre porque Aníbal finalmente se quita la vida impidiendo su inminente asesinato.

Incluso después de su muerte, a Escipión no lo dejan en paz. Su muerte revitaliza la odiosidad del partido adversario, del cual es su jefe Marco Porcio Catón" (Liv. 38.54). Debido a una iniciativa de este último, se abre una nueva investigación para saber que hay detrás de la tributación de Antíoco. Esta ves, el blanco de los ataques no puede ser Publio, por lo que el objetivo es Lucio. Como consecuencia de esto, es sometido a juicio, por lo que Lucio junto a sus lugartenientes son llamados a declarar, para ser finalmente acusados. Siguiendo el estilo del Africano, Lucio declara que todo el dinero que el había recibido, había sido depositado en las cuentas del Estado, rechazando entregar los comprobantes, por lo que es llevado a prisión. Su primo, Publio Escipión Nasica, presenta una protesta documentada y convincente, pero el pretor declara que dada la sentencia no hay otra alternativa que ordenar la encarcelación, a menos que el acusado pague al Estado la multa impuesta, ante la cual, Graco interviene nuevamente para salvar de la desgracia a sus enemigos personales. Usando su autoridad de tribuno, ordena la absolución en mérito a los servicios que había prestado a Roma y decreta en cambio, que el pretor cobre lo que sumen los bienes de Lucio. El pretor en consecuencia, manda a los cuestores con el fin de que ejecuten el procedimiento, no encontrando señales del dinero que presuntamente los Escipiones habían recibido; ni mucho menos se llega a la cifra de la multa a la que Lucio había sido condenado (Liv. 38.60). Esta convincente prueba de la inocencia de los Escipiones provoca un repentino cambio en la opinión pública; el malestar que había contra los Escipiones se vuelve contra el pretor, sus consejeros y acusadores (Liv. 38.60).

Hay datos indirectos que nos permiten ver que la vida familiar de Escipión estuvo inspirada en principios morales sólidos. El apoyo de Tiberio Graco se puede explicar también por razones familiares. Su hija Cornelia es entregada como esposa a Tiberio Graco. Cornelia se convierte después en la madre de los Gracos. La manera en la cual ella los educa y los forma, los principios que les traspasa, explican que después se conviertan en los famosos reformadores, convirtiendo esa época en una de las más intensas de la historia de Roma (LAFFI, 1984, p.99-100). Más allá del ambiente doméstico, la influencia de Escipión en la historia social la podemos ver en el amor por la literatura griega a la que contribuyó a difundir en el mundo romano. Hombre de gran cultura intelectual, sabe hablar y escribir en griego como el latín. En las fuentes está el rumor de que 
Escipion el Africano: un político moderno

habría escrito sus memorias en griego. Al dominio del griego debe sus conocimientos de filosofía griega que transforma en un estilo de vida que queda reflejado en sus actos y discursos conocidos. El gusto por la corrección y la buena crianza, el amor por las letras, es un gran admirador del poeta Enio, que queda reflejado al disponer que en su tumba se ponga su busto al lado del suyo en su tumba.

La rehabilitación de Publio Cornelio Escipión el Africano, ocurrida después de su muerte, ciertamente no es un buen argumento para consolarlo en los últimos y dramáticos años de su vida. Escipión, representa el paso a individuos con una nueva concepción de la guerra y con una diversa mentalidad, la de las ideas imperialistas en Roma. Con Escipión aparece una nueva mentalidad: la voluntad de conquista. De alguna manera Escisión es un precursor, porque se anticipa al modo de hacer y actuar en la política en los tiempos modernos. Alejada la figura de este hombre, la República no conocerá en lo menos 50 años nada similar, ni a nadie que tenga el carisma y la visión política y estratégica del Africano.

\section{Bibliografía}

ASTIN, A. E. Cato the Censor. Oxford, 1978.

ASTIN, A. E.Scipio Aemilianus. Oxford, 1967.

AYMARD, J. Scipion L'Africain et les chiens du Capitole. Revue des Estudes Latines, XXXI, p. 111-116, 1953.

BANDELLI, G. I processi degli Scipioni: le fonti. Index, III. p. 304-342, 1972.

BRIZZI, G. Scipione e Annibale. La Guerra per salvare Roma. Bari, 2009.

BUONO-CORE V., R. Aspectos de la lucha política en Roma en la segunda mitad del siglo III a.C. Valparaíso, 1983.

CASSOLA, F.I Gruppi politici romani nel III secolo A.C. Trieste, 1962.

CASSOLA, F. La politica di Flaminino e gli Scipioni. Labeo, VI, 1, p. 105-130, 1960.

CLEMENTE, G. "Esperti" ambasciatori del Senato e la formazione della politica estera romana tra il III e II secolo a.C. Athenaeum, III-IV, p. 319-352, 1976.

CLEMENTE, G. La Guerra annibalica. Storia di Roma, II, 1. Torino, 1990, p.79-90.

DE REGIBUS, L. Il processo degli Scipioni. Torino, 1921.

DEVELIN, R. Scipio Africanus imperator. Latomus, XXXVI, p. 110-113, 1977.

DOREY, T. A. Scipio Africanus as a party leader. Klio, XXXIX, p. 191-198, 1961.

DOREY, T. A. Il Censore e l'Africano. Genova, 1959.

FRACCARO, F. I processi degli Scipioni. Opuscula, I. Pavia, p. 263-415, 1956.

GABBA, E. II consenso popolare alla politica espansionistica romana fra il III e il ii sec. A.C. Papers and Monographies, American Academy Rome, XXIX, p. 115-129, 1984.

GABBA, E. Rome and Italy in the second century B.C. C.A.H., VIII, Cambridge, p. 197-243, 1989.

GABBA, E. P. Cornelio Scipione Africano e la legenda., Athenaeum, n.s. LIII, p. 3-17, 1975. (=Aspetti culturali dell'Imperialismo romano, Firenze, 1993, p. 113-131).

GAGÉ, J. La "rogatio Petillia" et le procès de Publius Scipion. RPh, LXXIX, p. 34-64, 1953. 
Raúl Buono-Core V.

GRIMAL, P. Le siècle des Scipions. Rome et l'hellénisme au temps des guerres puniques. Paris, 1975.

GRUEN, E.S. The "fall" of the Scipion. En: Leaders an Masses in the Roman World. Studies in Honor of Zwi Yavetz, al cuidaddo de I. Malkin, Z.W. Rubinsohn, Leiden-New York-Köln, 1995, p. 59-90.

HALLWARD, B.L. Scipione e la vittoria. Storia del mondo antico, VI, trad. It. Milano, p. 284318, 1975.

HAYWOOD, R.M. Studies on Scipio Africanus. Westport, 1933.

HARRIS, W.V. War and Imperialism in Republican Rome (327-70 B.C.). Oxford, 1979.

LAFFI, U. La colonizzazione romana tra la guerra latina e la guerra annibalica. Dialoghi di Archeologia, ser. III, 6, p. 23-33, 1988,2; (=La colonización romana entre la guerra latina y la edad de los Gracos: aspectos institucionales, en "Emilio Gabba-Umberto Laffi, Sociedad y política en la Roma republicana (siglos III-I a.C.), p.61-77, Pisa, 2000.

LAFFI, U. Reformas y reacción en la época de los Gracos. Semanas de Estudios Romanos, II, Valparaíso, p.93-102, 1984.

LEVI, M.A. Inizi di Scipione Africano e di una età di cambiamenti. DHA, 23, p.145-153, 1997.

MARTELLI, F. Fgr. Hist., F36. RSA, III, p.123-131, 1978.

MC DONALD, A.H. Scipio Africanus and Roman Politics in the second century B.C. JRS, 28, p.153-164, 1938.

MOMIGLIANO, A. Annibale Politico. La Cultura, N.S., XI, I, , pp. 61-72, 1932.

NICOLET, C. Les idées politiques a Rome sous la République. Paris, 1970.

NICOLET, C. Le De Republica (VI, 12) et la dictature de Scipion. Revue des Etudes Latines, XLII, p. 212-230, 1964.

PASCHOUD, F. Roma aeterna: études sur le patriotisme romain dans l'occident latin à l'époque des grandes invasions. Institut Suisse de Rome, 1967.

RIDLEY, R.T. Was Scipio Africanus at Cannae? Latomus, XXXIV, p. 161-165, 1975.

SCULLARD, H.H. Scipio Africanus: Soldier and Politician. Bristol, 1970.

SCULLARD, H.H. Scipio Africanus in the Second Punic War. Cambridge, 1930.

TEDESCHI, A. Conflitto d'età e conflitto d'opinione: Q. Fabio Massimo, Scipione l'Africano e la spedizione anticartaginese in Africa. Aufidus, XXVII, p. 17-43, 1995.

WALBANK, F.W. The Scipionic Legend. PCPhS, CXCIII, p. 54-69, 1967.

ZECCHINI, G. Scipione in Spagna: un approccio critico alla tradizione polibiano-liviana. En Hispania terris ómnibus felicior. Premesse ed isiti di un processo di integrazione. Atti del Convengo Internazionale, Cividale del Friuli, 27-29 settembre 2001, a cura di G. Urso. Pisa, 2002, p. 87-103. 



\title{
VOCES CRÍTICAS SOBRE LA POLÍTICA IMPERIALISTA ROMANA: EL CASO DE CAYO SALUSTIO CRISPO.
}

\author{
Marta Sagristani ${ }^{*}$ \\ Universidad Nacional de Córdoba - Argentina
}

\section{Introducción}

Según una de las versiones míticas sobre la fundación de Roma, la violencia y el asesinato marcaron la historia de la ciudad desde sus orígenes. Numitor, rey de Alba Longa fue destronado por su hermano Amulio, quien lo desterró y procedió a matar a todos sus hijos varones. Sólo dejó viva a Rea Silvia, su única hija, obligándola a dedicarse al culto de Vesta, para asegurarse su virginidad. Un día en que la joven se encontraba durmiendo a la orilla de un río, el dios Marte se enamoró de ella y la poseyó. Producto de esta unión, la joven tuvo dos gemelos, a los que Ilamó Rómulo y Remo. Temerosa de la ira de Amulio, colocó a sus hijos dentro de una cesta, en el río Tíber, para que no sufrieran el mismo camino que sus tíos. Los gemelos sobrevivieron amamantados por una loba, Luperca, y luego fueron recogidos por un pastor, Fáustulo. Ya adultos, los hermanos regresaron a Alba Longa, mataron a Amulio y repusieron en el trono a su abuelo Numitor, quien les donó unos territorios al noroeste del Lacio. Allí eligieron el lugar para erigir la nueva ciudad, que sería Roma, en una llanura rodeada por siete colinas a orillas del Tíber. Pero la disputa por el poder derivó en un nuevo asesinato. Tras delimitar el recinto de la ciudad con un arado, Rómulo juró matar a todo aquel que lo traspasara sin su permiso. Ambos hermanos discutieron por el nombre de la ciudad y, mediante un ardid, Rómulo se impuso a Remo. Éste, enojado, discutió con su hermano y borró el surco de los límites de la futura ciudad. Cumpliendo el juramento, Rómulo lo asesinó. Una vez concluido el acto de la fundación, Rómulo se vio obligado a traer colonos desde otras regiones para poblar la ciudad, y como éstos eran en su mayoría varones, les procuró esposas mediante el rapto de las sabinas. A partir de la guerra contra los sabinos, la pequeña ciudad continuó creciendo a costa de los pueblos vecinos: el primer conflicto entre Roma y Veyes tuvo lugar durante el reinado de Rómulo.

Otra versión mítica, la leyenda de Eneas y los troyanos, se remonta más allá de la época de Rómulo y Remo, pretendiendo dar cuenta de los contactos entre romanos y griegos. La leyenda narra la historia de Eneas, hijo del príncipe

\footnotetext{
* Profesora Adjunta Full Time, cátedra Historia Antigua General, Escuela de Historia, Universidad Nacional de Córdoba (R. A.). Correo postal: Europa 248 - Barrio San Martín CP 5008 - Córdoba - Argentina. Correo electrónico: marta.sagristani@gmail.com
} 
Voces críticas sobre la política imperialista romana

Anquises y de la diosa Afrodita, casado con Creúsa, una de las hijas del rey de Troya. El personaje es uno de los grandes héroes del ejército de Troya y el único que sobrevive a la destrucción de la ciudad. Luego de abandonar su vieja patria, guiando a los pocos soldados y ciudadanos que han quedado en pie, llega al antiguo Lacio con la misión de fundar una nueva ciudad, la futura Roma. Pero la idílica paz de los comienzos se trunca rápidamente por el conflicto, ya que los troyanos, según Virgilio, se vieron poseídos por la pasión y la irracionalidad de la guerra exterior e interior (Verg. G. 4.8y ss; G. 4.73-74) ${ }^{1}$. En un principio, la leyenda de Eneas fue utilizada para destacar la hostilidad entre griegos y romanos, aunque más tarde se transformó en una herramienta útil para reconciliarlos y convencer a los griegos de que debían aceptar la dominación romana como algo positivo (CORNELL, 1999, p.90-91).

Si bien hoy se está de acuerdo en que las versiones recogidas por la tradición literaria sobre los orígenes de Roma no pueden ser consideradas como un relato histórico, en el sentido preciso del término, no es menos cierto que estas leyendas fundacionales, teñidas de un fuerte contenido ideológico, nos permiten conocer la mentalidad de los romanos que las crearon y reprodujeron, y, en particular, la conciencia que tenían de sí mismos y cómo pretendían que los vieran los demás pueblos. En este sentido, es significativo que los romanos hayan elegido a Marte, el dios de la guerra, como padre de Rómulo, y que Eneas sea reconocido en la saga homérica, como el más valiente de los héroes troyanos (después de Héctor). Entonces, ¿deberíamos considerarlas antihistóricas o, como sostiene Cornell, "la alternativa sería suponer que, lejos de historizar los mitos, lo que hicieron los romanos fue imponer un marco mítico a una tradición histórica?" (CORNELL, 1999, p.105). Vistas desde esta perspectiva, las leyendas estarían reflejando una experiencia real, a saber, la decisión de un pueblo de construir una versión mítica de su historia, para explicar cómo y por qué Roma había llegado a convertirse en una potencia imperial, adueñándose de todo el mundo conocido. Proyectando hacia el pasado acontecimientos posteriores, estas versiones pseudo históricas buscarían justificar la dominación romana, signada por la violencia de los conflictos sociales internos y por las guerras que emprendió contra los pueblos extranjeros, persiguiendo el objetivo de constituirse en una entidad política panmediterránea ${ }^{2}$.

Hacemos nuestras las palabras de Moses Finley, quien define a Roma como "un Estado conquistador implacable desde el principio del registro de su historia" (FINLEY, 1986, p.86). Sin embargo, en el presente artículo no vamos a trabajar sobre los objetivos y las motivaciones que llevaron al Estado romano a constituirse en una potencia imperialista. Nuestra intención es limitarnos a analizar un aspecto de tan extensa problemática, rescatando a aquellas voces que, perteneciendo a la nobleza romana, hicieron oír sus críticas a la manera en que el Estado romano 
había encarando la conquista del mundo. Para ello, tomaremos los trabajos de Cayo Salustio Crispo, un pensador crítico de las prácticas políticas de la elite dirigente de su época.

Cayo Salustio Crispo provenía de una familia ecuestre de origen rural, pues era natural de Amiterno, pequeña ciudad de la Sabina, adonde había nacido en el año 87 a. C. Siendo muy joven partió a Roma para dedicarse a la política, una de sus grandes pasiones. Desde que se inició en esa actividad, fue opositor de la facción de los optimates, enemigo de Cicerón y partidario de las ideas de César, a quien apoyaba, como se desprende de la lectura de su monografía sobre la conjuración de Catilina, en la que se ocupa de despegarlo de cualquier responsabilidad en la conspiración ${ }^{3}$. A lo largo de su carrera, ejerció los cargos de cuestor, tribuno de la plebe y senador. En el año 50 a. C., tras estallar la guerra civil, fue expulsado del Senado y pasó a ocupar altos cargos en el ejército cesariano. Luego de tres años, con el triunfo de César, fue repuesto en su cargo de senador, y al año siguiente, gracias a su protector, fue designado como procónsul en la provincia de África. A la muerte de César se apartó de la actividad política y se dedicó a su otra pasión, escribir obras históricas sobre su pasado reciente.

Salustio es considerado como el creador de la historia como género literario. En todas sus obras se encargó de narrar y analizar los acontecimientos de la vida política de los que fue testigo directo. Fue uno de los intérpretes de la crisis de la República, y se mostró siempre preocupado por reflexionar sobre las causas que llevaron a la caída del sistema de gobierno. En todos sus trabajos está presente la crítica sobre el accionar de la elite dirigente, a la que hace responsable del progresivo deterioro institucional y del abandono de las tradiciones de los antepasados. En su primera monografía, De coniuratione Catilinae, se ocupa de la sublevación encabezada por Catilina, durante el consulado de Cicerón, en el año 63 a. C. En ella advierte que la República romana se está descomponiendo, y hace responsable de este proceso casi exclusivamente a la corrupción moral, aunque no deja de mencionar la importancia que tienen los factores económico-sociales en el progresivo deterioro institucional. Muestra la decadencia generalizada de la sociedad romana, pero destaca en particular el comportamiento de la nobilitas, ganada por un desmedido afán de lucro y de poder. En Bellum lugurthinum insiste en esta crítica, argumentando que una guerra que podría haber sido de rápida resolución para Roma, se prolongó en el tiempo gracias a la corrupción imperante entre los nobiles, que aceptaban los sobornos del rey númida. Cuestiona la voracidad de los miembros de la nobilitas que, preocupados por mantener su poder hegemónico y por acrecentar su riqueza, mediante la apropiación desmedida del ager publicus ${ }^{4}$, descuidaban la situación de pobreza e indigencia en la que estaba sumida la plebe ${ }^{5}$. Es de destacar que, tanto en esta obra como en 
Voces críticas sobre la política imperialista romana

De coniuratione, el autor presenta la ruina y destrucción de Cartago como el punto de inflexión a partir del cual se inicia la decadencia de la República romana. Su obra más ambiciosa, Historiae, consta de cinco libros y abarca un breve período histórico (los años 78 a 67 a. C.) pero, lamentablemente, sólo se conservan cuatro discursos, dos cartas, y algunos fragmentos. En ella se ocupa de narrar los sucesos posteriores a la muerte de Sila, destacando las características nefastas de su ejercicio del poder. Salustio toma al dictador como el prototipo de las prácticas políticas de la elite dirigente, que derivaron en el cruento enfrentamiento entre las facciones nobiliarias, conflicto que incidió de manera decisiva en la crisis de las estructuras republicanas ${ }^{6}$.

A partir de que Roma comenzó su expansión por la península itálica, entró en contacto, sucesivamente, con una gran diversidad de pueblos, a los que fue sometiendo y anexando. La conquista de nuevos territorios se aceleró en el año 348 a.C., cuando los romanos vencieron a los latinos y campanios, posteriormente a los samnitas, sabinos y umbrios. A fines del siglo IV, también ellos terminaron con el dominio etrusco, y en el año 272 a.C. sometieron a los griegos que habitaban en el sur de Italia. Pero a partir del siglo II a.C., el Estado romano comenzó una guerra sistemática y permanente, con la finalidad de extender los límites de su dominación más allá del control de toda la península itálica y del Mediterráneo, avanzando hacia horizontes cada vez más lejanos ${ }^{7}$. Hacia mediados del siglo I a.C., Roma, como lo resaltaba con orgullo Cicerón, se había convertido en la dueña de todo el mundo ${ }^{8}$. Tras sucesivas conquistas, los romanos habían logrado conformar un gran imperio y, a la manera de una profecía auto cumplida, habían hecho realidad los deseos de Rómulo, de ver mea Roma caput orbis terrarum sit (Liv. 1.16). Los beneficios imperiales transformaron a Roma en una ciudad esplendorosa, donde los nobiles hacían ostentación de su riqueza. La economía de subsistencia se transformó en una economía de mercado, gracias al aumento de la productividad de la actividad agrícola, que comenzó a reemplazar al campesinado libre por mano de obra esclava, para el trabajo en los grandes latifundios. Los éxitos militares permitieron transferir a Roma la riqueza obtenida como botín de guerra, que se vio complementada con los impuestos que pagaban los pueblos vencidos, incorporados al imperio como provincias. No obstante, más allá de la euforia que embargaba a la mayoría de la elite dirigente romana, ya hacia tiempo que habían comenzado a manifestarse los efectos negativos de la expansión, que, con el tiempo, desembocarían en la caída del sistema republicano de gobierno.

A la hora de analizar las causas de la crisis de la República, la tradición literaria romana insiste, casi unánimemente, en que éstas se encontraban en las transformaciones que se habían operado en la elite dirigente romana durante el siglo II a.C., ganada por el nuevo ideal de dominación universal y, 
consecuentemente, de los beneficios económicos devengados de la conquista de nuevos territorios. En opinión de Polibio, a partir de esta época la expansión romana abandonó su carácter disperso para responder a un plan ordenado y sistemático", cuyo objetivo último era alcanzar el control de "todo el mar y de toda la tierra" ${ }^{10}$. La consecuencia última de la conquista del Mediterráneo, tras haber vencido a Cartago, fue el cambio de actitud que provocaron los sucesivos éxitos militares en la mentalidad de la elite dirigente, a saber, la toma de conciencia de que ya no quedaban enemigos a los que temer y respetar ${ }^{11}$. Así mismo, los éxitos de las campañas militares emprendidas por Roma también influyeron en el cambio de mentalidad de los romanos, ya que, según Polibio, éstos se abandonaron a la ambición de poder, al lujo y a la comodidad, apartándose de las costumbres de los antepasados. Si bien esta explicación es excesivamente parcial y deja de lado otros factores, tanto o más importantes, que contribuyeron a la crisis de la República, lo cierto es que pone de manifiesto las transformaciones que se produjeron a lo largo del siglo II a.C., en el ámbito de la ideología y de las prácticas de la elite dirigente romana ${ }^{12}$.

Los senadores y caballeros, motivados ahora por un fuerte interés en acaparar riquezas y disfrutar de un lujo equiparable al de las monarquías helenísticas con las que habían entrado en contacto, se mostraban entusiastas con la política de dominio universal promovida por Roma. Como resultado de ésta, grandes extensiones de tierra pasaron a manos de la nobilitas, a lo que hay que agregar las ingentes cantidades de oro y plata, de esclavos que venían a sustituir a la mano de obra libre, menos dispuesta a aceptar la superexplotación de los terratenientes, $y$, finalmente, los cargos en la administración de las provincias, que ofrecían a los gobernadores una interesante fuente de enriquecimiento. Porque, aunque en un principio, como sostiene William Harris, "las guerras romanas tuvieron su origen y apoyo en el ethos social, y especialmente en la ideología de la gloria y del prestigio" (HARRIS, 1989, p.2), lo cierto es que, cuando los beneficios de la conquista comenzaron a llegar a Roma, los nobiles dejaron de lado los valores éticos tradicionales -como la obtención de laus y gloria a través de campañas militares exitosas y del desempeño de altas magistraturas-, los que fueron reemplazados, progresivamente, por la satisfacción de intereses más concretos, de tipo económico, que les ofrecía la política imperialista $^{13}$.

Pero no todos los ciudadanos romanos aprobaban la política imperialista impulsada por el Estado. Una de las voces que se alzaron contra la poderosa vocación de poder que había ganado a quienes decidían los destinos de Roma, fue la de Salustio. En uno de los fragmentos conservados de las Historias, se encuentra una carta dirigida a Arsases, rey de los partos, por Mitrídates, rey del 
Voces críticas sobre la política imperialista romana

Ponto, en la que éste denuncia los abusos desmedidos de la opresión imperial romana:

\begin{abstract}
¿Acaso ignoras que los romanos volvieron hacia aquí sus armas, después de que, avanzando hacia Occidente, el Océano les marcó el límite? ¿Que al principio nada tenían si no era robado: casa, cónyuges, campos, imperio? ¿Convienes conmigo en que fueron fundados, sin patria ni padres, como peste para el mundo entero, a quienes nada detiene, ni humano ni divino, a la hora de devastar y destruir a los amigos o aliados, tanto lejanos como próximos, pobres como ricos, y considerar enemigo todo lo que no sea esclavo, en especial los reinos? (Sal. Hist. 4.69.17)
\end{abstract}

El texto de la carta deja traslucir la posición política que sostiene el propio Salustio, quien está criticando, a través del personaje, la política militar que impulsaba el Senado. Como sostiene Santos Yaguas, el autor utiliza este recurso para explayarse con más libertad, al poner en boca de Mitrídates, un enemigo declarado de Roma, sus opiniones sobre la desastrosa política exterior romana, sin quedar personalmente expuesto (SANTOS YAGUAS, 1998, p.236).

Salustio era conciente de que esta nueva actitud frente a la guerra gozaba de un gran consenso social y era aceptada por la mayoría de los romanos, no sólo por quienes eran los directos beneficiarios, los nobiles, sino también por la plebe urbana y rústica ${ }^{14}$. Sin embargo, no dejaba de expresar su opinión crítica, aún en soledad y sabiendo que, muy probablemente, su voz no sería escuchada, pero con la convicción de que, con su silencio, estaría avalando una realidad social y política que lo abrumaba:

Todo aquel que fuera muy rico y particularmente capaz de hacer daño, era considerado bonus, porque defendía el estado presente de cosas" (Sal. Hist. fr. 1.12)

Salustio cuestionaba fuertemente la relajación de la conducta de los miembros de las elites dirigentes, que habían dejado de lado los valores éticos de sus antepasados, como la virtud, el heroísmo y el honor ${ }^{15}$, para sustituirlos por la ambición de poder y el deseo desenfrenado de acumular riquezas:

Creció primeramente la pasión del dinero, luego la del poder; éstas fueron como pábulo de todas las maldades: la avaricia desterró la buena fe, la rectitud y las demás virtudes; en su lugar introdujo la insolencia, la crueldad, el olvido de los dioses y la venalidad en las cosas todas. (Sal. Jug. 10.3)

La nueva oportunidad que ofrecían las guerras de conquista para las elites dirigentes romanas, que les permitía obtener riquezas abundantes y rápidas, dependía del acceso a las más altas magistraturas, el consulado y la pretura, especialmente a la primera, que permitía la obtención de las mejores provincias o 
de las campañas más lucrativas. En esos tiempos, el consulado se había transformado en una magistratura a la que accedía de manera exclusiva un pequeño grupo de familias nobles, que gracias a la política acrecentaban su riqueza patrimonial. La nobilitas, más que cualquier otro grupo de estatus, puede ser definida por sus relaciones con la política, ya que ésta era su actividad dominante. Sus relaciones con la tierra tenían también una finalidad política, pues su apropiación abusiva del ager publicus les permitía disponer de una clientela que les garantizaba su control hegemónico del poder. Al respecto del control monopólico de la nobilitas sobre los cargos de decisión política, Salustio denunciaba que:

...el consulado se lo pasaba la nobleza de mano en mano. No había hombre nuevo, por muy esclarecido que fuese, o por extraordinarias que fuesen sus hazañas, que no fuera tenido por indigno y como mancillado para aquel cargo (Sal. Jug. 63.7)

La expansión imperial había creado las condiciones para la emergencia de nuevos actores sociales, con intereses claramente diferenciados y, la mayor parte de las veces, enfrentados a los de la nobilitas. La irrupción en el escenario político de estos nuevos grupos de interés comenzó a atentar contra la estabilidad del sistema, garantizada hasta entonces por la concordia ordinum, y dio paso a luchas cada vez más violentas en el seno de la elite dirigente (NICOLET, 1977, passim). Una de las fracturas se produjo entre la nobilitas y los caballeros dedicados a los negocios y las finanzas, los publicani y negotiatores (GABBA, 1972, p.764-805). Como un ejemplo del conflicto de intereses desatado entre los órdenes superiores, Salustio, en su monografía De Bellum lugurthinum, destacaba la conducta de Cayo Mario, quien, para alcanzar el consulado en el 107 a.C., no dudó en romper los lazos de clientela que lo unían a la familia de los Metelos y se enfrenta al Senado (Sal. Jug. 64.1-4). Para Salustio, Mario estaba expresando el comportamiento seguido por la elite ecuestre dedicada a los negocios, que no se decidía a romper del todo con sus orígenes, ya que conservaba siempre la posibilidad de retornar al cursus honorum, ya que, en realidad, era más lo que la unía que lo que la separaba de la nobilitas (Sal. Jug. 85.9). De todos modos, Salustio también cuestionaba el comportamiento de los miembros del orden ecuestre, por haber adoptado las mismas prácticas políticas de la nobilitas:

Hasta los homines novi, que antes solían aventajarse a la nobleza por su virtud, se esfuerzan ahora en llegar a los honores y los mandos con trampas y violencias, no ya por sus buenas cualidades: como si la pretura, el consulado todas las cosas de esta especie dieran por sí mismas gloria y grandeza, y no dependiera su valor del mérito de aquel que las desempeña (Sal. Jug. 5.7) 
En las consideraciones preliminares de esta monografía, Salustio vuelve a insistir en que las causas de la decadencia y la devastación sufridas por Italia habían sido el resultado de la irracional política militar seguida por las elites dirigentes:

Es mi intención referir la guerra que hizo el pueblo romano contra lugurta, el rey de los númidas; primeramente en atención a su magnitud, encarnizamiento y variedad de éxitos; en segundo lugar, porque en ocasión de ella se hizo frente por primera vez al orgullo de la nobleza. Fue esta última una porfía que perturbó todo lo divino y lo humano y que llegó a tal grado de demencia que las pasiones políticas no terminaron sino con la guerra y la devastación de Italia. (Sal. Jug. 5.1-3)

Otra fractura en la estructura social romana se produjo al interior del orden senatorial, entre la nobilitas y el resto de los senadores, marginados de hecho de las decisiones más trascendentes para el Estado, como consecuencia del control hegemónico que aquélla ejercía sobre los resortes básicos del Estado. Las fracturas en el seno de la elite dirigente ya se habían cristalizado en los momentos previos a que se desatara la tercera Guerra Púnica. Según cuenta Polibio, que fue testigo de las últimas fases de la guerra, las opiniones respecto a la decisión romana de volver a enfrentarse una vez más con su viejo rival en el Mediterráneo estaban divididas:

Unos aprobaron la acción de los romanos, diciendo que para defender su imperio habían tomado medidas sabias y propias de estadista. Pues destruir esta fuente de perpetua amenaza... era de hombres inteligentes y previsores. Otros adoptaron el punto de vista opuesto, alegando que en vez de mantener los principios con los que habían conseguido la supremacía, estaban abandonándolos poco a poco por ansia de poder (Plb. 36.9.)

Antes de tomar la decisión de declararla se produjo un gran debate en el Senado romano. Por un lado estaba la facción que sostenía acaloradamente que no había que destruir a Cartago, pues su presencia activa en el Mediterráneo evitaría que Roma se volviera excesivamente poderosa, lo que contribuiría a acentuar la decadencia moral de la República. Al respecto, Salustio denuncia las funestas consecuencias que se sucedieron a la decisión política que finalmente primó en el debate:

Pero una vez que se engrandeció la república,... que fueron sometidos en guerras grandes reyes; dominadas por las armas gentes feroces $y$ repúblicas poderosas; destruida Cartago hasta sus cimientos, la rival del poder romano, y abiertos para Roma los mares y las tierras todas, la fortuna comenzó a mostrar sus rigores y a turbarlo todo. (Sal. Cat. 10.1-3) 
Por su parte, aquellos que impulsaban una solución drástica para Cartago, sostenían que ésta, gracias a su desarrollo económico, a su prosperidad y a su poderío militar, estaba convirtiéndose nuevamente en una amenaza para Roma ${ }^{16}$. El líder de esta facción era Catón el Viejo, quien, apelando a los viejos temores de los romanos, argumentaba en el Senado sobre la necesidad de reiniciar la guerra contra los cartagineses y daba fin a todos sus discursos con la petición Delenda est Cartago (Plut. Cat.Ma. 27). Fue tan efectiva su retórica, que logró inclinar a su favor las opiniones de los senadores indecisos. Ahora Roma ya tenía una justificación para avanzar sobre Cartago y hacerla desaparecer de la faz de la tierra ${ }^{17}$.

En la medida en que las representaciones ideológicas no hacen más que poner de manifiesto las realidades sociales, es innegable que, a partir de la destrucción de Cartago, se operaron cambios en la mentalidad de la elite dirigente, producto de los crecientes beneficios económicos que podía obtener gracias a la política militar impulsada desde el Estado. Pero los cambios también alcanzaron al conjunto de la ciudadanía, aunque en este caso el impacto de la expansión imperialista no fue para nada positivo. Los campesinos libres sufrían las consecuencias negativas de la guerra, perdían sus parcelas, desatendidas por la larga duración de las campañas, y migraban a las ciudades para ir a engrosar la masa creciente de pobres. Es lógico entonces que, en una situación de miseria extrema, se volvieran a enrolar voluntariamente en el ejército, motivados no por un sentimiento patriótico sino porque los generales les ofrecían la ilusión, mediante el reparto de parcelas al finalizar las campañas, de recuperar su estatus de pequeños propietarios.

Si bien en los comienzos de la expansión muchos romanos debieron luchar en las guerras emprendidas por Roma con la esperanza de obtener oportunidades de ascenso social, tierras y botín (motivos más que suficientes para explicar el alto porcentaje de campesinos en las legiones), y, probablemente, la política exterior del Senado haya gozado de cierto grado de consenso entre la ciudadanía, la situación fue cambiando hacia mediados del siglo I a.C., cuando la guerra civil irrumpió con violencia, desestabilizando el sistema sociopolítico basado en la concordia ordinum. El Estado romano comenzó a dar muestras del agotamiento de sus instituciones, que se revelaban incapaces de contener y canalizar las demandas de los nuevos actores sociales; el conflicto amenazaba con destruir los vínculos que mantenían unida a la sociedad en un sistema político que había funcionado hasta entonces de manera eficaz. La plebe se encontraba dispersa y ligada por vínculos de clientela a diferentes patronos, los caudillos militares que, tras la promesa de reparto de tierras, manipulaban su voluntad política, embarcándola en luchas que le eran ajenas, y que enfrentaban a pobres contra pobres. Los miembros de las elites senatorial y ecuestre se enfrentaban en una lucha despiadada por espacios de poder, y las instituciones del Estado daban 
Voces críticas sobre la política imperialista romana

muestras de una degradación creciente, producto de la avaricia, la codicia y la corrupción de sus dirigentes políticos. Así lo resumía Salustio:

...antes de la destrucción de Cartago, el Senado y el pueblo romano se repartían pacífica y equitativamente la administración del Estado; no había rivalidad por el lustre o el poder; el miedo de los enemigos mantenía a la ciudad en las prácticas virtuosas; pero al salir de sus corazones aquel miedo, entraron en ellos aquellas otras cosas que suelen seguir a la prosperidad: la disolución y el orgullo... Por lo demás, la nobilitas, formando facción, tenía más poder, mientras que la fuerza de la plebe se debilitaba, disuelta y repartida en su muchedumbre; tanto en la guerra como en el interior del Estado se vivía al arbitrio de quienes detentaban el poder; en sus manos estaban el tesoro, las provincias, las magistraturas, las honras y los triunfos; el pueblo se veía oprimido por el servicio militar y la indigencia; el botín de guerra lo arrebataban y partían los generales con unos pocos... De este modo había irrumpido la codicia acompañada del poder, sin límite ni freno, lo contaminaba y devastaba todo, no tenía respeto ni veneración por cosa alguna, hasta que cayó precipitada por si misma... y como una conmoción terrestre, surgió la discordia entre los ciudadanos. (Sal. Jug. 41.2-10)

A partir de la lectura de sus obras, podemos concluir que, para Salustio, la expansión imperialista romana era la causa del comienzo de la decadencia interna que estaba afectando a la República, expresada en la corrupción generalizada de la sociedad, debido a la irrupción desmesurada de la ambitio y la avaritia. Sus preocupaciones giraban alrededor del descontrol de una elite dirigente que, a medida que aumentaban las recompensas económicas del imperio, competía con intensidad creciente por los cargos políticos más elevados y el afán de lucro y prestigio, descuidando no sólo la salud de las instituciones sino, además, la situación de miseria creciente en que se debatían la plebe urbana y los campesinos. Cuanto más preocupada estaba por satisfacer sus intereses privados, menos atención ponía sobre la realidad social, que reflejaba una distancia cada vez mayor entre ricos y pobres. La plebe urbana estaba en mejores condiciones que la plebe rústica, ya que gozaba de algunas prebendas que les ofrecían los nobiles, a fin de controlar una situación de conflictividad latente. Pero los campesinos que se embarcaban en las campañas militares, siguiendo a un caudillo que les prometía una salida de la miseria, eran concientes de la precariedad de su situación, ligada a un jefe que podía perder su poder y con ello, tiraba por la borda sus expectativas de mantener la propiedad de sus parcelas de tierra, a partir de la aplicación de la proscriptio por parte de los vencedores.

Salustio consideraba que, tanto la nobilitas como los miembros del orden ecuestre, partidarios de una política de expansión imperialista que les permitía acrecentar sus riquezas, se mostraban indiferentes a los daños que ésta habría de 
acarrear sobre el destino de la República romana. La codicia los había llevado a embarcarse en sangrientas luchas entre romanos, en las que ya no se respetaban los códigos morales y se violaban las instituciones. Para Salustio, esta conducta, egoísta y suicida, los hacia responsables de la crisis que desembocaría en el advenimiento de un régimen político autocrático. Consideramos que la voz de Salustio, hecha desde la perspectiva de un hombre que se había apartado voluntariamente de la política activa, no debe haber sido escuchada por los actores sociales que obtenían los mayores beneficios de la expansión imperial, inmersos en el fragor de una lucha por la satisfacción de sus intereses materiales. Igualmente, era imposible que ella llegara a los sectores sociales más perjudicados por la conquista, en la medida en que éstos estaban entrampados en las redes clientelares que los unían a los poderosos.

Es verdad que las ideas de Salustio sobre la crisis de la República pueden pecar de parciales, en la medida que consideraba como factor casi excluyente, el cambio de mentalidad operado en las elites dirigentes, que habían dejado de lado la valoración de la búsqueda del honor y el prestigio a través de hazañas militares justas y defensivas, para suplantarlas por una concepción que valoraba el enriquecimiento individual y la búsqueda de poder. El autor no ponderó en demasía la incidencia de otros factores, de orden económico, como los intereses de los grandes terratenientes esclavistas, o de los ecuestres, devenidos en negotiatores, navicularii y publicani, que impulsaban la extensión de los límites del imperio para expandir sus mercados; o de orden político, como la necesidad de un Estado en crecimiento, de aniquilar enemigos (reales o convertidos en tales) eliminando así cualquier vestigio de oposición, que interfiriera en el objetivo de alcanzar la dominación de todo el mundo conocido. No obstante, debemos rescatar que Salustio si tuvo en cuenta un aspecto de gran relevancia, relacionado con las prácticas sociales, a saber, el peso que tenían los lazos clientelares que, para su época, ya atravesaban a toda la sociedad romana en un círculo vicioso de favores y lealtades individuales y cuyas consecuencias fueron nefastas para los pobres ${ }^{18}$. Si bien opinaba que "sólo unos pocos prefieren la libertad, porque la mayoría sólo busca amos justos" (Sal. Hist. 4.69.18), no por eso dejó de denunciar que la crisis de valores y la degradación institucional que afectaban a la República habían llevado a que el pueblo, otrora soberano, hubiera concluido acuerdos que lo relegaban a la servidumbre (Sal. Cat. 20.7-9). Además, como señala Luciano Canfora (CANFORA, 2000, p.51), Salustio centró "su actividad historiográfica precisamente en el problema de la corrupción política como elemento 'sustancial' de la praxis política romana" y es en este sentido que debemos reconocer el aporte de sus escritos para la reconstrucción de la mentalidad de una elite que estaba más preocupada por embarcarse en luchas por espacios de poder, que por evitar la degradación institucional que conduciría, 
Voces críticas sobre la política imperialista romana

más tarde o más temprano, a la caída del sistema republicano de gobierno. Es más, en la medida en que este sistema había dejado de ser funcional a sus intereses, ya se habían comenzado a escuchar voces que, al amparo de un clima ideológico propicio, apostaban a la llegada de un princeps salvador, que pusiera orden en el caos. De allí, a la instauración de un régimen monárquico centralizado, mediaba un solo paso, que se ocupó de dar Augusto.

\section{Bibliografía}

ANDREAU, J. Un anthropologie politique de Rome: servitude et grandeur politiques dans la Rome républicaine. Annales E. S. C., Paris, no 4, p.756-763, 1977.

ANDREAU, J. Économie, societé et politique à la fin de la République romaine: un débat. Annales E. S. C., Paris, 35 Année - no 5, p.912-919, Septembre - Octobre. 1980.

BRUNT, P.A. Amicitia in the Late Roman Republic. In: SEAGER, R. (ed.)The Crisis of the Roman Republic; studies in political and social history, Cambridge, Heffer ands Sons, 1969, p.197-218.

CANFORA, L. Julio César un dictador democrático. Barcelona: Ariel, 2000.

CASCAJERO, J. Lucha de clases e ideología en la tardía República. Gerión, 8, Madrid, p.115139, 1990.

CORNELL, T. J. Los orígenes de Roma, c. 1000-264 a. C. Barcelona: Crítica, 1999.

DE STE. CROIX, G. E. M. La lucha de clases en el mundo griego antiguo. Barcelona: Crítica, 1988.

FINLEY, M. El nacimiento de la política. Barcelona: Crítica, 1986.

GABBA, E. Mario e Silla. ANRW, I, I, Berlin - New York, p.764-805, 1972.

HARRIS, W. Guerra e imperialismo en la Roma republicana-327-70 a. C. Madrid: Siglo XXI, 1989.

LOPEZ BARJA, P. y LOMAS SALMONTE, F. Historia de Roma. Madrid: AKAL, 2004.

NAVARRO, F. El siglo II a.C. en Roma, entre la continuidad y el cambio. In: GÓMEZ PANTOJA, J. (coord.). Historia Antigua (Grecia y Roma). Barcelona: Ariel, 2003. p.419462.

NICOLET, C. Roma y la conquista del mundo mediterráneo, 264-27 a.C. Barcelona: Labor, 1982.

NICOLET, C. Les classes dirigeantes romaines sous la République: ordre sénatorial et ordre équestre. Annales E. S. C., Paris, 32 ${ }^{\mathrm{e}}$ Année - no 4, p.726-755, Juillet-Aout, 1977.

NICOLET, C. Économie, société et institutions à Rome au II siècle av. J. C.: de la lex Claudia à l'ager exceptus. Annales E. S. C., Paris, $35^{\mathrm{e}}$ Année - no 5, p.871-894. Septembre Octobre, 1980.

NORTH, J. A. Democratic Politics in Republican Rome. Past and Present, Oxford, no 126, p.3-21. Feb, 1990.

PINA POLO, F. El último siglo de la República Romana. In: GÓMEZ PANTOJA, J. (coord.). Historia Antigua (Grecia y Roma). Barcelona: Ariel, 2003. p.463-499.

PINA POLO, F. Ideología y práctica política en la Roma tardorrepublicana. Gerión, 12, Madrid, p.69-94, 1994.

SALINAS DE FRÍAS, M. Roma y el Mediterráneo Occidental durante el Siglo Il a.C. In: GÓMEZ PANTOJA, J. (coord.) Historia Antigua (Grecia y Roma). Barcelona: Ariel, 2003. p.391462. 
SANTOS YANGUAS, N. Los fragmentos de las Historias de Salustio: su valor histórico. In: Espacio, Tiempo y Forma, Serie II, Historia Antigua, Oviedo, p.221-239. 1998.

\section{Notas}

${ }^{1}$ Con respecto a este mito, T. J. Cornell $(1999$, p.8) opina que: "Según la tradición que ha llegado hasta nosotros, la leyenda de Rómulo está relacionada con la de Eneas. Nadie duda de que esta circunstancia representa una síntesis artificial de dos leyendas originalmente distintas, pero todavía se discute cuándo y cómo se produjo esa síntesis. Si Rómulo ya había sido reconocido como fundador de la ciudad en la época arcaica, verosímilmente cabría concluir que Eneas habría sido una adición relativamente tardía. Pero la cosa es más complicada, y existen buenas razones para pensar que también Eneas fue reconocido en Roma y en el Lacio en una época muy temprana".

${ }^{2}$ Polibio se admiraba de la rapidez y la efectividad de la conquista impulsada por el Estado romano que, en menos de sesenta años, había logrado someter a casi todos los pueblos de la tierra, sin que nadie, tras la derrota de Cartago en el 202, hubiera tenido el poder de ofrecerle resistencia o, al menos hubiera mostrado la voluntad de hacerlo (Plb. 1.2.7).

${ }^{3}$ A pesar de la ubicación de Salustio en el bando de César y la facción de los populares, para Juan Cascajero (1990, p.124, n.2,) está clara su pertenencia a la elite dirigente, como se puede constatar en el tono general de su monografía De coniuratione Catilinae, donde manifiesta su crítica por la desmesura en la que ha caído la plebe. Consideramos que esta afirmación no agrega nada nuevo a la figura de Salustio, ya que es más que sabido que en Roma (al igual que en Grecia), todos los dirigentes políticos eran de extracción aristocrática. Lo que importa es destacar el grado de conciencia y sensibilidad que algunos manifestaban por la penosa situación de los más desposeídos. En esta obra, Salustio, más allá de expresar sus críticas a la conducta de Catilina, no deja de mencionar que éste, a pesar de su origen noble, había tenido por costumbre defender los intereses de los pobres en la vida pública (Sal. Cat. 35.3: "publicam miserorum causam pro mea consuetudine suscepi"). Además, el que Salustio haya escogido como tema para una de sus monografías la insurrección impulsada por Catilina, al ver frustradas, por causa de la nobilitas, sus posibilidades de avanzar en el cursus honorum por la vía legal, nos parece más que sugerente. En ella, el autor destaca la magnitud de un movimiento de masas que involucraba a todo el espectro social romano y que incluía en sus filas a los pobres del campo y la ciudad. Es la primera vez en la historia romana en que vamos a encontrar a la plebe luchando unida contra los ricos. Y su conocimiento se lo debemos agradecer a Salustio, quien, al tomarlo como su objeto de análisis, se ocupó de rescatarlo para la posteridad.

${ }^{4}$ Salustio pone en boca de Memmio, tribuno de la plebe en el año 111 a. C. la siguiente reflexión: “...todas las cosas divinas y humanas se hallaban en Roma bajo el control de unos pocos" (Sal. Jug. 31.20).

${ }^{5}$ Salustio define a la plebe como un sector social desposeído, compuesto por "artesanos y gente del campo en su totalidad, cuyos bienes y crédito se hallaban sólo en sus manos" (Sal. Jug. 73.6).

${ }^{6}$ En un artículo en el que analiza el valor histórico de las Historiae de Salustio, N. Santos Yanguas (1998, p.224) considera que: "Tradicionalmente se ha venido considerando que en las historias se hallan reflejadas a la perfección las tendencias esenciales representadas en 
las dos monografías de Salustio constituidas en el fondo por la polémica antinobiliaria, que se enfoca hacia la expansión de la clases dirigentes, así como por la advertencia del peligro de subversión social que subyacía en aquellos momentos en la capital del Estado. En realidad, resulta evidente que ambos aspectos logran equilibrarse entre sí sin llegar a eliminarse en ningún momento del relato histórico, a pesar de que tampoco consigan unirse nunca en una verdadera síntesis política".

${ }^{7}$ Con respecto al impulso de conquista que movilizaba a los romanos, W Harris (1989, p.3) sostiene: "Algunos historiadores, enfrentados a las pruebas a favor de los múltiples beneficios de la guerra y la expansión, responderán que los romanos en general, fueran cuales fuesen los efectos de la política romana, no deseaban extender su poder, al menos de forma consciente. A decir verdad, lo más probable es que no abundaran las ocasiones de articular este deseo general, suponiendo que hubiera entre los romanos una actitud común. Y las limitaciones de nuestras fuentes de información al respecto son graves. Pero el deseo existía: Polibio informó de él correctamente (pese a alguna opinión reciente). Y se pueden encontrar otros testimonios, prácticamente ignorados por los narradores modernos de la expansión romana, en las fuentes adecuadas".

${ }^{8}$ Cicerón se preguntaba: "este pueblo nuestro... por cuyo imperio es sujetado ahora el orbe de la tierra ¿por la justicia o por la sapiencia se hizo, de muy pequeño, el más grande de todos?" (Cic. Rep. 3.15.24).

${ }^{9}$ Sobre el debate historiográfico planteado alrededor de la existencia o no de un "imperialismo" romano, y de si la política exterior romana estuvo guiada por un plan coherente y sistemático, como podría desprenderse de una lectura de Polibio demasiado apegada al texto, M. Salinas de Frías (2003, p.415-417) se inclina por pensar que: "Parece evidente que hacia el 200 a.C. Roma no se planteaba un 'programa' de dominación universal y que, al menos en la primera mitad de este siglo, los pasos que dio fueron titubeantes y no permiten ver una unidad de conjunto".

${ }^{10}$ Polibio consideraba que las guerras púnicas constituyeron el hito histórico a partir del cual cambió la política exterior romana: "En las épocas anteriores a ésta los acontecimientos del mundo estaban como dispersos, porque cada una de las empresas estaba separada en la iniciativa de conquista, en los resultados que de ellas nacían y en otras circunstancias, así como en su localización. Pero a partir de esa época la historia se convierte en algo orgánico, los hechos de Italia y los de África se entrelazan con los de Asia y con los de Grecia, y todos comienzan a referirse a un único fin" (Plb. 1.2.3-5).

${ }^{11}$ Polibio: "Por esto hemos establecido en estos acontecimientos el principio de nuestra obra, porque en la guerra mencionada los romanos vencieron a los cartagineses $y$, convencidos de haber logrado ya lo más importante y principal de su proyecto de conquista universal, cobraron confianza entonces por primera vez para extender sus manos al resto: se trasladaron con sus tropas a Grecia y a los países de Asia" (Plb. 1.2.5-7).

${ }^{12}$ Al respecto, rescatamos la centralidad que le reconocía Moses Finley $(1986$, p.87.) al aspecto conquistador de la historia de Roma, cuyo rasgo más evidente fue la manera en que impactó en la constitución de la elite política, en la selección y comportamiento de los líderes políticos.

${ }^{13}$ En opinión de F. J. Navarro (2003, p.431) las elites romanas estaban ganadas por una ideología pragmática: "La clase dirigente romana había desarrollado una mentalidad 
lucrativa que la llevaba a aprovechar las nuevas oportunidades: el comercio y otras actividades financieras no eran consideradas reprobables, porque servían al fin último de acrecentar el patrimonio y la consistencia del grupo familiar".

${ }^{14}$ Sobre el consenso que tenía la política imperialista entre la plebe pobre, es sugerente el análisis de Moses Finley (1986, p.150): "Desenmarañar las motivaciones de este incesante afán por la guerra y la conquista no es fácil. Hay que ser debidamente comprensivo con las consideraciones psicológicas o estratégicas, como patriotismo, gloria militar, interés nacional, defensa nacional; también ante las esperanzas de botín. Para la mayoría de las ciudades-estado griegas y tribus itálicas era lo único que se obtenía. En cambio para Atenas y Roma había otra perspectiva, decisiva para comprender su política, esto es, los beneficios materiales del imperio. En Atenas eran variados, con la conquista de tierras como componente significativo; en Roma, la tierra y el asentamiento se convirtieron en el factor dominante. No quiero decir con esto que los ciudadanos al asistir a la asamblea tomaran sus decisiones en base a un simple cálculo de sus posibilidades de adquirir tantos acres de tierra confiscada al enemigo. Pero lo que sí pretendo es que las cleruquías atenienses y lo que los romanos llamaron tierra pública debieron estar presentes en el subconsciente de los ciudadanos, cuando se discutía algún asunto relacionado con la conquista o el imperio; que en los asuntos exteriores esta clase de interés fue crítico en la respuesta popular ante lo que parece a menudo superficialmente que no son más que disputas personales por la gloria y el poder entre los miembros de la elite."

${ }^{15}$ Salustio añoraba los buenos viejos tiempos: "Fomentábanse, pues, las buenas prácticas, así en la guerra como en la paz, la concordia era grande, muy rara la avaricia; lo justo y bueno tomaban entre ellos más fuerza de la naturaleza que de las leyes. Sus rencillas no eran más que con sus enemigos; entre los ciudadanos no había otra emulación que la de la virtud. Eran esplendidos en el culto de los dioses, parcos en sus propias casas, leales para con sus amigos; y con estas dos cualidades atendían a su propio bien y al de la república" (Sal. Jug. 9.1-4).

${ }^{16}$ Plutarco: "Fue enviado Catón cerca de los cartagineses...Como encontrase, pues, aquella ciudad no maltratada y empobrecida como se figuraban los romanos, sino brillante en juventud, abastecida de grandes riquezas, llena de toda especie de armas y municiones de guerra, y que acerca de estas cosas no pensaba con abatimiento, le pareció que no era manera aquella de que los romanos se cuidaran de arreglar los negocios y la recíproca correspondencia de los númidas y Masinisa, sino más bien de pensar en si no tomaban una ciudad antigua enemiga, a la que tenían grandemente irritada, y que se había aumentado de un modo increíble, volverían pronto a verse en los mismos peligros" (Plut. Cat.Ma. 26).

${ }^{17}$ Sobre las implicancias de la teoría romana de la guerra justa, G. E. M De Sainte Croix (1988, p.387) hace una sugestiva reflexión: "Los romanos fingían muchas veces que habían conseguido su imperio casi contra su voluntad, mediante una serie de acciones defensivas, que era fácil que parecieran verdaderamente virtuosas si se las presentaba con la apariencia de que se habían llevado a cabo en defensa de otros, especialmente de los "aliados" de Roma. De ese modo, según Cicerón, los romanos se hicieron 'dueños de todas las tierras" en el curso de unas acciones emprendida "para defender a sus aliados', sociis defendis (Cic. Rep. 3.23-25)". 
${ }^{18}$ Salustio: “Quien busque el poder no tendrá mejor ayuda que la del hombre más pobre, porque no se siente vinculado a su propiedad, dado que no tiene ninguna, y estima honorable todo aquello por lo que se le paga" (Sal. Jug. 86). 


\title{
FLÁVIO JOSEFO E O CERCO ROMANO A JOTAPATA (67 d.C.)
}

\author{
João Gouveia Monteiro \\ Universidade de Coimbra - Portugal
}

\section{O contexto histórico-geográfico}

Quando Flávio Josefo nasceu, em 37 ou 38 d.C., a região da Síria-Palestina estava longe de ser um território homogéneo e pacificado. Para o compreendermos melhor, convém que recuemos dois séculos e meio ${ }^{1}$.

Em 200 a.C., na sequência da batalha de Panion, o rei selêucida Antíoco III conseguiu tornar-se senhor da Palestina, da cidade de Jerusalém e do seu precioso Templo. Trinta anos mais tarde, Antíoco IV Epifânio continuaria a luta contra os Ptolomeus do Egipto pela posse da totalidade do território sírio.

Com a chegada dos selêucidas à Terra Santa, a Judeia mudou, em especial porque o modelo grego começou a impor-se nas camadas superiores das regiões conquistadas e se incrementou o desenvolvimento urbano. A Judeia conheceu então um doloroso processo de aculturação, como prova o facto de os judeus que conhecemos terem passado a ter dois nomes próprios: um hebraico e outro grego. A ocupação selêucida gerou anti-corpos que nos ajudam a compreender a Revolta dos Macabeus (liderados por Judas), ocorrida em 168 a.C. e que acabou por estar na origem da formação do Estado judaico. O ano de 143-142 a.C. (o primeiro da era dos asmoneus) marca simbolicamente o nascimento do Estado judaico independente.

Cerca de três quartos de século mais tarde deu-se a anexação da Síria pelos romanos. Em 66-64 a.C., Pompeu Magno, depois de derrotar Mitridates (rei do Ponto), ocupou o território sírio eliminando as últimas reminiscências da monarquia selêucida. O pretexto para a intervenção militar de Pompeu foi uma guerra civil que estalara no seio do reino asmoneu de Jerusalém (entre os filhos de Alexandre Janeu e de Salomé: Hircano II e Aristobulo II). Ao fim de três meses de cerco, o general romano (a quem os irmãos desavindos haviam apelado) conseguiu capturar a Cidade Santa, tendo a maior parte dos combates travados durante esta operação tido lugar em redor ou no próprio grande Templo!

Quando se tornaram senhores de Jerusalém, os romanos começaram por manter o Asmomeu Hircano II (67-63 a.C.) na condição de Sumo-sacerdote. Contudo, na sequência das guerras civis que brotaram em Roma, os partos da

\footnotetext{
* Faculdade de Letras da Universidade de Coimbra. Centro de História da Sociedade e da Cultura (Universidade de Coimbra). Rua do Tirado 125, 3040-806 Coimbra. E-mail: jgmonteiro@mail.telepac.pt. Tel.: 239-947-538 // 96.55.83.320.
} 
Flávio Josefo e o cerco romano a Jotapata (67 d.C)

Mesopotâmia, em 40 a.C., invadiram o país a que os romanos chamaram Palestina e instalaram o príncipe asmoneu Antígono em Jerusalém, como seu cliente. Três anos mais tarde, porém, com o apoio de Marco António e do Senado romano, um idumeu de nome Herodes (antigo tetrarca da Galileia, filho do prefeito assassinado da Judeia, Antípater, um ex-apoiante de Júlio César) tornouse rei de Jerusalém, após um cerco de quatro meses à Cidade Santa que redundou num massacre horrível. Antígono seria executado e Herodes (um Edomita, da raça de Esaú) contando com o beneplácito romano e até com algum apoio asmoneu (pois casara habilmente com uma princesa asmoneia, Mariana), viria a reinar como monarca dos judeus da Palestina até 4 a.C., controlando um território mais extenso do que o próprio reino de David. Com ele, político astuto, Jerusalém tornou-se numa das mais importantes metrópoles do Oriente e também numa cidade solidamente protegida: a célebre fortaleza Antónia; o palácio de Herodes, com as suas três torres gémeas; etc. (Armstrong, 2002, p.125-127).

Poucos anos após a morte de Herodes (que não preparara devidamente a sua sucessão, o que fomentou uma tremenda agitação social ${ }^{2}$ ), o primeiro imperador romano, Octávio Augusto (27 a.C. - 14 d.C.), a quem Herodes erigira aliás um templo em Samaria, constituiria a província romana da Judeia, ainda que tal não tivesse representado exactamente o fim da presença monárquica diluída sob a forma de tetrarquias ou de micro-reinos. Para além da submissão da Judeia (dividida e confiada a prefeitos) e da Galileia (mais a norte), Augusto desenvolveu importantes acções diplomáticas junto dos partos. O seu sucessor, Tibério (14-37 d.C.), anexaria ainda os Estados de Filipe (a leste da Galileia). Acentuava-se, deste modo, a presença romana na Terra Santa, embora com a preocupação comum de evitar ofender a sensibilidade religiosa dos crentes e de cooperar com os Sumosacerdotes mais sensatos e diplomatas, como Caifás (18 d.C.). Daí o célebre episódio recordado por Vidal-Naquet (1977, p.86): à pergunta “Crucificarei o vosso rei?" feita, segundo João, pelo procurador Pôncio Pilatos aos judeus, responderam os Sumo-sacerdotes: "Nós não temos outro rei a não ser César"...

A presença romana apresentava, todavia, muitas fragilidades, agravadas por certas provocações de Pilatos em Jerusalém e Cesareia (em 26 d.C.) e pelo grande abalo causado, quatro anos depois, pelo aparecimento da figura de Jesus, cujo comportamento religioso e social inclusivo tinha implicações apocalípticas que o próprio Caifás não podia aceitar (o que levou à crucificação de Jesus, da qual resultaria contudo um movimento renovador ainda mais fecundo, como bem documenta a história dos seus principais seguidores, em especial a de Paulo de Tarso). Outro sinal de instabilidade é dado pela veemente resistência judaica à intenção do imperador Calígula de colocar uma sua estátua no santuário de Jerusalém (41 d.C.). Compreende-se, pois, que o seu sucessor, Cláudio, aspirando 
apaziguar os Judeus, tenha nomeado como rei da Palestina judaica o neto de Herodes, Agripa I (40-44 d.C.).

A morte prematura do bem sucedido Agripa I obrigou - sendo Agripa II ainda demasiado novo para reinar - a uma interessante solução de continuidade: Cláudio (41-54 d.C.) enviou um novo governador romano para a Judeia, mas apenas com o título de procurador, enquanto o jovem Agripa II conservou uma posição destacada no governo. Apesar do surgimento de profetas que prometiam a expulsão dos romanos (ao tempo dos procuradores Cumano e Félix), acabou por se estabelecer um modus vivendi entre a Judeia e Roma: em 59 d.C., o rei Agripa II recebeu autorização para fixar residência no antigo palácio dos Asmoneus, enquanto o procurador romano ocupava o de Herodes sempre que visitava Jerusalém. O Templo foi finalmente acabado e a cidade gozou de alguma autonomia, sendo governada conjuntamente por Agripa II e pelo Sumo-sacerdote, que cooperavam de forma positiva com o procurador romano em Cesareia (Armstrong, 2002, p.146).

No séc. I d.C., a Judeia era, assim, um território de grande complexidade, o interior contrastando com as cidades gregas ou helenizadas da região costeira. À Judeia propriamente dita e à Idumeia (mais a sul) acrescentava-se, a norte, a Samaria, um verdadeiro lugar de passagem para quem circulava de Jerusalém para a Galileia. Segundo Josefo, nos anos após o estabelecimento da província romana da Judeia os samaritanos mostraram-se súbditos rebeldes e inimigos característicos dos judeus. Em Samaria, tal como na Judeia, eclodiram movimentos de tipo messiânico no final da missão do procurador Pôncio Pilatos (26-36 d.C.).

Se Cesareia era, prudentemente, a capital política, Jerusalém era a capital religiosa e a maior cidade da Judeia. No entanto, só o olhar simplificador da chancelaria romana a poderia considerar uma polis grega. A cidade, praça-forte e sede do Templo, além de mercado, era profundamente heterogénea: a cidade alta estava muito helenizada, mas a cidade baixa (e não só) permanecia classicamente oriental. Esta diversidade palestiniana e judaica é confirmada por Flávio Josefo, que numa célebre descrição inserta em $A$ Guerra dos Judeus (J. BJ 3.3.35-47) ( $^{3}$ opõe a alta Galileia (nos flancos do Líbano) à baixa Galileia (mais profundamente helenizada, o lugar do ensinamento de Jesus).

Parece também claro que, no seio dos movimentos revolucionários de que nos dá conta Josefo, conviveriam messianismo e ruralidade. A um messianismo revolucionário e dinástico acrescentavam-se, quer uma prática social 'terrorista' (cf. o movimento dos sicários), quer a fundação e o desenvolvimento de novas seitas político-religiosas. Compreende-se o espanto de autores como Tácito perante o fenómeno do messianismo judaico. 
Flávio Josefo e o cerco romano a Jotapata (67 d.C)

Quando rebenta a revolta de 66 d.C. continua a haver um rei judeu, moderado e conciliador: Agripa II, cujo território se estende ao Nordeste da Judeia. É muito instrutivo o discurso de advertência aos judeus colocado por Josefo na boca de Agripa II, por ocasião da deflagração da revolta: "Não existe no mundo inteiro um único povo no seio do qual não se encontre uma fracção da nossa raça. Se vós fazeis a guerra, os inimigos deles degolá-los-ão a todos e, por causa da decisão fatal de uns poucos, não existirá uma cidade que não fique saciada de sangue judaico" (J. BJ 2.16.399). Este discurso terá, claro, de ser perspectivado levando em linha de conta as esperanças de Josefo na monarquia romana. Como escreve Vidal-Naquet (1977, p.93-94), o escritor "esforça-se por desviar em direç̧ão ao imperador romano, único monarca 'frio' que poderia governar o país judaico, a corrente que se dirigia, se não para a conquista do mundo, pelo menos para a subversão de que Judas e os seus são para ele os símbolos. Face ao messianismo, ele raciocina possuindo, exactamente como os 'Judeus', o evangelho de João".

Resta considerar a questão do divisionismo no seio dos judeus. Para VidalNaquet (1977, p.108), a explicação para as várias facções judaicas presentes na guerra de 66-73 d.C. radica na falta de força do nacionalismo judaico do séc. I d.C.. Tudo aquilo que configuraria o cimento do Judaísmo do pós-70 d.C. (o desenvolvimento da sinagoga, uma criação da diáspora; a multiplicação dos escribas sem estarem sob o controlo do Templo; etc.) não tinha ainda encontrado o seu lugar no seio das instituições antigas; e, aparentemente, não havia condições para a criação de novas instituições, ou de grupos sociais capazes de funcionar como um elemento unificador. Por tudo isto, o que se passa na Palestina é um resumo trágico da situação em que se encontra o Judaísmo no séc. I d.C.. Mais do que a derrota final dos judeus, o que é verdadeiramente notável é a amplitude da sua resistência!

\section{A revolta}

Convém agora apresentar os contornos genéricos da revolta judaica que despoletou a guerra de 66-73 d.C., culminando os movimentos de massas que surgiram desde inícios do séc. I d.C.. Para este conjunto de eventos, Josefo constitui a nossa principal testemunha.

Logo após a morte de Herodes, que durante o seu reinado afastara cruamente toda a oposição ao seu domínio, a agitação popular entra, como vimos, em crescendo. A Judeia está repleta de salteadores, há sinais muito inquietantes de generalização da anarquia e de carnificinas (até mais contra compatriotas judeus do que contra os romanos), vivemos no período dos chamados "reis efémeros". O apoio do imperador Nero, em 59-60 d.C., aos síriofenícios helenizados da Judeia (os 'gregos'), contra os 'habitantes sírios' de 
Jerusalém, ao tempo em que Félix era procurador (59-60 d.C.), avolumou consideravelmente o mal-estar.

Desde 60 d.C., a situação agrava-se pois Roma começa a nomear como procuradores da Judeia quadros de menor envergadura. Foi o caso de Alibino (6062 d.c.), que parece ter aceitado subornos dos bandidos judeus que aterrorizavam os que cooperassem com Roma, mas também o de Géssio Floro (64-66 d.C.), que manteve esta prática e que, quando judeus e residentes sírios de Cesareia entraram em conflito, tomou a decisão fatal de requisitar dinheiro ao tesouro do Templo para suprir as suas carências financeiras. Para muitos, as causas concretas da ruptura entre Roma e a Judeia acham-se na reacção a estas exacções de Floro, as quais motivaram uma explosão de violência em Jerusalém, com lutas de rua entre judeus e soldados romanos. A isto acresceu a rejeição dos sacrifícios em nome de César por parte dos ministros do culto judaicos, sob instigação do comandante do Templo (Eleazar), uma reacção que teve implicações políticas e, sobretudo, religiosas: Javé torna-se de novo no Deus de Israel; surgem novas moedas, de prata e não de bronze, com símbolos religiosos e legendas sugestivas (p.ex., sobre a "Liberdade de Sião", a "Redenção de Sião", "Jerusalém-a-Santa"); etc.

Sem conseguir restabelecer a ordem, Floro é obrigado a fugir da cidade, onde a guarnição romana é massacrada. Pede então auxílio a Caio Céstio Galo, legado imperial na Síria, que reúne à pressa um exército e marcha sobre os rebeldes, alcançando Jerusalém em finais de 66 d.C.. Espantado pela dimensão da revolta, Céstio Galo sofreu alguns revezes e acabou por retirar, mas a coluna romana foi duramente fustigada quando descia pela estreita passagem de BerthHoron, sofrendo 5.780 baixas (GOLDSWORTHY, 2007, p.373)! Nero seria então obrigado a enviar o seu melhor general, Vespasiano (com 57 anos de idade), para esmagar a insurreição judaica.

Entretanto, na Judeia começavam a grassar as lutas internas, com muita aristocracia rural e algumas cidades a mostrarem-se contrárias a uma guerra com Roma, opção que também não granjeava a simpatia de saduceus e de muitos fariseus (mais preocupados com a religião do que com a política). Como vimos, o rei Agripa II ainda tenta convencer os rebeldes a fazerem a paz, mas o aparecimento de um partido novo e radical (os zelotas), apoiado por apenas uma pequena parte da população da Palestina, como que tornou a guerra inevitável. Os cristãos, pelo seu lado, marcados pelo avolumar da tensão entre a sua Igreja e a ortodoxia judaica estabelecida, assim como pela execução de Tiago (irmão de Jesus) por ordem do Sumo-sacerdote, optaram por abandonar Jerusalém e rumar à Transjordânia (Armstrong, 2002, p.144-147).

Em síntese, era o culminar de um ciclo de inquietude no seio da sociedade judaica da Palestina. Muitas das revoltas destas décadas parecem ter tido uma 
Flávio Josefo e o cerco romano a Jotapata (67 d.C)

base camponesa, concentrando-se sobretudo em Jerusalém, em particular no Templo. É certo que não podemos ignorar a existência de algumas (mais raras) revoltas urbanas, como por exemplo as ocorridas sob Pôncio Pilatos, antes de 31 d.C., quando este procurador tentou introduzir em Jerusalém insígnias com a efígie imperial, ou construir um aqueduto a expensas do Tesouro do Templo. Mas o grosso da revolta era protagonizado pelos camponeses da Judeia, indiciando que, como comenta Josefo, toda a Judeia estava doente.

Paradoxalmente, a revolta do Verão de 66 d.C., em Jerusalém, foi, no seu início, sobretudo urbana, concentrando, por um lado, o rei Agripa II (mais os principais cidadãos, os chefes religiosos e os fariseus mais notáveis) na cidade alta, e, por outro, os sediciosos e os revolucionários na cidade baixa e no Templo. Para compreendermos a profundidade da explosão contestatária temos também de lembrar o massacre dos judeus levado a cabo, nesse mesmo ano, em Cesareia, em Citópolis, em Gadara e em Áscalon. Na verdade, a reacção judaica à notícia do massacre da capital da Judeia foi tremenda, ajudando a explicar a citada chacina da guarnição romana de Jerusalém. Seguiram-se mortes e incêndios diversos de Gadara até Gaza, passando por Áscalon e por Sebasta. Os confins desérticos da Idumeia, onde populações judaizadas e populações árabes eram vizinhas, também não estavam menos agitados.

O massacre da guarnição romana de Jerusalém foi impressionante. Nas primeiras horas da revolta, os soldados refugiaram-se nas torres da fortaleza da Cidade Santa, aí enfrentando uma verdadeira luta de classe. Seriam, porém, forçados a capitular, dando lugar a uma espécie de governo revolucionário provisório, chefiado pelo Sumo-sacerdote Haná, a quem coube preparar (parece que mal) Jerusalém para resistir à mais que certa resposta de Roma. Nesta altura, Eleazar e os zelotas impuseram-se ao povo e começaram a suceder-se as medidas económicas e sociais tomadas pelos revoltosos judaicos, um pouco à maneira das cidades gregas: destruição (pelos sicários, que também promoveram a abolição das dívidas) de arquivos, libertação de escravos, execução de gente rica, tiragem à sorte para o acesso a altos cargos, radicalização dos jovens contra os mais velhos, etc. (Vidal-Naquet, 1977, p.102-103).

Em Julho de 67 d.C., os samaritanos, em estado latente de revolta, viramse encurralados na sua montanha sagrada e foram massacrados pelas tropas do legado romano Sexto Vetuleno Cereal (J. BJ 3.7.307-315). Mais decisiva ainda seria a queda da Galileia, na sequência da tomada de Jotapata por Vespasiano, em Julho de 67 d.C.. Este acontecimento conduziria à entrada em Jerusalém, em finais de 67 d.C., de uma multidão de refugiados da Galileia sob o comando de João de Gischala (que fora um encarniçado rival de Josefo pelo controlo da Galileia), assim como dos chefes dos salteadores do mundo rural. Isto ajuda a explicar a intervenção massiva do grupo dos zelotas e os excessos e infâmias que, 
a partir de então, seriam praticados na capital religiosa da Judeia, como Josefo noticia no seu amplo e comovente relato do cerco de Jerusalém, em 70 d.C. (J. BJ 5 e 6).

Entrou-se então numa fase de verdadeira guerra civil judaica dentro de Jerusalém, com uma forte intervenção rural e com os zelotas no poder enfrentando o "povo" do Sumo-sacerdote Haná. Esta autêntica 'guerra de classes' foi durante algum tempo arbitrada por João de Gischala e o equilíbrio reinante acabou por conduzir ao apelo feito aos idumeus de Simão bar Giora pelos zelotas. Disso resultou a morte de Haná e a pilhagem da Cidade Santa pelos idumeus de Simão, gerando uma situação calamitosa que Josefo considerou como o prenúncio do fim de Jerusalém e do Estado judaico.

O cerco de Jerusalém terminaria com a vitória romana, o incêndio do Templo e a derrocada da Cidade Santa. O triunfo de Vespasiano e de Tito conduziria à ocupação permanente da Palestina. À conquista de Jerusalém seguirse-iam as tomadas de Heródio, de Maqueronte e a tristemente célebre captura, pelo legado Lúcio Flávio Silva, em 73 d.C., de Masada (onde a resistência judaica, que reunia muitos extremistas zelotas, optou pelo suicídio colectivo).

Como comenta Vidal-Naquet (1977, p.95-96), a guerra judaica de 66-73 d.C. consiste numa insurreição seguida de uma grande destruição; trata-se de um drama nacional que, segundo o mesmo autor, não deixa de lembrar os acontecimentos da Revolução Francesa ou os da Comuna de Paris, com os seus gritos de "liberdade ou morte!".

\section{A narrativa e o seu autor}

Como vimos, Flávio Josefo nasceu em 37 ou em inícios de 38 d.C. (no início do principado de Calígula), no seio de uma família sacerdotal. Descendia, por via materna, dos reis asmoneus. Aos 14 anos tornou-se "doutor da Lei" e, pouco mais tarde, completou o seu périplo por diferentes seitas judaicas e impôs a si mesmo um período de retiro no deserto.

Em 64 d.C., Josefo acompanhou a Roma um grupo de padres que foi detido pelo procurador Félix. Nessa aflição, tentou intervir junto do imperador Nero no sentido de obter a libertação dos seus companheiros. Na altura, descobriu com espanto que o mimo favorito do imperador era um judeu e que a esposa de Nero era, provavelmente, uma convertida! Graças a eles, Josefo obteria a libertação dos seus camaradas.

Nascido para ser rabino, as circunstâncias acabaram por fazer de Josefo um Reitor. Em 66 d.C., após a insurreição que expulsou os romanos de Jerusalém, ele era já o comandante-em-chefe da frente Norte, na Galileia - a mais exposta ao contra-ataque romano. No final do cerco de Jotapata, na Galileia, Josefo viu-se refugiado numa gruta juntamente com 40 companheiros. Viveu então um dilema 
Flávio Josefo e o cerco romano a Jotapata (67 d.C)

cruel: aceitar a fuga para o lado romano ou optar pelo suicídio, como pretendiam os seus correligionários? Josefo começa por propor uma rendição honrosa, mas os companheiros não aceitam qualquer capitulação e dão-lhe a escolher entre a morte dos bravos e a dos traidores. Contrário ao suicídio, Josefo propõe uma alternativa: a degolação recíproca, após tiragem à sorte (o n.o 2 mataria o n. 1 , o n. -3 executaria o n.o 2 e assim sucessivamente). Esta opção foi aprovada, mas Josefo teve a habilidade suficiente para ficar para o fim, circunstância providencial e que ele aproveitou, convencendo o seu único companheiro sobrevivo a salvarem-se os dois...

Josefo passou então para o acampamento romano, tendo recebido inúmeros favores da parte de Vespasiano e de seu filho Tito. No cerco de Jerusalém, Tito usaria Josefo para tentar convencer os habitantes da cidade a render-se. O procedimento não resultou, mas revela a integração de Josefo no meio romano, o que ajuda também a explicar o seu casamento com uma jovem cativa de Cesareia, ao que parece por indicação de Vespasiano (Vidal-Naquet, 1977, p.66).

Certo é que Josefo passou a viver em Roma e foi na cidade eterna que escreveu a sua obra, durante os principados de Vespasiano (69-79 d.C.), de Tito (79-81 d.C.) e de Domiciano (81-96 d.C.), concluindo em 93 d.C. as Antiguidades Judaicas e, em 93-96 d.C., o Contra Apião. Nas suas narrativas, Josefo surge como um mediador entre judeus e romanos, tentando justificar a guerra praticada pelos primeiros. Em A Guerra dos Judeus, oferece aos gregos e aos romanos um "memorial dos altos feitos" (Vidal-Naquet, 1977, p. 12). O seu texto, apesar de grego, contém a versão romana dos acontecimentos que pontuaram de sangue a Guerra Judaica de 66-73 d.C.: "Trata-se da guerra dos romanos contra os judeus, e não da guerra entre os judeus e os romanos tal qual ela teria podido ser escrita por um observador parta" (Vidal-Naquet, 1977, p.13). As suas fontes são romanas, ou próromanas, e a sua versão dos trágicos acontecimentos constituiu a versão oficial romana dos mesmos, tendo sido caucionada e rubricada por Tito, que ordenou a respectiva publicação. Ao que parece, também o rei Agripa II, o rei-cliente judaico que acompanhara Vespasiano e Tito, escreveu (segundo diz Josefo) 62 cartas atestando a veracidade do relato do escritor! Para este, Deus estava com Roma, a herdeira do mundo antigo e de quem os próprios atenienses se haviam tornado escravos...

Josefo é um autor importantíssimo para o conhecimento da máquina militar romana e, nesse sentido, ele recorda Políbio (203-120 a.C.) na sua tentativa comum de compreender o exército que os havia vencido: "Eu dei estas explicações detalhadas não tanto porque o meu desejo consista em exaltar os romanos, mas mais para consolar os povos que foram submetidos por eles e para fazer reflectir aqueles que poderão ter a tentação de se sublevar" (J. BJ 3.5.108). 
Entretanto, Josefo, apesar de advogar juntos dos judeus a causa dos seus senhores romanos, patenteia um grande orgulho em ser judeu, salientando nas suas narrativas a grande firmeza de alma deste povo e a sua extraordinária capacidade para suportar a sedição, a fome, a sede, a guerra e as maiores calamidades. Este quadro surge bastante enfatizado na medida em que, perante a Roma imperial, Josefo apresenta Jerusalém e a Judeia "num isolamento esplêndido e aterrador". E é esta função de mediação desempenhada por Josefo que justifica o comentário-síntese de Pierre Vidal-Naquet: "Existe Roma e existem os judeus: entre os dois, existe Josefo" (Vidal-Naquet, 1977, p.16).

Sabemos que A Guerra dos Judeus foi publicada entre 76 e 79 d.C., ou seja, escassos anos após o termo do conflito. No day after deste confronto, Josefo escreveu, em aramaico, a sua obra, que enviou "aos povos estrangeiros [bárbaros] do interior da Ásia” (J. BJ 1.3). Como explica Vidal-Naquet (1977, p.18), "é para esses não-gregos, a fim de lhes evitar os padecimentos que os judeus da Palestina tinham sofrido ao resistir ao Império Romano, para os judeus de Babilónia, para os de Adiabene, na Alta Mesopotâmia, cujos reis se tinham convertido ao Judaísmo, para os Árabes, para os habitantes do Império parta, que Josefo tinha, logo no dia seguinte à guerra, escrito a sua obra - em aramaico", que confessa tratar-se da sua língua materna.

A versão inicial da obra de Josefo perdeu-se para sempre. Todas as versões de que dispomos derivam do texto grego; no início de $A$ Guerra dos Judeus (J. BJ 1.3), Josefo explica, aliás, que traduz para grego a obra que compôs originalmente em aramaico (um aspecto que confirma a ideia da helenização da Palestina). Segundo alguns autores, a retórica de Josefo remonta a Eurípides, do mesmo modo que talvez seja possível encontrar um paralelo sugestivo entre os títulos e os inícios de A Guerra dos Judeus, por um lado, e da História da Guerra do Peloponeso, de Tucídides, por outro (Vidal-Naquet, 1977, p.15 e 20).

Usando fontes escritas e orais, romanas, aramaicas e hebraicas, Josefo compôs portanto uma narrativa de forte sentido pedagógico, exemplar, e, além disso, ponderada. Na obra que mais nos interessa, $A$ Guerra dos Judeus, só os moderados têm realmente voz: sobretudo Josefo, Agripa II, o Sumo-sacerdote Haná, os chefes romanos (em especial, Tito, por quem o escritor nutre um afecto particular). As excepções (como Eleazar em Masada-73 d.C., ou Simão em Jerusalém) são raras.

Podemos questionar o grau de integração de Josefo no mundo romano, após a sua captura em Jotapata. Não é fácil responder a esta pergunta, pois desconhecemos se Josefo (cujo nome romano deverá ter sido Titus Flavius Josephus $^{4}$ ) fez carreira no Império e sob que forma. De Vespasiano, Josefo recebeu terras, uma casa e uma pensão. Suetónio menciona-o como um "nobre cativo" que prediz o império para Vespasiano. Segundo Vidal-Naquet (1977, p.28), 
Flávio Josefo e o cerco romano a Jotapata (67 d.C)

talvez a sua pensão equivalesse à de 100.000 sestércios que Vespasiano atribuiu aos Reitores latinos e gregos pela primeira vez. Se esta hipótese for verdadeira, então o tratamento dispensado a Flávio Josefo equivaleria à condição de um alto funcionário.

O percurso e as opções de Josefo suscitaram uma apreciação divergente. Um cristão como Eusébio de Cesareia elogiou-o, considerando-o "de longe o mais célebre dos judeus do seu tempo", aos olhos de romanos e de não-romanos, o que lhe valeria uma estátua em Roma e a honra da presença das suas obras mais sérias nas grandes bibliotecas coevas. Já o israelita Z. Yavetz vê Josefo como simples membro de um séquito inferior do imperador romano, ao lado de médicos, de mágicos, de filósofos e de bufões, nunca tendo recebido o título oficial de "amicus Caesaris" (Vidal-Naquet, 1977, p.28).

Tito Flávio Josefo permaneceu perto de três décadas instalado em Roma, na condição de homem livre, aí se tornando "o historiador da guerra da Judeia, o historiador do povo judeu face a Roma (em Antiguidades), o defensor da lei judaica e da antiguidade judaica face aos Alexandrinos (em Contra Apião), o historiador de si mesmo (na Autobiografia)" (Vidal-Naquet, 1977, p.29). É uma felicidade tremenda, que devemos relacionar com o triunfo do Cristianismo no mundo romano, podermos dispor hoje da obra completa deste notável escritor, a quem S. Jerónimo chamou "o Tito Lívio grego" ${ }^{5}$ e que o Ocidente latino leu, pelo menos até à Contra-Reforma, quase como um texto sagrado. $O$ ponto alfa da sua narrativa da Guerra Judaica situa-se em 170 a.C., por altura dos acontecimentos que agitaram a Judeia na época de Antíoco IV Epifânio; o ponto ómega prolongase para além da captura de Masada (em 73 d.C.), na direcção do Egipto e da Cirenaica, mas Josefo tinha planos para mais, pois sabemos que em 93 d.C. o infatigável historiador tinha intenção de escrever "de novo, em resumo, a guerra e aquilo que nos aconteceu até ao presente dia" (J. AJ 22.267).

Teodoro Reinach considerou Flávio Josefo como "nem um grande espírito, nem um grande carácter, mas sim um composto singular de patriotismo judaico, de cultura helénica e de vaidade ${ }^{\prime 6}$. Historiador brilhante, Judeu controverso (traidor, sem dúvida, no contexto político-militar do seu tempo), a ele devemos uma das mais minuciosas descrições da fabulosa máquina militar romana em acção no séc. I d.C., e nós trataremos agora de a aproveitar o melhor possível, centrando-nos no cerco de Jotapata por Vespasiano, em 67 d.C..

\section{O cerco romano a Jotapata ${ }^{7}$}

O relato de Flávio Josefo sobre os acontecimentos militares de 67 d.C. começa por uma breve referência aos raides de Plácido (chefe militar romano) na Galileia e seu subsequente avanço para Jotapata ${ }^{8}$, considerada a chave-militar de toda a província. Tendo tomado conhecimento do ataque de Plácido, os 
habitantes de Jotapata decidiram aguardá-lo fora da cidade. Daí resultou um ataque bem-sucedido aos romanos, com os judeus a tirarem partido do seu equipamento mais ligeiro e a combaterem de longe a infantaria pesada, evitando o corpo-o-corpo (J. BJ 3.6.112-113).

Josefo descreve depois a ordem de marcha de Vespasiano no seu avanço entre Ptolemaida (Acre) e Jotapata ${ }^{9}$. Na sequência desta marcha, Vespasiano alcança as fronteiras de Galileia. Os seus preparativos para cercar as fortalezas geram um grande terror entre os judeus e daí resulta que Josefo se veja subitamente abandonado por compatriotas seus, restando-lhe um pequeno número de soldados fiéis, com os quais se refugia em Tiberíades (J. BJ 3.6.127-131).

No capítulo seguinte (Livro III, cap. 7), Josefo recorda a tomada de Gabara (na Galileia, c. 25 km a leste de Ptolemaida) e a matança e incêndio então perpetrados pelos soldados de Vespasiano, exprimindo o seu ódio pela nação judaica e o seu desejo de vingar o crime por esta anteriormente cometido contra o legado Céstio Galo. Perante a progressão adversária, Josefo, alarmado, decide enviar um relatório a Jerusalém, solicitando que se opte entre a rendição ou o envio de um reforço capaz (J. BJ 3.7.132-140).

Vespasiano parece ansioso por atacar Jotapata, uma excelente base dos adversários. Para tanto, envia um destacamento de infantaria e de cavalaria com a missão de aplanar os acessos, visto tratar-se de um caminho de montanha, muito pedregoso. Em quatro dias, "abrem ao exército uma larga estrada" (J. BJ 3.7.141-142). No dia seguinte (8 de Junho), Vespasiano alcança Jotapata (aonde Josefo também já chegou) e enceta os preparativos do cerco. Vespasiano parece contente por saber da presença de Josefo, pois era o inimigo de quem mais queria apoderar-se, por ser "o mais inteligente" deles (J. BJ 3.7.144)...

Plácido e o decurião Aebútio bloqueiam então a cidade de modo a impedir Josefo de fugir. O acampamento romano é instalado, para pavor dos judeus que assistem à distância. Os romanos formam três linhas de cerco (duas de infantaria, reforçadas por uma exterior, de cavalaria) e cortam todas as saídas aos sitiados. Porém, parecem esquecer-se de que a ausência de um caminho de fuga galvaniza quase sempre a coragem dos de dentro (J. BJ 3.7.144-149).

Dá-se depois o primeiro ataque romano contra a posição exterior dos judeus (que aguardavam o inimigo em frente às muralhas). Josefo consegue repelir o ataque romano (arqueiros, fundibulários e tropa de infantaria comandada por Vespasiano). O combate foi duro e duraria até à noite, provocando muitas baixas: 13 mortos e grande número de feridos, do lado romano; 17 mortos e cerca de 600 feridos, entre os judeus (J. BJ 3.7.150-154).

Nos dias seguintes têm lugar outros ataques romanos e diversos contraataques judeus, sob a forma de surtidas fulgurantes. Os soldados romanos começam a sentir alguma vergonha por não conseguirem chegar rapidamente à 
Flávio Josefo e o cerco romano a Jotapata (67 d.C)

vitória. Porém, a verdade é que a fortaleza de Jotapata era quase inexpugnável: dispunha de uma posição natural muito forte e só do seu lado norte era mais acessível, o que levara Josefo, quando fortificou a cidade, a incluir esse troço dentro da própria muralha. Além disso, a cidade era quase invisível, pois estava rodeada de montanhas (J. BJ 3.7.155-160).

Vespasiano reúne o seu conselho de guerra, onde se decide a construção de um terraço ou rampa de assalto, em terra, do lado norte. Os romanos vão em busca de terra e de pedras nas montanhas vizinhas. A isto reagem os de dentro fazendo tiro a partir das muralhas, o que obriga os romanos a estender caniços sobre as paliçadas, para conseguirem construir o pontão. Mas os judeus não desarmam e lançam pedregulhos sobre as cortinas de protecção dos romanos e todo o género de projécteis, com grande algazarra (J. BJ 3.7.161-165).

Josefo explica depois como Vespasiano instalou de forma concêntrica, à volta daquela parte do muro, 160 engenhos de tiro que transportara consigo: catapultas que projectavam dardos com um som estridente; e balistas que arremessavam pedras com um talento (c.26 kg) de peso. Os romanos lançavam também dardos inflamáveis e um chuveiro de flechas, batendo não só a muralha mas todo o espaço interior de Jotapata. Uma multidão de arqueiros árabes e todos os lançadores de dardos e fundibulários actuava em simultâneo com os engenhos. Quanto à reacção judaica, consistia sobretudo em organizar surtidas que visavam arrancar as protecções dos construtores da rampa de assalto, atacar os respectivos operários, destruir a rampa e incendiar as paliçadas. Por isso, Vespasiano decidiu unir os telheiros de protecção do terraço de assalto de modo a dificultar os ataques, conseguindo conter melhor as incursões judaicas (J. BJ 3.7.166-170).

Entretanto, a rampa tinha já a altura da muralha, o que obrigou os judeus a sobrelevar o muro, protegidos por uma paliçada fixada à muralha e revestida por peles de bois frescas e húmidas. Um regime de trabalho intensivo, de dia e de noite, permitiu aos judeus elevar o muro uns 20 côvados (c.13,20 m), incorporando torres e ameias, o que gerou um grande desalento entre os romanos. Ao mesmo tempo, os sitiados insistiam nas surtidas, recorrendo a todas as manhas do banditismo e concretizando o maior número possível de pilhagens e de incêndios (J. BJ 3.7.171-177).

Perante isto, Vespasiano optou por conter a resposta armada e por bloquear a cidade, na esperança de a render pela fome (ou pela sede): esgotados pela privação dos alimentos, os judeus não seriam capazes de combater a sério. De facto, dentro de Jotapata, se os víveres não escasseavam (a não ser o sal), havia por outro lado pouca água já que as cisternas eram apenas alimentadas pela chuva e estava-se a entrar no Verão. Tal facto forçou Josefo a organizar um racionamento rigoroso, causador de grandes padecimentos. Do alto das colinas 
que rodeavam a cidade, os romanos podiam até observar os ajuntamentos dos sitiados para distribuição de água, aproveitando para fazer tiro de catapulta sobre essas pequenas multidões. Compreendendo que o adversário apostava no esgotamento das cisternas, Josefo recorreu a um estratagema: um grande número de habitantes surgiu nas muralhas com as vestes ensopadas, para dar aos romanos a ilusão de que a água abundava na cidade! Foi o estupor entre os romanos, que se sentiram desencorajados. Aí, Vespasiano decidiu voltar ao ataque, que era aliás, segundo Josefo, o que os judeus mais queriam para poderem morrer combatendo, com glória, e não ressequidos pela fome ou pela sede (J. BJ 3.7.178-189).

Neste ponto, o escritor introduz na sua narrativa uma petite histoire muito saborosa: a partir da cidade havia um caminho secreto que permitia aceder à ravina do lado ocidental, a qual era de tal modo inacessível que os postos de guarda romanos a negligenciavam. Ora, Josefo conseguia fazer passar por aí os seus 'correios', que levavam e traziam do exterior cartas e abastecimentos preciosos. Quando exploravam este caminho improvável, os mensageiros judaicos tinham instruções para avançarem "o mais possível a quatro patas" sempre que passassem perto das sentinelas romanas. Inclusivamente, levavam peles de animais pelas costas, de maneira a serem tidos por cães, caso fossem avistados de noite! Todavia, os Romanos acabaram por descobrir o estratagema e a ravina começou a ser guardada (J. BJ 3.7.190-192).

$\mathrm{O}$ assédio complica-se e Josefo decide preparar com os dirigentes judaicos a sua fuga. Porém, a população apercebe-se e implora-lhe que fique e que resista com eles até ao fim, pois Josefo era como um comandante de um navio, sem o qual toda a esperança de resistir se esvairia. O líder argumenta que lhes poderia ser mais útil fora do que dentro da cidade, pois reuniria os Galileus e abriria uma segunda frente; e alega que os soldados de Vespasiano queriam sobretudo era capturá-lo, pelo que, se ele partisse, os romanos abandonariam o cerco. Tudo em vão: os sitiados pressionam Josefo para que fique pois acreditam que, se ele ficar, nada de horrível poderá acontecer-lhes. Assim, Josefo regressa aos combates diários, que se traduzem em surtidas judaicas constantes para tentar incendiar as protecções da rampa de assalto dos romanos (J. BJ 3.7.193-206).

Como os romanos tinham dificuldade em responder a tais ataques (devido ao seu equipamento ser demasiado pesado para perseguir os sitiados que fugiam para dentro da fortaleza), Vespasiano ordena à infantaria pesada que evite o combate com aquela gente desesperada e aposta sobretudo nos arqueiros árabes e nos fundibulários e lançadores de pedra sírios para repelir os judeus; ao mesmo tempo, os numerosos engenhos de tiro não param de trabalhar. Em resposta, quando se acham aquém da zona de impacto desses engenhos de longo alcance, os judeus forçam o corpo-a-corpo, revezando as suas tropas mais fatigadas 
Flávio Josefo e o cerco romano a Jotapata (67 d.C)

através de um sistema de roulement coordenado a partir de dentro (J. BJ 3.7.207212).

Nesta altura, Vespasiano (que já estava a ficar com a impressão de ser ele o sitiado) decide pôr em acção um aríete. A grande eficácia e a potência deste dispositivo de vaivém, movimentado por uma grande quantidade de servidores e equipado com uma cabeça de ferro, merece a Josefo o seguinte comentário: "Não existe torre suficientemente sólida ou muro suficientemente espesso que possam, mesmo que aguentem o primeiro choque, resistir a golpes repetidos" (J. BJ 3.7.217). Ao mesmo tempo, os servidores das catapultas e dos outros engenhos de tiro aproximam as suas máquinas o suficiente para poderem atingir os judeus que, a partir das ameias, tentam impedir a aproximação do aríete. 0 mesmo fazem os arqueiros e os fundibulários ao serviço de Vespasiano. Assim, os judeus não ousam assomar aos muros e os romanos conseguem colocar o aríete em posição, cobrindo-se com caniçadas ligadas umas às outras e revestidas de peles (para sua protecção e da própria máquina). Ao primeiro golpe do aríete, o muro estremeceu e ouviu-se um clamor formidável vindo de dentro da cidade, "como se ela já tivesse sido capturada" (J. BJ 3.7.221)! (J. BJ 3.7.217-221).

Coube então a Josefo recorrer a um dispositivo para neutralizar o aríete: alguns sacos de palha pendurados nos muros e descidos pelo meio de cordas foram interpostos entre a cabeça da máquina e a zona do muro que estava a ser batida, de modo a amortecer os golpes. Mas aí os soldados de Vespasiano deitaram mão a grandes varas com ferros de foice nas pontas, com as quais cortavam as cordas dos sacos almofadados... Josefo recorre ao fogo, preparado através de uma mistura de madeira seca, de betume, de pez e de enxofre: um incêndio começa então a grassar por todo o lado, consumindo os trabalhos dos romanos (J. BJ 3.7.222-228).

A narrativa de Josefo abre aqui um parêntese para enaltecer o heroísmo de Eleazar, um nativo de Gaba que atacou sozinho o aríete, e de dois irmãos galileus que se excederam em bravura (J. BJ 3.7.229-233).

Nesta fase da operação, judeus de tochas na mão circulam pelo exterior da muralha e procuram aniquilar abrigos e máquinas da 5. e da 10. a legiões. Quanto aos romanos, tentam proteger tudo com terra (engenhos e materiais em madeira) e recolocam o aríete no ponto mais frágil do muro, ou seja, onde ele já tinha operado. É neste momento que Vespasiano é ferido num pé por uma flecha lançada do muro: soa o alarme entre os sitiadores, mas trata-se de uma ferida superficial (J. BJ 3.7.234-239).

Podemos depois desfrutar das páginas mais emocionantes sobre o cerco de Jotapata. Massacrados pelos engenhos romanos, os Judeus vão caindo, mas resistem sempre. Muitos tombam dos muros e agonizam lá em baixo. Nessa noite, o fogo acaba por tornar os judeus num alvo iluminado e eles caem com os 
golpes de escorpiões e de balistas que nem chegam a ver. Os projécteis das catapultas romanas matam vários de uma assentada, enquanto as pedras das balistas desmontam ameias e cunhais. Um tiro de balista chega mesmo a arrancar a cabeça a um homem que está junto de Josefo, lançando o respectivo crânio a três estádios de distância. Uma mãe grávida leva com um míssil no ventre, tendo o bebé sido projectado cerca de 100 metros! As máquinas romanas emitem silvos e ruídos arrepiantes. Os corpos dos sitiados caem do alto, uns sobre os outros, e a acumulação de cadáveres é tal que facilita o acesso à muralha por parte dos soldados romanos. Enquanto isso, a montanha em volta de Jotapata ecoa os sons dramáticos do combate, tornando aquela numa noite memorável. O muro acaba por ceder e os Judeus, sem mais opção, põem os seus próprios corpos a colmatar as brechas, enquanto os Romanos se preparam para adossar as escadas de assalto à muralha (J. BJ 3.7.240-252).

Ao nascer do sol, os romanos organizam um ataque em várias linhas: i) os cavaleiros mais bravos desmontam e formam três colunas de assalto frente aos troços derrubados do muro; estão couraçados e munidos de lança, prontos a penetrar logo após a colocação das escadas de assalto; ii) atrás deles, posiciona-se a infantaria de elite; iii) ao resto da cavalaria caberá cobrir a ligação à montanha para evitar as fugas; iv) atrás deste cordão de cavalaria estão os arqueiros, os fundibulários e os engenhos de tiro. Em simultâneo, Vespasiano manda preparar o encosto de escadas às partes intactas da muralha para forçar os judeus a dividir as suas forças (J. BJ 3.7.253-257).

A esta ofensiva respondeu Josefo do seguinte modo: i) colocou os combatentes mais fatigados (ou mais idosos) na parte boa da muralha, onde a defesa era mais fácil; ii) nas brechas abertas pelos romanos posicionou os homens mais fortes, em grupos de seis tirados à sorte (incluindo ele próprio); iii) depois, deu ordem a todos para taparem os ouvidos no momento do grito de guerra romano; iv) mandou também que, contra os projécteis, apoiassem um joelho em terra, os homens escondidos atrás dos escudos, um pouco recuados, enquanto os adversários esvaziavam as aljavas; v) quando os romanos tivessem as escadas encostadas à muralha, os judeus deveriam avançar, com a ajuda dos seus próprios engenhos, e vingar a sua gente; vi) as mulheres foram mandadas recolher para não desmoralizarem os outros com os seus gritos de terror (J. BJ 3.7.258-263).

As trombetas romanas dão então o sinal de ataque. Sucede-se um grito de guerra terrível, completado por disparos comandados por um sinal. Os romanos colocam as plataformas de assalto em posição, mas logo a seguir os judeus lançam-se ao ataque e impedem-nos de as utilizar. Inicia-se um corpo-a-corpo letal, em que os romanos levam vantagem por conseguirem organizar-se de modo a que tropas frescas substituam rapidamente as que se encontram esgotadas, ou 
Flávio Josefo e o cerco romano a Jotapata (67 d.C)

que são repelidas; além disso, estão bem protegidos na cabeça e no tronco e actuam em bloco cerrado (J. BJ 3.7.265-269).

Nesta aflição, Josefo manda derramar óleo a ferver sobre a 'tartaruga' romana que avança para a muralha. $\mathrm{O}$ ardil resultou, causando uma dor imensa e a desorganização da tropa de progressão romana (o óleo aquecia depressa e arrefecia devagar, por causa da gordura). Os romanos vêem-se aprisionados nas suas lorigas e capacetes, não conseguindo escapar à queimadura: saltam e contorcem-se de dor, caindo nas rampas de assalto e chocando com os camaradas que chegam para os socorrer. Os judeus aproveitam a situação e começam a matá-los por trás (J. BJ 3.7.271-275).

Logo a seguir, Josefo ordena o derrame de feno-grego (uma planta leguminosa) fervido sobre as tábuas dos passadiços de assalto: alguns romanos desequilibram-se, caem de costas e são espezinhados, enquanto outros são projectados sobre a rampa, onde os dardos judaicos os trespassam. Mais libertos do corpo-a-corpo, os judeus aproveitam para fazer tiro sobre os adversários. Ao cair da tarde, Vespasiano recolhe os seus homens. Muitos, furiosos, insistem em continuar a combater. Mas as baixas já são significativas; os defensores de Jotapata perdem só seis homens, mas mais de 300 feridos são conduzidos para o interior da cidade. Tudo isto aconteceu no dia 8 de Julho (J. BJ 3.7.277-282).

Vespasiano decide então elevar o terraço de assalto e manda construir três torres de 50 pés (c.15 m) forradas de ferro (para serem mais resistentes ao fogo), as quais instala na própria rampa, recheadas de atiradores de vário tipo (dardeiros, arqueiros, fundibulários) e até com engenhos ligeiros lá dentro. 0 novo dispositivo é eficaz: os atacantes estão agora demasiado altos para os judeus os conseguirem atingir e os sitiados nem sequer os avistam bem! Assim, os homens de Josefo trocam a defesa das ameias por novas surtidas. As baixas aumentam dia após dia (J. BJ 3.7.284-288).

Neste ponto, Josefo explica que Trajano (o comandante da 10. legião) foi então enviado para tomar a cidade rebelde de Yafa (perto de Nazaré), à frente de um destacamento de 1.000 cavaleiros e 2.000 infantes. Tito acabaria por secundar esta bem sucedida operação, consumada no dia 13 de Julho. Josefo estima que terão morrido umas 15.000 pessoas (J. BJ 3.7.289-306).

Em Jotapata, ao 47. dia de cerco, a rampa de assalto ultrapassa já a altura da muralha. Um desertor informa então os romanos de que a melhor hora para atacarem é na última vigia ${ }^{10}$, pois devido à intensidade do sono as sentinelas têm tendência para adormecer. O mesmo informador avisa também os romanos de que os de dentro estão esgotados, sendo poucos aqueles que se acham em condições de lutar. Vespasiano desconfia, pois os judeus costumavam ser muito leais entre si (e até havia casos de torturados que não falavam, nem no momento 
da crucificação); ainda assim, decide seguir a pista e preparar o ataque (J. BJ 3.7.316-322).

À hora prevista, os romanos avançam para a estocada final com Tito e o tribuno Sabino na frente, acompanhados por alguns soldados da 5. a e da 10. legiões. Degolam as sentinelas que dormem, enquanto, mais atrás, Plácido e o tribuno Sexto Calvário fazem entrar as suas tropas. Os sitiados dormem e um nevoeiro intenso também ajuda os assaltantes. Os judeus são apanhados de surpresa. Dá-se uma matança brutal na descida da cidadela, com os defensores a serem esmagados nas ruelas e a escorregar pela colina. A carnificina é de tal ordem que os próprios soldados de elite de Josefo se juntam num extremo da praça para se matarem uns aos outros antes de serem apanhados. Alguns judeus refugiam-se numa torre, a norte, mas também acabam degolados. Entre os romanos regista-se apenas a baixa do centurião António, enganado por um judeu refugiado numa gruta. A matança prolonga-se pelos dias seguintes, em todos os esconderijos, subterrâneos e cavernas. Mais uma vez, só as mulheres e as crianças são poupadas. No total, Josefo fala em 40.000 mortos e em 1.200 prisioneiros. Conquistada a praça, Vespasiano manda arrasar a cidade e incendiar as respectivas fortificações. Para a história, fica a data da captura de Jotapata: 20 de Julho do ano 67 da era de Cristo (J. BJ 3.7.323-339).

No capítulo seguinte (cap. 8 do Livro III), Flávio Josefo relata ainda a busca de Josefo pelos romanos. Encontrado numa gruta ligada a uma cisterna funda, é convidado a sair, com garantia de salvaguarda da sua vida. Mas Josefo vacila e só o envio de um terceiro emissário (o tribuno Nicamor, seu amigo) o leva a admitir arriscar, num momento em que os soldados romanos ameaçavam já pôr fogo à caverna. Josefo lembra-se então dos sonhos em que Deus lhe anunciou o sofrimento dos judeus e os destinos futuros dos imperadores romanos. Logo a ele, que "era intérprete dos sonhos e hábil a decifrar as revelações ambíguas da divindade" (J. BJ 3.8.352). Tomado por uma inspiração profética, Josefo decide render-se para poder anunciar o futuro (como profeta e servidor de Deus, e não como traidor). Mas os seus 40 companheiros de gruta não estão de acordo e ameaçam-no de morte. Foi aí que Josefo engendrou o estratagema de organizar um suicídio colectivo por degolação, tendo o cuidado de se deixar ficar para o final de modo a conseguir salvar-se (J. BJ 3.8.340-391)...

Nicamor conduz finalmente Josefo a Vespasiano. Uma grande multidão de romanos acorre para observar o líder judeu. Tito, impressionado com a determinação de Josefo e com a sua juventude, pressiona o pai para conseguir a sua graça. Mas Vespasiano sujeita Josefo a uma guarda apertada e faz tenção de o enviar a Nero. Então, Josefo pede para falar a Vespasiano em particular (só na presença de Tito e de mais dois amigos deste). Segue-se o discurso em que Josefo se apresenta como profeta e em que profetiza mesmo a subida ao trono imperial 
Flávio Josefo e o cerco romano a Jotapata (67 d.C)

por parte de Vespasiano e, depois, por Tito ${ }^{11}$. Perante isto, Vespasiano hesita, desconfiado. Mas a verdade - explica o escritor - é que o general tinha as suas ambições imperiais e pôde confirmar (junto de prisioneiros judaicos) que Josefo já havia previsto a capitulação de Jotapata ao 47. dia, bem como a sua própria captura! Sendo assim, Vespasiano começa a acreditar no seu prisioneiro mais ilustre. Mantém Josefo bem guardado, mas, sob a influência de Tito, dá-Ihe boas prendas e trata-o muito bem (J. BJ 3.8.392-408).

Logo no início do capítulo 9 deste Livro III de A Guerra dos Judeus, Flávio Josefo remata a sua narrativa do cerco de Jotapata. Para explicar que, a 23 de Julho de 67 d.C., Vespasiano deixou Jotapata, rumo a Ptolemaida e, depois, a Cesareia, onde os romanos foram bem recebidos (J. BJ 3.8.409-410).

Termina aqui um dos principais episódios da Guerra Judaica de 66-73 d.C.. Em breve o cenário da narrativa se deslocará para Jerusalém, onde, no Verão de 70 d.C., decorrerá um cerco sanguinário que arrasará a Cidade Santa e o seu precioso Templo. Josefo também lá estará, mas agora do outro lado da trincheira, junto ao seu amigo Tito. Vespasiano já será, então, imperador. E Josefo chamarse-á agora, et pour cause, Tito Flávio Josefo...

\section{Documentação}

FLAVIUS JOSEPHE. La Guerre des Juifs. Traduit du grec par Pierre Savinel. Paris : Les Éditions du Minuit, 1977.

\section{Bibliografia}

ARMSTRONG, Karen. Jerusalém. Uma Cidade, Três Religiões. Ttrad. port. de Eduarda Correia. Lisboa: Temas e Debates, 2002).

GOLDSWORTHY, Adrian. Generais Romanos. Os homens que construíram o Império romano. Trad. port. de Carlos Fabião. Lisboa: A Esfera dos Livros, 2007.

VIDAL-NAQUET, Pierre. "Du bon usage de la trahison", in Flavius Josèphe, La Guerre des Juifs, traduit du grec par Pierre Savinel, Paris : Les Éditions du Minuit, 1977.

\footnotetext{
Notas

${ }^{1}$ Para a contextualização que aqui apresentamos, usaremos sobretudo Pierre Vidal-Naquet (1977), Karen Armstrong (2002) e Adrian Goldsworthy (2007).

${ }^{2}$ Herodes matou a sua esposa Mariana e três dos seus filhos, por conspirarem contra ele. Aos outros três filhos (Arquelau, Filipe e Antipas), nunca concedeu poderes e, quando morreu, deixou dois testamentos. O destino do reino ficou por isso nas mãos de Augusto, que chamou a Roma os três pretendentes, tendo o Senado optado por nomear Arquelau como etnarca da Judeia, e Antipas e Filipe como tetrarcas da Galileia, da Pereia e das outras regiões do Norte. As políticas impiedosas de Arquelau acabariam por levar à sua deposição e desterro, em 6 d.C.. A partir daí, a Judeia foi governada por prefeitos romanos, tendo Cesareia por capital. Cf. Armstrong (2002, p.137-139).

${ }^{3}$ Utilizaremos neste trabalho a edição francesa de $A$ Guerra dos Judeus referida na nota 1. 
4 Segundo o princípio dos tria nomina romanos, o praenomen e o nomen eram normalmente os nomes dos imperadores no poder no momento da atribuição da cidadania, enquanto o cognomen recordava o patronímico do beneficiário. Recorde-se que Josefo recebeu a liberdade das mãos do imperador Vespasiano (Titus Flavius Vespasianus). ${ }^{5}$ Citado por Vidal-Naquet (1977, p.30).

${ }^{6}$ Citado por Vidal Naquet $(1977$, p.33).

${ }^{7}$ Cf. J. BJ 3.6-8.110-408.

8 Jotapata: hoje Yodfat (a meio-caminho entre S. João de Acre e Tiberíades).

${ }^{9}$ Segundo Vidal-Naquet (1977, p.315), o exército de Vespasiano, que incluía três legiões com artilharia, cavalaria, infantaria e trem de apoio, devia formar uma coluna com mais de $15 \mathrm{~km}$ de extensão, para a qual é estimável um tempo de escoamento de mais de três horas.

${ }^{10}$ Julgo que equivalerá, aproximadamente, ao período entre as $4 \mathrm{~h}$ e as $7 \mathrm{~h}$ da manhã.

${ }^{11}$ A predição de Josefo é mencionada por Suetónio (Suet. Ves. 5), que escreve no final do séc. I - início do séc. II d.C. 

Seção IV

PODER E RELIGIÃO NO IMPÉRIO 



\title{
PODER E RELIGIÃO NA ÁSIA MENOR: O CULTO IMPERIAL
}

\author{
José Geraldo Costa Grillo* \\ Universidade Federal de São Paulo - Brasil \\ Pedro Paulo A. Funari \\ Estadual de Campinas - Brasil
}

\section{Introdução}

O estudo da política tem longa tradição - e, em certo sentido, a própria narrativa historiográfica -, estando atrelado às lides do poder. O historiador grego Heródoto preocupou-se com as relações entre gregos e persas, assim como Tucídides escreveu sua obra a partir da contraposição entre as cidades gregas em guerra (FUNARI e SILVA, 2009). Portanto, na origem da narrativa histórica, como gênero literário, o poder, kratos, esteve ligado à coerção física e à luta, polemos. Esta dimensão militar e bruta da força permeou, também, ainda que de forma diversa, a nascente ciência histórica moderna, motivo pelo qual reis e generais continuaram a ocupar lugar de destaque no discurso histórico. O século XX viria a testemunhar uma ampliação das preocupações do historiador e o poder foi relacionado a outras esferas da atuação humana, em particular, às representações, sentimentos, identidades e sensibilidades. Poder e saber passaram a serem termos correlacionados e em constante conexão (RAGO e FUNARI, 2009).

Um dos aspectos relevantes dessa ênfase no simbólico tem sido o estudo das conexões entre poder e religiosidade ou conjunto de sentimentos relativos às forças superiores, mágicas ou espirituais. Segundo as concepções dos próprios antigos, os deuses e as manifestações de forças desconhecidas faziam parte da vida quotidiana, nas formas mais variadas e freqüentes. Mesmo um autor como Tucídides, historiador considerado pelo positivismo como precursor da descrição neutra e imparcial, não deixava de mencionar a fortuna, tykhe, e o mesmo pode ser dito, a fortiori, dos restantes antigos para os quais, claro, o próprio amor, Eros, era uma força divina (FUNARI, 2009, p.41-52).

Professor Adjunto da Universidade Federal de São Paulo e pós-doutorando na Universidade Estadual de Campinas sob a supervisão do Prof. Dr. Pedro Paulo A. Funari. Bolsista da FAPESP.

** Professor Titular da Universidade Estadual de Campinas, Coordenador do Centro de Estudos Avançados da Unicamp/CEAv (www.gr.unicamp.br/ceav). 


\section{Poder e religião na Ásia Menor: o culto imperial}

A separação moderna entre razão e religião viria a tardar a expansão da atenção aos aspectos simbólicos e religiosos das manifestações de poder, mas estes estudos expandiram-se, de forma exponencial, nas últimas décadas, tanto na análise das sociedades modernas, como antigas. Tanto o mundo grego como o romano, passaram a ser objeto de abordagens relativas às dimensões políticas das religiosidades. O mundo romano ocidental, de língua oficial latina, testemunhou a expansão de obras sobre o culto imperial, os templos dedicados aos mais variados cultos, os sacerdócios, mas também as práticas de alguma forma ligadas à religião, como as lutas de gladiadores (GARRAFFONI, 2010).

O Mediterrâneo oriental, com sua tradição de uso do idioma oficial e de comunicação grego, ou koine, foi também objeto de atenção, em particular pelas suas diversas características peculiares, a começar da sua situação de comunicação entre o Ocidente latino, de um lado, e toda a imensa diversidade cultura oriental. O mundo romano oriental sempre esteve em contato, por tradição milenar, com a Mesopotâmia, a Pérsia e daí para a Índia e mais adiante. Destas regiões provinham inúmeras concepções e práticas religiosas, que se mesclavam, de forma criativa e inovadora, com outras tantas variedades locais, também milenares. Se o mundo romano, no geral, pode ser caracterizado como uma imensa mescla cultural e política, tanto o mais era a parte oriental desse mesmo mundo. Ali, conviviam judeus, egípcios, e uma miríade de povos e culturas, cada uma delas com sua própria variedade interior de pontos de vista e comportamentos.

O culto imperial romano constituiu um aspecto dos mais marcados de relação entre poderes, saberes, prenhe de conflitos. Júlio César foi divinizado após sua morte e seu sobrinho Otávio foi, em vida, alçado à condição espiritual de augusto, título antes do âmbito das coisas divinas, que humanas. Portanto, o Principado iniciou-se sob o signo de uma representação sobrenatural do poder e a própria titulatura imperial fundava-se nessas pretensões divinas, pois os príncipes eram divinizados e os governantes eram diui filii, filhos de um deus. Os templos dedicados aos príncipes foram inaugurados já com o primeiro imperador e os sacerdotes do culto imperial seguiram na esteira.

O culto imperial foi, portanto, um elemento central nas negociações das relações de poder durante o período do Principado. O Mediterrâneo oriental testemunhou uma série de conturbações em torno das práticas e crenças religiosas. O judaísmo, em particular, com sua imensa diversidade e difusão, por meio de várias comunidades espalhadas em muitas partes, tanto no interior como fora dos limites do Império Romano, foi um elemento importante neste contexto. Desde a época de Alexandre o Grande, os judeus passaram a fazer parte da órbita grega, primeiro, e greco-romana, em seguida, sem nunca perder suas especificidades, com seus conflitos internos. Duas grandes tradições, grosso 
modo, contrapunham-se: as vertentes mais populares, ligadas à vida de labuta diária, que hauria sua religiosidade do profetismo e das experiências extáticas. A comunicação com as forças superiores dava-se, portanto, de forma mais autônoma, em relação às autoridades constituídas, com conotações latentes ou explícitas de contestação social. Por outro lado, aqueles grupos mais cômodos formavam parte das elites tanto sociais como religiosas que, de alguma forma, tinham que se haver com as potências imperiais que controlavam, manu militari, os judeus.

Essas contradições e conflitos internos no judaísmo, ou, em outros termos, sua heterogeneidade prenhe de embates, levaram tanto a seguidas crises internas, como a confrontações com as autoridades locais e imperiais. As duas grandes revoltas judaicas do Principado, suprimidas com a destruição do Templo de Jerusalém, em 70 d.C., e depois da cidade de Jerusalém, em 130 d.C., com o sucessivo banimento dos judeus da sua própria terra, mostram, de forma evidente e explosiva, esse quadro de conflitos internos e com o domínio imperial. Os movimentos de seguidores de Jesus de Nazaré, surgidos nessa época e nestas circunstâncias, fazem parte deste imenso manancial cultural, social e político que vicejava no judaísmo. Os movimentos cristãos não constituíam uma unidade, nem mesmo entre aqueles que viriam a triunfar, séculos depois, e propor uma narrativa ortodoxa e unívoca dos seguidores de Jesus. De certo modo, será apenas com o imperador Constantino, no século IV, que será estabelecida uma única doutrina, reta via e trajetória, narrada a posteriori. Durante todo o Principado, os movimentos que se inspiravam em Jesus eram muito variados e contraditórios, em conflitos também não só com as autoridades, muitas vezes, mas com outros grupos (NOGUEIRA, FUNARI, COLLINS, 2010).

Muitas vezes, tais conflitos e contradições aparecem como se fossem, para as pessoas da época, como uma luta política, contra a opressão econômica e social. Assim, os movimentos messiânicos, escatológicos e apocalípticos foram, não poucas vezes, interpretados como se fossem, para si mesmos, associações e órgãos de luta por justiça social. No entanto, mesmo na época moderna e contemporânea, movimentos sociais como os sem-terra, no Brasil, apresentamse, para si mesmos, como voltados para o cumprimento de uma missão religiosa: a terra é de Deus e não pode ser apropriada, comercializada. Trata-se de uma concepção religiosa e não é, portanto, à toa, que tais movimentos assumam um caráter religioso profundo e indissociável de suas expressões e manifestações.

Se isto é assim no ápice do capitalismo e do racionalismo, tanto mais devemos levar em conta os aspectos subjetivos e simbólicos na Antiguidade. A luta social e política, por motivações econômicas e materiais, não se apresentava separada das representações espirituais e, ao contrário, elas estavam no centro de tais conflitos e embates. A espiritualidade não era, pois, um epifenômeno, um 


\section{Poder e religião na Ásia Menor: o culto imperial}

simples manto diáfono a cobrir os verdadeiros interesses e embates, mas não deixava de definir os termos mesmos, os instrumentos conceituais que eram agenciados para a negociação das relações de poder. Só assim se entende a morte, sacrifício supremo e testemunho maior do desapego à materialidade, resultado tão comum, freqüente e repetitivo no âmbito das relações entre o poder imperial romano e os movimentos judaicos e cristãos. A crucificação de Jesus, os martírios dos seus seguidores, as mortes dos revoltosos judeus, tudo isso só tem sentido se considerarmos que a esfera espiritual foi determinante na autorepresentação de tantas pessoas (CHEVITARESE, CORNELLI e SEVATICI, 2006).

O culto imperial representava, se considerarmos a relevância das autorepresentações simbólicas, um elemento central para o exercício do poder romano, mas, ainda mais, para a afirmação de identidades fundadas em concepções religiosas que não podiam admitir essa prática simbólica. Neste capítulo, o culto imperial na província da Ásia Menor será explorado à luz destas considerações e, como veremos, não convém subestimar sua relevância para compreender as relações de poder.

\section{O culto imperial na província da Ásia Menor}

A relação entre poder e religião tem sido realçada nas pesquisas sobre $o$ culto imperial, desde a obra de Simon R. F. Price (1984), na qual concebe o culto imperial como um sistema que, ao mesmo tempo, definia a posição do imperador e formava em grande medida a rede de poder que constituía o tecido social, em suma, um modo de conceituação do mundo, que, junto com a política e diplomacia, construiu a realidade do império romano.

Na província da Ásia Menor (Cf. MITCHELL, 1995), onde a unidade básica da organização política era a cidade (polis), as cidades gregas tinham de ajustar seus ideais de autonomia e de liberdade estabelecidos no passado à realidade presente do domínio romano. Ao longo do tempo, do período helenístico ao romano, esses ideais praticamente se extinguiram; o que não significou o fim das cidades gregas, pois o governo romano limitava-se à manutenção da ordem, arrecadação de impostos e administração da justiça. Com a finalidade de prover uma estrutura administrativa para a província, os imperadores mantiveram as cidades como comunidades organizadas (poleis), permitindo, no mais das vezes, que permanecessem com governo próprio e com poderes locais. Da perspectiva romana, entretanto, as cidades provinciais, sejam quais fossem, eram unidades integrantes do amplo sistema imperial de administração e controle. Portanto, uma a uma teve de estabelecer seu lugar e sua postura face ao domínio romano.

Diante dessa nova situação, as cidades da Ásia Menor tiveram de se sujeitarem ao domínio romano, e, apesar da diversidade de suas culturas locais, a resposta dada em comum para esse problema foi, segundo Price (1984), encontrar 
um lugar para o imperador romano no âmbito dos cultos tradicionais aos seus deuses. Já habituadas com os cultos helenísticos aos dirigentes, não lhes foi estranho sintonizar o culto ao imperador com essa prática. Todavia, algumas mudanças foram efetuadas na dinâmica do culto. Diferentemente dos decretos helenísticos sobre os cultos reais, que descrevem simplesmente as benfeitorias políticas do rei, os de Augusto estabeleciam comparações entre suas ações e as dos deuses. Uma vez que os deuses desde tempos remotos eram descritos como benfeitores, Augusto passou a ser tido como benfeitor de todo o mundo. 0 arcabouço fundamental do culto ao imperador era formado pelos festivais imperiais. A maneira encontrada de introduzir o imperador na vida da comunidade foi adaptar um festival tradicional em honra da principal divindade local. Através de assimilações, identificações e de dedicações conjuntas da cidade, o imperador entrava em relacionamento íntimo com os deuses tradicionais de cada cidade.

O culto imperial provocou transformações nas cidades. O espaço físico foi reorganizado. Mudanças arquitetônicas aconteceram em todas as cidades que tinham templos imperiais; pois, se culto ao imperador era a tentativa de prover um lugar para ele, era natural que a expressão física desse lugar se encontrasse no interior de seu espaço cívico, isto é, integrado ao centro da vida religiosa, política e econômica da comunidade. Portanto, os templos imperiais situavam-se, geralmente, nas posições mais destacadas no interior da cidade. Assim alocados, os templos imperiais inscreviam, no coração da cidade, uma expressão permanente do imperador, criando, conforme Paul Zanker (1988), uma espécie de palco arquitetônico no qual ele se fazia lembrar constantemente a todos os moradores da cidade. Lembrança visual que não se esgotava nos aspectos arquitetônicos; fazia-se também presente nas representações pictóricas, nas estátuas espalhadas alhures e nas moedas com sua efígie, as quais circulavam em toda parte. Em suma, era uma linguagem visual, surgida no contexto das formas de se homenagear o imperador, vindo a desembocar num sistema de comunicação no qual se integravam as imagens e o simbolismo do império.

A remodelação do espaço físico afetou as identidades das cidades. Os estudos arqueológicos dos espaços religiosos da cidade grega (Cf. ÉTIENNE, MÜLLER, PROST, 2000) têm apontado uma relação entre templos e sociedade: uma vez que suas construções envolviam boa parte da população e, sobretudo, as autoridades da cidade, eles encarnam uma imagem determinada que a cidade intenta mostrar de si mesma, de acordo com sua ideologia e sua história. Esses monumentos de natureza religiosa eram um dos lugares privilegiados de memória, pois exprimiam, através de suas pinturas, esculturas (estatuária e baixos-relevos) etc., mitos, lendas e tradições locais em torno dos quais se estabeleciam os traços identitários das cidades. Nesse sentido, as cidades da Ásia 


\section{Poder e religião na Ásia Menor: o culto imperial}

Menor exprimiam suas identidades pela preservação das tradições gregas, estabelecendo cultos antigos, usualmente envolvendo deuses do Olimpo, mas atualizados por mitos e lendas locais que os relacionam à fundação da cidade, a exemplo do culto de Ártemis em Éfeso (Cf. OSTER, 1990).

Diante da nova cena, entretanto, em que o imperador tem um papel importante, as cidades já não podem ter o sentimento de pertença de antes. Como interpretar essa situação? Deixaram os gregos de serem gregos? Tornaramse romanos? Não, de modo nenhum! Esse tipo de mudança não precisa necessariamente ser explicado através de polaridades com romanos de um lado e gregos de outro; trata-se de um processo de interação entre a cultura grega e a romana. Ambas se modificam nesse contato: assim como as cidades gregas foram modificadas, Roma não é mais a mesma: o imperador também teve de manter a organização política das cidades e adaptar seu culto aos cultos dos reis helenísticos pré-existentes. A questão não se colocava mais em termos de ser grego ou romano, mas sim em como, de modo paradoxal, permanecer grego tornando-se romano. Identidades não são exclusivas, mas combinatórias (Cf. WOOLF, 1994; 1997). Como ressalta Maurice Sartre (2007), em numerosas cidades da Ásia Menor, a identidade grega já era dupla: as cidades se tomam ao mesmo tempo por gregas e por gálatas, lídias, lícias, frígias etc. Não há dúvida de que a dominação romana as forçou a assumirem uma nova identidade, pois, Roma deveria incitar as cidades das províncias a se sentirem "romanas". Todavia, tratase de uma identidade suplementar, que se agrega às já existentes e as modifica. Assim, a identidade grega das cidades da Ásia Menor foi se modificando pouco a pouco e em ritmos diferentes conforme os lugares e seus contextos. Como Roma nunca procurou impor sua cultura, as cidades puderam se sentir romanas sem o ser culturalmente.

\section{Reações adversas: o caso do Apocalipse}

No processo de elaboração identitária, o sentimento partilhado de pertencer a um determinado grupo realiza-se a partir do defrontamento com o outro e as identificações podem ser de aceitação ou de rejeição. Nesse sentido, a dinâmica da participação promovida pelo culto imperial teve o êxito de conseguir que o mesmo pudesse ser assimilado e de gerar, de modo geral, a coesão. Entretanto, o culto imperial, como uma representação do poder, causou naturalmente reações adversas. Esse nos parece ser o caso de João e sua audiência no livro neotestamentário do Apocalipse.

Escrito numa linguagem metafórica e mitológica o livro impõe dificuldades para sua interpretação. Não há como fazer assertivas categóricas sobre a identidade de seu autor e de seu público, a data, o conteúdo temático e a finalidade da obra. Em seu texto (Cf. Bíblia de Jerusalém, 1992), o autor se nomeia 
"João" e alega ter recebido uma "revelação" (N.T. Apoc. 1.1), quando se encontrava na ilha de Patmos no mar Egeu (N.T. Apoc. 1.9); sua audiência, ao que tudo indica, constitui-se das igrejas localizadas em cidades da Ásia Menor: "João, às sete Igrejas que estão na Ásia"; "Escreve o que vês, num livro, e envia-o às sete Igrejas: Éfeso, Esmirna, Pérgamo, Tiatira, Sardes, Filadélfia e Laodicéia” (N.T. Apoc. 1.4 e 11). João era tido por essas igrejas como um profeta e, segundo a tradição eclesiástica, era da igreja de Éfeso. Considerando-se elementos internos e externos ao texto, a datação mais aceita recai na última década do século I d.C. (Cf. KÖSTER, 1995).

No início do livro, João dirige-se a cada uma dessas igrejas por missivas (Cf. N.T. Apoc. 2.1-3.22) que têm a finalidade comum de exortá-las a permanecerem perseverantes face às perseguições, tribulações, sofrimentos e conflitos pelos quais estão passando. No decorrer do livro, as visões das duas bestas apresentam o mesmo clima hostil às suas comunidades:

Vi então uma Besta que subia do mar. [...] E o Dragão Ihe entregou seu poder, seu trono, e uma grande autoridade. [...] Cheia de admiração, a terra inteira seguiu a Besta. [...] E adorou a Besta dizendo: "Quem é comparável à Besta e quem pode lutar contra ela? [...] Deram-lhe permissão para guerrear contra os santos e vencê-los; e foi lhe dada autoridade sobre toda tribo, povo, língua e nação. [...] Se alguém tem ouvidos, ouça: "Se alguém está destinado à prisão, irá para a prisão; se alguém deve morrer pela espada, é preciso que morra pela espada". Nisso repousa a perseverança e a fé dos santos (N.T. Apoc. 13.1-10).

Vi depois outra Besta sair da terra. [...] Toda autoridade da primeira Besta, ela exerce diante desta. E ela faz com que a terra e seus habitantes adorem a primeira Besta. [...] Ela seduz os habitantes da terra, incitando-os a fazerem uma imagem em honra da Besta [...]. Foi-lhe dado até mesmo infundir espírito à imagem da Besta, de modo que a imagem pudesse falar e fazer com que morressem todos os que não adorassem a imagem da Besta (N.T. Apoc. 13.11-18).

Há, portanto, uma autoridade externa às comunidades, fisicamente ausente, porém presentificada por uma imagem, e outra autoridade interna que Ihe promove o culto. João rechaça ambas as autoridades, bem como o culto à primeira, e exorta às igrejas a tomarem a mesma atitude. Sua recusa advém do conflito que se estabelece em sua noção de poder, a qual está intimamente ligada à sua crença religiosa. Desde o início, no endereçamento das cartas, ele diz escrever da parte de Deus e de Jesus Cristo, "o Príncipe dos reis da terra" e ao qual "pertencem a glória e o domínio" (N.T. Apoc. 1.5-6). Deus é "aquele que está sentado no trono" e Jesus Cristo é o "Cordeiro imolado", aos quais "pertencem o louvor, a honra, a glória e o domínio" (N.T. Apoc. 5.13). Na concepção de João, eles 


\section{Poder e religião na Ásia Menor: o culto imperial}

são, portanto, os únicos detentores de autoridade para governar e somente eles merecem ser cultuados.

Apesar desses elementos, as tentativas de especificar a quem concretamente João se opõe configuram-se num verdadeiro campo de embates. A relação com o culto imperial é geralmente posta em pauta, ora para defender, ora para refutar. Leonard L. Thompson (1990) está entre os que entendem não ter o culto imperial um papel no livro do Apocalipse. Os cristãos, de modo geral, recusariam participar de qualquer culto, inclusive aí o imperial, que não fosse o de seu deus. O cristianismo compunha-se de diversos grupos na Ásia Menor, sendo que somente o de João é hostil à cultura urbana, contratando com aqueles ligados a Paulo ao autor de Atos dos Apóstolos, que são abertos à inter-relação com seu contexto social. Não houve, nessa região, opressão ou perseguição generalizada aos cristãos como João dá a entender. Esses conflitos são frutos de sua visão de mundo:

Ele antecipa o conflito, o qual decorre de sua posição fundamental de que a Igreja e o mundo pertencem a forças antitéticas. Em outras palavras, João estimula sua audiência a se ver em conflito com a sociedade, um conflito que é uma parte de sua visão de mundo (THOMPSON, 1990, p.174).

Um dos principais defensores da conexão do Apocalipse com o culto imperial, Stephen J. Friesen (1995; 2001) argumenta que o livro deve ser compreendido em seu contexto local como parte das lutas de ideologias religiosas, pois ele representa um ataque contra questões fundamentais da organização social na Ásia Menor do final do primeiro século d.C.

Quando a Ásia Menor tornou-se uma província romana, foi instituído um Concílio (koinon) provincial, constituído de pessoas importantes que representavam as cidades. Tinha uma jurisdição limitada, mas era responsável pela administração dos cultos imperiais e indicava o sumo sacerdote a cada ano. Levando esse dado em conta, alguns autores propuseram que a Besta que vem da terra, à qual João se opõe, fosse esse Concílio. Friesen, por seu turno, apoiado nos estudos arqueológicos, sobretudo, das inscrições gravadas nos templos, prefere pensar que a Besta é uma referência de João a todos que atuam no que denomina de a rede de instituições sócio-religiosas, promovidas pela instalação do culto imperial, incluindo o Concílio, representantes municipais, os sacerdotes responsáveis pelo culto local, entre outros.

Isso faz ainda mais sentido, se levarmos em conta que a materialidade do culto imperial manifestava-se nos templos instalados com essa finalidade em várias cidades, inclusive algumas das mencionadas por João. O Concílio provincial foi encarregado de três cultos imperiais: o primeiro, por volta de 27 a.C., estabeleceu em Pérgamo, dedicado à deusa Roma e a Augusto; depois, aproximadamente cinqüenta anos mais tarde (cerca de 26 d.C.), outro em 
Esmirna, dedicado a Tibério, Lívia, sua mãe e esposa de Augusto, e ao Senado; por fim, em 90 d.C., dedicou, em Éfeso, um templo imperial aos Sebastoí (lat. Augustii), isto é, a vários imperadores, com a finalidade de incluir juntamente com imperador Domiciano e sua esposa Domícia, os já falecidos, Vespasiano e Tito.

Considerando que Éfeso era a metrópole da província e que o Sebastéion e o Apocalipse são da mesma época, Friesen estabelece um vínculo entre eles. Nesse sentido, entende que, ao denunciar o culto imperial, João não ataca um fenômeno religioso marginal, pois o mesmo desempenhou, cada vez mais ao longo do tempo, um importante papel na sociedade, afetando-a em muitos níveis.

Como já expressamos acima, com respeito ao livro do Apocalipse devemos evitar afirmações de cunho categórico. Thompson tem razão ao afirmar que o cristianismo era constituído de diversos grupos, entre os quais o de João era um caso à parte, e que não há evidências de uma perseguição generalizada contra os cristãos; mas, sua proposta de que João antecipa futuros conflitos como resultado de sua visão de mundo é tanto quanto imaginativa. Ainda que não nos seja mais possível explicar essa questão, se João esperava da parte de sua audiência anuência às idéias, algum vínculo com a realidade elas haveriam de ter. $\mathrm{A}$ proposta de Friensen é mais sedutora, pois estabelece um contexto histórico e social verossímil para a ambientação do Apocalipse. O culto imperial não foi um fenômeno religioso marginal; pelo contrário, marcou e influenciou toda a sociedade, inclusive João e sua audiência. Sua interpretação da Besta que vem da terra é coerente com o ambiente do culto imperial, mas não deixa de ser apenas uma hipótese.

Seja como for, o que podemos tomar como certo é que João representa uma voz real e destoante no interior da sociedade mais ampla, que se faz ouvir nas cidades às quais se dirige, entre as mais importantes da província.

\section{Conclusão}

À luz das pesquisas atuais, o culto imperial não pode mais ser tomado como um fenômeno religioso superficial ou marginal na vida social das cidades provinciais; muito ao contrário, foi um elemento integrante e essencial da realidade do império romano. Esfera marcada pelo encontro e pela união de poder e de religião, o culto imperial esteve a estruturar o tecido social e a construir perfis identitários. Contribui, portanto, de forma significativa, para que se possa estudar e verificar a diversidade social, cultural e das relações de poder, não só na província da Ásia Menor, da qual nos ocupamos, mas também nas demais regiões do império romano onde se instalou. 
Poder e religião na Ásia Menor: o culto imperial

\section{Agradecimentos}

Agradecemos aos seguintes colegas: André Leonardo Chevitarese, John Collins, Gabriele Cornelli, Roland Étienne, Renata Senna Garraffoni, Paulo Nogueira, Monica Selvatici, Glaydson José da Silva e Greg Woolf. Mencionamos o apoio institucional da UNICAMP, da UNIFESP, do CNPq e da FAPESP. A responsabilidade pelas ideias restringe-se aos autores.

\section{Documentação}

BÍBLIA DE JERUSALÉM. São Paulo: Paulinas, 1973. Nova edição revista, 1992.

\section{Referências bibliográficas}

CHEVITARESE, A.; CORNELLI, G.; SELVATICI, M. Jesus de Nazaré, uma outra história. São Paulo : Annablume/FAPESP, 2006.

ÉTIENNE, R.; MÜLLER, C.; PROST, F. Archéologie historique de la Grèce antique. Paris: Ellipses, 2000.

FRIESEN, S. J. The Best from the land: Revelation 13:11-18 and social setting. In: BARR, D. L. (Ed.). Reading the book of Revelation: a resource for students. Atlanta: Society of Biblical Studies, 2003. p. 49-64.

FRIESEN, S. J.Imperial cults and the Apocalypse of John: reading Revelation in the ruins. Oxford: Oxford University, 2001.

FRIESEN, S. J.The cult of the Roman emperors in Ephesos: temple wardens, city titles, and the interpretation of the Revelation of John. In: KÖSTER, H. (Ed.). Ephesos metropolis of Asia: an interdisciplinary approach to its archaeological, religion, and culture. Valley Forge: Trinity, 1995. p. 229-250.

FUNARI, P.P.A. Gregos. Religiões que o mundo esqueceu, São Paulo: Contexto, 2009, p. 4152.

FUNARI, P.P.A.; SILVA, G.J. Teoria da História. São Paulo: Brasiliense, 2009.

GARRAFFONI, R.S. Gladiadores na Roma Antiga. São Paulo: Annablume/Fapesp, 2010.

KÖSTER, H. Introduction to the New Testament: II, History and literature of Early Christianity. New York; Berlin: Walter de Gruyter, 1982. $2^{\text {nd }}$ ed., 1995.

MITCHELL, S. Anatolia: land, men and Gods in Asia Minor. I, The Celts in Anatolia and the impact of Roman rule. Oxford: Clarendon, 1995.

NOGUEIRA, P.; FUNARI, P.P.A.; COLLINS, J. Identidades fluidas no Judaísmo e Cristianismo antigos. São Paulo: Annablume/FAPESP, 2010.

OSTER, R. Ephesus as religious center under the Principate. I, Paganism before Constantine. In: HAASE, W. (Hrsg.). Aufstieg und Niedergang der römischen Welt, II - Geschichte und kultur Roms im Spiegel der neueren Forschung. Prinzipat, 18.3 - Religion (Heidentum: die religiösen Verhältnisse in den Provinzen [Forts.]). Berlin; New York: Walter de Gruyter, 1990. p. 1661-1728.

PRICE, S. R. F. Rituals and power: the Roman imperial cult in Asia Minor. Cambridge: Cambridge University, 1984.

RAGO, M.; FUNARI, P.P.A. Subjetividades Antigas e Modernas. São Paulo: Annablume/FAPESP, 2009.

SARTRE, M. Romanization en Asie Mineure? In: URSO, Gianpaolo (a cura di), Tra Oriente e Occidente. Indigeni, greci e romani in Asia Minore. Atti del convegno internazionale. 
José Geraldo Costa Grillo e Pedro Paulo A. Funari

Cividale del Friuli, 28-30 settembre 2006. I convegni dela Fonazione Niccolò Canussio, 6. Pisa: ETS, 2007. p. 229-245.

THOMPSON, L. L. The book of Revelation: Apocalypse and empire. Oxford: Oxford University, 1990.

WOOLF, G. Becoming Roman, staying Greek: culture, identity and the civilising in the Roman East. Proceeding of the Cambridge Philological Society, 40, p. 116-143, 1994.

WOOLF, G. Beyond Romans and natives. World Archaeology, 28, p. 339-350, 1997.

ZANKER, P. The power of images in the Age of Augustus. Ann Arbor: University of Michigan, 1988. 



\title{
CONTROVÉRSIAS NA IDENTIDADE CRISTÃ SEGUNDO EUSÉBIO DE CESAREIA, EM HISTÓRIA ECLESIÁSTICA*
}

\author{
Edalaura Berny Medeiros \\ Fábio Vergara Cerqueira \\ Universidade Federal de Pelotas - Brasil
}

\begin{abstract}
Escrever a História, ou construir um discurso sobre o passado, é sempre um ir ao encontro das questões de uma época. A História se faz como uma resposta a perguntas e questões formuladas pelos homens em todos os tempos. Ela é sempre uma explicação sobre o mundo, reescrita ao longo das gerações que elaboram novas indagações e elaboram novos projetos para o presente e para o futuro, pelo que reinventam continuamente 0 passado. (PESAVENTO, 2005, p.59)
\end{abstract}

A influência do cristianismo na cultura ocidental é inegável. Em que pese a grande mudança verificável no comportamento do homem do século $\mathrm{XXI}$, em matéria de religiosidade, não há como ofuscar o fato de que somos profundamente marcados pelos conceitos e orientações fornecidos pela corrente judaico-cristã triunfante. Estamos nos referindo à facção judaica seguidora do nazareno Jesus, a qual nasceu no século I, cresceu no contexto do Império Romano e atingiu o seu ápice político em 380, sob Teodósio (347-395), com a derrota do último líder da oposição pagã, Nicômaco Flaviano (VÍLCHEZ, 2012, p.33).

O desenvolvimento do cristianismo foi tramado por constantes e sucessivos embates de cunho político-religioso ${ }^{1}$. Aqui é importante frisar que no Império Romano não havia uma distinção muito clara entre questões políticas e religiosas, pois tudo era do interesse do imperador, que cumulava com suas atribuições políticas o cargo de líder religioso (pontifex maximus). Portanto, quando nos referimos à união que se deu entre religião cristã e política romana,

\footnotetext{
* O presente artigo resulta da adaptação da Dissertação de Mestrado apresentada ao Programa de Pós-Graduação em História da Universidade Federal de Pelotas no ano de 2012, sob orientação do Prof. Dr. Fábio Vergara Cerqueira.

${ }^{* *}$ Mestre e licenciada em História e bacharel em Direito pela UFPel. E-mail: edalaura@hotmail.com. Agradeço imensamente a confiança e colabolação dos demais organizadores, em especial, meu orientador de mestrado, bem como o inestimável auxílio dos Professores Dr. a Monica Selvatici e Dr. Gilvan Ventura da Silva.

${ }^{* * *}$ Professor Associado II do Departamento de História da UFPel. fabiovergara@uol.com.br
} 


\section{Controvérsias na identidade cristã segundo Eusébio de Cesareia}

estamos tratando da entrada definitiva das concepções cristãs na maneira de organizar e pensar as questões políticas ${ }^{2}$.

Voltando ao que se refere às ideias que triunfaram ao longo da história da igreja, percebemos que elas efetivamente ostentam o mérito de vitoriosas, pois, em boa parte, foram cunhadas através de imensos debates teóricos, filosóficos e religiosos. Em outras palavras, a análise da história da igreja nos permite visualizar um permanente esforço de reafirmação de poder e de hegemonia sobre a interpretação das sagradas escrituras ${ }^{3}$.

Um excelente exemplo de embate interno, que transparece o esforço de reafirmação de uma corrente teórica através discurso, está na Carta de Paulo aos Gálatas, redigida entre os anos de 54-55. Nela, o apóstolo se reporta enfurecido contra os pregadores que defendiam a prática da circuncisão e dos demais dispositivos da lei judaica, contrapondo a essa "justificação pelas obras" com o que chama de "justificação pela fé" (BROWN, 2004, p.621-9).

O tema dessa análise versa igualmente sobre controvérsias internas à igreja, todavia, não em seus primeiros anos, mas, no momento particular que exsurgiu do período conhecido como Anarquia Militar, denominado Império Romano Tardio. A Anarquia Militar foi um período de cerca de cinquenta anos (235 - 284) de crise generalizada provocada por problemas sucessórios, doenças e invasões bárbaras. Recebe essa denominação porque, em geral, o trono era ocupado por integrantes do exército. Segundo Ana Teresa Marques Gonçalves (2006, p.188), este período é caracterizado por problemas de diversas ordens, que envolviam crise política, militar, econômica, moral e religiosa. A partir do questionamento e reorganização do cenário social que emerge desse período de crise, verifica-se o nascimento de uma nova organização social, marcada por mudanças inicialmente políticas, com a formação da tetrarquia, por Diocleciano, e, posteriormente, religiosas, com a aproximação verificável entre o cristianismo e a administração imperial iniciada pelo tetrarca e posterior unificador do império, conhecido como o primeiro imperador cristão: Flávio Valério Constantino (272337).

Pretendemos, através das linhas que seguem, lançar um olhar crítico sobre o esforço de um cristão erudito do século IV para propor noções comportamentais aos demais cristãos, através da técnica de delimitação identitária formada pela oposição binária entre dois grupos existentes no Império Romano Tardio: cristãos e pagãos. Com isso, não se pretende ofuscar a importância das comunidades judaicas do período, o fato é que os atritos entre cristãos e pagãos são os que transparecem com mais intensidade na segunda parte da obra utilizada como fonte, onde o autor narra os eventos de sua contemporaneidade. Passemos, pois, à análise do documento suso. 
O objeto de nossa pesquisa é a obra pioneira da historiografia cristã, denominada História Eclesiástica ${ }^{4}$, escrita pelo bispo Eusébio de Cesareia (263339). História Eclesiástica é o livro que narra a história da Igreja, desde sua fundação, com Jesus Cristo, Filho de Deus, e concretização das profecias do Antigo Testamento, até o início do século IV, culminando com a unificação do poder imperial nas mãos de Constantino. Mais precisamente, Eusébio conclui a obra narrando os acontecimentos de 324, quando Constantino derrota o coimperador Licínio. Na introdução à obra, Roque Frangiotti (2000, p.23) assevera que, ao concluir sua narrativa no ano de 324, Eusébio evitou tratar dos episódios que envolveram o Concílio de Niceia, para não expor os conflitos internos à igreja, que motivaram o evento.

Os temas abordados por Eusébio são resumidos por T. Barnes (1981, p.129) da seguinte maneira: a sucessão dos bispos e imperadores; a história interna da igreja; escritores e mestres cristãos; o desenvolvimento da heresia; o destino dos judeus e a perseguição dos cristãos. H. A. Drake (2002, p.356-7) reúne os assuntos em cinco pontos: os bispos das mais famosas sés de cada geração; os trabalhos dos portadores de Palavra de Deus; o destino dos judeus; as heresias; as perseguições e os mártires. Para ele, a escolha dos temas é reveladora dos propósitos do autor: ao invés de tratar de milagres e relíquias, Eusébio se concentrou nos pontos essencialmente institucional e clerical, antecipando, em mais de um século, o princípio que passa a governar a história da igreja: "a igreja está nos bispos". Pela análise da obra, é possível constatar que os olhos de Eusébio estão voltados para os exemplos individuais que pontuaram a história do cristianismo.

Segundo Barnes (1981, p.128), nessa obra, Eusébio estabelece paradigmas identitários para tratar o cristianismo como uma identidade, a partir de novos elementos de coesão, diferente do estabelecimento de uma etnia, língua ou cultura comum. Para Eusébio, os cristãos se diferenciam por constituir uma "raça" moralmente superior. Dessa forma, a história dos cristãos não será a história de guerras e soldados, mas a história do povo que venceu através de uma guerra pacífica, eternizando os ensinamentos de verdade por sua bravura diante do martírio. Drake (2008, p.422), por sua vez, utiliza a expressão cunhada por Benedict Anderson - "comunidades imaginadas" - para definir o grupo cristão, que se autodefinia pela história e conjunto de crenças que partilhavam.

Para Drake (2002, p.356), Eusébio se preocupou com um assunto nunca antes analisado. Portanto, a originalidade da obra repousa em seu próprio objeto, que estimulou a elaboração de um novo método para a organização de registros dispersos e incompletos de povos que não se autodefiniam a partir das tradicionais categorias de identidade política, social ou cultural. Dessa forma, seu pioneirismo, para além da escolha do objeto e do desenvolvimento de um 


\section{Controvérsias na identidade cristã segundo Eusébio de Cesareia}

método próprio para organizá-lo e analisá-lo, encontra-se na criação de características de uma identidade para organizar fatos e eventos dentro de uma ótica particular, a teleológica. Desde o início de sua narrativa, Eusébio deixa evidenciada essa visão finalista dos acontecimentos:

Não quero outro exórdio a não ser o da realização da "economia" de nosso Salvador e Senhor Jesus, o Cristo de Deus. (Eus. HE 1.2)

E aponta, também, sua metodologia:

Colherei nesta espécie de prado espiritual as passagens mais apropriadas dos autores antigos, tentando reuni-las organicamente numa descrição histórica. (Eus. HE 1.4)

Antes da Grande Perseguição (303-313), a obra já estava publicada, mas apenas com os sete primeiros livros (BARNES, 1981, p.128). Os três últimos, Eusébio os escreveu porque sentiu a necessidade de registrar os acontecimentos que presenciou direta e indiretamente no contexto da perseguição de Diocleciano. Sobreviveu a ela porque se refugiou entre Fenícia, Egito e Arábia, onde coletou informações para a sua obra Mártires da Palestina, cuja versão enxuta compõe o livro VIII da HE. Por ocasião da promulgação do Edito de Tolerância, em 311, retornou à Cesareia e foi ordenado bispo em 313. (FRANGIOTTI, 2000, p. 10)

Eusébio utilizou exemplos de cristãos e pagãos para a narrativa dos eventos que presenciou. Essa escolha conferiu contradições à sua exposição, as quais foram sanadas pela lógica de seu discurso, cuja função "didática" faz com que a mensagem de fortalecimento da identidade cristã, pela ótica da formação de identidades por oposição binária, justifique impropriedades, contradições e até mesmo omissões.

Para Kathryn Woodward (2009), é a marcação da diferença que permite a construção de referenciais simbólicos, os quais, dentro de um sistema classificatório de percepção do mundo, constituem uma peça crucial para a construção da imagem do grupo. Tomaz Tadeu da Silva (2009, p.75), por sua vez, assevera que "as afirmações sobre diferença só fazem sentido se compreendidas em sua relação com as afirmações sobre identidade. (...) Assim como identidade depende da diferença, a diferença depende da identidade. Identidade e diferença são, pois, inseparáveis". Para Regina Maria da Cunha Bustamante (2006, p.111), o estudo da diferença depende da análise dos mecanismos utilizados para a formação da unidade social e cultural de um grupo, em um determinado momento histórico. Ou seja, importa na compreensão de que a identidade implica um conjunto de atribuições, próprios de uma época e de um grupo social, que, reconhecendo a pluralidade de sua composição e das inter-relações existentes, passam a se reconhecer e se diferenciar a partir desses contatos. 
Não almejamos elaborar um inventário dos elementos constitutivos da identidade cristã do século IV, mas apenas contribuir para os estudos voltados à análise das obras do nosso autor, lançando luzes sobre os pontos contraditórios de seu discurso. Entendemos que essa contradição não é voluntária e tampouco percebida por Eusébio, mas temos que as questões que serão colocadas foram tangenciais ao interesse do autor com a feitura da obra, qual seja, apresentar aos cristãos as origens remotas de sua religião, sua trajetória e o cumprimento da economia divina, com o fito de fortalecer o sentimento de pertença pelo enaltecimento dos feitos realizados pelos grandes líderes cristãos.

A nova identidade cristã, que transparece no discurso de Eusébio, em certo sentido é responsável pela proposta de uma nova identidade pagã, pois, como assevera Foucault, o discurso de verdade está diretamente relacionado com as instituições de poder.

É justamente a regra que permite que seja feita violência à violência e que uma outra dominação possa dobrar aqueles que dominam. Em si mesmas as regras são vazias, violentas, não finalizadas; elas são feitas para servir a isto ou àquilo; elas podem ser burladas ao sabor da vontade de uns ou de outros. O grande jogo da história será de quem se apoderar das regras, de quem tomar o lugar daqueles que se utilizam, de quem se disfarçar para pervertê-las, utilizá-las ao inverso e voltá-las contra aqueles que as tinham imposto; de quem, se introduzindo no aparelho complexo, o fizer funcionar de tal modo que os dominadores encontrar-se-ão dominados por suas próprias regras. As diferentes emergências que se podem demarcar não são figuras sucessivas de uma mesma significação; são efeitos de substituição, reposição e deslocamento, conquistas disfarçadas, inversões sistemáticas. (FOUCAULT, 1979, p.25-6)

Entendemos que, no discurso de Eusébio, é possível verificar a ocorrência da estigmatização ${ }^{5}$, pois o autor, em sua descrição de ícones dos grupos sociais rivais, transparece um esforço de delimitar elementos positivos inerentes aos cristãos, atentando para os aspectos negativos da alteridade, no caso, os pagãos. Tais contradições, por certo, encontram-se fortemente imbuídas pelo temor de uma reviravolta política, acompanhado da euforia decorrente da recente "virada" na estrutura de poder, que, em uma geração, colocou o cristianismo na condição de portador do discurso de verdade - compreendida nos termos propostos por Foucault:

(...) a verdade não existe fora do poder ou sem o poder. (...) A verdade é deste mundo; ela é produzida nele graças a múltiplas coerções e nele produz efeitos regulamentados de poder. Cada sociedade tem seu regime de verdade, sua "política geral" de verdade: isto é, os tipos de discurso que ela acolhe e faz funcionar como verdadeiros (...) o estatuto daqueles que 


\section{Controvérsias na identidade cristã segundo Eusébio de Cesareia}

têm o encargo de dizer o que funciona como verdadeiro. (FOUCAULT, 1979, p.12)

Focamos nos elementos que compõem a identidade cristã sugerida por Eusébio, que, em nossa opinião, vem expressa nos exemplos de personagens notáveis. Os cristãos são representados como figuras boas em todos os aspectos, enquanto os pagãos são introduzidos como indivíduos menores, inferiores, dados a toda sorte de mau comportamento. Partindo dessa premissa, queremos demonstrar que, no afã de elaborar uma demonstração "didática" da conduta esperada do cristão, assim como de apontar as atitudes reprováveis dos inimigos da fé, Eusébio não identificou qualquer contradição em sua exposição. Frise-se que essa ausência não compromete seu discurso, aliás, qualquer contradição fulminaria o próprio viés totalizante do mesmo. O importante é evidenciar a forma com que os fatos, visivelmente contraditórios, são perfeitamente alinhados à teoria proposta por Eusébio.

Em última análise, compreendemos que a questão de fundo da narrativa, o fato em si, utilizado para ilustrar certa visão de mundo, no caso, uma identidade, acaba em segundo plano, uma vez que o interesse do narrador não é exatamente o registro dos fatos, mas a valorização da identidade de seu grupo.

\section{História Eclesiástica: elementos contraditórios}

Entendemos que Eusébio contribuiu para a elaboração de uma nova identidade, através da delimitação de valores que, no seu entendimento, transpareciam na conduta dos cristãos notáveis, a saber: Constantino e os mártires da Grande Perseguição, dos quais destacamos Orígenes (182-254), fundador da Escola de Cesareia, onde Eusébio recebeu sua formação religiosa. Os mártires foram cristãos que enfrentaram tortura e morte pela fé que professavam, sem permitir que o terror abalasse suas convicções religiosas.

Nos termos propostos por Norbert Elias, o desviante comporta o outsider e o transgressor da norma de conduta interna a uma coletividade:

Afixar o rótulo de "valor humano inferior" a outro grupo é uma das armas usadas pelos grupos superiores nas disputas de poder, como meio de manter sua superioridade social. Nessa situação, o estigma social imposto pelo grupo mais poderoso ao menos poderoso costuma penetrar na autoimagem deste último e, com isso, enfraquecê-lo e desarmá-lo. (ELIAS \& SCOTSON, 2000, p. 24)

$\mathrm{Na} H E$, Eusébio apresenta três tipos de inimigos da fé: os judeus, os hereges e os perseguidores/pagãos. O termo pagão indicava pessoas que viviam no meio rural, nos pagos, alheios aos ensinamentos cristãos. Por esse motivo, a palavra passou a servir como designação indiscriminada para aquele que não era 
cristão, abarcando as diversas religiões politeístas, e criando, assim, um "rótulo" para sua alteridade, como prescreve Silva:

A exclusão se converte num fenômeno social mais complexo e turbulento, no entanto, quando ela não apenas dá margem à categorização dos grupos sociais, mas quando tal categorização é acompanhada de uma intensa carga valorativa informada, o mais das vezes, por concepções extraídas do senso comum, manipulando-se assim os princípios de classificação e divisão social com o propósito de submeter um grupo e/ou indivíduo, de situá-lo numa posição subalterna, o que acarreta, em contrapartida, o reforço dos códigos de conduta do grupo que opera esse tipo de distinção. Em suma, a exclusão exprime a sua face mais perversa quando ela é acompanhada por um processo de estigmatização, ou seja, pela atribuição de rótulos visando, por um lado, a minar a identidade daqueles que são excluídos e, por outro lado, a intensificar o carisma daqueles que possuem autoridade para excluir (...). (SILVA, 2009, p.23)

A primeira contradição na narrativa de Eusébio é localizada por Andréia Cristina Lopes Frazão da Silva: Eusébio omite o fato de as perseguições aos cristãos decorrerem de iniciativas do poder imperial, logo, do Estado. Para ela, Eusébio não reconhece qualquer incompatibilidade entre igreja e Império. Vejamos:

Para a $H E$, as perseguições aos cristãos sempre foram fomentadas pelos inimigos da fé cristã, incluindo as iniciativas de alguns imperadores maus. Mas os mártires cristãos suportaram os sofrimentos e mantiveram intacta a revelação de Cristo, conquistando o reconhecimento da população e dos próprios imperadores. Ou seja, os relatos das perseguições foram um dos argumentos apologéticos utilizados na $H E$ para demonstrar que a Igreja cristã do século IV, purificada pelo sofrimento, representava a religião verdadeira. (FRAZÃO, 2008, p.2)

Assim, Eusébio realiza uma individualização do oponente, apontando cada um dos imperadores favoráveis às perseguições como os verdadeiros inimigos da fé cristã. A concentração da reprovação na figura do imperador, e a sua desqualificação moral, afasta a atenção da possibilidade de que as perseguições representem a manifestação de uma sociedade enfurecida e contrária às práticas cristãs. Em outras palavras, ao manter o foco em um imperador específico, este responde exclusivamente pelos atos intentados contra os cristãos.

Dentro do argumento colocado por Frazão, é possível localizar ainda uma segunda contradição: a dupla condição do mártir, que sustenta, ao mesmo tempo, a qualidade de cristão fervoroso, exemplo de fé, mas também sofre as humilhações de uma morte tormentosa e, muitas vezes, sem herdeiros. A situação do mártir contradiz a teoria de Eusébio na qual associa a morte infausta 


\section{Controvérsias na identidade cristã segundo Eusébio de Cesareia}

e sem herdeiros dos imperadores inimigos do cristianismo ao castigo por uma conduta reprovável em vida. Vejamos:

Ao invés de seu predecessor Constâncio, ótimo e suavíssimo imperador, que exercera dignamente o poder, durante todo o reinado, e tendo se mostrado, aliás, muito acolhedor e beneficente para com todos (de fato, manteve-se alheio à luta contra nós, preservou de dano e vexações os súditos, adoradores de Deus, não destruiu as igrejas e nada absolutamente empreendeu contra nós), recebeu a recompensa de um fim de vida realmente feliz e três vezes abençoado e, ao morrer, foi o único a deixar feliz e gloriosamente o império a seu filho legítimo, sucessor no poder, em tudo prudente e piedoso. (Eus. HE 8, Ap.4)

Como é possível depreender pela análise da transcrição acima, Constantino teve morte tranquila e com herdeiros, graças à boa conduta em vida. Encontramos em Constantino uma terceira contradição, que reside na omissão de suas práticas reprováveis e na exacerbação dos atos idênticos praticados pelos imperadores inimigos da fé. Antes de tratar de Constantino, passemos à análise dos relatos das mortes dos demais imperadores.

O final trágico dos imperadores inimigos do cristianismo, a vitória e as qualidades cristãs de Constantino, são assuntos recorrentes nos livros VIII e IX. Estabelecendo um paralelo entre a conduta reprovável em vida em contraponto com a situação de morte, Eusébio relata o final dos imperadores pagãos, pois, para ele, "não convém passar sob silêncio qual o termo da vida de todos eles" (Eus. HE 8, Ap.1). São eles: Maximino, que "pereceu de morte vergonhosa", sob Licínio (Eus. HE 8.13.15); Maxêncio, que padece sob as tropas de Constantino, nas cercanias de Roma, recebendo um Salmo na narrativa de sua morte, "Ele cava e aprofunda um buraco, mas cai na cova que fez. Sua maldade se volta contra a cabeça, sobre o crânio the cai a própria injustiça" (SI.7.16-17 apud Eus. HE 9.9.6); Licínio, que governava o Oriente, dividindo o Império com Constantino, imperador do Ocidente, e que, segundo Eusébio, foi "atacado de demência", perdendo o poder para Constantino (Eus. HE 9.9.1); e, por fim, Galério, o "primeiro responsável da desastrosa perseguição e muito antes da entrada em ação dos outros imperadores" (Eus. HE 8, Ap.1), cuja fatal enfermidade mereceu uma descrição pormenorizada, digna de transcrição, tanto na $H E$ quanto na obra biográfica do imperador, também de autoria de Eusébio, denominada Vida de Constantino ${ }^{6}$ (340-341):

Com efeito, de repente brotou um abcesso nas partes mais escondidas do corpo; depois uma úlcera profunda com fístula, e esses males incuráveis corroeram-lhe as entranhas, onde formigava uma quantidade enorme de vermes; elas exalavam um cheiro pestilento. Toda a corpulência resultante da gula e que antes da moléstia comportava dobras de excessiva gordura, 
Edalaura Berny Medeiros e Fábio Vergara Cerqueira

pôs-se a apodrecer e oferecia aos circunstantes um espetáculo intolerável e assustador.

Dentre os médicos, uns não puderam de forma alguma suportar o estranho e intenso mau cheiro, e foram degolados; outros, impotentes para aliviar todo esse inchaço, para o qual não restava possibilidade de salvação, sem compaixão foram mortos. (Eus. HE 8.16.4-5)

O caso de Galério também merece de nossa parte uma atenção especial. Para Eusébio, as chagas suportadas pelo imperador constituíam um castigo de Deus, pelos males impostos aos cristãos. Dessa maneira, Galério teria promulgado o Edito de Tolerância, em 311, para se reconciliar com o Deus dos cristãos. Então, no apêndice do oitavo livro, Eusébio narra que o imperdador, após o Edito, "logo se viu livre de suas dores, mas por breve tempo, e morreu." (Eus. HE 8, Ap.1)

O interesse em relatar o final trágico dos perseguidores do cristianismo é verificável nos escritos de Eusébio, assim como de Lactâncio (240-320), que redigiu uma obra denominada $A$ morte dos perseguidores. Ambas as iniciativas associam o sofrimento da morte dos perseguidores a um castigo de Deus pela postura que assumiram, como inimigos do cristianismo (DRAKE, 2002, p.359). Mas, como já mencionado, os mártires também passaram por morte ignominiosa, o que, num primeiro momento, contradiz a teoria do castigo divino pessoal. Ou seja, os mártires, que, em Eusébio assumem a condição de exemplos de conduta cristã, são assim reconhecidos e enaltecidos justamente por padecerem de morte sofrida.

Eusébio foi testemunha ocular de alguns martírios, registrando-os com riqueza de detalhes em sua obra. Para que possamos apreciar o teor de sua narrativa, transcrevemos o seguinte excerto, no qual relata o martírio de cristãos na Tebaida:

Nós mesmos vimos, estando no próprio local, grande número de mártires sofrerem juntos, num só dia, uns a decapitação, outros o suplício do fogo, de tal forma que se o ferro mortífero ficava embotado e gasto era esmigalhado e os próprios carrascos, fatigados, alternavam-se uns aos outros.

Então, contemplamos o admirável ardor, o poder verdadeiramente divino, a coragem dos que acreditaram no Cristo de Deus. Pois, enquanto se pronunciava a sentença contra os primeiros, alguns acorriam de outro lado para o tribunal, diante do juiz. Declaravam-se cristãos, sem se inquietarem por causa dos tormentos nem das diversas espécies de suplícios aos quais se expunham; mas falavam com inteira liberdade, corajosamente, da religião do Deus do universo e recebiam alegres, risonhos, bem-humorados a sentença final de morte, cantando hinos e dando graças ao Deus do universo até o último suspiro. (Eus. HE 8.9.4-5) 


\section{Controvérsias na identidade cristã segundo Eusébio de Cesareia}

Na contramão da individualização do inimigo, portanto, há a generalização da Igreja, ou seja, os mártires, enquanto exemplos de fé, não podem ter sido merecedores de suas mortes trágicas. Dessa maneira, o mártir seria aquele que paga pelos erros de todos os cristãos. Para melhor explicitar essa questão, devemos analisar o teor do seguinte trecho, que consiste numa espécie de introdução à segunda parte da obra, quando Eusébio passa a narrar os acontecimentos de seu tempo:

Ultrapassa nossas forças expressar de modo adequado a grandeza e a
qualidade do respeito e da liberdade de que, antes da perseguição
contemporânea, usufruía a pregação da religião do deus do universo,
anunciada por Cristo a todos os homens, gregos e bárbaros, a fim de ser
vivida. (...)
Mas, a inteira liberdade degenerou em relaxamento e descuido, nós nos
invejávamos, injuriávamos mutuamente, e quando havia oportunidade,
pouco faltava para que nos combatêssemos com as armas, ou com as
lanças das palavras; os chefes em desavença com os chefes, o povo contra
o povo. A maldita hipocrisia e a dissimulação haviam atingido o mais alto
grau de malícia. Então, como habitualmente, o juízo de Deus, que
governava com suavidade e medida, era protelado (ainda se reuniam as
assembleias). Foi entre irmãos que pertenciam ao exército que começou a
perseguição. (Eus. HE 8.1.1.7)

Ou seja, foi o mau comportamento dos cristãos, em tempos de paz, que provocou a ira de Deus, ocasionando as perseguições de sua contemporaneidade. Nessa ótica, Eusébio teria evitado relacionar a morte trágica dos mártires com eventual conduta pregressa reprovável, mas estende a responsabilidade a toda a coletividade dos cristãos.

Para Eusébio, os mártires são os cristãos mais perfeitos e completos, pois, com sua coragem, não se deixavam dobrar, mesmo sob graves torturas. Não negavam a fé, garantindo, portanto, a salvação eterna e demonstrando, com seu sacrifício, o valor e a verdade do cristianismo. Desta forma, o autor descreve diversos martírios, ressaltando detalhes, muitas vezes macabros, com o objetivo, sobretudo, de demonstrar que todo aquele sofrimento não foi em vão; ao fim, a Igreja alcançara a vitória (FRAZÃO, 2008, p.15).

Dessa maneira, Eusébio evitou macular a imagem do mártir deitando suspeita sobre sua conduta pregressa. Além da morte tormentosa, a morte sem herdeiros também era negativa. Nesse ponto, também é possível verificar incoerência, bastando uma breve análise da trajetória do mártir mais admirado por Eusébio: Orígenes. Além de padecer sob martírio, ao que se sabe, Orígenes morreu sem herdeiros, pois realizou autocastração quando ainda era jovem, o que gerou muitas críticas na época (BARNES, 1982, p.84). 
Em contraposição à narrativa da vida dos imperadores inimigos do cristianismo, Eusébio se refere a Constantino como um grande homem e grande imperador.

Foi certamente desta forma que o rei soberano, Deus do universo e Salvador, contra tiranos muito ímpios, suscitou Constantino, (...) foi imperador, filho de imperador, piedoso, oriundo de pai piíssimo e sapientíssimo (...) (Eus. HE 9.9.1)

Drake afirma que Constantino não foi retratado como o habilidoso negociador, paciente construtor de consensos e ardente reformador judicial, senão através de breves referências. Pelo contrário, Constantino é retratado como um filho da Igreja, inteiramente voltado para erradicar a sujeira dos ímpios. A deliberada descrição do imperador demonstra que era do interesse de nosso autor promover certas ideias a respeito do cristianismo através da descrição de seus principais, no caso, o imperador. Ocorre que sua narrativa, como qualquer outra, não é despida de interesse e, para Drake, Eusébio escolhe o que lhe parece mais importante para dar significado à trajetória do imperador, de acordo com seu próprio esquema conceitual. (2002, p.357-358)

Segundo Drake (2002, p.359), os cristãos enquadravam todos os acontecimentos em seu modo explicativo, o que implicava em um viés óbvio em suas narrativas. Afirma que Eusébio não está fora dessa situação e aponta outras contradições, sintetizando-as nos seguintes tópicos: o primeiro dos tetrarcas a morrer não foi nenhum dos inimigos da fé, mas Constâncio I, o pai de Constantino, que teve pouca participação nas perseguições aos cristãos; afirma que aqueles que ergueram as mãos contra Deus morreram sem herdeiros, enquanto Constâncio I e Constantino os tiveram em abundância, mas omite que Constantino mandou matar seu primogênito Crispo (e sua esposa Fausta), e, o que Eusébio já não presenciou foi que, apesar de ter deixado três filhos, aquele que subiu ao trono alguns anos depois foi um de seus dois sobrinhos, Juliano, que era contrário ao cristianismo; e, por fim, outra contradição que a história vindoura revelará, a queda do Império Romano nas mãos dos inimigos, destino evitado pelos pagãos por um milênio. Para Drake (2002, p.359-360), os cristãos ignoraram tais reveses em suas narrativas, mantendo o foco no que lhes era interessante para justificar seu ponto de vista. Mas afirma que não é por isso que Eusébio deixou de estar comprometido com a narrativa da verdade, pois sua manifestação resulta do esforço para elucidar o sentido implícito da história.

As arbitrárias omissões de Eusébio sobre Constantino foram entendidas por Burckhardt, no século XIX, como desonestidade (DRAKE, 2002, p.357). Martín Garruchaga (2010, p.63), autor da introdução à obra Vida de Constantino, de Eusébio de Cesareia, por sua vez, afirma que o bispo não possuía grande discernimento acerca das forças que compunham seu cenário social, o que o 


\section{Controvérsias na identidade cristã segundo Eusébio de Cesareia}

impossibilitava de entender a conjuntura de sua época. Ao contrário, concentrouse na contraposição de Constantino aos demais soberanos, adotando a lógica do tirano castigado por Deus. Por fim, critica o estilo de escrita do autor ${ }^{7}$.

Drake (2002, p.351-2) resume o esforço cristão afirmando que seus eruditos nada tinham de obtusos, mas, ao contrário, voluntariamente assumiram o registro dos acontecimentos, atentando para as questões que efetivamente auxiliassem a organizar seu complicado passado ${ }^{8}$. E alerta ainda que, obviamente, Eusébio não escreveu a $H E$ de forma desinteressada, pois apesar de seu apreço pelo uso dos documentos, era seletivo, partidário e tinha a preocupação de interpretar os eventos a partir de seu próprio aparato conceitual. Além disso, informa que a inovação de Eusébio em relação à historiografia clássica grecoromana, que se restringia à narrativa dos eventos do ponto de vista do vício ou da virtude do indivíduo, é que, agora, o vício e a virtude são atribuídos a todo o grupo, enquanto a explicação dada aos acontecimentos, que outrora recaía sobre o destino ou fortuna, agora repousava no pecado e retribuição, pois o vício, para além de um atributo pessoal, traz, agora, a ira de Deus. Tratando o pecado e retribuição como a força motriz da história, Eusébio apresenta uma nova explicação para os acontecimentos, dentro do paradigma da Providência divina (DRAKE, 2002, p.357-362).

Assim, é imensa a contribuição da $H E$ para a sua contemporaneidade, solucionando conflitos internos e externos ao cristianismo com uma explicação global dos acontecimentos históricos. Não podemos olvidar sua importância também para o historiador atual, que, através da análise dessa rica e atraente obra, tem a oportunidade de se colocar mais próximo dos embates que marcaram o complexo contexto da Antiguidade Tardia.

Entendemos que o esforço de enaltecimento do cristianismo estava acima do trabalho de relatar os fatos que davam aporte aos exemplos. Assim sendo, dentro do discurso identitário de Eusébio, as contradições apontadas (ausência de incompatibilidade entre Igreja e Estado - com a individualização do inimigo na figura do imperador e a coletivização dos cristãos, cujos pecados foram pagos pelo sofrimento dos mártires; o mártir como exemplo de conduta e enfrentando, ao mesmo tempo, morte trágica e sem herdeiros, que contrapõe a justificativa do castigo de Deus, com a morte nefasta e sem herdeiros dos imperadores inimigos do cristianismo; deliberadas omissões de Constantino em contraponto com a descrição pormenoroizada das atitudes reprováveis dos imperadores pagãos) são suprimidas em nome de explicação que confere coerência aos acontecimentos, uma explicação que propõe o enaltecimento das figuras cristãs e a depreciação de seus inimigos. 


\section{Considerações finais: a incoerência obscurecida em nome do discurso totalizante}

A transição do paganismo para o cristianismo, no seio do Império Romano, ocorreu de forma gradual, mesmo sob o reinado de um imperador cristão. 0 primeiro, em movimento de declínio, ante o desmantelamento das estruturas políticas e sociais que lhe davam suporte, e o segundo, em franco crescimento, após o término das perseguições e graças às contribuições de Constantino, que se valeu de sua condição de liderança política para suprimir as dissenções internas e fornecer estímulo financeiro e político aos cristãos e seus bispos.

O cristianismo dividia o cenário religioso com o judaísmo e com o conjunto de religiões oriundas das tradições greco-romanas e orientais, denominado paganismo. $\mathrm{O}$ embate entre seus adeptos gerou uma série de conflitos teológicos, morais e políticos, que fomentaram uma extensa produção de textos com ofensas recíprocas, por parte dos líderes religiosos e filósofos.

Graças à atitude dos cristãos frente às perseguições, representada pelos mártires, que enfrentavam corajosamente os suplícios, alguns se entregando voluntariamente às autoridades para receber a pena capital, o cristianismo recebeu grande notoriedade. 0 trabalho dos teóricos cristãos contribuiu para o seu crescimento. Diante das adversidades, o movimento se tornava cada vez mais coeso. Porém, como nosso próprio autor reconhece (Eus. HE 8.8), em períodos de paz, os cristãos voltavam sua atenção para as questões teológicas e comportamentais, promovendo contendas internas. As múltiplas interpretações das Escrituras provocaram desentendimentos entre as lideranças cristãs, os quais dificilmente seriam resolvidos sem a participação de uma grande força externa, a mão imperial.

Portanto, os elementos identitários presentes na $H E$ são utilizados por Eusébio com o evidente propósito de elaborar uma narrativa que responda à necessidade de justificar o cristianismo, um novo elemento de destaque na conjuntura social do século IV. Para a elaboração da primeira parte de sua obra histórica, a qual foi escrita durante a Pequena Paz da Igreja (260 a 303), Eusébio utilizou escritos antigos que remetem à história dos hebreus e dos cristãos. Já, no que concerne aos acontecimentos de sua contemporaneidade, além de carecer de registros reconhecidos e respeitados por sua condição de histórico, como é o caso do Antigo Testamento, a história do cristianismo sofre uma crise, diante das perseguições imperiais. Dessa forma, para empregar coerência à sua retórica, Eusébio elege o sofrimento dos mártires como exemplo de conduta, enaltecendo o sofrimento dos cristãos condenados à morte, e apresentando o imperador cristão como enviado de Deus para a realização da vitória do cristianismo sobre as demais religiões. 


\section{Controvérsias na identidade cristã segundo Eusébio de Cesareia}

Detivemo-nos na comparação traçada entre Constantino e alguns imperadores anticristãos que participaram da Tetrarquia (Maximino, Maxêncio, Licínio e Galério). O enaltecimento da figura de Constantino, através da supressão do registro de suas atitudes reprováveis e pelo enaltecimento de suas qualidades, deixa transparecer um esforço de valorização daquele personagem, que entendemos como um ícone do cristianismo. Assim, pela dificuldade para delimitar os elementos formadores da identidade cristã, nosso autor recorre à narrativa da história desse grupo, que não possuía nenhum elemento aparente de vinculação (étnica, cultural, familiar, ou de outra ordem), senão a crença no Messias. Portanto, a história é utilizada como uma ferramenta para o estreitamento dos laços identitários dessa coletividade, e, por sua vez, os exemplos de personagens notáveis desempenham o papel de ilustrar o comportamento almejado do verdadeiro cristão. O enaltecimento dos feitos realizados pelos personagens selecionados conferia valor à identidade defendida pelo nosso autor. Da mesma forma, a depreciação da alteridade, no caso, o paganismo, aumentava o apreço pela identidade defendida.

Para que sua retórica não se desvie de sua lógica interna, Eusébio empregou valores diferentes na narrativa dos cristãos (o nós) e dos pagãos (o eles). Através da presente análise, foi possível verificar que o sofrimento da morte do cristão é valoroso, enquanto o sofrimento da morte do pagão é o resultado de sua conduta pregressa. Assim, fica em segundo plano a morte com herdeiros, considerada uma dádiva de Deus, quando o alvo da descrição é um mártir cristão, como Orígenes. Vemos, ainda, que, no intento de preservar imaculada a imagem de Constantino para a posteridade, Eusébio, deliberadamente, omite suas atitudes reprováveis. Enfim, para a narrativa dos fatos de sua contemporaneidade, Eusébio lançou mão de exemplos de cristãos em contraposição a alguns exemplos de pagãos, organizando os fatos e valores de forma a se enquadrarem na lógica de seu discurso. Sob esse prisma, é possível localizar um viés pedagógico na narrativa de nosso autor.

Portanto, a narrativa de Eusébio é comprometida com sua realidade, nela o autor demonstra amplo entendimento sobre as questões político-religiosas de seu tempo. Acreditamos que Eusébio possuía grande discernimento de seu contexto histórico, sobretudo da importância da intervenção imperial para a unificação da Igreja, sem a qual o seu crescimento restaria comprometido. O que pode ser considerado como falta de compreensão dos fatos, em verdade consiste na maneira como o autor visualiza e expõe as questões de seu tempo. Em suma, compreendemos que Eusébio, ao escrever a obra objeto de nossa pesquisa, desempenhou aquilo que se propôs, pois pretendia narrar a história da Igreja, destacando a participação de certos personagens (Eus. HE 1.1-2). 
Não ousamos questionar a verdade de suas alegações. Não há dúvida de que se trata de uma obra historiográfica. Eusébio elaborou sua narrativa acreditando na produção de um texto fiel aos acontecimentos selecionados, ou seja, estava comprometido com o registro da verdade, o que é demonstrado pela seleção e transcrição de suas fontes. Quando tratamos de "verdade", nos referimos ao modelo proposto por Foucault (1979, p.12) - "regimes de verdade", ou seja, um discurso que, para aquela coletividade funcionava como verdadeiro.

Tampouco pensamos que haveria de ser diferente. A lógica interna de um discurso totalizante não fornece elementos para a supressão de contradições, haja vista que sequer considera a existência delas. Sustentamos que as controvérsias não são suprimidas pela explicação, pois o discurso, em si, não possui esse condão. Mas, é em nome desse discurso, que Eusébio propõe uma lógica para os acontecimentos históricos, no caso a "economia" de Deus (Eus. HE 1.1-2). Em última análise, se o autor considerar que existam tais incoerências, o próprio esforço de explicação da realidade se esvazia.

Eusébio marcou a história como um verdadeiro porta-voz de seu tempo. Basta compreendermos suas intenções e o modelo de sua narrativa para que possamos usufruir dos elementos que nos permite vislumbrar acerca do contexto em que viveu e produziu. Sendo assim, é indispensável destacar que a presente análise, de nenhuma forma, pretende macular a genialidade de nosso autor. Apenas nos propusemos retornar ao registro de sua contemporaneidade para observar sua compreensão acerca de algumas questões de relevo, estendendo aos estudiosos da antiguidade um novo convite para o estudo do período, através da obra de Eusébio de Cesareia, tão extensa quanto fascinante.

Fontes primárias:

EUSÉBIO DE CESAREIA, História Eclesiástica. Introdução e notas complementares de Roque Frangiotti. São Paulo: Paulus, 2000.

EUSEBIO DE CESAREA, Vida de Constantino. Introducción, traducción y notas de Martín Garruchaga. Madrid: Gredos, 2010.

\section{Referências bibliográficas:}

BARNES, T. Constantine and Eusebius. Cambridge: Harvard University Press, 1981.

BROWN, R. Introdução ao Novo Testamento. São Paulo, SP: Paulinas, 2004.

BUSTAMANTE, M.R. da C. Práticas Culturais no Império Romano: Entre a Unidade e a Diversidade. In: SILVA, G.V. da \& MENDES, N.M. Repensando o Império Romano. Perspectiva Socioeconômica, Política e Cultural. Rio de Janeiro-Vitória: MAUADEDUFES, 2006, p.109-136.

DRAKE, H. A. Constantine and the bishops. London: The Johns Hopkins University Press, 2002.

DRAKE, H. A. The church, society and political power. In: CASIDAY, A. \& NORRIS, F. (orgs.) The Cambridge History of Christianity: Constantine to c. 600. Vol.2. New York: Cambridge University Press, 2008, p.403-428. 


\section{Controvérsias na identidade cristã segundo Eusébio de Cesareia}

ELIAS, N. \& SCOTSON, J.L. Os Estabelecidos e os Outsiders. Rio de Janeiro: Jorge Zahar, 2000.

FOUCAULT, M. Microfísica do Poder. Rio de Janeiro: Edições Graal, 1979.

FRANGIOTTI, R. Introdução e notas complementares. In: EUSÉBIO DE CESAREIA, História Eclesiástica. São Paulo: Paulus, 2000, p. 9-28.

FRAZÃO, A.C.L. Cristãos X Judeus: A intolerância religiosa da Igreja Triunfante. Revista Teológica, Rio de Janeiro, ano 14 (nova fase), n. 17, 1999, p.16-22.

FRAZÃO, A.C.L. Reflexões Sobre os Martírios, a Obra História Eclesiástica de Eusébio de Cesareia e a Hagiografia Cristã. In: Ciclo de Debates em História Antiga. Dialogando com Clio, 18, I 2008, Rio de Janeiro. Anais Eletrônicos do XVIII Ciclo de Debates em História Antiga. Rio de Janeiro: Lhia, 2008. (CD-ROM) p.1-26.

GARRUCHAGA, M. Introducción. In: EUSEBIO DE CESAREA, Vida de Constantino. Madrid: Gredos, 2010, p. 7-121.

GONÇALVES, A.T.M. Os Severos e a Anarquia Militar. In: SILVA, G.V. da \& MENDES, N.M. Repensando o Império Romano. Perspectiva Socioeconômica, Política e Cultural. Rio de Janeiro-Vitória: MAUAD-EDUFES, 2006, p. 175-191.

MEDEIROS, E.B. Constantino e os Cristãos: A Ascensão do Cristianismo como Religião Oficial do Império Romano e o Desenvolvimento da Intolerância. In: CERQUEIRA, F. \& SELVATICI, M. (orgs.). Religião e Poder, do Mundo Antigo ao Moderno: Ensaios Acadêmicos. Pelotas: LEPAARQ/UFPel, p.211-236, 2009.

MOMIGLIANO, A. As Raízes Clássicas da Historiografia Moderna. São Paulo: Edusc, 2004.

PESAVENTO, S.J. História \& História Cultural. Coleção História \& ... Reflexões. 2. ed. 1. reimp. Belo Horizonte: Autêntica, 2005.

ROSA, C.B da. A Religião na Urbs. In: SILVA, G.V. da \& MENDES, N.M., in: Repensando o Império Romano. Perspectiva Socioeconômica, Política e Cultural. Rio de JaneiroVitória: MAUAD-EDUFES, 2006, p.137-159.

SILVA, G.V. Vertentes da intolerância religiosa no Império Romano: o caso dos Judeus. In: CERQUEIRA, F.V.; POZZER, K.M.P.; NOBRE, C.K. (Eds). Fronteiras e Etnicidade no Mundo Antigo. Anais do V Congresso da Sociedade Brasileira de Estudos Clássicos 2003, Pelotas. Canoas: ULBRA, 2005. p.167-178.

SILVA, G.V. Desvio social, exclusão e estigmatização: notas para o estudo da "História dos marginais". Dimensões, UFES, vol. 23 , 2009, p.13-29.

SILVA, T.T. da. A produção social da identidade e da diferença. In: SILVA, T.T. da. et al. (org.) Identidade e Diferença: A Perspectiva dos Estudos Culturais. Petrópolis, RJ: Vozes, 2009, p.73-102.

VÍLCHEZ, F. P. A Tradição e a Sobrevivência das Fontes Gregas e Latinas. In: OLIVEIRA, J.C.M. \& SELVATICI, M. Textos e representações da antiguidade: transmissão e interpretação. Maringá: Eduem, 2012.

WOODWARD, K. Identidade e diferença: uma introdução teórica e conceitual. In: SILVA, T.T. da. et al. (org.) Identidade e Diferença: A Perspectiva dos Estudos Culturais. Petrópolis, RJ: Vozes, 2009, p.7-72. 


\section{Notas}

${ }^{1}$ Sobre o embate social entre correntes religiosas diversas no seio do Império Romano, sugerimos a leitura de BUSTAMANTE (2006) e ROSA (2006).

${ }^{2}$ Sobre a fusão entre o pensamento cristão e a hierarquia imperial romana, um trabalho bastante esclarecedor é SILVA (2005).

3 Em MEDEIROS (2009) buscamos evidenciar alguns aspectos do cristianismo institucionalizado que se distanciaram do ideário primitivo do grupo, sobretudo no que concerne ao esforço de manter o afastamento entre questões temporais e religiosas.

${ }^{4}$ A obra História Eclesiástica, à qual nos referiremos também como $H E$, é a mais conhecida e citada das obras de Eusébio (FRANGIOTTI, 2000, p.23). Foi escrita em duas partes, a primeira é composta pelos sete primeiros livros, que retratam a história do cristianismo, desde o nascimento de cristo até o ano de 303, e a segunda parte, composta pelos três últimos livros, foi registrada especialmente para narrar a atitude dos cristãos durante o período que ficou conhecido como "Pequena Paz da Igreja" (260-303), o descontentamento de Eusébio para com o relacionamento entre os cristãos e a vitória do cristianismo sobre o mundo, através de Constantino. Eusébio também narrou uma série de martírios impingidos durante a Grande Perseguição (303-313), que foi a última perseguição imperial sofrida pelos cristãos. Foi testemunha ocular de muitos martírios, e transcreve-os com riqueza de detalhes em sua obra.

${ }^{5}$ Para compreender essa questão, nos valemos do estudo realizado pelos pesquisadores Norbert Elias e John L. Scotson, que gerou a obra Os Estabelecidos e os Outsiders. A partir da análise sociológica aplicada a uma comunidade denominada Winston Parva, realizaram um estudo teórico acerca da rivalidade entre grupos que ocupam diferentes situações de poder, sendo que os habitantes mais antigos daquela comunidade consideravam-se superiores aos recém-chegados, utilizando como justificativa elementos subjetivos, quando, em verdade, se estava diante de uma relação de poder imposta por questões estruturais. Resumidamente, a delimitação dos grupos se firmava no discurso de enaltecimento do estabelecido em detrimento do outsider, ofuscando a relação material que dava aporte à rivalidade.

${ }^{6}$ El caso es que, no bien hubo dado <éste>, por primera vez, comienzo al acoso de las iglesias, y contaminada su alma con la sangre de los justos y piadosos, la represalia enviada por Dios lo alcanzó empezando por su propia carne y no se detuvo hasta llegar al alma. Pues un repentino absceso le surge en medio de las partes innombrables de su cuerpo; después, una llaga fistulosa en la parte baja y una incurable corrosión de todo ello hasta las más íntimas entrañas, de donde dícese que bullía gran cantidad de gusanos y brotaba un hedor de muerte, dado que toda la mole corpórea, por la abundante ingestión de alimentos, se había transformado en una inmensa masa grasienta, que cuando comenzó a pudrirse, ofrecía un espetáculo insufrible y horripilante a los que se acercaban. (Eus. VC. 2.57.1-3)

${ }^{7}$ El segundo desencanto se sufre cuando se espera un refinado gusto literario a un dominio en el campo de la composición. Su estilo es, en general, pomposo, obscuro y pretencioso, y la mezcla de metáforas es cuando menos chocante. (...) Su manera de escribir es un reflejo de su carácter, y como escribía, así era Eusebio. Más acumulativo que productivo, más pedestre que genial, más registral que especulativo. En el orden religioso, llama la atención 
en un hombre de la Iglesia, sin ninguna dispersión que lo desviara de ese solo centro, lo estereotipado de sus expresiones, sin una nota personal. (GARRUCHAGA, 2010, p. 63)

8 "increasingly took charge of the record, they quite naturally focused their attention on those parts that helped them understand and make sense of their own complicated past". (DRAKE, 2002, p.351-2) 


\title{
O SIGNIFICADO DO CONTRA NOS DISCURSOS POLÍTICO- RELIGIOSOS DA ANTIGUIDADE TARDIA: O CONTRA OS GALILEUS DO IMPERADOR JULIANO - 361-363 D.C.
}

\author{
Margarida Maria de Carvalho \\ Daniel de Figueiredo \\ Universidade Estadual Paulista - Brasil
}

\section{Introdução}

Os panegíricos no período da Antiguidade Tardia se proliferaram, sobretudo, no século IV d.C., pois foram elevados à categoria de documentos oficiais do Império Romano. Assim, existiriam os panegíricos elogiosos - os quais enalteciam figuras como a de imperadores ou pessoas ilustres - diga-se de passagem, os mais trabalhados pela historiografia, e os repulsivos, isto é, aqueles que falavam contra os imperadores ou eram adversos a grupos político-religiosos.

Em nosso caso, temos como fito contribuir com uma interpretação de um dos muitos discursos do Imperador Juliano que chegaram às nossas mãos: o Contra os Galileus. Tal arrazoado foi, largamente, analisado pelo viés religioso, como se Juliano tivesse escrito realmente um discurso contra os cristãos, sejam adeptos a quaisquer das correntes cristãs do período assinalado. Partimos do princípio que, nessa época, a questão religiosa está imbricada na esfera políticocultural, típica da Antiguidade Tardia. No decorrer de nossa análise, mostraremos como, a partir das passagens do tratado mencionado, a preocupação de Juliano não se detinha somente ao aspecto religioso - como sua leitura à primeira vista nos direciona - mas, sim, ao político-religioso, refletindo em questões administrativas e culturais. Contra os Galileus, dessa forma, possui um caráter também educativo.

Contra os Galileus foi redigido, por Juliano, entre julho de 362 d.C. e março de 363 d.C. durante a sua permanência em Antioquia, cidade com status de metrópole, que se localizava na região atual da Síria. Nesse arco temporal, o Imperador filósofo preparava sua campanha militar contra os Persas. Antioquia sempre teve um destaque importante no Império, pois funcionava como um

\footnotetext{
* Professora de História Antiga do Departamento de História e do programa de Pósgraduação em História da UNESP, Franca. Coordenadora do Grupo do Laboratório de Estudos sobre Império Romano da UNESP, Franca. E-mail: margomc@terra.com.br

** Mestre em História Antiga pelo Programa de Pós-graduação em História da UNESP, Franca., sob orientação da Profa. Dra. Margarida Maria de Carvalho. E-mail: d.fig@uol.com.br
} 
O significado do Contra nos discursos político-religiosos da Antiguidade Tardia

verdadeiro campo de preparação bélica. Dessa maneira, Libânio, sofista neoplatônico, amigo e correspondente de Juliano, nos apresentou o tratado Contra os Galileus:

Como o inverno fazia grandes as noites, junto a outros brilhantes discursos, atacou os livros que fazem desse homem da Palestina deus e filho de deus, e em uma larga e dura polêmica demonstrou que tais honras são pura irrisão e tagarelice; e neste tema se mostrou mais sábio que o velho de Tiro ${ }^{1}$. (Lib. Or. 18.178).

Tudo indica que o momento era propício para que Juliano demonstrasse sua indignação a tudo que se lhe opunha a concretizar a sua administração do Império de acordo com a sua teologia política. Dessa maneira, aquele foi o momento em que o Imperador escreveu Misopogon, isto é, um tratado contra os antioquianos e o já citado Contra os Galileus, ou o mesmo que Contra os Cristãos. Ressaltamos que o epíteto Galileus seria uma tática depreciativa utilizada por Juliano para se referir aos adeptos de uma seita surgida na remota Galiléia durante o Principado. De acordo com André Leonardo Chevitarese e Gabrielle Corneli (2007, p.41-69), a Galiléia ao tempo de Jesus Cristo era uma região da Palestina marcada pelo entroncamento das culturas helênica e hebraica e sempre se mostrou uma província problemática desde a ocupação romana por Pompeu, em 63 a.C. A acentuada resistência cultural do povo galileu parece tê-los associado, no imaginário romano, a grupos ligados à marginalização social.

$\mathrm{O}$ tratado julianino que chegou até nós, por fragmentos, foi reproduzido a partir de uma refutação a ele feita por Cirilo, bispo de Alexandria, entre os anos de 433 e 441 d.C. O título dessa refutação é: Em Defesa da Santa Religião Cristã contra os Livros do ímpio Juliano, mais conhecido como Contra Juliano, sendo dedicada ao Imperador Teodósio II (WRIGHT, 1923, p.313-317). O Contra os Galileus de Juliano teria sido composto, inicialmente, por três livros. Segundo José Garcia Blanco e Pilar Gimenez Gazapo (2001, p.9), para cada livro de Juliano, Cirilo escreveria dez para refutá-los. Porém, somente o primeiro livro do Imperador, a partir daquela refutação do bispo alexandrino, alcançaria os dias atuais. R. Joseph Hoffmann (2004, p.77), especulou que as matérias dos livros II e III de Juliano poderiam ter constituído um ataque mais direto ao cristianismo do que o conteúdo do livro I. Para ele, não era estranho que a existência da própria refutação de Cirilo possa ter sido suprimida em função de seu conteúdo perigoso para Igreja no período medieval. Temos em mente que Hoffmann, ao fazer esse comentário, estaria levando em consideração somente o aspecto religioso, desconsiderando a conexão existente entre esse campo e o político.

Aliada à forma fragmentária em que a obra foi recuperada, acrescenta-se a costumeira parcialidade com que escritores e copistas da igreja tratavam os discursos que Ihes eram desfavoráveis. Nas palavras do próprio Cirilo, no livro II 
de sua inventiva Contra Juliano, o religioso deixa claro que responderia a todas as blasfêmias de Juliano contra Jesus Cristo, ignorando, porém, as palavras que em sua concepção eram muito ofensivas. Daí podermos deduzir as limitações e dificuldades de reconstrução do arrazoado:

Mas, como eu disse, da sua boca aberta sem reservas ele [Juliano] espalhou muitas espécies de calúnias ao nosso comum Cristo Salvador e derramou contra Ele dissonantes observações. Absterei de responder com similares detalhes e aviso aos partidários sensatos, ignorar aquilo que nas suas palavras arriscaria sujar o espírito pelo simples contato. Esforçarei por combater esse [método de] "combate", por denunciar em todas as ocasiões seu hábito de escárnio que fala errado e irrelevantemente sem mesmo ser capaz de chegar a dizer uma coisa verdadeira. (Cyr.Alex. Jul. 2.2)

A titulo de complementação, acrescentamos que as edições do discurso aqui utilizadas foram da Editorial Gredos (2001), Loeb Classical (1923). Resta referenciarmos que a maioria dos tradutores insere a polêmica Cirilo versus Juliano como se fosse uma disputa binária em torno da polêmica: cristianismo versus paganismo, tendência essa que dominou a historiografia da década de 80 do século passado. Em conformidade com Averil Cameron (1991, p.122), aludimos que não podemos resumir tal polêmica dessa maneira, haja vista que obscureceríamos inúmeras questões reais cujo significado ia além do mero conflito religioso; sendo assim, as disputas seriam político-culturais.

\section{As metas de Juliano em Contra os Galileus}

Como já anunciamos, ao nos debruçarmos sobre uma leitura mais profunda da inventiva supracitada, alinhando ao contexto histórico em que aquela foi produzida, notamos que a reflexão político-religiosa de Juliano perpassava por assuntos administrativos como, também, pela natureza da ideologia política imperial. Outro detalhe a ser destacado é que, nesse discurso, o príncipe filósofo discute a relação entre os pensamentos e dogmas dos gregos, hebreus e cristãos. Dessa forma, exercendo comparações entre seus principais pensamentos, Juliano utilizou-se do próprio conflito que havia entre hebreus e cristãos, ou seja, sobre suas concepções sobre o Deus único e Jesus Cristo, para reforçar a idéia do lógos grego. Essa razão grega, para o Imperador, seria dotada dos princípios filosóficos do neoplatonismo, uma cultura filosófica própria de sua época que trazia consigo ingredientes políticos e religiosos.

No início de Contra os Galileus, Juliano indicou que a sua intenção seria "tratar sobre todos os chamados dogmas fundamentais" (Jul. Gal. 41 E). Ao comparar a crença dos gregos e as crenças judaicas, para ele, os cristãos haviam subvertido ambas e delas conservando apenas certas noções fundamentais. Dessa forma, sua intenção seria lançar em descrédito o logos cristão e estabelecer uma 


\section{O significado do Contra nos discursos político-religiosos da Antiguidade Tardia}

supremacia do logos grego. Logo, segundo Juliano: "[...] comparemos somente ponto por ponto, que tipo de palavras disse o deus de Moisés e quais foram as do deus de Platão" (Jul. Gal. 57 E).

Em todo o discurso Contra os Galileus, Juliano adotou uma linha de ataque de maneira incisiva e direta, estabelecendo uma grande relação de tensão com os seus interlocutores. Vide a passagem abaixo:

Está bem, parece-me, expor a todos os homens as causas pelas quais me convenci de que a maquinação dos galileus é a invenção de uns homens composta por maldade. [...] quero dizer em primeiro lugar que qualquer que deseje refutar-me deve, como em um tribunal, não se ocupar de nada alheio nem, como se diz, acusar por sua parte até que haja feito a defesa de seus próprios pontos de vista (Jul. Gal. 39 A).

De antemão, podemos perceber que Juliano procurou antecipar-se aos ataques que certamente receberia por parte daqueles que se sentissem contrariados com as suas opiniões, pois era uma característica do período a utilização de elaborados discursos retóricos como réplicas às críticas discursivas, da parte de todos os intelectuais envolvidos. Juliano usou carregados adjetivos para qualificar não só os cristãos como também os judeus. Ao listarmos os nomes mais brandos atribuídos por Juliano, vimos que ele classifica os judeus como pessoas dotadas de coração de pedra e os cristãos como impostores maledicentes. Diga-se de passagem, Juliano não foge à regra da formatação retórica típica dos Contra, isto é, das inventivas repulsivas ao adotar em seu arrazoado um vocabulário virulento.

Segundo Maria Jose Hidalgo de la Vega (1990, p.183), Juliano apoiava-se nos princípios do neoplatonismo para acreditar que seu Imperium $^{2}$ havia sido decretado pelos deuses, em especial Hélios-Mitra, que o teria instigado a sair de sua vida contemplativa e a exercer o poder político. Em que pese o pensamento claro da autora, acrescentamos que a vida contemplativa em Juliano não se resumia em passar o tempo tentando entrar em contato com os deuses, mas, sim, a explanação da necessidade de se ter uma vida interativa entre a crença nos deuses e a busca da solução dos problemas do Império Romano.

Os filósofos nos ordenam imitar os deuses na medida do possível, e esta imitação está na contemplação dos seres. Que isto se produza sem paixão e se baseie na liberação da paixão, creio que é evidente, ainda que eu não o diga; pois na medida em que nos mantemos livres de paixão, dispostos à contemplação dos seres, nesta medida nos fazemos iguais a deus. (Jul. Gal. $171 \mathrm{D}$ e E).

Assim, Juliano também se posicionou da seguinte forma: “[...] 0 conhecimento de deus se dá entre os homens não por aprendizado, mas por natureza" (Jul. Gal. 52 B). Esse seu pensamento inspirou-se no filósofo 
Margarida Maria de Carvalho e Daniel de Figueiredo neoplatônico Jâmblico, o qual em sua obra De Mysteriis, afirma-nos: “[...] nossa natureza tem em seu fundo o conhecimento inato dos deuses, superior a toda crítica e opção, anterior à racionalidade e à demonstração" (lamb. Myst. 1.3). Portanto, o discurso filosófico neoplatônico dessa época considerava a verdade como já revelada aos homens; da mesma forma como pensavam os estóicos, já existia em todos os homens noções inatas, postas neles pela Natureza ou pela Razão Universal. Nas palavras de Pierre Hadot (2004, p.220-221), estas centelhas do logos permitiriam um primeiro conhecimento das verdades fundamentais que 0 discurso filosófico deveria se esforçar para desenvolver e elevar a um nível plausível de compreensão.

Em contraste com o pensamento julianino, o logos cristão se apoiava numa manifestação reveladora do seu deus, ou seja, ela se dava por aprendizado. Esse tipo de pensamento, numa perspectiva política, era o que legitimaria a existência de um grupo de exegetas os quais estariam incumbidos de traduzir essa revelação, justificando, assim, a organização de uma hierarquia privilegiada detentora da verdade.

Desse modo, como Imperador, Juliano incluiria no rol dos problemas que ele julgava importante sanar, medidas que iriam contrariar os interesses da hierarquia cristã em formação. Ele teria identificado nela as pretensões de constituir-se como suporte político-ideológico de legitimação do poder imperial, o que contrariava as suas concepções teológico-filosóficas sobre a natureza da realeza.

Porque se o criador imediato do universo fosse o que anuncia Moisés, nós temos opiniões melhores sobre ele, ao supor que é o pai comum do todo e que há outros deuses locais que estão subordinados a ele e são como delegados do rei, administrando cada um de forma diferente sua província [...] Convém, pois, crer que o deus dos hebreus não é o criador de todo o universo e que não exerce sua autoridade sobre todas as coisas, senão que mais bem há que crer, como disse, que está restrito e tem um império limitado junto com os demais deuses.(Jul. Gal. 106 C).

Cabe ressaltar que de forma alguma essas pretensões de Juliano estariam deslocadas do contexto da sociedade romana de meados do século IV d.C. Muitas foram as tentativas posteriores de associar a imagem desse Imperador a de um visionário anacrônico e perseguidor de cristãos. A título de exemplo, Paul Veyne (2009a, p.107-109) afirma-nos que, embora tenha exercido o poder por pouco tempo, Juliano em nenhum momento teve a sua autoridade contestada, seja pelo exército romano, seja pela elite que lhe dava sustentação. Após a sua morte em campo de batalha contra os persas, a escolha do seu sucessor recairia sobre Salústio, um eminente colaborador de Juliano não-cristão que, contudo, declinaria da indicação. 

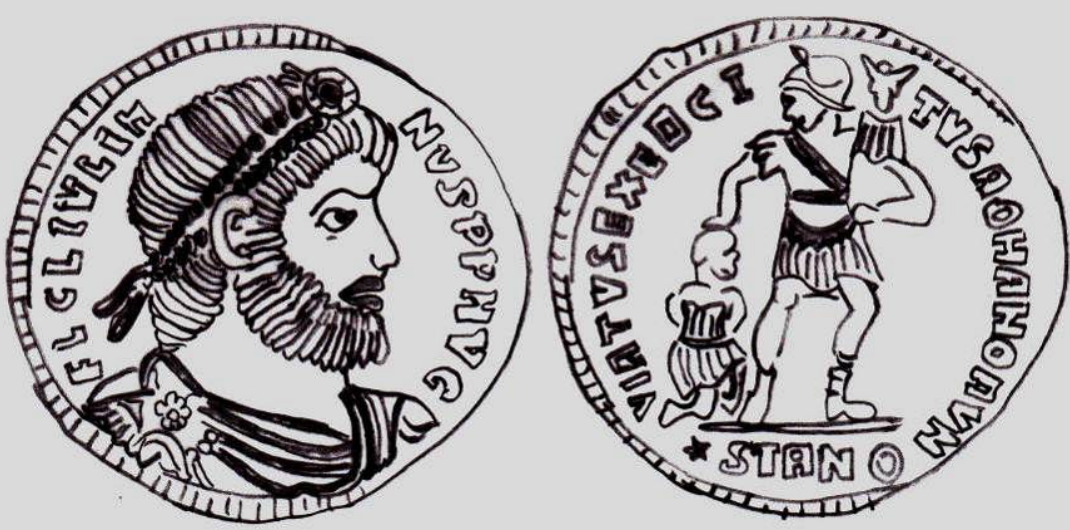

Fig. 1 - Solidus de Juliano: o reverso traz uma referência ao poderio militar do Império romano ${ }^{3}$ Desenho: F. Vergara Cerqueira

Podemos afirmar que uma das medidas mais polêmicas adotada por Juliano foi aquela lei, editada em 362, em que ele proibiu aos cristãos o ensino da retórica e da gramática (CTh. 13.3.5; Jul. Ep. 61c; Amm.Marc. 25.4.20). Juliano seria duramente atacado pelos cristãos por esse motivo e receberia críticas até mesmo entre seus admiradores. Isso se daria em um momento em que o discurso cristão se sofisticava, buscando empreender seus métodos de persuasão a partir do que já Ihe era familiar, ou seja, a retórica helênica (CAMERON, 1991, p.38):

Por que desgastam vós nos ensinamentos dos gregos [textos], se a leitura de vossas escrituras os é suficiente? (Jul. Gal. 229C). [...] que voltem à igreja dos galileus e que comentem Mateus e Lucas. (Jul. Ep. 61c).

Durante o governo de Juliano, um grande conflito teológico já se desenrolava dentro da comunidade cristã relacionado à questão trinitária, que buscava definir a relação entre as pessoas divinas. Conflitos dessa naturaza não só estavam relacionados à tentativa de definir um dogma como ortodoxo. Traziam, também, no seu bojo divergências de natureza política, que eram fomentadas pelos partidos que se formavam para defender os seus interesses. Na maioria das vezes, a intervenção do poder imperial se fazia necessária para o restabelecimento e a manutenção da ordem ${ }^{4}$. Durante o governo de Constâncio II, imperador ariano, antecessor de Juliano, diversos bispos do partido niceno seriam desterrados por não partilharem da corrente cristã à qual se filiava esse Imperador. Conforme nos relata o historiador Sócrates Escolástico, Juliano "ordenou que voltassem os bispos exilados e os devolvessem seus bens confiscados" (Soc. HE 3.1. 48). Essa medida nos indica que, no seu intuito de privilegiar o helenismo, Juliano, ao indultar os bispos cristãos-nicenos, visava a 


\section{Margarida Maria de Carvalho e Daniel de Figueiredo}

fomentar as rivalidades já existentes, naquele momento, dentro do movimento cristão. Tudo nos leva a crer que seu objetivo seria o de barrar a até então relação ascendente que, desde do imperador Constantino, essas facções buscavam manter com o poder político. Em diversos trechos do seu Contra os Galileus, Juliano tenta demonstrar o que ele entendia como incoerente na formulação da doutrina da Trindade pelos cristãos:

Sois tão desventurados que nem sequer guardais os ensinamentos que os hajam transmitidos os apóstolos e hajam sido obrigados, piorando-os e fazendo-os mais ímpios por seus sucessores. Porque nem Paulo se atreveu a dizer que Jesus era deus, nem tão pouco Mateus, nem Lucas, nem Marcos. [...] "Ninguém jamais viu a deus; o filho unigênito, que está no seio do pai, ele nos o revelou" (N.T. Ev.Jo. 1.18). [...] parece que nem João atreveu a dizê-lo. Que há acreditado [Moisés] em um só deus, no de Israel, o disse no Deuteronômio: "Para que mostre que o Senhor teu deus é um só deus e não há outro deus exceto ele" (V.T. Dt. 4.35) e, todavia, acrescenta: "E reflita no teu espírito que o senhor teu deus é o deus que está acima no céu e abaixo na terra e não há outro deus exceto ele" (V.T. Dt. 4.39). [...] Assim, pois, isto disse Moisés insistindo em que existe um só deus, porém esses [os cristãos] quiçá dirão: tão pouco nós dissemos que haja dois ou três; porém eu demonstrarei que também dizem isso tomando por testemunha a João quando disse: "No princípio foi a palavra e a palavra estava junto a deus e a palavra era deus" (N.T. Ev.Jo 1.1). Vês que se diz que estava junto a deus? Logo seja o que nasceu de Maria, seja algum outro [...] isso agora em nada diferencia; os deixo por suposto a batalha a vós; no entanto, basta atestar que disse "junto a deus" e "no princípio", pois como concorda isso com a doutrina de Moisés? (Jul. Gal. 261E, 262B e C, 327A, 333C e D destaques do autor).

Sobre essa medida, na opinião de Amiano Marcelino, Juliano a teria tomado "pois sabia por experiência que nenhuma fera era tão perigosa para os homens como os próprios cristãos entre si" (Amm.Marc. 22.5.4).

Juliano também nos leva a entender que ele seguia o princípio de que havia poucas razões para que as autoridades romanas proibissem ou desencorajassem a adoração dos deuses locais, pois a norma era que a religião estava ligada a uma específica cidade ou grupo étnico (RIVES, 2000, p.260). A regra não deveria ser diferente para o deus cristão e seus seguidores. Assim, ele nos dá essa indicação:

[...] Diga-me, pois, qual é a causa dos celtas e dos germanos serem valorosos; os gregos e os romanos em geral políticos e humanitários e, ao mesmo tempo, firmes e belicosos; os egípcios mais inteligentes e engenhosos, inábeis para a guerra; e afeminados os sírios e, ao mesmo tempo, inteligentes, exaltados, vãos e bons para aprender. [...] Assim, pois, se estas diferenças se hajam feito cada vez maiores e mais importantes 


\section{O significado do Contra nos discursos político-religiosos da Antiguidade Tardia}

sem intervenção de uma providência maior e mais divina, para que vamos esforçar-nos inutilmente e render culto a quem não vela em absoluto por nós? Com efeito, ele não se ocupa nem de nossas vidas, nem das nossas características nem dos nossos costumes, nem do nosso bom governo nem de nossas instituições políticas, todavia convém que receba honras de nossa parte? Em absoluto. (Jul. Gal.138B e C)

Para Juliano, então, se o deus cristão havia dito a Moisés: "Israel é meu filho, meu filho primogênito" (V.T. Ex. 4.22), o judaísmo, e por extensão o cristianismo, poderia, então, ser tratado como mais um culto étnico (FOWDEN, 2001, p.84). E como para Juliano cada povo teria o Deus que merecesse, o dos judeus Ihes caía bem, rancoroso e invejoso, "um deus zeloso que castiga nos filhos os pecados dos pais" (V.T. Ex. 20.5). Um deus também fraco, pois os judeus nem sequer um Estado possuíam, vagavam pelo mundo. Ao contrário, o Império Romano fora revestido de glória desde o seu início pela proteção dos seus deuses:

[...] por que haveis desertado para os judeus, mostrando-se desagradecidos com nossos deuses? Acaso por que os deuses concederam a Roma reinar e aos judeus serem livres por pouco tempo, estar submetidos sempre à escravidão e viver como estrangeiros? (Jul. Gal. 209D).

Nessa linha de pensamento, já que o deus dos cristãos era o mesmo dos hebreus, que aqueles não viessem propagar os seus ensinamentos, que seriam específicos, na concepção de Juliano, para todo o Império, nem tampouco buscassem subverter as suas estruturas de sustentação político-ideológicas. Ou seja, que ficassem restritos aos rincões da Galiléia, pois lá eles não se sentiriam "perseguidos".

Como ressaltamos anteriormente, a filosofia neoplatônica não era baseada numa revelação da verdade divina, mas, sim, num grupo de práticas e tradições que foram estabelecidas através do contato entre os mortais e os deuses que possibilitavam àqueles obter os favores divinos. Uma de suas práticas básicas, de relevância para que entendamos o discurso e as atitudes de Juliano, se refere ao seu caráter ritualístico. O centro daquela filosofia estava no ritual e não na fé e as práticas sacrificiais eram de fundamental importância para se estabelecer o contato e a troca entre as esferas humana e divina. Pode-se dizer que se tratava de um tipo de acordo contratual em que se esperava que cada um cumprisse com as suas obrigações. Para tanto, tornava-se importante o envolvimento da comunidade como um todo para granjear a boa vontade dos deuses a fim de que algum sucesso fosse obtido. Ao mesmo tempo, o engajamento dos cidadãos no culto público criava um senso de comunidade no sentido cívico, reforçando a identidade entre eles (RIVES, 2000, p.253-256).

Pois os hebreus possuem leis estritas referentes aos cultos e seus rituais e preceitos são inumeráveis e requerem a vida e a profissão sacerdotal. 0 
Margarida Maria de Carvalho e Daniel de Figueiredo

legislador ao proibir render culto a todos os deuses, salvo a um somente, cuja "parcela é Jacob e Israel, sua parte de terra por herança" (V.T. Dt. 32.9) não disse só isso, senão que acrescentou, segundo creio: "Não injuriarás aos deuses" (V.T. Ex. 22.28), porém a maldade e a audácia dos seus sucessores [cristãos], que querem arrancar do povo toda reverência, pensou que a blasfêmia acompanhara a falta de culto, que é o único que vós haveis tirado dali, porque, no mais, nada tens parecido aos judeus. (Jul. Gal. 238C).

A corrente filosófica neoplatônica, a qual Juliano estava associado, incorporou, ao longo da Antiguidade Tardia, diversos elementos místicos orientais à religiosidade romana. Como um seguidor do filósofo Jâmblico, Juliano era também adepto da teurgia ${ }^{5}$, cujas práticas, em grande medida, reforçariam o uso dos ritos sacrificiais como forma de aproximação com os deuses (DOODS, 1947, p.56). Tal era o envolvimento de Juliano nessas práticas que em várias ocasiões ele seria satirizado pelos escritores cristãos do seu tempo, como o fez João Crisóstomo nessa passagem:

Agora Juliano era um constante visitante de Daphne, suas mãos cheias de oferendas e acompanhado por uma multidão de vítimas sacrificiais: e depois de tê-las sacrificado num horrível banho de sangue ele importunaria o deus [Apolo] exigindo respostas dos oráculos para os problemas que iam à sua mente. (Joh.Chry. Bab. 15.80).

Pensamos que os problemas que iam à mente de Juliano relacionavam-se a missão que ele acreditava estar investido, ou seja, de revitalizar e reorganizar o Império, sob os valores próprios do helenismo, que, segundo ele, estava ameaçado pela administração desastrosa dos seus antecessores cristãos. Juliano parece estar convencido de que o seu projeto político fora predestinado por eleição divina e os sonhos e sinais que ele recebia dos deuses através do mito tinham por finalidade orientá-lo na sua missão de governar o mundo para salvar a humanidade. Dessa forma, a sua teoria política se expressa numa cosmogonia que coloca ao Império romano não só um conceito político, mas também religioso, ou seja, uma réplica na terra da organização celeste. Isso reafirmaria o caráter divino do governante (basileu), que deveria legislar e governar de acordo com a parte divina do seu ser (HIDALGO DE LA VEGA, 1995, p.233-249). Para tanto, os ritos sacrificiais ocupavam importante papel na formulação da sua teologia política. Nesse sentido, Juliano busca destacar a incongruência entre judeus e cristãos no que se refere a tais práticas:

Por que separando de nós não respeitais as leis dos judeus nem observais o que Ihes diz Moisés? Alguém de qualquer forma dirá olhando irritado: tão pouco os judeus sacrificam. Porém, eu mesmo os refutarei, que tens a vista frouxa: em primeiro lugar, que nada das demais coisas legisladas pelos 


\section{O significado do Contra nos discursos político-religiosos da Antiguidade Tardia}

judeus as tem vós em observância; em segundo lugar, que os judeus sacrificam em suas próprias casas [...] pois estão privados do seu templo. Porém, por que não sacrificais? Como eu mesmo disse no princípio, quando queria demonstrar que os judeus estão de acordo com os gentios, salvo em crer que existe um só deus. (Jul. Gal. 306A e B).

De modo diferente das religiões tradicionais da Antiguidade Tardia como o judaísmo e o neoplatonismo, tudo indica que o sacrifício de sangue representava uma confrontação aos cristãos. Segundo Scott Bradbury (1995, p.346), tratava-se de um elemento dos cultos tradicionais que absolutamente os cristãos não poderiam suportar. Parece que tais práticas relembravam-nos dos martírios outrora infligidos aos seus antepassados. Posteriormente à morte do Imperador, alguns escritores cristãos, dentre eles Gregório de Nazianzo, buscam atribuir ao imperador o rótulo de perseguidor dos cristãos, uma vez que, para eles, essa prática do sacrifício em Juliano parecia representar uma politização dos assuntos religiosos:

No que [...] nem Diocleciano [...] nem [...] Maximiano planejaram jamais, nem Maximiano [...] isso o pensou aquele [Juliano] [...] havia de privar aos cristãos de toda liberdade da palavra, apartando-os dos recrutamentos, das assembléias e celebrações políticas e dos tribunais; com efeito, não se podia utilizar quem não sacrificasse nos altares diante das vítimas [...] E o sábio raciocínio desse príncipe assassino e legislador ilegal [...] era que "é próprio da nossa lei não participar [os cristãos] nem no combate, nem nos juízos, nem possuir nenhuma magistratura, nem considerar nada como próprio, senão viver em outro lugar, e largar as coisas daqui como se não existissem. (Greg.Naz. Jul. 4.96-97).

Podemos deduzir do discurso de Gregório, no seu Contra Juliano, que se tratava de um artifício retórico, largamente empregado no seu Contra repulsivo, com a finalidade de construir uma imagem negativa do Imperador e desacreditar as suas ações políticas (CARVALHO, 2010, p.151). A reação virulenta desse bispo parece atestar a ameaça que a teologia política de Juliano representou ao avanço do cristianismo dentro do Império Romano. Não existem evidências de que Juliano tivesse editado alguma lei que proibisse aos cristãos o exercício das suas atividades como cidadãos romanos, inclusive, muitos deles seguiram nos seus postos na corte imperial durante o governo desse imperador (ARCE, 1976, p.208220). Porém, conforme uma carta enviada a Artábio, Governador da Província do Eufrates, Juliano demonstra a sua preferência por aqueles que veneram os deuses, o que pode ter influenciado as suas nomeações para o governo:

$\mathrm{Eu}$, pelos deuses, não quero nem matar os galileus, nem golpeá-los injustamente, nem que sofram nenhum outro tipo de desgraça, porém afirmo rotundamente, no entanto, preferir aqueles que veneram os deuses, 
Margarida Maria de Carvalho e Daniel de Figueiredo

pois a loucura dos galileus tem estado a ponto de subverter tudo, enquanto que pela benevolência dos deuses todos nós temos salvado. Por isso devemos honrar aos deuses, assim como aos homens e cidades que os veneram. (Jul. Ep. 83).

Juliano nos dá uma indicação dessa sua preferência em Contra os Galileus ao sugerir, ironicamente, que os cristãos seriam maus administradores tomando por base o que lhes ensinava as suas Escrituras:

Escutai um belo e político conselho: "Vendei vossos bens e dai aos pobres; fazei para vós bolsas que não envelheçam" (N.T. Ev.Luc. 12.33). Quem pode dizer algo mais político do que essa ordem? Porque se todos a obedecêssemos, quem seria o comprador? Quem louvar esse ensinamento, que se impuser, não manteria nem uma cidade, nem um povo, nem uma só casa. Pois se tudo for vendido, como poderia existir uma casa ou uma família digna? Ademais, ao ser vendido tudo ao mesmo tempo do que existe na cidade, não poderia encontrar comerciante é algo evidente. (Jul. Gal. Frag. 4).

\section{Considerações Finais}

Dessa forma, tendo como objeto de análise o Contra os Galileus, de Juliano, procuramos demonstrar que, embora a política seja uma modalidade da prática social, revestida de um caráter próprio, não deixa de ter relações com outros domínios (COUTROT, 2003, p.357), e em especial com a religião durante a Antiguidade Tardia romana. Isso nos possibilita entender as metas que Juliano tinha para a sua administração do Império a partir de uma documentação que, à primeira leitura, nos remete, aparentemente, a questões religiosas.

Os discursos de Juliano, não apenas o Contra os Galileus, refletem a atmosfera de riqueza cultural da sociedade romana do seu tempo. As suas formulações teológico-filosóficas são densas e estão carregadas de significados político-culturais. Os discursos retóricos da Antiguidade Tardia, sejam eles de escritores não-cristãos ou cristãos, nos mostram o vigor de uma sociedade que buscava se adaptar aos imensos desafios que lhes eram presentes. Acreditamos que Contra os Galileus, especificamente, admite outros vieses de leitura, dada a sua riqueza de conteúdo. A que buscamos oferecer aqui foi aliar a teologia política de Juliano às ações por ele empreendidas durante o seu Principado. Com isso, pudemos constatar que o embate que ele travou com seus adversários está longe de se constituir em apenas uma mera contenda religiosa. Tratava-se de um embate entre forças poderosas que buscavam apoderar-se do controle dos meios que formam e guiam a imaginação coletiva (BACZKO, 1985, p.298). Os seus discursos, no contexto político-religioso do séc. IV d.C., tentavam modelar comportamentos, mobilizar energias e legitimar poder. 


\section{O significado do Contra nos discursos político-religiosos da Antiguidade Tardia}

A causa de Juliano e seus seguidores não saiu vitoriosa, pela sua morte prematura e pelos rumos que tomou a sucessão Imperial. Assim, nos é indicativo que as ações de Juliano, que listamos anteriormente, poderiam ter feito do cristianismo apenas mais uma seita não ilícita dentro do Império.

\section{Documentação}

AMIANO MARCELINO. Historia (Res Gestae). Tradução de Maria Luisa Harto Trujillo. Madrid: Akal Clássica, 2002.

BíBLIA de Jerusalém: Antigo e Novo Testamento. São Paulo: Paulus, 2002.

CÓDIGO THEODOSIANO. In: JULIANO. Contra los Galileos, cartas y fragmentos, testimonios, leyes. Introducciones, traducción y notas por José García Blanco y Pilar Jiménez Gazapo. Madrid: Editorial Gredos S.A., 1982. (Parte Extractos de los Códigos de Teodósio y Justiniano).

CYRILLE D'ALEXANDRIE. Contre Julien. Tome 1, livres I et II. Translation by P. Burguière and P. Evieux. Paris: Les Editions du Cerf, 1985.

GREGÓRIO DE NAZIANZO. Contra Juliano. In: CARVALHO, Margarida Maria de. Paidéia e retórica no séc. IV d.C.: a construção da imagem do Imperador Juliano segundo Gregório de Nazianzeno. São Paulo: Annablume/FAPESP, 2010.

IAMBICHUS. De mysteriis. Translated with an Introduction and Notes by Emma C. Clarke, John M. Dillon and Jackson P. Hershbell. Atlanta: Society of Biblical Literature, 2003.

JULIAN. Against the Galileans. Translation by R. Joseph Hoffmann. Amherst, NY: Prometheus Books, 2004.

Against the Galileans. In: The works of the Emperor Julian. Vol. 3. Translation by Wilmer Cave Wright. Cambridge, Ma: Harvard University Press, 2006.

JULIANO. Contra los Galileos, Cartas y fragmentos, Testimonios, Leyes. Traducción de José Garcia Blanco y Pilar Jiménez Gazapo. Madrid: Gredos, 2001.

JULIANO. Cartas. In: JULIANO. Contra los Galileos, cartas y fragmentos, testimonios, leyes. Introducciones, traducción y notas por José García Blanco y Pilar Jiménez Gazapo. Madrid: Editorial Gredos, 2001.

JOHN CHRYSOSTOM. Homily on St. Babylas. Translated M. M. Morgan. In: TOUGHER, Shaun. Julian the Apostate. Edinburgh: Edinburgh University Press, 2007.

LIBANIUS. Funeral oration for Julian. Or. XVIII. Adapted from the translation by A. F. Norman. In: TOUGHER, Shaun. Julian the Apostate. New York: Columbia University Press, 2007.

SOCRATES. Church History. Translated A. C. Zenos. In: TOUGHER, Shaun. Julian the Apostate. New York: Columbia University Press, 2007.

\section{Bibliografia}

ARCE, Javier. Los cambios em la administración Imperial y Provincial com el Emperador Fl. Cl. Juliano (362-363). Hispania Antiqua: revista de historia antiga. Valladolid, Universidad de Valladolid, v. 6, p.208-220, 1976.

BACZKO, Bronislaw. Imaginação social. In: Enciclopédia Einaudi. Lisboa: Imprensa Nacional, Casa da Moeda, 1985, p.296-332.

BLANCO, J. G.; GAZAPO, P. J. Introducción. In: JULIANO. Contra los Galileos, cartas y fragmentos, testimonios, leyes. Introducciones, traducción y notas por José García 
Margarida Maria de Carvalho e Daniel de Figueiredo Blanco y Pilar Jiménez Gazapo. Madrid: Editorial Gredos S.A., 2001a. (Parte Contra los Galileos).

BRADBURY, Scott. Julian's pagan revival and the decline of blood sacrifice. Phoenix, 49, p.331-356, 1995.

BROWN, Peter. Society and the Holy in Late Antiquity. Berkeley and Los Angeles: University California Press, 1982.

CAMERON, Averil. Christianity and the Rhetoric of Empire: the development of Christian discourse. Berkeley: University of California Press, 1991.

CARVALHO, Margarida Maria de. Paidéia e retórica no séc. IV d.C.: a construção da imagem do Imperador Juliano segundo Gregório de Nazianzeno. São Paulo: Annablume/FAPESP, 2010.

CARVALHO, Margarida Maria de. Relações conflituosas entre o Imperador Juliano e a cidade de Antioquia. In: CARVALHO, Margarida Maria de; LOPES, Maria Aparecida de S.; FRANÇA, Susani Silveira Lemos (Orgs.). As cidades no tempo. São Paulo: Olhos d'Água, 2005, p.113-123.

CHEVITARESE, André L.; CORNELLI, Gabriele. Judaísmo, Cristianismo e Helenismo: Ensaios acerca das interações culturais no Mediterrâneo Antigo. São Paulo: Annablume, 2007.

COUTROT, Aline. Religião e política. In: REMOND, René (Org.). Por uma história política. Tradução de Dora Rocha. Rio de Janeiro: Ed. FGV, 2003.

DODDS, E. R. Os gregos e o irracional. Tradução de Paulo Domenech Oneto. São Paulo: Escuta, 2002.

FIGUEIREDO, Daniel de. Teologia política no séc.: IV d.C.: a relevância da Teurgia em Juliano, o Imperador. In: Revista História e-História. UNICAMP, vol. 1, p.1-17, 2009.

FOWDEN, Garth. Varieties of Religious Community. In: BOWERSOCK, Glen Warren; BROWN, Peter; GRABAR, Oleg. (Org.). Interpreting late antiquity: essays on the postclassical world. Cambridge, Ma: Harvard University Press, 2001.

HADOT, Pierre. O que é filosofia antiga? Tradução de Dion David Macedo. São Paulo: Loyola, 1999.

HIDALGO DE LA VEGA, Maria Jose. Intelectural, la realeza y el poder político em El Imperio romano. Salamanca: Ediciones Universidad de Salamanca, 1995.

HIDALGO DE LA VEGA, Maria Jose. Teologia política de Juliano como expresión de la controvérsia paganismo-cristianismo em el siglo IV. In: Cristianismo y aculturación em tiempos del Imperio Romano. Antig, Crist. Vol. VII. Murcia/Esp., 1990.

HOFFMANN, R. Joseph. Julian's Against the Galileans. Amherst/NY: Prometheus Books, 2004.

PAPA, Helena Amália. Cristianismo ortodoxo versus cristianismo heterodoxo: uma análise político-religiosa da contenda entre Basílio de Cesareia e Eunômio de Cízico (Séc.: IV d.C.). Dissertação de Mestrado. FHDSS/UNESP, Campus Franca, 2009.

RIVES, James. Religion in the Roman empire. In: HUSKINSON, Janet. Experiencing Rome: culture, identity and power in the Roman empire. New York: Routledge, 2000, p.245275.

TOUGHER, Shaun. Julian the Apostate. Edinburgh: Edinburgh University Press, 2007.

VEYNE, Paul. O Império Greco-romano. Tradução de Marisa Motta. Rio de Janeiro: Elsevier, 2009. 
O significado do Contra nos discursos político-religiosos da Antiguidade Tardia

VEYNE, Paul. Quando o nosso mundo se tornou cristão. Tradução de Artur Morão. Lisboa: Texto e Grafia, 2009a.

VEYNE, Paul. Sexo e poder em Roma. Tradução de Marcos de Castro. Rio de Janeiro: Civilização Brasileira, 2008.

WRIGHT, Wilmer Cave. Introduction Against the Galileans. In.: The works of the Emperor Julian. Vol. III. Cambridge/Ma: Loeb Classical Library, 1923, p.313-317.

\section{Notas}

${ }^{1}$ Aqui, Libânio se refere ao filósofo neoplatônico Porfírio.

${ }^{2}$ Imperium: concepção romana de poder (VEYNE, 2009, p.14).

${ }^{3}$ Fig. 1. Fonte: http://www.mlahanas.de/Greeks/Medieval/Bio/JulianTheApostate.html. Acesso em 17/08/2010.

4 Sobre a Controvérsia Trinitária vide PAPA, 2009. http://www.dominiopublico.gov.br/pesquisa/DetalheObraForm.do?select_action=\&co_obra=16 1582.

${ }^{5}$ A palavra teurgia que aparece apenas no século II d.C., parece ter sido criada pelo autor ou pelos autores dos Oráculos Caldeus, para designar ritos capazes de purificar a alma e seu "veículo imediato", o corpo astral, a fim de permitir-lhes contemplar os deuses. Esses ritos comportavam abluções, sacrifícios e invocações que utilizavam palavras rituais freqüentemente incompreensíveis. (DODDS, 2002, p.56-60). 
Seção V

MUNDO PROVINCIAL E GRUPOS ÉTNICOS 



\title{
REPRESENTACIÓN DE LA ETNIA VÉNETA EN AB URBE CONDITA DE TITO LIVIO
}

\author{
Agustín Moreno* \\ Universidad Nacional de Córdoba - Argentina
}

\section{Introducción}

En el prefacio de su $A b$ Urbe Condita, Tito Livio manifiesta que su interés es escribir únicamente sobre la historia del pueblo romano. Esta idea será remarcada en otros pasajes, donde el autor afirma que sólo se referirá a los acontecimientos de la historia de otro pueblo en la medida en que estos hechos tengan alguna relevancia para los romanos (Liv. 8.24.18; 31.1.1-5; 33.20.13; 35.40.1; 39.48.6; 41.25.8), para justificar la exclusión de ciertos sucesos de su obra. Siguiendo este objetivo, el historiador narrará la conquista del mundo por Roma. Mundo cuyo centro es Roma, y más específicamente el Capitolio. ${ }^{1}$ Es esta postura romanocéntrica la que regirá el inventario de virtudes y vicios morales con que tanto los personajes como los pueblos que desfilan en la obra serán juzgados (Liv. 9-11; MOORE, 1989, p.157-9).

Tito Livio, al referirse a los diferentes pueblos, sea en un excurso sea en el cuerpo principal del texto recurrirá a distintos elementos que forman parte del bagaje de la tradición etnográfica, cuyo origen puede establecerse en el siglo VI a.C. en la región del Asia Menor y que, ya una generación antes de la suya, se advierte como un componente bien establecido en la literatura latina. Así se observa, por ejemplo, en De Bello Gallico de Julio César en los excursos sobre Britania (Caes. Gal. 5.12-14) y sobre los galos y los germanos (Caes. Gal. 6.11-28); o en lugurtha de Salustio en la digresión sobre África (Sal. Jug. 17-19). Los elementos que se pueden encontrar en los textos etnográficos, que por cierto en escasos pasajes se encuentran todos juntos, son: la geografía física de la región tratada, el clima, la producción de la región (agrícola, minera, etc.), orígenes y características de sus habitantes y la organización política, militar y social. El empleo de estos elementos tiene como finalidad introducir el resto del mundo al lector, hacer familiar aquello de lo que se relata. Esto se aprecia con claridad en la campaña de Manlio Vulso narrada por Tito Livio (Liv. 38.12-27). Allí, a medida que avanza el ejército del cónsul, se construye un mapa mental hasta el Tauro, límite del imperio romano en ese momento, a través de ríos, mares, marismas, ciudades,

\footnotetext{
*Adscripto de Historia Antigua en la Universidad Nacional de Córdoba y becario doctoral del Consejo Nacional de Investigaciones Científicas y Técnicas (CONICET), Centro de Estudios Avanzados, U.N.C. Correo electrónico: agustinmoreno2003@yahoo.com.ar
} 
Representación de la etnia véneta en Ab Urbe Condita de Tito Livio

leyendas, explicaciones etimológicas y referencias a la riqueza agrícola de Asia Menor que presentan por medio de una "retórica de la alteridad" el temperamento y costumbres de los pueblos con que se topan los romanos en su avance, así como también permiten anticipar las consecuencias de la campaña del cónsul. ${ }^{2}$

Los investigadores actuales que estudian esta cuestión en la literatura grecolatina han tendido a enfatizar que las digresiones no han de considerarse segmentos aislados dentro de las obras. Aquellas que tratan sobre geografía han de ser vistas como el teatro en donde se desarrollan los acontecimientos relatados; otras que tratan sobre costumbres o migraciones de pueblos sirven para formar una base de lo que se analizará a continuación en el relato principal. ${ }^{3}$

En este trabajo nuestro interés se circunscribe a las referencias sobre el pueblo véneto en $A b$ Urbe Condita. Las mismas han llamado la atención de los estudiosos modernos, quienes han tendido a verlas como expresiones del sentimiento piadoso de Tito Livio hacia su ciudad natal, Patavio. ${ }^{4}$ Siguiendo este punto de vista, nuestro objetivo es reconocer la representación que hace el historiador de dicho pueblo a partir de los diferentes elementos de la tradición etnográfica que nos proporciona.

\section{Anténor y los troyanos que se asientan en el norte de Italia}

El episodio de Anténor con que inicia el libro primero de Ab Urbe Condita no ha pasado desapercibido para los estudiosos contemporáneos. Ha llamado la atención la referencia a dicho personaje al comienzo de la obra, pues éste no tiene ninguna relación con los romanos. Ello ha dado pie a dos posibles razones, las cuales no se excluyen entre sí. Por un lado, dicha mención se debería al sentimiento piadoso que el historiador profesaba por su ciudad natal; y por otro, también tendría como objetivo subyacente enfatizar en el texto la relación entre Patavio y Roma. Relación que Tito Livio no sería el primero en señalar. ${ }^{5}$ Ahora bien, sin negar estas razones, Feldherr (1998, p.112-3 y 164) ha demostrado que el pasaje sobre Anténor dista de ser una simple alusión al héroe fundador de su ciudad natal. Feldherr ha mostrado que en ese pasaje se esconde el deseo del autor por señalar a su lector que la leyenda que une a Roma con Troya no es la única existente en Italia y que, tal como su relato abandona la historia de Anténor para avocarse a la historia de Eneas y sus descendientes, también allí está presente la elección de la ciudadanía romana sobre la de Patavio. Todo ello tiene, claro está, una vinculación con el problema de la ciudadanía en el contexto en el que escribe el historiador romano, la Roma augustea posterior a las guerras civiles.

Ahora bien, ¿cuál es la caracterización que se hace de Anténor? La obra comienza: lam primum omnium satis constat Troia capta in ceteros saevitum esse 
Troianos, duobus, Aeneae Antenorique, et vetusti iure hospitii et quia pacis reddendaeque Helenae semper auctores fuerant, omne ius belli Achiuos abstinuisse (Liv. 1.1.1). ${ }^{6}$ El relato de Tito Livio, regido por la ambigüedad del satis constat ${ }^{7}$, señala una sola versión de las leyendas de Eneas y Anténor entre las distintas que existían. El autor pone el acento en aspectos positivos y atribuye tanto a uno como a otro héroe las mismas virtudes entrelazando no sólo por el común origen troyano, sino también por medio de factores morales el futuro de sus respectivos descendientes, romanos y patavinos. ${ }^{8}$

La imagen de un Anténor fiel a Troya, que sólo logra salvarse de la muerte a manos de los aqueos por una vieja ley de hospitalidad y por ser partidario de la paz y de la entrega de Helena, no es la única que circulaba por el Mediterráneo. Sabemos por Dionisio de Halicarnaso y por Servio que existía, ya en tiempos de Tito Livio, una variante que presentaba a los Antenóridas como traidores (D.H. 1.46.1. Serv. Ad Aen. 1.242. THALLON, 1924, p.49). Esta segunda versión es posterior a la seguida por el historiador paduano, quien recoge lo dicho por Homero en la Ilíada $^{9}$, aunque presenta tal como señala Thallon (1924, p.52) a un Anténor rejuvenecido. ${ }^{10}$ De este modo, se atribuye al fundador de Patavio ${ }^{11}$ el respeto por la hospitalidad, práctica que gozaba de gran estima no sólo entre griegos sino también entre romanos. ${ }^{12}$ Igualmente, el ser partidario de la pax y de la devolución de Helena, que había sido raptada, tienen una connotación positiva. Aquí se debe pensar en el respeto por los tratados; ${ }^{13}$ tema que tendrá mucha resonancia en el libro primero cuando se narre los reinados de Numa Pompilio, Tulio Hostilio y Anco Marcio.

No hay que considerar el desalojo de los eugáneos por vénetos y troyanos (Liv. 1.1.3) como una contradicción con el punto anterior, dado que no había ningún pacto entre ellos. El historiador recurre, simplemente, al empleo de dos temas que son comunes en la historiografía antigua para explicar cambios bruscos en una región: la inmigración y la guerra (BURNS, 2003, p.8). Por otra parte, la leyenda tiene muchas similitudes con las tradiciones narradas por el historiador patavino en Liv. 1.1.1-8 al tratar las peripecias de Eneas. Ambos jefes troyanos arriban a un lugar llamado Troya. En la primera versión, Eneas derrota a los aborígenes capitaneados por Latino; mientras que en la segunda, luego de una entrevista y sin batallar, se estrechan lazos de amistad entre ambos pueblos. En la medida en que ninguna de estas leyendas es preferida sobre la otra, bien podemos pensar que siendo la de los vénetos similar a la primera, no tendría tampoco rasgos negativos a ojos del autor. ${ }^{14}$ En este sentido, comparto la postura de Feldherr sobre la presentación de la leyenda de Anténor como una prueba de que la leyenda que une a Troya con Eneas no era la única existente. Por ello, no debemos buscar una diferencia entre ambas leyendas, que nos haga pensar en la superioridad de un pueblo sobre otro. 
Representación de la etnia véneta en Ab Urbe Condita de Tito Livio

El último aspecto que nos interesa considerar aquí es lo que atañe al origen de los vénetos. Sabemos que la conexión entre Anténor y los vénetos de Paflagonia es posterior a Homero. Ogilvie $(1970$, p.36) señala que puede datar de la época de la penetración comercial griega en esa zona del Adriático. Tito Livio relata que, luego de la caída de Troya, los vénetos procedentes de Paflagonia, muerto su rey, migraron y que junto con ellos marchó Anténor. Esta versión es próxima a la que narra Estrabón (Strab. 12.3 .8 y 13.1.53), y no es la primera entre los romanos que atribuye estirpe troyana a los vénetos que viven en Italia. Plinio afirma que Catón ya lo aseveraba (Plin. HN 2.130; WILLIAMS, 2001, p.76-8). Sin embargo, ésta no era la única tradición que circulaba. El mismo Estrabón, en 4.4.1, duda en atribuir una ascendencia celta a los vénetos de Italia, relacionándolos con los que combatieron con César y estaban establecidos junto al Atlántico. Por su parte, Polibio dice de ellos que son un linaje muy antiguo, similar en la vestimenta y costumbres a los galos, aunque hablaban un lenguaje distinto (Plb. 2.17.5-6. WALBANK, 1957, p.183). Es probable que Tito Livio no presente esta segunda posibilidad debido a que en el imaginario grecolatino se tenía de los galos una visión sumamente negativa (WILLIAMS, 2001; MITCHELL, 2005). Por otra parte, retomar la versión que los une a Troya le permite crear un pasado más glorioso, relacionado con las virtudes de Anténor y entrelazar la historia de su pueblo con la de Roma. Porque, más allá de que la persona de Tito Livio en la obra opta, como sostiene Feldherr, por la ciudadanía y la historia de Roma, eso no significa que olvide su origen patavino. $Y$, como señala Marincola (n.5), en toda obra historiográfica se esperaba por parte del autor alguna referencia que diera gloria a su ciudad natal.

Sobre la geografía de la región donde se asientan los vénetos se nos informa poco aquí. El historiador se limita a indicar que la misma se ubica entre los Alpes y el mar, en lo más recóndito entrante del mar Adriático (Liv. 1.1.2-3). Por ello, conviene dejar para más adelante el análisis de este tipo de información, ya que en otro pasaje posterior se hace alusión de un modo más detallado.

\section{Los etruscos dominan el norte de Italia, excepto la región de los vénetos ${ }^{15}$}

El pasaje en el que nos centraremos trata sobre el poderío que los etruscos ostentaron en el norte de Italia antaño (Liv. 5.33.7-11). Este excurso forma parte de una digresión mayor sobre los galos, que comenzaban a migrar a la región (Liv. 5. 33-35.3). Allí se describe la distribución de los pueblos en el territorio antes de la llegada de los invasores, quienes por su fuerza irán quitando tierras a los antiguos ocupantes y terminarán por cambiar la geopolítica de la región. ${ }^{16}$

Nos limitaremos aquí al excurso sobre los etruscos, pues, es allí en donde el historiador hace referencia a los vénetos. El autor indica que la influencia de aquéllos era tan notoria en la zona que los itálicos y los griegos denominaron a los 
mares que rodean Italia a partir de ellos, dado que su población se extendía de un mar al otro. Éstos se asentaron en doce ciudades de un lado de los Apeninos y enviaron colonias al otro lado, ocupando la zona entre el Pado y los Alpes; excepto Venetorum angulo qui sinum circumcolunt maris (Liv. 5.33.10). La descripción geográfica es similar a la que se nos proporcionó en el pasaje del libro primero: venisse in intimum maris Hadriatici sinum (Liv. 1.1.2). Y se contrapone a renglón seguido con el territorio alpino que habitan los retos, también de origen etrusco, quos loca ipsa efferarunt ne quid ex antiquo praeter sonum linguae nec eum incorruptum retinerent (Liv. 5.33.11). La descripción de la comarca véneta se lleva a cabo de forma más acabada en el libro décimo. Sin embargo, aquí se puede advertir que se explicita la cercanía al mar y, a través del río Pado y los Alpes, se delimita el ángulo que conforma la llanura que habitan los vénetos. La relevancia de dicha descripción se hace más notoria con la ubicación de los retos en los Alpes. Así, Tito Livio retoma un tópico de la literatura clásica que apunta a marcar la sociabilidad de un pueblo. Con respecto a esta idea existía una suerte de ambivalencia para los antiguos, como marca Isaac (2006, p.246): "there is an obvious ambivalence regarding the desirability of communication between peoples. Trade and commerce are the vehicles for the corruption of much that is valuable, but peoples who are entirely cut off from the rest of the world have no merit either". La discusión de la situación de una ciudad o pueblo con respecto al mar o a otros pueblos parece tener sus comienzos en el siglo VI a.C. con Jenócrates. Dentro de la literatura griega la cuestión fue retomada por Platón (Plat. Lg. 4.704b-705b), Tucídides (Thuc. 1.7) y Aristóteles (Arist. Pol. 7.6.1327a). La presencia de esta idea en la literatura latina está presente ya en las obras de César (Caes. Gal. 1.1.3), de Salustio (Sal. Cat. 10.1; Jug. 17-19) y de Cicerón (Cic. Rep. 2.3.5-6.11) (ISAAC, 2006, p.239-247; MORSTEIN-MARX, 2001, p.183-8). El mismo Tito Livio hará referencia a este aspecto en un discurso de Camilo, que se asemeja a las palabras de Cicerón en De Republica 5.10: Non sine causa di hominesque hunc urbi condendae locum elegerunt, saluberrimos colles, flumen opportunum, quo ex mediterraneis locis fruges deuehantur, quo maritimi commeatus accipiantur, mari uicinum ad commoditates nec expositum nimia propinquitate ad pericula classium externarum, regionum Italiae medium, ad incrementum urbis natum unice locum (Liv. 5.54.4). ${ }^{17}$

Así, por un lado la proximidad al mar trae aparejado tanto el peligro de la corrupción de las costumbres como el riesgo de sufrir un repentino ataque. Por otro lado, el completo aislamiento torna salvaje el carácter de los pueblos. De este modo, se entiende que los retos por su hábitat efferarunt. Mientras que los demás etruscos representan el polo opuesto. Su exceso de contacto con el mar (Liv. 5.33.9), los expone tanto a la corrupción moral. El caso de los vénetos estaría en un estado medio, tal vez el ideal a los ojos de los lectores antiguos. Pues 
Representación de la etnia véneta en Ab Urbe Condita de Tito Livio

aunque tienen contacto con el mar muchas de sus poblaciones están tierra adentro, como vimos, en una planicie entre el mar y los Alpes.

Un último aspecto que cabe mencionar con respecto a este pasaje, y que también será manifestado de modo más explícito en el pasaje que analizaremos a continuación, es el poder militar de los vénetos. En la digresión se muestra como el poder de los etruscos es tal que dominan todo el norte de Italia, sin embargo el territorio de aquéllos se mantiene independiente.

\section{Victoria de los patavinos sobre los griegos de Cleónimo}

El fragmento que narra la expedición de Cleónimo a Italia es interesante en la medida en que teniendo este hecho relación con Roma, el espacio que le dedica a los sucesos en que se ve involucrado el pueblo romano es superado por la digresión de los acontecimientos en que se ven implicados los vénetos (Liv. 10.2.1-15). Los estudiosos modernos sostienen que la incorporación en la narración de estos últimos sucesos se debe al sentimiento patriótico del historiador patavino por su ciudad natal, sus costumbres y la geografía en donde está ubicada. ${ }^{18}$

El pasaje comienza con dos versiones de lo que hizo Cleónimo en el sur de Italia: la derrota del espartano a mano de un ejército consular o la huida sin haber trabado combate. Luego sigue una descripción desde el mar de la costa itálica (importuosa Italiae litora ${ }^{19}$ ) hasta medioque sinu Hadriatico ${ }^{20}$, expresión que repite sendas frases de los dos apartados vistos arriba y que parece ser un eco del trayecto de Anténor.

A continuación, se aprecia una comparación implícita entre los ilirios, liburnos e istros y los vénetos. Los primeros son gentes ferae et magna ex parte latrociniis maritimis infames (Liv. 10.2.4) ${ }^{21}$. Mientras que los segundos son, por un lado, campesinos que viven en una suerte de confederación de pueblos próximos al mar, pero separados de éste por unas colinas. Por el otro, están habituados a las armas, mas no por actividades relacionadas al pillaje, sino por la necesidad de defenderse frente a la amenaza de sus vecinos, los galos. Aquí, claramente, debemos tomar la referencia a los galos como un lugar común dentro de la literatura latina, e incluso helenística. Más allá, que desde el libro quinto el historiador nos ha relatado el cambio de la geopolítica de Italia del norte con la migración de este pueblo, lo que aquí se pone de manifiesto es el uso retórico que se hace de ellos en la medida que en el imaginario historiográfico son conocidos por su ferocitas y por sus constantes excursiones de pillaje. ${ }^{22}$ En ese sentido, podemos ver que el impacto ante el lector es mayor que si se hubiera nombrado en su lugar a los etruscos. Aquí, se puede apreciar claramente como el historiador marca la polaridad civilización y barbarie. El véneto descripto como campesino, hace referencia a la cuestión de la agricultura vinculada a la 
civilización, lugar común dentro de los relatos etnográficos (Hom. Od. 9.106-115; Strab. 17.3.13). Mientras que la referencia a la piratería o al pillaje en el caso de los otros pueblos marcaría un rasgo de barbarie (CLAVEL-LÉVÊQUE, 1978, p.25). Polaridad que también se ve en el ámbito militar. Los vénetos son presentados como campesinos soldados, clara alusión al ideal romano (Cato Agr. Praef. 3; Liv. 42.34). Esto tiene una vinculación directa también con la concepción que se tiene de cómo debe hacerse la guerra. Los pueblos dedicados al pillaje o la piratería combaten como bandidos, mientras que la forma romana de practicar la guerra es concebida bajo ciertas reglas y ritos. $^{23}$ De este modo, se puede percibir la diferencia con los griegos, quienes se alejan de sus naves por el atractivo que les produce el pillaje, mientras que la juventud patavina tendrá un comportamiento más prudente en su ataque. Por ello mismo se terminará produciendo su victoria final.

Un último aspecto que podemos mencionar es que los patavinos tienen naves, pero son para uso en el río o la laguna. Esto debe hacernos pensar en aquello que señalábamos arriba acerca de la sociabilidad. El no mencionar barcos para uso marítimo propias de los vénetos da a entender el poco contacto con el mar que tenían, a diferencia de los etruscos. Ello implica a ojos de un lector romano el hecho de que las ciudades están resguardadas de una posible amenaza física o moral venida de allí.

Esto nos lleva a pensar en la construcción que hace Livio del territorio que habitan los vénetos y a plantear la hipótesis de que los diferentes datos que emplea en su descripción no son tan anecdóticos como se creyera, guarden o no relación directa con la realidad como señala Walsh. Incluso, se pueden comparar con aquellos textos que tratan de la localización de Roma. Si pensamos en Patavio, vemos que es cercana al mar, a poco más de catorce millas nos da a entender el texto. Igualmente, la conexión con éste es accesible por un río que permite la circulación de naves, aunque de un calado menor. Estos puntos la hacen bien situada para prepararse y repeler un ataque llegado del mar, como de hecho se nos relata en este pasaje. ${ }^{24}$ En ambos casos, se señala que hay colinas, stagna $^{25}$, y que están en una planicie ${ }^{26}$. Con esto no queremos aseverar que el autor pretende señalar su ciudad o su región como un símil exacto de Roma. La diferencia principal radica, por ejemplo, en que esta última ocupa un lugar de preeminencia en el Mediterráneo por estar en el centro de Italia, y por tanto del mundo conocido. No obstante, hay que ver en la descripción un claro propósito por realizar una representación positiva de su lugar de origen y a sus habitantes.

De este modo, el pasaje narra tres victorias seguidas de los vénetos y la retirada del "rey" Cleónimo con un quinto de su flota, sin haber logrado abordar ninguna zona del mar Adriático: ni aquélla sin puertos, ni donde habitan los pueblos salvajes, ni la de los descendientes de Anténor. Con respecto al error de 
Representación de la etnia véneta en Ab Urbe Condita de Tito Livio

dar el título de rey al jefe espartano, Braccesi sostiene que el mismo derivaría de la épica local. ${ }^{27}$ Aunque posiblemente, Tito Livio lo emplee para dar un aspecto aún más glorioso a los acontecimientos que tienen como protagonistas a sus conciudadanos. Nótese que en el relato, Patavio es presentada como la ciudad más importante entre los vénetos, es desde allí que se organiza el contraataque y sale el ejército vencedor.

El fragmento finaliza poniendo de manifiesto la pietas de los vénetos quienes dedican los espolones y despojos de los griegos en el templo viejo de Juno. Esto es enfatizado por Tito Livio, quien indica que aún existen personas en su época que los vieron (uiderunt) ${ }^{28}$ y que señala que a partir de esa gran victoria naval se instauró, como recuerdo, una competición de embarcaciones en la ciudad. $^{29}$ La pietas de los vénetos parecería estar enfatizada también de otro modo indirecto. La idea de que un viejo templo en honor a Juno sigue en pie todavía en la época de Tito Livio indica el respeto no sólo por la diosa, sino también por la religión que profesaban los vénetos. A este respecto, se puede pensar en el pasaje Liv. 4.20.7, en dónde se subraya la importancia de la labor de Augusto que erigió o restauró los templos de Roma, o en las críticas ante la indiferencia hacia la religión entre sus contemporáneos (Liv. 3.20.5; 8.11.1).

\section{Sedición en Venecia}

En el libro cuarenta y uno, encontramos la última referencia a los vénetos que nos interesa tratar aquí. Allí podemos leer que, por una sedición entre patavinos, se pidió la intervención de los romanos en Venecia y que un conflicto similar en Etolia hizo que también se debiera enviar legados a dicha región (Liv. 41.27.3-4). El texto dice: Consules uotis in Capitolio nuncupatis in prouincias profecti sunt. ex iis M. Aemilio senatus negotium dedit, ut Patauinorum in Uenetia seditionem conprimeret, quos certamine factionum ad intestinum bellum exarsisse et ipsorum legati attulerant. legati, qui in Aetoliam ad similis motus conprimendos ierant, renuntiarunt coerceri rabiem gentis non posse. Patauinis saluti fuit aduentus consulis; neque aliud, quod ageret in prouincia, cum habuisset, Romam redit. $^{30}$

El texto marca una comparación entre lo que pasó en cada lugar. En ambos pueblos se produjo una sedición que devino en guerra intestina. ${ }^{31}$ En el caso de los vénetos, éstos pidieron, por medio de sus diputados, la mediación de los romanos. Cediendo de este modo su autonomía interna en pos de un problema que, al haber producido daños en el tejido social, parece haberse salido de control para los propios patavinos llegando a una intestinum bellum que puede destruir la comunidad. La intervención de Roma en este tipo de problemas marca por un lado la superioridad no sólo política, sino también moral de ésta frente a los demás pueblos del mundo, a los que debe gobernar y educar (MINEO, 2006, p.22 y 
ss.). De este modo, se puede advertir la superioridad de Roma sobre el pueblo del norte de Italia, que recurre a ella para restablecer la concordia.

Por otra parte, el historiador también señala la diferencia de los vénetos con respecto a los etolios. A partir de la sedición, a la que bien podemos considerar como un venenum (Liv. 2.44.8; 3.67.6), advertimos que la naturaleza de ambos pueblos se hace notoria en las distintas reacciones que manifestaron ante la ayuda de los representantes de Roma. Entre los patavinos la llegada del cónsul fue la salvación, mientras que en el caso de los etolios, la rabia de estos hizo imposible el auxilio romano. Aquí no sólo se contrapone la enfermedad de los segundos con la salud de los primeros, ${ }^{32}$ sino también se pone de manifiesto el uso del estereotipo peyorativo de los etolios para marcar una vez más un aspecto positivo acerca de los vénetos. La imagen de aquellos como un pueblo bárbaro, ha mostrado Antonetti (1990, p.139-141) analizando los pasajes 34.24.3-4 y 35.12.1, es una interpretación propia de Tito Livio. ${ }^{33}$ Así, una vez más el historiador patavino por medio de una comparación implícita dará una imagen de su pueblo destacada. Incluso, llama la atención que no se explaye en la solución impuesta por el cónsul, su sola presencia restableció la concordia. Compárese, por ejemplo, con la intervención de los romanos en la sedición de Ardea en 4.9-10 donde se decapita a los cabecillas del movimiento y se incorporó sus bienes al común de la ciudad.

\section{Conclusión}

A lo largo de este trabajo hemos analizado la representación que hace Tito Livio de los vénetos a través de los elementos etnográficos. En el pasaje del libro primero hemos visto como expone el origen y característica de sus habitantes uniendo el componente véneto con el troyano. Eso le permite, por un lado, siguiendo tal vez a Catón, vincular a su pueblo natal con los romanos y, por otro, glorificar el pasado de Patavio por medio de su héroe fundador Anténor a quien se le atribuyen virtudes morales.

La construcción positiva de la imagen de los vénetos en el texto se complementa en el libro quinto y décimo. Allí se los presenta como un pueblo de campesinos, recurriendo al tema de la agricultura como un elemento funcional que permite establecer una polaridad entre civilizados y bárbaros. Polaridad que se verá enfatizada por la designación de los ilirios, liburnios e istrios como piratas, al igual que la alusión al pillaje de los espartanos o al de los ataques constantes de los galos. Todo lo cual se contrapone al ideal de campesino soldado con que se describe a los vénetos, cualidad que en el pasado le permitió mantenerse fuera del dominio etrusco. Por otra parte, la polaridad se remarca con la idea de ferocitas que engloba a retos, ilirios, liburnos, istrios, galos y, posteriormente, a los etolios. 
Representación de la etnia véneta en Ab Urbe Condita de Tito Livio

Sobre su relación frente al mar, podemos sostener que aunque tienen naves, no se dice nada acerca de un posible comercio marítimo. Esto, como vimos está íntimamente relacionado a la idea de sociabilidad de los pueblos y le permite al historiador marcar una diferencia entre su pueblo y los etruscos, cuyo contacto con el mar es resaltado con la mención acerca de que de ellos derivan el nombre de los mares que rodean a Italia. Diferencia que también se observa en el caso de los retos, cuyo excesivo aislamiento los tornó salvajes. En el caso de Patavio, observamos que su relación con el mar es presentada de un modo similar a la que se señala en el caso de Roma. Igualmente, notamos cómo estas dos ciudades se asemejan en otros aspectos de la descripción geográfica como la presencia de colinas, stagna y planicie.

En lo que atañe a la religión, la única alusión es a un viejo templo de Juno. A través del mismo se enfatiza la piedad del pueblo. Por un lado, de forma directa en la medida que los restos de los enemigos espartanos son dedicados a la diosa. Por otro lado, de forma indirecta, en la medida que Tito Livio indica que aún el templo que es viejo sigue en pie. Así, marca el respeto hacia la diosa y por la religión.

La organización política aparece primero en el episodio de Cleónimo, donde los poblados vénetos actúan como una confederación, al menos defensiva, donde la ciudad más importante es Patavio. Su integración por Roma no la tenemos debido a la pérdida de los libros de la obra en donde seguramente se la relata. Sin embargo, en el fragmento del libro cuarenta y uno vemos como se comportan en una relación de dependencia frente a Roma, cediendo autonomía interna para frenar la sedición y volver a la concordia.

Esta representación que hace Tito Livio de los vénetos o, al menos, su aporte a la cristalización de un estereotipo positivo de éstos asociado a virtudes morales en el imaginario romano tendrá sus ecos posteriores. Ya Virgilio hablará de ese pueblo que vive pacíficamente en el norte (Verg. A. 1.247) ${ }^{34}$, y Plinio el joven (Plin. Ep. 1.14.6; MÉTHY, 2009) y Marcial (Mart. 6.42.4; 11.16.7) lo pondrán de manifiesto también.

\section{Fuentes}

M. TULIO CICERÓN. Sobre la República. Introducción, traducción, apéndice y notas. D’Ors, A. Planeta DeAgostini, 1995.

LIVY. Rome's Mediterranean Empire. Books Forty-one to Forty-Five and the Periochae.

Traducción, introducción y notas de Chaplin, J. E. Oxford: University Press, 2007.

TITE-LIVE. Histoire Romaine. París : Les Belles Lettres, 1940-.

TITO LIVIO. Historia de Roma desde su fundación. Traducción de Villar Vidal, J. A. Madrid:

Ed. Gredos, 1990-.

\section{Bibliografía}

ANTONETTI, C. Les Étoliens. Image et religion. Annales Littéraires de l'Université de Besançon. Paris: Les Belles Lettres, 1990. 
Agustín Moreno

BOLCHAZY, L.J. Hospitality in Antiquity: Livy's concept of its humanizing force. Chicago: Ares Publishers Inc., 1995

BOTTERI, P. Stasis: le mot grec, la chose romaine, Metis. Vol. 4. №1, p.87-100, 1989.

BURNS, T.S. Rome and the Barbarians, 100 B. C. - A. D. 400. Baltimore/London: The Johns Hopkins University Press, 2003.

CLAVEL-LEVEQUE, M. Brigandage et piraterie: représentations idéologiques et pratiques impérialistes au dernier siècle de la République. Dialogues d'histoire ancienne, Vol. 4, $\mathrm{N}^{\circ} 1$, p.17-31, 1978.

FELDHERR, A. Spectacle and society in Livy's history. Berkeley/Los Angeles/London: University of California Press, 1998.

GABBA, E. True History and False History. Classical Antiquity. JRS, 71, p.50-62, 1981.

GIROD, M.R. La Géographie de Tite-Live. ANRW, p.1190-1229, 1982.

GLARE, P.G. W. (ed.). Oxford Latin Dictionary. Oxford: Oxford Clarendon Press, 1968.

HARTOG, F. El espejo de Heródoto. Buenos Aires: Fondo de Cultura Económica, 2003 (1980).

HELLEGOUARC'H, J. Le vocabulaire latin des relations et des partis politiques sous la république. Paris: Les Belles Lettres, 1972.

ISAAC, B. The invention of Racism in Classical Antiquity. Princeton University Press, 2006 (2004).

JACOB, Ch. Geografía y etnografía en la Grecia antigua. Barcelona: Bellaterra, 2008.

JAEGER, M. Livy's Written Rome. University of Michigan Press (Ann Arbor), 1997.

KRAUS, C.S. 'No Second Troy': Topoi and Refoundation in Livy, Book V, TAPA. p.267-289, 1994.

KRAUS, C.S. y WOODMAN, A.J. Latin Historians. Greece \& Rome, New Surveys in the Classics 27, Oxford: Oxford University Press, 1997.

LÓPEZ RAMOS, J. Excursus, etnografía y geografía: un breve recorrido por la tradición historiográfica antigua (de Heródoto a Amiano Marcelino). Nova Tellus, 26.1., p.259319, 2008.

LUCE, T.J. Design and structure in Livy: 5.32-55. TAPA, 102, p.265-302, 1971.

MARINCOLA, J. Authority and tradition in ancient historiography. Cambridge University Press, 2004.

METHY, N. Le monde romain dans les lettres de Pline le jeune: espace et valeurs. Mnemosyne, 62, p.237-249, 2009.

MILES, G.B. History and memory in Livy's narrative. In: MILES, G. B. Livy. Reconstructing Early Rome. Ithaca/London: Cornell University Press, p.8-74, 1997.

MILES, G.B. The Cycle of Roman History in Livy's First Pentad. In: MILES, G. B. Livy. Reconstructing Early Rome. Ithaca/London: Cornell University Press (=1986, AJPh, 107), p.1-33, 1997.

MINEO, B. Tite-Live et l'histoire de Rome, Sofía: Klincksieck, 2006.

MITCHELL, S. The Galatians: Representation and Reality, en Erskine, A., A Companion to the Hellenistic World, Blackwell Publishing, 2005, p.280-293.

MOORE, T.J. Artristry and ideology: Livy's Vocabulary of Virtue, Athenäum, 1989.

MORSTEIN-MARX, R. The Myth of Numidian Origins in Sallust's African Excursus (lugurtha 17.7-18.12), AJPh, Vol. 122, N², p.179-200, 2001. 


\title{
Representación de la etnia véneta en Ab Urbe Condita de Tito Livio
}

OAKLEY, S. A Commentary on Livy, Books VI-X. Vol. I-IV. Oxford: Clarendon Press, 20042007 (1997-2005).

OGILVIE, R.M. A Commentary on Livy, Books 1-5. Oxford: Clarendon Press, 1970.

SALLER, R. Review on L. J. Bolchazy, Hospitality in Early Rome. Chicago. Ares Publiser, 1977. AJPh, Vol. 100, N 3 . The Johns Hopkins University Press, p.465-8, 1979.

SYME, R. Salluste, trad. de Robin, P. Paris : Les Belles Lettres. 1982.

THALLON, I.C. The tradition of Antenor and its historical possibility, AJA, 28, p.47-65, 1924.

THOMAS, F. Lands and peoples in Roman poetry. The ethnographical tradition, Cambridge philological Society, 1982.

WALBANK, F. W. A historical commentary on Polybius. Vol. 1. Oxford Clarendon Press, 1957.

WALSH, P.G. Livy. His historical aims and methods. Cambridge University Press, 1963.

WILLIAMS, J.H.C. Beyond the Rubicon. Romans and Gauls in Republican Italy. Oxford: Oxford University Press, 2001.

WOODMAN A.J. Rhetoric in classical historiography. London/New York: Routledge, 1988

\begin{abstract}
Notas
${ }^{1}$ Más allá de que la fundación de Roma se hiciera en el Palatino, la disposición del Capitolio como centro del mundo romano se puede apreciar ya en Liv. 1.10.7, donde se menciona el templo de Júpiter Feretrio, el primero que se consagró en la ciudad. La centralidad del Capitolio está presente de forma explícita en el libro primero nuevamente cuando se narran los hechos en torno al dios Término y a la aparición de una cabeza con rasgos intactos (Liv. 1.55.4-6). Esos mismos temas son retomados en Liv. 5.54.7 por Camilo para enfatizar una vez más la centralidad del Capitolio en el imperio romano. Este punto es analizado por Jaeger (1997, p. 1 y ss.) en el pasaje Liv. 45.27.5-28.6, en donde el historiador romano relata la gira de Emilio Paulo por Grecia. Haciendo referencia a la visión romanocéntrica y a la organización del espacio y del tiempo en la obra en su análisis, sostiene Jaeger (1997, p.3 y 4-5): "Paullus'other actions after Pydna convey clearly a sense of Roman ascendancy, and Livy's description of his trip asserts that Rome is now the cultural center of the world. The narrative, therefore, reflects some fundamental convictions about the organization of space: Rome is the center of the empire it rules, and the Capitoline, the fixed center of Roman religion and home of the gods who are the source of Rome's supremacy, is the center of Rome...For Livy, space, time, Roman national memory, and the cultural practices that reinforce national identity all start from this center move outward, and then return, as action oscillates annually between events at home and in the field, and as the city expands, collapses, and grows back stronger than before in Books 1-6. The Capitoline, then, is both the center of Roman space and a Janus-like beginning and ending point for temporal cycles". Cfr. asimismo, Kraus, 1994, p.281.

${ }^{2}$ Sobre la tradición etnográfica ver Thomas (1982, p.1-7) y López Ramos (2008, p.259-306). Cfr. Gabba (1981, p.53 y 58-60) sobre los relatos utópicos y la literatura paradoxográfica. Sobre la importancia de las digresiones topográficas en la retórica de la historiografía, Woodman (1988, p.84-5 y 106 n.51). Para el caso particular de los excursos etnográficos en las obras de Salustio ver Kraus and Woodman (1997, p.39-41); Syme (1982, p.129 y 159160) y Morstein-marx (2001), con más referencias bibliográficas. Sobre la "retórica de la alteridad", Hartog (2003, p.207-245)
\end{abstract}


${ }^{3}$ Este aspecto ya aparece claramente visible en Heródoto (Thomas, 1982, p. 1; Jacob, 2008, p.65) y los historiadores latinos no rompen con esta norma. Así sobre Salustio dirá Thomas al analizar el excurso sobre África: "The description is by no means gratuitous...for action is to be understand in terms of both setting and participants"(1982, p.4). Ver también Morstein-Marx (2001, p.179). Sobre las digresiones en general, ver López Ramos (2008, p.262) y Ogilvie (1970, p.700-1), quien al tratar la digresión acerca de los galos en el libro quinto de Tito Livio (Liv. 5.33.4-35,3), afirma haciendo alusión al excurso de Salustio sobre África y al de Britania de Tácito en el Agricola: "it can be seen from the practice of other historians ...that such digressions were inserted to heighten suspense and to focus attention on the drama which is about to unfold".

${ }^{4}$ Sobre su nacimiento en Patavio hablan San Jerónimo (ad Euseb. Chron ad ann. Abr. 1958); Marcial (Mart. 1.61.3); Asinio Polión (citado por Quint. Inst. 1.5 .56 y 8.1.2); Asconio Pediano (Asc. Corn. 68) y Sidonio Apolinar (Sidon. Carm. 2.189 y 23.146).

${ }^{5}$ Sobre la referencia a su región de origen sin establecer su relación con ella ver Marincola (2004, p.273). Sobre la idea del sentimiento piadoso hacia Patavio ver Walsh (1963, p.2) y Ogilvie (1970, p.37). Sobre la relación entre Roma y Patavio cfr. Ogilvie (1970, p.36). Para posturas de Bolchazy (1977) y Thallon (1924) ver nota 8.

6 "Para empezar, está comúnmente admitido que, después de la conquista de Troya, hubo un ensañamiento contra todos los troyanos; únicamente dos, Eneas y Anténor, en razón del derecho de una antigua hospitalidad y por haber sido siempre partidarios de la paz y la devolución de Helena, fueron eximidos por los griegos de la aplicación de cualquier ley de guerra" (Liv. 1.1.1). Las traducciones que emplearemos son las de Villar Vidal.

${ }^{7}$ La expresión satis constat ha llamado la atención de Bolchazy (1977, p.78-80), quien al analizar la variedad de leyendas que hablan sobre Eneas, asevera que la expresión denota consenso o acuerdo y que la fuerza de la expresión está un escalón debajo de constat. Sin embargo, Miles (1997, p.20) sostiene que es un error traducir satis como "generalmente" y afirma: "It is best, perhaps, simply to acknowledge the ambiguity of the phrase's value and to take it as an expression of the narrator's own ambivalence toward his material".

${ }^{8}$ Thallon $(1924$, p.48) hace notar que la relación entre ambos héroes ya puede apreciarse en la llíada, cuando dos de los hijos de Anténor, Acamante y Arquéloco, acompañan a Eneas (Hom. Il. 2.822-3). Por su parte, Bolchazy (1977, p.89) concluye que tras el emparejamiento entre Eneas y Anténor subyace la idea de que el historiador buscaba enorgullecer a su patria natal. Asimismo, indica que la atribución de las mismas cualidades de Anténor a Eneas se habría dado por un proceso de atracción. Aquí, como en el pasaje del libro XLI analizado más adelante, parece estar presente aquello que señala López Ramos como aspecto propio de la etnografía latina: la historia de las relaciones entre el pueblo del cual se habla y Roma (2008, p.301).

${ }^{9}$ La vieja ley de hospitalidad hace referencia a la ocasión en que Anténor hospedó a Menelao y Odiseo (Hom. II. 2.207). La devolución de Helena aparece en Hom. II. 3.148-159; 7.347-353.

${ }^{10}$ Vale aclarar también que la vinculación de este héroe con Italia es posterior a Homero.

${ }^{11}$ En el texto titoliviano la relación entre el héroe troyano y la fundación de Patavio se sobreentiende. Pero, en la misma época encontramos la referencia a dicho acontecimiento en la Aeneis de Virgilio (Verg. A. 1.247). 
${ }^{12}$ Sobre la importancia de la hospitalidad para Tito Livio, así como en la antigüedad, es muy interesante el libro de Bolchazy (1977), aunque varios de sus aseveraciones han recibido una dura crítica por parte de Saller (1979).

${ }^{13}$ Claramente, se puede advertir un eco en Hom. II. 7.345-353.

${ }^{14}$ No pienso que se deba ver en este pasaje una contraposición entre los accionares atribuidos a Eneas y a Anténor, dado que la relación de ambos pueblos se da con mucha posterioridad en el tiempo y Tito Livio no teje en lo que nos ha llegado de la obra relación con estos mitos. Al enfatizar este punto, tengo en mente el análisis que hace MorsteinMarx (2001, p.192-5) de las similitudes y diferencias en el origen mítico de los númidas y de los romanos tal como Salustio los presenta en lugurtha y Catilina respectivamente.

${ }^{15}$ La concepción espacial de Italia teniendo como frontera los Alpes se puede ver, por ejemplo, en Liv. 1.2.5 ó 39.54.11.

${ }^{16}$ Ogilvie señala dos aspectos importantes de esta digresión: "The two threats, from Etruria and from Gaul, are the climax of the first five books, showing Rome for the first time as a stable political community...It would have been pointless to give an ethnographical digression on Rome; so L., instead of describing the invaded country, describes the invaders and, by touching on Etruria (Liv. 33.7-11) as well as Gaul, bridges the gap between the two halves of the book". Cuestiones estas que se advierten con claridad en los análisis de Kraus (1994), Miles (1997, p.75-109) y Luce (1971).

17 “No sin razón los dioses y los hombres eligieron este sitio para fundar la ciudad, unas colinas tan sanas, un río a mano por el que transportar los productos desde las zonas del interior y recibir el tráfico marítimo, un mar cercano para nuestra comodidad y no expuesto por su excesiva proximidad al peligro de las flotas extranjeras; en el centro de Italia, en un enclave único hecho a propósito para el crecimiento de la ciudad" (Liv. 5.54.4). Traducción de D'ors. Cfr. Cic. Rep. 5.10.

${ }^{18}$ Esto es señalado por Walsh (1963, p.40-1), Girod (1982, p.1197), Oakley (2007, p.54-5). El énfasis puesto por Walsh sobre este punto se debe a que para él Tito Livio se habría apartado de la postura polibiana sobre la importancia de la geografía para el historiador. A partir de allí, tanto Walsh como numerosos estudiosos de la obra de Tito Livio habrían remarcado sus excesivos errores en la materia y, con ello, sus pocos conocimientos. Por su parte, Girod (1192-3) defiende a Tito Livio sosteniendo que la indiferencia de la que se lo acusa en relación a la geografía se debe a la pérdida de los libros CIII y CIV, en donde había digresiones sobre la Galia y sobre Germania. Para Girod, este cambio de la importancia de la geografía en esos libros de la obra tiene que ver con una adaptación del historiador a los intereses de sus contemporáneos. La postura crítica de Walsh fue revisada y criticada por Woodman (1988, p.83-90), quien ha demostrado que la referencia geográfica de la que habla Cicerón está implícita en el esquema analítico que emplea Tito Livio en su obra. Asimismo, Woodman indicó que la geografía a la que se referían los autores antiguos tenía que ver con eso y no con descripciones detalladas tal como lo entendemos hoy. En ese sentido, el uso retórico del nombre de un pueblo bastaría para dar una referencia geográfica al lector.

${ }^{19}$ Sobre esta expresión ver Thomas (1982, p.126 y ss.) y Oakley (2007, p.58).

${ }^{20}$ La descripción desde el mar no culmina en este punto, sino que continúa una vez que llegan los espartanos a territorio véneto. 
${ }^{21}$ Es por ello, y por la falta de puertos del lado itálico, que Cleónimo se interna hasta los parajes de los segundos. Para otras referencias a estos pueblos en la literatura grecolatina cfr. Oakley (2007, p.58)

${ }^{22}$ Sobre el uso retórico de los nombres de los pueblos bárbaros, ver Burns (2003, p.22 y 74).

${ }^{23}$ La oposición entre estos dos tipos de conducirse en la guerra está claramente expuesto por Estrabón en varios pasajes de su libro tercero sobre Hispania. El procedimiento romano para hacer la guerra se advierte en el libro primero de $A b$ Urbe Condita en la descripción del rito fecial y, asimismo, se aprecia en la descripción de los acontecimientos que hacen a la política exterior cada año.

24 Para la misma idea, pero sobre Roma, cfr. 5.54.4.

${ }^{25}$ Para la región véneta ver Liv. 10.2.5. Cerca del Palatino: Liv. 1.4.4-5; 1.6.4 y 1.7.3.

${ }^{26}$ En el véneto: Liv. 10.2.5. En la región de Roma: Liv. 5.54.3.

${ }^{27}$ Citado por Oakley (2007, p.64). Este autor indica, basándose en OLD, que el uso de rex para demás parientes de la familia real existe, aunque en la poesía.

${ }^{28}$ Sobre la superioridad de la vista sobre otros sentidos en la historiografía ver Marincola (2004, p.63-86).

${ }^{29}$ Oakley (2007, p.54) afirma sobre este cierre de episodio: "in characteristically Livian fashion, the whole narrative is rounded off with the implications of this victory for the later periods". Sobre este punto cfr. el volumen I, p.127-8. Sobre referencias a dichas competiciones en otros autores Oakley (2007, p.54).

30 "Los cónsules, después de pronunciar los votos en el Capitolio, partieron hacia sus provincias. Uno de ellos, Marco Emilio, fue encargado por el senado de reprimir en Venecia la revuelta de los patavinos, los cuales, según habían informado sus propios diputados, se habían crispado hasta llegar a una guerra intestina a causa del enfrentamiento entre facciones. Los embajadores que habían ido a Etolia para sofocar unos disturbios similares volvieron diciendo que no se podía controlar la rabia de la población. La llegada del cónsul fue la salvación para los patavinos, y como éste no tenía ninguna otra misión que cumplir en la provincia regresó a Roma". Aquí, parece haber un error, dado que Marco Emilio fue cónsul el año precedente. El error puede deberse como se señala en las diferentes traducciones (Oxford, Belles Lettres) a un error del autor o del copista. Salvo que sean los sucesos los que han sido cambiados de año.

${ }^{31}$ Sobre el término seditio y su relación con certamine factionum ver Hellegouarc'h (1972, p.135-7). Sobre seditio, su etimología, pero especialmente sobre su relación con la "stásis" griega cfr. Botteri (1989).

${ }^{32}$ Se puede ver en OLD especialmente la segunda acepción de salus y la segundo sentido de rabies. La concepción de lo político y lo social a través de una metáfora biológica queda de manifiesto en el apólogo de Menenio Agripa en el libro segundo (Liv. 2.32.8-12), donde se muestra cómo la intestina seditio del cuerpo puede destruir el organismo. Aquí, la situación parece similar, la seditio se ha tornado intestinum bellum.

${ }^{33}$ Sobre el segundo de los pasajes asevera el autor "ce bref passage est un témoignage précieux d'une réflexion romaine sur l'histoire grecque: il opère la fusion du modèle interprétatif grec avec le modèle romain" (Antonetti, 1990, p.141). 
Representación de la etnia véneta en Ab Urbe Condita de Tito Livio

${ }^{34}$ Oakley (2004, p.110) hace notar como un punto a tener en cuenta que varios libro de $A b$ Urbe Condita son anteriores a Aeneis. 


\title{
O RISÍVEL, O LASTIMOSO E O RIDENTE EM METAMORFOSES DE APULEIO: A DINÂMICA DAS RELAÇÕES SOCIAIS NA ROMA PROVINCIAL
}

\author{
Luciane Munhoz de Omena \\ Universidade Federal de Goiás - Brasil
}

\begin{abstract}
Como não ter Deus? Com deus existindo, tudo dá esperança; Sempre um milagre é possivel, o mundo se resolve. Mas, se não tem Deus, há-de a gente perdidos no vai-vem, e a vida é burra.
\end{abstract}

Guimarães Rosa

Grande Sertão: Veredas

Nesse artigo proponho discutir sobre as relações sociais nas províncias romanas a partir de duas comemorações descritas em Metamorfoses, de Lúcio Apuleio: uma dedicada à deusa Ísis e a outra ao deus do Riso. As festas exprimem sempre uma concepção de mundo, não apenas isto, mas também, como coloca Guarinello (2001), geram identidade entre os participantes, o compartilhamento do símbolo comemorado e se inscrevem também na memória coletiva. Nesse sentido a narrativa apuleiana permite que tracemos um perfil das estruturas sociais, culturais e políticas romanas do século II d.C.

\section{O RISÍVEL: UMA SÁTIRA DA DEGRADAÇÃO SOCIAL}

Balançando os braços com alternados esforços, tentava mover-me à maneira das aves. De penugem, entretanto, ou de penas, nenhum sinal; mas meus pêlos, sim, se espessaram em crina, minha mimosa pele se endurece como couro; a extremidade das minhas mãos, cessando o número dos dedos, todos eles se juntaram; da parte mais baixa da minha espinha, saiu uma longa cauda. O meu rosto, agora, torna-se uma face monstruosa, a boca se rasga, as narinas se abrem, e a beiçada fica pendente; minhas orelhas, com descompassado aumento, estão hirtas de hórridos pêlos (Apul. Met. 3.24).

Não há nada mais degradante e que seja motivo de riso do que ser transformado em um asno (ou como diriam alguns, num burro). Essa metamorfose escrita e dramatizada pelo protagonista Lúcio compõe a narrativa apuleiana, daí, o título Metamorfoses ou $O$ asno de Ouro. O protagonista Lúcio, aparentando pela linha materna com o filósofo Plutarco, viaja à Hípata e, nesta localidade, envolve-se com as artes mágicas, transformando-se em asno, passa por inúmeras dificuldades, para voltar a forma humana na festa dedicada à deusa 
$O$ risível, o lastimoso e o ridente em Metamorfoses de Apuleio

Ísis (Apul. Met. 11). A transformação em asno se deve a um erro cometido pela escrava Fótis. Esta tentando transformá-lo em ave, assim como o fez com sua senhora Panfília, passa o ungüento errado, mas o avisa que na manhã seguinte colheria rosas e, tão prontamente, seu amante voltaria a forma humana. Entretanto, na mesma noite, bandidos assaltam a casa de seu hospedeiro Milão e o levam juntamente com os objetos roubados, marcando assim, o início de várias aventuras, que servem para retratar os costumes da sociedade romana provincial (e.g. festas, adultérios, assassinatos, práticas mágicas, etc).

Nossa análise parte de dois elementos essenciais: o estilo de texto e a questão do riso como desencadeador do ultraje e da sublimação dentro das relações sociais nas províncias romanas do século II d.C.

1. Primeiramente, o enredo apresenta um conteúdo satírico-fantástico, que privilegia a paródia como veículo de relatos fantasiosos (MOTTA, 2006, p.165). O absurdo é inserido na narrativa a partir da metamorfose. Trata-se de uma narrativa de aventuras, de costumes (BAKHTIN, 1998) e de confissão (MOTTA, 2006), visto que o asno - Lúcio - narra suas próprias desventuras, traçando assim "suas aventuras, confessando no lugar do heroísmo, a fragilidade e os sofrimentos contidos num ritual de peregrinações" (MOTTA, 2006, p.161-2). Intensifica-se a consciência de seu sofrimento pelo castigo externo das agressões corporais. Tal consciência, como propõe Motta, reflete uma esfera de perdição da qual poderá retornar, "porque o circuito da representação realista faz o destino do homem girar pelas voltas desse labirinto simbólico, cujo ponto mais alto de afloração é o das relações humanas" (MOTTA, 2006, p.218).

Essa representação realista possui um traço indispensável e ambivalente: trata-se de um estado de transformação, mas ainda incompleto por aparecerem o estágio da morte e do nascimento. A própria metamorfose em asno comporta elementos do "baixo material e corporal", imprimindo valores de degradação e regeneração (BAKHTIN, 1999). O protagonista, após todos os infortúnios, retorna a forma humana pela intervenção da deusa Ísis, fazendo-o aprender pelo sofrimento. Esse caráter regenerador é positivo em termos sociais, pois, Lúcio entra para o colégio dos pastóforos da deusa e é elevado a ordem dos decuriões.

A salvação de Lúcio é evidente, no entanto, uma exceção, porque, a representação realista evidencia sempre situações de degradação humana: os personagens são sempre dramatizados pela angústia, constituídos pela figura "fragilizada do homem anti-herói, colocando em cena o drama de suas angústias particulares" (MOTTA, 2006, p.245). Lúcio é um anti-herói, oscila entre os movimentos de queda e redenção. Entretanto, outras personagens, assim como as femininas são representadas pela inconsequência, pôr utilizarem a magia sem a permissão dos deuses, aliás, de forma independente, visando aos interesses próprios e como parte de uma trama realista, sobrevivem causando desordens e 
não recebem sanções sociais. A personagem Panfília, esposa de Milão, é um exemplo de imprudência: a maga mantem sobre a cidade certa proeminência conquistada pelo medo, pois, seu conhecimento mágico poderia ser exercido contra os citadinos ou contra indivíduos, os quais atuassem contrariamente aos objetivos da feiticeira. No livro II, Apuleio condena-a pela boca de Birrena: "Guarda-te, guarda-te energicamente dos perigosos artifícios e da sedução criminosa dessa Panfília, mulher do Milão que tu dizes ser teu hospedeiro. Ela passa por mágica de primeira ordem, e entedida em todos os gêneros de encantamentos sepulcrais" (Apul. Met. 2.5).

A crítica apuleiana refere-se à postura de Panfília, principalmente, por utilizar a magia por motivos tão torpes quanto à infidelidade, deixar os afazeres de dona-de-casa confiando-lhes a escrava Fótis e até dando-Ihe autonomia, e, por fim, a maior reprovação encontra-se na postura passiva do marido (Apul. Met. 2.12). Este tipo de condenação faz parte da representação realista, e proporciona aos homens à visualização do

drama de si mesmo e da simbolização do inferno de sua vida, representado na alegoria da metamorfose de sua queda. Tendo como fundo do palco o espectro da morte de sobreaviso, o seu drama não lhe reserva a possibilidade de vitória. É a vitória da ironia que comandará a derrota de sua nova trajetória (MOTTA, 2006, p.170).

Ou seja, a ironia indica a vitória do "verme vencedor" (ALLAN POE, 1981, p.955 Apud MOTTA, 2006, p.171), garantindo, assim, o triunfo de Panfília, uma mulher que utiliza seu tempo praticando a arte mágica, a qual lhe serve como uma forma de exercitar e ampliar sua autonomia. Apuleio, contudo, mais do que recriminar sua atuação faz críticas ao descaso masculino. A narrativa é um tipo de precaução quanto aos rumos do que o autor considera por declínio social, qual seja: a mudança de comportamento das mulheres. Panfília representa mulheres, as quais surgem em razão de os homens não as controlarem.

2. O segundo elemento a ser vislumbrado é o riso, pois, é uma das características da narrativa apuleiana, pôr estruturar-se, juntamente, com o gênero de representação realista, em que todas as situações sociais apresentadas na narrativa são risíveis. Ora, a passividade de Milão, frente à autonomia de Panfília, torna-o ridículo. O comando de Fótis, escrava de Panfília, na relação sexual com Lúcio, colocando-o em posição de passividade, demonstra o domínio da personagem feminina sobrepondo-se a potestas masculina (Apul. Met. 2.9-10). Não é sem motivo, que este mesmo personagem degrada-se com a transformação em asno, logo, torna risível sua condição anterior, que deixa ser dominado por uma mulher e, ainda mais, uma mulher de condição escrava, tornando, dessa forma, sua degradação mais cômica, mais condenável. Ou em outras situações representadas na narrativa, as quais extrapolam o núcleo 
O risível, o lastimoso e o ridente em Metamorfoses de Apuleio

doméstico, incluindo outras esferas de poder como o banditismo, a fuga de escravos ou a própria inoperância das estruturas de domínio romano, criticado por Apuleio, através de seu conhecido Píteas, que se encarregava da anona e exercia também a função de edil. Este, após cumprimentar Lúcio, pois, há muito não o via, pergunta o valor pago por seus peixes, e ao descobrir que o repasto custou vinte denários, descontrola-se, obrigando Lúcio a apontar o vendedor. Ao aproximar-se deste, Píteas, pensa puni-lo, apenas por ter jogado os peixes no chão, pisando-os e aos gritos, repreende o velhinho. O modo como agiu o edil, tornou-se ridículo aos olhos do protagonista, pois, o vendedor foi somente afrontado publicamente, não devolveu a quantia a Lúcio e este sim, perdeu com a performance de Píteas: voltou a casa de seu hospedeiro Milão, com as mãos abanando, sem os víveres de seu jantar (Apul. Met. 2.24-25).

Essas são características zombeteiras por apresentarem realidades grotescas como a ineficiência de Píteas, visto que o leitor-ouvinte é conduzido, assim como o protagonista, a uma resolução eficiente na qual, espera-se, pelo menos, ter o dinheiro ou a diminuição do valor da mercadoria, mas, pelo contrário, perde-se tempo e capital. Evidencia-se, dessa forma, o predomínio de um mundo instável em que tudo é possível, em que todos os valores desaparecem.

Nessas aventuras grotescas, não há nem bem nem mal, belo e feio, mas simplesmente peripécias que determinam o riso embaraçado e vagamente perturbador. É um romance diabólico, a começar por seu herói, já que se trata das tribulações de um asno, animal que encarna os maus instintos, as forças maléficas, a sensualidade desenfreada (MINOIS, 2003, p.95).

Esta diabolização da narrativa apuleiana caracteriza a suposta adaptação das Metamorfoses, do satirista grego Luciano de Samósata. Conforme Minois (2003, p.67), este "zomba dos zombadores, ri dos que riem e duvida do ceticismo, atinge a negação absoluta, o nada", quer dizer, ao considerar a vida uma comédia grotesca e absurda, tudo é passível de ridículo: filósofos, deuses, charlatões e até ele mesmo.

Deve-se demarcar, sobretudo, a existência de dois risos em Apuleio:

O primeiro riso é o profano, o do dia-a-dia, o do cotidiano, retratado nas cenas de autonomia das personagens femininas, as quais atuam sempre por interesses próprios, como vimos anteriormente, ou a descrição apuleiana acerca da avareza de Milão, "um homem que possui haveres em abundância, mas desacreditado por sua extrema avareza e sórdida baixeza" (Apul. Met. 1.21). Uma derrisão que se aproxima das sátiras de Samósata por prevalecer um riso agressivo, desvelando a criação de uma ilusão, de um logro, pois, a sociedade constitui-se por seres degradantes e são estes, os quais darão ritmo a vida. É risível a avareza de Milão e ainda mais deplorável: é roubado em sua própria domus, evidenciando-se a inutilidade de sua mesquinhez, para mostrar o quanto 
a existência humana é alardeada pela ironia e pela instabilidade: o desfrute de sua riqueza será aproveitado por um grupo de bandidos (Apul. Met. 3.28).

O segundo riso é o sagrado, que por estar vinculado às divindades, permite a busca através delas da ordenação social e do equilíbrio. Diferentemente de Samósata nos quais os imortais em - $A$ assembléia dos deuses e Diálogos dos deuses - são ridículos por se queixarem de seus trabalhos e, com isso, passam o tempo brigando. Em Apuleio, a salvação dos homens e a conquista de benesses nos planos político e social dar-se-ão pelas intervenções divinas, diferentemente da proposta do satirista grego. O que caracteriza um dos eixos centrais da narrativa apuleiana: o descrédito dos homens pelos deuses. Tomo como ponto de partida, duas narrativas inseridas nas Metamorfoses:

1. A jovem Psiquê, filha de um rei, dotada de rara beleza não consegue casar-se pelo fato de os homens terem receio de sua formosura. Tal perfeição ganha fama, a tal ponto que se estende para além das fronteiras do reino, gerando, com isso, a crença de que se trata de uma deusa e não de uma mortal. A população descuida-se da manutenção do culto da deusa Vênus e, então, a divindade possuída de grande cólera manda uma série de desgraças ao reino de Psiquê. Seu pai preocupado com os infortúnios e com o destino de sua filha, sem uma relação matrimonial, encaminha-se até o oráculo e recebe a aterradora notícia:

Sobre o rochedo escarpado, rei, expõe a tua filha, para o himeneu de morte, pomposamente enfeitada. Então não esperes para teu genro, criaturas originadas de mortal estirpe, mas um monstro cruel e viperino, que voa pelos ares e, feroz e mau, não poupa ninguém (Apul. Met. 4.33).

Esta penalização sofrida pela jovem princesa se dá por um elemento importantíssimo caracterizado pela incredulidade dos homens na deusa Vênus. Isso promove dois problemas relacionáveis: ao deixar de ser cultuada, Vênus é afastada da memória coletiva dos homens e, por consequência, o reino é assolado por desequilíbrios sociais, pois, há uma preeminência do sagrado, embora a crítica apuleiana se concentre na incredulidade de seus contemporâneos.

2. A segunda narrativa refere-se ao desrespeito do protagonista aos cultos religiosos, porque, assim como Méroe (Apul. Met. 1) e Panfília (Apul. Met. 2), Lúcio utiliza a magia como forma de manipulação de poderes superiores sem o auxílio das divindades. $O$ culto religioso se separa da magia por responder pela crença em seres sobrenaturais, os quais regem conscientemente o mundo de acordo com sua persuasão, enquanto, a magia é o produto das operações de leis imutáveis, por conseguinte, o conhecimento e a intervenção das feiticeiras nestas leis naturais é quem produzirá a magia, sem a presença dos deuses. 
A reprovação de Apuleio as práticas mágicas perpassa a não ritualização dos cultos aos deuses, assim como apresenta-se no conto de Psiquê e Cupido, na qual Vênus deixa de ser cultuada e, consequentemente, ritualizada. Há um entrelaçamento entre o culto religioso e a magia, posto que a transformação de Lúcio-Asno em humano deve-se a uma intermediação mágica, que se estabelece pela interferência direta da deusa Ísis em sua procissão, através da ingestão de rosas disponibilizadas por seu sacerdote (Apul. Met. 11). No mesmo livro, o autor posiciona a deusa acima dos homens e até mesmo de outras divindades, para enfatizar seu poder e demonstrar a seus contemporâneos a superioridade de Ísis: se comparada a atuação das feiticeiras, as quais agem de forma individualizada, tornam-se insignificantes, pois a deusa comanda o todo.

Para demonstrar a grandeza e a imponência de Ísis, após a aparição da deusa na praia, Lúcio-Asno sem questionar a ordem divina, aproxima-se do sacerdote e ingeri as rosas, mas antes de comê-las, eis que observa: "de todos os lados, como num dia de festa, e mais propriamente de triunfo, grupos animados enchiam as ruas" (Apul. Met. 11.7). A primeira vista, temos a alegria do personagem em despojar-se da figura de asno, mas também pode-se observar, a partir de suas palavras, uma ação coletiva, levando-se em consideração o envolvimento de toda a cidade de Concréias, colônia de Corinto (Apul. Met. 10.35), experimentando sentimentos e emoções, os quais são seguidos dos "prelúdios da grande pompa gradualmente se [avançando], ornada belíssimamente segundo o votivo de zelo de cada um" (Apul. Met. 11.8).

Daí considerar a procissão isíaca uma comemoração festiva, pois, interpreto-a como um fenômeno social por implicar uma ação coletiva, na qual se enfatizam sentimentos e emoções experimentadas pelos participantes. Não é sem motivo, que houve um cuidado pessoal, de cada um dos representantes de Concréias, para que a festa agradasse a divindade e, assim a população pudesse alcançar seus favores, do mesmo modo que Lúcio.

Sendo assim, apresentam-se na procissão isíaca mulheres esplêndidas vestidas de branco, as quais exprimem alegrias com vários gestos: "floridas com coroas da Primavera, tiravam as pétalas de seus seios e as jogavam no chão pelo caminho por onde marchava o cortejo sagrado" (Apul. Met. 11.9). Além de mulheres participam homens com fachos, velas de cera, para evidenciar as benções daquela de quem se originam os astros do céu. Seguindo a procissão, incluem-se ainda as sinfonias de flautas, o coro composto por jovens nobres cantando um poema dedicado a deusa, e, então, "aflui grande multidão de iniciados nos sagrados mistérios, homens e mulheres de todas as hierarquias e toda a idade, resplandecentes com a brancura imaculada de suas túnicas de linho" (Apul. Met. 11.10). Os sacerdotes dos sagrados ritos são ilustres cidadãos com "vestimentas de linho branco que, apertada no peito e pendendo até os pés, 
conduziam os insignes despojos dos potentíssimos deuses" (Apul. Met. 11.10). O primeiro deles carrega um barquinho de ouro, o segundo leva em suas mãos dois altares, o terceiro ergue uma palma feita de folha de ouro, o quarto

mostrava o emblema da justiça - a mão esquerda com a palma aberta: naturalmente lenta, despojada de agilidade e segurança, a esquerda parecia, mais que a direita, convir a justiça. Levava ele, na outra mão, um vasinho de ouro arredondado em forma de mama, com a qual fazia libações de leite. Um quinto tinha uma caixa de ouro carregada de raminhos de ouro, e o sexto, uma ânfora (Apul. Met. 11.10).

Os indivíduos e suas posições na procissão seguem o ordenamento social, ou seja, as funções especiais são delegadas aos cidadãos ilustres, como os sacerdotes dos ritos sagrados, o coro, os quais cantam cantigas à deusa ou o grão sacerdote, que ao finalizar o cortejo, entoa as últimas preces, para depositar os presentes e os objetos votivos no barco (Apul. Met. 11.16), enquanto, a turba de iniciados nos cultos mistéricos, homens e mulheres de todas as idades e posições sociais, vestidos de linho seguem o cortejo (Apul. Met. 11.10). Ao final da procissão, o grão sacerdote dirige-se ao templo, juntamente, com os demais sacerdotes e os iniciados, para convocar o grupo dos pastóforos da deusa e pronunciar os votos de prosperidade aos agentes sociais, representados pelo domínio romano através do príncipe soberano, do senado, da ordem eqüestre e do povo romano.

Esse pronunciamento demarca, primeiramente, as boas relações do culto isíaco com a auctoritas romana, com o poder oficial. Devemos recordar que alguns cultos mistéricos como o de Ísis foram reprimidos por serem cerimônias secretas e poderem "ocultar perigosas reivindicações da massa popular, que aderia a elas em grande número" (SCARPI, 2004, p.166). Augusto proibi a celebração dos rituais de Ísis no interior do pomoerium, no governo de Tibério é ordenado a demolição do santuário e sua imagem é jogada no Tibre, enquanto, no século de Apuleio, as autoridades permitem a realização do culto e todo o seu cerimonial. 0 último livro das Metamorfoses é um reflexo dessa oficialização. Como vimos, Lúcio Apuleio descreve em detalhes a realização da procissão e dos ritos de iniciação à deusa através da transformação do Asno-Lúcio em homem (Apul. Met. 11.6) e, talvez a associação mais relevante seja à do culto com os poderes romanos e seus domínios, pois, segundo as palavras do protagonista, a proteção incluiria também os navegadores e os "navios que, no mundo inteiro, estão sob a lei do nosso império" (Apul. Met. 11.17).

Ora, a utilização do pronome "nosso" indica uma assimilação de uma identidade romana por parte de Apuleio, a partir disto, deve ser mencionado que o autor nasceu na cidade de Madaura, província africana localizada entre a Numídia e a Getúlia. Como afirma o próprio autor em Apologia (Apul. Apol. 24.1): "quanto à minha pátria ela está situada entre os limites da Numídia e da Getúlia. 
O risível, o lastimoso e o ridente em Metamorfoses de Apuleio

Eu declarei de fato que era semi-númida e semi-getulo", portanto, temos um africano que se identifica com sua região de origem, mas se inclui como pertencente ao poderio romano.

No entanto, essa integração não elimina a manutenção das "identidades étnicas", pois, mantiveram-se por todo o império, por isso, a autodenominação de Apuleio como sendo semi-númida e semi-getulo ou mesmo o imperador Septímio Severo ser africano. São, justamente, as identidades étnicas, as quais se tornam presentes em discursos como no diálogo entre Birrena e Lúcio nas Metamorfoses, na qual a anfitriã afirma que a cidade de Hípata, sua pátria, é esplendorosa pelos templos, banhos e outros edifícios públicos, se comparada às diversões na cidade de Roma - um forasteiro ativo em nada perderia. Este discurso suscita, pelo menos, uma questão: Hípata é tão equipada de divertimentos quanto a cidade de Roma (Apul. Met. 2.19). Esta, considerada ainda neste período grande centro, é um contra-exemplo para dignificar as belezas da cidade de Birrena e evidenciar a relevância dela como parte do imperium. A personagem procura construir certa identidade enquanto cidadã de Hípata, permitindo, dessa forma, manter-se ligada aos grupos aos quais se identifica culturalmente, se reconhecendo como iguais e se distinguindo, ao mesmo tempo, de outros setores sociais e de outras regiões do império romano. Como nos lembram Gonçalves e Rocha,

uma forma de se vestir, de se comportar, uma linguagem específica, pode simbolizar adesão a um determinado processo de identificação, gerando fidelidades e lealdades a um determinado grupo, mas também o afastamento de outros setores sociais, com os quais o processo de identificação não se define (2006, p.12-3).

Esse processo de assimilação das elites a potestas romana e, ao mesmo tempo, o destaque às identidades étnicas, enquanto, processo identitário, levame a afirmar, assim como o fez Guarinello, de que o Império Romano, pelo menos até o IV século, constituiu-se pela multiplicidade cultural e, mais ainda, o governo imperial sempre teve como pretensão "gerenciar e controlar essa diversidade". As formas de gerenciamento, dependeu de época para época, mas, de modo geral, e aqui mencionarei apenas uma, a qual interliga-se a presença do culto de Ísis em Concréias, que é o sincretismo religioso, definido por Guarinello, como sendo uma releitura e uma inserção das "crenças locais num panteão pluriétnico, permanentemente aberto à incorporação de novas divindades (GUARINELLO, 2009, p.152-53).

Temos a presença de um culto egípcio, com todo o seu aparato, praticado por elites locais e demais grupos sociais sob os auspícios do poder romano, sendo, portanto, um instrumento de legitimação da posição das autoridades romanas e da supremacia das elites nas cidades do Império. Embora a procissão de Ísis esteja hierarquizada socialmente, a crença em seu culto e a necessidade de os homens 
seguirem suas ritualidades, para assim, se aproximarem da divindade, os motiva à realização da festa, por isso, a procissão ísiaca é um polo de agregação entre os devotos, assim como também é um elemento identitário e, por conseguinte, diferenciador do domínio romano.

Ao lado dessa "pomposa procissão propriamente dita da deusa da Salvação" (Apul. Met. 11.9), apresenta-se uma procissão de mascarados, composta pelo riso, pelo escárnio e com encenações realizadas pelo povo, as quais retratam os diversos grupos sociais e seus símbolos a exemplo do magistrado com o feixe e a púrpura, o gladiador reconhecidamente com perneiras, escudo, capacete e espada ou a presença de ornamentos indicando o costume de as matronas usarem adornos nos cabelos, o que torna evidente o pertencimento dessas mulheres à aristocracia (Apul. Met. 11.8).

O que é de extrema relevância, pois, alguns autores interpretam as festas como sendo momentos em que se "instaura e constitui um outro mundo, uma outra forma de experimentar a vida social, marcada pelo lúdico, pela exaltação dos sentidos e emoções - com um forte acento hedonista e agonístico - e, mesmo, em grande medida, pelo não-social" (PEREZ, 2002, p.18). Nessa procissão, Apuleio mostra-nos, contrariamente a Perez, uma forte presença dos elementos sociais como filósofos, magistrados, mulheres aristocratas, caçadores, gladiadores, soldados, entre outros, os quais formam a sociedade romana provincial. Daí o ato festivo, sendo produto da realidade social, compor-se de conflitos, tensões, censuras e as estruturas de poder (GUARINELLO, 2001, p.272), as quais são presenciadas pelas brincadeiras jocosas deste cortejo.

O lúdico e o exagero não eliminam a caracterização social, mas, em nosso caso, acrescenta um importante fator: o elemento popular do festejo apuleiano que se constitui por representações caricatas desses agentes sociais. Este riso explícito, dado pelas bufonarias, em que setores aristocráticos são representados de forma ridícula assim como "uma ursa domesticada, que era levada em uma liteira com o ornato de uma matrona" (Apul. Met. 11.8), indica sim uma inversão da ordem, mas essa carnavalização não exclui a representação e a ordem social, muito pelo contrário, o riso assegura as estruturas de poder, o renascimento e, ao mesmo tempo, garante a participação da multitudo no espetáculo a partir de suas próprias expressões acerca de si, que também refletem a representação destes setores acerca do universo dos nobres.

\section{ENTRE LÁGRIMAS E RISOS:}

Nessa perspectiva, pode-se afirmar um outro elemento, proposto pelo professor Trabulsi, em seu livro intitulado - Dionisismo, poder e sociedade na Grécia até o fim da época clássica - de que o culto isíaco, assim como o dionísiaco, foram os únicos a receberem um ritual por parte de todos os egípcios 
O risível, o lastimoso e o ridente em Metamorfoses de Apuleio

(2004, p.130). Baseando-se nos manuscritos de Heródoto, estabelece "uma correspondência, uma identificação, entre as divindades gregas e as divindades egípcias. Neste quadro, Dioniso é o equivalente de Osíris. Seria melhor dizer que ele é Osíris" (TRABULSI, 2004, p.133). Como propõe Fortuna (2005, p.78), é possível estabelecer a partir de Dioniso, sua relação com Osíris, pois, este

era o juiz e senhor dos mortos, por conseguinte, regenerador da vida. Só, que, assim como a morte não afetou a imortalidade do filho de Zeus nascido duas vezes, Osíris também é concebido como o "morto imortal", assim como Plutão é o "imortal deus da morte". Representam mortes de catábase e de anábase (quando uma divindade nasce, morre, nasce, morre, torna a nascer e torna a morrer), sucessivamente ${ }^{1}$.

No Egito Antigo, Osíris é celebrado em duas instâncias que se alternam: pela tristeza (provocado pelo choro) e pela alegria (provocado pelo sorriso) o que se aproxima de Dioniso, pois, nas cerimônias dionisíacas existiam representações de tristeza e alegria, especialmente, nas apresentações cênicas. Esse riso sagrado pode ser vislumbrando em outra passagem das Metamorfoses, precisamente no festejo do deus do Riso, no qual o personagem Lúcio pensa que será punido pela morte de três jovens e entra em desespero chorando, enquanto, a multidão às gargalhadas se descontrola. Esta representação cênica é parte da ritualidade das cerimônias do deus do Riso e, ao mesmo tempo, pode ser relacionada às festividades de Dioniso e Osíris. Por isso, seguindo a assertiva de Trabulsi (2004), mesmo se tratando de autores como Heródoto e Apuleio, os quais viveram em épocas distintas, estabeleço a seguinte hipótese: dada a influência do culto dionisíaco no Egito e, ao mesmo tempo, a proximidade do autor madaurense aos cultos mistéricos isíacos, suponho algumas correspondências entre os deuses Dioniso e o Riso no que se referem ao êxtase desvairado, ao riso, às encenações, às metamorfoses entre outros aspectos.

A festa do Riso é introduzida no enredo, no momento em que Lúcio, após um convite de Birrena, vai a um banquete em sua residência. Saí tarde da noite, quando é abordado por três bandidos e num ato de defesa mata-os, protegendo a si próprio e a casa de seu hospedeiro, Milão. No dia seguinte foi preso e julgado pelas mortes. Começa então a brincadeira sagrada. Lúcio, sem saber, e, com isso passando por todos os temores de um julgamento, descobre ao final ser apenas parte de um ritual: uma festa dedicada ao deus do Riso. O protagonista após o desfecho da festa é agraciado com homenagens, sendo oferecido a ele, honras extraordinárias: é nomeado patrono da cidade de Hípata e elevam uma estátua de bronze (Apul. Met. 3.11).

Lúcio é escolhido por dois motivos. O primeiro e o mais óbvio: por ser um forasteiro, assim não reconheceria o gracejo da festa; e, em segundo, por pertencer ao grupo de notáveis, engrandeceria o momento festivo - com sua 
dignidade - e o reconhecimento do deus ao próprio Lúcio e à cidade, conquistando os seus favores e a sua amizade. O que fica evidente é que, além da proteção do deus, Lúcio receberia vantagens tão sólidas quanto a honra: a partir dela, o protagonista poderia aumentar seu círculo de relações e ampliar igualmente seus benefícios.

Mesmo obtendo vantagens, Lúcio deveria ser ridicularizado no festejo e, por isso, sente-se estupefato ao descobrir que tudo não passara de uma brincadeira: matara apenas três odres. De acordo com a narrativa, "nenhuma palavra haverá capaz de exprimir o imprevisto de tal espetáculo. Os cadáveres de nossos degolados eram três odres estufados com rasgões" (Apul. Met. 3.9).

Essa comicidade dramatizada por Lúcio apresenta-se no teatro, assim como nas festas dionisíacas. Estas apareceram inicialmente nos concursos de tragédia, em 501 a.C. e as comédias, quatro anos mais tarde. As peças eram animadas por "um coro de sátiros, personagens fantasmagóricos, companheiros de Dionísio e dirigidos por um bêbado lúbrico, Silênio" (MINOIS, 2003, p.36). Dioniso é o patrono do teatro e as representações estão inseridas em suas festas (TRABULSI, 2004, p.144), por isso, encontram-se em suas festividades a mistura entre a ilusão e o real.

Assim como no festejo do deus do Riso: seu cenário principal é o teatro "onde se apresenta a sociedade oficial e, inversamente em que se manifesta o protesto popular" (BALANDIER, 1982, p.12) - e é, neste local, que se encena o julgamento do protagonista Lúcio, no qual se evidencia uma alegria especial e "licenciosa" do pensamento e da imaginação. Em meio ao espetáculo, Lúcio é apanhado na casa de seu hospedeiro, por ordem dos magistrados e arrastado até o Fórum. Sem compreender o que esta acontecendo, não impõe nenhuma resistência, apenas avança com "os olhos tristemente baixados para o chão" (Livro III, II). Quando percebe, vê uma multidão que o seguia, formando um cortejo e escuta, em uníssono, o povo exigir que o julgamento acontecesse no teatro. De acordo com suas palavras:

Amontoaram-se nos corredores de acesso e até nos vigamentos do teto. Muitos se atracaram às colunas, abraçando-as. Outros se suspenderam às estátuas. Encheram as fendas das janelas e as aberturas todas - todos ávidos de ver, tanto que se esqueceram do perigo a que se expunham. Então, os funcionários da cidade me avançaram, como uma vítima, atravessando a cena, e me colocaram no meio da orquestra (Apul. Met. 3.2).

Monta-se uma audiência no teatro e Lúcio é acusado por um homem de certa idade - o que proporciona veracidade à narrativa - de ter matado cruelmente três jovens. O espetáculo é ainda mais dramatizado no momento em que entraram duas mulheres desconhecidas, provavelmente do povo, pedindo 


\title{
O risível, o lastimoso e o ridente em Metamorfoses de Apuleio
}

que o acusado sofresse as devidas penalidades. Segundo a aclamação delas, a misericórdia pública deveria socorrer "ao menos a criancinha, deixada sem proteção nos seus verdes anos e oferecei o sangue desse bandido, como expiação, às vossas leis e à ordem pública" (Apul. Met. 3.8). Diante da aclamação das duas mulheres, o magistrado mais velho - duvidoso da acusação - e não encontrando o escravo que o acompanha, ordena a tortura de Lúcio. Este, desesperado, sem a presença de seu escravo e tendo somente suas palavras contra as acusações, vê os instrumentos de tortura: o fogo, a roda e os látegos (Apul. Met. 3.9).

Sem muito o que fazer, chora e observa um fenômeno perturbador: a multidão às gargalhadas (Apul. Met. 3.2). O povo se descontrola no ápice da cena: as gargalhadas e os gestos aumentam vertiginosamente no momento em que se revela a morte apenas de três odres. Segundo Lúcio:

Então, o riso, que alguns tinham tido a malícia de reprimir por um momento, explodiu livremente e se propagou através da multidão. Uns, no excesso da alegria, cacarejavam, outros seguravam a barriga com as duas mãos para que fizesse menos mal e foi com uma transbordante satisfação que todos deixaram o teatro, voltando-se para olhar-me (Apul. Met. 3.10).

Assim como na narrativa apuleiana, o riso dionisíaco "é democrático todos podem rir - é popular e universal (FORTUNA, 2005, p.86). Estes rituais são acompanhados por desordens verbais o que gera o riso e, por consequência, a proteção e o contato com o mundo divino. Cria-se, na narrativa apuleiana, uma ilusão de punição, com a inclusão de possíveis torturas e uma multidão ululante exigindo a condenação de Lúcio. Como acentua Fortuna (2005, p.103), Dioniso

\begin{abstract}
é um deus frenético, incitador de sons caóticos, os sons enlouquecedores das multidões eufóricas, que mais enlouquecidas ficam com sua dança e sua música se não o honram como devem (...). Dioniso é o deus que desencadeia a embriaguez, o delírio e a alucinação" e, dessa forma, o riso e o choro eram carnavalizados, "liberando, ao mesmo tempo, lágrimas entre gargalhadas e gargalhadas entre lágrimas.
\end{abstract}

Essa carnavalização associada ao grotesco nas dionisíacas apresentam-se por animais como bodes, corujas, asnos, os quais servem para ridicularizar "todos os estados da vida e todas as posições do poder. Imagens alegóricas mistas formadas pelo humano e pelo animal reivindicam, amedrontam, podendo, consentaneamente, divertir" (FORTUNA, 2005, p.95). Esta ridicularização apresenta-se na narrativa apuleiana a partir de duas fases: Lúcio passa por uma prova em que é degradado, para, somente posteriormente renascer com algo favorável: as honras e o favor do deus do Riso. No livro XI, Apuleio apóia-se na mesma perspectiva: após todos os infortúnios sofridos pelo Lúcio-Asno, retorna a sua antiga forma: a de homem. 
O sofrimento na narrativa foi o caminho iniciático de Lúcio: é necessário tornar-se um "espantalho cômico" (Bakhtin, 1999), para finalmente se regenerar e conquistar os favores da deusa Ísis, qual seja: entrar para o colégio dos pastóforos e elevar-se à ordem dos decuriões qüinqüenais. Além da ridicularização de Lúcio, que evidencia o grotesco, a narrativa apresenta a festa do deus por uma carnavalização social, pelo descarrego de tensões reprimidas e pelo êxtase ${ }^{2}$. Assim como a carnavalização dionisíaca provoca a confusão universal, a abolição da ordem e das hierarquias, instalando a orgia, o caos e novas experimentações, a festividade do Riso, apresenta uma intencionalidade em ridicularizar os grupos sociais, as autoridades e o caráter oficial da sociedade romana provincial. Como propõe Minois (2003, p.36),

a loucura, doce para seus fiéis, terrível para seus inimigos. Esse intermédio de burlesco primário vem lembrar que o riso da loucura é necessário para o equilíbrio da cidade; porque ele se opõe ao logos racional representado por Apolo ou Atenas: Deus da loucura, da embriaguez, da ilusão, das forças misteriosas e selvagens da natureza como um Outro Mundo, de riquezas gratuitas que é preciso saber colher, saborear e alegremente festejar, Dioniso é necessário ao equilíbrio da cidade.

A contravenção, o deboche, a ridicularização de um notável, representado por Lúcio, atuam como inversões sociais, para ao final do ato festivo, manter-se a ordem social, pois, como na festa grega antiga, o riso ritualizado exorciza a desordem, os desvios e a bestialidade original (MINOIS, 2003, p.33). Esses desvios coletivos promovem, parafraseando Machado (2006, p.214), em relação a Dioniso, mas também em relação ao Riso, "a desintegração do eu, uma abolição da subjetividade até o total esquecimento de si: um desprendimento de si próprio, a dissolução do eu no mundo, um abandono ao êxtase divino, à loucura mística do deus da possessão". Uma renúncia de si com o objetivo de alcançar não apenas o êxtase divino, mas também, por meio destas comemorações, instaura-se a possibilidade de se colocar em um ato coletivo, em um ato social, não mais como indivíduos, mas como cidadãos que se unificam em torno de um objetivo comum: a crença no poder desses deuses.

A meu ver, podemos, a partir da comemoração ísiaca e a dos mascarados, as quais ocorrem na cidade de Concréias, interpretá-las como pontos de equilíbrios. Assim como proposto por Minois, comparando Dioniso, Apolo ou Atenas, pode-se pensar o culto isíaco como forma de celebrar o logos racional, enquanto o cortejo dos mascarados e o festejo do deus do Riso celebram a desordem que surge

sob a forma do riso e, ao mesmo tempo, é morta pelo riso, pela autoderrisão e pelas zombarias mútuas de todos esses atores mascarados que encarnam, cada um, um aspecto das proibições e medos. De um só 
O risível, o lastimoso e o ridente em Metamorfoses de Apuleio

golpe, a ordem social é recriada e confortada em sua normalidade. (MINOIS, 2003, p.33)

Esse riso ritualístico é imprescindível na narrativa apuleiana, podendo ser percebido no conto de Telifrão. Este narra ao protagonista Lúcio, em um banquete na casa de Birrena, suas desventuras ocorridas em um funeral público. Esse, precisando de dinheiro submete-se ao serviço de uma vigília fúnebre, para impedir o assalto tempestivo de feiticeiras, as quais roubam as partes do morto com os dentes, para realizar, com este material, suas artes mágicas (Apul. Met. 2.21-30). No dia seguinte, no ritual público do enterro, o tio do morto denuncia o assassinato de seu ente querido pela adúltera e o próprio cadáver, por interferência mágica, não só confirma o assassinato, mas conta acerca da mutilação do corpo do guardião feito pelas feiticeiras: metamorfoseadas em doninhas, chamando pelo nome do morto, atraem Telifrão, e retiram de seu corpo orelhas e nariz, reconstituindo-os com cera.

Ora, o que é interessante dessa ridicularização é a localidade: ocorre em um funeral público, pois, trata-se de um homem notável, por isso, o cortejo, passa pelo fórum. Nessa procissão, temos o envolvimento da multitudo, aclamando por justiça, solicita a condenação da adúltera e da assassina; esta por sua vez, nega às denúncias e o acusador principal, o tio do cádaver, com interesses próprios, os quais não foram explicitados no enredo, mas podem se associar à herança, a legitimidade de sua família no campo político, a qual estava sendo humilhada publicamente com o adultério entre outras motivações, conduziu a execração pública da adúltera. Ao mesmo tempo em que se apresentam as lamentações do tio, a revolta da multidão, surge na procissão, após a descoberta da amputação das partes do corpo de Telifrão, a pilhéria e o burlesco (Apul. Met. 2.30).

Essas situações aparecem de forma cadenciadas com o desfecho final, qual seja: o riso desenfreado da multitudo. Embora Minois (2003, p.96) interprete este conto somente pelo viés do grotesco, provocado pela mutilação das partes do corpo de Telifrão, em minha suposição, trata-se de um riso ritualístico, pois, tratase de mais uma comemoração ao deus do Riso, para assegurar aos cidadãos de Hípata, a cura, o renascimento, o ordenamento social e as permanências das estruturas de poder e, ao mesmo tempo, garante a mobilização e a participação da multitudo no espetáculo.

Pode-se, portanto, visualizar essa característica risível em todos os contos, ainda que exista também o grotesco, a pilhéria em situações do cotidiano, as quais foram anteriormente discutidas como no comportamento de avareza de Milão, o festejo dos mascarados e o do deus do Riso apresentam-se por risos ritualísticos, os quais são representados por divertimentos e encenações realizadas pelo povo, retratando os diversos grupos sociais por brincadeiras jocosas (Apul. Met. 11.7). O riso apuleiano tem um caráter, sobretudo, 
regenerador: depois do sofrimento, os personagens conquistam os favores dos deuses. Lúcio entra para o colégio dos pastóforos da deusa e é elevado a ordem dos decuriões, ao passo que Telifrão se salva da malfadada experiência com as feiticeiras, passando a ver a magia com respeito, alerta os convivas sobre os perigos dessas magas. Este caráter regenerador e iniciático dos personagens é acompanhado igualmente por um elemento imprescindível do festejo: o caráter unificador, pois, trata-se da mobilização de cidadãos de Hípata e de Concréias, envoltos na crença e na ritualidade, que os motiva para a realização das festas, sendo, por conseguinte, polos de agregações entre os devotos como símbolo de uma identidade.

\section{Fontes:}

APULEIO, L. Oeuvres complètes d'Apulée. Trad. Henri Clouard. Paris: Librairie Garnier Frères,19-?

APULEIO, L. O asno de Ouro. Tradução de Francisco Antônio de Campos. Portugal: EuropaAmérica, 1990.

\section{Bibliografia:}

BAKHTIN, M. A cultura popular na Idade Média e no Renascimento. Brasília: Universidade de Brasília, 1999.

BAKHTIN, M. Questões de literatura e de estética. A teoria do romance. Tradução de Bernadini, A. F.; Júnior, J. P.; Nazário, H. S.; Andrade, H. F. São Paulo: UNESP, 1998.

BALANDIER, G. O poder em cena. Brasília: UNB, 1982.

CONFINO, A. Collective Memory and Cultural History: problems of method. The American Historical Review, vol. 102, no 5, December, p.1386-1403, 1997.

FORTUNA, M. Dioniso e a comunicação na Hélade: o mito, o rito e a ribalta. São Paulo: Annablume, 2005.

GUARINELLO, N.L. Festa, trabalho e cotidiano. In: István Jancsó; Íris, Kantor. Festa, Cultura e sociabilidade na América portuguesa. São Paulo: Edusp, 2001, p.969-975.

GUARINELLO, N.L. Império Romano e Identidade Grega. In: FUNARI, P. P. A.; SILVA, Maria A. de. Política e identidades no mundo antigo. São Paulo: Annablume, FAPESP, 2009.

GONÇALVES, A.T.M. As comemorações severianas: festejando e construindo memórias. In: LESSA, F.S.; BUSTAMANTE, R.M.C. (org.). Memória e Festa. Rio de Janeiro: Mauad, 2005.

GONÇALVES, Ana Teresa Marques; ROCHA, Leandro Mendes. Identidades e Etnicidades: conceitos e preceitos. In: Silva, Gilvan Ventura da; NADER, Maria Beatriz e FRANCO, Sebastião Pimentel (orgs). As identidades no tempo. Ensaios de gênero, etnia e religião. Vitória: EDUFES, 2006.

MACHADO, R. Nietzsche e a representação do dionisíaco. In: O nascimento do trágico: de Schiller a Nietzsche. Rio de Janeiro: Jorge Zahar, 2006, p.202-246.

MINOIS, G. História do riso e do escárnio. São Paulo: UNESP, 2003.

MOTTA, S.V. O engenho da narrativa e sua árvore genealógica. Das origens a Graciliano Ramos e Guimarães Rosa. São Paulo: UNESP, 2006.

OGDEN, D.; LUCK, G.; GORDON, R.; FLINT, V. Bruxaria e magia na Europa: Grécia antiga e Roma. São Paulo: Madras, 2004. 


\section{O risível, o lastimoso e o ridente em Metamorfoses de Apuleio}

PEREZ, L.F. Antropologia das efervescências coletivas. In: PASSOS, Mauro. A Festa na vida. Significado e imagens. Rio de Janeiro: Vozes, 2002, p.15-58.

ROSA, G. Grande sertão: veredas. Rio de Janeiro: Nova Fronteira, 2006.

SCARPI, P. Egito, Roma, Grécia, mesopotâmia, Pérsia. Politeísmos: as religiões do mundo antigo. São Paulo: HEDRA, 2004.

TRABULSI, A.D. Doinisismo, poder e sociedade na Grécia até o fim da época clássica. Belo Horizonte : UFMG, 2004.

\section{Notas}

${ }^{1}$ Ainda segundo Fortuna (2005, p.79), Osíris também ensinou ao povo o cultivo dos grãos. Diferentemente da vinha, foram o trigo e a cevada, que cresciam selvagens, descobertos por sua esposa Ísis. Diz a lenda ter sido Osíris o primeiro a colher os frutos das árvores, atar as parreiras e pisar a uva para o vinho. Assim como Dioniso, Osíris desejou comunicar as descobertas a toda a humanidade e pelo mundo vagou durante muito tempo, incentivando o desenvolvimento da agricultura (vinha e cerveja de cevada) por onde passasse".

${ }^{2} \mathrm{O}$ riso e a visão carnavalesca do mundo, que estão na base do grotesco, destroem a seriedade unilateral e as pretensões de significado incondicional e intemporal e liberam a consciência, o pensamento e a imaginação humana, que ficam assim disponíveis para o desenvolvimento de novas possibilidades (BAKHTIN, 1999, p.43). 


\title{
PODER E TERRITÓRIO: O ALTO ALENTEJO ENTRE O IMPÉRIO E A ANTIGUIDADE TARDIA
}

\author{
André Carneiro* \\ Universidade de Évora - Portugal
}

\section{Entre a realidade histórica e o desejo historiográfico}

Nas três últimas décadas o conhecimento existente sobre a paisagem romana ampliou-se dramaticamente. Ao longo dos diversos territórios que pertenceram ao Império temos hoje uma leitura totalmente diferente daquela que a investigação construiu à década de oitenta do século XX. Estes avanços permitem-nos hoje perceber um quadro muito mais complexo, plural e denso nos diversos matizes constituintes de um período que constituiu um momento áureo na densidade e variedade das formas de ocupação humana dos territórios sob a sua égide.

Sem aprofundar muito os diversos feixes de transformação que influíram na perspectiva dos investigadores, pode-se considerar que a ruptura ocorreu por duas ordens maiores de factores.

Uma de âmbito estritamente objectivo, material e vinculada às evidências de terreno. Decorre da progressiva identificação de um conjunto tipológico de unidades de povoamento que foi afinal muito mais variado do que se pensava. 0 avanço da pesquisa (quer por questões relacionadas com as novas agendas de investigação, quer pela emergência da arqueologia preventiva e da minimização de impactos no decurso de obras), dedicando-se gradualmente à detecção de outros pontos de habitação dotados de menor monumentalidade, veio demonstrar algo que uma leitura atenta das fontes já deixava antever: que a paisagem romana apresentava uma espantosa diversidade nas suas unidades de povoamento.

A segunda alteração resulta de um novo paradigma de investigação, que paulatinamente se descentrou dos cânones tradicionais para uma leitura mais

\footnotetext{
* Docente no Departamento de História da Universidade de Évora. Investigador do CHAIAUÉ: Centro de História da Arte e Investigação Artística da Universidade de Évora. O presente estudo está englobado no âmbito da dissertação de Doutoramento em Arqueologia na Universidade de Évora "Povoamento rural no Alto Alentejo em época romana. Vectores estruturantes durante o Império e Antiguidade Tardia", com trabalhos de campo autorizados pelo IGESPAR e que contou com financiamento da Fundação para a Ciência e Tecnologia (FCT). Os trabalhos de SIG foram realizados por Éder Veiga e Ana Carriço sob a orientação do Professor Miguel Marques, da EPRAL de Évora. ampc@uevora.pt
} 


\section{Poder e território: o Alto Alentejo}

descomprometida e menos romanocêntrica. E aqui entramos no domínio subjectivo de uma secular disciplina que foi progressivamente arquitectando uma visão canonicamente assente na valorização do seu próprio domínio de estudo. Ou seja, a análise da paisagem romana foi tranquilamente (porque de forma acrítica e sem discussão) enaltecendo de forma cada vez mais sólida aquela que no fundo resultava ser a mais paradigmática forma de habitação que em si mesmo materializava os conceitos do Imperium e da pax romana: a villa descrita pelos agrónomos clássicos, com a acrescida vantagem de ser este o elemento que pela monumentalidade das suas evidências arquitectónicas ainda hoje mais se distinguia nos campos e mais atraía o esforço de escavação e descrição (proporcionando os achados mais imediatos e espectaculares). Desta forma, os próprios investigadores centraram o seu olhar na villa enquanto grande unidade agro-pecuária e latifundiária (de acordo com a leitura conservadora deixada pelos agrónomos) que de forma hegemónica se estendia pelos campos, criando uma paisagem inteiramente dominada por estas grandes unidades que constituíam a marca mais notável do poder civilizador de Roma.

Esta atitude derivava assim:

a) de uma leitura excessivamente rigorosa e à letra das fontes, esquecendo o seu comprometimento político-cultural fundado em discurso de matriz eminentemente conservadora;

b) de uma postura historiográfica que procurava valorizar a marca de criação imperial da villa como epítome máximo de uma civilização e de um poder político, esquecendo outras formas de habitar o campo e subvalorizando as préexistências do fundo indígena.

c) de uma visão ambivalente da vida rustica no campo assente em um paradoxo: por um lado o interesse pelo estudo da paisagem rural enquanto emblema do espírito latino, mas privilegiando o elemento urbano por excelência dessa paisagem, o edifício da villa e seus urbana ornamenta, esquecendo os próprios espaços mais ligados à vertente rústica destas propriedades ${ }^{1}$.

De modo algo paradoxal, com o advento das posturas processualistas esta leitura radical da investigação tradicional encontrou campo fértil para a sua ampliação e concretização. A aplicação de métodos importados de outras disciplinas, em especial da Geografia Física (como os polígonos de Thiessen ou os modelos de von Thünen) permitiram contar, medir, quantificar e no fundo padronizar a paisagem, repartindo de forma equitativa e a-priorística as diversas unidades, como se o espaço fosse um todo homogéneo, sistémico e standardizado que se estendia até ao infinito.

Em resumo, até tempos recentes a paisagem romana era constituída pelo "padrão-villa" enquanto marca civilizacional de um poder centralizado mas visualmente omnipresente em cada província e em cada lugar. Estas unidades, 
cada uma delas pequenas-Romas em si mesmo, por serem dotadas de um conjunto de elementos constituintes da opulenta vivência clássica, estabeleciam a marca da presença de um momento dourado na história da Humanidade que, pela monumentalidade dos seus vestígios, comprovava ainda hoje a grandeza desse poder. Outras formas de habitar eram insuficientemente conhecidas, desinteressantes para a investigação e, na parca materialidade dos seus restos, um mero testemunho da atávica rudeza das gentes indígenas que assim se mantinham à margem do Império ou incapazes de serem englobadas pelo novo poder civilizador.

Nos últimos anos, porém, a visão alterou-se por completo. Sabemos hoje que a paisagem romana não foi equitativamente povoada nem repartida ad infinitum. Que os impactos da romanidade foram desiguais e diferenciados, funcionando em diversas escalas, consoante as especificidades locais. E que a leitura à letra dos textos clássicos, esquecendo a sempre necessária exegese, criava vícios de interpretação, por não considerar que estes foram uma produção de autor, expressando assim mensagens, ora subliminares ora explícitas, que resultavam ideologicamente comprometidas e que deste modo não correspondiam de todo a situações materialmente observáveis na própria época de produção desses textos ${ }^{2}$.

Nos trabalhos de campo outro factor influía, pois os arqueólogos tendiam a registar as recomendações contidas nos textos clássicos para a implantação dos sítios na paisagem, que permitiam identificar com grande clareza no terreno as condições ideais de enquadramento espacial. Ou seja, no terreno, se os sítios eram encontrados nos critérios gerais definidos nos textos (meia-encosta com boa exposição solar, proximidade de recursos hídricos e solos de aptidão elevada, ampla visibilidade envolvente, proteç̧ão dos ventos de Norte, procurando a amoenitas tão exaltada...) confirmava-se a ideia pré-concebida e dispensava-se o investigador de procurar outras implantações que fugissem à norma. Assim, as regularidades aumentavam.

Finalmente, a diferente percepção de leitura foi também construída a partir de uma visão muito mais desestruturada e complexizante que o mundo pós-moderno hoje tem de si próprio. A ideia de um Império que se impôs às realidades pré-existentes, subsumindo-as no todo global, é difícil de gerir no mundo contemporâneo em que vivemos, um mundo pluricentrado, multivariado e muito mais problematizante. Como resultado, a Romanização é hoje entendida como um complexo fenómeno de interacção cultural, e a paisagem que evoluiu no quadro imperial é assim percebida como tendo sido criada mediante uma poderosa interacção entre o poder de Roma e as estruturas vivenciais indígenas, daí resultando um processo reactivo que foi moldando de forma específica os diversos quadros existentes ${ }^{3}$. 


\section{Poder e território: o Alto Alentejo}

Mas esta percepção da complexidade que hoje temos já deveria ter sido notada há mais tempo. É claramente fruto do mundo em que vivemos, mas a bem dizer, já uma leitura atenta dos textos clássicos deixava antever que a filosofia da construção do Império que Roma criou não se assemelhava a outras experiências na História da Humanidade, como o Império Mongol ou o Napoleónico, por exemplo. Na verdade, a vontade de Roma foi muito particular, e a criação de aí resultante assumiu contornos fortemente originais.

\section{Os diversos olhares de Roma}

O Império romano caracteriza-se pela sua especificidade. Funcionou de modo próprio, com motivações particulares e que se foram alterando em processos muito complexos respondendo a diversas circunstâncias internas e externas. Como nenhum outro, foi fortemente reactivo e adaptável, com cambiantes específicas em função dos interesses metropolitanos mas também das realidades locais.

São os factos históricos que nos permitem construir esta leitura, mas no fundo também os textos da época já expressam de forma clara o pragmatismo latino.

Apiano, historiador do século II d.C., conta-nos que uma das preocupações fundamentais dos imperadores seus contemporâneos se centrou na gestão do adquirido (App. Praef. 7). A filosofia de actuação estratégica deixou de estar centrada na ampliação territorial para passar a olhar para a consolidação dos territórios já absorvidos. Ou seja, Roma voluntariamente travou o seu processo de expansão territorial. Mais surpreendente ainda, mesmo quando alguns embaixadores de reinos exteriores ao Império, os designados "bárbaros", ofereciam os seus haveres e os seus habitantes como súbditos, viam as suas intenções recusadas com o pretexto de não serem de qualquer utilidade para o Império. Roma em nada ganharia com a integração dessas gentes no seu aro.

Este facto recorda-nos o pragmatismo imperial romano. Em certos territórios não interessava prosseguir a expansão territorial. Certas áreas não tinham nada para oferecer, e portanto o olhar de Roma não se dirigia para essa direcção. E este fenómeno não era meramente exterior, ou seja, direccionado para os territórios ainda não conquistados. Na realidade, este desinteresse edificador verificava-se nos âmbitos territoriais do próprio Império, onde o investimento era muito diferenciado. Em termos gerais observamos que em certas áreas existia uma intenção de desenvolvimento e exploração, mas em outros casos os recursos esgotavam-se rapidamente, assistindo-se ao abandono dos mesmos, ou então não havia de todo um esforço promotor concertado que conduzisse a uma sustentação de crescimento. Deste modo, dentro das fronteiras imperiais existiram sempre extensões pouco povoadas ou onde as estruturas 
indígenas preservaram a sua identidade, assistindo-se a uma presença romana escassa ou mesmo nula.

Desta forma, o Império caracterizou-se por ser uma máquina pragmática, organizada e funcional, montada de acordo com motivações precisas, coerentes entre si e fortemente actuantes em função dos meios que se pretendem atingir. Ou seja, direccionadas para elementos estratégicos prioritários, privilegiados em função de outros secundários onde o impacto foi obviamente menor ou mesmo inexistente.

O desafio para a investigação de territórios reside agora na capacidade de diagnosticar em áreas concretas as diversas cambiantes possíveis. Ou seja, em vez de entender a paisagem como um todo homogéneo, perceber como a paisagem romana pode ser encarada enquanto fenómeno complexo, variado e funcionando em diversas escalas, com diferentes impactos e materialidades.

\section{Dados Geográficos}

A área em estudo corresponde genericamente à região designada por Alto Alentejo. Abrange todo o actual distrito de Portalegre e ainda os concelhos de Estremoz, Vila Viçosa e Borba (pertencentes ao actual distrito de Évora), estando geograficamente delimitada por alguns acidentes naturais (bacias hidrográfica do Tejo e Guadiana, serras de S. Mamede e d'Ossa) e pela actual fronteira administrativa com Espanha, situada a Oriente. Caracteriza-se aliás pela proximidade com a actual Extremadura espanhola, sendo este um dado relevante para a época em estudo, visto que nesta área se encontrava a capital administrativa da província da Lusitania, a urbs de Augusta Emerita. Ou seja, [esta] foi uma região que em época imperial era o natural espaço de extensão da metrópole provincial para Ocidente, no sentido do Atlântico.

Este facto ajuda a explicar o forte investimento que a região recebeu em época romana, materializado na construção de três roteiros viários principais que surgem descritos no Itinerário de Antonino, uma tábua de estradas do século III. Estes caminhos, com a designação de XII, XIV e XV, ligavam a capital provincial ao seu porto de mar atlântico, a cidade de Olisipo, actual Lisboa. Orientadas no sentido Este/Oeste, rompem por completo com os tradicionais caminhos da transumância e das migrações pastoris que estão alinhadas em eixos Norte/Sul. Este exemplo mostra como a geografia territorial do Império rasgou os quadrantes tradicionais que organizavam o espaço onde até aí pessoas e bens circulavam, de modo a criar um novo entendimento geo-estratégico de acordo com os interesses da metrópole provincial. Os diversos monumentos e obras de arte que foram edificados ao longo do percurso das três estradas demonstram também a dimensão do investimento aqui realizado e o modo como o Império pretendeu redimensionar esta área territorial. Infelizmente falta-nos ainda uma 


\section{Poder e território: o Alto Alentejo}

outra dimensão de percepção (nomeadamente a proveniente das fontes epigráficas, muito escassas nesta região) para percebermos se esta promoção infra-estrutural se deveu à acção das elites locais ou foi concretizada a partir de determinações superiores.

Um dos elementos mais interessantes, contudo, reside na aparente ausência de um tecido urbano que promovesse e centralizasse as redes viárias e a arquitectura do povoamento rural. Sabendo como o Império romano é a civilização da urbs, e como este modelo enforma toda a dinâmica vivencial, resulta algo paradoxal que no Alto Alentejo tenhamos um aparente vazio de cidades ou de espaços semi-urbanos ${ }^{4}$. Comprovadamente apenas temos a cidade de Ammaia, que no entanto apresenta-se descentrada, porque situada no terço superior da área regional, e distante dos principais itinerários, em especial das já mencionadas três vias de ligação Olisipo/Augusta Emérita. Ou seja, a cidade não se assume como um pólo ordenador de âmbito regional como aconteceu por exemplo com Ebora Liberalitas Iulia ou Pax Iulia, as outras grandes urbs do actual Alentejo, que inclusivamente desempenharam plenamente o seu papel de caput viam e têm uma posição centralizadora face ao seu territorium.

Para o Alto Alentejo apenas temos conhecimento de outro núcleo que poderá ter assumido funções de âmbito urbano. Neste caso com o aliciante suplementar de se ter conseguido uma ligação entre uma menção literária e a realidade arqueológica. Encontra-se em Alter do Chão, onde desde há muito se suspeitava o vínculo da localidade com a mansio Abelterium na via XIV do Itinerário de Antonino. Os recentes projectos de investigação permitiram definitivamente comprovar esta situação, embora seja ainda prematuro perceber o perfil de ocupação e de organização deste local.

O tecido urbano na área em estudo aparece assim algo desestruturado, sendo difícil de perceber se essa seria uma realidade já existente na época ou se é uma impressão provocada pela deficiência da pesquisa que ainda não identificou com segurança alguns locais concretos. Porque na realidade não foi ainda determinada uma correspondência entre as escassas menções conhecidas e as realidades materiais no terreno, funcionando este desfasamento a vários níveis.

Analisemos este ponto a partir dos escassos dados disponíveis. Desta forma, listem-se as menções existentes a eventuais aglomerados secundários na região que ainda não foram localizados.

a) Em primeiro lugar, comecemos pelas possíveis mansiones que estão mencionadas no Itinerário de Antonino:

\begin{tabular}{|l|l|l|}
\hline Via XII & Via XIV & Via XV \\
\hline Ad Atrum Flumen & Matusarum & Fraxinum \\
\hline Dipo & Ad Septem Aras & Montobriga \\
\hline Evandriana & & Ad Septem Aras \\
\hline
\end{tabular}


Apesar dos esforços da investigação ${ }^{5}$ continua a não ser possível localizar no terreno com um mínimo de segurança os locais de implantação destas entidades. Não sabemos a sua exacta localização, a sua relação física com os itinerários nem a sua estrutura de povoamento, ou seja, se seriam povoados de matriz urbana, se estariam alinhados ao longo da via, concentrados, dispersos, aglomerados...

b) Epigraficamente temos apenas uma menção a um vicus:

IOVI / OPTVMO / MAXVMO / VICANI / CAMALO / C [...] IN [?], epígrafe encontrada em Monte do Chocanal (Crato e Mártires, Crato) (IRCP no 609; RP 6/104). Infelizmente não resulta explícita nem a designação do local ${ }^{6}$ nem a menção dos dedicantes, podendo tratar-se de um povoado de filiação indígena, como geralmente se interpretam estes locais (assistindo-se então a uma manifestação de lealdade para com o poder imperial, talvez sincretizando uma divindade indígena à figura tutelar do panteão), ou em alternativa de uma fundação por colonos romanos, eventualmente em contexto de fixação de militares após o seu licenciamento. Seja como for, embora a menção toponímica seja explícita e o local tenha aparentemente sido relocalizado, a sua correspondência com o vicus levanta fundadas dúvidas ${ }^{7}$.

c) Outras menções epigráficas menos explícitas:

DEE SANCTE / BVRRVLOBRI[I] / [G]ENSI Q(uintus?) I(ulius?) EM(eritus?) / $[A($ nimo $)] \bullet L($ ibens $) \cdot V($ otum $) \cdot S($ olvit $)$, encontrada em termo desconhecido do concelho de Elvas ${ }^{8}$. Um dedicante de grande relevância antroponímica, pois apresenta tria nomina, e um topónimo complexo, pois com esta menção se sustentou a hipótese de a actual cidade de Elvas se implantar sobre uma hipotética Burrolobriga. Mas até ao momento a eventual ocupação elvense em época romana ainda não foi esclarecida, pelo que a situação permanece indefinida.

Em resumo) Desta forma se materializa um paradoxo. Temos algumas menções toponímicas cuja correspondência material não se consegue ainda efectuar. De aqui resulta um aparente vazio de estruturas urbanas ou protourbanas, mas afinal sabemos literária e epigraficamente que elas existiriam. A explícita menção de um vicus ou as mansiones viárias noticiadas mostram-nos locais dotados de algum tipo de centralidade, mesmo que de segundo nível e portanto distante do plano urbanístico que uma cidade necessariamente implicava.

Mas o que mesmo assim ressalta da análise é o facto de nenhum destes locais se assumir como uma urbs, como uma cidade dotada de espaços de sociabilidade e com magistraturas locais promotoras de funções urbanas. Mesmo 


\section{Poder e território: o Alto Alentejo}

que não os conheçamos, seriam sempre sítios secundários, de perfil especializado (funções viárias ou sagradas como elementos primaciais, mesmo que possam também ter desempenhado outros papéis) e distantes do que efectivamente entendemos por uma cidade, de acordo com o sentido classicizante da palavra. No Alto Alentejo esse papel parece ter sido reservado exclusivamente para Ammaia, que mesmo assim se apresenta geograficamente descentrada face à região de implantação e ao conjunto de estradas que a percorre.

Em síntese, temos um tecido urbano - ou melhor dizendo, de povoados com potencial centralizador - ainda insuficientemente conhecido, situação que poderemos imputar exclusivamente ao atraso da investigação.

Analisemos agora os dados referentes ao povoamento rural.

\section{Um povoamento multivariado}

Uma das primeiras preocupações do presente projecto de investigação centrou-se na necessidade de, pela primeira vez, reunir toda a informação arqueológica referente aos sítios rurais de época romana no Alto Alentejo. Desde logo se pressentiu o profundo desequilíbrio da investigação e da massa de dados existente, situação que, sendo determinante para a análise explicativa, aqui exigiria um esforço de enquadramento que extravasa o presente estudo.

O conjunto de dados assim reunido em primeira instância foi então cartografado (Figura 1), de modo a se poderem extrair leituras preliminares, necessariamente sujeitas a revisões futuras, mas que de algum modo permitiriam lançar feixes de análise.

Vejamos os dados sob duas perspectivas.

a) Quanto à ocupação do território:

Neste amplo espaço podemos encontrar três tipos de estratégias de povoamento. As manchas de concentração de sítios permitem definir áreas de centralidade, zonas de maior espaçamento inter-sítio e áreas praticamente despovoadas ou onde a ocorrência de locais se deve a factores específicos e concretos.

1. Territórios centrais: aqueles que apresentam maior densidade na distribuição de sítios. Encontramos maiores índices de povoamento ao longo dos itinerários das vias, dos (poucos) núcleos urbanos e dos melhores terrenos agrícolas. Estes pontos de povoamento materializam-se em villae de grande aparato e monumentalidade. Algumas destas unidades são grandes espaços de economia agro-pecuária, muitas são apenas locais de representação de domini pertencentes ou associados às elites urbanas. Nas zonas centrais, com maior número de sítios, o tecido de povoamento parece ter sido reservado quase em 
exclusivo para as villae que apresentam grande visibilidade do ponto de vista da sua expressão material. Por toda esta área encontra-se um padrão de povoamento sobretudo estruturado em grandes villae, especialmente junto ao vale do Guadiana, com uma cultura material exuberante e um conjunto de evidências arquitectónicas e artefactuais que plenamente inserem estes sítios nas correntes materiais e culturais do Império. A distribuição destas villae é obviamente desigual, observando-se concentrações em torno de duas áreas mais localizadas: em torno a Ammaia, nos concelhos de Castelo de Vide e Marvão, por vezes com uma forte densidade, mas onde se evidencia uma cultura material um pouco menos rica e mais vinculada ao fundo indígena; e depois, em torno ao Guadiana e às principais vias de trânsito (XII, XIV, XV), com villae de grande monumentalidade e impacto na paisagem da época, que em vários casos prolongam a sua ocupação para períodos para além do fim do Império.

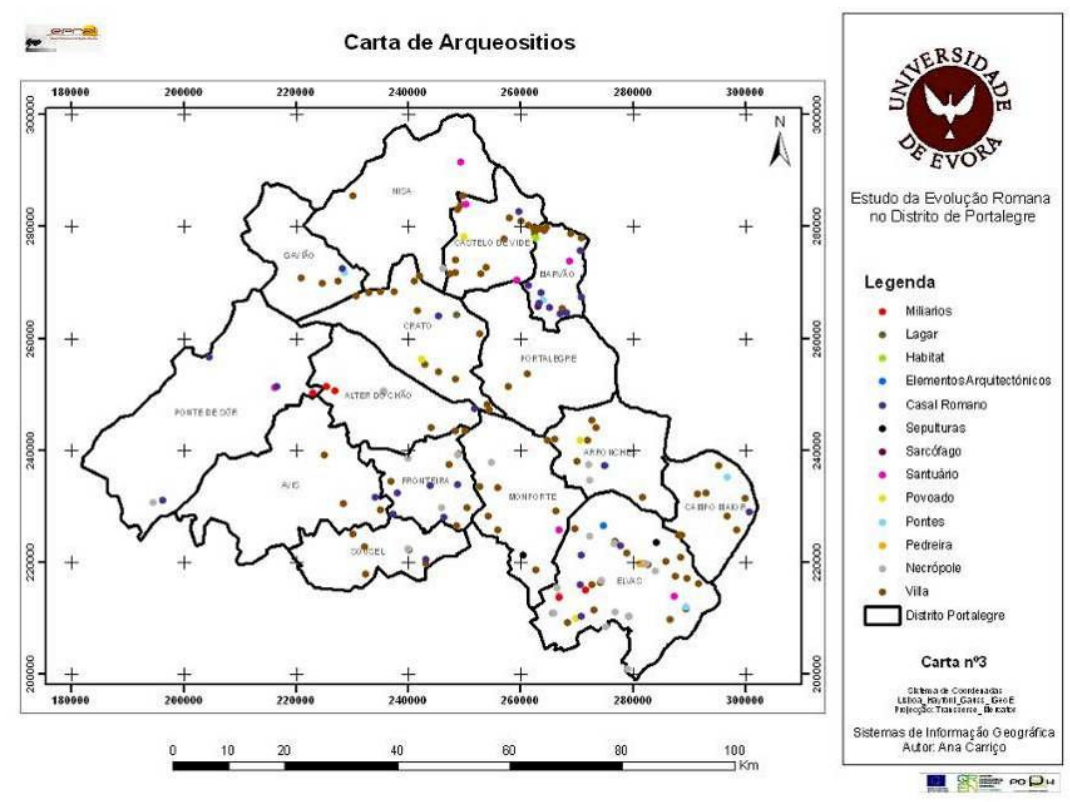

Figura 1.

Geo-referenciação preliminar de 2007 que reuniu a informação então disponível sobre sítios romanos e tardo-antigos na zona em estudo.

2. Territórios periféricos: áreas que apresentam uma concentração média de sítios e onde percebemos também que a cultura material que cada local apresenta é igualmente de índice médio. São pontos ocupando os espaços 


\section{Poder e território: o Alto Alentejo}

deixados livres entre as grandes villae mas beneficiando da proximidade de solos de elevada capacidade agrícola e de linhas de água secundárias com caudal permanente que sustentam pequenas unidades rurais. Nestas áreas predominam os casais de tipo agrícola ou alguns povoados que poderão ter desempenhado funções proto-urbanas, como mansiones e vici ou povoados de tipo aldeia.

3. Territórios ultra-periféricos: em áreas quase desertas e praticamente despovoadas. Por aqui encontra-se uma arquitectura de povoamento desestruturada, sem organização coerente e baseada em sítios autónomos e isolados, próximo de recursos específicos, como de itinerários viários ou de elementos de rentabilidade económica (nomeadamente de mineração ou pedreiras). De um modo geral observa-se que nas paisagens pedologicamente menos aptas, onde hoje dominam os terraços fluviais de cascalheira e de mato arbustivo, a rarefacção de sítios é notória, sendo que ao longo de larguíssimas extensões praticamente não existem pontos de povoamento. São claramente áreas que, por insuficiências de aproveitamento económico, não estimularam a colonização e o incremento romano, ou seja, onde a densidade de presença humana foi praticamente nula ou vestigial.

\section{b) Quanto à organização do povoamento:}

Neste tecido de povoamento podemos definir alguns padrões específicos ${ }^{9}$ :

a) povoamento disperso - em áreas de forte investimento agro-pecuário observa-se que os locais - geralmente as grandes villae - se espalham pela paisagem, repartindo entre si o território de forma espaçada (mesmo que nem sempre homogénea). Os fundi estariam bem delimitados (ainda que para já as fronteiras nos pareçam hoje impossíveis de reconstituir), com uma elevada densidade populacional ocupando espaços repartidos de acordo com as possibilidades dos diversos domini. Ou seja, uma rede de povoamento estruturada e definida de acordo com os interesses específicos do que poderíamos designar como uma elite urbana com posses e proveitos rurais (e de aí podermos observar a proximidade destas villae às urbs ou aos circuitos viários de escoamento preferencial).

b) povoamento agrupado - motivado pela existência de recursos específicos de elevado valor económico ocasionando a presença de uma rede de pontos independentes entre si que se concentram em torno desses valores: a bacia aurífera do Tejo ou o pagus marmorarius de Estremoz poderão ser exemplos. Por aqui encontramos elevadas densidades de sítios atraídos por recursos económicos de rápido retorno. Seria interessante perceber que tipo de pessoas se deslocava para estes locais (mais uma vez falta-nos a dimensão epigráfica), mas será de esperar que a especialização laboral convocasse artífices exteriores, e eventualmente até de pontos distantes do Império $^{10}$. 
Arqueologicamente observamos que a especificidade dos recursos existentes motivou uma concentração de sítios em seu torno, criando um "enxameamento" de pontos de povoamento. Infelizmente, a laboração posterior em alguns destes casos (penso sobretudo nas pedreiras marmóreas) ou a ausência de prospecções intensivas impede-nos de perceber devidamente esta rede de locais e a sua interacção ${ }^{11}$.

c) povoamento alinhado - ao longo de traçados viários encontramos um continuum de lugares que segue esses percursos, motivando um espaçamento sequencial de sítios ao longo da paisagem. Em determinados pontos percebemos que os itinerários funcionaram como um recurso apelativo para a fixação de pessoas, com sítios que se alinham ao longo do traçado, ora imediatamente junto, ora a curta distância. $\mathrm{O}$ abastecimento de bens e produtos e a possibilidade de escoamento de matérias-primas e de circulação de pessoas foram certamente factores preferenciais nesta escolha de localização. No caso das villae temos a facilidade de acesso proporcionada pela estrada, que muito agradava aos seus proprietários $^{12}$.

Outro elemento que funcionou como recurso estratégico terá sido a rede hidrográfica. Resulta revelador observar que alguns cursos de água secundários, de médio porte, foram escolhidos para a implantação de vários sítios ao longo do seu traçado. Tal não se verifica nas linhas de água principais - o Tejo, certamente devido ao alcantilado das margens, e o Guadiana, talvez devido à irregularidade e impetuosidade do seu caudal - mas em seus afluentes mais domesticáveis, o que se prende também com a construção de barragens e açudes necessários à implementação de uma prática agrícola de regadio. Como resultado, alguns pequenos rios funcionaram como factores preferenciais de povoamento, pois ao longo dos seus cursos dispõem-se vários sítios arqueológicos.

Estamos portanto distantes de uma paisagem standardizada e homogénea. Quer nos padrões de distribuição, quer na estrutura da rede de povoamento, observamos importantes distorções nesta área regional, por vezes ocorrendo de forma brusca entre espaços vizinhos. Zonas de denso povoamento contrastam com outras onde parece ter existido uma baixíssima densidade populacional; áreas de propriedades repartidas contrastam com outras onde notamos a polarização ou o alinhamento sequencial de sítios. E não estamos ainda em momento de podermos definir o perfil de ocupação de cada local, pois seria interessante introduzir este nível de leitura. Ou seja, seria muito revelador perceber qual a funcionalidade de muitos destes sítios, se mais dedicados à vocação agro-pecuária, ou a funções comerciais, ou sagradas, ou vinculados à mineração... Tal só poderá ser conseguido com o intensificar de escavações que nos permitam perceber o que cada um destes locais efectivamente foi. Da mesma forma seria necessário elevar os índices epigráficos, ainda muito escassos, quer 


\section{Poder e território: o Alto Alentejo}

nas inscrições pétreas, quer nos grafitos sobre cerâmica, sendo estes importantes para avaliar o nível de literacia e de envolvimento cultural destas comunidades. Assim se poderia progredir na leitura, criando patamares em que mais variáveis analíticas poderiam ser introduzidas. Mas infelizmente a irregularidade da investigação arqueológica no Alto Alentejo ainda não nos permite funcionar nessa órbita.

Seja como for, o que parece resultar evidente desta primeira reunião de dados assenta na ideia que as redes de povoamento romano no Alto Alentejo apresentam uma organização que reflecte o investimento Imperial e as realidades económicas que o meio naturalmente oferecia. Quer isto dizer que as redes de povoamento são multivariadas, como já foi afirmado. Agem de acordo com interesses específicos, em perspectivas profundamente pragmáticas. O poder central terá estabelecido directivas que são concretizadas no terreno de acordo com os interesses estratégicos do Império, não hesitando em criar uma nova geografia de raiz, obliterando o pré-existente. Proporcionadas as condições infraestruturais, compete aos privados organizar o tecido de povoamento.

Certos recursos económicos foram prioritários e motivaram a atracção no estabelecimento. A mineração ou as pedreiras são exemplos já citados e arqueologicamente mais óbvios ${ }^{13}$. Quanto aos recursos agro-pecuários e à exploração do meio, seguramente foram deixadas a privados, que construíram grandes estruturas fundiárias para a sua laboração. Em zonas de solos adequados e de uma rede hidrográfica densa observamos que as villae foram o elemento de povoamento preferencial ${ }^{14}$. Em áreas menos aptas, ou mais distantes das vias, os casais ou os pequenos povoados de tipo aldeia poderão ter sido a base de instalação para comunidades menos sólidas do ponto de vista da sustentação económica, operando em condições subsistenciais mais precárias.

O papel do Estado central baseou-se na criação de uma rede viária que pusesse em contacto os distintos mercados. Estes corredores de circulação constituíram-se posteriormente como os elementos fundadores de uma rede de povoamento que os tomou como eixo prioritário. Ou seja, no Alto Alentejo vemos uma dupla dinâmica: por um lado a acção estatal, criando infra-estruturas de funcionamento; por outro a iniciativa privada, a cargo de potentiores de elevada capacidade económica que operavam distribuindo entre si os melhores recursos de acordo com as possibilidades de investimento de cada um. O que viria a emergir seria uma paisagem fortemente hierarquizada, dinâmica, inter-actuante e onde se torna evidente uma constante adequação entre os recursos disponíveis e a infra-estruturação agora construída.

Como já foi lembrado, faltam-nos muitos dados essenciais para a análise. Um desses vectores reside, por exemplo, na percepção do papel que as comunidades indígenas tiveram. Seria interessante perceber se estes territórios 
centrais já o seriam em momento pré-romano, articulando as redes de povoamento da Idade do Ferro. Tal para já não resulta claro, mas cada vez mais parece óbvio que o impacto romano transformou completamente a paisagem, criando uma nova mundividência. Em especial as três vias terão desempenhando um papel fundamental, rasgando os horizontes em que até então funcionava esta região e criando um nível de inserção nas dinâmicas do Império que a capital provincial sabiamente saberá articular e gerir. A paisagem que neste momento se implementa é profundamente romana, pragmática, estruturada e organizada de modo a maximizar as potencialidades económicas deste território.

O outro dado essencial para análise poderá eventualmente ser ultrapassado com futuras descobertas epigráficas e através de escavações sistemáticas e metódicas em sítios arqueológicos. Destina-se a procurar perceber o papel dos promotores privados neste processo. Quem eram os terra tenentes, que motivações tinham para a gestão do território, como organizaram entre si os diversos latifúndios e repartiram propriedades dividindo o espaço ${ }^{15}$. Como eram os espaços arquitectónicos em que residiam e como investiram na criação ou beneficiação de estruturas de transformação agrícola e produção industrial. Em que nichos económicos apostaram preferencialmente e como congregaram as comunidades que habitavam localmente ${ }^{16}$. Em resumo, torna-se fundamental conhecer o papel das elites privadas e o modo como as redes clientelares e as relações de poder se foram estruturando e implementando, articulando-se com as formas de ocupação do território.

Finalmente, o dado essencial que nos falta reside na densificação do espaço. Faltam-nos nomes, locais, materiais arqueológicos, contextos, estratigrafias, plantas de sítios, etc. A convergência de indicadores permitir-nos-á lançar outros feixes de análise, mas de momento a presença romana no Alto Alentejo apresenta-se-nos ainda demasiado indefinida, demasiado vazia para podermos proceder a uma análise sustentada.

\section{Durante a Antiguidade Tardia: evoluções finais}

Embora não existam sequências estratigráficas que permitam ler os ritmos de evolução, parece existir uma grande estabilidade nos principais sítios rurais, nomeadamente nas villae. Até ao século $\mathrm{V}$ não parece existir uma radical transformação dessa rede de povoamento.

Em leitura geral, as grandes villae permanecem ocupadas ${ }^{17}$. Os nexos de continuidade encontram-se nos territórios que em época imperial pareciam mais "romanizados", e por isso conservam a sua identidade e vitalidade. Ou seja, os sítios de maior dinâmica durante o século III e IV parecem conservar essa energia durante as décadas seguintes, mantendo-se em actividade durante algum tempo $^{18}$. 


\section{Poder e território: o Alto Alentejo}

As villae menos estruturadas, de "segunda ordem", parecem ter um fim mais prematuro, eventualmente sendo englobadas em fundi de maiores dimensões devido à concentração das propriedades fundiárias e entretanto abandonadas ou reconvertidas funcionalmente ${ }^{19}$.

Olhemos agora para as dinâmicas gerais, respeitantes às redes de povoamento. Aqui observamos o mesmo problema resultante da ausência de dados estratigráficos e de cronologias gerais.

Os primeiros sítios a ser abandonados serão os locais ultra-periféricos que oferecem menores garantias para a subsistência económica dos seus ocupantes. Esta retracção manifesta-se deixando vazios nas áreas onde a densidade populacional já em época imperial era mais débil e que agora aparecem completamente vazias. As zonas de menor aptidão agrícola ou onde os recursos eram escassos são agora deixadas vazias, mostrando como o Império foi também, do ponto de vista demográfico, um momento de dinâmica excepcional na presença antrópica na região. Quando surgem os indicadores de crise, ou de instabilidade, são estes os primeiros locais a serem abandonados no momento de retracção das redes de povoamento ${ }^{20}$. Deste modo, os dados referentes ao século $\checkmark$ mostram-nos já o que parece ser o vazio de presença humana em largas margens destes territórios.

Muitos dos locais periféricos são também progressivamente abandonados, resistindo aqueles que se encontram mais próximo de recursos estratégicos (vias ou solos de elevada aptidão agrícola). Neste refluxo, muitos dos sítios em territórios periféricos deslocam-se para cotas mais elevadas ou para locais mais "escondidos" na paisagem, assistindo-se progressivamente à substituição de um modelo de povoamento aberto e voltado para a circulação de pessoas e bens por outro mais fechado, desestruturado e com os sítios isolados entre si. Em especial nas zonas montanhosas da Serra de S. Mamede, com relevos mais alcantilados e propícios à insularização dos sítios, parece ser este o modelo predominante, com povoados ocupando cotas mais elevadas ou zonas de mais difícil acesso. Também junto a alguns cursos de água parecem surgir povoados de tipo "lacustre", à semelhança de outras regiões ${ }^{21}$.

Como foi referido, parece ser nos territórios centrais e nos sítios mais romanizados que os nexos de continuidade serão maiores ${ }^{22}$. Mas seria fundamental perceber os modos de consolidação deste processo. É provável que com o colapso da administração Imperial a primazia no terreno passasse para as mãos dos poderosos domini locais, que foram congregando à sua volta os valores económicos, políticos e sociais. Todavia, não sabemos como se desenrolou este processo, tão-pouco sabemos como se processava o exercício do poder em época Imperial nesta área regional - se a cargo das magistraturas locais, se de poderes provinciais, se já com algum papel relevante por parte de privados. 
Mesmo sem determos muitas chaves de percepção deste processo, o que a visão cartográfica preliminar nos permite perceber é o modo como são os sítios mais plenamente inseridos nos circuitos do Império (e como tal, do poder e das redes de influência) aqueles que melhor resistem ao avanço do tempo. Ao longo do século $\mathrm{V}$ e mesmo do $\mathrm{VI}$ parecem ser as villae monumentais os lugares que chamam a si a centralização das redes de sociabilidade. Esta progressiva centralidade parece fazer-se por duas vias.

Por um lado pelo reforço e ampliação das estruturas de transformação agrícola (como os lagares e adegas de Torre de Palma em Monforte que são progressivamente beneficiados), que parecem ganhar funções acrescidas, ou seja, deixando de servir unicamente para a laboração da propriedade em que estão inseridas para passarem a receber produções de outros sítios. Aqui poderemos entrever um processo de concentração fundiária que seria conveniente conhecer com maior profundidade ${ }^{23}$.

O outro vector fundamental para a transformação das redes de dependência será a consolidação do Cristianismo. Não sendo este o momento ideal para desenvolver o tema, parece lógico supor que a construção de basílicas rurais nesta região (seguramente Torre de Palma, possivelmente São Pedro dos Pastores em Campo Maior, São Pedro em Sousel, Silveirona em Estremoz, São Pedro de Almuro em Monforte....) implica uma ruralização das redes de dependência social, com o acréscimo de poder e influência de domini que teriam estes locais de culto integrados nos seus fundi ${ }^{24}$.

Em todo este processo podemos ler duas tendências nos sistemas de povoamento: o refluxo dos modelos de povoamento imperiais, agora quase confinados aos lugares centrais devido ao abandono dos territórios periféricos e ao quase-abandono dos lugares periféricos, o que implica que durante o século $\mathrm{V}$ e parte do VI os lugares habitados são aqueles que em momento anterior já eram os melhor consolidados; e, embora seja ainda muito cedo para o afirmar com segurança, o que parece ser a progressiva transferência da esfera do poder que passa dos agentes públicos para as mãos dos promotores privados, mediante o duplo expediente da concentração e ampliação dos meios de produção e da construção e da manutenção dos locais de culto público, agora nas suas propriedades.

\section{Leitura geral}

A visão que hoje temos da paisagem romana continua a ser condicionada por alguns pré-conceitos (no sentido etimológico do termo) construídos por sucessivas gerações historiográficas. O modo como o Império construiu a paisagem humanizada foi ditado por interesses específicos, por um fortíssimo pragmatismo baseado em interesses económicos e vivenciais concretos. Entender 


\section{Poder e território: o Alto Alentejo}

o território como um todo homogéneo baseado em sucessões de fundi articulados em torno de grandes villae é efectivamente esquecer o modo como a sociedade itálica encarou a expansão territorial e a edificação de um Império.

No Alto Alentejo vemos o modo como a rede de povoamento se estendeu de acordo com uma lógica pragmática. Espaços fortemente monumentalizados e plenamente inseridos nos circuitos imperiais; zonas mistas, com menor densidade populacional e a manutenção de uma identidade específica; e áreas extensas onde encontramos poucas gentes, com assentamentos ditados por motivações muito particulares. Um território diverso, heterogéneo e onde o papel dos centros urbanos permanece para já indefinido em larga medida.

O povoamento da Antiguidade Tardia conserva elementos de continuidade nos territórios onde o impacto do Império foi maior. Os espaços periféricos e ultra-periféricos são lentamente esvaziados, mostrando como a época romana foi também um período de apogeu demográfico. Se o Império romano significou um momento áureo na densidade de ocupação do território (o que, note-se, é diferente de densidade populacional, significando antes a existência de múltiplos sítios vocacionados para a exploração de recursos específicos que são abandonados quando estes se esgotam), será óbvio que para momentos de retracção sejam as áreas marginais as primeiras a serem abandonadas.

Nos territórios centrais, contudo, a impressão que fica é a de uma grande estabilidade e resistência à evolução do tempo preservando as marcas imperiais por longo tempo. Regressando a Apiano vemos que resistiram melhor os terrenos da marca romana, enquanto os espaços que não eram úteis a Roma são os que mais rapidamente se despovoam.

\section{Agradecimentos}

Presto o meu agradecimento, pelos trabalhos de SIG, a Éder Veiga, Ana Carriço e Professor Miguel Marques. 


\section{Bibliografia}

\section{a) Siglas:}

IRCP = Encarnação, José d'. Inscrições Romanas do Conventus Pacensis. Coimbra: IAFLUC, 1984.

RP = Alarcão, Jorge de. Roman Portugal. London: Warminster \& Phillips, 1988.

\section{b) Mencionada no texto}

ALARCÃO, J. de. As vias romanas de Olisipo a Augusta Emerita. Conímbriga, vol. XLV, Coimbra, p.211-251, 2006.

BROGIOLO, G.P.; CHAVARRIA ARNAU, A. El final de las villae y las transformaciones del territorio rural en Occidente (siglos V-VIII). In: FERNÁNDEZ OCHOA, F.; GARCÍAENTERO; GIL SENDINO (eds). Las villae tardorromanas en el occidente del Imperio. Arquitectura y función. IV Coloquio Internacional de Arqueología en Gijón, Gijón, Ediciones Trea, 2008, p.193-213.

CARNEIRO, André. A cartografia dos cultos religiosos no Alto Alentejo em época romana: uma leitura de conjunto. Hispania Antiqva, no 33-34, 2009-2010, p.237-272.

CARNEIRO, André. Em pars incerta. Estruturas e dependências agrícolas nas villae da Lusitânia. Conímbriga, Coimbra, IAFLUC, vol. XLIX, 2010, p. 225-250.

CHAVARRIA ARNAU, A. El final de las villae en Hispania (siglos IV-VIII). Turnhout (Bibliothéque de l'Antiquité Tardive 7), Brepols Publishers, 2007.

CUNHA, M.W. As necrópoles de Silveirona (Santo Estevão, Estremoz). Do mundo funerário romano à Antiguidade Tardia. (O Arqueólogo português. Supl. 4), Lisboa: MNA, 2008.

DYSON, S. II. The romanization of the countryside. Introduction. In: BARKER, G.; LLOYD, J. (eds). Roman landscapes: archaeological survey in the mediterranean region. London: British School at Rome (Archaeological Monographs of the British School at Rome 2), 1991, p.27-28.

GREENE, K. The Archaeology of the Roman Economy. London: Batsford, 1986.

LEWIT, T. 'Vanishing villas': what happened to elite rural habitation in the West in the 5th6th c.? Journal of Roman Archaeology, vol. 16, p.260 -274, 2003.

MANTAS, V. A sociedade luso-romana do município de Ammaia. In: GORGES, J. G.; NOGALES BASARRATE, T. (coord.). Sociedad y cultura en Lusitania romana, IVa mesa redonda internacional, Mérida, Junta de Extremadura, 2000, p.391-420.

MARZANO, A. Roman villas in central Italy. A social and economic history. Leiden-Boston : Brill, 2007.

RAYNAUD, C. Les campagnes en Gaul du Sud-Est dans l'Antiquité Tardive et le Haut Moyen Âge. Zephyrus 53-54, Salamanca, p.473-507, 2000-2001.

SAA, M. de. As grandes vias da Lusitânia: O itinerário de Antonino Pio. 6 volumes, Lisboa: Ed. Autor, 1956-1967.

TERRENATO, N. The Auditorium site in Rome and the origins of the villa. Journal of Roman Archaeology, Volume 14, p.5-32, 2001.

VAN OSSEL, P.; OUZOULIAS, P. Rural settlement economy in Northern Gaul in the Late Empire: an overview and assessment. Journal of Roman Archaeology, volume 13, p.133-160, 2000.

VASCONCELOS, J.L. de. Religiões da Lusitânia. Lisboa, 3 vols. [Vol. II: 1905], 1905-1913. 


\section{Poder e território: o Alto Alentejo}

VIGIL-ESCALERA GUIRADO, A. El modelo de poblamiento rural en la Meseta y algunas cuestiones de visibilidad arqueológica. In: LOPEZ QUIROGA, MARTINEZ TEJERA, MORÍN, (eds) Gallia e Hispania en el contexto de la presencia "germánica" (s. V-VII). Balance y perspectivas. Actas de la mesa redonda, Madrid, 19-20 Deciembre 2005 (BAR International Series 1534), Oxford, 2006, p.89-108

WICKHAM, C. Una historia nueva de Alta Edad Media. Europa y el mundo mediterráneo, 400-800. Barcelona: Crítica, 2009.

\section{Notas}

${ }^{1}$ Sobre o tema realizei uma tentativa de síntese em Carneiro, 2012.

${ }^{2}$ Nicola Terrenato (2001, p.124-25) realçou recentemente que até ao momento não foi encontrado qualquer exemplo de villa que corresponda ao austero modelo catoniano onde não existe qualquer concessão ao conforto. Pelo contrário, em todas as estruturas até hoje consideradas a componente de otium e de voluptas está bem exaltada em termos de planimetria e de aparato decorativo, correspondendo ao modelo helenístico do paradeysos.

3 Em perspectiva mais abrangente, a valorização das formas de povoamento especificamente romanas insere-se no âmbito de fronteiras de estudo onde os investigadores enaltecem excessivamente os seus próprios objectos de investigação. Ou seja, um estudioso do Império romano tende implicitamente a valorizar o seu domínio de estudo face a outras formulações específicas existentes dentro do universo de estudo mas que não foram criadas pela marca itálica (que portanto são de substrato indígena). É o processo que Chris Wickham (2009, p.37) designa de "solipsismo cultural" que no fundo ocorre em qualquer domínio de trabalho, mas que em entidades culturais fortes tende a subsumir as realidades próximas. O conceito fica materializado na provocadora afirmação de Stephen Dyson (1991, p.27): "It is probably an overstatement to claim that many Romanists are really closet colonialists at heart [...]. Essential to this type of thinking is the notion that in the western part of the Roman empire, the creation of the new order required the extermination of the natives and their replacement by a largely Roman population. For political and ritual reasons, Roman generals emphasised and even exaggerated the casualties they had inflicted on the groups that they had conquered. Historians both ancient and modern have stressed the number of slaves that were taken from areas that the Romans conquered. The picture that results from these two processes is one in which the native population is either eliminated or reduced to a marginal existence".

${ }^{4}$ A menos que esta rarefacção urbana denuncie uma grande vitalidade do povoamento rural: "[...] the density of rural settlements is so great that the significance of towns (or even villages) is proportionally reduced. Local markets, and craft activities independent of towns, must have been of considerable importance, and must be taken into account in an analysis of the economy in general. [...]" (GREENE, 1986, p.109).

${ }^{5}$ Ver as múltiplas tentativas feitas por Mário Saa (1956-1967) ao longo dos vários volumes da sua controversa obra. Para uma análise mais recente e fundamentada, Alarcão (2006).

${ }^{6}$ Os vicani camalo[cani?, censis?]. 
${ }^{7}$ No inventário nacional de sítios arqueológicos a respectiva ficha menciona uma área de cerca de $1200 \mathrm{~m}^{2}$, que obviamente parece pouco coincidente com a importância de um vicus. Quanto a um muro construído com grandes blocos de granito, aqui poderíamos ter um elemento de maior vulto, eventual podium de uma estrutura. De acordo com a Base de Dados Endovélico, http://www.igespar.pt/, consultada em Abril de 2010. Ver Carneiro, 2009-2010.

${ }^{8}$ Leite de Vasconcelos (1905, p.174) indica-nos assim a menção da peça: "estive no Museu de Elvas, onde vi uma lapide apparecida nessa cidade [...]", mas não apresenta pormenores quanto à descoberta, presumindo-se que tenha surgido no núcleo urbano. Ver também IRCP no 566.

${ }^{9}$ Seguindo as terminologias de Vigil-Escalera Guirado (2006, p.90) e partilhando das observações do autor: "En lengua inglesa existen una serie de términos específicos para referirse a determinados tipos de asentamientos rurales en función de su tamaño (stead/farmstead, hamlet, village). Granjas, aldeas y pueblos no son un exacto equivalente en español [...]."

${ }^{10}$ A percentagem de clunienses já notada por Vasco Mantas (2000) na cidade de Ammaia pode ser um sintoma desta situação.

${ }^{11}$ Para além das situações motivadas por recursos específicos, é de notar que o território teria uma relevante presença de povoados agrupados, mesmo em zona de grande densidade de villae. Em todos os pontos do Império é muito rara a presença de sítios com vincado modelo esclavagista (contradizendo a proposta columeliana), sendo por isso de assumir que o recurso a mão-de-obra livre que habitaria nas imediações seria mais frequente que o geralmente considerado. Veja-se, por exemplo, a perspectiva de Chris Wickham (2009, p.401): “[...] en todas las épocas existió una materia prima de fácil disponibilidad con la que organizar unas relaciones de producción de tipo esclavista. [...] Sin embargo, los esclavos constituyen un riesgo. Cuanto más numerosos sean, más peligroso y caro resulta controlarlos. Además, es preciso mantenerlos, tanto en las temporadas de bonanza como en las de penuria, en los años buenos y en los malos, mientras que los trabajadores asalariados podían ser despedidos y los tenentes confiados al producto de sus propias parcelas. Para poder cubrir estos riesgos, la utilización de esclavos presupone la existencia de unos elevados niveles de beneficio por la venta de los productos." Ver também a opinião de Chavarría Arnau (2007, p.55).

${ }^{12}$ Alguns destes diverticuli privados de acesso às propriedades ainda hoje se encontram preservados ou servindo como caminhos vicinais. Sobre o facto de as propriedades próximas de traçados viários serem as mais pretendidas por compradores, ver o exemplo fornecido por Plínio o Jovem quando o seu amigo Tranquillus pretende adquirir uma casa de campo com fáceis acessos (Plin. Ep. 5.1.24).

${ }^{13}$ Para outras produções mais difíceis de rastrear na evidência arqueológica ver Carneiro, no prelo.

${ }^{14} \mathrm{O}$ sistema repete-se para outras regiões do Império. Ver, por exemplo, o estudo de Marzano (2007, p.177) para o centro de Itália: "The farther one travels from towns, the more the size of villas diminishes; their production must consequently have been intended mostly for self-consumption, since smaller fundi imply a smaller or nonexistent surplus.. 
${ }^{15}$ Como é óbvio, à medida que avança a dissolução do Império o papel das elites rurais vai aumentando, pelo que seria de toda a conveniência poder caracterizá-los de forma mais apurada, situação dramaticamente dificultada com a redução dos índices epigráficos e dos conjuntos funerários. Como afirma Chris Wickham (2009, p.698), "una jerarquía organizada en torno a los centros rústicos es obviamente una jerarquía que concede prioridad a los terratenientes", pelo que seria fundamental poder proceder à sua análise no contexto da evolução das economias microrregionais.

${ }^{16}$ Por exemplo, Plinio deixou-nos referências sobre um conjunto de grandes investidores que se dedicaram às produções vitivinícolas (Plin. NH 48-49). Todos eram libertos que decidiram reinvestir na terra os proveitos conquistados no artesanato e comércio, formando um novo grupo de promotores agrícolas.

${ }^{17}$ Mesmo que possam existir ligeiras descontinuidades do ponto de vista topográfico, ou seja, pequenas cambiantes, com a existência de permanências não sequenciais. Tal parece ser o caso de Silveirona (Estremoz), conforme estudado por Mélanie Wolfram Cunha (2008) ou de Terrugem (Elvas), com conjunto de referências em RP 6/217. Em ambos os casos as estruturas romanas são depredadas e reutilizadas em espaços paleocristãos, cuja implantação não se faz sobre estas, mas em espaços anexos. Arqueologicamente podemos falar de sítios de estratigrafia horizontal em vez de sítios de estratigrafia vertical como é mais habitual.

${ }^{18}$ Seria interessante perceber se, além de continuarem habitados, manteriam os mesmos ambientes, ou se entrariam em mutação que os desprendesse dos cânones estéticos clássicos, agora "socialmente irrelevantes" como propõe Tamara Lewit (2003, p.268).

${ }^{19}$ Ver o caso da Itália central mencionado por Annalisa Marzano (2007, p.211, e reflexões em p.212-213) com documentação literária. Para a Hispânia ver os vários trabalhos de Chavarría Arnau (Cf. 2007, p.7-138).

${ }^{20}$ Não é original chegar a esta conclusão, pois tal tem sido verificado em vários pontos do Império. Talvez a primeira constatação tenha sido feita por Van Ossel e Ouzoulias (2000, p.9-140)

${ }^{21}$ No Alto Alentejo tal acontece pelo menos nas actuais albufeiras de Póvoa e Meadas e de Caia. O fenómeno foi detectado na Gália: "Au contraire, des zones vides ou peu fréquentées jusqu'alors, en particulier basses vallées, deltas et régions lagunaires, font l'objet d'une intense colonisation aux IVe et Ve siècles." (RAYNAUD, 2000-2001, p.492). Como refere o autor, talvez tal se deva ao incremento de práticas de pastorícia e de agricultura em terraços fluviais modelados pelo Homem, como aliás no Alto Alentejo também ainda hoje se nota, dada a presença de parcelamentos que deverão ter correspondido a áreas de cultivo entre o povoado e a linha de água. Ver também Brogiolo e Chavarría Arnau (2008, p.204). Tirando estes casos específicos, poucos pontos de povoamento parecem ser criados neste período, situação que de resto já foi notada para outras regiões (VAN OSSEL, OUZOULIAS, 2000, p.137).

${ }^{22}$ Situação que parece repetir o que sucede em outras províncias: “En las tierras más fructíferas, son muy pocas las zonas en que se observan casos relevantes de abandono del campo, según empiezan a mostrarnos los análisis polínicos. Lo mismo implica el hecho habitual de que los microtopónimos romanos de grandes zonas de Francia o Italia hayan llegado hasta nosotros, así como las pautas romanas de división de los campos de labor en 280 
centurias o espacios cuadrangulares que pueden apreciarse en Italia o en Túnez y las particiones premedievales de parcelas - de regularidad sólo levemente inferior - que son características de Inglaterra. Todos estos hechos son otros tantos argumentos que contradicen cualquier tipo de teoría que postule la existencia de grandes catástrofes en el sistema agrario" (WICKHAM, 2009, p.779).

${ }^{23}$ No Alto Alentejo terão ocorrido importantes processos de concentração fundiária, com o abandono ou condenação de sítios em favor de outros. Apesar dos escassíssimos dados estratigráficos e artefactuais, parece ser plausível pensar na existência de duas fases de encerramento na ocupação de sítios. Para uma visão mais geral desta evolução ver Chavarría Arnau (2007, cap.IX).

${ }^{24}$ Entre a bibliografia disponível sobre o processo ver as considerações de Alexandra Chavarría Arnau (2007, cap.X). 



\title{
O PODER DURANTE A ANTIGUIDADE TARDIA NO IMPÉRIO ROMANO OCIDENTAL E NA LUSITANIA EM PARTICULAR
}

\author{
Mélanie Wolfram* \\ Universidade de Évora - Portugal
}

A Antiguidade Tardia, período com contornos cronológicos ainda mal definidos entre o século IV e o século VIII, pode ser vista sob duas perspectivas contrastantes. Se a entendermos na perspectiva decadentista temos o declínio do Império romano do Ocidente. Pelo contrário, podemos olhar para este período como um momento de crescimento ou como o primórdio da sociedade altomedieval. Tudo depende do ponto de vista do historiador. Estamos num momento charneira em que se desvanece um mundo organizado à volta de um Estado centralizador - Roma -, e onde, simultaneamente, nasce uma nova sociedade baseada em torno de duas capitais - Roma e Constantinopla - assim como no poder local dirigido pelo clero.

Esta nova sociedade cristã é porém fruto do mundo romano pagão e intrínseca a ele. Quando tudo parece desmoronar-se, isto é

i) a complexa organização logístico-militar de um Império em constante guerra,

ii) o funcionamento administrativo caracterizado por uma estratigrafia interminável de cargos municipais,

iii) a estrutura religiosa com construção e manutenção de templos, organização de inúmeras festividades em nome do imperador e dos deuses do Olimpo,

iv) a economia ultra especializada e centrada em Roma;

quando todos esses aspectos da vida romana começam a vacilar, existe uma entidade que, como por efeito de balança, se fortalece e cria uma teia que segura todos os pontos desta sociedade, não os deixando morrer por completo mas transformando-os à sua maneira: a Igreja cristã.

Os séculos IV, V e VI d.C. representam o momento em que a Igreja se vai sobrepondo a todos os níveis da sociedade, no plano religioso mas também administrativo, social, económico e militar. A partir do século IV, será esta instituição religiosa que gerará todo o mundo ocidental, e este processo durará

*melanie.wolfram1@gmail.com. O presente estudo está englobado no âmbito da dissertação de doutoramento concluída pela signatária em 2012, intitulada "A cristianização do mundo rural no Sul da Lusitania", financiada pela FCT e realizada em cotutela na Faculdade de Letras da Universidade de Lisboa e na Faculdade de Sorbonne Paris IV. 


\section{O poder durante a Antiguidade Tardia}

até ao início do século XX, quando o Estado se separa da Igreja ${ }^{1}$. De um ponto de vista dogmático, as bases da Igreja ficam quase intocadas desde o século IV até à Reforma no século XVI.

Para se poder perceber a evolução de um mundo romano pagão para o mundo tardo-antigo cristão temos obrigatoriamente que olhar para o funcionamento do poder no Império romano ocidental. A transferência do poder para as mãos dos bispos e dos grandes latifundiários laicos é sem dúvida a resposta para entender o nascimento do mundo proto-medieval. Após uma breve introdução ao surgimento da Igreja, exporemos o papel dos bispos na sociedade tardia e a consequente transformação da geografia urbana e rural.

\section{O lento surgimento de uma hierarquia}

Quando se estuda a história da Igreja a data de 313 do Édito de Milão costuma ser o momento de início do verdadeiro desenvolvimento desta Instituição. No entanto, desde meados do século I d.C. começam a surgir comunidades cristãs no Oriente que rapidamente se vão espalhar pelo Império ocidental, a começar por Roma. O apóstolo Pedro é erradamente considerado como o primeiro bispo da Igreja de Roma uma vez que este conceito não existia naquela altura. Nenhuma fonte documental atesta o papel de Pedro como fundador da comunidade cristã de Roma (PIETRI, 2000, p.176), sabendo-se somente que sofreu o martírio durante a perseguição de Nero por volta de 65 d.C. A informação acerca de Paulo é igualmente escassa, sabendo-se que morreu pela mesma altura do que Pedro. A comunidade cristã constituía-se na altura por pequenos agrupamentos em casas privadas, as chamadas "igrejas domésticas", geralmente casas de gente abastada que tinha meios para acolher um grupo de pessoas (SAXER, 2000, p.385). Pedro deverá ter sido aquele que instruiu e escolheu os responsáveis por estas comunidades. A primeira ocorrência de um bispo em Roma data de 92/93 d.C. com o bispo Clemente, uma das personagens relevantes que marca o início da chamada "Grande Igreja", síntese de todas as correntes cristãs e helenísticas do século I d.C.

Os apóstolos, aquando das suas viagens evangelizadoras, deixavam um ou vários responsáveis em cada comunidade que seriam supostos substituí-los durante as suas ausências. Serão estes responsáveis que, naturalmente, continuaram a obra dos apóstolos depois destes morrerem (SAXER, 2000, p.307). Os anciões escolhidos para divulgar a Boa Nova não eram forçosamente pessoas de idade mas pessoas instruídas, denominadas por Clemente de Roma de "presbyteri" (ancião) ou "episcopos" ("inspector") sem diferenciação clara destes termos (DUCHESNE, 1920, p.8). Apesar de o termo "laico" já existir, não há ainda uma clara separação entre o clero e o povo instruído. Esta divisão só será perceptível a partir do final do século II através dos escritos de Tertuliano. 
Em meados do século II os textos de Justino são vagos no que concerne à organização da Igreja em Roma. Na sua descrição da celebração eucarística refere-se "àquele que preside" (Just. Mart. Apol. 1.65.3.5; 67.4.5-6), "aos que chamamos diáconos"(Just. Mart. Apol. 1.65.5; 67. 5), "àquele que faz a leitura” (Just. Mart. Apol. 1.67.4), o que mostra como a realização dos sacramentos prevaleceu à clara definição dos seus actores.

É deste período que data a menção do bispo de Roma acerca de Pio como sendo o primeiro presbítero relativamente aos presbíteros das outras comunidades. A prevalência da Igreja de Roma perante as restantes comunidades percebe-se facilmente no contexto de primazia que Roma exercia no Império e da antiguidade da sua comunidade cristã. De uma maneira geral e bastante unânime considera-se que o processo de cristianização tenha começado no Império ocidental em meio urbano, onde residia o episcopos, por volta dos séculos IV-V, e se tenha propagado pelo mundo rural a partir de finais do século V- VI d.C. (MARTIN DE CÁCERES, 1995).

O papel dos bispos na comunidade começou assim progressivamente a impor-se, não sendo no entanto possível entender os diferentes passos deste processo uma vez que a organização das comunidades em cada cidade se fazia de maneira bastante independente e heterogénea (JONES, 1973). Acredita-se que a organização administrativa se reflectiu directamente no desenvolvimento das instituições eclesiásticas (RUCQUOI, 1993, p.59). Nos primeiros concílios do século IV ainda não havia o cuidado de agrupar as igrejas por províncias civis (DUCHESNE, 1920, p.17-20). O termo de diocesis aparece pela primeira vez no Concílio I de Toledo (400) e a partir de então significa sempre um território sob a jurisdição de um bispo (SOTTOMAYOR MURO, 2004, p.283).

Apesar destes testemunhos documentais, a primazia de uns bispos sobre outros nunca foi clara para os historiadores pois, à excepção de Roma e de outras cidades como Jerusalém ou Antioquia cuja supremacia se entende de um ponto de vista da antiguidade da sua comunidade cristã ou numa perspectiva política e económica, as relações de poder entre os bispos das outras cidades não correspondem sempre a estes critérios. Esta falta de clareza reflecte-se em todo o Império. Assim, e como exemplo, a importância de Milão em finais do século IV é essencialmente devida ao carisma do seu bispo Ambrósio (DUCHESNE, 1920, p.33).

A ideia de que cada cidade tinha o seu bispo é uma realidade teórica que não contrapomos. No entanto, de um ponto de vista arqueológico, não é possível ainda comprovar a presença de um complexo episcopal para cada uma delas e é difícil entender complexo baptismais (que supõem a presença de bispo, pelo menos até ao século VI) em meios rurais. No caso da Lusitania o papel predominante de Mérida é claro, no entanto já não é possível explicar a existência de uma basílica rural com funções baptismais em Torre de Palma (Monforte) por 


\section{O poder durante a Antiguidade Tardia}

não se conhecer a que território episcopal faria parte. Pelo contrário, a ausência de basílica cristã nas cidades de Ammaia (Marvão) ou de Mirobriga (Santiago do Cacém) pode ser um factor explicativo para entender o seu abandono no decorrer do século V. Assim sendo, além de questões económicas óbvias em que certas cidades são progressivamente abandonadas, também deverá haver questões de conflitos de poder entre territórios episcopais em que a Igreja resolvia favorecer um bispado em detrimento de outro. Até que a questão dogmática fosse resolvida com a conversão de Recaredo em 589, existiam recompensas feitas a bispos por pertencerem ao campo dogmático do imperador, como por exemplo Potâmio de Lisboa recompensado com fundi fiscalis por Constâncio II ao ter abjurado da ortodoxia em favor do campo ariano (CHAVARRIA ARNAU, 2007, p.40). Não se sabe onde na Lusitania se situavam estas terras imperiais mas significa que um território rural foi oferecido a um bispo por "favor" e se continuarmos nas suposições, podemos pressupor que uma igreja foi construída no local, porventura com baptistério, que passou a atrair população laica que dantes se deslocava para outra localidade. Esta suposição totalmente hipotética e sem bases concretas serve unicamente para demonstrar que as construções de igrejas naquela altura dependiam de questões que nos podem parecer hoje em dia totalmente aleatórias quando, na realidade, tinham uma razão de ser muito específica. Este exemplo de Potâmio também nos demonstra que não havia ainda nestes primeiros séculos da Igreja uma regra ou uma sistematização na edificação de igrejas, o que torna o trabalho do historiador árduo e reduzido quase a um estudo de caso a caso ${ }^{2}$.

\section{O papel dos bispos na sociedade tardo-romana}

Até ao século IV d.C. , e contrariamente ao que geralmente se escreve acerca do poder do bispo, este detinha um poder meramente religioso. Os cargos civis foram duradouramente detidos por notáveis pagãos e a assimilação do bispo com o patronus não é imediata (LEPELLEY, 1998, p.18). O papel principal do bispo na cidade era a prática da caridade, a distribuição de esmolas e o cuidado dos necessitados, sobretudo as viúvas e os órfãos. O peso do bispo junto das autoridades tinha sobretudo a ver com o seu prestígio religioso, mais do que o seu cargo civil. Se o patronus praticava o evergetismo e ajudava os seus clientes mais necessitados, o seu objectivo não era o de um dever moral como sucedia com o bispo, mas antes uma maneira de demonstrar o seu poder sobre a clientela e de manter um status social inquestionável. Esses favores implicavam como resposta uma presença assídua dos clientes no momentos das saudações ao patrão e nos cortejos urbanos, devido ao vínculo contratual entre patrões e os seus clientes. Este tipo de retribuições não existiam na primeira fase da história 
da Igreja. O bispo ajudava os necessitados sem nenhuma vinculação jurídica, o que nos impede de falar de um patronus propriamente dito (LEPELLEY, 1998, p.20).

Todavia é necessário recuar até ao período de Diocleciano para perceber como durante o século IV e $\mathrm{V}$ os bispos se substituíram de forma gradual aos poderes locais civis. A fragmentação do território imperial durante a Tetrarquia conduziu a uma organização em dois níveis, dioceses e províncias, rapidamente acrescida de uma administração militar territorial, os ducados, uma disposição que se manteve em termos gerais até Justiniano. Esta multiplicação de cargos levou a que os postos inferiores tivessem paulatinamente perdido prestígio perante a população, pois estavam sempre mais longe de representar dignamente a figura do Imperador (CARRIÉ E ROUSSELLE, 1999, p.678). Esta crescente desconsideração da população para com os "pequenos governadores" tornou-os gradualmente menos credíveis e assim menos eficazes para impor a vontade imperial.

Paralelamente a esta realidade política, e independentemente dela, com a Paz da Igreja a comunidade cristã cresce consideravelmente, o que obriga a uma maior organização e hierarquização do clero. O bispo torna-se assim não só o líder da comunidade de laicos como também de uma trama cada vez mais complexa envolvendo o clero. Nota-se progressivamente um recrutamento de bispos nas camadas mais altas da sociedade. No contexto de enfraquecimento da classe política que acabámos de ver, as intervenções da Igreja nos assuntos civis tornaram-se imprescindíveis e quanto mais poderoso fosse o bispo mais peso tinha num assunto litigioso. Assim, um bispo com conhecimentos jurídicos e administrativos era um bom protector para os seus fiéis, e se fosse detentor de um elevado poder económico, tornava-se naturalmente evergeta. Desta forma, o acesso ao episcopado por parte dos aristocratas era igualmente promovido pelo próprio povo que se sentia assim mais bem protegido ${ }^{3}$. O caso do bispo Zenão de Mérida que colabora com o dux godo Salla em 487 para a reconstrução da ponte sobre o Guadiana, descrita numa inscrição encontrada nessa ponte, mostra claramente como este bispo tinha uma autoridade equivalente à do governador militar da cidade (JORGE, 2002, p.121). Além de participar no restauro de edifícios públicos, o bispo também se transformou - em substituição ao patronus - no novo construtor de edifícios religiosos que se tornaram os novos eixos de atracção da cidade tardia.

Não existe propriamente uma topografia específica da cidade tardia. Cada cidade evoluiu de maneira particular, sem se saber sempre a razão para o crescimento de umas e o abandono de outras.

O abandono geral das cidades na Antiguidade Tardia é uma ideia ultrapassada, sabendo-se que além das cidades que decaíram durante os séculos V-VI (como por exemplo Ammaia, Mirobriga ou Conimbriga) também houve 


\section{O poder durante a Antiguidade Tardia}

cidades em funcionamento como Emerita (apesar de uma redução de perímetro habitado), Olissipo, Myrtilis, Ossonoba e Pax Iulia. No que se refere aos edifícios religiosos acredita-se no entanto que a maior parte das igrejas era, nos séculos IV e $V$, construída fora do centro da cidade, ainda intramuros e que, com o abandono progressivo dos edifícios públicos romanos, começassem a ser construídas em zonas mais centrais. As igrejas episcopais eram comummente integradas num conjunto complexo de construções que incluíam, além da igreja:

i) a escola episcopal onde os catecúmenos eram iniciados ao baptismo,

ii) o próprio baptistério que, até ao século VII era realizado por imersão e se localizava numa estrutura anexa à igreja,

iii) a casa ou palácio do bispo.

Este chamado "complexo episcopal" podia atingir dimensões monumentais, com várias fases de construção e reconstrução, acrescentando por vezes igrejas anexadas às já existentes ${ }^{4}$. Na Lusitania não temos nenhum exemplo escavado de complexo episcopal: o Liber vitas Sanctorum Patrum emeritensium refere a existência de um baptistério adjacente à igreja catedral que se situaria sob a actual igreja de Santa Maria em Augusta Emerita, o que pressupõe fazer parte de um conjunto monumental, se bem que estes dados tenham que ser confirmados arqueologicamente (MATEOS CRUZ, 2005, p.55).

Em Mértola, a monumentalidade e beleza dos mosaicos da piscina octogonal situada no espaço público do forum, com paralelos em vários baptistérios no Sul da Gália (TORRES e MACIAS, 1993; 2005), devia fazer parte de um complexo episcopal. No entanto, até hoje, ainda não se encontraram nas imediações nenhumas estruturas semelhantes a uma igreja ${ }^{5}$ ou uma casa episcopal.

Existem mais referências documentais acerca de conjuntos episcopais como em Valência, Barcelona, Toledo, Sevilha ou Córdoba, alguns deles arqueologicamente comprovados como o de Tarragona (MATEOS CRUZ, 2005, p.58) e de Barcelona (ORIOL GRANADOS, 1995). Porém, os exemplos mais bem conservados deste tipo de construção são os conjuntos de Recopolis perto de Toledo e o de Tolmo de Minateda também na Cartaginense (GUTIÉRREZ LLORET et al., 2005). Este último, apesar de ser um conjunto já do século VII, é o único caso hispânico de uma cidade construída quase ex novo e com a vantagem de não ter sido destruída por construções posteriores. O complexo monumental religioso foi construído na parte alta da cidade, frente à acrópole, e compõe-se de uma igreja com três naves, um baptistério, um cemitério ad sanctos e o palácio episcopal.

Nos primeiros tempos era unicamente o bispo que tinha direito de baptizar e de realizar a eucaristia, o que explica a importância dos edifícios onde estes sacramentos eram efectuados. Através dos concílios apercebemo-nos que diáconos e presbíteros rurais podiam realizar estes sacramentos mas com a 
obrigatória passagem do bispo, no mínimo com periodicidade anual, para a realização da última unção baptismal e da bênção dos alfaias litúrgicas. Esta indicação documental corrobora a existência de baptistérios que fariam parte de um complexo eclesiástico rural, sem se saber ao certo a partir de quando teriam sido construídos. Temos alguns exemplos de baptistérios rurais na Lusitania, como por exemplo o da villa de Milreu (Estói), o da villa Torre de Palma (Monforte), ou na zona de Mérida o baptistério da villa de Casa Herrera ou o da villa de El Gatillo de Arriba, entre outros.

Como já vimos, além de praticar estes sacramentos e de auxiliar a população necessitada, o bispo geria uma verdadeira burocracia eclesiástica que implicava a governação da sua igreja. Consoante a importância do bispado, ele tinha a seu cargo um clero menor como os notarii que executavam todo o tipo de trabalho burocrático (organização de arquivos, redacção de documentos, entrega de missivas ou assessoria privada ao bispo). Os bispos tinham igualmente o papel de defensores ecclesiae quando tinham de intervir nas questões litigiosas com as autoridades civis. Num bispado grande, o metropolitano podia ser auxiliado por defensores que detinham unicamente esta função. A última grande actividade do bispo era a actividade edilícia. A partir da Paz da Igreja, com a autorização oficial da prática do culto cristão, o número de igrejas cresce sob a directa alçada do bispo. Além da construção, era preciso ter em conta toda a parte de gestão de património já existente e do património doado que representava uma parte importante dos bens da Igreja (SOTINEL, 1998, p. 107, 117).

Por fim, o papel do bispo não se resumia somente a liderar a comunidade urbana, como também geria a comunidade rural e o clero das paróquias dependentes da sua cidade. Contudo, além do sacramento do baptismo que obrigava o bispo a deslocar-se às aldeias ou às villae, o papel dos mártires e mais tarde dos santos é sem dúvida o fenómeno que mais contribuiu para uma nova geografia religiosa.

A importância do culto aos mártires era incomensurável até a Paz da Igreja e transformou-se em culto dos santos a partir de finais do século IV ${ }^{6}$. Estranhamente as práticas funerárias mantiveram-se durante muito tempo intocadas e o culto dos mortos privado até ao século V (ou mesmo VI) manteve-se igual ou próximo ao culto pagão. A Igreja não teve legislação própria nestas matérias privadas durante os primeiros séculos (RÉBILLARD, 2003). Contudo, com o tempo começou a ser necessário controlar e organizar a massa cada vez mais importante de pessoas que se deslocava para venerar um santo à necrópole suburbana ou rural. A forma de controlar estas práticas foi criando procissões que transitavam entre a catedral urbana até às basílicas suburbanas e por fim às basílicas rurais. Além desta maneira de controlar as idas massivas a necrópoles públicas, o bispo tinha igualmente que manter uma disciplina entre o clero rural, 


\section{O poder durante a Antiguidade Tardia}

cujas práticas eram amiúde repreendidas nos diversos concílios do séc. IV (VIVES, 1963).

\section{Uma nova geografia social e religiosa}

O controlo de uma entidade urbana sobre um espaço rural existia no mundo romano pagão. A realização de vias e cadastros tinha como principal âmbito o de recolher os impostos. No que se refere ao contexto religioso, existiam santuários localizados em sítios sagrados como florestas, montanhas ou fontes que fossem venerados pela população. Na Lusitania, vários santuários são conhecidos epigraficamente como por exemplo o santuário de Nossa Senhora da Graça (Nisa) à divindade Quangeus (CARNEIRO, 2009-2010), o santuário em Santana do Campo (Arraiolos) à divindade Carneus (SCHATTNER, 1999) ou, o mais importante da Lusitania: o santuário a Endovellicus, divindade psicopompa ou com virtudes medicinais, localizado em São Miguel da Mota (Alandroal). Estes santuários - sobretudo o último - tinham possivelmente um sacerdócio permanente para acolher os cultuantes. No entanto não há menção de nenhuma organização imperial, tal como acontecia aos cultos imperiais e às divindades urbanas. Os cultos aos templos rurais eram actos individuais e sem relação de dependência à civitas correspondente.

A partir de meados do século III mas com mais vigor a partir do século IV, começam a ser venerados os mártires e os santos em necrópoles suburbanas ou mesmo rurais. Como já vimos, a massa populacional cresce e a Igreja sente a necessidade de organizar o caos que se cria nestes sítios públicos. Se o culto privado aos mortos continua sem grandes legislações por parte da Igreja, o culto público aos mortos começa a ser alvo de regras estabelecidas nos diversos concílios do século IV e V (VIVES, 1963). Tenta-se abolir as práticas pagãs como a do banquete funerário, a das vigílias nocturnas, a das carpideiras etc. para tentar incutir unicamente o canto de textos litúrgicos. Através dos concílios papais notase que mesmo as missas nas igrejas rurais tiveram que ser controladas uma vez que a veneração dos mártires ofuscava a veneração ortodoxa à Trindade. Por cima ou perto dos túmulos começam-se a construir mausoléus ou pequenas basílicas funerárias que por vezes ganhavam uma tal importância que obrigavam à construção de uma verdadeira igreja. Assim, do culto privado dos mortos passase para um culto público, gerido pelo bispo da civitas. O caso mais conhecido da Lusitania é sem dúvida o de Santa Eulália de Mérida, jovem mártir que morreu sob as perseguições de Diocleciano e cujos louvores são cantados no Peristephanon de Prudêncio em finais do século IV. O túmulo de Eulália encontrava-se na necrópole extra-muros de Mérida. Começou a ser venerado, foi construído numa primeira fase um mausoléu que teria sido vandalizado aquando da chegada dos Suevos em 439 (ARCE, 2002, p.185-186), sobre o qual foi mandada 
construir a uma basílica (que se encontra sob a actual basílica a Santa Eulália). As procissões deviam assim começar na igreja catedral de Santa Maria ${ }^{7}$, continuar para a basílica suburbana de santa Eulália, prosseguindo talvez até à zona do xenodoquium, ou seja, um centro de acolhimento aos peregrinos.

Dois fenómenos aparecem assim nesta nova geografia religiosa: a crescente importância dos subúrbios, deixando o centro imperial em segundo plano, bem como uma nova ligação religiosa entre a cidade e o campo, que traduz um controlo episcopal sobre o território, preparando assim o passo para uma nova geografia religiosa alto-medieval.

\section{Notas finais}

A Antiguidade Tardia caracteriza-se pelo lento surgimento de uma Igreja que, de um começo desorganizado e pouco claro, se vai estruturando à medida que as instituições imperiais se vão desagregando. $O$ dado mais relevante parece ser o modo como o processo decorre de forma inversa ao que seria habitual esperar, ou seja, as funções são criadas e só em momento posterior são fixadas e denominadas. Este facto deve-se ao súbito crescimento da Igreja, que ocorreu de modo inesperado e adiantando-se ao próprio rumo dos acontecimentos.

Neste processo gradual emerge a figura do bispo, que progressivamente irá fixando as suas competências e assumindo funções deixadas vagas pelo esvaziamento dos cargos da administração civil. Ao longo do século IV o seu âmbito de acção vai alastrando para as comunidades rurais, onde os edifícios de culto vão centralizar o quotidiano das populações em volta. Durante o século $V$ a principal preocupação dos concílios residirá precisamente na fixação das normas e procedimentos que irão organizar a nova vivência religiosa.

\section{Bibliografia}

ARCE, J. Mérida tardorromana (300-580 d.C.). Cuadernos Emeritenses, 22, Mérida: Museo Nacional de Arte Romano, 2002.

BONNET, C. Les origines du groupe épiscopal de Genève. Comptes-rendus des séances de I'Académie des Inscriptions et Belles-lettres. n. ${ }^{\circ}$ 3, p.414-433, 1981.

CARNEIRO, A. A cartografia dos cultos religiosos no Alto Alentejo em época romana: uma leitura de conjunto. Hispania Antiqva, no 33-34, 2009-2010, p.237-272.

CARRIÉ, J.-M.; ROUSSELLE, A. L'Empire romain en mutation des Sévères à Constantin (192337). (Col. Nouvelle Histoire de l'Antiquité, 10). [s.l.]. Paris: Editions du Seuil, 1999, p.651-718.

CHAVARRIA ARNAU. El final de las villae en Hispania ( siglos IV-VIII). Turnhout: Brepols Publishers, 2007.

DUCHESNE, L. Origines du culte chrétien. Etude sur la liturgie latine avant Charlemagne. 5a edição. Paris: E. de Boccard, 1920.

GUERRA, A.; SCHATTNER, T.; FABIÃO, C.; ALMEIDA, R. São Miguel da Mota (Alandroal/Portugal). 2002. Bericht über die ausgrabungen im heligtum des Endovellicus. Madrider Mitteilungen, 46, p.184-234, 2005. 


\section{O poder durante a Antiguidade Tardia}

GUTIÉRREZ LLORET, S.; ABAD CASAL, L.; GAMO PARRAS, B. Eio, lyyuh y el Tolmo de Minateda (Hellín, Albacete): sede episcopal a Madîna islámica. VI Reunio d'Arqueologia Cristiana. Barcelona: Institut d'Estudis Catalans, 2005, p.345-370.

JONES, A. H. M. The later Roman Empire. 284-602. A social economic and administrative survey. 2 vols. Oxford: Basil Blackwell, 1973.

JORGE, A. L'épiscopat de Lusitanie pendant l'Antiquité Tardive (IIlè - VIlè siècles). Trabalhos de Arqueologia, 21, 2002.

LÉGASSE, S. Les autres voies de la mission (de l'Orient jusqu'à Rome). In: MAYEUR, J.- M. et al. (dir.). Histoire du Christianisme (Des origines à 250), T. 1, [s. I.], Desclée, 2000, p.155-187.

LEPELLEY, Cl. Le patronat épiscopal aux IVè et Vè siècles : continuités et ruptures avec le patronat classique. In: REBILLARD, E., SOTINEL, C. (ed.), L'évêque dans la cité du IVè au Vlè siècle. Image et autorité. Rome: Collection de l'Ecole Française de Rome, 248, 1998, p.17-33.

LOPES, V.; MACIAS, S. Mértola na Antiguidade Tardia. VI Reunio d'Arqueologia Cristiana. Barcelona: Institut d'Estudis Catalans, 2005, p.449-464.

MARTÍN DE CÁCERES, E. Cristianización y arqueología cristiana primitiva de la Lusitania: las áreas rurales. IV Reunió d'Arqueología Cristiana Hispanica. Barcelona: Institut d'Estudis Catalans, 1995, p.359-375.

MATEOS CRUZ, P. Los orígenes de la cristianización urbana en Hispania. VI Reunio d'Arqueologia Cristiana. Barcelona: Institut d'Estudis Catalans, 2005, p.49-62.

ORIOL GRANADOS, J. Notes per a l'estudi de la basilica i del conjunt episcopal paleocristà de Barcelona. Valoricio de la primeira fase. IV Reunio d'Arqueologia Cristiana. Barcelona: Institut d'Estudis Catalans, 1995, p.121-131.

PIETRI, et al. Histoire du Christianisme (des origines à 250). [S.I.]. Desclée, 2000.

REBILLARD, É. Religion et sépulture. L'Église, les vivants et les morts dans l'Antiquité Tardive. Paris: Éditions de l'École des Hautes Études en Sciences Sociales. 2003.

RUCQUOI, A. Histoire médiévale de la Péninsule ibérique. Paris, Editions du Seuil, 1993, p.774.

SAXER, V. L'organisation des Églises héritées des apôtres (70-180). In: MAYEUR, J.- M. et al. (dir.). Histoire du Christianisme (Des origines à 250). T. 1, [s. I.], Desclée, 2000, p.155187.

SCHATTNER, T. Die dorfkirche von Sant'Ana do Campo. Beobachtungen an einem ungewöhlichen römischen Tempel. Madrider Mitteilungen, 40, p.189-217, 1999.

SOTTOMAYOR MURO, M. Términos de la organización territorial eclesiástica de los concilios hispanorromanos y visigodos. In: BALMELLE, C., CHEVALIER, P., RIPOLL, G. (ed.). Mélange d'Antiquité Tardive II. De Infima Antiquitate Studiola in Honorem Noël Duval. Brepols Publisher, 2004, p.283-297.

VIVES, J. Concílios visigóticos e hispano-romanos. Madrid: ConsejoSuperior de Investigaciones Cientificas; Instituto Enrique Flórez, 1963. 


\section{Notas}

${ }^{1}$ Em Portugal, a lei da Separação do Estado das Igrejas data de 20 de Abril de 1911.

${ }^{2}$ A primeira sistematização de construção de igrejas e mosteiros deveu-se a São Leandro (Concilio de Toledo em 633) e depois a Santo Isidoro no século VII.

${ }^{3}$ Veja-se o exemplo de Piniano, marido de Melânia a Jovem, a quem o povo de Hipona queria forçar a tornar-se presbítero por deter uma fortuna incomensurável (August. Ep.125 e 126 apud LEPELLEY, 1998, p.25).

${ }^{4}$ Os exemplos mais notáveis de complexos episcopais encontram-se na Gália (Aix-enProvence, Tours, Arles) ou como o caso paradigmático das catedrais de Notre-Dame e de Saint-Pierre em Genebra (BONNET, 1981).

${ }^{5}$ A basílica a que se referem os autores é a basílica civil romana (LOPES e MACIAS, 2000, p.457).

${ }^{6}$ Os mártires serão sempre venerados mas a partir da Paz da Igreja não há mais mártires «novos» pelo facto óbvio das perseguições terem cessado. Os novos mártires passam a ser os chamados "homens santos", isto é, bispos ou presbíteros ou mesmo laicos que tivessem tido um especial empenho moral na sociedade.

${ }^{7}$ É interessante notar que o decumanus que passa ao lado da sede episcopal paleocristã se chama hoje Calle Santa Eulália. 



\title{
LA TRANSICIÓN ENTRE LA ANTIGÜEDAD Y EL FEUDALISMO: LOS VÁNDALOS
}

\author{
Carlos García Mac Gaw \\ Universidad de Buenos Aires \\ Universidad Nacional de La Plata \\ Argentina
}

En este artículo analizaremos brevemente la forma en que se ha pensado el paso del mundo antiguo al feudalismo, especialmente desde la perspectiva del materialismo histórico. ${ }^{1}$ Argumentaremos a favor de la comprensión del Imperio Romano desde el concepto de Modo de Producción Tributario, relegando así al esclavismo como el elemento central de análisis. Este corrimiento de la problemática transicional tiene como consecuencia enfocarnos en la cuestión tributaria y en las transformaciones operadas en el paso del Imperio Romano a los reinos romano germánicos especialmente en relación con las políticas de la tierra, revalorizando las especificidades regionales. Nos centraremos luego en el caso vándalo para observar una transición en particular.

\section{El esclavismo y la transición}

Durante el período stalinista soviético, se desarrolló un marxismo evolucionista que colocaba al esclavismo (sinónimo de la antigüedad clásica) como una fase del desarrollo de la historia humana hacia el capitalismo, pasando previamente por el feudalismo, para arribar finalmente al socialismo. ${ }^{2}$ Así, la transición del mundo antiguo al feudalismo se pensó básicamente como el paso del modo de producción esclavista al modo de producción feudal. La revolución china abrió un proceso importante de discusiones teóricas en el seno del marxismo. En la Unión Soviética, esos enfoques comenzaron a transformarse en el período post-stalinista, y se produjo una renovación y progresiva independencia de los partidos comunistas europeos junto con un avance de las ideas antiimperialistas en diferentes regiones del mundo que sostuvieron procesos políticos revolucionarios. ${ }^{3}$ En el campo de la historia, esto significó la revalorización de textos olvidados de Marx (1971), así como la renovación de ciertas problemáticas centrales. La transición del feudalismo al capitalismo que había sido el objeto clásico del análisis de los marxistas, cedió paso a nuevos enfoques, como el del Modo de Producción Asiático. ${ }^{4}$

Un artículo que puede resultar clásico para ilustrar la forma en que era concebido el paso del esclavismo al feudalismo es el de E. M. Staerman (1981), "La caída del régimen esclavista", donde se planteaba la crisis de las relaciones 
La transición entre la antigüedad y el feudalismo: los vándalos

esclavistas a fines del siglo II, y un momento de vuelco a nuevas relaciones sociales que se produciría con la crisis del siglo III. Staerman señalaba la irrupción de los pueblos exteriores del Imperio "aliados de las grandes masas", la derrota de los grupos esclavistas, el paso del principado (que representaba al núcleo de los propietarios de esclavos) al dominado (donde estaban representados los intereses de la clase de los grandes propietarios terratenientes), y el reemplazo en el plano económico del esclavo por el colono. Para la autora, la época de Constantino se podía vincular con "la instauración del régimen feudal". ${ }^{5}$ Textos como los de Finley (1982), Esclavitud antigua e ideología moderna, Anderson (1983), Transiciones de la antigüedad al feudalismo, o de Ste. Croix (1988), La lucha de clases en el mundo griego antiguo, reconocen algunos de estos elementos básicos aunque con importantes diferencias capaces de resignificar las lecturas tradicionales sobre estos problemas.

La idea de la decadencia del Imperio fue central para autores como Weber (1981, p.55-7), quien la explicó por el retroceso de la ciudad y la desaparición gradual del comercio; Rostovtzeff (1957), quien encontraba su explicación por el ascenso de los sectores populares; o Demougeot (1959), quien la concibió a partir de las invasiones germánicas. Otras miradas destacaron los vínculos de continuidad matizando la idea de la decadencia, ya sea a partir de una historia cultural desde donde se construye la idea de una antigüedad tardía, como Marrou (1977 y 1983) y P. Brown (1989), o desde los aspectos económicos desarrollados por la escuela de los fiscalistas. ${ }^{6}$ El progresivo desarrollo de la arqueología otorgó un formidable impulso a los estudios sobre el fin del mundo antiguo y los comienzos de la sociedad feudal (NOBLE, 2006, p.1-27). Pero poco a poco, la idea de una transición del esclavismo al feudalismo fue perdiéndose en estas nuevas formas de abordar el tema. Incluso hasta la idea de una "transición", concepto que tiene una fuerte carga para significar el paso de un modo de producción a otro, fue reemplazada por términos como el de la "transformación", una palabra con una menor relación con estas tradiciones historiográficas y, por lo tanto, con una mayor independencia. ${ }^{7}$ Sin embargo, es nuestra intención retomar aquí el concepto de la transición entre los modos de producción, lo que nos lleva a reconsiderar el lugar que en ella cumplirían las relaciones de producción esclavistas.

Como se ha visto en el caso de Staerman, las perspectivas transicionales se construyeron desde el análisis del paso del esclavismo al colonato. Sin embargo, los dos extremos de ese tránsito han sido cuestionados en tanto realidades objetivas establecidas. Señalo algunos aspectos.

En primer lugar, cabe echar dudas sobre el alcance de las relaciones esclavistas de producción en el Imperio Romano, tanto en cuanto a su extensión geográfica como a su centralidad económica para entender en función de ellas la 
racionalidad propia de la formación social romana (GARCÍA MAC GAW, 2007). Las "zonas" esclavistas del Imperio organizadas sobre la unidad productiva de la villa, restringidas a Italia y Sicilia (FINLEY, 1982, p.100), a la vez deben matizarse con áreas no esclavistas. Tampoco en estas áreas resulta dominante la agricultura de plantación: en Apulia, la cría de ganado y la esclavitud estaban estrechamente asociadas desde el siglo II a.C., sobre todo con la cría ovina basada en la trashumancia (Varro RR 2.10. VERA, 1992-3, p.309. MARTIN, 1974, p.286-8). Además, la permanencia de los pequeños propietarios se constata aún en las zonas centrales esclavistas (GARNSEY, 1998, p.95-6. FRANK, 1975, p.172 ss.).

En segundo lugar, disiento con las posiciones de Finley $\left(1982\right.$, p.103) ${ }^{8}$ y de Ste. Croix (1988, p.161) $)^{9}$ que caracterizan a la sociedad romana como "esclavista" al entender que la mayor parte de los recursos de las clases propietarias terratenientes provienen de la explotación de dicha fuerza de trabajo en el marco de la villa. Se dejan así de lado los ingresos extraordinarios provenientes de la guerra (tributo y botines), que deberían considerarse como prioritarios hasta las reformas fiscales del período de Diocleciano, y la producción central de la economía doméstica campesina, libre o dependiente. Desde mi perspectiva la producción esclavista fue siempre marginal a la estructura económica básica, incluso durante el período que muchos historiadores caracterizan como central para el desarrollo de la economía esclavista de plantación en el mundo romano (GARCÍA MAC GAW, 2006, p.39-40; 2007, p.107-11).

Por otro lado, es discutible la supuesta uniformidad de la villa como sistema productivo a partir de la cual se piensa el Modo de Producción Esclavista. ${ }^{10} \mathrm{El}$ "sistema de plantación" construido a partir de los textos de los agrónomos latinos en realidad debería ser pensado como un tipo de explotación entre otros. Así, en la villa puede coexistir un área explotada por el terrateniente o un villicus en forma directa a partir de la organización del trabajo esclavo en bandas, con la explotación de parte de la propiedad con colonos libres (bajo la forma de locatio conductio: DE NEEVE, 1984, p.4-13). Ambas formas pueden articularse con la incorporación de trabajo estacional libre por parte de sus mismos colonos, o incluso sobre temporeros (mercenarii) ajenos al fundo (RATHBONE, 1981). En general los historiadores entienden que existe una variación en la forma de la explotación de la villa caracterizada por un avance de la tenencia de la tierra en detrimento de su explotación directa basada en el trabajo esclavo. Sin embargo, el colonato no se puede plantear como la consecuencia del hundimiento del sistema de la villa esclavista, sino que desde el s. II a.C. se puede rastrear como un fenómeno que emerge paralelamente al del esclavismo rural y tiene a lo largo de su existencia una remarcable estabilidad (DE NEEVE, 1984, p.1157 y 143, quien lo sitúa preferentemente en el s. I; WHITTAKER, 1999 [1987], p.92-4). Más bien habría que plantear que el colonato es uno de los factores que explican el desarrollo de la villa. El uso de los esclavos no se circunscribe a la organización en 
La transición entre la antigüedad y el feudalismo: los vándalos

bandas, sino que desde la república tardía ya se constata la presencia de los servi quasi coloni. Se trata de los esclavos asentados en la tierra que reproducen sus condiciones de existencia y rompen con el imaginario dominante de la ergástula construido desde la obra de Columela (VEYNE, 1981; GILIBERTI, 1988; VERA, 1995; DE STE. CROIX, 1988, p.280-2; CAPOGROSSI COLOGNESI, 1982, p.344-8). ${ }^{11}$ Hay que tener en cuenta además que los instrumenta parecen más bien esclavos adjuntados a la unidad doméstica de los colonos, y su explotación es diferente a la de los esclavos en banda. ${ }^{12}$ Tampoco resulta claro un paso de la villa al latifundio, en la medida en que es difícil caracterizar a este último como un "sistema económico" alternativo a la villa. ${ }^{13}$

Quisiera discutir también la idea de una mayor racionalidad organizada sobre la explotación esclavista, lo que caracterizaría a este modo de producción por un mayor desarrollo en sus fuerzas productivas. ${ }^{14}$ El período de la difusión de la villa, no parece ser el producto de una transformación en la racionalidad económica de los propietarios romanos, sino más bien la consecuencia de una coyuntura excepcional, que Domenico Vera entiende como una fase de la economía drogada (sic) que se extiende entre el 160 y el 50 a.C. Así, Vera (19921993, p.303) discute con Carandini, estigmatizando "il pianto inconsolabile sulla morte della villa schiavistica": esta racionalidad económica, puesta a competir con las provincias, entró en decadencia, lo que habla poco a favor de tal "racionalidad" que aparece especialmente conectada con los mecanismos del imperialismo de rapiña. ${ }^{15}$

Finalmente, el fin del sistema esclavista en relación con el número de los esclavos y de las formas de su aprovisionamiento también puede ser cuestionado. Finley (1982, p.166-71) ya había planteado la necesidad de abandonar la teoría del cese de las conquistas para explicar la crisis del esclavismo. ${ }^{16}$ Sin embargo, desde nuestra perspectiva, al no hacer hincapié en un "período esclavista" se desvanece la necesidad de explicar su crisis. Como el mismo autor indica (FINLEY, 1982, p.160 ss.), el siglo III supone un avance progresivo sobre la capacidad de los grupos más humildes para impedir su sujeción a diversas formas de dependencia personal. Pero la pervivencia de la esclavitud durante el tardoantiguo me lleva a dudar sobre la posibilidad de pensar en un antes y un después del esclavismo durante el Imperio Romano (BLOCH, 1980; BONASSIE, 1993; WHITTAKER, 1999 [1987], p.103; SAMSON, 1992). ${ }^{17}$ Como ha indicado J. Annequin (1985, p.209-13), un aspecto importante para tener en cuenta es la relación entre la producción esclavista y la distribución-circulación. ${ }^{18}$ Lo que hace que la economía esclavista sea periférica a la centralidad de la Formación Social Romana es que nunca controló la distribución y la circulación, las que se estructuran de acuerdo al papel dominante que ejercen las relaciones tributarias. 


\section{El fin del Imperio y la organización de los reinos romano-germánicos}

Dejemos por un instante la problemática del esclavismo y observemos el fin del Imperio y la organización de los reinos germánicos. En su reciente libro, Framing the Middle Ages, Chris Whickam propone que el mayor cambio singular que tomó lugar cuando se rompió el imperio occidental fue el colapso del sistema tributario. El autor indica que un sistema político que está basado en la tributación es fundamentalmente diferente en su estructura básica de uno que no lo está (WHICKAM, 2005, p.58). ${ }^{19}$ En un estado basado idealmente en la tributación donde la riqueza es apropiada sobre casi toda la gente, el sistema fiscal provee una base económica independiente para el poder político, y es capaz de subvencionar los gastos militares y una compleja burocracia, encargada de controlar el sistema de recolección de impuestos (además de la administración y la justicia) que en principio también puede funcionar independientemente de los intereses aristocráticos. Sin embargo esta separación entre la aristocracia y el estado raramente es completa, puesto que la aristocracia también tiende a dominar la administración fiscal y militar. En contraste, un estado ideal basado en la tierra es aquél en el que la riqueza de los gobernantes está derivado no de la totalidad de la población, sino sólo de los habitantes que pagan rentas en la tierra dominada en forma directa por aquéllos. La administración es simple porque el sistema tributario está ausente o es rudimentario, los principales oficiales dependientes del gobernante son sus representantes locales y los líderes militares, cuya base también está en la tierra, al igual que la totalidad del ejército. Toda recompensa política está dominada por la "política de la tierra", es decir cesiones de tierra o de rentas a oficiales o poderosos aristócratas a cambio de sus lealtades. Sus problemas derivan básicamente de la finitud de la tierra disponible y de la fragmentación regional que recurrentemente aparece en estos sistemas. Wickham (2005, p.59-60) entiende que lo que ocurrió durante los s. V y VI en el occidente romano no fue un cambio drástico de un sistema basado en el impuesto a uno basado en la tierra, ni de un cambio brusco de un ejército asalariado a uno asentado en la tierra, sino más bien de un cambio del balance entre el dinero y la tierra, de un ejército básicamente pago (aunque a veces recibía tierras) a uno básicamente sostenido sobre la tierra (aunque a veces suplementado por las larguezas reales durante las campañas, etc.). ${ }^{20}$

Encuentro que algunas de estas ideas son centrales para ayudarnos a organizar una explicación de la transición. Como resulta evidente, debemos partir de presupuestos diferentes a la teoría clásica sobre la transición del esclavismo al feudalismo. El primero es que el modo de producción dominante en el Imperio Romano durante los s. IV y $\mathrm{V}$ es el tributario, resultado de una evolución a partir de lo que llamaría un sistema tributario del subtipo Antiguo en el período anterior. ${ }^{21}$ El segundo es que esto nos lleva necesariamente a resituar el papel de 
La transición entre la antigüedad y el feudalismo: los vándalos

las relaciones esclavistas en la transición al feudalismo. Si partimos de un análisis que pone en el centro la cuestión del tributo en relación con el estado, se produce un cambio completo en la centralidad que el esclavismo tiene en la evolución hacia el tardoantiguo. En este sentido se puede observar el interés que en la obra de Wickham se pone en el estudio de los circuitos fiscales y la interacción de los diferentes espacios productivos a través del papel determinante que le cabe al estado romano en la organización de tales políticas. Este paso del estado tributario centralizado a los estados organizados sobre las aristocracias militares ligadas a la tierra parece ser el gran cambio que se produce, al menos en el occidente europeo. ¿Es que acaso podemos todavía hablar de una transición del esclavismo al feudalismo?

Si dejamos de lado la cuestión del esclavismo, aún cabe preguntarse, ¿Existe una transición al feudalismo? De hecho el Imperio Romano funcionó como un aglutinante en los procesos socioeconómicos unificándolos a escala mediterránea. La progresiva separación de ambas partes del Imperio, oriente y occidente, rompe dicha unidad. La organización de los reinos romano-germánicos en occidente tuvo por consecuencia un movimiento centrífugo que colocó a escala local ciertas lógicas de cambio social que antes debían analizarse en principio desde el centro imperial. Resulta determinante en esta caracterización el papel que le cupo al estado romano como factor de integración políticoeconómico a través del tributo. Probablemente este sea uno de los motivos que nos señale la importancia de los aspectos políticos en la transformación que sufre el occidente europeo (GARCÍA MAC GAW, 2003a). Las características de las diferentes regiones se empiezan a delinear a partir de un sustrato común romano articulado con tendencias locales, más algunos de los factores propios de los pueblos que se instalan allí. En este sentido vale la pena recordar la tesis que había esbozado P. Anderson (1983, p.110-126), quien partía de los estados romanogermánicos de la primera oleada de las invasiones -caracterizados por el mantenimiento de una dualidad entre los grupos de origen germánico y los grupos romanos-, a los estados producto de una segunda oleada en relación con centros de emisión de los invasores más cercanos y que permitieron un asentamiento mayor de sectores campesinos. En estos últimos el dualismo habría pasado al recuerdo y se observaría una presencia dominante de los elementos de origen germánico en ellos. En contraposición a las perspectivas historiográficas anteriores que trataban de entender el proceso de síntesis del feudalismo a partir de criterios genealógicos, Anderson (1983, p.155-174) planteaba la necesidad de construir una tipología del feudalismo europeo. Esta transición entre dos modos de producción está caracterizada por el autor (ANDERSON, 1983, p.136) como "catastrófica" y no como "acumulativa", a diferencia de la transición del feudalismo al capitalismo. Para Wickham el resultado de la descomposición del 
estado romano es algo similar a una "piel de leopardo". Esta es una idea poderosa que pone incluso en cuestión el presupuesto historiográfico de que la transición es una, y el resultado es por ende unitario. Cabría entonces hacer una crítica a la idea de la transición como uniformidad desde y hacia una singularidad. El desmembramiento del Imperio es paulatino, los procesos no son uniformes, los agentes que intervienen son diversos, por consiguiente resulta coherente pensar que estos procesos no desembocan en una única salida.

El "feudalismo" fue colocado como objeto histórico en lugar del "imperio romano", más allá de los elementos económicos que determinaran el criterio de unidad de este último (el esclavismo, la política, el tributo). Sin embargo esta unidad es relativa en la medida en que las unidades político-económicas resultantes de la desagregación imperial y de la constitución de los reinos romano-germánicos son objetos de estudio en sí mismos (y más allá del impulso que podemos encontrar en el desarrollo de las historiografías "nacionales" europeas que han intentado retrotraer el origen de la nación al surgimiento de estos reinos). Ya en el texto de Anderson sobre las transiciones el enfoque era necesariamente una sumatoria de singularidades, de igual manera que en el reciente texto de Wickham lo son las regiones que aísla para su estudio. ${ }^{22}$

La articulación entre el estado romano y los elementos germánicos nos lleva necesariamente a la cuestión de los asentamientos de los pueblos germanos en el Imperio. Especialmente este aspecto ha sido caro a la perspectiva de los fiscalistas que hicieron hincapié en la permanencia de las estructuras impositivas imperiales durante los reinos romano-germánicos para plantear una continuidad en lugar de una transición. Entra aquí en la discusión la cuestión planteada por Goffart (1980) sobre si los jefes militares germanos obtuvieron el derecho a percibir impuestos sobre las tierras que se les concedían, o el derecho al uso de las mismas. ${ }^{23}$ Goffart ha realizado la crítica a la historiografía pro-germánica que encontraba una unicidad en un pasado utópico en que la nación goda habría preexistido a las "invasiones", y en donde hundía las raíces la nación germana. De esta manera se precavía en su libro de la forma en que aparecería presentada su historia de las técnicas de acomodamiento entre bárbaros y romanos: "the history we write should explicitly reflect the diversity and disunity of the peoples that the Roman Empire faced across its borders" (GOFFART, 1980, p.25). ${ }^{24}$ No obstante ello, en su texto ha tratado de destacar el papel central que le cupo a una forma de instalación. En realidad hubo varias formas de ocupación de territorios por parte de los germanos, y la organización de los espacios y las relaciones sociales como producto de la interacción con el mundo romano necesariamente deben contemplar estos matices. Desde la batalla de Adrianópolis (a. 378) los romanos asentaron con asiduidad germanos en sus territorios. ${ }^{25}$ La realización de un foedus respondía a situaciones contingentes de la política y del balance militar entre los 
La transición entre la antigüedad y el feudalismo: los vándalos

ejércitos romanos y germanos, con lo cual probablemente sea difícil poder establecer una norma. Esto podía ir desde conceder una tierra bajo la forma de hospitalidad a incorporar a los vencidos como laeti, dediticii y tributarii, asentados principalmente en las provincias occidentales y cerca de las fronteras durante los siglos III y IV (WHITTAKER \& GARNSEY, 2001, p.279 ss.). ${ }^{26}$ La particularidad de los asentamientos de Visigodos, Burgundios y Alanos en el siglo $V$ refuerzan esta perspectiva de análisis. ${ }^{27}$

Esta compleja problemática se refleja en la evolución de las clases sociales que intervienen en este proceso histórico. Se constituyen nuevas clases de estado y las aristocracias bárbaras asumen el control de nuevos sistemas estatales caracterizados por el manejo de menores recursos económicos y un alcance territorial mucho más restringido que en el Imperio Romano. Si bien estamos ante sociedades polarizadas en clases sociales, los niveles de concentración de riqueza de la aristocracia demuestran un proceso de empobrecimiento. Los ricos son menos ricos, y esto está en relación con la incapacidad de apropiarse de niveles de excedentes similares a los que se daban en el Imperio. Uno de los indicios de ello es el abandono de la piedra y de las estructuras monumentales para las construcciones y la difusión de la madera en las residencias de los aristócratas. ${ }^{28}$ La contracción de las ciudades y el descenso de los niveles de intercambio comercial son igualmente índices sugestivos. En la sumatoria de la renta privada y del tributo necesariamente debe de haber ocurrido un descenso significativo (WICKHAM, 2005, p.706-20, 823-4 y 826-8). Los ejemplos de terratenientes que pierden sus propiedades, como el caso de Paulino de Pella, o Protadio y Victorino que aparecen en el texto de Rutilio Namaciano, nos muestran mecanismos de este proceso, que no necesariamente debe de haber sido uniforme. ${ }^{29} \mathrm{El}$ empobrecimiento de las clases aristocráticas se puede pensar tanto por un descenso relativo de la tasa de explotación como por la reducción del total de trabajadores explotados, lo que se corresponde con el surgimiento de espacios en donde la aristocracia no tiene la capacidad de apropiarse de rentas y donde la base económica se organizaría a partir de unidades campesinas independientes y con bajos niveles de polarización social (lo que WICKHAM, 2005, p.535-50, caracteriza como Modo de Producción Campesino). ${ }^{30}$ Incluso esto parece desencadenarse ya antes del hundimiento definitivo del Imperio occidental en partes de su territorio, con la separación de la Armórica en el turbulento período de comienzos del siglo V (DRINKWATER, 1992, p.214-16).

En definitiva, y para resumir algunas de estas ideas, podríamos decir que: 1. la transición que se produce en el fin del Imperio no es desde un Modo de Producción Esclavista a un Modo de Producción Feudal, sino que se pasa de un Modo de Producción Tributario a una diversidad de Modos de Producción; 2. la relativa uniformidad de una Formación Económico Social Feudal de alcance 
europeo es producto de un proceso posterior; 3. el período posterior a la caída del Imperio Romano presupone un mejoramiento de las condiciones de vida en una amplia franja de los sectores campesinos, ya sea por una disminución relativa de las tasas de explotación como por una mayor independencia del campesinado; y 4. El esclavismo ocupa un lugar marginal en esta problemática, cuya centralidad está en relación con las formas de tributación y la extracción de la renta de tipo servil.

Trataremos de observar ahora, a grandes rasgos, cómo se desarrolló este proceso en una de las áreas del Imperio occidental que resultó central para su existencia, haciendo especial hincapié en la forma en que se organizó el asentamiento de los germanos.

\section{Desde el Rin a Cartago}

Hasta la caída de Cartago y de las provincias africanas, el poder romano en el occidente era todavía dominante, aunque con graves signos de debilidad, respecto del resto de los pueblos germánicos establecidos dentro de las fronteras del Imperio. Entre el 440 y el 480 el balance de poderes cambia. Los vándalos asentados en el Africa, bajo el liderazgo político de Geiserico, se transformaron en una formidable amenaza. El estado romano con sede en Ravena se transformó así en un actor político más entre otros poderes, -hunos, visigodos, francos, burgundios-, y los vándalos surgieron como el más poderoso entre todos ellos en el occidente, mientras el Imperio Romano con sede en Constantinopla logró mantener el control sobre el oriente.

Los vándalos ingresaron al Imperio Romano dentro de un grupo más amplio de pueblos germanos durante las invasiones del 407. El generalísimo Estilicón implementaba su política militar frente a los germanos enfocado especialmente en función de la disputa que mantenía con oriente. La corte oriental había tratado de debilitar la capacidad ofensiva occidental, cuyos ejércitos habían participado en reiterados levantamientos de usurpadores, especialmente de la zona de la Galia. El último de ellos, el de Eugenio, sofocado por Teodosio I, supuso el traslado de las mejores tropas occidentales hacia el oriente. De esta manera se limitaron en cierta forma las capacidades defensivas en la frontera del Rin, orientando la política militar antes al control interno que a la capacidad defensiva externa. En un período breve de tiempo, se produce el cruce del Rin de las tribus germanas y, probablemente como consecuencia de ello, el levantamiento de Constantino III en Britania, cuyos ejércitos pasaron luego a la Galia. Mientras tanto, en la zona del norte de Italia se movían los ejércitos de Alarico. El paso de las tribus vándalas, alanas y suevas por la Galia hacia Hispania se enmarca en estos conflictos. Zósimo indica una victoria de parte de Constantino sobre los bárbaros en los meses siguientes, probablemente antes de 
La transición entre la antigüedad y el feudalismo: los vándalos

octubre del 409. Pero este enfrentamiento se habría producido sólo a los efectos de consolidar el poder del usurpador sobre la zona del Ródano. ${ }^{31}$ El objetivo de Constantino estaba puesto antes en el conflicto por la corona que en la sumisión de los ejércitos germanos. Las tropas de Estilicón seguían la misma lógica y trataban de asegurar el predominio de Honorio por sobre la amenaza del usurpador. $^{32}$

Los bárbaros abandonaron las Galias y se dirigieron a Hispania, probablemente porque después de haber sometido a saqueo a los galorromanos habrían agotado las reservas de alimentos allí disponibles (COURTOIS, 1955, p.51). El paso a Hispania se produce poco después de la cosecha, $y$, aunque menos rica, la provincia permanecía todavía intacta lo que les garantizaba pasar el invierno con provisiones a la mano. Los bárbaros se repartieron luego los territorios de Hispania. ${ }^{33}$ Según Orosio (Or. 7.43.14), los reyes de estos pueblos se habían dirigido al emperador para que legitimara su establecimiento en Hispania acordándoles el estatuto de federados, pero el gobierno imperial prefirió enviar a los visigodos para enfrentarlos bajo el mando de su rey Wallia. Estas campañas continuaron durante un par de años y recién en el 418 fueron aniquilados los vándalos silingos y los alanos (Hyd. 60 y 62). Los hasdingos recibieron bajo su protección a los alanos que habían sobrevivido (Hyd. 68). A partir de entonces el imperio continuó con la vieja política de tratar de enfrentar a los germanos entre sí, favoreciendo a unos y otros alternativamente. Suevos y vándalos hasdingos se enfrentaron en el 419 sin resultados concluyentes. Los vándalos se asentaron durante algunos años en la Bética central, y en el 425 pillaron Carthago Spartaria (Cartagena), las Baleares, e Hispalis (Sevilla) (Hyd. 86), y terminaron derrotando a las tropas imperiales bajo el mando de Castino porque el apoyo esperado desde el Africa por Bonifacio no llegó (Prosp. Chr. a. 425). En el año 429, ya bajo la dirección de Geiserico, derrotan a los suevos poco antes de cruzar el Mediterráneo y dirigirse hacia la Mauretania Tingitana (Hyd. 90).

Los textos que señalan el asentamiento de los vándalos en Hispania se reducen a Hidacio (Hyd. 49) y Procopio (Procop. Vand. 1.3.3). Hidacio no indica realmente que se trate de un pacto con los romanos. Procopio, por su lado, señala que Honorio había otorgado a los vándalos la instalación en la península bajo la condición de que se abstuvieran de realizar depredaciones y de que en ningún caso se reconocía que se volvían propietarios definitivos de las tierras que ocupaban, haciendo reserva de la prescripción de los treinta años que en este caso no era aplicable (COURTOIS, 1955, p.57). Isidoro sigue a Hidacio, pero señala que los vándalos habían roto el foedus (Isid. 73: rupto foedere pacis) de donde podría deducirse una intervención imperial. Si se considera que la única fuente de Isidoro aquí es Hidacio, entonces habría que pensar que se trata más bien de una 
expresión sin el contenido técnico que normalmente le otorgamos a la palabra foedus, o que Hidacio no se preocupó en señalar este detalle.

La sucesión de conflictos entre suevos y vándalos en los años 419/420 y 429 , sumado al choque con los visigodos en 416/418 por iniciativa imperial, explicaría su paso al África y el interés de encontrar un lugar que no estuviera sujeto a una competencia tan feroz en la lucha por los espacios. Este territorio aún no estaba desvastado por las tribus germánicas y era la provincia más rica del imperio occidental (COURTOIS, 1955, p.157). ${ }^{34}$ ¿Porqué los vándalos no intentaron asentarse en Hispania siendo que en los enfrentamientos con romanos y suevos salieron generalmente triunfantes? Cualesquiera hayan sido las condiciones jurídicas bajo las cuales los hasdingos ocuparon tierras en la península y las precauciones tomadas por los juristas romanos (Procop. Vand. 1.3.3), parece que la sociedad vándala era todavía en el 429 esencialmente tribal y todavía no había incorporado la noción de Estado (COURTOIS, 1955, p.58). Esta idea es interesante porque desde las modernas perspectivas historiográficas resultaría un corolario lógico. Pero esta salida "natural" al período de las migraciones entre fines del siglo IV y su definitivo establecimiento en Africa, necesariamente debe ser el resultado de un proceso en el cual el modelo de organización preexistente en los asentamientos de Panonia antes de entrar al Imperio no resultaba adecuado a las nuevas condiciones que les imponía su contexto histórico.

En su avance hacia el oeste por el Africa, pasaron por la Mauretania y Numidia. A partir de junio del 430 sitian la ciudad de Hipona, y recién en agosto del 431 logran tomarla. En el 435 el tratado de Hipona reguló las relaciones entre los vándalos y el Imperio. De acuerdo con Isidoro y Próspero, Ravena les otorgó una porción del territorio africano, que se habría extendido entre las ciudades de Sitifis (Setif) y Calama (Guelma) (COURTOIS, 1955, p.170). ${ }^{35}$ En el 438 Geiserico atacó Sicilia, asediando durante el 440 Palermo y Lilibeo, los puertos de la costa occidental que eran la ruta natural hacia Puteoli y Ostia. En octubre del 439 los vándalos se mueven repentinamente hacia el oriente $\mathrm{y}$, quebrando el pacto establecido, rápidamente conquistan Cartago. En el año 441, Teodosio II inicia una reconquista inconclusa porque la flota debe volver hacia el oriente para solucionar conflictos militares en ese frente. Finalmente, en el año 442, un nuevo tratado legaliza prácticamente la totalidad de las conquistas vándalas en Africa. ${ }^{36}$ De acuerdo con Procopio, el emperador habría logrado percibir un tributo anual (probablemente hasta el a. 455: MODÉRAN, 2002, p.94) en contrapartida por el reconocimiento de la legitimidad del rey vándalo, recibiendo también al hijo mayor de Geiserico, Hunerico, como rehén (Procop. Vand. 1.4.13). ${ }^{37}$ 
La transición entre la antigüedad y el feudalismo: los vándalos

\section{El estado vándalo en Africa}

La naturaleza del Estado de los vándalos, en relación con los criterios de continuidad-discontinuidad que han dominado la historiografía del fin del Imperio, no resulta fácil de discernir. ${ }^{38}$ Los vándalos no dejaron ningún corpus jurídico similar al de los francos, visigodos o lombardos. Por lo tanto los elementos disponibles para analizar la existencia del Estado a través de sus instituciones son muy fragmentarios. La mayoría de los textos son apologéticos, de autores cristianos que presentan la realidad desde las persecuciones promovidas por los vándalos arrianos y tienen una visión catastrófica, como es el caso de las obras de Victor de Vita, Fulgencio de Ruspe, o la Vita Fulgentii de Ferrando. ${ }^{39}$ A estos criterios está asociado el sentido de la palabra vandalismo, acuñada por Gregorio de Blois en 1794, cuando protesta por la destrucción de libros y monumentos ligados con la monarquía y la iglesia acaecida durante los turbulentos años de la revolución francesa. Este juicio negativo se extendía también a los godos, aunque estos fueron luego rehabilitados. Sospecho que los vándalos quedaron en el olvido porque no tienen ninguna historia nacional que desde el s. XIX los reivindicara, como en el caso de la española, la alemana, la italiana o la francesa. Ch. Courtois (1955), en Les Vandales et l'Afrique, fue uno de los primeros en denunciar tal enfoque de las obras cristianas en contra de una tradición consolidada, motivo por el cual no se le ahorraron críticas a su obra. ${ }^{40}$ Sin embargo, los estudios arqueológicos recientes demuestran que la imagen de decadencia transmitida por los católicos africanos no se corresponde con la vitalidad urbana y el empuje económico del período vándalo, especialmente hasta entrado el umbral del siglo VI (AIELLO, 2005, p.265; WICKHAM, 2005, p.641 y 721-24; CALIRI, 2004, p.1694-5; TORTORELLA, 1986; PANESI, 1986). ${ }^{41}$

La cuestión del estatuto del Estado vándalo aparece como un elemento central para explicar sus consecuencias en la reorganización de la ocupación de la propiedad territorial y el control sobre las tierras africanas. La historiografía se dividió básicamente entre quienes planteaban la existencia de un Estado totalmente independiente del Imperio Romano, como L. Schmidt (1942) y Ch. Courtois (1955) -seguidos actualmente por Y. Modéran (2002); y quienes entendieron al reino vándalo como uno más entre los grupos foederati, como $\mathrm{F}$. Clover (1993, VIII y X) y J. Durliat (1997). ${ }^{42}$ En nuestro caso compartimos la opinión del primer grupo, básicamente a partir de la evidencia provista por las fuentes en un sentido general, así como por el hecho de la manifiesta independencia asumida por los vándalos reiteradamente frente a los emperadores romanos en diversas situaciones (cf. MODÉRAN, 2002, p.95-7). La consecuencia directa de esta lectura de los acontecimientos es asumir que los vándalos no se impusieron ninguna limitación en la forma en que se establecieron en el territorio de África, y no se ajustaron a ningún modelo de ocupación de las tierras preexistente. En 
contra de una lectura generalizadora de los sucesos históricos como la planteada por Goffart, nuestro enfoque apunta más bien a observar el proceso de desmembramiento del estado romano como producto de diferentes tensiones y lógicas regionales articuladas con la crisis del gobierno central. Como señala Modéran (2002, p.97-8), "la question de l'installation des Vandales en Afrique peut, et doit donc, être abordée de manière autonome, sous un angle exclusivament africain."

De acuerdo con Víctor de Vita las tierras confiscadas a los romanos africanos se habrían dividido en dos regiones: al ejército se le asignaron tierras en la zona central de la Proconsular, mientras que las tierras pertenecientes a la corona o a su entorno se encontraban en la zona de la Bizacena, Numidia, Getulia y Abaritana (Vict.Vit. Vand. 1.13). ${ }^{43}$ Es probable que el objetivo de esta extraña repartición fuera el de no fragmentar la presencia de por sí escasa de los vándalos en el territorio africano, puesto que su número probablemente ascendiera a cerca de un $20 \%$ de la población total (COURTOIS, 1955, p.218).

Procopio presenta las cosas de forma distinta: los grandes dominios pertenecientes a los hombres notables y más ricos junto con su dinero habrían sido tomados para los dos hijos del rey, Hunerico y Gento, mientras que las propiedades de menor importancia habrían sido distribuidas entre los vándalos (Procop. Vand. 1.5 .11 ss.). Dice que el resto de las propiedades de los libios, que eran a la vez numerosas y excelentes, fueron distribuidas entre la nación de los vándalos (bandilon ethnos), y como resultado de ello fueron llamados "lotes vándalos" (kleroi bandilon). Además indica que Geiserico ordenó que todas las tierras que les correspondían tanto a sus hijos como al resto de los vándalos no estuvieran sujetas a ningún tipo de tributación. Y agrega que el resto de las tierras que no le parecieron lo suficientemente buenas habían quedado en manos de sus propietarios, pero debían pagar sumas tan grandes como tributo al gobierno que no les quedó nada a aquellos que habían retenido sus granjas.

Courtois $(1955$, p.279) piensa que ambas informaciones podrían corresponderse si se piensa que en la Proconsular sólo se habrían confiscado las pequeñas propiedades, mientras que en las provincias periféricas la corona se habría apropiado de los grandes dominios, y se hace corresponder el ejército de Víctor de Vita con los vándalos de Procopio. Esto no quiere decir que la totalidad de los grandes dominios habrían quedado a salvo en la Proconsular, pero en términos generales se corresponde con el hecho de que la zona de las tierras vándalas se sitúa en esta última provincia mientras que la persistencia de las propiedades romanas se encuentra en Bizacena. Estos indicios se refuerzan por el hecho de que las unidades rurales habrían sido respetadas y la división de las tierras se habría efectuado siguiendo una lógica basada en la practicidad: la distribución de las propiedades de tamaño mediano entre los soldados como si se 
La transición entre la antigüedad y el feudalismo: los vándalos

tratara en realidad de lotes naturales (COURTOIS, 1955, p.283). Modéran (2002, p.103), siguiendo a Schmidt y a Courtois, razona en esta misma dirección. Para el autor resulta evidente que los kleroi Bandilon de Procopio eran idénticos a las tierras divididas funiculo hereditatis de Victor de Vita, limitando estas asignaciones solo a la Proconsular. Pero interpreta que las provincias que Geiserico se "reservaba" para sí, de acuerdo a Victor, son de hecho los territorios sobre los cuales se percibían los impuestos: "le roi se les "réservait» dans le sens où il entendait en tirer des ressources fiscales, ce qui était exclu, aux dires de Procope, dans la Proconsulaire lotie aux Vandales." Esta inferencia está confirmada por un fragmento de Victor de Vita. ${ }^{44}$ Mientras que la Proconsular estaba exenta de impuestos el resto de las provincias debía pagarlos. ${ }^{45} \mathrm{De}$ acuerdo con la interpretación de Modéran (2002, p.107-10) este estatuto particular de la Proconsular se correspondía con una zona religiosa reservada únicamente a la práctica del cristianismo arriano identificado con la etnía de los vándalos. De esta forma se explica una política doble llevada a cabo por Geiserico, por un lado un exclusivismo religioso progresivamente afirmado en la región propiamente "vándala", por el otro una política de tolerancia en el resto de las provincias africanas hacia los católicos. ${ }^{46}$

La desposesión material de los terratenientes africanos se verifica por la orden del emperador Valentiniano III enviada al pretorio del prefecto para disponer de tierras en Mauretania Cesariense y Sitifense y asignarlas a los dignatarios desposeídos de la Proconsular y de Bizacena. La Novella del 445 (Nov.Valent. 13.1 y 9, del 21 de junio) hace referencia a las tierras que habían sido devueltas por los vándalos y permanecían ahora bajo la autoridad imperial (prouinciae africanae ad ius nostrum pertinentes). ${ }^{47}$ Allí se informa de la presencia de un grupo de provinciales de Numidia y Mauretania Sitifense enviados frente al emperador para exponer los problemas de sus regiones, especialmente en materia de justicia e impuestos (COURTOIS, 1955, p.175, n.7), y se toma la decisión de rebajar el tributo fiscal a un octavo a los habitantes de esas regiones (CALIRI, 2004, p.1697). Por otro lado, la Novella 34 del 13 de junio del 451 legisla para las provincias de Numidia, Mauretania Cesariense y Sitifense, distribuyendo 13000 centurias $^{48}$ exentas de impuestos por cinco años, ex desertis locis, en la provincia de Numidia a los honorati Afri y possessores nudati hostili vastatione, además de repartir 2000 solidos de acuerdo al mérito de las personas. En las otras dos provincias se repartieron tierras indebidamente ocupadas que eran de derecho enfitéutico y de la domus imperial (CALIRI, 2004, p.1700). ${ }^{49}$ Como lo indican claramente estas disposiciones imperiales, algunas propiedades habían sido efectivamente confiscadas y la corte arbitraba medidas para lograr que algunos de esos possessores accedieran a tierras del fisco. ${ }^{50}$ 
L. Schmidt (1942) postuló la excepción vándala en relación con el modelo de asentamiento señalado por CT 7.8 .5 (a. 398) luego nombrado por Ferdinand Lot como el régimen de la hospitalidad (SCHWARCZ, 2004, p.49). Goffart (1980, p.171-5) vio en el sistema de la hospitalitas no una base para la división de la tierra sino para asignar el pago de raciones a los federados. Este autor no analizó en profundidad el caso vándalo, sino que se circunscribió a la Galia e Italia, planteando una similitud en ese sistema para las distribuciones de tierras de Geiserico (GOFFART, 1980, p.68, n.20 y 212, n.15). El autor se basó en Procopio y Victor de Vita, pero no retomó la Nov.Valent. 34. Goffart fue seguido por Durliat $\left(1985\right.$, p.383) quien se centró con más detenimiento en el África. ${ }^{51}$ Recientemente Schwarcz (2004, p.55) insiste en la perspectiva de Durliat y señala que el pasaje de Victor de Vita 1.13 (...exercitui uero Zeugitanam uel proconsularem funiculo hereditatis diuisit,...) muestra que la mayor parte del territorio concedido por el foedus del 442 terminó bajo el control real, mientras que el África Proconsular debía financiar el ejército federado, y que la división entre el rey y su ejército no era una división de la tierra sino simplemente significaba que el ingreso de la provincia Proconsular financiaba el ejército, y el resto de las provincias al rey, su corte y sus oficiales. Se apoya en la interpretación que hace de Victor de Vita su traductor, J. Moorhead, quien entiende que Victor cita literalmente un fragmento de I Chr. 16.17-20 de la Vulgata. ${ }^{52}$ Por lo tanto no se le debería dar al texto la interpretación que tradicionalmente se le ha dado, es decir que la provincia del África Proconsular fue dividida por la cuerda en lotes de tierra y que la mayor parte del ejército fue asentado allí. Lamentablemente para la posición de Schwarcz y Durliat, nada dice tampoco Victor respecto de que lo asignado habría sido el tributo sobre la tierra para que se dividiera entre los componentes del ejército vándalo. Aún cuando la interpretación de Moorhead fuera la correcta, el uso de la cita por parte de Victor sencillamente podría haber sido porque la tierra realmente había sido dividida de forma similar a la indicada en la Biblia, es decir repartida en heredades. Wickham (2005, p.90-1) plantea que lo sorprendente es que Geiserico haya asentado a sus hombres en la tierra, cuando en el África el sistema fiscal estaba intacto y los ejércitos romanos siempre habían sido principalmente asalariados. Si hubiera que proponer un caso en el que un rey germánico dividiera las percepciones fiscales, este debería haber sido el de África. Sin embargo, los vándalos ya habían estado asentados en la tierra en Hispania. Cuando entraron en el África en realidad no se convirtieron en un ejército romano, ni siquiera nominalmente, sino que se transformaron rápidamente en una clase aristocrática militarizada. A diferencia de los ejércitos romanos que nunca constituyeron una elite, los ejércitos germánicos sí lo fueron, y la propiedad sobre la tierra se correspondía con ello. Así Wickham $(2005$, p.86) asume la factibilidad de que se impusieran procedimientos ad hoc antes que la teoría 
La transición entre la antigüedad y el feudalismo: los vándalos

tradicional de la hospitalitas y señala que todo modelo que plantee una uniformidad, aunque fuera meramente administrativa, en realidad violenta la evidencia que nosotros tenemos para la confusión del siglo $\mathrm{V}$.

\section{Conclusiones}

Ya habíamos señalado en las conclusiones parciales que el fin del Imperio implica la transición de un Modo de Producción Tributario a una diversidad de Modos de Producción. Se trata de un proceso que no es uniforme, cuya centralidad está en relación con las formas de tributación y la extracción de la renta de tipo servil, y donde el esclavismo ocupa un lugar marginal. La condición de los grupos campesinos probablemente haya mejorado en relación con el período tardoimperial.

La evolución del caso vándalo se puede ver como un laboratorio para los sucesos que se darían en el continente europeo, ya que se trata de la creación del primer reino romano-germánico, aún tomando en cuenta la conquista posterior de Justiniano. Se han desarrollado últimamente estudios sobre la estructura de su administración, que rompen con la idea del conflicto permanente entre romanos cristianos y vándalos arrianos. La historiografía actual tiende a desmitificar la lectura de las fuentes cristianas y observa un proceso de integración que fue interrumpido por la conquista bizantina.

La caída de las provincias africanas en manos de los vándalos tuvo un peso determinante para la crisis final del Imperio Romano. Esto tiene dos elementos centrales que lo constituyen. En primer lugar, el cese de la transferencia de la annona desde África a Roma (¿a. 442-455?), lo que significó la necesidad de recurrir a fuentes de abastecimiento secundarias para mantener el funcionamiento de la administración de la corte imperial y de los ejércitos bajo control directo del emperador. En segundo lugar, la progresiva ampliación de la hegemonía vándala sobre el Mediterráneo occidental desde la muerte de Valentiniano III (455), lo que llevó a la organización de "I'empire du blé", de acuerdo a la expresión de Ch. Courtois. Esto significó el control de los espacios secundarios de producción de cereales: Sicilia, Cerdeña, junto con el resto de las islas mediterráneas occidentales que eran los jalones de la circulación mercantil (Baleares y Córcega especialmente).

Este caso corrobora la imposibilidad de establecer una regla en relación con las formas en que se organizaron las apropiaciones de tierras y los asentamientos de los germanos en el Imperio, que varían de acuerdo a las diferentes condiciones en que se producen. La única norma que se puede rastrear como resultado de la caída del estado romano es la fragmentación de sus espacios. El África es una muestra palpable de ello: como resultado observamos la organización de un estado romano-germánico, ocupación de tierras por la 
aristocracia germana junto con la persistencia de distintos tipos de propiedad romana, supervivencia de la estructura de la civitas como sistema político en la escala más básica, ${ }^{53}$ organización de pequeños reinos bajo el poder de indígenas bereberes romanizados (Camps, 1984), y, en ciertos casos tribalización. Vale decir que el paso al tardoantiguo y la trancisión al feudalismo es un proceso complejo carente de linealidad modélica.

\section{Bibliografía}

AIELLO, V. Vittore de Vita e la legislazione Vandala in Africa. In: ATTI DELL'ACCADEMIA ROMANISTICA COSTANTINIANA, XV CONVEGNO INTERNAZIONALE IN ONORE DI CARLOS CASTELLO. Roma: Edizioni Scientifiche Italiane, 2005, p.253-283.

AIELLO, V. I Vandali nell'Africa romana: problemi e prospettive di ricerca. Mediterraneo Antico, n. 8.2, p.547-569, 2005a.

AIELLO, V. Che fine ha fatto l'élite burocratica romana nel regno dei Vandali. In: LIZZI, R. (Ed.). Le trasformazione delle "élites» in età tardoantica. Roma: L'Erma di Bretschneider, 2006, p.15-40.

AMIN, S. Sobre el desarrollo desigual de las formaciones sociales (Ensayo introductorio por M. Barceló). Barcelona, 1976.

ANDERSON, P. El modo de producción asiático. In: ANDERSON, P. El estado absolutista. México: Siglo XXI, 1985, p.476-568 [1a Ed.: Lineages of the Absolutist State. London: New Left Books, 1974].

ANDERSON, P. Transiciones de la antigüedad al feudalismo. México: S. XXI, 1983 [1 ${ }^{\mathrm{a}}$ Ed.: Passages from Antiquity to Feudalism. London: New Left Books, 1974].

ANDREAU, J. et MAUCOURANT, J. À propos de la «rationalité économique» dans l'antiquité Gréco-Romaine. Une interprétation des thèses de D. Rathbone [1991]. Topoi, Lyon, $\mathrm{n}$. 9, p.47-102, 1999.

ANNEQUIN, J. Formes de contradiction et racionalité d'un système économique. Rémarques sur l'esclavage dans l'Antiquité. Dialogues d'Histoire Ancienne, n. 11, p.199236, 1985.

ASTARITA, C. Construcción histórica y construcción historiográfica de la temprana edad media. Stud. Hist. Ha Med., n. 25, p.247-69, 2007.

BANAJI, J. Agrarian change in Late Antiquity. Oxford: Oxford Univ. Press, 2002.

BLOCH, M. Cómo y por qué terminó la esclavitud antigua. In: BLOCH, M. y otros. La transición del esclavismo al feudalismo. Madrid: Akal, 1980, p.159-94 [1a.. Ed.: Annales E. S. C., p.30-43 y 161-70, 1947.].

BLOCH, M. y otros. La transición del esclavismo al feudalismo. Madrid: Akal, 1980.

BONASSIE, P. Del esclavismo al feudalismo en Europa occidental. Barcelona: Crítica, 1993.

BROWN, P. El mundo en la antigüedad tardía. De Marco Aurelio a Mahoma. Madrid: 1989 [1aㅡ.: 1971].

BURGESS, R. W. From Gallia Romana to Gallia Gothica: the view from Spain. In: DRINKWATER \& ELTON, (eds.). Fifth-century Gaul: a crisis of identity? Cambridge: Cambridge Univ. Press, 1992, p.19-27.

BURNS, T. S. The settlement of 418. In: DRINKWATER \& ELTON, (eds.). Fifth-century Gaul: a crisis of identity? Cambridge: Cambridge Univ. Press, 1992, p.53-63. 
La transición entre la antigüedad y el feudalismo: los vándalos

CALIRI, E. Praedia pistoria e possessores africani in età vandalica: a proposito di Valentiniano III, Nov. 34. In: KANHOUSSI M., RUGGERI P., VISMARA C. (a cura di). L'Africa romana. Ai confini dell'Impero: contatti, scambi, conflitti. Atti del XV convegno di studio. Tozeur, 11-15 dicembre 2002, 3 vol. Sassari: Carocci Editore, 2004, p.1693710.

CAMPS, G. Rex gentium Maurorum et Romanorum. Recherches sur les royaumes de Maurétanie des $\mathrm{VI}^{\mathrm{e}}$ et $\mathrm{VII}{ }^{\mathrm{e}}$ siècles. Antiquités Africaines, n. 20, p.183-218, 1984.

CANDAU, J. M. Introducción, traducción y notas. In: ZÓsIMO. Nueva Historia. Madrid: Ed. Gredos, 1992.

CAPOGROSSI COLOGNESI, L. Grandi Proprietari, contadini e coloni nell'Italia romana (I-III D.C.). In: GIARDINA, A. (ed.). Società Romana e Impero Tardoantico, 4 Vols. Roma-Bari: 1986, Vol. 1, p.325-365.

CHESNEAUX A., PARAIN CH. et TUILIER A. Etat et Classes dans l'Antiquité esclavagiste. Recherches Internationales à la lumière du marxisme, n. 2, mai-juin, 1957.

CLOVER, F. M. The Late Roman West and the Vandals. Aldershot: Variorum Collected Studies, 1993.

CORTÉS, F. Y CUÉLLAR, O. Lenin y Chayanov, dos enfoques no contradictorios. Nueva Antropología, n. 31, p.63-101, 1986.

COURTOIS, C. Les Vandales et l'Afrique. Paris, 1955.

DA GRACA, L. Reflexiones metodológicas sobre el estudio comparativo de Chris Wickham. Edad Media Rev. Hist., n. 9, p.265-97, 2008.

de NEEVE, P. W. Colonus. Amsterdam: J. C. Gieben, Publisher, 1984.

de STE. CROIX, G. E. M. La lucha de clases en el mundo griego antiguo. Barcelona: Ed. Crítica, 1988.

DEMOUGEOT, E. La formation de l'Europe et les invasions barbares. Paris, 1979.

DRINKWATER, J. The Bacaudae of fifth-century Gaul. In: DRINKWATER, J. \& ELTON, H. (eds.). Fifth-century Gaul: a crisis of identity? Cambridge: Cambridge Univ. Press, 1992, p.208-17.

DRINKWATER, J. \& ELTON, H. (eds.). Fifth-century Gaul: a crisis of identity? Cambridge: Cambridge Univ. Press, 1992.

DURLIAT, J. Les finances municipales africaines de Constantin aux Aghlabides. BACTHS, nouv. sér., n. 19 B, 1985, p.377-86.

DURLIAT, J. Les finances publiques de Diocletien aux Carolingiens (284-889). Sigmaringen, 1990.

DURSTON, J.W. Clase y cultura en la transformación del campesinado. Revista de la Cepal, n. 16, p.155-77, 1982.

DYSON, S. L. The Roman Countryside. London: Duckworth, 2003.

ÉTIENNE, R. Recherches sur l'ergastule. In: Actes du Colloque 1972 sur l'Esclavage, Annales littéraires de l'Université de Besançon 163, Centre de Recherches d'Histoire Ancienne, Vol. 11. Paris: Les Belles Lettres, 1974, p.249-66.

EVANS, K. Plebs Rustica. The Peasantry of Classical Italy, II. American Journal of Ancient History, n. 5, p.19-47, 1980.

FINLEY, M. Esclavitud Antigua e Ideología Moderna. Barcelona: Crítica, 1982. 
FOSTER, G. M. La sociedad campesina y la imagen del bien limitado. In: BARTOLOMÉ L. J. \& GOROSTIZA E. E. (eds.). Estudios sobre el campesinado latinoamericano. La perspectiva de la antropología social. Buenos Aires: Periferia, 1974, p.57-90.

FRANK, T. An Economic Survey of Ancient Rome. T. VI . New York: Octagon Books, 1975.

GARCÍA MAC GAW, C. La ciudad estado y las relaciones de producción esclavistas en el Imperio Romano. In: GALLEGO, J. Y GARCÍA MAC GAW, C. (eds.). La ciudad en el Mediterráneo Antiguo. Buenos Aires: Ed. del Signo y Facultad de Filosofía y Letras-UBA, 2007, p.87-124.

GARCÍA MAC GAW, C. La transición del esclavismo al feudalismo y la villa esclavista. Dialogues d'Histoire Ancienne, n. 32/2, p.27-42, 2006.

GARCÍA MAC GAW, C. Roma: La crisis del siglo III y el Modo de Producción Tributario. In: HALDON, J. Y GARCÍA MAC GAW, C. (eds.). El modo de producción tributario (Sección monográfica), Anales de Historia Antigua, Medieval y Moderna, n. 35, p.97-119, 2003.

GARCÍA MAC GAW, C. Conclusiones. Sobre la importancia de los elementos superestructurales en la caracterización de los modos de producción. In: HALDON, J. Y GARCÍA MAC GAW, C. (eds.). El modo de producción tributario (Sección monográfica), Anales de Historia Antigua, Medieval y Moderna, n. 35, p.219-32, 2003a.

GARNSEY, P. Peasants in Ancient Roman Society. In: GARNSEY, P. (Edited with addenda by SCHEIDEL, W.). Cities, peasants, and food in classical antiquity: essays in social and economic history. Cambridge: Cambridge Univ. Press, 1998, p.91-106.

GIARDINA, A. Le due Italie nella forma tarda dell'Impero. In: GIARDINA, A. (ed.). Società Romana e Impero Tardoantico, 4 Vols. Roma-Bari, 1986, p.1-36.

GIARDINA, A. (ed.). Società Romana e Impero Tardoantico, 4 Vols. Roma-Bari, 1986.

GILIBERTI, G. Servus quasi colonus. Napoli, 1988.

GOFFART, W. Barbarians and Romans A.D. 418-584. The Techniques of Accomodation. Princeton: Princeton Univ. Press, 1980.

GOFFART, W. Rome, Constantinople and the Barbarians. In: GOFFART, W. Rome's Fall and After. London and Ronceverte: The Hambledone Press, 1989, p.1-32.

HALDON J. Y OTROS. El modo de producción tributario: una discusión interdisciplinaria (Sección monográfica). Hispania, 58/3, n² 200, p.797-968, 1998.

HALDON J. Y GARCÍA MAC GAW C. (eds.). El modo de producción tributario (Sección monográfica), Anales de Historia Antigua Medieval y Moderna, n. 35, p.5-232, 2003.

HARRIS, W. V. Child-Exposure in the Roman Empire. Journal of Roman Studies, n. 84, p.122, 1994.

HARRIS, W. V. Demography, Geography and the Sources of Roman Slaves. Journal of Roman Studies, n. 89, p.62-75, 1999.

HARRISON, M. The peasant mode of production in the work of A.V. Chayanov. Journal of Peasant Studies, n. 4, 323-36, 1977.

HEATHER, P. The emergence of the Visigothic kingdom. In: DRINKWATER, J. \& ELTON, H. (eds.). Fifth-century Gaul: a crisis of identity? Cambridge: Cambridge Univ. Press, 1992, p.84-94.

HEATHER, P. La caída del imperio romano. Barcelona: Crítica, 2006.

HEYNIG, K. Principales enfoques sobre la economía campesina. Revista de la Cepal, n. 16, p.115-42, 1982. 
La transición entre la antigüedad y el feudalismo: los vándalos

HINDESS B. \& HIRST P. Los modos de producción precapitalistas. Barcelona: Península, 1979.

KONSTAN, D. Marxismo y esclavismo romano. In: AA. VV. El marxismo y los estudios clásicos. Madrid: 1981, p.127-148 [1a Ed.: Arethusa, n. 8, p.145-69, 1975].

KOVALIOV, S. I. El vuelco social del siglo III al V en el Imperio Romano de occidente. In: BLOCH, M. Y OTROS. La transición del esclavismo al feudalismo. Madrid: Akal, 1980, p.109-29.

LIEBESCHUETZ, J. H. W. G. Barbarians and Bishops. Oxford, 1998.

LIEBESCHUETZ, J. H. W. G. Cities, Taxes and the accomodation of the Barbarians. The theories of Durliat and Goffart. In: NOBLE, T. (ed.). From Roman Provinces to Medieval Kingdoms. London-N. York: Routledge, 2006, p.309-23 [1 ${ }^{\text {a }}$ Ed.: In: POHL W. Kingdoms of the Empire: The integration of barbarians in late Antiquity, Leiden: Brill, 1997].

LIEBESCHUETZ, J. H. W. G. Gens into regnum: The Vandals. In: GOETZ H. W., JARNUT J. \& POHL W. (eds.). "Regna» and "Gentes». The Relationships between Late Antiquity and Early Medieval Peoples and Kingdoms in the Transformation of the Roman World. Boston-Leiden: Brill, 2003, p.55-83.

MARX, C. Formas que preceden a la producción capitalista. In: MARX, C. Elementos fundamentales para la crítica de la economía política (Grundrisse), 1857/8, Vol. I. México: S. XXI, 1971, p.433-79.

MARROU, H. I. Décadence romaine ou Antiquité tardive? III-VI siècle. París, 1977.

MARROU, H. I. Saint Augustin et la fin de la culture antique. Paris: Ed. E. de Boccard, 1983 [1ㅁ Ed.: 1958].

MARTIN, R. "Familia rustica": les esclaves chez les agronomes latines. In: Actes du Colloque 1972 sur l'Esclavage. Annales littéraires de l'Université de Besançon, 163, Centre de Recherches d'Histoire Ancienne, Vol. 11. Paris: Les Belles Lettres, 1974, p.267-97.

MATHISEN, R. W. Fifth-century visitors to Italy: business or pleasure? In: DRINKWATER, J. \& ELTON, H. (eds.). Fifth-century Gaul: a crisis of identity? Cambridge: Cambridge Univ. Press, 1992, p.228-38.

MEIKSINS WOOD, E. Peasant-citizen and slave. The foundations of the Athenian democracy. Londres: Verso, 1988.

MODÉRAN, Y. La chronologie de la Vie de saint Fulgence de Ruspe et ses incidences sur I'histoire de l'Afrique vandale. MEFRA, n. 105.1, p.135-88, 1993.

MODÉRAN Y. L'établissement territorial des Vandales en Afrique. Antiquité Tardive, n. 10, p.87-122, 2002.

MODÉRAN Y. Une guerre de religion: les deux églises d'Afrique à l'époque vandale. Antiquité Tardive, n. 11, p.21-44, 2003.

NOBLE, T. Introduction: Romans, barbarians, and the transformation of the Roman Empire. In: NOBLE, T. (ed.). From Roman Provinces to Medieval Kingdoms. London-N. York: Routledge, 2006, p.1-27.

NOBLE, T. (ed.). From Roman Provinces to Medieval Kingdoms. London-N. York: Routledge, 2006.

PANELLA, C. Le merci: produzioni, itinerari e destini. In: GIARDINA, A. (ed.). Società Romana e Impero Tardoantico, 4 Vols. Roma-Bari, 1986, Vol. 3, p.431-59. 
RATHBONE, D. W. The development of agriculture in the ager Cosanus during the Roman Republic: problems of evidence and interpretation. Journal of Roman Studies, n. 71, p.10-23, 1981.

ROSTOVTZEFF, M. Social and Economic History of the Roman Empire. Oxford, 1957.

SALRACH, J. M. Del estado romano a los reinos germánicos. En torno a las bases materiales del poder del estado en la antigüedad tardía y la alta edad media. In: De la Antigüedad al Medioevo, s. IV-VIII, III ${ }^{e r}$ Congreso de Estudios Medievales. Madrid: Fundación Sánchez Albornoz, 1993, p.97-142.

SAMSON, R. Slavery, the Roman legacy. In: DRINKWATER, J. \& ELTON, H. (eds.). Fifthcentury Gaul: a crisis of identity? Cambridge: Cambridge Univ. Press, 1992, p.218-29.

SCHEIDEL, W. Quantifying the Sources of Slaves in the Early Roman Empire. Journal of Roman Studies, n. 87, p.156-69, 1997.

SCHMIDT, L. Geschichte der Wandalen. Lepzig: 1942 [1a Ed.: 1901].

SCHWARCZ, A. The Settlement of the Vandals in North Africa. In: MERRILLS, A. H. (ed.). Vandals, Romans and Berbers: New Perspectives on Late Antique North Africa. Aldershot: Ashgate, 2004, p.49-59.

SHANIN, T. Peasantry: delineation of a sociological concept and a field of study. European Journal of Sociology, n. 2, p.289-300, 1971.

SIVAN, H. Town and Country in late antique Gaul: the example of Bordeaux. In: DRINKWATER, J. \& ELTON, H. (eds.). Fifth-century Gaul: a crisis of identity? Cambridge: Cambridge Univ. Press, 1992, p.132-43.

STAERMAN, E. M. La caída del régimen esclavista. In: BLOCH, M. Y OTROS. La transición del esclavismo al feudalismo. Madrid: Akal, 1980, p.59-107 [1 ${ }^{\mathrm{a}}$ Ed.: Vestnik Drevnei Istorii, n. 2, 1952].

TANNENBAUM, N. Chayanov and economic anthropology. In: DURRENBERGER E. P. (ed.). Chayanov, peasants, and economic anthropology. San Diego: 1984, p.27-38.

TORTORELLA S. La ceramica fine da mensa africana dal IV al VII secolo d.C. In: GIARDINA, A. (ed.). Società Romana e Impero Tardoantico, 4 Vols. Roma-Bari, 1986, Vol. 3, p.211-25.

VERA, D. Schiavitù rurale e colonato nell'Italia imperiale. Scienze dell'Antichitá. Storia, archeologia, antropologia, n. 6-7, p.291-339, 1992-1993.

VERA, D. Dalla 'villa perfecta' alla villa di Palladio: sulle trasformazioni del sistema agrario in Italia fra principato e dominato. Athenaeum, n. 83 , fasc. 1, p. 189-211 y fasc. 2, p.33156, 1995.

VERLINDEN, C. L'esclavage dans l'Europe médiévale. Paris, 1955.

VEYNE, P. Le dossier des esclaves colons romains. Rev. Hist., n. 265/1, 1981, p.3-25.

VILAR, P.¿Economía campesina? In: VILAR, P. Iniciación al vocabulario del análisis histórico. Barcelona: Grijalbo-Crítica, 1980, p.265-311.

WEBER, M. La decadencia de la cultura antigua. Sus causas sociales. In: BLOCH, M. Y OTROS. La transición del esclavismo al feudalismo. Madrid: Akal, 1980, p.35-57.

WHITTAKER, C. R. Labour supply in the later Roman Empire. In: WHITTAKER, C. R. Land City and Trade in the Roman Empire. Aldershot: Variorum Collected Studies, 1999, p.IV 171179 [1 $1^{\text {a }}$ Ed.: Opus, n. 1, p. 171-79, 1982].

WHITTAKER, C. R. Circe's Pigs: From Slavery to Serfdom in the Later Roman World, In: WHITTAKER, C. R. Land City and Trade in the Roman Empire. Aldershot: Variorum 
La transición entre la antigüedad y el feudalismo: los vándalos

Collected Studies, 1999, p.V 88-120 [1 ${ }^{\text {a }}$ Ed.: FINLEY, M. I. (ed.). Classical Slavery. London, 1987].

WHITTAKER, C. R. Land City and Trade in the Roman Empire. Aldershot: Variorum Collected Studies, 1999.

WHITTAKER C. R. \& GARNSEY P. Rural Life in the Later Roman Empire. In: CAMERON A. \& GARNSEY P. (eds.). The Cambridge Ancient History, Vol. XIII, The Late Empire, A.D. 337425. Cambridge: Cambridge Univ. Press, 2001, p.277-311.

WICKHAM, CH. La otra transición: del mundo antiguo al feudalismo. Stud. hist. Ha ant., n. VII, 1989, p.7-35 [1a ed.: P\&P, n. 103, 1984, p.3-36].

WICKHAM, CH. La chûte de Rome n'aura pas lieu. Le Moyen Age, n. 99, p.107-26, 1993.

WICKHAM, CH. La singularidad del Este. In: HALDON J. Y GARCÍA MAC GAW C. (eds.). EI modo de producción tributario (Sección monográfica), Anales de Historia Antigua Medieval y Moderna, n. 35, p. 5-232, 2003, p.185-218 [1a Ed.: Journal of Peasant Studies, n. 12, p.166-96, 1985].

WICKHAM, CH. Framing the Early Middle Ages. Europe and the Mediterranean 400-800. Oxford, 2005.

WOOD, N. I. Continuity or calamity: the constraints of literary models. In: DRINKWATER, J. \& ELTON, H. (eds.). Fifth-century Gaul: a crisis of identity? Cambridge: Cambridge Univ. Press, 1992, p.9-18.

WORSLEY, P. Economías campesinas. In: SAMUEL R. (ed.). Historia popular y teoría socialista. Barcelona, 1984, p.169-76.

ZELIN, K. K. Principios de clasificación morfológica de las formas de dependencia. In: ANNEQUIN, J. Y OTROS. Formas de explotación del trabajo y relaciones sociales en la antigüedad clásica. Madrid: Akal, 1979, p.55-92 [1a Ed.: Recherches Internationales à la lumière du marxisme, n. 84, 1975].

\section{Notas}

${ }^{1}$ La primera parte de este trabajo ha sido tomada con algunas modificaciones de: García Mac Gaw C. G. El modo de producción esclavista: ¿Qué transición? In: Atti del XXXII Colloquio GIREA: Forme di dipendenza nelle società di transizione, Messina, 15-17 maggio 2008, en prensa.

${ }^{2}$ Una visión crítica con bibliografía en Konstan, 1981.

${ }^{3}$ Para observar su reflejo en la historia antigua véase, por ejemplo, Chesneaux, Parain y Tuilier (1957). Una crítica importante desde el propio marxismo soviético al evolucionismo stalinista en Zelin (1979).

${ }^{4}$ En 1978 la editorial Akal publica el libro de AA. VV. Primeras sociedades de clase y modo de producción asiático. Madrid; conformado por artículos escogidos ya publicados en SUR LE MODE DE PRODUCTION ASIATIQUE (préface de SURET-CANALE, J.). Paris: Editions Sociales, 1974 (2ª ed.); y PRÉMIÈRES SOCIÉTÉS DE CLASSES ET MODE DE PRODUCTION ASIATIQUE. In: Recherches Internationales à la lumière du marxisme, n. 57-58, janv-avril 1967. Véase también Anderson, 1985.

${ }^{5}$ Véase igualmente Kovaliov (1981).

${ }^{6}$ Fiscalistas: Goffart (1980), Durliat (1990); véase un estado de la cuestión en Salrach (1993). Una crítica a Durliat en Wickham (1993). 
${ }^{7}$ Nos referimos al Programa de la European Science Foundation, The Transformation of the Roman World, y a los textos publicados que llevan ese título como resultado del avance de las investigaciones; cf. Noble (2006).

${ }^{8}$ Señala que los hombres libres dominaban el laboreo a escala reducida mientras los esclavos prácticamente monopolizaban la producción a gran escala, "de donde se sigue que los esclavos constituían el principal volumen de los ingresos inmediatos de la propiedad (esto es, los ingresos distintos de los que procedían de fuentes políticas...)".

${ }^{9}$ Véase en general el apartado III.4 (p.160-208). Es verdad que el autor trata de utilizar el concepto más amplio de "trabajo no libre", que incluye al servil y a la esclavitud por deudas, pero no resulta claro qué consecuencias teóricas se derivan de esa utilización que no es sistemática. Cf. la crítica de Meiksins Wood (1988, p.42-80).

${ }^{10}$ Un acercamiento general sobre la villa en Dyson (2003).

${ }^{11}$ Capogrossi Colognesi (1982, p.345) entiende que la presencia en los testimonios jurídicos recoge la "difusión y la normalidad" de esta relación en el campo entre los s. I y III. Alfeno, del último siglo de la república, se refiere dos veces en el Dig. (15.3.16 y 40.7.14) a los servi quasi coloni. Véase el análisis de Giliberti (1988, p.29-51), sobre ambas leyes y las consecuencias que de ellas saca. Esas consideraciones de tipo jurídico tienen, obviamente, un correlato en el análisis de las formas de explotación: la evidencia temprana (en relación con lo que se llamaría el período central esclavista) de formas que no implican la explotación directa de los dominios por parte de la clase terrateniente absentista, usando de manera elástica a la fuerza de trabajo esclava, y sin caer en el "modelo" de la plantación esclavista varroniana o columeliana.

12 Plinio señala algunas de las vicisitudes por las que pasa al comprar una villa (Plin. Ep., 3.19). Se queja porque el propietario anterior ha vendido a los esclavos de sus colonos, sujetos en garantía (pignora), por las deudas atrasadas (reliqua colonorum) que estos tenían. Como la tierra carece de estos cultivadores (sed haec terrae imbecillis cultoribus fatigatur), Plinio tiene que incluir en el costo de la compra a estos esclavos (sunt ergo instruendi eo pluris), que deben ser buenos (frugi mancipiis), luego caros, pues él no acostumbra utilizar los esclavos encadenados (vincti). La referencia a la ausencia de labradores es en relación con nuevos colonos que sean capaces de reemplazar a los existentes en la finca. Como éstos últimos no poseen sus instrumentos, él mismo debe hacerse cargo del costo para reequiparlos. Se debe observar que el funcionamiento de este establecimiento implicaría o una explotación mixta, parte a expensas del propietario y parte en alquiler, o la totalidad en alquiler; pero con la particularidad de que el propietario proveería los esclavos -instrumentos- a los arrendatarios. Estos arrendatarios caracterizados como coloni, evidentemente son pequeños locatarios que arriendan un lote, de acuerdo a sus posibilidades económicas que, como se deduce de la carta, son bastante penosas como para no poder disponer de los esclavos necesarios para ayudarlos en la labranza. Sobre los instrumenta véase García Mac Gaw (2007, p.107-9).

${ }^{13}$ Sobre el latifundio véase la discusión que plantea Evans (1980, p.24-5). Sobre la crisis de la villa, véase Vera (1995, p.189-200), con posiciones críticas respecto del alcance de la crisis económica de la Italia imperial (especialmente p.196-99). Vera (1992-1993, p.309), señala que uno de los tipos difundidos de unidad agrícola era la finca con casa de colonos 
libres, y, según una praxis habitual, también eran alquiladas a esclavos con su familia, como la hacienda de Juvenal. Sobre la ergástula véase Étienne (1974).

14 García Mac Gaw (2007, p.97-8). Sobre la racionalidad económica cf. AndreauMaucourant (1999, especialmente p.60 y 89-97); Vera (1995, p.206-7). Giardina (1982, p.23 ) rastrea las causas de lo que él llama la disgregación del Modo de Producción Esclavista identificadas por algunos autores con el problema de la "inelasticidad" de la villa: una estructura incapaz de crecer más allá de un cierto límite como no fuera a expensas de un aumento desmesurado de los costos improductivos, debido especialmente a las exigencias por el control de la mano de obra. El proceso de concentración de la tierra -proliferación de unidades productivas no contiguas- habría llevado e un decaimiento en la calidad de la gestión. Este enfoque presupone un juego de las variables económicas productivas desde una perspectiva moderna para el análisis de una economía de escala. Especialmente porque pone en el centro de la cuestión a los costos de producción y la inelasticidad de la Unidad Productiva (UP). Resultaría perfectamente lógico el siguiente planteo: si una villa con 30 esclavos y 10 supervisores rinde $X$ beneficio, otra villa en las mismas condiciones daría lo mismo. Si es rentable tener $X$ beneficio de una UP, es igualmente rentable tener $2 X$ beneficio de 2 UP. Con lo que estamos ante un falso problema.

${ }^{15}$ Cf. Rathbone (1981, p.13-15); es necesario destacar que en los modelos económicos que este autor construye para comparar los diferentes tipos de productividad (entre la fuerza de trabajo esclava como única dotación, esclava complementada con la libre, sólo libre, y con el sistema de aparcería) es significante el hecho de que el trabajo esclavo no era más económico, en términos de rentabilidad, que el libre.

${ }^{16}$ El autor señala básicamente al comercio como fuente para la esclavitud. Resultaría más coherente pensar en la articulación de formas distintas de aprovisionamiento que coexisten: la razzia, el mercado y la reproducción sumada a la exposición de niños. Véase ahora la discusión entre Harris (1994 y 1999), y Scheidel (1997), sobre la cuestión.

${ }^{17}$ Referencias a las leyes de los códigos germánicos en relación con los esclavos: Verlinden (1955, I.1, p.61-101) sobre leyes visigóticas, y I.2, p. 637-728, sobre leyes burgundias y sálicas; quien considera que existe una disminución de la mano de obra esclava en los siglos II y III, lo que explica las transformaciones operadas en la economía antigua y el desarrollo del colonato, aumentando luego el abastecimiento como consecuencia de las guerras con los germanos durante los siglos III-V (p.47-9). Giardina (1982, p.33) indica que en el tratado de Paladio (Opus agriculturae) la distinción entre esclavos y libres era irrelevante a los fines de la organización del trabajo. Así aparece en otras fuentes contemporáneas como en las posesiones sicilianas de Melania y Piniano, donde trabajaban miles de esclavos. Desde el punto de vista de la organización productiva, la actividad de estos trabajadores no difería de aquella de los colonos. En este sentido el tratado de Paladio puede ser considerado como el testimonio más importante que guarda la antigüedad tardía sobre la equiparación entre colonos y esclavos. Wickham (2005, p.268-9) señala que el libro de Paladio era popular en el período carolingio pero dice que es significativo que el interés de ese texto por el control de la organización de la infraestructura agrícola no se extendiese a ninguna de la relaciones del trabajo. Para W. no existe ningún signo de que tuviera trabajadores agrícolas que no fueran tenentes (libres o no libres); las secciones de Columella que se refieren al manejo de los esclavos no son 
retomadas por Paladio. Concuerda entonces con Giardina (1982, p.31-6) y Vera (1995, p.342-52), que, si el modo esclavista todavía hubiera sido una parte importante en la experiencia de Paladio, éste no habría podido evitar discutir sobre ello. Indica que el Modo de Producción Esclavista estaba ciertamente restringido puesto que lo hace sinónimo del sistema de plantación.

${ }^{18}$ El enfoque del autor se sustenta, en contra de nuestra opinión, en el presupuesto de un Modo de Producción Esclavista como herramienta básica del análisis de las sociedades antiguas.

${ }^{19}$ Aspectos que ya estaban en cierta forma avanzados en Wickham (1989 y 2003). Sobre el Modo de Producción Tributario véase Amin (1976); Haldon y otros (1998); Haldon y García Mac Gaw (2003).

${ }^{20}$ Estos dos sistemas así presentados son más bien tipos ideales que en la realidad histórica no aparecen tan claramente diferenciados (el emperador romano era a su vez un terrateniente que obtenía significativos ingresos del control de sus tierras; y generalmente los sistemas basados en la tierra en general también se apoyaban sobre recolecciones parciales de tributos).

${ }^{21}$ Sobre el Modo de Producción Antiguo véanse Marx (1971); Hindess \& Hirst (1979, p.83111). Cf. García Mac Gaw (2003, p.115-9), para la caracterización de un Modo de Producción Tributario del subtipo Antiguo y el paso a un modo plenamente tributario después de la crisis del siglo III.

${ }^{22}$ Véase ahora da Graca (2008, especialmente “2 ¿Para qué sirve comparar?”).

${ }^{23}$ Cabe también considerar el emplazamiento ya no sólo de los jefes, sino de los colonos campesinos germanos que habrían tomado tierras en propiedad: véase Astarita (2007, p.251).

${ }^{24}$ Al respecto cabe agregar que si bien la hipótesis de Goffart es interesante, no deja en ningún momento de ser sólo una hipótesis, porque no está comprobada; en el mismo sentido Wickham $(2005$, p.85) y Liebeschuetz (1998, p.74). Esta hipótesis podría resultar válida para Italia de acuerdo a la documentación que el autor presenta. Sin embargo en ese caso no se trata de un asentamiento realizado por el estado romano, sino sencillamente del copamiento del aparato del estado, con lo cual estamos hablando de otra lógica. Pero no ocurre así para visigodos y burgundios, cuando el Imperio romano es todavía quien organiza los asentamientos en una situación de conflicto, pero no habiendo perdido aún una capacidad militar. ¿Qué razón tendría el estado para desprenderse, lisa y llanamente, de los recursos que le permitían reproducirse? Esto tendría sentido para el caso de Italia, justamente por el hecho del control sobre el aparato del estado por parte de un nuevo grupo. Con lo cual se refuerza la postura de Goffart en relación a la desunión y diversidad de los bárbaros, a pesar de que en su libro intenta establecer una única forma de asentamiento de los pueblos germanos en el Imperio. La misma idea en Wickham, 2005, p.86: "But any model that supposes a smooth, merely administrative, changeover does violence to the evidence we have for the confusion of the fifth century". Sobre la variedad de estrategias por parte del estado romano cf. Burns (1992, p.57-63).

${ }^{25}$ Sobre Adrianópolis véase ahora Heather (2006, p.221-38).

${ }^{26}$ La importancia de estos grupos desde el punto de vista de la producción rural es que trabajaban en tierras por las cuales pagaban un tributo, como el término tributarii indica. 
Su status no era idéntico. Vd. Amm.Marc. 28.5.15; CTh. 13.11 .10 (para el caso de asentamientos en Italia). Un ejemplo bien conocido es el caso de los sciri, un grupo huno derrotado en el 409 que fue ofrecido a los terratenientes para trabajar sus tierras como coloni: CTh. 5.6.3. Cf. Whittaker (1999 [1987], p.107), quien asimila a los sciri a la categoría de "servile rural labour". Véase también Whittaker (1999 [1982], p.172).

${ }^{27}$ Sólo para indicar la complejidad de este proceso conviene recordar algunos de los problemas sobre la realidad de la Galia del s. V: Burgess (1992, p.24-5), señala la presencia de mercenarios de origen romano vendiendo sus servicios al rey Teoderico, y ejércitos godos realizando una suerte de protectorado sobre Hispania occidental actuando como un tercer partido entre romanos y suevos; Wood (1992, p.17), rastrea la permanencia de los contactos epistolares entre nobles romanos de clase senatorial, aunque sujeta a las relaciones diplomáticas entre reinos germánicos vecinos (los contactos de Avito, Enodio y Sidonio sujetos a las intrigas políticas entre godos y burgundios); Mathisen (1992), estudia los movimientos de la clase aristocrática durante ese período de turbulencia, así como el abandono de sus tierras por algunos de ellos; Burns (1992), indica la imposibilidad de ceñirnos a un único modelo para estudiar las relaciones entre romanos y germanos.

${ }^{28}$ Wickham (2005, p.476-81); señala un cambio en los patrones de asentamiento centrado especialmente en el abandono de la villa entre los años 400 y 700 . Destaca el proceso de sustición en los materiales, pasando al uso de spolia y de madera. Para el autor esto es producto de un cambio cultural que relaciona con el proceso de militarización -más tardío en áreas más lejanas a las fronteras-, destaca también una asimilación con el entorno campesino y señala que esto no debe ser observado como un mecanismo de germanización. Para Wickham éstas no son expresiones de una crisis económica o política aunque indica que este cambio debió necesariamente afectar las relaciones de poder en las áreas rurales. Sin embargo creo que podría verse aquí también la evidencia de un proceso de decaimiento en los mecanismos de acumulación de excedentes por parte de los sectores aristocráticos. Cf. Banaji (2002, p.262, en general véase “Appendix 5", p.257-68, con una crítica al modelo de W).

${ }^{29}$ La villa de Leoncio que describe Sidonio es un ejemplo de ello: Sivan (1992, p.138-41); Heather (1992, p.90); para Rutilio Namaciano (Rut.Nam. apud HEATHER, 1992, p. 93).

${ }^{30}$ Cf. la crítica a la utilización de este concepto en de Ste. Croix (1988, p.247-8) y Vilar (1980). Sobre el campesinado como concepto y la economía campesina vd. Durston (1982); Foster (1974); Heynig (1982); Shanin (1971); Worsley (1984). El fundamento de estas ideas se encuentra en los análisis avanzados por Chayanov, sobre esta cuestión vd. Cortés \& Cuéllar (1986); Harrison (1977); Tannenbaum (1984).

${ }^{31}$ Zósimo señala que después de acuchillar a la mayor parte de los bárbaros no los habían perseguido, permitiéndoles recuperarse de este revés para luego volver a congregarse y estar de nuevo en condiciones de combatir (Zos. 6.3).

32 Candau (1992, p.511, n.4) señala que Constantino "posiblemente hubo de recurrir a pactos en virtud de los cuales los bárbaros quedaron establecidos en determinadas zonas del territorio galo".

${ }^{33}$ Hidacio (Hyd. 49), Isidoro (Isid. 73), Orosio (Or. 7.40.9), fijan el año 411, la Chronica Gallica a. 511 (557), el año 412; Courtois (1955, p.53) señala su preferencia por la fecha más tardía, en razón de que para ese año los visigodos habían llegado a las tierras del 
sudoeste de la Galia, cerrando así toda posibilidad a suevos, alanos y vándalos de volver sobre sus pasos. Les quedaba entonces abierto el paso hacia el sur o la instalación en Hispania. Isid. 73: Deo miserante, conversi, sorte in possessionem sibi ejus provincias dividunt. Hyd. 49: Subversis memorata plagarum grassatione Hispaniae provinciis, barbari ad pacem ineundam, Domino miserante conversi, sorte ad inhabitandum sibi provinciarum dividunt regiones. Gallaeciam Wandali occupant et Suevi, sitam in extremitate Oceani maris occidua. Alani Lusitaniam et Carthaginiensem provincias, et Wandali cognomine Silingi Baeticam sortiuntur. Hispani per civitates et castella residui a plagis, barbarorum per provincias dominantium se subjiciunt servituti.

${ }^{34}$ Según Procopio, el paso al Africa fue fruto de la convocatoria del comes Bonifacio en su conflicto con Aecio (Procop. Vand. 1.3.30). En general los historiadores griegos de las épocas posteriores retoman esto como un dato. Sin embargo no existe ninguna referencia en Hidacio. Courtois (1955, p.156) siguiendo a Schmidt lo descarta, la reconciliación de Bonifacio con el imperio habría ocurrido antes del paso de los vándalos al Africa y no después, como señala Procopio.

35 Isid. 74: Cui Valentinianus Junior, Occidentis imperator, non valens obsistere, pacem mittit, et partem Africae quam Vandali possiderent tanquam pacifice dedit, conditionibus ab eo sacramenti acceptis ne quid ultra invaderet. Prosp. Chr. a. 439 (PL vol 27 col 0719): Pax facta cum Vandalis, data eis ad habitandum per Trigetium Africae portione, III idus Februarii, Hippone.

${ }^{36}$ Prosp. Chr. a. 446 (PL 27 col 0723): Cum Genserico autem ab Augusto Valentiniano pax confirmata, et certis spatiis Africa inter utrumque divisa est.

37 En general se entiende que este tratado corresponde al del año 442 y no al del 435 . Véase bibliografía en Caliri (2004, p.1697, n.14). Modéran (2002, p.92-4) entiende que estos detalles brindados por Procopio sobre el tratado en realidad señalan la calidad de un estado cliente, "amigo y aliado" (philos te kai summakhos) del pueblo romano, y no de un grupo federado.

38 Permanencia de algunas instituciones del estado romano durante el período vándalo: notarii (AIELLO, 2006, p.29), el proconsul Carthaginis (Vict.Vit. Vand. 3.28), iudices provinciarum (Vict.Vit. Vand. 3.3-14) y también flamines perpetui (LIEBESCHUETZ, 2003, p.30). Continúan funcionando las asambleas provinciales (LIEBESCHUETZ, 2003, p.29) y el orden de los decuriones se mantiene activo en su función de recolectar tributos (AIELLO, 2006, p.31), mantienen el nombre de procuratores y se trata de grandes propietarios en quienes la monarquía delega tales funciones, quienes probablemente hayan pagado para ejercerlas (Vit.Fulg.1.2, y 14). Vd. Clover (1993, X).

${ }^{39}$ Sobre Victor vd. Aiello (2005); sobre la Vita Fulgentii vd. Modéran (1993) y Modéran (2003), sobre el conflicto entre arrianos y católicos en Africa, que no será analizado aquí.

${ }^{40}$ Sobre Courtois vd. Aiello (2005a, p.547-51); y la crítica que le realiza Modéran (1993, p.186).

${ }^{41}$ Procopio indica que las medidas de reorganización financiera emprendidas luego de la conquista de Justiniano provocaron reacciones entre los africanos (Procop. Vand. 2.8.25). Un indicio de que, probablemente, las exacciones del período vándalo no hayan sido tan abusivas como se nos transmite (COURTOIS, 1955, p. 259). 
42 Véase un estado de la cuestión sobre las posiciones historiográficas en Modéran (2002,
p.88-97), donde el autor a la vez justifica su toma de posición a favor de la percepción del
reino vándalo como un Estado independiente. ${ }^{43}$ PL vol 58 col 0186A: Disponens quoque singulas quasque provincias, sibi Byzacenam Abaritanam, atque Getuliam, et partem Numidiae reservavit; exercitui vero Zeugitanam vel proconsularem funiculo haereditatis divisit.

${ }^{44}$ Vict.Vit. Vand. 1.22:...etiam illis sacerdotibus qui in his regionibus versabantur, quae regiones palatio tributa pendebant.

${ }^{45}$ Resulta obvio, por lo tanto, que existen tierras que quedan en manos de la aristocracia romana. Atestiguadas, por ejemplo, en las Tablettes Albertini como en el caso de Fl. Geminio Catullino (COURTOIS, 1955, p.277). Victor de Vita dice que en el 484 el procónsul de Cartago Victoriano de Hadrumeto era el hombre más rico del Africa (Vict.Vit. Vand. 3.27). Fulgencio posee ciertas tierras para la misma época (Vit.Fulg. 1) y un tal Silvestrio, notable de Bizacena, cede un terreno a Fulgencio para la construcción de un monasterio (Vit.Fulg. 10). Otras referencias a propiedades romanas más pequeñas en Vit.Fulg. 1.40, $1.48,16$.

${ }^{46}$ Diferentes referencias heurísticas sostienen esta interpretación: prohibición de ordenar obispos de las provincias de Zeugitana y Proconsular luego de la muerte del obispo de Cartago Deogratias en el 457 (Vict.Vit. Vand. 1.29); el número decreciente de obispos católicos en estas provincias en relación con el número estable en las restantes de acuerdo a la información de la Notitia provinciarum et civitatium Africae; la expulsión de Fulgencio de Ruspe de la provincia Proconsular cuando decide abandonar el monasterio de la Bizacena que lo albergaba, luego de lo cual vuelve a Bizacena en donde funda con total libertad varios monasterios financiados por propietarios romanos ricos (Vit. Fulg. 5-6).

${ }^{47}$ Evidentemente hace referencia a las tierras que antes habían estado ocupadas por los vándalos y luego fueron abandonadas en su movimiento hacia Cartago. Estas tierras habían vuelto al control imperial de acuerdo al tratado establecido en el 442. Estos detalles señalan con claridad que, si bien se habían reconocido por causa de la fuerza las posesiones de los vándalos, el estado romano finalmente trataba de contener la situación, en la medida de lo posible, dentro de un marco de legalidad que permitiera gestionar la reconstrucción de los territorios recuperados. La muerte del emperador en el 455 es el preludio de la desaparición de cualquier intervención romana en la región, por lo menos hasta la llegada de las tropas bizantinas. Las citas tomadas de Courtois (1955, p.175).

48 centuria $=200$ iugeras $=400$ actus $=50$ ha aproximadamente.

49 De acuerdo a lo señalado por Caliri (2004, p.1701-4), en el caso de los praedia pistoria referidos en la ley, se salvaguardaba el derecho del collegium pistorum de percibir los ingresos correspondientes a la enfiteusis otorgada, aún cuando la Novella preveía que las tierras en manos de los enfiteutas podían pasar a sus herederos. Es decir que los honorati Afri no se habrían convertido en propietarios de tales tierras desde el punto de vista estrictamente jurídico.

${ }^{50}$ Otros ejemplos de tales confiscaciones y que muestran a los expulsados buscando asilo en otras partes del Imperio: un tal Caelestiaco (Theod. Ep. 34 y 36), y Gordiano, el abuelo de Fulgencio (Vit.Fulg. 1). 
${ }^{51}$ Durliat $(1985$, p.383) dice que "les rois avaient réparti les soldats dans tout le pays et leur avaient affecté des 'lots' qu'il ne faut pas considérer comme des terres à exploiter mais comme des assiettes fiscales dont l'impôt payait leur solde". Véase ahora un buen estado de la cuestión sobre la tesis de Goffart y la forma en que ésta ha sido retomada por Durliat, desde una perspectiva fuertemente crítica -especialmente hacia el último- centrada en el Africa romana en Modéran (2002, p.98-102). Liebeschuetz (2006, p.318) es igualmente crítico.

52 Tibi dabo terram Chanaam in funiculum hereditatis vestrae. (MOORHEAD, J. Victor of Vita: history of the Vandal persecution. Liverpool: Liverpool University Press, 1992).

53 En el 455 parece que la autoridad romana había desaparecido en la Cesariense, la Sitifense y la parte de la Numidia que estaba fuera del control vándalo. La expansión de Justiniano probablemente recuperó algunos de estos territorios aunque de forma fragmentaria. La Notitia prouinciarum et ciuitatum Africae (MGH auct.ant. 3.63-71) permite observar la continuidad de la vida urbana en esas regiones fuera del Imperio. 



\section{INDEX LOCORUM*}

Ammianus Marcellinus (Amm.Marc.)

(Historicus)

$$
\begin{aligned}
& 22.5 .4-\text { p. } 219 \\
& 25.4 .20-p .218 \\
& 28.5 .15-p .320
\end{aligned}
$$

Appianus (App.) (Historicus)

Bella Civilia $(B C)$

$$
2.102-\mathrm{p} .23
$$

Punica (BP)

$$
154-\text { p. } 130
$$

Hispanica (Hisp.)

$$
6.23-\mathrm{p} .132
$$

Praefatio (Praef.)

$$
7-\text { p.264 }
$$

Apuleius (Apul.) (Scriptor Botanicus)

$$
\text { Apologia (Apol.) }
$$$$
24.1-\text { p. } 251
$$

Metamorphoses (Met.)

$$
\begin{aligned}
& 1-\text { p.249 } \\
& 1.21-\text { p.248 } \\
& 10.35-p .250 \\
& 11-\text { p. } 246 \\
& 11-\text { p. } 250 \\
& 11.6-\text { p. } 251 \\
& 11.7-\text { p. } 250 ; \text { p. } 258 \\
& 11.8 \text { - p. } 250 ; \text { p. } 253 \\
& 11.9 \text { - p. } 250 ; \text { p. } 253 \\
& 11.10 \text { - p.250; p.251 } \\
& 11.16-\text { p.251 } \\
& 11.17-\text { p. } 251 \\
& 2-\text { p. } 249 \\
& 2.5-\text { p. } 247 \\
& \text { 2.9-10-p.247 } \\
& 2.12-\text { p. } 247 \\
& 2.19-\text { p. } 252 \\
& \text { 2.21-30-p. } 258 \\
& \text { 2.24- } 25-\text { p. } 248 \\
& 2.30-\text { p. } 258 \\
& 3.2-\text { p. } 255 ; \text { p. } 256 \\
& 3.8-\text { p. } 256
\end{aligned}
$$

$$
\begin{aligned}
& 3.9-\text { p. } 255 ; p .256 \\
& 3.10-p .256 \\
& 3.11-p .254 \\
& 3.24-p .245 \\
& 3.28-p .249 \\
& 4.33-\text { p. } 249
\end{aligned}
$$

Aristoteles (Arist.) (Philosophus)

Politica (Pol.)

$$
\text { 7.6.1327a - p.233 }
$$$$
1305 \text { b } 39 \text { ss }- \text { p.94 }
$$

Asconius Pedianus (Asc.)

in Cornelianam (Corn.)

$$
68-\text { p. } 241, \text { n. } 4
$$

Augustus (Aug.) (Imperator)

Res Gestae (RG)

$$
6.15-\text { p. } 62
$$

Aurelius Augustinus (August.) (Theologus) Epistulae (Ep.)

$$
\begin{aligned}
& 125-\text { p.293, n.3 } \\
& 126-\text { p.293, n.3 }
\end{aligned}
$$

Caesar, lulius Caesar (Caes.) (Imperator) de Bello Gallico (Gal.)

$$
\begin{aligned}
& 1.1 .3-p .233 \\
& 1.40 .5-6-p .17 \\
& 1.40 .6-p . \\
& 2.11 .1-p .17 \\
& 2.20-p .16 \\
& 2.20 .3-4-p .16 \\
& 4.1-p .17 \\
& 5.12-14-p .229 \\
& 6.11-28-p .229 \\
& 7.30-p .30, n .16
\end{aligned}
$$

Cato, M. Porcius (Cato) de Agri Cultura (Agr.) Praef. 3 - p.235

* Índice organizado por Fabio Vergara Cerqueira e Edalaura Berny Medeiros, com o apoio do acadêmico Fabiano Pretto Neis (UFPel). 


\section{Index locorum}

\section{Chronica Gallica}

$$
\text { a. } 511-\text { p. } 320, \mathrm{n} .33
$$

Cicero, M. Tulius (Cic.) (Orator et Philosophus)

Epistulae ad Atticum (Att.)

13.33a-p.31, n.25

13.35-36-p.23

Pro Caelio (Pro Cael.)

33-4 - p.115, n.35

de Republica (Rep.)

2.3.5-6.11-p.233

3.15.24-p.158, n. 8

3.23-25-p.159

$5.10-$ p. 242, n. 17

de Senectut e (Sen.)

$37-$ p.115, n. 35

Cyrillus Alexandrinus (Cyr.Alex.)

Contra Julianum imperatorem (Jul.)

$$
2.2-\text { p. } 215
$$

Dionysius Halicarnassensis (D.H.)

(Historicus)

Antiquitates Romanae

1.46.1. - p.231

Diogenes Laertius (D.L.)

Vitae Philosophorum

$1.94-p .80$

Digesta (Dig.)

15.3.16 - p.317, n.11

40.7.14-p.317, n.11

$50.16-$ p. 113, n. 2

50.16.195.1 - p.113, n.10

50.16.195.4-p.131, n.6

Dio Cassius (Dio Cass) (Historicus)

\section{Historia Romana}

$$
\begin{aligned}
& 43.23 \text { - p. } 23 \\
& 43.49 .3-\text { p. } 23 \\
& 43.50 .1-\text { p. } 23 \\
& \text { 58.11.5 - p. } 92, \text { n. } 28 \\
& \text { 59.10.1-2 - p.60 } \\
& \text { 59.12.1-p. } 93, \text { n. } 40 \\
& \text { 59.13.3 - p. } 58
\end{aligned}
$$

\author{
59.16.2-4-p.57 \\ 59.16.5-6-p.57 \\ 59.2.6-3.1-p.93, n. 35 \\ 59.22.5-23.2-p.67, n.11 \\ $59.23 .3-$ p. 62 \\ $59.24 .2-$ p. 92, n. 32 \\ $59.24 .8-$ p. 56 \\ $59.27 .1-$ p. 62 \\ 59.27.2-6-p.68, n.23 \\ $59.28 .1-$ p. 68, n. 22 \\ 59.8.1-3-p.93, n.44 \\ $59.8 .2-p .55$ \\ 60.5.7-8-p.62 \\ 62.13.3-p.95, n.66 \\ $62.27-$ p. 94, n. 63 \\ 63.3.4 - p.98, n.113 \\ 64.2.1-3.4-p.98, n.109 \\ 66.6 .2 - p.98, n.115 \\ $66.7 .2-$ p. 97, n.101 \\ $67.11 .3-$ p.97, n.96 \\ 67.12.2-4-p.96, n.91 \\ $67.12 .3-$ p. 96, n.91 \\ 67.13.2 - p. 96, n.90 \\ 67.14 - p. 96, n. 85 \\ 67.14.3-p.97, n.95 \\ 67.3.1 - p.96, n.79 \\ $67.6 .3-$ p.98, n.105
}

Diodorus Siculus (Diod.) (Historicus)

Bibliotheca Historica

$32.34-$ p.138

Eusebius Caesariensis (Eus.) (Historicus et Theologus)

Historia eclesiástica (HE)

1.1-2-p.209

$1.2-$ p.198

$1.4-$ p.198

8.1.1.7-p.204

$8.8-$ p. 207

8.9.4-5-p.203

$8.13 .15-$ p. 202

8.16.4-5-p.203

8, Ap.1-p.202; p.203

8, Ap. 4 - p.202

9.9.1- p.202; p.205

$9.9 .6-$ p.202 
Vita Constantini (De vita Imperatoris Constantini) (VC)

$$
\text { 2.57.1-3-p.211, n.6 }
$$

Festus, Sex. Pompeius (Fest.)

(Grammaticus Latinus) s.v. diffarreatio - p.114, n.22

Gaius (Iureconsulti)

Instituitiones (Inst.)

$$
\begin{aligned}
& 1.55 \text { - p.115, n.25 } \\
& 1.110-\text { p.114, n.16 } \\
& 1.111-\text { p.114, n.19 } \\
& 1.112-\text { p.114, n.18 } \\
& 1.113 \text { - p.114, n.17 }
\end{aligned}
$$

Gregorius Nazianzenus (Greg.Naz.) (Sanctus, Orator et Theologus)

Contra Julianum (Jul.)

$$
\text { 4.96-97-p.222 }
$$

Hidatius (Hyd.)

Chronica

$$
\begin{aligned}
& 49-\text { p. } 304 ; \text { p.320, n. } 33 ; p .321, \\
& \text { n.33 } \\
& 60-p .304 \\
& 62-p .304 \\
& 68-p .304 \\
& 86-p .304 \\
& 90-p .304
\end{aligned}
$$

Homerus (Hom.) (Epicus)

Ilias (II.)

$$
\begin{aligned}
& 2.207-p .241, n .9 \\
& 2.822-3-p .241, \text { n. } \\
& 3.148-159-p .241, n .9 \\
& 7.345-353-p .242, n .13 \\
& 7.347-353-p .241, n .9 \\
& \text { sea (Od.) } \\
& 9.106-115-p .235
\end{aligned}
$$

Odyssea (Od.)

lamblichus (lamb.) (Philosophus) de Mysteriis (Myst.)

$$
1.3-\text { p. } 217
$$

Isidorus Hispalensis (Isid.) (Historicus) Historia de Regibus Gothorum

Vandalorum et Suevorum (Hist.)

$$
\begin{aligned}
& 73-\text { p.304; p.320, n.33; p.321, } \\
& \text { n.33 } \\
& 74-\text { p.321, n. } 35
\end{aligned}
$$

Johannes Chrisostomum (Joh.Chry.) De sancto Babyla (Bab.)

$$
15.80-\text { p. } 221
$$

Josephus (J.) (Historicus)

Antiquitates Judaicae $(A J)$

$$
\begin{aligned}
& 10.1 .2-\text { p. } 62 \\
& 18.256-p .93, n .35 \\
& 18.8 .2-p .68, n .22 \\
& 19.1 .13-p .58 \\
& 22.267-\text { p.170 }
\end{aligned}
$$

Bellum Judaicum (BJ)

$$
1.3-\text { p.169 }
$$

2.16.39-p.164

3.3.35-47-p.163

3.5.108-p.168

3.6.112-113-p.171

3.6.127-131-p.171

3.6-8.110-408-p.179, n.7

3.7.132-140-p.171

3.7.141-142-p.171

3.7.144-p.171

3.7.144-149-p.171

3.7.150-154-p.171

3.7.155-160 - p.172

3.7.161-165-p.172

3.7.166-170-p.172

3.7.171-177-p.172

3.7.178-189- p.173

3.7.190-192-p.173

3.7.193-206-p.173

3.7.207-212-p.174

3.7.217-p.174

3.7.217-221-p.174

3.7.221-p.174

3.7.222-228-p.174

3.7.229-233-p.174

3.7.234-239-p.174

3.7.240-252-p.175

3.7.253-257-p.175

3.7.258-263-p.175 


$$
\begin{aligned}
& \text { 3.7.265-269-p.176 } \\
& 3.7 .271-275-p .176 \\
& 3.7 .277-282-p .176 \\
& 3.7 .284-288-p .176 \\
& 3.7 .289-306-p .176 \\
& 3.7 .307-315-p .166 \\
& 3.7 .316-322-p .177 \\
& 3.7 .323-339-p .177 \\
& 3.8 .340-391-p .177 \\
& 3.8 .352-p .177 \\
& 3.8 .392-408-p .178 \\
& 3.8 .409-410-p .178 \\
& 5-p .167 \\
& 6-p .167 \\
& 7.6 .6-p .97, \text { n.101 }
\end{aligned}
$$$$
\text { Vita (Vit.) }
$$

$$
\text { 76.422-429-p.67, n.15 }
$$

Julianus Imperator (Jul.)

$$
\begin{aligned}
& \text { Epistulae (Ep.) } \\
& 61 \mathrm{c}-\mathrm{p} .218 \\
& 83-\mathrm{p} .223
\end{aligned}
$$

Contra Galilaeos (Gal.)

$$
\begin{aligned}
& 39 a-p .216 \\
& 41 e-p .215 \\
& 52 b-p .216 \\
& 57 e-p .216 \\
& 106 c-p .217 \\
& 138 b-c-p .220 \\
& 171 d-e-p .216 \\
& 209 d-p .220 \\
& 229 c-p .218 \\
& 238 c-p .221 \\
& 261 e-p .219 \\
& 262 b-c-p .219 \\
& 306 a-b-p .222 \\
& 327 a-p .219 \\
& 333 c-d-p .219 \\
& \text { frag. } 4-p .223
\end{aligned}
$$

Justinianus (Just.) (Imperator)

Constitutio Imperatoriam (Const.Imp.)

$$
\begin{aligned}
& \S 1-p .119 \\
& \S 2-p .119 \\
& \S 6-p .118
\end{aligned}
$$

Instituitiones (Inst.)

$1-\mathrm{p}$.

$1.2-$ p.121

1. $2.1-$ p. 122

$$
\begin{aligned}
& 1.2 .2-\text { p.122 } \\
& 1.3-\text { p.123 } \\
& 1.3 .2-\text { p.122 } \\
& 1.4-\text { p.121 } \\
& 1.5 .3-p .123 \\
& 1.6 .2-\text { p.123 } \\
& 1.8 .2-\text { p.123 } \\
& 2.19 .6-\text { p.124 } \\
& 2.20 .3-\text { p.124 } \\
& 3.1 .15-\text { p.124 } \\
& 4.11 .7-p .119
\end{aligned}
$$

lustini Martyris (Just.Mart.)

Apologiae pro Christianis (Apol.)

$$
\begin{aligned}
& 1.65 .3 .5-p .285 \\
& 1.65 .5-p .285 \\
& 1.67 .4-p .285 \\
& 1.67 .4 .5-6-p .285 \\
& 1.67 .5-p .285
\end{aligned}
$$

Lex Duodecim Tabularum (Lex XII Tab.)

$$
6.1-\text { p. } 115, \mathrm{n} .28
$$

$8.21-$ p. 115, n. 34

Libanius (Lib.) (Sophista)

Orationes (Or.)

$18.178-$ p. 214

Livius, Titus (Liv.) (Historicus)

$$
\text { Ab Urbe Condita }
$$

$$
\begin{aligned}
& \text { 1.1.1 - p.231 } \\
& \text { 1.1.1 - p.241, n. } 6 \\
& \text { 1.1.1-8 - p.231 } \\
& 1.1 .2-\text { p. } 233 \\
& \text { 1.1.2-3-p.232 } \\
& 1.1 .3-\text { p. } 231 \\
& 1.2 .5-\text { p. } 242 \text {, n. } 15 \\
& \text { 1.4.4-5 - p.243, n.25 } \\
& \text { 1.6.4 - p.243, n. } 25 \\
& \text { 1.7.3 - p.243, n. } 25 \\
& \text { 1.10.7-p.240, n.1 } \\
& 1.16-p .148 \\
& 1.49 \text { ss }- \text { p.90, n.2 } \\
& \text { 1.55.4-6 - p.240, n. } 1 \\
& \text { 2.32.8-12-p.243, n.32 } \\
& 2.44 .8-\text { p. } 237 \\
& 3.20 .5-p .236 \\
& 3.67 .6-p .237
\end{aligned}
$$




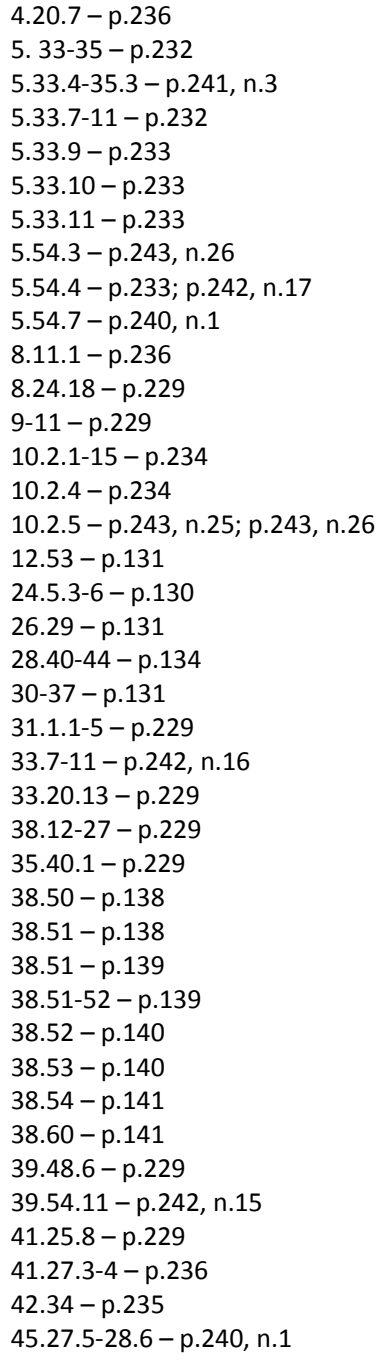

Martialis, M. Valerius (Mart.)

(Epigrammaticus latinus)

Epigrammata

$$
\begin{aligned}
& 1.61 .3-\text { p. } 241, \text { n. } 4 \\
& 6.42 .4-\text { p. } 238 \\
& 11.16 .7-\text { p. } 238
\end{aligned}
$$

Monumenta Germaniae Historica.

Auctores antiquissimi. (MGH auct.ant.) 3.63-71 - p.323, n.53

Novum Testamentum (N.T.) Apocalypsis (Apoc.)

$$
\begin{aligned}
& 1.1-\text { p.189 } \\
& 1.4-189 \\
& 1.5-6-\text { p.189 } \\
& 1.9-\text { p.189 } \\
& 2.1-3.22-\text { p.189 } \\
& 5.13-\text { p.189 } \\
& 11-\text { p.189 } \\
& 13.1-10-\text { p.189 } \\
& 13.11-18-\text { p.189 }
\end{aligned}
$$

Evangelium secundum Joannem(Ev.Jo.)

$$
\begin{aligned}
& 1.1-\text { p. } 219 \\
& 1.18-p .219
\end{aligned}
$$

Evangelium secundum Lucam (Ev.Luc.)

$$
12.33-\text { p. } 223
$$

Novella Valentiniani III (Nov.Valent.)

$$
\begin{aligned}
& 13.1-\text { p.308 } \\
& 13.9-\text { p.308 } \\
& 34-\text { p.309 }
\end{aligned}
$$

Orosius, Paulus (Or.) (Historicus) Historiae Adversus Paganos

$$
\begin{aligned}
& 7.40 .9 \text { - p. } 320, \text { n. } 33 \\
& 7.43 .14-\text { p. } 304
\end{aligned}
$$

Petronius (Petron.)

\section{Satyricon}

$$
\begin{aligned}
& 26.9-\text { p. } 37 \\
& \text { 28.7-8-p.49, n. } 3 \\
& 28.8-\text { p. } 50, \text { n. } 6 \\
& \text { 29.3-8-p.49, n. } 3 \\
& \text { 30.2-3-p.49, n. } 3 \\
& \text { 30.4-6-p.50, n.16 } \\
& \text { 30.7-11-p.51, n.27 } \\
& 32.3-\text { p.50, n.16 } \\
& 32.4-\text { p. } 49, \text { n. } 3 \\
& 33.2-\text { p. } 49, \text { n. } 3 \\
& \text { 34.2-3-p.49, n. } 3 \\
& \text { 34.6-7-p.51, n. } 20 \\
& 34.8-p .37 \\
& \text { 36.5-8 - p.49, n. } 4 \\
& \text { 37.1-8-p.49, n. } 4
\end{aligned}
$$




\section{Index locorum}

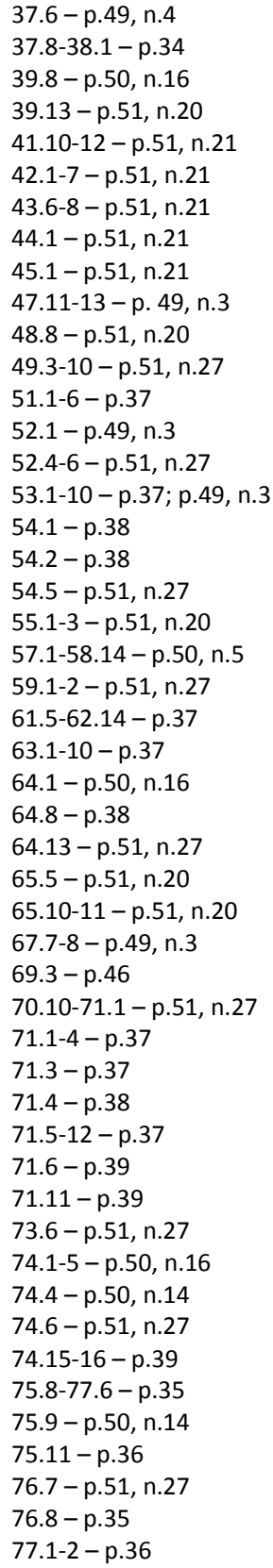

$$
\begin{aligned}
& \text { 77.4-p.50, n.14 } \\
& 77.6-\text { p.35 } \\
& 77.7-78.8-p .37 \\
& 100.6-7-p .40 \\
& 101.2-\text { p.40 } \\
& 101.4-5-p .41 \\
& 101.6-p .41 \\
& 103.5-6-p .41 \\
& 104.5-p .41 \\
& 105.5-11-p .41 \\
& 108.9-14-p .41 \\
& 109.1-p .41 \\
& 114.6-p .42 \\
& 115.9-11-p .42 \\
& 115.20-p .43 \\
& 116.1-9-p .44 \\
& 117.6-8-p .44 \\
& 124.2-4-p .45 \\
& 125.1-p .45 \\
& 125.3-4-p .45 \\
& 141.1-p .45 \\
& 141.2-4-p .46 \\
& 116.9-p .46 \\
& 136.1-p .46 \\
& 137.12-p .46 \\
&
\end{aligned}
$$

Philo Alexandrinus (Philo) (Philosophus) de Legatione ad Caium Imperatorem (Leg.)

$$
\begin{aligned}
& 5.30-p .59 \\
& 10.66-p .58 \\
& 13-p .93, n .35 \\
& 16-p .93, n .44 \\
& 19-p .93, n .44 \\
& 30.198-p .68
\end{aligned}
$$

Philostratus (Philostr.) (Sophista)

Vita Apollonii (VA)

$$
\begin{aligned}
& 7.8-\text { p. } 96, \text { n. } 84 \\
& 7.33-\text { p. } 96, \text { n. } 84 \\
& 8.7 .10-p .96, n .84
\end{aligned}
$$

Plato (Plat.) (Philosophus)

$$
\begin{aligned}
& \text { Leges (Lg.) } \\
& \text { 4.704b-705b - p.233 }
\end{aligned}
$$

Republica (Rep.)

$9.573 d-575-p .94, n .58$ 
Polybius (Plb.) (Historicus)

Historiae

$$
\begin{aligned}
& \text { 1.2.3-5 - p. } 158, \text { n.10 } \\
& 1.2 .5-\text { p. p.158, n.10 } \\
& 1.2 .5-7-\text { p.158, n.11 } \\
& 1.2 .7-\text { p.157, n.2 } \\
& 2.17 .5-6-\text { p. } 232 \\
& 10-\text { p.133 } \\
& 10.3-\text { p.130 } \\
& 10.4-5-\text { p.131 } \\
& 15.18-\text { p.130 } \\
& 23.14-\text { p.137 } \\
& 24.9-\text { p.137 } \\
& 28.3-\text { p.133 } \\
& 36.9-\text { p.152 } \\
& 38.21 .2-3-\text { p. } 138 \\
& 38.22-\text { p.138 } \\
& 40.2-5-\text { p.133 }
\end{aligned}
$$

Plinius Secundus, C. (Plin.) (Rerum Naturalium Scriptor)

Historia Naturalis (HN)

$$
\begin{aligned}
& 2.130-p .232 \\
& 7.121-p .23
\end{aligned}
$$

Plinius Caecilius Secundus, C. (Plin.) Epistulae (Ep.)

$$
\begin{aligned}
& 1.14 .6-p .238 \\
& 1.5-p .96, n .90 \\
& 3.19-p .317, n .12 \\
& 4.11-p .95, n .76 \\
& 5.1 .24-p .279, n .12 \\
& \text { gyricus (Pan.) } \\
& 14-p .98, n .105 \\
& 50.5-p .97, n .98
\end{aligned}
$$

Panegyricus (Pan.)

Plutarchus (Plut.) (Biographus et Philosophus)

Vitae Parallelae, Alexander (Alex.)

$$
61 \text { - p.99, n.126 }
$$

Vitae Parallelae, Cato Major (Cat.Ma.)

$$
\begin{aligned}
& 27-\text { p.153 } \\
& 26-\text { p.159 } \\
& 39.3-\text { p. } 68, \text { n.19 }
\end{aligned}
$$

Procopius Caesarienses (Procop.)

de Bello Vandalico (Vand.)

1.3.3 - p.304; p.305

$1.3 .30-p .321$

$1.4 .13-$ p.305

1.5.11 ss. - p. 307

$2.8 .25-$ p. 321

Prosperus Aquitanus (Prosp.) Chronica (Chr.)
a. $425-$ p. 304
a. 439 - p. 321, n. 35
a. 446 - p. 321, n. 36

Quintilianus, M. Fabius (Quint.) (Rhetor Latinus)

Declamationes (Decl.)

$$
\begin{aligned}
& 322 \text { - p. } 94, \text { n. } 60 \\
& 329 \text { - p.90, n.2; p.94, n.58 }
\end{aligned}
$$

Institutio oratoria (Inst.)

$$
\begin{aligned}
& 1.5 .56-p .241, \text { n. } 4 \\
& 3.6 .78-p .94, \text { n. } 58 \\
& 8.1 .2-p .241, n .4
\end{aligned}
$$

Rutilius Namantianus (Rut.Nam.)

Dereditu suo

$$
\text { p.320, n.29 }
$$

Sallustius Crispus (Sal.) (Scriptor et Historicus latinus)

Catilina (Cat.)

$$
\begin{aligned}
& 10.1-\text { p. } 233 \\
& 10.1-3-p .152 \\
& 20.7-9-p .155 \\
& 35.3-p .157, n .3
\end{aligned}
$$

Historiae (Hist.)

$$
\begin{aligned}
& 4.69 .17-p .150 \\
& 4.69 .18-p .155 \\
& \text { fr. } 1.12-p .150
\end{aligned}
$$

lugurtha (Jug.)

$$
\begin{aligned}
& \text { 5.1-3-p. } 152 \\
& 5.7-\text { p.151 } \\
& 9.1-4-p .159, \text { n.15 } \\
& 10.3-\text { p.150 } \\
& 17-19-\text { p.229 } \\
& 31.20-\text { p.157, n.4 } \\
& 41.2-10-\text { p.152 } \\
& 63.7-\text { p.151 } \\
& 64.1-4-p .151 \\
& 73.6-p .157, \text { n.5 } \\
& 85.9-\text { p.151 }
\end{aligned}
$$




$$
86-\text { p.160, n.18 }
$$

Seneca, L. Annaeus (Sen.) (Philosophus latinus)

$$
\begin{array}{r}
\text { Controuersiae (Con.) } \\
5.8-\text { p. } 94, \text { n.58 } \\
9.4-\text { p. } 94, \text { n.58 }
\end{array}
$$

Servius (Serv.) (Grammaticus Latinus) In Vergilii carmina commentarii (ad Aen.)

$$
1.242-\text { p. } 231
$$

Sidonius Apollinarius (Sidon.)

Carmina (Carm.)

$$
\begin{aligned}
& 2.189-\text { p. } 241, \text { n. } 4 \\
& 23.146-\text { p. } 241, \text { n.4 }
\end{aligned}
$$

Socrates Scholasticus (Soc.)

Historia Ecclesiastica (HE)

$$
\text { 3.1. } 48-\text { p. } 218
$$

Strabo (Strab) (Geographus)

$$
\begin{aligned}
& 12.3 .8-\text { p. } 232 \\
& 13.1 .53-\text { p. } 232 \\
& 17.3 .13-\text { p. } 235
\end{aligned}
$$

Suetonius Tranquillus, Gaius. (Suet.) (Grammaticus et Historicus Latinus) De Vita Caesarum. Augustus (Aug.) $19-$ p.59

De Vita Caesarum. Calígula (Cal.)

$10.2-$ p.76

$11-$ p.93, n.37

$15.2-$ p.93, n.36

$15.4-$ p.93, n.39

17.1 - p.92, n.32

$18.2-$ p. 59

$19-$ p. 92, n. 35

20 - p.92, n.35;

22 - p.76; p.92, n.33

22.1 - p.61; p.66, n.1

$23.2-$ p. 76

$24-$ p. 76

$25.1-$ p. 76

$26-$ p. 76

$26.2-$ p. 57

26.4 - p.58; p.69, n.25
$27.1-$ p.93, n.37

29-31-p.76

29.1 - p.60; p.61; p.93, n.38; p.95, n.70; p.97, n.97

30.2 - p.49, n.3; p.93, n.39; p.98, n.117

$31-$ p. 77

32-33-p.77

$32.2-$ p. 96, n. 80

$32.3-$ p. 61

$33-$ p.93, n.44

34-35-p.77

$34.1-$ p.69, n.25

34.2 - p.61; p.62;

$35.1-$ p.61; p.62

$36.1-$ p.77

$36.2-$ p.93, n.40

$37-$ p.77; p.94, n.54

$38-42-$ p. 77

38.1 - p.94, n.57; p.97, n.98

43ss - p.77

48.1 - p.93, n.41

49.1 - p.77; p.79

$49.2-$ p.93, n.42

$49.3-$ p.77

$50.1-$ p.93, n.43

$50.2-$ p.93, n.44

$51.1-$ p.93, n.45

$51.2-$ p. 78

$52-$ p. 78

$53.1-$ p.94, n.47

$54.1-$ p.94, n.47

$55.1-$ p.62; p.78

$55.3-$ p. 78

56 ss - p.78; p.95, n.73

56.1-p.97, n.104; p.98, n.114

De Vita Caesarum. Claudius (Cl.)

$9.1-$ p.67, n.11

$33.1-$ p. 85

$44-$ p. 80

De Vita Caesarum. Domitianus (Dom.)
$3.2-p .81$
$4-p .81$
4-5-p.97, n.99
$5-$ p. 81
$6.1-$ p. 95, n. 75
$7-9-p .81$
$8.4-$ p. 95, n.76
$9.1-$ p. $81 ;$ p. 83 


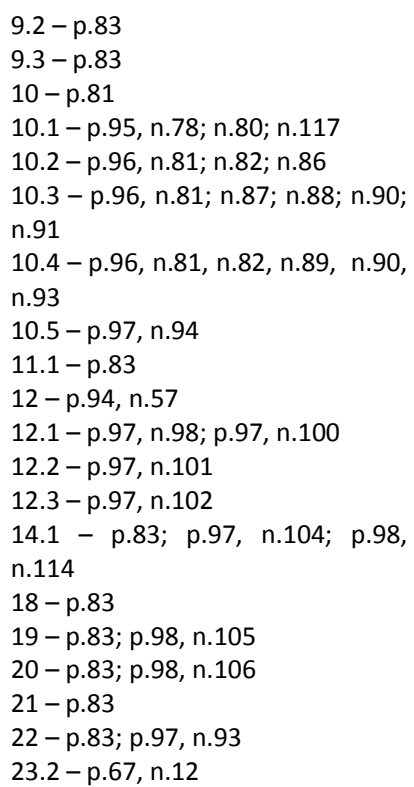

De Vita Caesarum. Galba (Gal.)

12.1 - p.98, n.107

$12.2-$ p. 84

$14-16-$ p. 84

$14.1-$ p. 98, n. 108

$14.2-$ p. 98, n. 110

$14.3-$ p. 98, n. 111

$15.1-$ p. 98, n. 112

$15.2-$ p. 98, n.113

16.1-p.98, n.114,

$18.1-$ p. 92, n. 34

De Vita Caesarum. Iulius (Jul.)

40.1 - p.98, n.120

40-44-p.86

$44-$ p. 23

44.4 - p.93, n. $42 ;$ p.98, n.12; p.98,

n.122

45.1-2-p.86

$45.3-p .86$

46-47-p.86

$48-p .86$

$49-$ p.86; p.86

$50.1-$ p. 99, n. 124

$50.2-$ p. 86

50-52-p.86

$51-$ p.99, n.125

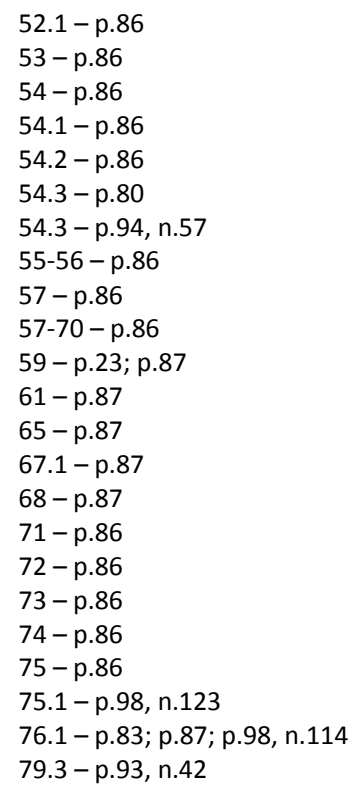

De Vita Caesarum. Nero (Nero)

$9-$ p.78

$10.1-$ p.78

11-13-p.78

$14-$ p.79

$15-$ p.79

$16.2-$ p. 94, n. 48

16-17-p.79

$18-$ p.79

$19.3-$ p. 94, n. 49

20-25-p.79

$26.1-$ p. 94, n. 50

$26.2-$ p. 79

$27.1-$ p.79

27.2-3-p.79

28. - p. 94, n. 51

$28.2-$ p.79

$29-$ p.79

$30.1-$ p. 94, n. 54

$30.2-$ p. 80

$30.3-$ p. 80

$31.1-$ p. 94, n. 55

$31.2-$ p. .94, n. .56

$32.1-$ p. 94 , n. 57

$32.4-p .80$

33.1 - p.80; p.94, n.61 

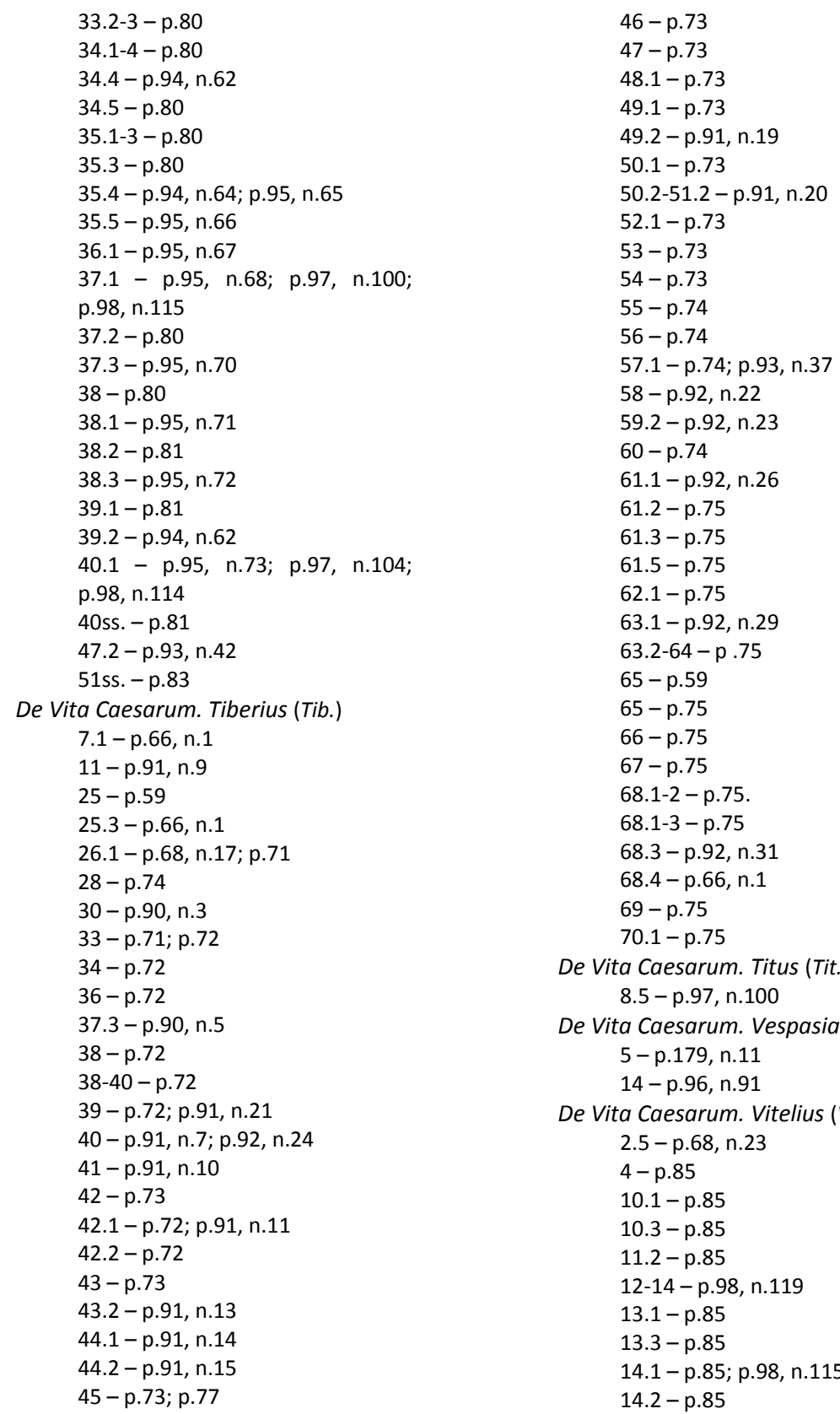

De Vita Caesarum. Titus (Tit.) 8.5 - p.97, n.100

De Vita Caesarum. Vespasianus (Ves.) 5-p.179, n.11 $14-$ p.96, n.91

De Vita Caesarum. Vitelius (Vit.) $2.5-$ p.68, n.23 $4-p .85$ $10.1-$ p.85 $10.3-$ p. 85 $11.2-$ p.85 12-14-p.98, n.119 $13.1-p .85$ $13.3-p .85$ $14.1-p .85 ; p .98, n .115$ $14.2-$ p. 85 
14.3 -p.96, n.80; p.98, n.117

$14.4-$ p. 98, n. 118

$14.5-$ p. 98, n.119

Tacitus, Cornelius (Tac.) (Historicus)

Agrícola (Ag.)

$$
2 \text { - p.96, n.90 }
$$$$
40-\text { p.98, n.105 }
$$

Annales (Ann.)

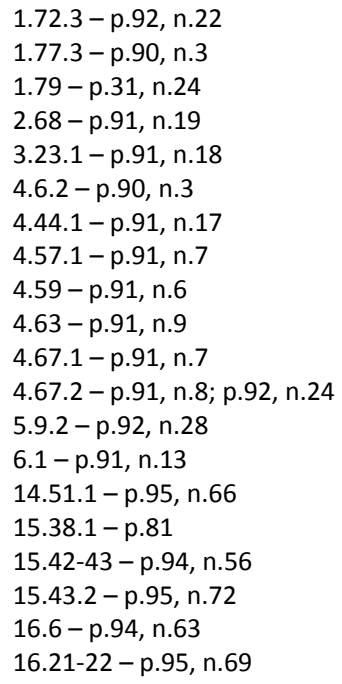

Historiae (Hist.)

1.7.2 - p.98, n.108

$1.13 .1-$ p. 98, n. 110

$1.20-$ p. 98, n. 112

1.49. - p.98, n.109

1.49.4-p.98, n.108

3.39.1 - p.98, n.116

3.67.2-p.98, n.119

Theodosius (Theod.)(Imperator)

Codex Theodosianus (CTh)

5.6.3 - p. 320

13.3.5 - p.218

13.11.10-p.320

Epistulae (Ep.)

$34-$ p. 322, n. 50

$36-$ p. 322, n. 50
Thucydides (Thuc.) (Historicus) Historiae

$$
\text { 1.7-p.233 }
$$

Ulpianus (Ulp.) (Iureconsulti) Liber singularis regularum (Reg.)

$$
9-\text { p.114, n.18 }
$$

Varro, M. Terentius (Varro) (Grammaticus et Historicus Latinus)

Res Rusticae (RR)

$$
2.10-\text { p. } 297
$$

Velleius Paterculus (Vell.) (Historicus Latinus)

Prologomena Historiae Romanae

$$
2.86 .2-\text { p.67, n.17 }
$$

Vergilius (Verg.)(Epicus latinus)

Aeneida (A.)

$1.247-$ p.238

$1.247-$ p. 241, n. 11

Georgicas (G.)

4.73-74-p.146

$4.8 \mathrm{y}$ ss. - p. 146

Vetus Testamentum Graece redditum

(V.T.)

1, Chronica (/ Chr.)

16.17-20-p.309

Deuteronomium (Dt.)

$32.9-$ p. 221

$4.35-$ p. 219

$4.39-$ p. 219

Exodus (Ex.)

$$
\begin{aligned}
& 4.22-\text { p. } 220 \\
& 20.5-\text { p. } 220 \\
& 22.28-\text { p. } 221
\end{aligned}
$$

Victor de Vita (Vict.Vit.) (Historicus)

Historia persecutionum Africe per Grisericum et Hunericum Vandalorum reges (Vand.)

$$
\begin{aligned}
& 1.13 \text { - p. } 307 \\
& 1.22-\text { p. } 322, \text { n. } 44 \\
& 1.29-\text { p. } 322, \text { n. } 46 \\
& 3.27-\text { p. } 322, \text { n. } 45
\end{aligned}
$$


Index locorum

$$
\begin{aligned}
& \text { 3.28-p.321, n.38 } \\
& \text { 3.3-14-p.321, n.38 }
\end{aligned}
$$

Vita Fultentii (Vit.Fulg.)

$$
\begin{aligned}
& 1-\text { p. } 322, \text { n. } .5 ; \text { p. } 322, \text { n. } 50 \\
& 1.2-\text { p. } 321, \text { n. } 38 \\
& 1.40-p .322, \text { n. } 45 \\
& 1.48-p .322, \text { n. } 45
\end{aligned}
$$

$$
\begin{aligned}
& \text { 5- } 6-\text { p. } 322, \text { n. } 46 \\
& 10-\text { p. } 322, \text { n. } 45 \\
& 14-\text { p. } 321, \text { n. } 38 \\
& 16-\text { p. } 322, \text { n. } 45
\end{aligned}
$$

Zosimus (Zos.)(Historicus) Historia Nova

$$
6.3-p .320, n .31
$$




\section{Volumes publicados na Colecção Humanitas SUPPLEMENTUM}

1. Francisco de Oliveira, Cláudia Teixeira e Paula Barata Dias: Espaços e Paisagens. Antiguidade Clássica e Heranças Contemporâneas. Vol. 1 - Línguas e Literaturas. Grécia e Roma (Coimbra, Classica Digitalia/CECH, 2009). 288 p.

2. Francisco de Oliveira, Cláudia Teixeira e Paula Barata Dias: Espaços e Paisagens. Antiguidade Clássica e Heranças Contemporâneas. Vol. 2 - Línguas e Literaturas. Idade Média. Renascimento. Recepção (Coimbra, Classica Digitalia/CECH, 2009). 199 p.

3. Francisco de Oliveira, Jorge de Oliveira e Manuel Patrocínio: Espaços e Paisagens. Antiguidade Clássica e Heranças Contemporâneas. Vol. 3 - História, Arqueologia e Arte (Coimbra, Classica Digitalia/CECH, 2010). 331 p.

4. Maria Helena da Rocha Pereira, José Ribeiro Ferreira \& Francisco de Oliveira (Coords.): Horácio e a sua perenidade (Coimbra, Classica Digitalia/CECH, 2009). $180 \mathrm{p}$.

5. José Luís Lopes Brandão: Máscaras dos Césares. Teatro e moralidade nas Vidas suetonianas (Coimbra, Classica Digitalia/CECH, 2009). 461 p.

6. José Ribeiro Ferreira, Delfim Leão, Manuel Tröster \& Paula Barata Dias (eds): Symposion and Philanthropia in Plutarch (Coimbra, Classica Digitalia/CECH, 2009). $573 \mathrm{p}$.

7. Gabriele Cornelli (Org.): Representações da Cidade Antiga. Categorias históricas e discursos filosóficos (Coimbra, Classica Digitalia/CECH/Grupo Archai, 2010). 173 p.

8. Maria Cristina de Sousa Pimentel e Nuno Simões Rodrigues (Coords.): Sociedade, Poder e Cultura no Tempo de Ovídio (Coimbra, Classica Digitalia/CECH/CEC/ $\mathrm{CH}, 2010) .288 \mathrm{p}$.

9. Françoise Frazier et Delfim F. Leão (eds.): Tychè et pronoia. La marche du monde selon Plutarque (Coimbra, Classica Digitalia/CECH, École Doctorale 395, ArScAn-THEMAM, 2010). 298 p.

10. Juan Carlos Iglesias-Zoido: El legado de Tucídides en la cultura occidental. Discursos e historia (Coimbra, Classica Digitalia/CECH, ARENGA, 2011). 301 p.

11. Gabriele Cornelli, O pitagorismo como categoria historiográfica (Coimbra, Classica Digitalia/CECH, 2011). 265 p.

12. Frederico Lourenço, The Lyric Metres of Euripidean Drama (Coimbra, Classica Digitalia/CECH, 2011). 451 p.

13. José Augusto Ramos, Maria Cristina de Sousa Pimentel, Maria do Céu Fialho, Nuno Simões Rodrigues (coords.), Paulo de Tarso: Grego e Romano, Judeu e Cristão (Coimbra, Classica Digitalia/CECH, /CHUL, CEC, 2012). 306 p. 
14. Carmen Soares e Paula Barata Dias (coords.), Contributos para a história da alimentação na antiguidade (Coimbra, Classica Digitalia/CECH, 2012). 116 p.

15. Carlos A. Martins de Jesus, Claudio Castro Filho, José Ribeiro Ferreira (coords.), Hipólito e Fedra - nos caminhos de um mito (Coimbra, Classica Digitalia/CECH, 2012). 228 p.

16. José Ribeiro Ferreira, Delfim F. Leão, \& Carlos A. Martins de Jesus (eds.): Nomos, Kosmos \& Dike in Plutarch (Coimbra, Classica Digitalia/CECH, 2012). 277 p.

17. José Augusto Ramos \& Nuno Simões Rodrigues (coords.), Mnemosyne kai Sophia (Coimbra, Classica Digitalia/CECH/CHUL, 2012). 200 p.

18. Ana Maria Guedes Ferreira, O homem de Estado ateniense em Plutarco: o caso dos Alcmeónidas (Coimbra, Classica Digitalia/CECH, 2012). 396 p.

19. Aurora López, Andrés Pociña \& Maria de Fátima Silva (coords.), De ayer a hoy: influencias clásicas en la literatura (Coimbra, Classica Digitalia/CECH, 2012). $594 \mathrm{p}$.

20. Cristina Pimentel, José Luís Brandão \& Paolo Fedeli (coords.), O poeta e a cidade no mundo romano (Coimbra, Classica Digitalia/CECH/CEC, 2012). 240 p.

21. Francisco de Oliveira, José Luís Brandão, Vasco Gil Mantas \& Rosa Sanz Serrano (coords.), A queda de Roma e o alvorecer da Europa (Coimbra, Imprensa da Universidade de Coimbra, Classica Digitalia, 2012). 252 p.

22. Luísa de Nazaré Ferreira, Mobilidade poética na Grécia antiga: uma leitura da obra de Simónides (Coimbra, Imprensa da Universidade de Coimbra, Classica Digitalia, 2013). 472 p.

23. Fábio Cerqueira, Ana Teresa Gonçalves, Edalaura Medeiros \& José Luís Brandão, Saberes e poderes no mundo antigo. Vol. I - Dos saberes (Coimbra, Imprensa da Universidade de Coimbra, Classica Digitalia, 2013). 282 p.

24. Fábio Cerqueira, Ana Teresa Gonçalves, Edalaura Medeiros \& Delfim Leão, Saberes e poderes no mundo antigo. Vol. II - Dos poderes (Coimbra, Imprensa da Universidade de Coimbra, Classica Digitalia, 2013). 336 p. 

OBRA PUBLICADA

COM A COORDENAÇÃO

CIENTÍFICA

\section{Centro de Estudos \\ ECH}

- $\mathbf{U}$

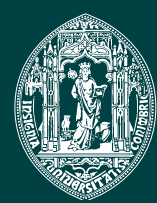

C •
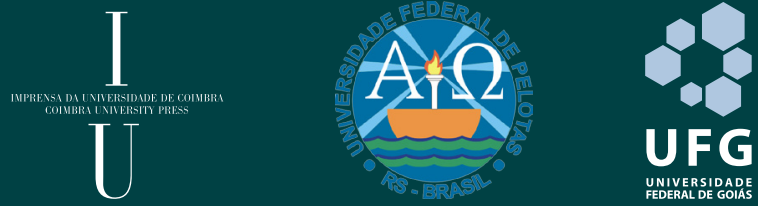